
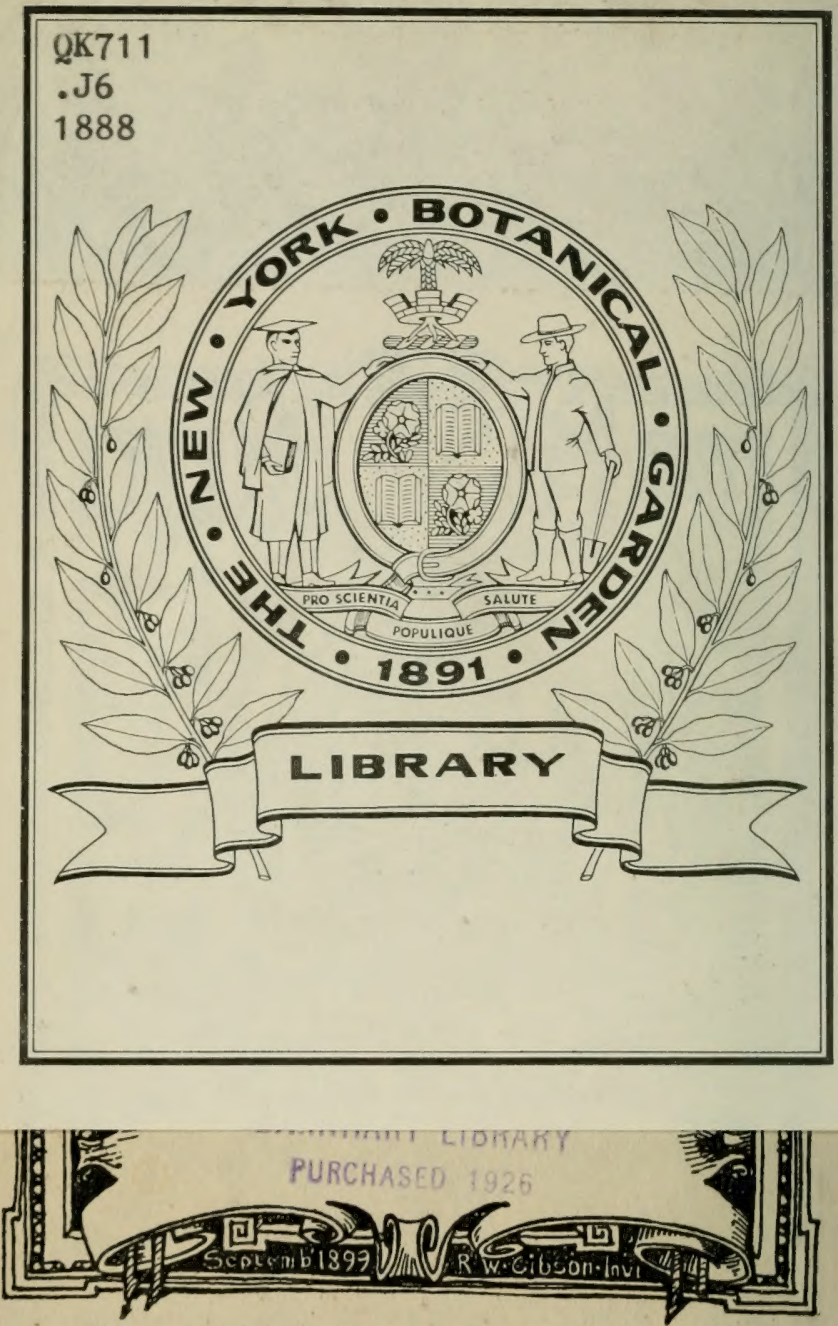





\section{HOW CROPS GROW.}

A TREATISE ON THE

\section{CHFMICAI COMPOSITION, STRUCTURE AND LIFE OF T'HE PLANT,}

FOR

ALL STUDENTS OF AGRICULTURE.

WTTH NUMEROUS ILLUSTRATIONS AND TABLEG OF ANALYSES.

BY

SAMUEL W. JOHNSON, M. A.,

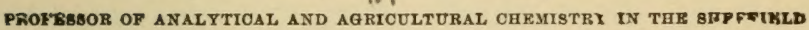
SOTENEIFIO SOBOOL OF YALE COLLEGE; OHEMIST TO THE OCNNEOTIOUT BTATE AGRICULTURAL SOCIETY: MEMBEQ GF THE NATIONAL AOADEMY OF BCIKNCEB.

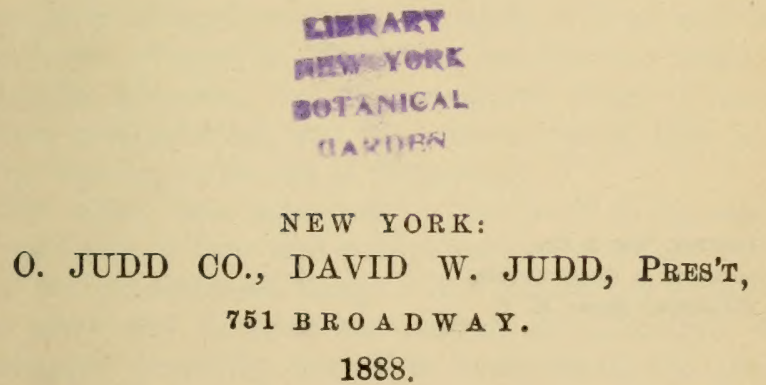

1888. 


\section{QKVIII

Entered according to Act of Congress, in the year 1869, ty ORANGE JUDD \& CO.,

st the Clerk's Office of the District Court of the Unitıd States for the Southern District of New-York.

Lovejox, Sos \& Co., EXECTROTXPERs \& STEREOTXPERe,

15 Vandewater Street, N. Y. 


\section{GISRATY \\ NASTY YORK \\ BET ANIEAL \\ CIAKIBPEN \\ PREFACE.}

For the last twelve years it has been the duty of the writer to pronounce a course of lectures annually upon Agricultural Chemistry and Physiology to a class in the Scientific School of Yale College. This volume is a result of studies undertaken in preparing these lectures. It is intended to be one of a series that shall cover the whole subject of the applications of Chemical and Physiological Science to Agriculture, and is offered to the public in the hope that it will supply a deficiency that has long existed in English literature.

The pregres, of these branches of science during recent years has been very great. Thanks to the activity of numerous English, French, and especially German investigators, Agricultural Chemistry has ceased to be the monopoly of speculative minds, and is well based on a foundation of hard work in the study of facts and first principles. Vegetable Physiology has likewise made remarkable advances, has disencumbered itself of many useless accumulations, and has achieved much that is of direct bearing on the art of cultivation.

The author has endeavored in this work to lay out a groundwork of facts sufficiently complete to reflect a true and well-proportioned image of the nature and needs of the plant, and to serve the student of agriculture for thoroughly preparing himself to comprehend the whole 
subject of vegetable nutrition, and to estimate accurately how and to what extent the crop depends upon the atmosphere on the one hand, and the soil on the other, for the elements of its growth.

It has been sought to present the subject inductively, to collate and compare, as far as possible, all the facts, and so to describe and discuss the methods of investigation that the conclusions given shall not rest on any individual authority, but that the student may be able to judge himself of their validity and importance. In many cases fulness of detail has been employed, from a conviction that an acquaintance with the sources of information, and with the processes by which a problem is attacked and truth arrived at, is a necessary part of the education of those who are hereafter to be of service in the advancement of agriculture. The Agricultural Schools that are coming into operation should do more than instruct in the general results of Agricultural Science. They should teach the subject so thoroughly that the learner may comprehend at once the deficiencies and the possibilities of our knowledge. Thus we may hope that a company of capable investigators may be raised up, from whose efforts the science and the art may receive new and continual impulses.

In preparing the ensuing pages the writer has kept his eye steadily fixed upon the practical aspects of the subject. A multitude of interesting details have been omitted for the sake of comprising within a reasonable space that information which may most immediately serve the agriculturist. It must not, however, be forgotten, that a valuable principle is often arrived at from the study of facts, which, considered singly, have no visible connection with a practical result. Statements are made which may appear far more curious than useful, and that have, at present, a simply speculative interest, no mode being apparent by which the farmer can increase his crops or diminish his labors by help 
of his acquantance with them. Such facts are not, how. crer, for this reason to be ignored or refused a place in our trentise, nor do they render our book less practical or less valuable. It is just such curious and seemingly useless facts that are often the seeds of vist alvances in industry and arts:

For those who have not enjoyed the alvantages of the schcols, the author has sought to unfold his suljects by suck regular and simple steps, that any one mily easily master them. It has also been attempted to aclapt the work in form and contents to the wants of the class-room by a strictly systematic arrangement of topies, and by division of the matter into convenient paragraphs.

To aid the student who has access to a chemical laboratory and desires to make himself practically fumiliar with the elements and compounds that exist in plants, a number of simple experiments are described somewhat in detail. The repetition of these will be found extremely useful by giving the learner an opportmity of sharpening his puceptive powers, as well as of deepening the impressions of study.

The author has endeavored to make this volume complete in itself, and for that purpose has introduced a short section on The Food of the Plant. In the succeeding volume, which is nearly ready for the printer, to be entitled "IIow Crops Feer," this subject will be amplified in all its details, and the atmosphere and the soil will be fully discussed in their manifold Relations to the Plant. A third volume, it is hoped, will be prepared at au early day upon Cultivation; or, the Inprovement of the Soil and the' Crop by Tillage and Manures. Lastly, if time and strength do not fill, a fourth work on Stock Feerling and Dairs Produce, considered from the point of view of chemical and physiological science, may finish the series.

It is a somree of deep and continual regret to the writer that his efforts in the field of agriculture have been mostly 
confined to editing and communicating the results of the labors of others.

Ire will not call it a misfortune that other duties of life and of his professional position have fully employed his time and his energies, but the fact is his apology for being a middle man and not a producer of the priceless com. modities of science. He hopes yet that circumstances may put it in his power to give his undivided attention to the experimental solution of numerous problems which now perplex both the philosopher and the farmer; and he wonld earnestly invite young men reared in familiarity with the occupations of the farm, who are conscious of the power of investigation, to enter the fields of Agricultural Science, now white with a harvest for which the reapers are all too few. 


\section{ACKNOWLEDGMENTS.}

The author would express his thanks to his friend Dr. Peter Collier, Professor of Chemistry in the University of Vermont, for a large share of the calculations and reductions required for the Tables pp. 150-6.

Of the illustrations, fig's $3,4,5,7,47,63$, and 64 , were drawn by Mr. Lockwood Sanford, the engraver. For others, acknowledgments are due to the following authors, from whose works they have been borrowed, viz.:

Schleiden.-Fig's $10,13,17,19,30,48,49$, and 50, Physiologie der Pflanzen und Thiere.

SAcns.-Fig's 56 and 6.5, Sitzungsberichte der Wiener Akademie, XXXVII, 1859, and fig's 22, 38, 40, 41, 42, 43, 59, 66, 69, 70, and 71, Experimental-Physiologie der Pflanzen.

PAY ev.-Fig's 11, 12, and 23, Precis de Chimie Indus. trielle.

Duchartre.-Fig's 60 and 61, Eléments de Botanique.

KüHN. - Fig's 18, 21a, 29, and 34, Ernährung des Rindviehes.

HartiG.-Fig's 20, 21b, 32, Entroickelungsgeschichte des Pflanzenkeims.

Unger.-Fig. 26, Sitzungsberichte der Wiener Alademie. XLIII, and fig. 55, Anat. u. Phys. der Pfunzen.

Sснаснт.-Fig's 33, 37, 44, Anatomie der Gewoвchse, fig's $51,53,54$, and 62 , Der Baum, and fig's 52, 57, ano 58, Die Kartoffel und ihre Rrankheiten.

Henfrey.-Fig's 36 and 39, Jour. Roy. Ag. Soc of Fingland, Vol. XIX, pp. 483 and 484. 


\section{'IABLE OF CONTENTS.}

Istrodection .......................................... 17

DIVISION I.-CHENICAL COMPOSITION OF THE PLANT.

Ctuaf, I. - The Volatile Paft of Plants. ........................ 28

1. Distinctions and Definitions....................... 28

2. Elements of the Volatile Part of Plants......................... 31 Carbon, IIydrogen, Oxygen, Nitrogen, Sulphur, Phosphor. us, Ultimate Composition of Organic Matter............ a

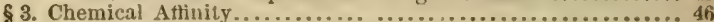

4. Vegetable Organic Compounds or Proximate Elements....... 52

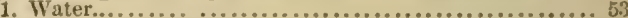

2. Cellulose Group.............................. 55

3. Pectose "

4. Vegetable Acids..................................... 85

5. Fats.... $\ldots \ldots \ldots \ldots \ldots \ldots \ldots \ldots \ldots \ldots \ldots \ldots \ldots \ldots \ldots$, s9

6. Albuminoids...........................................

Appendix, Chlorophyll, etc......................109

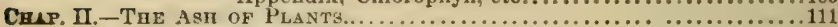

\$1. Ingredients of the Ash..................................111

Non-metallic Elements................................112

Carbon and its Compounds.........................113

Sulphur "t" "6 "

Phosphorus " " "

Silicon " " " 6 . .

Metallic Elements....................................123

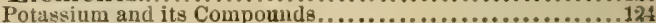

Sodium "6 "6 "

Calcium "4 " "

Macnesium and its Compounds......................126

Iron

Manganese " " "

8alts....

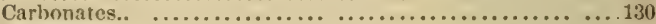

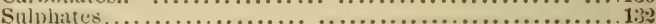

Phosphates..............................................

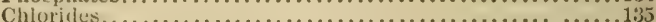

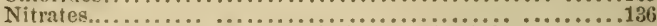

5 2. Qunatity, Distribution, and Variations of the $\mathrm{A} \& \mathrm{~h} . . . . . . . . .138$

Table of Proportions of Ash in Vegetable Matter..............139

\$ 3. Special Composition of the Ash of Agricultural Plants.........147

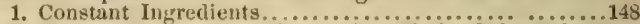

2. Uniform composition of normal specim's of given plant.148

Table of Ash-analyses............................

3. Composition of Diflerent parts of Plant..............157

4. Like composition of similar plants...................159

5. Variability of ash of same species..........................

6. What is normal composition of the ash of a plant ?.....163

7. To what extent is each ash-ingredient essential or accidental.......................................66

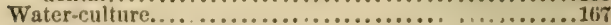

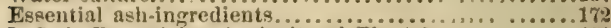

Is Sodia Essential to Agricultural Plasts. . . . . ........... 172

Oxide of Iron indispensable....................... 178

Oxide of Manganese unessentis.................. 179

Is chlorine indispensable ?........................... 1E]

Silica is not essential........................... 183

Ash-ingredients taken up in excess................. 18 ?

Disposition of supertluous matters..................189

State of Ash-ingredients in plaut....................193

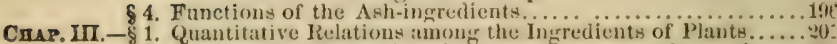

2. Cuantitative Relations amoner the In

Composition and Growth of the Oat Plant..................20

DIVISION I: -THE S'TRUCTURE OW THE PLAN' AND OFFICES OF ITS ORGANS.

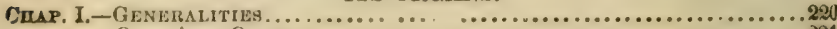

Organlsm, Organs..... . ............................2al 
ETAP. II.-Pri Hatt Elements of ORgantc Structure. .. ........... 22\%

$\$ 1$. The Vegetable Cell.................................. 222

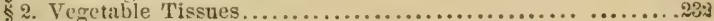

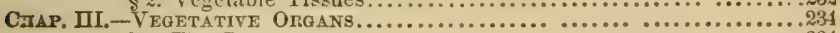

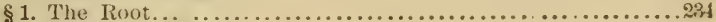

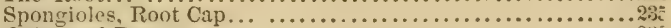

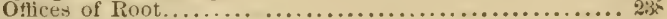

Delicacy of Structure..............................

Apparent Search for Food.............................241

Root-hairs....................................243

Contact of Roots with Soil........................215

Absorption by loot.................................24s

Soil Roots, Water Roots, Air Roots...................... 25:

Excretions.................................... 258

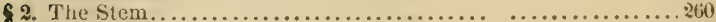

Buds..........................................................

Layers, Tilleriug..............................2tit

Root-Stocks.........................................

Tubers......

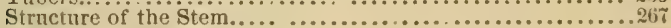

Endogenous Plants................................. .

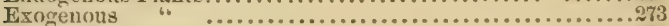

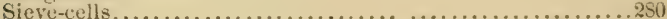

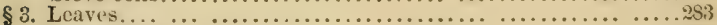

Leaf Pores........................................

Exhalation of Water Vapor...................................

Ontices of Foliare... ...............................290

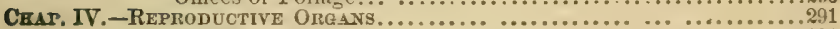

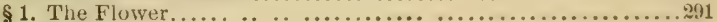

Fertilization...........................................

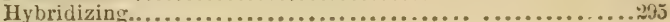

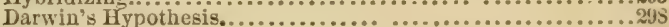

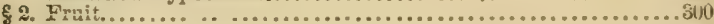

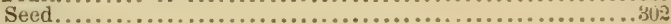

Endosperm........................................... 80.

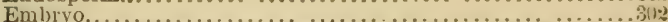

\$ 3. Vitality of seeds and their influence on the Plants they produce.\$(1)

Duration of Vitality.................................. 30 .

Use of old, unripe and light seeds.......................80"

Church's Experiments on Seed Wheat............................308 DIVISION III.-LIFE OF THE PLANT.

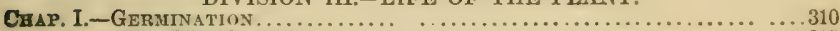

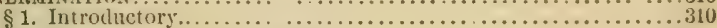

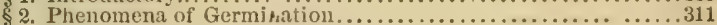

3. Conditions of Germination.............................. 312

Proper Depth of Sowing.............................. 316

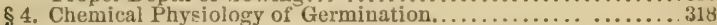

Chemistry of Malt......................................... 319

Cre - II. \$ 1. Food of the Plant when independent of the Sced...............

§. The Juices of the Plant. Their Nature and Movements.... 330 Flow of sap...........................................3

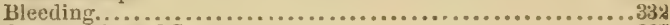

Composition of Sap...................................

Kinds of Sap...................................... 333

Motion of Nutrient Matters...............................

8 3. Causes of Motion of the Juices.........................346

Porusity of Tissues.....................................316

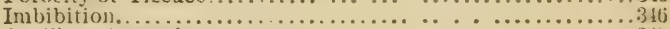

Capillary Attraction..................................

siquid Diffusion. ...................................

O*mose or Membrane Diftusion...................................

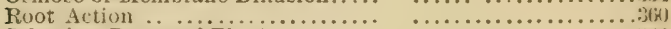

Selective Power of Plant.......................................

\$4. Mechanical Effects of Osmose...............................

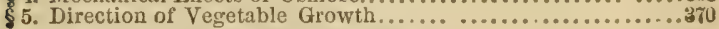

APPENDIX.-TABLES.

TaBle I.-Composition of the Asti of Agricuit'i I'lumts and Pruducts. Averages.370 
TARr.E II -Composition of Fresh or Air-dry Agricult"l Prciducts in 1.000 parte..33! TABLE III.-Proximate Composition of Agricultural Plant, and Prolucts.....3s 35 TABLE IV.-Detailed Analyses of Iread Grains............................3s3 TABLE V.-Detailed Aualyses of Potatoes.............................. 389 TABLE VI.-Detailed Analyses of Sugar Beets... . . . . . . . . . . . . . . . . 389 TABLE VII.-Composition of Fruits... ... ........................ 390 TABLE VIII.-Fruits atranged in the Order of their Content of Sugar..........393 TABLE IX.-Fruits arranged in the Order of their Content of Free Acid.......393 TABLE X.-Fruits arranged according to proportions between Acid, Sugar, etc..393 TABLE SI.-Fruits arranzed accorling to the proportions between Water,

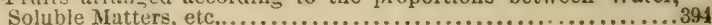

TABLE XIL_Proportion of Oil in Seeds................................ 39

\section{N D E X.}

Absorption by the root.... 239, 250,251 Access of air to interior of Plant...288 Acids, Definition of............... 86

" Test for................... 87

Acid elements..................113

Adhesion.......................26, 349

Agriculture, Art of .............. 17

Agricultural products, Composition

in 1,000 parts.... . ...........381

Agricuitural science, Scope of......24 Experiment-Stations of Germany.........24

Air-pasages in plaut.............. 285 Air-roots....................... . $25 \%$ Akene ........................201 Albumin....................... 96 AJbuminoids, Characters and composition................... 94

Albuminoids in animal nutrition...104 "6 Diffision of...........3tit " in oat-plant.......211, 215 " Miutual relations of...103 “ Proportion of, in vege-

table products................ 109

Albnrnum....................282 Alcohol from saiv-dust............. . 75

Aleurone.....................105 Algae....................177, 223

Alkali-earths...................125 "6 Function of..........197

" " Metals..............125

Alkali-metals ... ................123

Alkalies ..................86, 124 " Test for.................. 87

Functiou of .............. 194

Alkaloids.......................110

Alum, decomposed by diffision... 364

Alumina..........................124

Aluminum.......................1 1 29

Ammunia, Carbonate............. 49 in plants............108

"Salts of ... plät............137

Amy'nisls...................... (5) Transformation of........ 78

Anhydrous phosphoric acid........117

" silicic acid............120

. sulphuri: acid...........115

Anther.........................

A patite ........................ 1;

apple ceills of.. . .............
Arabic acid................... 70

Arabin........................ 70 Arendt, Estimation of sulphur and sulphuric acid.................195

Arendt, Study of oat-plant...........204 Analysis of oat-plant...... 141

Argol........................ 8s

Arrow root.................. 63 Arsenic in plants..............123, 196 Art and Seience.................. 17 Artificial fecundation................ 295 Ash-Ingredients ..............112, 138 "6 "6 Excess of ......... 187 posed of ...................189 Ash-Ingredients, Function of, in plant.....................196 Ash-Ingredients, The indispensable.146 " " State of, in plant...193 Ash of plants... ..............30, 111 "6 Aualyees, Tables of. 150,376 " "Composition of, normal.......................16i3 Ash of plants, Composition of, variations in ..............157, 163 Ash of oat-crop...............21:, $216^{6}$ "Proportions of, Tables...... 139, 145 " " " " variations in ...143 Asparagus, Ash-analyses..........176 Assimilation.................... 325 Atmosphere, Oflices of ............ 329 Atoms........................ 47 Atomic weight...............47, 48 Avenin. ........................ Azote........................ Bark......................2 $269,2 \pi 5$ "Ash of... ............. 380 Barley, Ash-analyses...150, 153, 160, 378 " Proximate analyses......... 337 " P " " Root-cap of................. " Reothairs of.. ............. Barley-Sigar................... 73 Baryta in plants................. 196 Bases, Definition of ............. 86 Bassorin...................... 71 Batst-cells.................270, 275 Bast-'Tismue.....................2333 Bayberry tullow................. 91 Bean. Ash-analyses..........152, 15i, 379

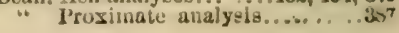


Bean, Leaf, Section of.

Seed..................................

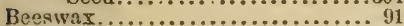

Beet sugrar...................... 73

Berry ...........................301

Bicarhonate of potakh..............130

Bicarbonate of soda...............131

Biennial plants.................251

Bitartrate of potash .............. 88

Bleeding of vine............ .250, 332

Blight............................223

Blcud-fibrin.................... 9s

Bone-black........................ 32

Bonsphosphate..................135

Bread graius, Detailed anaiyses.... 383

Bretschneider, Study of oat-plant...201

Bromine..... .......................119

Btucite .........................127

Bucliwheat, Ash-analyses....15\%, 153

Buckwheat, i'roximate ana.ysis.....................$$
\text { tailed................. }
$$

Buds, Structure of................261

Development under pressure. 368

Butyrin ......................267

Cabbage, Section of stem, fig..... 56

Cactus senilis, Lime salt in...........191

Caesium........................125 Action in oat.............196

Caffein............................111

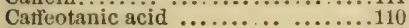

Calcium .....................125

Callous............................31:

Calyx ..............................

Cambium ............271, 272, 276, 280

Cane surar....................... $\tau_{2}$

Capillary attraction...................39

Carkmel......................... 7.

Carbon, Properties of ............... 31 In ash....................113

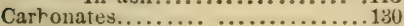

Cartonate of lime...................131 " potash..................120 soda....................131

Carhonic acid....................113 "as food of plant..... 328 " " in ash-analyses....... 149

Carbonization...................32

Carrot, Ash-analyses........155, 156, 377

Casein.............................100

Cassava ....................... (64

Caulerpa proiffera, fig...............230

Causes of directive power...........371

" " motion of juices............. 16

Caustic potash.....................124 soda........................125

Cauto tree.. ..................... 183

Cell-contents......................228

" membrane, Thickening of.... 227

" multiplication.. ...............231

" Structure of................. 2\%4

Cells, Forms of......................226

"t Size of..................... .230

Cellular plants........................2

"6 tissue.....................233

Cellulose.
Cellnlose, Composition.......... 80 . Estimation...............

" Group................... 55

"6 Test for.................. 59

Quantity of, in plants.....6 62

Cerasin ...................... 71

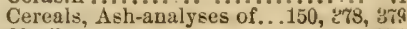

Chaff.... .....................294

Ash of .......................

Chemical affinity................ 46 "6 "6 overcome by os-

mose................... $26 t$

Chemical combination............. 46 decomposition........... 40

Chemistry.... .................. 26

Clierry tum.................... it

Chlorhydric acid.......................118

Chloricles.....................118, 135

Chloricle of ammonium, decomposed by plant..................171

Chloride of tiarnesium.............. 11

" " Potassium................ 135

. " "Sodium....................186 Chlorine.......................... function in plant...........1:9 in straud plants.............183

Chlorophyll..................105, $\approx 55$ requires irou.......... 2u0

Charch, on specitic gravity of seeds.308 Circulation of sap................3it

Citric acid........................ 83

Citrates............................

Classes........................... $2 y^{3}$

Classification.........................?

Clover, Ash of ....................... soluble and insoluble ash-in.

gredients.. .................194

Clover, washed by rain. .................

Coagniation.................... 96

Cochineal tiucture, test for acids and alkalies................... 87

Colloitls......................... 35

Combustion...................... 25

Common Salt.....................136

Compesite plants................... 300

Concentration of plant-food...........171

Concretions in plant................190

Coniferous plants...................

Copper in plants...............129, 196

Curk....................2.26, $2^{27}$

Corn-starch ... ................. 63

Corolla...........................29:

Cotton, ash-analyses............... 156 tiber, fig........... 5t, 227 seed cake, Aualysis of..378, $38^{\circ}$

Cotyledon. ...............268. 303 Crops, composition in 1,000 parts.. 381 Cuniferous plants.............300, 304 Crude cellulose....................... 60 Cryptogams....................223, 299 Crystalloid aleuroue................... Crystalloids...................... Crystals in plant............... 190, 192 Cubic centimeter................... 58 Culms...........................2b?

Cyanides............................14

Cyanogen.................... 
Cyannphyll...................110

Darwill on insect-fertilization......295

Hypothesis of.............298

Decimal system of weights........ จิ

Detlaqration.....................136

Definite Proportions, Law of... ...47

Deliquescent.....................135

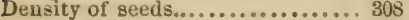

Depth of sowing...................316

DeItrin......................69

Diastasc.........................321

Dicalcic phosphate............... 134

Dicotyledonous seeds...............303

Diftusion of liquids...............351

Diflusion-rates....................35\%

Diœcious plauts.................294

Direction of growth..................... .

Disodic phosphate.............1:1

Domble flowers. .................. . . 2993

Drains stopped by roots............253

Drupe......................300

Dry weather, Effect of, on plants...144

Ducts ................234,272

Dundonald's treatise on Ag. Chemistry...

Elements of Matter.............. 25

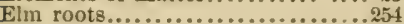

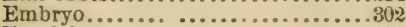

Emulsin...........................101

Endogens.........................238

Endogenous plants..........268, 303

Endosmose...................... . 35.5

Endosperm . .....................3

Epidermis.. . . . . . . . . . . . . . . . 269 of leaf.............285, 287

Equisetum................... 18 Equivalent replacement of bases...201 Eremacansis................... 37 Estimation of Albuminoids.........108

\begin{tabular}{|c|c|c|}
\hline & 60 & Celluloso...... 60 \\
\hline 66 & 66 & Fat......... \\
\hline 66 & 64 & $\ldots \ldots \ldots 66,76$ \\
\hline 66 & \$6 & $\ldots \ldots \ldots \ldots \ldots 76$ \\
\hline 6 & 66 & Water............ 54 \\
\hline
\end{tabular}

Etherial oils.............. 90

Excretion of mineral matters from

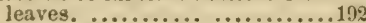

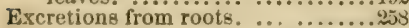
Exhalation of water from foliage

....................287, 332

Exogenous plants...........237, 273, 303

Exocrens .... .....................237

Exosmo=e...................... 350

Experiment-Stations of Germany...

Extension of roots................210

Extractive Mintters.............................

Exudation of ash-ingredients.......189

Eyes of potato.................237

Funilies.....................219

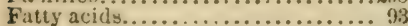

Fats ........................ 89 .6 converted into starch.............318

Fat in oat crop................211, 215 - Proportions of, in " Products................... 9

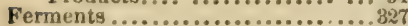

Furtilization....................29y

Yibor
Fiber in oat crop............ 210, 214

Fibrin...... 98

Field-beet, ash-analyses,... 155,176 377

"6 prox. 6 ... .... 38 .

Flax fiber, tig...............56, 227

Flesh fibrin $\ldots . . . . . . . . . .56,9$

Fleshy roots....................251

Flower............................ 291

Flow of sap.................... 331

Fluorine in plants............119, 195

Fodder plants, Ash of ................

Foliage, Oftices of............... . 290

white in absence of rori 199

Food of Plant...................... 327

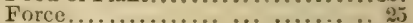

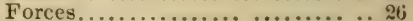

Formative layer...................224

Formulas, Chemical.............. 50

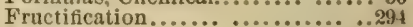

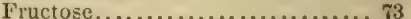

Fruit.................... 300

Fruits, Ash of...................379

Composition of...................

Fruit sugar...................73

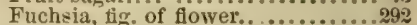

Fungi.........................223

Gases, how distributed throughout

the plant....................365

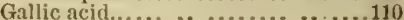

Gallotannic acid...................110

Gelatinous Silica. ...........122, 12:3

Genus ; Genera....................298

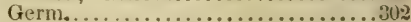

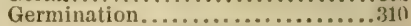

Conditions of .........312

Chemic'l Physiology of.31s

Phenomena of........ 311

Temperature of.........312

Girdling... ............. $312,313,34$

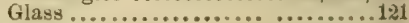

Glauber's Salt...................132

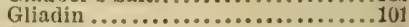

Gtobulin.................... 97

Glucose............................. $\gamma_{1}$

Glucosides..................7\%, 110

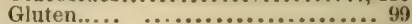

Gluten-Casein...................100

Glycerin........................ . 93

Gourd fruits.............................

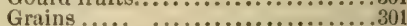

Ash of ........................ 379

Grain ........................ 58

Grape Sugar..................... *4 Granses, ash-analyses............157, 37ti " prox." Gravitation, influence on growtk,..371 Growth ...................2:31 of roots....................

Downward and upward. ...372

Gum, Amount of, in plants........ 72

Gum Arabic.................. 70

Gum Tramanth................. ซi, 79

Gun Cotton..................... 58

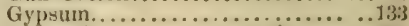

Gyde, Exp. on root-excretion...... 2v? Ilaberlandt, on vitality of secds.... 306 IInmoglobin ...................997

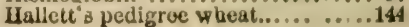


Ballier, Exp's on absurption of pig-

ments by plant................366

Hazel leaves, loss by solution.... ...190

Heart-wood ....................2s2

Heavy metals........................127

Henrici's Exp. with raspberry roots.251

Herbaceous stems................ 28:

Honey-dew................... $\tau_{6}$

Hooibrenk. artificial fecundation. ..295

Borse-chestnut, Ash-analyses of....159

Hybrid, Hybridizint.............2 245

Hydrated phosphoric acid..........11\%

"6 silica..................121

" sulphuric acid.............116

IIydrate of lime................1:t;

"6 " magnesia................127

"6 " potash ....................124

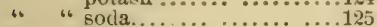

Hydration of membranes.............357

Hydrochloric acid..................118

Hydrogen...................... 39, 112 in Germination..........323

Imbihition. ...................316

Imbibing power...................347, 348

Imbricated.....................262

Introduction................... 17

Inorganic matter.... ........... 29

Intercellular spaces................2296

Interuodes....................262

Inulin.... ..................... is

Iodine in plauts.................119, 196

"b Solution of ................ 59

Lron ............................

Function of ........................

Isomerism.................... 81

Jurnsalem Artichoke, Cell of .......221

Juices of the Plant................

Kernel...............................

Lactose................... is

Latent buds.......................2ti3

Laume Canariensis, Air-roots of....257

Laurin......................... . 90

Layers...........................264

Leached ashes.......................132

Lead in plants...................196

Leaf-green......................110

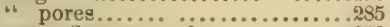

Leaves, Structure of...............2s 3 " office in nutrition........ . 323

$" 6$ of trees, Ach of ...............

" under artificial pressure.....369

Legume..........................301

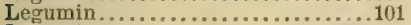

Legaminous plants... ... . . 302, 30 t

Legumes, ash-analyses.... 15:, 157, 379

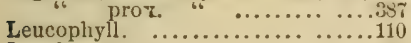

J.evulose......................

L:ebig on smali seeds................

6 " relations between $\hat{N}$ and

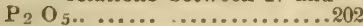

Light, effect on direction of growth. 375

Lioht seeds, "Plants frotion .........314

Lignin ......................... 57

Lime........................126

" essential to vegetation .......172

Lime-water.

36,126
Linolein.................... 90

L.quid Diffusion..................... 351

Lithia, Lithium...................

in plants................. 195

Litter, Ash of ................... 374

Lourlet, on vitality of seeds...... $3 m$

Madder crop......................195

Magazine, Root as.................. 25

Marnetic oxide of iron.............. 128

Magnesia.................... 1 Movements of, in oat.....219

Magnesium.................. 1:ti

Maize, ash-analyses.........151, 153,374

"6 prox. \& $\ldots \ldots \ldots \ldots \ldots . . . .35 i$

" paper................. 5.

" seed, Section of..............303

"6 stalk, "6 ".........268

Maizena ..................... 63

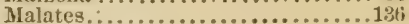

Malate of lime................. 88

Malic acid.......................88, 89

Malt, Chemistry of ................ 319

Maltuse ......................

Manganese........................ 128

"6 cannot replace iron.....201

Manna........................ it

Maple, Flow of eap from.............3 382 sugar.................... i

Marmarin....................... 99

Matter................ 25

Meadow hay, Ash of................ 376

Medullary rays. ................2 276

Membraue-diffinsion................... 354

Membranes, Influcnce on motion

of juices......................365

Metals.......................112

Metallic element8.................123

MIetapectic acid................. 83

Metarabic acid ..................... 71

Milk ducts....................281

Miillon's test....................... 96

Moisture, in Germination..........313

Molecular Weights.. .............. 4S

Molecules..................... 48

Mronzcious plants...................294

Monocotyledonous seeds ..........303

Monocalcic phosplate...............134

Motion caused by adhesion. ....350

Mould........ ................223

Mucidin.....................101, 321

Minltiple Proportione................ 48

Mummy wheat.... ................ 305

Muriate of soda..................... 136

Muriatic acid ......................119

Mustard, Root-hairs of...............24t

Mycose $\ldots \ldots \ldots \ldots \ldots \ldots \ldots \ldots$. it

Myristin........................ 90

Nasturtium, Cells of.................22\%

Nicotin......................... 110

Niter, nitrate of potash.............. 136

Nitrates in plants..............10s, 136

Nitrocellulose.. ................. 58

Nitrogren, Properties of............. 37
"6 in ash. .............112
"6 "Germination.......... 329
" relation to pliosphoric

acid. 
Nobbo \& Siegert, Erp. on backwheat..........................

Nodes.... .. ............... . 262 Nomenclature, Botanical...........299

Non-Metals ...................112

Norton's analyses of oat-plant..141, 204

Notation, Chemical............. 49

Nncleus....................422, 278

Nucleolus.......................2:4

Nat ........................

Natrisat matters in plant, Motion of. 40

Natrition of seedling... ...........318

" "plant................327

Oa!, ash-analysis.......151, $153,157,160$

« $\cdots \ldots \ldots \ldots \ldots \ldots \ldots \ldots 1,162,378$

" prox. " "

s6 crop, weight detailed............3 ss

" plant, Composition and growth of............204, 207, 214,217

Oat, proportions of ash in its different parts...................141

Oats, weight per bushel.............162

Offices of organs of plant.........220

Oil in seeds, etc............89,90,394

". of mustard....................114

" . vitriol..................42, 116

Oils, Properties of ................ 89

Old seeds, Plants from............307

Oleic acid....................... 98

Olein .......................... 90. 92

Orders......................

Organic matter..................

Organism......................

Organs...............................

Osmose.......................254

" mechanical effects on plant..367

Osmometer ......................

Ovaries... .............................2!3

Ovules..........................293

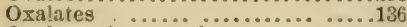

Oxalate of ammonia.............86 lime...................85, 86

Oralic "6 " in walnut......... 191

Oxide of iron....................

"6 6 " essential to plants.....178

" " " 6 State of, in plant... ...193

"6 $\quad$ "6 manganese in ash..... ...179

Oxides .......................... 37

"s of iron, described..............127

" " manganese, described... 128

Oxygen, Propertics of.............. $3: 3$

occurrence in ash.........113

6 in Arsimilation.............8:6

" "Germination...............314

Palmitic acid........................

Palmitin.......................90,

Jitrenchyma...................... $233^{3}$

Piupilisnacesus plants............. 299

Pappus............................301

Pea, ash-analysis..........152, 153, 379

" prox. " . .................

" ultimate analysis............ 45

I'earlash ....................... 1:30

Pectic acid.....................82, 84

peetisil...................... si

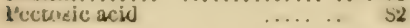

Pectose ....................... 81

Pedigree wheat......................14

Permeability of cells.............232

Peroxide of iron...................1 1us

Petals.........................291

Phanugams........................ 298

Phantum bouquets................ 5 ?

Pliloridzin ....................... T

Phosphate of lime................134

"t 6 soda.....................

" potash..............134

Phosphates............43, 44, 1i7, 133 function in plants......197 relation to albuminoids, 202

Phosphoric acid.............38, 44, 117

Phosphorite...................... 1 . $^{2}$

Phospharized oils................ 45,92

Phosphorus................43, 117 in albuminoids.........10) "fats of various plants. 92

Physics .......................... 26

Physiology........................ 27

Pinite.............................. 78

Pistils.................................293

Pith..... ....................269

rays.........................

Plastic Elements of Nutrition......104

Plaster of Paris..................133

Plumule........................303

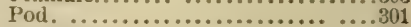

Pollarding..................... 261

Pollen.......................292

Polygonum coniolvilus, Fertilization

of, fig........................

Pome............................ 301

Porosity of yegetable tissues........346

Potato, ash-analyses...154, 162, 165, 377

" prox. analyses... ...........3st

" " " detailed.........389

"6 nltimate " ..............4 45

" leaf, Pores of, fig..............25

" stem, Section of, fig.........2s1

" sugar.................. 74

" tuber, Structure and Section

of, fig...............274, 277

Potato tuber, why mealy... ........., 226

Potash .....................121, 130

" jye..........................124

6 in strand and marine plants..178

Potassium....................124

Chloride of.................

Prosenchyma.......................2,

Protagon....................... 9:3

Protoplasm........................224

Protein bodies..................91, 103

Protoxide of iron......................127

manganese............128

Proximate Composition of Crops... 355

Elements ...............155

Prissic Acid.........................114

Putt-balls........................239

Pulp of fruits.....................

Quack grass......................2t6

quantitative relations among ingre-

dients of plant. .................201

Quartz....................... 120

Quercitamic icid................. 
Quercite

Radicle..................... 308

Red cluver hay, Uitimate analysis uf. 45

ts beet, Pigment of............. 667

"6 pine, Pith rays of.............276

" snow .....................223

Relations of Câlulose and Pec ose Groups.................... st

Relations of Fats to Amyloids..... 94 .6 "Veg. Acids to Amyloids.................... 89

Reproductive Örgans........... 222, 291

Rice, ash-analysis.........151, 152, 379

6. prox. .................357 " prox. "6 detailed ..............359

4 roots of..................252

Rind .........................275

Ringing of stems....................

Rock Crystal...................... . 120

Root-action, jmitated............... 361

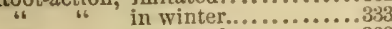

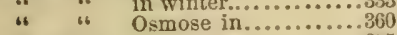

" cap.....................

" crops, ash-analyses........ 155, 377

"6 "6 prox. .. ...... 35\%, 359

" cuttings....................237

(6) distinguished from stem......236

.6 excretions................... 258

"6 hairs .....................243

" office in Nutrition............327

$"$ power of vine............24

-6 Seat of absorptive force in....219

"6 stock......................265

Rootlets....................... 238

Roots, Structure of................231

"6 Bursting of ................... 369

66 contact with soil.......... 245

". going down for water.........254

" Search of food by.........241

6 Quantity of................242

Rubidium ..........1:5

action on oat. ..........196

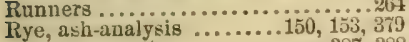

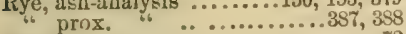

Saccharose...................

Sago.......................

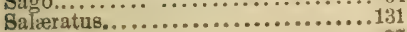

Salicin....................... 77

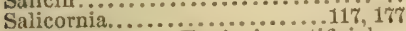

Salm-Horstmar, Exp's in artificial soils

166

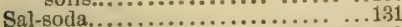

Saisola ..................... 177, 1s3

Salts, Definition of.............. $86^{\circ}$

$" 6$ in ash of plants............129

6) Properties of................ 87

Saltwort........................177

Samphire.........................

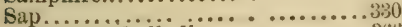

Acid and alkaline.............. $36 b^{\prime}$

6 ascending.....................310

" descending... .... .............341

" Composition of ..................337

"b of sunflower... ...............3.35

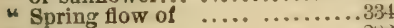

" truad.................... 282
Saponification... .............. 3 月

Saussure, exp. ol mint...........137

Saxifraga crustat $1 . . . . . . . . . . . .139$

Scotch fir, Wood-celis of, fig.... .. 279

Scouring rush .................. .181

Screw pine, Root cap of, fig..... . .23i

Sea-weeds, Potash in. . ....... ...195

Seed............... ....... . 302

"6 vessel..... ...............800

Seeds, constancy of composition... 145

Selecting power of plant.......324, 362

Sepals.... .....................292

Series......................... 298

Sesquioside of iron.............. 128

Sierc-cells ............................

${ }_{66}{ }_{6}$ in pith................... 313,345

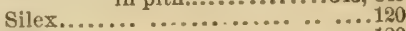

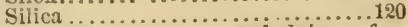
does not prevent lodging of

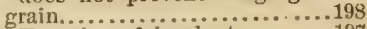

" Function of, in plant.......... 197

6 in ash... .................183

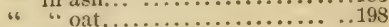

" " testile materials................ .

"6 unessential to plants.............183

Silicates. ....................120

Silicate of potash.................. 120

Silicic acid. ......................120

Silicon ........................119

Silk of maize...................291

Silver Fir, Roots of.............245

Silver-grain... .................2Ti

Skeletonized plants.............. 57

Soaps....................... 43

Soda..........................125

can it replace potash ?........176

$"$ essential to ag. plants?......1\%2

6. in strand and marine plants...1\%

"Variations of, in field-crops...173

Soda-2sh..................... 1:31

Sodium......................121

Chloride of ..............126

Sorghum sugar.............. 73

Soil, Ottices of......................3

Soil-roots......................252

Solution of starch in Germination. .3:2 for water-culture.........168

Soluble silica.... ................121

"6 starch....................... $3 * 2$

Species.........................2 . . .

Spirits of salt...................119

Spongioles.......................235

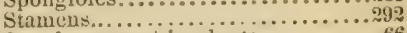

Starch, amount in plants........... 66 estimation..............66 66 in wood ......................3

.6 Properties of............... 6.3

"6 surar.................. 74

" Teet for..................6t

" unorg tnized.............. 64

Stearic acid ................. 93

Stearin........................9\%, 92

Stem, Endogenous ...............269 . .269

66, Exogtnous.................27s

6 Structure of..................2tit

Stems....................... . 801

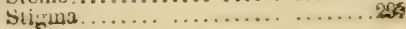


Stomata......................255

Stoul.........................265

Straw, ash-analyses........152, 153, 157 prox. "6............. 346

Structure of plant.................220

Suckers.........................266 Sugar-beet, ash-analyses.....154, 156, 158

Sngar estimation analyses.........3s .............

cereals................. 1

. sap ...........................

"6 of milk.............. 78

“Trommer's test for......... Ti

Bulphate of lime........................ "6 potash................. 132 " 4 soda................ 139

Sulphates.................43, 117, 132 .6 Function of............ 196 6 in clover................194 " reduced by plant...........190

Sulphides................... 42 Sulphide of potassium..............115

Sulphites........................115

Sulphocyanide of allyle............ 114

Sulphur ...................42, 114 in oats................. 194

Snlphureted hydrogen.............43, 115

Sulphurets..................... 42

Sul phuric acid ..............42, 116 in oat..............219

Sulphurous acid...............42, 115 Sulphydric acid....................... 43,115 Supercarbonate of soda............131 Superphosphate of lime...........135

Symbols, Chemical...............47

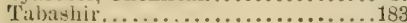

'Таниil...................77, 110

Tito-for ........................ 101

Tapioca.......................... (i)

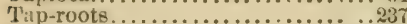

Tartaric acid....................88, 89

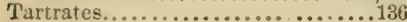

Tarsels of maize..................291 l'eak, Phosphate of lime in.........191

T'ension in plant.................372 T'ests for albuminoids.............96

I'extile plants, Ash of.....................

Theobromin.......................111

Thulaspi, var. calaminaris...........196

Tillering...........................265

Titanic acid.................123, 195

T'itanium ....................1243

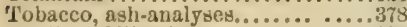
Silica in............... 185

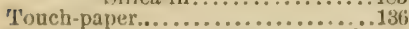

Tradescantia zebrina, Air-roots of. .257

Transformations of cell-contents...220

Translocation of substances in plant. ..................218

Trensplanting ..................255

Tricalcic phosphate...........131, 135

Truburs.........................26ti

T'uruip, ash-anaiyses........155, 106, 377 ". prox. "............887 Tuscan hat-wheat.... ...........141 Ultimate Composition of Vegetable Mititers

Viminelliferous plauts.
Unripe seed, Hants from.. ........30

Variation of ash-ingredier $t s$, limited....................147, 148

Varieties...........................29? Causes of .....................

Vascular bundle of maize staik.....2\%

Viascular-Tirene.................23ks

Vegetable acids ................. 85 albumin................... 97

6 casein..................100

" cell...................222

"6 fibrin $\ldots \ldots \ldots \ldots \ldots \ldots \ldots \ldots$ !

" $\quad$ ivory $\ldots \ldots \ldots \ldots \ldots \ldots \ldots \ldots . \ldots \ldots$

" nucilage.............. 71

" parchment............ 58 iissuc..............225, 23\%

Tegetative organs.............2.2., 231 Veins of the leaf.....................285 Vine, Bleeding of..................3.2 Viola calaminaris... ................196 Vitality of roots.............. 260 "6 "seeds............... 315

Vital Principle................... . 221

Water,Composition of............ 53

6. Estimation of ........... 55

6. Formation of............... 41

"6 imbibed by roots.............248

"6 "6 "6 seeds............360

" in air-dry plants............. 55

"6 "6 fresh plants.............. 54

"s of plant affected by soil... . . 369

4 "6 vegetation, Free..........55

Water-1) Hygroscopic.. 55

Water-culture...........................

Water-glass...................... 120

Water Roots.... ............. 252, 253

Wax................... 89, 90 6 in oat-plant................211 Well-water, used in water-culture, Composition of..............171 Wheat, ash-analyses...... 150, 152, 379

6 prox. "5 ...............357 "6 prox. "6 detailed..............3s8 "6 ultimate analyses ........ 45 "6 gum.................... 99 (6 struw, proximate analysis... 386 6. 6 ultimate "6 roots of..............246, 247

White of egg..................... 86 Wiegmann \& Polatroff, Exp. with cress......................146

Wiltiug................................... 34 Wolf, Exp. with buckwheat........164 Woud...................... 57 Amount of water in .......... 3:3;

“. Ish of....................

" cells........................ . . . . .

"6 "6 of cunifers................

"s paper..................... 54

Wondy-tiber.................... (iv

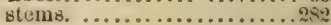

"6 tissue....... ............ 2i:

Yeast. .....................223, 231

Zamia spiralis, Root of.............25\% Zinthoplfyll..................110 Zinc........................120, 12 


\section{HOW CROPS GROW.}

INTRODUCTION.

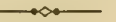

The objects of rgriculture are the production of certain plants and certain animals which are employed to feed and clothe the human race. The first aim, in all cases, is the production of plants.

Nature has made the most extensive provision for the spontaneous growth of an immense variety of vegetation; but in those climates where civilization most certainly attains its fullest development, man is obliged to employ art to provide himself with the kinds and quantities of vegetable produce which his necessities or luxuries demand. In this defect, or, rather, neglect of nature, agriculture has its origin.

The art of agriculture consists in certain practices and operations which have gradually grown ont of an ohserration and imitation of the best efforts of nature, or bare been hit upon accidentally.

The science of agriculture is the rational theory and exposition of the successful art.

Strictly considered, the art dail science of agriculture are of equal age, and have grown together from the earliest times. Those who first cultivated the soil by dig- 
ging, planting, manuring, and irrigating, had their sufficient reason for every step. In all cases, thought goes before work, and the intelligent workman always has a theory upon which his practice is planned. No farm was ever conducted with sut physiology, chemistry, and fihysies, any more than an aqueduct or a railway wris ever built without mathematics and mechanies. Every successful farmer is, tc some extent, a scientific man. Let him throw away the knowlerige of facts and the knowledge of principles which constitute his science, and he has lost the elements of his success. The farmer without his reasons, his theory, his science, can have no plan; and these ranting agriculture would be as complete a failure with him as it would be with a man of mere seience, destitute of manual, financial, and executive skill.

Other qualifications being equal, the more alvanced and complete the theory of which the farmer is the master, the more successful must be his firming. The more he knows, the more he can do. The more deeply, comprehensively, and clearly he can think, the more economically and advantageously can he work.

That there is any opposition or conflict between science and art, between theory and practice, is a delusive error. They are, as they ever hare been and ever must be, in the fullest harmony. If they appear to jar or stand in contradiction, it is because we have something false or incomplete in what we call our science or our art ; or else we do not perceive correctly, but are misled by the narrowness and aberrations of our vision. It is often said of a machine, that it was good in theory, but failed in practice. This is as untrue as untrue can be. If a machine has failed in practice, it is because it was imperfect in theory. It should be said of such a failure - the machine was good, judged by the best theory known to its inventor, but its incapacity tc work demonstrates that the thenry harl a flaw.

But, although art and science are hus inseparable, it 
must not be forgotten that their growth is nut altogether parallel. There are facts in art for which science can, as yet, furnish no adequate explanation. Art, though no older than science, grew at first more rapidly in vigor and in stature. Agrriculture was practised hundrecls and thonsands of years ago, with a success that does not compare unfavorably with ours. Nearly all the essential points of modern cultivation were regarded by the Romans before the Christian era. The annals of the Chinese show that their wonderful skill and knowledge were in use at a vastly earlier date.

So much of science as can be attained through man's unaided senses, reached considerable perfection early in the world's history. But that part of science which relates to things invisible to the unassisted eye, could not be developed until the telescope and the microscope had been invented, until the increasing experience of man and his improved art had created and made cheap the other inventions by whose aid the mind can penetrate the veil of nature. Art, guided at first by a very crucle and imperfectly developed science, has, within a comparatively recent period, multiplied those instruments and means of research whereby science has expanded to her present proportions. The progress of agriculture is the joint work of theory and practice. In many departments great advances have been made during the last hundred years; especially is this true in all that relates to implements and machines, and to the improvement of domestic animals. It is, however, in just these ilepartinents that an improved theory has had sway. More recent is the development of agriculture in its chemical and physiological aspects. In these directions the present century, or we might almost say the last 30 years, has seen more accomplished than all previous time.

The first book in the English language on the subjects which occupy a good part of the following pages, was written by a Scotch nobleman, the Earl of Dundonald, and 
was published at London in 1795. It was entitled: "A Treatise showing the Intimate Connection that subsistg between dgriculture and Chemistry." "The le:med Earl in his Introduction remarked that "the slow progress which agrieulture has hitherto made as a seience is to be ascribed to a want of education on the part of the cultiratore of the soil, and the want of knowledge in such an thors as have written on agriculture, of the intimate connection that subsists between the science and that of chemistry. Indeed, there is no operation or process, not merely mechanical, that does not lepend on chemistry, which is defined to be a knowledge of the properties of bodies, and of the effects resulting from their different combinations." Earl Dundonald could not fail to see that chemistry was ere long to open a spleulid fiture for the ancient art that always had been and always is to be the prime support of the nations. But when he wrote, no Jonger than seventy-two years ago, how feeble was the light that chemistry could throw upon the fundamental questions of agricultural science! The chemical nature of atmospheric air was then a discovery of barely 20 years' standing. The composition of water hal been known but 12 years. The only account of the composition of plants that Earl Dundonald coull give, was the following: "Vegetables consist of mucilaginous matter, resinous niatter, matter analogous to that of animals, and some proportion of oil. * * Besides these, regetables contain earthy matters, formerly held in sulution in the newly taken-in juices of the growing vegetalile." To be sure he explains by mentioning on subsequent pages that stareh belongs to the mucilaginous matters, and that, on analysis by fire, vegetables yield soluble alkaline salts and insoluble phosphate of lime. But these salts, he held, were formert in the process of Lurning, their lime excepted, and the fact of their keing taken from the soil and constituting the indispensable food of plawts, his Lor lship was una 
quainted with. The gist of agricultural chemistry with him was, that plants are "composed of gases with a smali proportion of calcareous matter;" for "although this discovery may appear to be of small moment to the practical farmer, yet it is well deserring of his attention and notice, as it throws great light on the nature and food of vegetables." The fact being then known that plants ab. sorb carbonic acid from the air, and employ its carbon in their growth, the theory was held that fertilizers operate by promoting the conversion of the organic matter of the soil or of composts into gases, or into soluble humus, which were considered to be the food of plants.

The first accurate analysis of a vegetable substance was not accomplished until 15 years after the publication of Dundonald's Treatise, and another like period passed before the means of rapidly multiplying good analyses had been worked out by Liebig. So late as 18:38, the Güttingen Academy offered a prize for a satisfactory solution of the then vexed question whether the ingredients of ashes are essential to vegetable growth. It is, in fict, during the last 30 years that agricultural chemistry has come to rest on sure foundations. Our knowledge of the structure and physiology of plants is of like recent development. What immense practical benefit the firmer has gathered from this advance of science! The dense populations of Great Britain, Belgium, Holland, and Saxony, can attest the fact. Chemistry has ascertained what vegetation absolutely demands for its growth, and points out a multitude of sourees whence the requisite materials for crops can bo derived. To be sure, Cato and Columella knew that ashes, bones, bird-dung and green manuring, as well as drainage and aeration of the soil, were good for crops; but that carbonic acid, potash, phosphate of lime, and compounils of nitrogen, are the chief pabulum of vegetation, they did not know. They did not know that the atınosphere dissolves the rocks, and converts inert stone into 
nutritive soil. These grand principles, understood in many of their details, are an inestimable boon to agriculture, and intelligent farmers have not been slow to apply them in practice. The vast trade in phosphatic and Peruvian guano, and in nitrate of soda; the great manufactures of cil of vitriol, of superphosphate of lime, of fish fertilizers; and the mining of fossil bones and of potash salts, are largely or entirely industries based upon and controlled by chemistry in the service of agriculture.

Every day is now the witness of new advances. The means of investigation, which, in the hands of the scientific experimenter, have created within the writer's memory such arts as photography and electro-metallurgy, and have produced the steam engine and magnetic telegraph, are working and shall continue to work progress in agriculture. This improvement will not consist so much in any remarkable discoveries that shall enable us "to grow two blades of grass where but one grew before," but in the gradual disclosure of the reasons of that which we have long known, or believed we knew, in the clear separation of the true from the seemingly true, and in the ex change of a wearying uncertainty for settled and positive knowledge.

It is the boast of some who affect to glory in the suffieiency of practice and decry theory, that the former is based upon experience, which is the only safe guide. Bur this is a one-sided view of the matter. Theory is also based upon experience, if it be truly scientific. The vaga. rizing of an ignorant and undisciplined mind is not theory. Theory, in the good and proper sense, is alwatys a deduc tion from facts, the best deduction of which the stock of facts in our possession admits. It is the interpretation of facts. It is the expression of the ideas which facts awaken when submitted to a fertile imagination and well-balanced judgment. A scientific theory is intended for the nearest possible approach to the truth. Theary is confessedly in. 
perfect, because our knowledge of facts is incomplete, our mental insight weak, and our judgment fallible. But the scientific theory which is framerl by the contributions of a multitude of earnest thinkers and workers, among whorn are likely to ba the most gifted intellects and most skillfu] hands, is, in $t_{s}$ ese days, to a great extent worthy of the Divine truth in nature, of which it is the completest hu. man conception and expression.

Science employs, in effecting its progress, essentially the same methods that are used by merely practical men. Its success is commonly more rapil and brilliant, because its instruments of observation are finer and more skillfully handled; because it experiments more industriously and variedly, thus commanding a wider and more fruitful experience; because it usually brings a more cultivated imagination and a more disciplined judgment to bear upon its work. The devotion of a life to discovery or invention is sure to yield greater results than a desultory application made in the intervals of other absorbing pursuits. It is then for the interest of the farmer to avail himself of the labors of the man of science, when the latter is willing to inform himself in the details of practice, so as rightly to comprehend the questions which press for a solution.

It is characteristic of our time that larye associations of practical agriculturists have recognized the immediate pecuniary advantage to be derived from the application of science to their art. This was first done at Edinburgh, in 18 13 , by the establishment of the "Agricultural Chem. istry Association of Scotland."

This organization limited itself to a duration of five jears. At the expiration of that time, its labors, which had been ably conducted by Prof. James F. W. Johnston, were assumed by the Hiyliand and Acricultural Society of Scotland, and have been prosecuted up to the present day by Dr. Anderson. The Royal Ag'l Soc. of England began to employ a consulting chemist, Dr. Lyon Playfair, in 1S 13 ; and since 1848 most valuable investigations, by Prof. Way and Dr. Vcelcker, have regularly appeared in its journal. Other British Ag'l Societies Lave followed these examples with more or less effect.

It is, however, in Germany that the most extensive and well-organized efforts have been made by associations of agriculturists to hel. their 
practice b5 developirg theory. In 1851 the Agricultural Societ 5 of Leip zig, (Leipziger Oeconomische Societ(et), established an Ag'l Experinuent Siation on its firm at Moeckern, near that city. This example was soon Initated in other parts of Germany and the neighboring countries; and at the present writing, 1867, there are of similar Experiment Stations in operatiou-in Prussia 10, in Saxony 4, in Bararia 3, in Austria 3, in Brunswick, Hesse, Thüringria, Anhalt, W'irtemberg, Baden, and Sweder, 1 cach, makiug a total of 26 , chiefly sustained by, and operating in, the interest of the agriculturists of those countries. These stations give con. stant employnent to 60 cliemists and vegetible physiologists, of whom a lare number are occupied largely or exclusively with theoretical investigrations, while the work of others is devoted to more practical mat. ters, as testing the value of commercial fertilizers. Since 1859 a journal, Die Landzoirthschaftlichen Versuchs-Stationen, (Agr'l Exp. Stations), has been published as the organ of these establishments, and the 9 volumes now completed, together with the numerons Reports of the Stations theuselves, have largely contributed the ficts that are made use of in the following pages.

In this country some similar enterprisea have been attempted, but have not been supported with a sufficient combination of talent and pecuniary outlay to ensure any striking sucess in the direction of agricultural chemistry. An imitation of the example set by Europenn associations is well worthy the consideration of our State Ag'l Societies, many of which could ensily command the funds for such an enterprise. It would be found that such a use of their resources would speedily strengthen their hold on the interest and regard of the communities they represent.

Agricultural science, in its widest scope, comprehends a vast range of subjects. It includes something from nearly every department of human learning.

The natural sciences of geology, meteorology, mechanics, physies, chemistry, botany, zoology and physiology, are most intimately related to it. It is not less concerned with social and political economy, with commeree and law. In the treatises of which this is the first, it will not be attempted to cover nearly all this ground, but some account will be given of eertain suljects whose understanding promises to be of the most direct service to the agriculturist. The theory of agrieulture, as founded on chemical, physical, and physiological science, is the topio of this and the succeeding volume. 
Sume preliminary propositions and definitions may be serviceable to the reader.

Science deals with matter and force.

Matter is that which has weight and bulk.

Force is the cause of changes in matter-it is appreciable only by its effects upon matter.

Force resides in and is inseparable from matter.

Force manifests itself in motion.

All matter is perpetually animated by force-is therefore never at rest. What we call rest in matter is simply motion too fine for our perceptions.

The different kinds of matter known to science have been resolved into not more than 62 elements or simple substances.

Elements, or ultimate elements, are forms of matter which have thus far resisted all attempts at their simplification.

In ordinary life we commonly encounter but 12 elements in their elementary state, viz:

$\begin{array}{ll}\text { Oxygen, } & \text { Mercury, } \\ \text { Nitrogen, } & \text { Copper, } \\ \text { Sulphur, } & \text { Lead, } \\ \text { Carbon, } & \text { Tin, } \\ \text { Iron, } & \text { Silver, } \\ \text { Zine, } & \text { Gold. }\end{array}$

The numberless other substances with which we are familiar, are mostly compounds of the above, or of 12 other elements, viz.:

$\begin{array}{ll}\text { Hydrogen, } & \text { Calcium, } \\ \text { Phosphorus, } & \text { Magnesium, } \\ \text { Chlorine, } & \text { Aluminum, } \\ \text { Silicon, } & \text { Manganese, } \\ \text { Potassium, } & \text { Chromium, } \\ \text { Sodium, } & \text { Nickel. }\end{array}$


We distinguish a number of forces, which, at:ling on or through matter, produce all material phenomena. In the subjoined scheme the recognized forces are to some extent clissified and defined, in a manner that may prove useful to the reader.

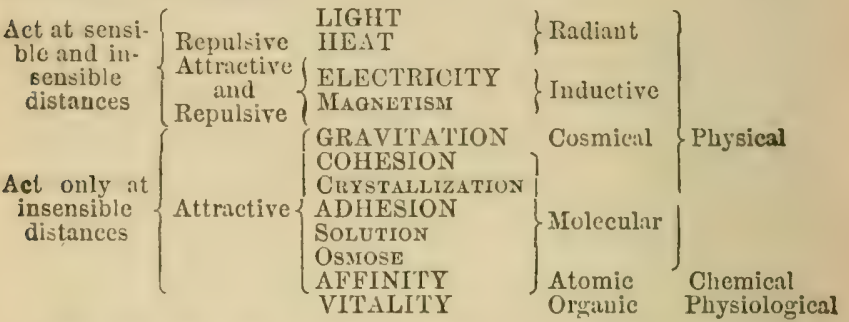

The sciences that more immeriately relate to agriculture are:

I.-Physics or natural philosophy,-the science which considers the general properties of matter and such of its phenomena as are not accompanied by essential change in its obvious qualities. All the forces in the preceding scheme, sive the last two, manifest theinselves through matter without destroying or masking the matter itself. Iron may be hot, luminous, or magnetic, may fall to the ground, be melted, welded, and crystallized; but it remains iron, and is at once recognized as such. The forces whose play does not disturb the evident characters of substances are physical.

II.-Chemistry,-the science which studies the properties peculiar to the various kinds of matter, and those phenomena which are accompanied by a furdamental shange in the inatter acted on. Iron rusts, wool burns, and both lose all the external characters that serve for their identification. They are, in fuct, converted into other substances. Aflinity, or chemical aflinity, unites two or more elements into compounds, unites compounds together into more complex compounds; and, under the influence of 
heat, light, and other agencies, is annulled or overcome, so that compounds resolve themselves into simpler combina. tions or into their elements. Chemistry is the science of composition and decomposition; it considers the laws and results of affinity.

III.-Physiology, which unfolds the laws of the development, sustenance, and death, of living organisms.

When we assert that the olject of agriculture is to derelop from the soil the greatest possible amount of certain kinds of vegetable and animal produce at the least cost, we suggest the topics which are most important for the agriculturist to understand.

The f:rmer deals with the plant, with the soil, with manures. These stand in close relations to each other, and to the atmosphere which constantly surrounds and acts upon them. How the plant grows, - the conditions under which it flourishes or suffers detriment,-the materials of which it is made, - the mode of its construction and organization,- - how it feeds upon the soil and air,- -how it serves as food to animals, - how the air, soil, plant, and animal, stand related to each other in a perpetual round of the most beautiful and wonderful transformations,these are some of the grand questions that come before us; and they are not less interesting to the philosopher or man of culture, than important to the farmer who depends upon their practical solution for his cornfort; or to the statesman, who regards them in their bearings apon the waightiest of political considerations. 



\title{
DIVISION $\Upsilon$.
}

\section{CIIEMICAL COMPOSITION OF 'IHE PLAN'T̃.}

\author{
CHAPTER I. \\ THE VOLATILE PART OF PLANTS. \\ $\S 1$. \\ DISTINCTIONS AND DEFINITIONS.
}

Organic and Inorganic Matter.-All matter may be divided into two great classes-Organic and Inorganic.

Organic matter is the product of growth, or of vital organization, whether vegetable or animal. It is mostly combustible, i. e., it may be easily set on fire, and burns away into invisible gases. Organic matter either itself constitutes the organs of life and growth, and has a peculiar organized structure, inimitable by art,-is made up of cells, tubes or fibres, (wood and flesh); or else is a mere result or product of the vital processes, and destitute of this structure (sugar and fat).

All matter which is not a part or proiluct of a living organism is inorganic or mineral matter (rocks, soils, water, and air). Most of the naturally occurring forms of inorganic matter which directly concern agricultural chem. istry are incombustible, and destitute of anything like ol* ganic structure.

By the processes of combustion and decay, organic mat ter is disorganized or converted into inorganic matter, while, on the contrary, by vegetable growth inorganic matter is organized, and becomes organic. 
Organie matters are in general characterzed by com. plexity of constitution, and are exceedingly numerous and various; while inorganic bodies are of simpler compos1tion, and comparatively few in number.

Voudtile and Fixed Matrer.-All plants and animals, taker as a whole, and all of their organs, consist of a volati.e and a fixed part, which may be separated by burning; the former-usually by far the larger share-passing into, and mingling with the air as invisible gases; the latterforming, in general, but from one to five per cent of the whole-remaining as ashes.

Experiment 1.-A splinter of wood heated in the flame of a lamp takes fire, burns, and yields volatile matter, which consumes with flame, nnd ashes, which are the only visible residue of the combustion.

Many organic bodies, products of life, but not essential vital organs, as sugar, eitric acid, etc., are ccropletely volatile when in a state of purity, and leave no ash.

Current Use of the Terms Organic and InorganIC.-It is usual among agricultural writers to confine the term organic to the volatile or destructible portion of vegetable and animal bodies, and to designate their ash-ingredients as inorganic matter. This use of the words is extremely inaccurate. What is found in the ashes of a tree or of a seed, in so far as it was an essential part of the organism, was as truly organic as the volatile portion, and by submitting organic bodies to fire, they may be entirely converted into inorganic matter, the volatile as well as the fixed parts.

Uritimate Elemients tilat Constitute tue Plant.Chemistry has demonstated that the volatile and destructible part of organic bodies is made up chiefly of four sub. stances, viz.: carbon, oxygen, hydrogen, and nitrogen, and contains two other elements in lesser quantity, viz. : sulphur and phosphorus. In the ash we may find phosphorus, sulphur, silicon, chlorine, potassium, sodium, cal. 
cium, magnesium, iron, and manganese, as well as uxygen, carbon, and nitrogen.*

These fourteen bodies are elements, which means in chemical language, that they cannot be resolved into other substances. All the varieties of vegetable and animal matter are componinds,-are composed of and may be re. solved into these elements.

The above fourteen elements buing essential to the organism of every plant and animal, it is of the highest importance to make a minute study of their properties.

\section{§2.}

\section{ELEMENTS OF THE VOlatile ParT OF PLANTS.}

For the sake of convenience we shill first consider the elements which constitute the destructible part of plants, viz. :
Carbon,
Oxygen,
Nitrogen,
- Hyilrogen, Sulphur, Phosphorus.

The elements which belong exclusirely to the ash will be noticed in a subsequent chapter.

Carbon, in the free state, is a solid. We are familiar with it in sereral forms, as limp-black, charcoal, anthracite coal, black-lead, and diamond. Notwithstanding the substances just named present great diversities of appearance and physical characters, they are identical in a certain chemical sense, as by burning they all yield the same product, viz. : carbonic acid gas.

That carbon consitutes a large part of plants is evident from the fact that it remains in a tolerably pure state after the incomplete burning of rooll, as is illustrated in the preparation of charcoal.

* Rarely, or to a slight extent, lithium, rubidium, iodine, bromine, flnorin han um, copper, zinc, and titanium. 
Exp. 2.-If a splinter of dry pir:e wood lie set on fire and the burning end be gradually passed into the mouth of a narrow tube, (see figure 1,) whereby the supply of air is cut off, or if it ve thrust into sand, the burning is incomplete, and a stick of charcoal remains.

Carbonization and charring are terms used to express the blackening of organic bodies by heat, and are due to the separation of carbon in the free or uncombined state.

The presence of carbon in animal matters also is shown by subjecting them to incomplete combustion.

ExP. 3.-Hold a knife-tlade in the flame of a tallow candle; the full access of air is thus prevented, $-\Omega$ portion of carbon escapes combustion, and is deposited ou the blade in the form

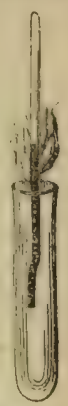

Fig. 1. of lamp-blacte.

Oil of turpentine and petroleum (kerosene,) contain so much carbon that a portion escapes in the fiee state as smoke, when they are set on fire.

When bones are strongly heated in closely covered iron pots, until they cease yielling any vapors, there remains in the vessels a mixture of impure carbon with the earthy matter (phosphate of lime) of the bones, which is largely used in the arts, chicfly for refining sugar, but also in the manufacture of fertilizers under the name of animal chascoal, or bone-black.

Lignite, bituminous coal, colie-the porous, hard, and lustrous mass left when bituminous coal is heated with a limiter access of air, and the metallic appearing gas-carbon that is found lining the iron eylinlers in which illuminating coal-gas is prepared, consist chiefly of carbon. They usually contain more or less incombustible matters, as well as oxygen, hydrogen, and nitrogen.

The different forms of carbon possess a greater or less de. gree of porosity and hardness, according to their origin and the temperature at which they are prepared.

Carloon, in most of its forms, is extremely indestructiblo 
unless exposed to an elevated temperature. Hence stakes and fence posts, if charred before setting in the ground, last longer than when this treatment is neglected.

The porous varieties of carbon, especially wood charcoal and bone-black, have a remarkable power of absorbing gases and coloring matters, which is taken advantage of in the refining of sugar. They also destroy noisome odors, and are therefore used for purposes of disinfection.

Carbon is the characteristic ingredient of all organic compounds. There is no single substance that is the exclusive result of vital organization, no ingredient of the animal or vegetable produced by their growth, that does not contain this element.

oxygen.-Carbon is a solid, and is recognized by our senses of sight and feeling. Oxygen, on the other hand, is invisible, odorless, tasteless, and not distinguishable in any way from ordinary air by the unassisted senses. It is an air or gas.

It exists in the free (uncombined) state in the atmosphere we breathe, but there is no means of obtaining it pure except from some of its compounds. Many metals unite readily with oxygen, forming compounds (oxides) which by heat separate again into their ingredients, and thus furnish the means of procuring pure oxygen. Iron and colper when strongly heated and exposed to the air acquire oxygen, but from the oxides of these metals (forge cinder, copper scale,) it is not possible to separate pure oxygren. If, however, th:o metal mercury (quicksilver) be kept for a long time at a boiling heat, it is slow $y$ converted into a red powder (red precipitate or oxide of mercury), which on being more strongly heated is decomposed, yielding metallic mercury and gaseous oxygen in a pure state.

The substance usually employed as the most convenient source of oxygen gas is a white salt, the chlorate of pot- 
ash. Exposed to heat, this body melts, and presently evolves oxygen in great abundance.

ExP. 4.-The following firure illustrates the apparatus employed for preparing and collecting this gas.

A tube of diflicultly fusible grass, 8 inches lone and $1 / 2$ inch wide, contains the oxide of mercury or chlorate of potash.* To its mouth is connected, air-tight, by a corls, a narrow tulie, the free extremity of which passes under the shelf of a tub nearly filled with water. The shelf has beneath, a saucer-shaped cavity openiug abore by a narrow orifice, orer which a bottle filled with water is inverted. Heat being applied to the

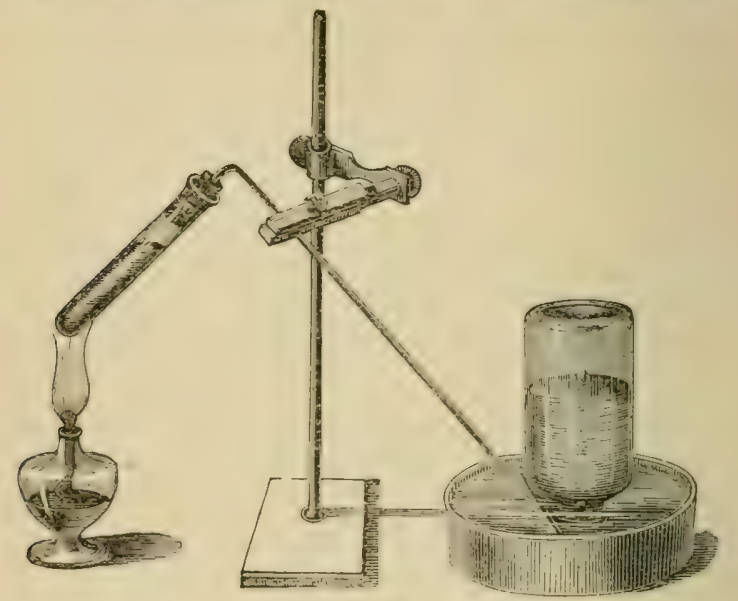

Fig. 2.

wide tube, the common air it contains is first expelled, and presently, oxygen bubbles rapilly into the bottle and displaces the water. When the bottle is full, it may be corked and set asicle, and its place supplied by anofler: Fill four pint bottles with the gats, and set them aside with theil mouths in tumblers of water. From one ounce of chlior.te of potash alsout a gallon of oxyeren gas may be thus obtainer, which is not quite pure at first, but becones nearly so on standing over water for forne hours. When the escape of gats becones slow and camnot be quickened by increased heat, remove the delivery-tube from the water, to prevent the latter receding and brealing the apparatus.

* Thr chlorate of potash is best mixed with about one-quarter its weight of powdered black oxide of manganese, as this facilitates the preparation, and renders the heat of a common spirit lamp suflicitnt. 
As this gas makes no peculiar impressions on the senses, we employ its behavior towards other bodies for its recognition.

ExP. 5.-Flace a burning splinter of wood in a ressel of oxygen (lifted for that purpose, moutb upward, from the water). The flame is at once greatly increased in brilliancy. Now remove the splinter from the bottle, blow out the flame, and thrust the still glowing point into the oxygen. It is instantly relighted. The experiment m:v dae repeated many times. This is the usual test for oxygen gas.

Combustion.-- When the chemical union of two bodies takes place with such energy as to produce visible phenomena of fire or flame, the process is called combustion. Bodies that burn are combustibles, and the gas in which a substance burns is called a supporter of combustion.

Oxygen is the grand supporter of combustion, and all the cases of burning met with in ordinary experience are instances of chemical mion between the oxygen of the atmosphere and some other body or bodies.

The rapidity or intensity of combustion depends upon the quantity of oxygen and of the combustible that unite within a given time. Forcing a stream of air into a fire increases the supply of oxygen and excites a more vigorous combustion, whether it be done by a bellows or re. sult from ordinary draught.

Oxygen exists in our atmosphere to the extent of about one-fifth of the brilk of the latter. When a burning body is brought into unmixed oxygen, its combustion is, of course, more rapid than in ordinary air, four-fifths of which is a gas, presently to be noticed, that is nearly indifferent in its chemical affinities toward most bodies.

In the air a piece of burning charcoal soon gces out; but if plunged into oxygen, it burns with great rapidity and brilliancy.

Exr. 6.-Attach a slender bit of charcoal to one end of a sharpened wire that is passed through a wide cork or card; heat the chrrcoal to redness in the flarue of a lamp, and tlen insert it into a bottle of oxygen, 
fig. 3. When the combustion has declined, a suitable test applied to the air of the bottle will demonstrate that another invisible gas lias taken

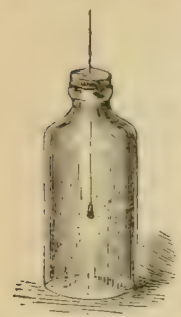

Fig. 3. the place of the oxygen. Such a test is lime-water.* On pouring some of this into the bottle and agitating vigorousiy, the preriously clear liquid becomes milky, and on standing, a white deposit, or precipitate, as the chemist terms it, gathers at the bottom of the ressel. Carbon, by thus uniting to oxygen, yields carbonic acid gas, which in its turn combines with lime, producing carbonate of lime. These substauces will be further noticed in a subsequent chapter.

Metallic iron is incombustible in the atmosphere under ordinary circumstances, but if heated to redness and brought into pure oxygen gas, it burns as readily as wood burns in the air.

ExP. 7.-Provide a thin knittinir neelle, heat one end red hot, and sharpen it by means of a file. Thrust the point thus made into a splinter of wood, (a bit of the stick of a match, $1 / 4$ inch long;) pass the other end of the needle through a wide, flat cork for a support, set the wood on fire, and immerse the needle in a bottle of oxygen, fig. 4. After the wood consumes, the iron itself takes tire and burns with vivid scintillations. It is converted into oxide of iron, a part of which will be found as a yellowish-red conting on the sides of the bottle; the remainder will fuse to black, brittle globules, which falling, often melt quite into the glass.

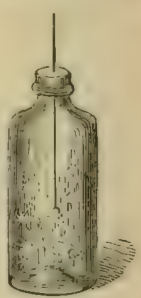

Fig. 4.

The only essential difference between these and ordinary cases of combustion is the intensity with which the process goes on, due to the more rapid access of oxygen to the combustible.

Many bodies unite slowly with oxygen-oxidize, as it is termer, --without these phenomena of light and intense heat which accompany combustion. Thus iron rusts, lear trinishes, word decrys. All these processes are eases of oxirlation, and cannot go on in the ahsence of oxygen.

Since the action of oxygen on wood and other organie

* To prepare lime-water, put a piece of unslaked lime, as larere as a chestnut, into a print of water, and alter it has fillen to powder, agitate the whole for a minute in a wrll stopjererel bottle. On standing, the excess of lime will settle, and the perfectly clear liquid above it is ready for use. 
matters at common temperatures is strictly analogous in a chemical sense to actual burning, Liebig has proposed the term eremacausis, (slow burning), to designate the chemical process which takes place in decay and putrefaction, and which is concerned in many transformations, as in the making of vinegar and the formation of saltpeter.

Oxygen is necessary to organic life. The act of breathing introduces it into the lungs and blood of animals, where it aids the important office of respiration. Animals, and plants as well, speedily perish if deprived of free oxygen, which has therefore been called vital air.

Oxygen his a universal tendency to combine with other substances, and form with them new compounds. With carbon, as we have seen, it forms carbonic acic. With iron, it unites in various proportions, giving origin to several distinct oxides, of which iron-rust is one, and anvilscales another. In decay, putrefiction, fermentation, and respiration, numberless new products are formed, the re. sults of its chemical affinities.

Oxygen is estimated to be the most abundant bolly in nature. In the free state, but mixed with other gases, it constitutes one-fifth of the bulk of the atmosphere. In chemical union with other bodies, it forms eight-ninths of the weight of all the water of the globe, and one-third of its solin crust-its soils and rocks, -as well as of all the plants and animals which exist won it. In fact there are but few compound substances occurring in ordinary experience into which oxygen does not enter as a necessary ingredient.

Nitrogen.-This body is the other chief constituent of the atmosphere, in which its oflice might appear to be mainly that of diluting and tempering the aftinities of oxygen. Indirectly, however, it serves other most important uses, as will presently be seen.

For the preparation of nitrogen we have only to remove the oxygen from a portion of atmospheric air. This mav 


\section{be accomplished more or less perfectly by a variety of} methods. We have just learneil that the process of burning is a chemical union of oxygen with the combustible. If, now, we can find a body which is very combustible and one which at the same time yields by union with oxygen a product that may be readily removed from the air in which it is formed, the preparation of nitrogen from ordinary air becomes easy. Such a body is phosphorus, a substance to be noticed in some detail presently.

Esr. 8. -The bottom of a dinner-plate is corered half an inch deep with water, a bit of chall hollowed out into a little cup is floated on the water by means of a large flat cork or a piece of wood; into this cup a morsel of dry phosphorus as large as a pepper-corn is placed, which is then set on fire and covered by a capacious glass bottle or bell jar. The phosphorus burns at first with a vivid light, which is presently obscured by a cloud of snow-like phosphoric acid. The combustion goes on, however, until nearly all the oxygen is remaved from the included air. The air is at first expanded by the heat of the flame, and a portion of it escapes from the vessel; afterward it diminishes in rolume as its oxygen is removed, so that it is needful to pour

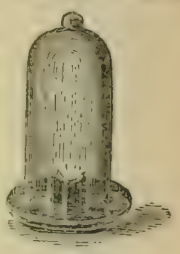

Fig. 5. water on the plite to prevent the external air from passing into the ressel. After some time the white fume will entirely fall, and be absorbed by the water, leaving the inclosed nitrogen quite clear.

Exp. 9. - Another instruetive method of preparing nitrogen is the following: $\Lambda$ h.undful of colperas (sulphate of protoxide of iron) is dissolved in half a pint of water, the solution is put into a quart bottle, a gill of liquid ammonia or fresh potash lye is added, the bottle stoppered, and the mixture vigorously agitited for some minutes; the stopler is then lifted, to allow fresh air to enter, and the whole is arain agitated as before; this is repeated occasionally for half an hour or more, until no further absorption takes place, wheu nearly pure nitrogen remains in the bottle.

Free nitrogen, under ordinary cireumstances, has scarcely any active properties, but is best characterized by its chemical indifference to most other bodies. That it is incapable of supporting combustion is proved by the first method we have instanced for its preparation.

Exr. 10. - 1 burning splinter is immersed in the bottle containing the

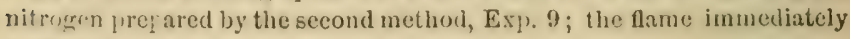
goes out. 
Nitrogen cannot maintain respiration, so that animals perish if confined in it. For this reason it was formerly called Azote (against life). Decay does not proceed in an atmosphere of this gas, and in general it is difficult to effect its direct union with other boclies. At a high temperature, especially in presence of baryta, it unites with carbon, forming cyanogen-a compond existing in Prussian-blue.

The atmosphere is the great store and source of nitrogen in nature. In the mineral kingilom, especially in soils, it occurs in small quantity as an ingredient of saltpeter and ammonia. It is a small but constant constituent of all plants, and in the animal it is a nerer-failing component of the working tissues, the muscles, tendons amil nerves, and is hence an indispensable ingredient of food.

IIydrogen.-Water, which is so abundant in nature, and so essential to organic existence, is a compound of two elements, viz.: oxygren, that has already been considered, and hydrogen, which we now come to notice.

Hydrogen, like oxygen, is a gas, destitute, when pure, of either odor, taste, or color. It does not occur naturally in the free state, except in small quantity in the emanations from boiling springs and volcanoes. Its preparation almost always consists in abstracting oxygen from water by means of agents which have no special affinity for hydrogen, and therefore leave it uncombined.

Sodium, a metal familiar to the chemist, has such an attraction for oxygen that it decomposes water with great rapidity.

Exp. 11.-Hydrogen is therefore readily procured by inverting a bottle full of water in a bowl, and inserting into it a bit of sodium is large as a pea. The sodium must first be wiper free from the naphtha in which it is kept, and then be wripped tirhtly in several folds of patper. On bringing it, thus prepared, under the mouth of the bottle, it floats u!ward, and when the water penetrates the paper, an abundant escape of uras occurs.

Met illic irom and zin" decompose water, uniting with 
oxygen and setting hydrogen free. This action is almost imperceptible, however, with pure water under ordinary circumstances, becatse the metals are soon coated with a film of oxile which prevents further contact. If to the water a strong acid be added, or, in case zinc is used, an alkali, the production of hydrogen goes on very rapidly, because the oxide is dissolved as fast as it forms, and is perfectly pure metallic surface is constantly presenterl to the water.

Exp. 12.-Into a bottle fitted with cork, fumel, and delivery tubes, fig. 6 , an ounce of iron ticks or zinc clippings is introduced, a gill of water is poured upon them, and lastly an ounce of oil of vitriol is added. A brisk effervescence shortly commences, owing to the escape of nearly pure hydrugen uas, which may be collected in a bottle filled with water as directed for oxygren. The first portions that pass over are mixed with air, and should be rejected, as the mixture is dangerously explosive.

One of the most striking properties of free

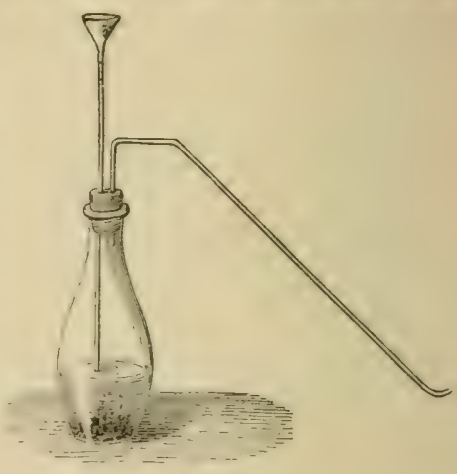

Fig. 6. hydrogen is its levity. It is the lightest body in nature, being fourteen and a half times lighter than common air.

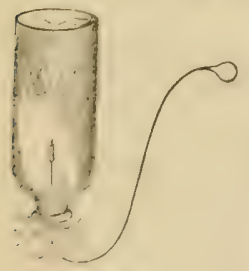

Fig. 7. It is hence used in filling balloons. Another property is its combustibility; it inflames on contact with a lighted taper, and burns with a flame which is intensely hot, though searcely luminous if the gas be pure. Finally, it is itself incapable of supporting the combustion of a taper.

Exp. 13,- - Ill these characters may be shown by the following single experiment. A bottie full of hyilrogen is lifted from the water over which it has been collected, and a taper attached to a bent wire, fig. 7 , is 
brought to its mouth. At first a slight explosion is heard from the sudden burning of a mixture of the gas with air that forms at the moutls of the vessel; then the gas is secn buruing on its lower surface with a pale flame. If now the taper be passed into the bottle it will be extingruished; on lowering it arain, it will be relighted by the burning gras; finally, if the bottle be suddenly turned mouth upwards, the light bydrogen rises in a sheet of flame.

In the above experiment, the hydrogen burns only where it is in contact with atmospheric oxysen; the product of the combustion is an oxide of hydrogen, the universally diffused compound, water. The conditions of the experiment do not permit the collection or identification of this water; its proluction can, however, readily be demonstrated.

Exp. 14. - The arrangement shown in fir. 8 may be employed to exhibit the formation of water by the burning of hydrogen. Hydrogen gas is generited from zinc and dilute acid in the two-necked bottle. Thus produced, it is mingled with vapor of water, to remove which it

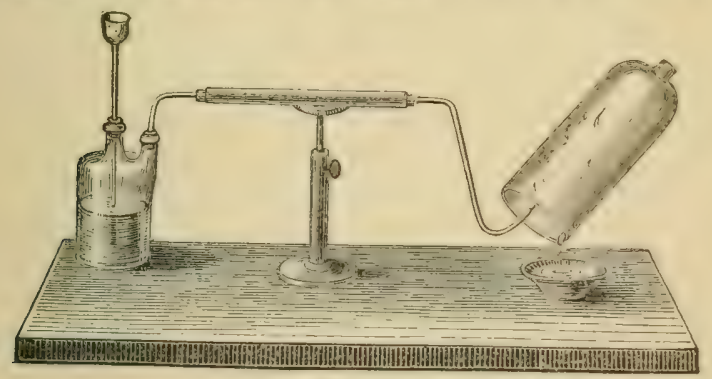

Fig, 8.

is made to stream slowly through in wide tuhe filled with framments of dried chloride of calcium, which desiceates it perfectly. After air hexs been entirely displuteel from the apparatus, the gas is innited at the upcurved end of the narrow tube, and in clean bell-glass is supported over the flame. Water collects at once, as dew, on the interior of the bell, and shortly flows down in drops into a vessel placed beneath.

In the mineral world we scarcely find hydrogen ocenrring in much quantity, sare as water. It is a constant ingredient of plants and animals, and of nearly all the numberless substances which are products of organic life. 
Hydrogen forms with earbon a large number of com. pounds, the most common of which are the volatile oils, like oil of turpentine, oil of lemon, etc. The chief illuminating ingredient of coal-gas (ethylene or olefiant gas,; the coal or rock oils, (kerosene, together with benzine and p:rraffine, aro so-called hydro-carbons.

Sulphur is a well-known solid substance, occurring in commerce either in sticks (brimstone, roll sulphur,) or as a fine powder (flowers of sulphur), having a pale yellow color, and a peculiar odor and taste.

Uncombined sulphur is comparatively rare, the commercial supplies being almost exclusively of volcanic origin; but in one or other form of combination, this element is universally diffused.

Sulphur is combustible. It burns in the air with a pale blue flame, in oxygen gas with a beautiful purple-blue flame, yielding in hoth cases a suffocating and fuming gas of peculiar nauseous taste, which is called sulphurous acid.

ExP. 15.-Heat a bit of sulplumr as large as a grain of wheat on a slip of iron or glass, in the flame of a spirit lamp, for observing its fusion, c smbustion, and the development of sulphurous acid. Furiher, scoop out a little hollow in a piece of chalk, twist a wire around the latter to serve for a hiudle, as in fig. 3 ; heat the challs with a frament of sulphur upon it until the latter ignites, and bring it into a bottle of oxygen gas. The purple flame is shortly obscured by the opaque white futue of the sulphurous acid.

Sulphur forms with oxygen another compound, which, in combination with water, constitutes common sulphuruc acid, or oil of vitriol. This is developed to a slight extent by the action of air on flowers of sulphur, but is pre. pared on a large scale for commerce by a complicated process.

Sulphur unites with most of the metals, yielding compounds known as sulphides or sulphurets. These exist in nature in large quantities, especially the sulphides of iron, copper, and lead, and many of them are valuable ores. 
Sulphides may be formed artificially by heating most of the metals with sulphur.

ExP. 16.-Heat the howl of a tobacco pipe to a low red heat in a stove or furuace; lave iu readiness a thin iron wire or watelx-spring made into a spiral coil; throw in the the sipe-bowl some lumps of sulphur, and when these melt and boil with formation of a red vapor or gas, int roduec the iron coil, previously heated to redness, into the sulphur vapor. The sulphur and iron unite; the iron, in fact, burns in the sulphur gas, giring rise to a black sulphicie of iron, in the same manner as in Exp. 7 it burned in oxygen gas and produced an oxide of iron. The sulplide of iron melts to brittle, round globules, and remains in the pipe-bowl.

With hydrogen, the element we are now considering unites to form a gas that possesses in a high degree the odor of rotten eggss, which is, in fict, the chief cause of the noisomeness of this kind of putridity. This sulbstance, commonly called sutphuretted hydrogen, also sulphydric acid, is dissolved in, and evolved abundantly from, the water of sulphur springs. It may be produced artificially by acting on some metallic sulphiles with dilute sulphurio acid.

FxP. 17.-Place a lump of the sulplide of iron prepared in Exp. 16 in a cup or wine-rlass, add a little water, and listly a few drops of oil of vitriol. Bubbles of sulphuretted bydrogen gas will shortly escape.

In soils, sulphur occurs almost invariably in the form of sulphates, compounds of sulphuric acid with metals, a class of bodies to be hereafter noticed.

In plants, sulphur is always present, though usually in small quantity. The turnip, the onion, mustard, horseradish, and assafœetida, owe their peculiar flavors to volatile oils in which sulphur is an ingredient.

Albumin, gluten and casein,-vegetable principles never absent from plant or animal,-possess also a small content of sulphur. In hair and horn it occurs to the amount of 3 to 5 per cent.

When organic matters are burned with full access of air, their sulphur is oxidized and remains in the ash as Eulphuric acid, or escapes into the air as sulphurous acid.

Phosphorus is an element which has such intense af 
finities for oxygen that it never occurs naturally in the free state, and when prepared by art, is usually obliged to be kept immersed in water to prevent its oxidizing, or eren taking fire. It is known to the chemist in the solid state in two distinct forms. In the more commonly occurring form, it is colorless or yellow, translucent, wax-like in appearance; is intensely poisonous, inflames by moderate friction, and is luminous in the dark, hence its name, derived from two Greek words signifying light-bearer. The other form is brick rel, opaque, far less inflammable, and destitute of poisonous properties. Phosphorus is extensively employed for the manufacture of friction matches. For this purpose yellow phosphorus is chiefly used.

When exposed sufficiently long to the air, or immerliately, on burning, this element unites with oxygen, form. ing a body of the ntmost agricultural importince, viz. . phosphoric acid.

ExP. 18.-Burn a bit of phospluorus under a bottle as in Exp. 8, omitting the water on the plate. The snow-like eloud of phos!horic aeid gathers partly on the sides of the bottle, but mostly on the plate. It attracts moisture when exposed to the air, and bisses when put into water. Dissolve a portion of it in water, and observe that the solution is acid to the taste.

In nature phosphorus is usually found in the form of phosphates, which are compounds of metals with phos. phoric acid.

In plants and animals, it exists for the most part as phosphates of lime, magnesia, potash, and soda.

The bones of animals contain a consilerable proportion (10 per cent) of phosphorus mainly in the form of phosphate of lime. It is from them that the phosphorus employed for matches is largely procured.

Exp. 19.-Burn a picce of bone in a fire antil it becomes white, or nearly so. The bone loses about half its weight. What remains is bone-earth or hone-ash, and of this 90 per cent is phosphate of lime.

Phosphates are readily formed by bringing together so lutions of various metals with solution of phosphoric acid. ExP. 20.-Pour into each of two wine or test glasses a small quantity 
of the solution of phosphoric acid obtained in Exp. 18. To one, add some lime-water (see note p. 36) until a white cloud or precipitate is perceived. This is a phosph ie of lime. Into the other portion, drop solution of alum. A translucent cloud of phosphate of alumina is immediately produced.

In soils and rocks, phosphorus exists in the state of such phosphates of lime, alumina, and iron.

In the organic world tue chemist has as yet detected phosphorus in other states of combination in but a few instances. In the brain and nerves, and in the yolk of eggs, an oil containing phosphorus has been known for some years, and recently similar phosphorized oils have been found in the pea, in maize, and other grains.

We have thus briefly noticed the more important characters of those six bodies which constitute that part of plants, and of animals also, which is volatile or destructible at high temperatures, viz. : carbon, hydrogen, oxygen, nitrogen, sulphur, and phosphorus.

Out of these substances chiefly, which are often termed the organic elements of vegetation, are compounded all the numberless products of life to be met with, either in the vegetable or animal world.

\section{ULTIMATE COMPOSITION OF VEGETABLE MATTER.}

To convey an idea of the relative proportions in which these six elements exist in plants, a statement of the ultimate or elementary percentage composition of several kinds of vegetable matter is here subjoined.

\begin{tabular}{|c|c|c|c|c|c|}
\hline & $\begin{array}{l}\text { Grain of } \\
\text { Wheat. }\end{array}$ & $\begin{array}{l}\text { Strano of } \\
\text { Wheat. }\end{array}$ & $\begin{array}{l}\text { Tubers of } \\
\text { Potato. }\end{array}$ & $\begin{array}{l}\text { Grain of } \\
\text { Peas. }\end{array}$ & $\begin{array}{l}\text { Hay of Red } \\
\text { Clover. }\end{array}$ \\
\hline Carbon.............. & . 46.1 & 48.4 & 44.0 & 46.5 & 47.4 \\
\hline Hydrogen.............. & - 5.8 & 5.3 & 5.8 & 6.2 & 5.0 \\
\hline Oxygen.................. & . 43.4 & 38.9 & 44.7 & 40.0 & 37.8 \\
\hline Nitrogen................. & 2.3 & 0.4 & 1.5 & 4.2 & 2.1 \\
\hline $\begin{array}{l}\Delta \text { sh, including sulphur } \\
\text { aud phosphorus }\end{array}$ & \} 2.4 & 7.0 & 4.0 & 3.1 & 7.7 \\
\hline & $100 . C$ & 100 & 100. & $: 00.0$ & 100.0 \\
\hline alpl & . 0.12 & 0.14 & 0.08 & 0.21 & 0.18 \\
\hline aosphorus... & - 0.30 & 0.80 & 0.34 & 0.34 & 0.20 \\
\hline
\end{tabular}


Our attention may now be directed to the study of sauk compounds of these elements as constitute the basis of plants in gencral; since a knowledge of them will prepare us to consider the remaining elements with a greater degree of interest.

Previous to this, however, we must, first of all, gain a slear idea of that force or energy, in virtue of whose action, chiefly, these elements are held in, or separated from their combinations.

\section{$\S 3$.}

\section{CHEMICAL AFFINITY.}

Chemical attraction or aflinity is the force which unites or combines troo or more substances of unlike character, to a new body different from its ingredients.

Chemical combination differs essentially from mere mixture. Thus we may mix together in a vessel the two gases oxygen and hydrogen, and they will remain uncombined for an indefinite time, occupying their original volume; but if a flame be brought into the mixture they instantly unite with a loud explosion, and in place of the light and bulky gases, we find a ferw drops of water, which is a liquid at ordinary temperatures, and in winter weather becomes solid, which does not sustain combustion like oxygen, nor itself burn as does hydrogen; but is a substance having its own peculiar properties, differing from those of all other bodies with which we are acquainted.

In the atmosphere we have oxygen and nitrogen in a state of mere mixture, each of theso gases exhibiting its own characteristic properties When brought into chemical combination, they are capable of yielding a scries of no less than fve distinct compounds, one of which is the so-called laughing gas, while the others form suffocating and corrosive vapors that are totally irrespirable. 
Chemical decomposition.-Water, thus composed or put together by the exercise of affinity, is easily decom. posed or taken to pieces, so to speak, by forces that oppose affinity-e. g., heat and electricity-or by the greater aftinity of some other body-e. g., solium-as already illustrated in the preparation of hydrogen, Exp. 11.

Definite proportions, - A further distinction between chemical union and mere mixture is, that, while two or more bodies may, in general, be mixed in all proportions, bodies combine chemically in comparatively few proportions, which are fixed and invariable. Oxygen and hydrogen, e. g., are found uniterl in nature, principally in the form of water; and water, if pure, is always composed of exactly one-ninth hydrogen and eight-ninths oxygen by weight, or, since oxygen is sixteen times heavier than hydrogen, bulk for bulk, of one volume or measure of oxygen to two volumes of hydrogen.

Atomic Weight of Elements,-On the hypothesis that chemical union takes place between atoms or indivisible particles of the elements, the numbers expressing the proportions by weight* in which they combine, are appropriately termed atomic weights. These numbers are only relative, and since hydrogen is the element which unites in the smallest proportion by weight, it is assumed as the standard. From the results of a great number of the most exact experiments, chemists have generally agreed upon the atomic weights given in the subjoined table for the elements already mentioned or described.

Symbols.-For convenience in representing chemical changes, the first letter, (or letters,) of the Latin name of the element is employed instead of the name itself, and is termed its symbol.

* Unless otherwise stated, parts or proportions by weight are always to bo anderstood. 
TABLE OF ATOMIC WEIGHTS AND STMBOLS OF ELEMENTH,

Element.

Hydrogen

Carbon

Oxygen

Nitrogen

Sulphur

Phosphorus

Chlorine

Mercury

Potassium

Sodium

Calcium

Iron
At. rot.

1

12

16

14

32

31

35.5

200

39

23

40

56
Symbol.

$\mathrm{H}$

C

$\mathrm{O}$

N

S

$\mathrm{P}$

Cl

Hg (Hydrargyrum)

K (Kalium)

$\mathrm{Na}$ (Natrium)

$\mathrm{Ca}$

Fe (Ferrum)

Nultiple Proportions, - When two or more bodies unite in several proportions, their quantities, when not expressed by the atomic weights, are twice, thrice, four, or more times, these weights; they are multiples of the atomic weights by some simple number. Thus, carbon and oxygen form two commonly occurring compounds, viz., carbonic oxide, consisting of one atom of each ingredient, and carbonic acid, which contains to one atom, or 12 parts by weight, of carbon, two atoms, or 32 parts by weight, of oxygen.

Molecular Weights of Compounds.-While elements unite by indivisible atoms, to form compounds, the compounds themselves combine with each other, or exist as molecrles, $\uparrow$ or aggregations of atoms. It has indeed been customary to speak of atoms of a compound body, but this is an absurdity, for the smallest parlicles of compounds admit of separation into their elements. The term molecule implies capacity for division just as atum excludes that idea.

* Latterly, chemists are mostly inclined to receive as the true atomic weights doulde the numbers that have been commonly employed, hylrogen, chlorine and a few others excepted.

+ Latin diminutive, signifying a little mass. 
The molecular weight of a compound is the sum of the weights of the atoms that compose it. For example, water being composed of 1 atom, or 16 parts by weight, of oxygen, and 2 atoms, or 2 parts by weight, of hydrogen, has the molecular weight of 18 .

The following scheme illustrates the molecular composition of a somewhat complex compound, one of the carbonates of ammonia.

Ammonia gas results from the union of an atom of nitrogen with three atoms of hydrogen. One molecule of ammonia gas unites with a molecule of carbonic acid gas and a molecule of water, to produce a molecule of carbonate of ammonia.

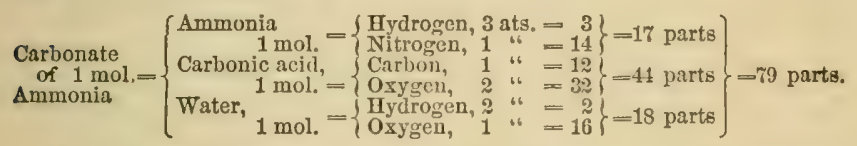

Notation of Compounds.-For the purpose of expressing easily and concisely the composition of compounds, and the chemical changes they undergo, chemists have agreed to make the symbol of an element signify one atom of that element.

Thus $\mathrm{H}$ implies not only the light, combustible gas hydrogen, but one part of it by weight as compared with other elements, and $\mathrm{S}$ suggests, in addition to the idea of the body sulphur, the idea of 32 parts of it by weight. Through this association of the atomic weight with the symbol, the composition of compounds is expressed in the simplest manner hy writing the symbols of its elements one after the other, thus: carbonic oxide is represented by $\mathrm{C} \mathrm{O}$, oxide of mercury by $\mathrm{Hg} \mathrm{O}$, and sulphide of iron by Fe S. $\mathrm{C} \mathrm{O}$ conveys to the chemist not only the fact of the existence of carbonic oxide, but also instructs him that its molecule contains an atom each of carbon and of oxygen, and from his knowledge of the atomic weights he gathers the proportions by weight of the carbon and oxygen in it. s. 
When a compound contains more than one atorn of at element, this is shown by appending a small figure to the symbol of the latter. For example: water consists of two atoms of hydrogen united to one of oxygen, the symbol of water is then $\Pi_{3} O$. In like manner the synacl of carbonic acid is $\mathrm{C} \mathrm{O}_{2}$.

When it is wished to indicate that more than one molso cule of a compound exists in combination or is concerned in a chemical change, this is done by prefixing a large figure to the symbol of the compound. For instance, two molecules of water are expressed by $2 \mathrm{H}_{2} \mathrm{O}$.

The symbol of a compound is usually termed a formula. Subjoined is a table of the formulas of some of the conpounds that have been already described or employed.

FORMULAS OF COMPOUNDS.

Name.

Water

Silphydric acid

Sulphide of iron

Oxide of Mercury

Carbonic acid (anhydrous)

Chloride of calcium

Sulphurous acid (anhydrous)

Sulphuric acid

Phosphoric acid
Formula. Molecular weight.

$\begin{array}{lr}\mathrm{H}_{2} \mathrm{O} & 18 \\ \mathrm{H}_{2} \mathrm{~S} & 34 \\ \mathrm{Fe} \mathrm{S} & 88 \\ \mathrm{Hg} \mathrm{O} & 216 \\ \mathrm{C} \mathrm{O}_{3} & 44 \\ \mathrm{Ca} \mathrm{Cl}_{2} & 111 \\ \mathrm{~S} \mathrm{O}_{2} & 64 \\ \mathrm{~S} \mathrm{O}_{3} & 80 \\ \mathrm{P}_{2} \mathrm{O}_{8} & 142\end{array}$

Empirical and Rational Formulas.-It is obvious that many different formulas can be made for a borly of com. plex character. Thus, the carbonate of ammonia, whose composition has alrealy been stated, (p. 49,) and which contains

$$
\begin{aligned}
& 1 \text { atom of Nitrogen, } \\
& 1 \text { " " Carbon, } \\
& 3 \text { atoms " Oxygen, and } \\
& 5 \text { " " Hydrogen, }
\end{aligned}
$$

may be most compactly expressed ky the symbol

$$
\mathrm{N} \mathrm{C} \mathrm{O}, \mathrm{H}_{6} \text {. }
$$


Such a formula merely informs us what elements anit how many atoms of each element enter into the composition of the substance. It is an empirical formula, being the simplest expression of the facts obt:ined by analysis of the substance.

Rational formulas, on the other haml, are intended ts convey some notion as to the constitution, formation, or modes of decomposition of the body. For example, the fact that carbonate of ammonia results from the union of one molecule each of carbonic acid, water, and ammonia, is expressed by the formula

$$
\mathrm{N} \mathrm{H}_{3}, \mathrm{H}_{2} \mathrm{O}, \mathrm{C} \mathrm{O}_{2} \text {. }
$$

A substance may have as many rational formulas as there are rational modes of viewing its constitution.

Equations of Formulas serve to explain the results of chemical reactions and changes. Thus the breaking up by heat of chlorate of potash into chloride of potassium and oxygen, is expressed by the following statement.

Chlorate of potash.

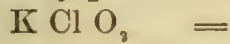

Chloride of potassium.

$\mathrm{K} \mathrm{Cl}$

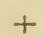

Oxygen.

The sign of equality, $=$, shows that what is written before it supplies, and is resolved into what follows it. The sign + indicates and distinguishes separate compounds.

The employment of this kind of short-hand for exhibit. ing chemical changes will find frequent illustration as we proceed with our subject.

Modes of Stating Composition of Chemical Compounds. -These are two, viz., atomic or moleruler statements and centesimal statements, or proportions in one hundred parts, (per cent, p. c. or ${ }^{\circ} \%_{0}$ ) These modes of expressing com. position are very useful for comparing together different compounds of the same elements, and, while usually the atomic statement answers for substances which are coinparatively simple in their composition, the statement per cent is more useful for complex bodies. The emmposition 
of the two compounds of carbon with oxygen is given be. low according to both methods.

\begin{tabular}{|c|c|c|c|c|c|}
\hline \multicolumn{4}{|c|}{ diomic. Per cent. } & \multicolumn{2}{|c|}{ Atomic. Per cent. } \\
\hline Carlon, (C.) & 12 & 42.86 & (C) & 12 & 27.27 \\
\hline Oxygen, $(0$ ) & 16 & 57.14 & $\left(\mathrm{O}_{2}\right)$ & 32 & 72.73 \\
\hline Carbonic_oxi le, & 28 & 100.00 & & & 100.00 \\
\hline
\end{tabular}

The conversion of one of these statements into the other is a case of sinple rule of three, which is illustrated in the following calculation of the centesimal compositior of water from its atomic formula.

Water, $\mathrm{H}_{2} \mathrm{O}$, has the molecular weight 18 , i. e., it consists of two atoms of hydrogen, or two parts, and one atom of oxygen, or sixteen parts by weight.

The arithmetical proportions subjoined serve for the calculation, riz.:

\begin{tabular}{|c|c|c|c|c|c|}
\hline $\mathrm{H}_{2} \mathrm{O}$ & Water & & H & & Hydrogen \\
\hline & 100 & $::$ & 2 & : & per cent sought $(-11.11+)$ \\
\hline $\mathrm{H}_{2} \mathrm{O}$ & Water & & 0 & & Oxygen \\
\hline 18 & 100 & 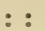 & 16 & : & per cent sought $(-88.88+)$ \\
\hline
\end{tabular}

By multiplying together the second and third terms of these proportions, and dividing by the first, we obtain the required per cent, viz., of bydrogen, 11.11; and of oxygen, 88.88 .

The reader must bear well in mind that chemical affinity manifests itself with very different degrees of intensity between different borlies, and is variously modified, excited, or annulled, by other natural agencies and forces.

\section{$\S 4$.}

VEgETABLE ORgaNiC COMPOUNDS OR PROXIMATE ELEMENTS.

We are now prepared to enter upon the study of the organic compounds, which constitute the vegetable structure, and which are produced from the elements carbon, oxygen, hydrogen, nitrogen, sulphur, and phosphorus, by the united agency of chemical and vital forces. The num. ber of distinet substances found in plants is practically unlimited. There are already well known to chemists hundreds of oils, acids, bitter principles, resins, coloring matters, ef c. Almost every plant contains some organic bodv 
peculiar to itself, and usually the same plant in its different parts reveals to the senses of taste and smell the presence of several indivilual substances. In tea and coffee occurs an intensely bitter "active principle," thein. From toluacco an oily liquid of eminently narcotic and poisonous properties, nicotin, can be extracted. In the orange are found no less than three oils; one in the leaves, one in the flow. ers, and a third in the rind of the fruit.

Notwithstanding the great number of bodies thus occuring in the regetable kingdom, it is a fer which form the bulk of all plants, and especially of those which have an agricultural importance as sources of food to man and animals. These substances, into which any plant may be resolved by simple, mostly mechanical means, are conveniently termeil proximate elements, and we shall notice them in some de. tail under six principal groups, viz:

1. W ATER.

2. The Cerlulose Group or Asryloids-Cellulose, (Wood,) Starch, the Sugars and Gums.

3. The Pectose Group-the Pulp and Jellies of Fruits and certain Roots.

4. 'The Vegetable Acids.

5. The Fats and Ons.

6. The Albuminom or Protein Bodies.

1. Water, $\mathrm{H}_{2} \mathrm{O}$, as already stated, is the most abundant ingredient of plants. It is itself a compound of oxygen and hydrogen, having the following centesimal composition:

$$
\begin{array}{ll}
\text { Oxygen, } & 88.88 \\
\text { Hydrogen, } & 11.11 \\
\hline 100.00
\end{array}
$$

It exists in all parts of the plant, is the immediate cause of the succulence of the tender parts, and is essential to the life of the vegetable organs.

In the following table are given the percentages of water in some of the more common agricultural products in the fresh state, but the pro 
portions are not quite constant, even in the same part of different specimens of any given plant.

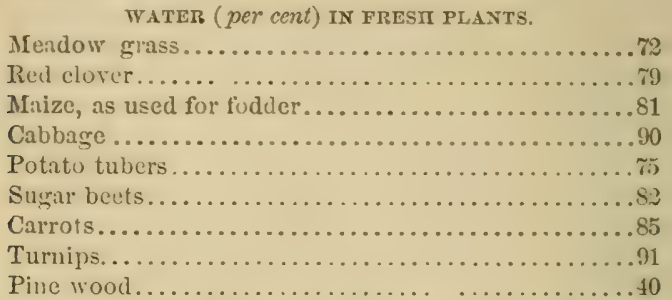

In living plants, water is usually perceptible to the eye or feel, as sap. But it is not only fresh plants that contain water. When grass is made into hay, the water is by no means all dried out, but a consi.lerable proportion remains in the pores, which is not recognizable by the senses. So, too, seasoned wood, flour, and starch, when seemingly dry, contain a quantity of invisible water, which can be removed by heat.

Exr. 21.-Into a wille glass tube, like that shown in fig. 2, place a spoonful of saw-lust, orstarch, or a little hay. Warm orer a limip, but rery slowly and cautiously, so as not to burn or blaclien the substance. Water will be expelled from the orranic matter, and will collect on the cold part of the tube.

It is thus obvious that vegetable substances may contain water in troo different comditions. Red clover, for example, when growing or freshly cut, contains about 79 per cent of water. When the clover is dried, as for making hay, the greater share of this water eseapes, so that the air-dry plant contains but about 17 per cent. On subjecting the air-dry clover to a temperature of $212^{\circ}$

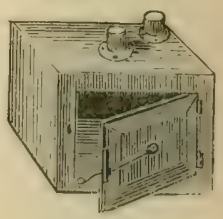

Fig. 9. for some hour, the water is completely expelled, and the substance becomes really dry.

To drive off all water from veretable matters, the chemist usually employs it wuter-bulle, firg. 9, consisting of a vessel of tin or copper plate, with double wall, between which is a spaec that maly bearly filled with water. The substance to be dried is placed in the interior chamber, 
the door is closed, and the water is lrought to boil by the lieat of a lamp or stove. The precise quantity of watel belonginer to, or contained in, a substance, is ascertained hy first weighing the substince, then drying it until its weight is constant. The loss is water.

In the subjoined table are given the arerage quantities, per cent, of water existing in various vegetable products when air-dry.

WATER IN AIR-DRY PLANTS.

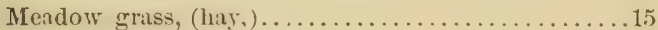

Red clover hay .............................

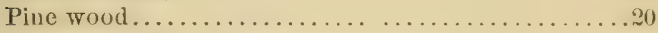

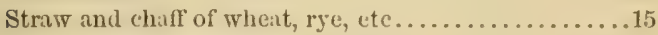

Bean straw . . . . . . . . . . . . . . . . . . . .

Wheat, (rye, oat, kernel..................... 1t

Maize kernel. .........................

That portion of the water which the fresh plant loses by mere exposure to the air is chiefly the mater of its juices or sap, and is manifest to the sight and feel as a liquid, in crushing the fresh plant; it is, properly speaking, the fiee water of vegetation. The water which remains in the airdry plant is imperceptible to the senses while in the plant, - can only be discovered on cxpelling it by heat or otherwise,-and may be designated as the hyy.oscopic water of vegetation.

The amount of water containel in either fresh or airdry vegetable matter is constantly fluctuating with the temperature and the dryness of the atmosphere.

2. Time Cellulose Group, ur time Amiroins.

This group comprises ('ellulose, Strerch, Inulin, Dextrin, Gum, Cane sugur, Finit sigar, and $G$ irane sugar:

These bodies, especially cellulose and starch, form by far the larger s'iare-perhaps seven-eighths-of all the dry matter of vegetation, and most of them are distributed throughout all parts of plants.

Cellulose, $\mathrm{C}_{12} \mathrm{H}_{20} \mathrm{O}_{10^{\circ}}$-Every agricultural plant is an agirregate of microscopic cells, i. c., is malle up of minute sacks or closed tubes, adhering to each other. 
Fig. 10 represents an extremely thin slice from the stem of a cabbage, magnified 230 di:meters. The united wills of two eells are seen in section at $a$, while at $b$ an empty space is noticecl.

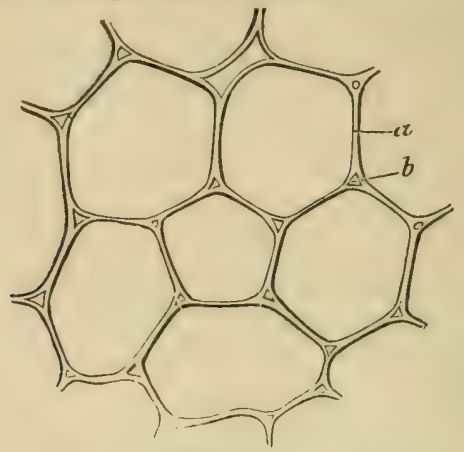

Fig. 10.

The outer coating, or wall, of the cell is cellulose. This substanee is accordingly the skeleton or framework of the

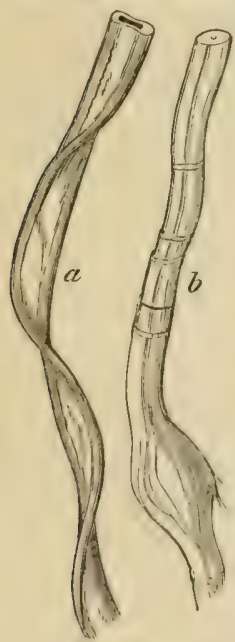

Figr. 11. plant, and the material that gives toughness and solidity to its parts. Next to water it is the most abundant body in the vegetable world.

All plants and all parts of all plants contain cellulose, but it is relatively most abundant in their stems and leaves. In seeds it forms a large portion of the husk, shell, or other outer coating, but in the interior of the seed it exists in small quantity.

The fibers of cotton, (Fig. 11, $a$, ) hemp, and flax, (Fig. 11,b,) and white eloth and unsized paper made from these materials, are nearly pure cellulose.

The fibers of cotton, hemp, and 1lax, are simply long and thick-walled cells, the appearance of which, when himhly magnified, is shown in fig. 11, where a represents the thinner, more soft, and collapsed cotton fiber, and $b$ the thicker and more durable fiber of linen. 
Wood, or woody fiber, consists of long and slender cells of various forms and dimensions, see p. 271,) which are deixcate when young, (in the sap wood,) but as they become older fill up interiorly lyy the deposition of repeated layers of cellulose, which is intergrown with a substance, (or substances,) called lignin.* The hard shells of nuts and stone fruits contain a basis of cellulose, which is impregnated with ligneous matter.

When quite pure, cellulose is a white, often silky or spongy, and translucent boly, its appearance varying somewhat according to the source whence it is obtained. In the air-dry state, it usually contains about $10^{\circ} \%_{0}$ of hygroscopic water. It has, in common with animal membranes, the character of swelling up when immersed in water, from imbibing this liquid; on drying again, it shrinks in bulk. It is tough and elastic.

Cellulose differs remarkably from the other bodies of this group, in the fact of its slight solubility in dilute acids and alkalies. It is likewise insoluble in water, alcohol, ether, the oils, and in most ordinary solvents. It is hence prepared in a state of purity by acting upon vegetable matters containing it with successive solvents, until all other matters are removed.

The "skeletonized" leaves, fruit vessels, ctc., which compose those beautiful objects called phantom bouquets, are commonly made by dissolving away the softer portions of fresh succulent jlants by a hot solu.

* According to F. Schuize, lignin impregnates, (not simply incrusts, the cell-wall, it is soluble in hot alkaline solutions, and is readily oxidized by nitrie acid. Schulze ascribes to it the composition

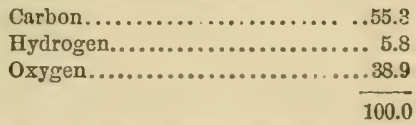

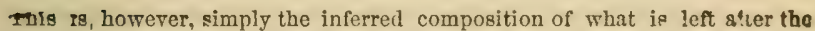
cellalose, etc., have been removed. Lignin cannot be separated in tse pure state, and has never been analyzed. What is thus designatec is probably a mix. ture of several distinct snbstrnces.

Lignin appears to be indigestible by herbivorous animale, (Grouven, V. Eof msister.) 
tion of caustic soda, and afterwards whitening the skeleton of floers that remains by me:ms of chloride of lime, (bleaching powder.) They are almost pure cellulose.

Slieletons may also be prepared by steepiner regetuble matters in a mix. ture of chlorate of pot:ss and dilute nitric acid for a number of days.

Exp. 22.-TC 500 culic centimeters, * (or one pint,) of nitric acid of density 1.1, ad 130 grams, (or one ounce,) of pulverized ehlorate of pol ash, and dissolve the latter by aritation. Suspend in this mixture a number of leaves, ete., tand let them remain undisturbed, at a teuperat ure not above $65^{\circ} \mathrm{F}$., until they are perfectly whitened, which may require from 10 to 20 days. The frreparations of leaves slunld be floated out from the solutions on slips of paper, washed :opinusly in clear water, and dried under pressure between folds of unsized pitper.

The fibers of the whiter and softer kinds of wood are now much $\mathrm{cm}$. ployed in the faturication of pilper. For this pu: pose the wood is rasped to a coarse powder by machinery, then freed from lignin, stareh, etc., by a hot solution of soda, and finally hleached with chloride of lime.

The huskis of maze have been suecesslully employed in Austria, bott for making paper and an inferior cordage.

Though cellulose is insoluble in, or but slightly affected by dilute acids and alkalies, it is dissolved or altered by these agents, when they are concentrated or hot. The result of the action of strong auils and alkalies is very various, according to their kind and the rlegree of strength in which they are employed.

The stronest nitric acid transforms cellulo=e into nitrocellulose, (pyroxfline, gun cotton, ) a body which bums explosively, and has been employed as a substitute for gunpowder.

Sulphuric acid of a certain strength, hy short contact with cellulose, con. verts it a tough, translucent substance which strongry resembles blidder or similar animal membranes. Paper, thus treated, becomes the vegetable parchment of commerce.

- On subsequent pages we shall make frequent use of some of the French decImal weights and measures, for the reasons that they are much more convenient than the English ones, and are now almost exclusively employed in all scientific trestises and investigations. For small weights, the gram, abbreviated gm., (equal to $15 \frac{1}{2}$ crains, nearly), is the customary unit. The unit of measure by vo:ame is the cubic centimeter, abbreviated c. c., (30 c. c. equal one fluid ounce nearly). Gram weights and ylass measures graduated into cubic centimeters are Purnished by all dealers in chemical apparatus.

+ Full-erown but not old lenves of the clm, maple, anil maize, heads of anripe urain, slices of the stem and joints of maize, etc., may be employed to furnish skeletons that will prove valuable in the study of the structure of these organe. 
Exr. 23.-To prepire parchment fnper, fill a large cylindrical test tube first to the depth of an inch or so with water, then pour in three times this bulk of oil of vitriol, and mix. When the liquid is perfectly cool, immerse into it a strip of unsized paper, and let it remain for about $15 \mathrm{sec}$ onds; then remove, and rinse it copiously in water. Lastly, so:k for some minutes in water, to which a little ammonia is added, and wash again with pure water. These washines are for the purpose of removing the acid. The suecess of this experiment depends upon the proper strength of the acid, and the time of immersion. If need be, repeat, varying these conditions slightly, until the result is obtained.

Prolonged contact with strong sulphuric acid converts cellulose into dextrin, anil finally into sugar, (sce p. 7..) Other intermediate products are, however, formed, whose nature is little understood; but the properties of one of them is employed as a test for cellulose.

ExP. 24.-Spread a slip of unsized paper uplon a clina plite, and pour upon it a few drops of the diluted sulphuric ncid of Exp. 23 . After some time the paper is seen to swell up and partiy dissolve. Now flow it witls a weak solution of iodine, * when these dissolved portions will assume a fire and inteuse blue rolor. This deportment is charieteristic of cellulose, and may be employed for its recognition under the microseope. If the experiment be repeated, using a larger proportion of acid, and allowing the action to continue for a consideribly longer time, the substance producing the blue color is itself destroyed or conrerted into sugar, aud addition of iodine has no effect.t

Boiling for some hours with dilute sulphurie acir also transforms cellulose into sugar, and, under certain circumstances, chlorhydric acid and alkalies have the same effect upon it.

The denser and more impure forms of cellulose, as they occur in wo dd and straw, are slowly acted upon by chemical agent:, and are not easily digestible by most animals; but the cellulose of young and succulent stems, leaves, and fruits, is digestille to a large extent, especially in the stomachs of animals which naturally feed on herbage, ard therefore cellulose ranks among the nutritive substances.

- Dissolve a frarment of iodine as large as a whear kernel in 20 c. c. of alcohol, add $100 \mathrm{c}$. c. of water to the solution, and prescrve in a well stopperel bottle.

+ According to Grouven, cellulose prepared from rye straw, (and impure ?) requires several hours' action of sulphtic acid before it will strike a blue color with iodine, (2ter Salzminder Bericht, $=46 \%$ ) 
Chemical composition of cellulose.-This body is a com. pound of the three elements, carbon, oxygen, and hydrogen. Analyses of it, as prepared from a multitude of sources, demonstrate that its composition is expressed by the formula, $\mathrm{C}_{12} \mathrm{H}_{20} \mathrm{O}_{10}$. In 100 parts it contains

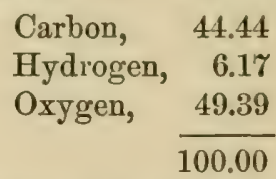

Mrodes of estimating cellulose.-In statements of the composition of plants, the terms fiber, woody fiber, and crucle cellulose, are often met with. These are applied to more or less impure cellulose, which is obtained as a residue after removing other matters, as far as possible, by alternate treatment with dilute acids and allialies, but without acting to any ureat extent on the cellulose itself. The methods formerly employed, and those by which most of our analyses have been mide, are coufessecly imperfect. If the solrents are too concentrated, or the temperature at which they act is too high, cellulose itself is dissolred; while with toc dilute reagents a portion of other matters remains unattacked. Tho method adopted by Henneherg, (Versuchs Stationen, VI, 497,) with quite good results, is as follows: 3 grams of the finely divided substince are boiled for half an hour with 200 cubic centimeters of dilute sulphuric acid, (containing $1 \frac{1}{4}$ per cent of oil of vitriol,) and after the substanco has settled, the acid liquid is poured off. The residue is boiled again for balf an hour with $200 \mathrm{c}$. c. of water, and this operation is repented a second time. The residual substance is now boiled half an hour with 200 c. c. of dilute potash lye, (containing $1 \frac{1}{1}$ per cent of dry calustic protash,) and after removing the alkaline liquid, it is bolled twice with water as before. What remains is brought upon a filter, and washed with water, then with alcohol, and, lastly, with ether, as lonir as these solvents talie up anything. This crude cellulose contains ash and nitrogen, for which corrections must be made. The nitrogen is ass:-med to belon to some albuminoid, and from its guantity the anount of the latter is calculated, (see p. 108.)

Even with these errections, the quantity of cellulose is not obtained with entire aceuracy, as is usually indicated by its apperance and its composition. While, aceording to V. IIfmeister, the crude cellulose thus prepared from the pea is perfectly white, that from wheat bran is brown, and that from rape-cake is almost black in color.

Grouven gives the folkowing analyses of two s:mples of erude cellulose obtained by a method essentially the same as we have deEcribed. (2te Salzmünater Bericht, p. 456.) 
Rye-strano fiber.

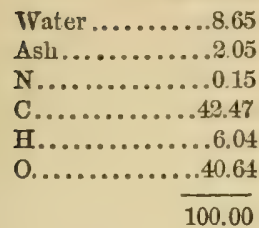

Linen fiber.

5.40

1.14

0.26

38.36

5.89

48.95

100.00

On deducting water and ash, and maling proper correction fos the nitro-en, the above samples, together with one of wheat-stra's fiber, analyzed by Henneberg, exhibit the followiner composition, compared with pure cellulose.

Rye-straw fiber. Linen fiber. Theat-stran fiber. Pure cellulose.

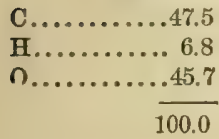

$\begin{array}{r}41.0 \\ 6.4 \\ 52.6 \\ \hline 100.0\end{array}$

$\begin{array}{r}45.4 \\ 6.3 \\ 48.3 \\ \hline 100.0\end{array}$

44.4

6.2

49.4

100.0

Franz Schulze, of Rostock, proposed in 1857 another methoul for estimuting cellulose, which bas recently, $(1866$, ) been shown to be more co:rect tlıan the one already described. Kühn, Aronstein, and H. Schulze, (Henneberg's Journal für Landwirthschaft, 1866, pp. 289 to 297, ) have applied this method in the following manner: One part of the dry pulverized substance, (2 to 4 grams, ) which has been previously extracted with water, alcohol, and ether, is pliced in a glass-stoppered bottle, with 0.8 part of chlorite of potash and 12 parts of nitric acid of specific grarity 1.10, and digested at a temperature not exceeding $65^{\circ} \mathrm{F}$. for 14 days. At the expiration of this time, the contents of the bottle are mixed with some water, brought upon a filter, and washed, firstly, with cold and afterwards, with hot water. When all the acid and soluble matters have been washed out, the contents of the filter are emptied into a beaker, and heated to $165^{\circ} \mathrm{F}$. for about 45 minutes with weak ammonia, (1 part commercial ammonia to 50 parts of water); the substance is then brought upon a weighed filter, and washed, first, with dilute ammonia, as long as this passes off colored, then with cold and hot water, then with alcohol, and, flnally, with ether. The substance remaining contains a small quautity of ash and nitrogen, for which corrections must he made. The fiber is, however, purer than that procured by the other method, and a somewbat larger quantity, (1/2 to $1, \frac{1}{2}$ per cent,) is obtained. The results appear to vary but about one per cent from the truth.

The arerage proportions of cellulose found in vario's vegetahlo vatters in the usual or air-dry state, are as follows: 
AMOUNT OF CELLULOSE IN PLANTS.

Per cent.

Fer cent.

Potato tuber.......... 1.1 Red clover plant in flower...10

Whent kernel........... 3.0

Wheat meal............ 0.7

Maize krmel...........5.5

Barley " $\quad \ldots . . . . . .8 .8 .0$

Oat " $\quad \ldots \ldots \ldots \ldots . . .10 .3$

Buckwheat kernel.......15.0

Red clover plint in flower...10

Timothy " ...........23

Maize cobs................38

Oat straw...............40

Wheat " ...............48

Rye " $\quad . . . . . . . . . . . . .54$

Starch, $\mathrm{C}_{12} \mathrm{H}_{20} \mathrm{O}_{10^{\circ}}$ - The cells of the seeds of wheat, corn, and all other grains, and the tubers of the potato, contain this fumiliar body in great abundance. It occurs also in the wood of all forest trees, especially in autumn and winter. It accumulates in extraordinary quantity in the pith of some plants, as in the Sago-palm, (INetroxylon Rumphii,) of the Malay Islands, a single tree of which may yield $800 \mathrm{lbs}$.

Starch occurs in greater or less quantity in every plant that has been examined for it.

The preparation of starch from the potato is very simple. The potato contains, on the average, $\gamma 6$ per cent water, 20 per cent starch, and 1 per cent of cellulose, while the remaining 3 per cent consists mostly of matters which are easily soluble in water. By grating, the potatoes are reduced to a pulp; the cells are thus broken and the starehgrains set at liberty. The pulp is then agitated on a fine sieve, in a stream of water. The washings run off milky, from suspended starch, while the cellulose is retained by the sieve. The milky fluid is allowed to rest in rats until the starch is deposited. It is then poured off, and the atarch is collected and dried.

Wheat-starch is eommonly made by allowing wheaten flour mixed with water to ferment for several weeks. By this process the gluten, etc., are converted into soluble matters, which are removed by washing, from the unalterEd starch.

Starch is now largely manufactured from milize. A 
dilute solution of caustic soda is nser to dissolve the albuminoids, see 1). 95. The starch and bran remaining, are separatel by diffusing both in water, when the bran rapidly settles, and the water being run off at the proper time, deposits the pure starch, corn-starch of commerce, also known as maizena.

Starch is prepared by similar methods from rice, horsechestnuts, and various other plants.

Arrovoroot is starch obtained by grating and washing the root-sprouts of Marantu Indira, and M. arundinacea, plants native to the West Indies.

ExP. 25.-Reduce a clean potato to pulp by means of a tin grater. Tie up the pulp in a piece of not too fine muslin, and squeeze it repentedly in a quart or more of water. The starch grains thus pass the meshes of the cloth, while the cellulose is retained. Let the liquid stand until the starch settles, pour off the water, and dry the residue.

Starch, as usually seen, is a white powder which consists of minute, rounded grains, and hence has a slightly harsh feel. When observed under a powerful magnifier, these grains often present characteristie forms and dimensions.

In potato-starch they are eger or kidney-shaped, and are

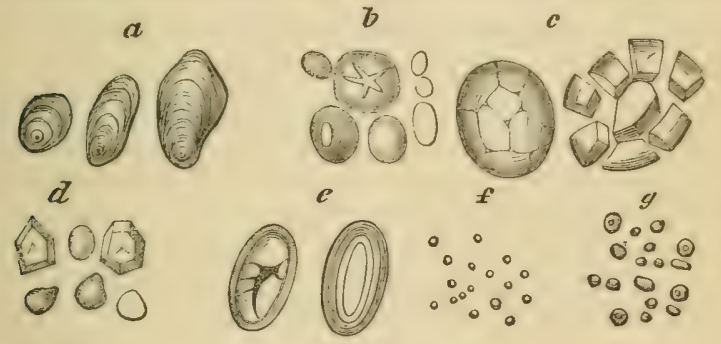

Fì.. 12.

distinctly marked with curved lines or ridges, which surround a point or eye; $a$, fig. 12 . Wheat-starch consists of grains shaped like a thick burning-gliss, or spectacle-lens, having a cavity in the centre, $b$. Oit-stareh is made up of compound grains, which are easily crushed into smaller 
granules, $c$. In maize and rice the grains are usually so densely packed in the cells as to present an angular (sixsided) outline, as in $d$. The starch of the bean and pea has the appearance of $e$. The minute starch-grains of the parsnip are represented at $f$, and those of the beet at $g$.

The grains of potato-starch are among the largest, being often 1-300th of an inch in diameter; wheat-starch grains are about 1-1000th of an inch; those of rice, 1-3000th of an inch, while those of the beet-root are still smaller.

Unorganized Sturch exists as a jelly in several plints, according to Schleiden, (Botanik p. 12\%). Dragendorff asserts, that in the seeds of colza and mustard the starch does not ocewr in the form of grains, but in an unorganized state, which he consiclers to be the same as that noticed by Schleiden.

The starch-grains are unacted upon by cold water, unless broken, (see Exp. 26,) and quickly settle from suspension in it.

When starch is triturated for a long time with cold water, whereby the grains are broken, the liquid, after fillering or standing until perfectly clear, contains starch in extremely minute quintity.

Then starch is heated to near builing with 1: to 15 times its weight of water, the grains swell and burst, or exfuliate, the water is absorbed, and the whole forms a jelly. This is the starch-paste used by the latudress for stiffening muslin. The stirch is but very slightly dissolved by this treatment; see Exp. 27. On freezing, it separates almost perfectly.

When starch-paste is dried, it forms a hard, horn-lilie mass.

Teprixa and Sigo are starch, which, from being heated while still moist, is partially converted into stareh-paste, and, on dryiug, acyuires a more or less translueent aspect. Tapioea is obtained from the roots of the Menilent, a plant which is cultivated in the West Indies aud Sonth Americ: Citsiate is a prepuration of the same starch, roasted. Sago is made in the: islands of the East Indian Archipelago, from the pith of palms. It is gramulated by forcinis the paste through metallic sieves. Both tapioea and sago are now imitated from potato starch.

Test for Sturch.-The chemist is enabled to recognize starch with the erreatest case and certainty by its peculiar deportment towards indine, which, when dissolved in watter or alcrhol and brought in contact with starch, gives it a beautiful purple or blue color. This test may be used even in microscopic observations with the utmost ficility. 
Exp. 26.- Shake together in a test tube, 30 c. c. of water and starch of the bulk of a kernel of maize. Add solution of iodine, drop hy drop, agitating until a fiint purplish eolor appears. Pour off half the liquid into another test tube, and add at onee to it one-fourth its bulk of iodine solution. The latter portion becomes intensely blue by transmitted, or almost black by reflected light. On standing, observe that in the first case, where starch preponderates, it settles to the bottom learing a colorless liquid, which shows the insolubility of starch in cold witer; the starch itself has a furple or red tint. In the case iodine wis used in excess, the deposited starch is blue-black.

Exp. 27.-Place a bit of starch as larre as a grain of whent in $30 \mathrm{c}$. c. of cold water and heat to boiling. The stareh is converted into thin, translueent paste. That a portion is dissolved is shown by filtering turougls paper and adcing to one-half of the filtrate a few clrops of iodine solution, when a perfectly clear blue liquid is obtained. The delic:acy of the reaction is shown by adding to 30 c. c. of water a little solution of iocline, and noting that $\alpha f^{\prime}\left(x^{\prime}\right.$ drops of the solution of starch suffice to make the large mass of liquid pereeptibly blue.

By the prolonged action of dry heat, hot water, acill, or alkalies, starch is converter first into dextrin, and finally into sugar (glucose), as will be presently noticed.

The same transformations are accomplishel by the action of living yeast, and of the so-callerl diastase of germinating seeds; see p. 328.

The saliva of man and plant-eating animals usually likewise dissolves starch at bloor heat by ennrerting it into sugar. It is much more promptly converted into sugar by the liquids of the large intestine. It is thus digesterl when eaten by animals. It is, in fact, one of the most important ingredients of the food of man and domestic animals.

The action of saliva demoustrates that starch-grains are not homogencous, but contain a small proportion of matter not readily soluble in this liquid. This remains as a delicate skeleton after the grains are otherwise dissolved. It is probubly cellulose.

The chemical composition of starch is identical with that of cellulose; see p. 60.

Air-dry starch always contains a considerable amount of hygroscopic water, which usually ringes from 12 to 20 per cent. 
Next to water and cellulose, starch is the most abundant ingredient of agricultural plants.

In the sulioined table are given the proportions contained in certain reretable products, as determined by Dr. Drayendorff. The quantities are, however, somewhat variable. Since the flgures below mostly refer to air-dry substances, the proportions of hywruscopic water are aleo giren, the quantity of which being changeable must be taken into ac count in making any strict comparisons.

AMOUNT OF STARCH IN PLANTS.

\begin{tabular}{|c|c|c|}
\hline & Water. & Stareh. \\
\hline & Per cent. & Per cent. \\
\hline Whent................. & 13.2 & 59.5 \\
\hline Whent flour........... & 15.8 & 68.7 \\
\hline Rye................ & 11.0 & 59.7 \\
\hline 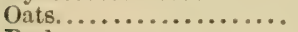 & 11.9 & 46.6 \\
\hline Barley................. & 11.5 & 57.5 \\
\hline Timothy seed.......... & 12.6 & 45.0 \\
\hline Rice (bulled)........... & 13.3 & 61.7 \\
\hline Peas.................. & 5.0 & 37.3 \\
\hline Beans (white)........... & 16.7 & 83.0 \\
\hline Clover seed.............. & 10.8 & 10.8 \\
\hline Flarseed................ & 7.6 & 23.4 \\
\hline Mustard seed............ & 8.5 & 9.9 \\
\hline Colza seed............. & 5.8 & 8.6 \\
\hline Teitow turnips *........ & substance & 9.8 \\
\hline Potatucs................ & y substance & 62.5 \\
\hline
\end{tabular}

Starch is quantitalively estimated by rarious methods.

1. In casc of potatoes or cereal grains, it may be determined rough $y$ oy direct mechanical separation. For this purpose 5 to 20 crams of the bubstance are reduced to fine division by grating (potatoes) or by soften. «ng in warm water, and crushing in a mortar (gritins). The pulp thus obtained is washed either upon a fine hair-siere or in a bay of muslin, until the water ruus off clear. The starch is allowed to settle, dried, and weighed. The value of this method depends upon the care employed in the operations. The amount of starch falls out too low, because it is impossible to break open all the minute cells of the substance analyzed.

2. In many cases starch maly be estimated with more precision by conrersion into sugar; see p. 76.

3. Dr. Dragenciorff, of the Rostock Lahoratory, proceeds with starch doterminations as folluws: The pulverized substance, after drying out all hy rroscopic moisture at $212^{\circ}$, is dicrested for 18 to 30 hours, at a temperiture of $212^{\circ}$, in 10 to 12 times its weight of a solution of 5 to 6 parts of hydrate of potisin in 9.1 to 95 parts of anhydrous alcoliol. The digestion must take place in senled glass tubes, or in a vilver res-al which admits of closing perfectly. By this treatment the

\footnotetext{
* A swect an 1 mealy turnip grown on light soils for table use.
} 
albuminoid substances, the fats, the sugrur, and dextrin, are brought into such a condition that simple washing with alcohol or water suffices to remove them completely. The chief part of the phosphoric and silicic acids is likewise rendered soluble. The starch-graing are not affected, neither does the cellulose undergo alteration, eith qualitatively or quantitatively. In fact, this treatment serves excellently to isolate sturch-grains for microscopic investigations. Besides starel? and cellulose nothing resists the action of alcoholic potash sare portion: of cuticle, yum, and some earthy salts.

When the digestion is finished, it is advisable, especially in case the substance is rich in fat, to bringr the conten's of the tube upon a filter while still hot, as otherwise potash-salts of the fitty acids may crystallize out. It is also well to wash immediately, first, with hot absolute alcolıol, then, with cold alcoliol of ordinary strength, and finally, with cold water until these several solvents remove nothing more. In the analysis of matters which contain much mucilage, as flixseed, the washing must be completed with alcolol of 8 to 10 per cent, to prevent the swelling up of the residue.

The filter should be of good ordinary (not Swedi-h) paper, should be washed with chlorhydric acid and water, dried it $212^{\circ}$, and weinhed. When the substance is completely washed, the filter and its contents are dried, first at $120^{\circ}$, and finally at $212^{\circ}$. The loss cousists of albuminoids, fat, sugar, and a part of the salts of the substance, and when the list three are separately estimated, it may serve to control the estimation, by elementary analysis, of the albuminoids.

The filter, with its eomtents, is now redueed to powder or slireds, and the whole is liented with water containing 5 per cent of chlorlyblric acid until a (lrop of the liquid no longer reacts blue with iodine. The treatment with potash leaves the stareh-grains in such a state of purity from incrusting matters, that their conversion into dextrin proceeds with wreat promptness, and is accomplished before the cellulose begins to be pereeptibly acted upon. By weighing the residue that remains from the action of chlorbydric acid, after washing and drying, the amount of cellulose, cork, lignin, gum, and insoluble fixed matters is found. By subtracting these from the weisht of the substance after exhaustion with potash, the quantity of starch is learned with great accuracy. The only error introduced by this method lies in the solution of some saline matters by the acid. The quantity is, howerer, so small as rarely to be apyreciablc. If needful, it can be taken iuto aecount by evaporating the acid solution to clryness, incinerating and weiching the residue By warming with concentrated malt-extract at $132^{\circ}$, the starch aione is taken into solution, and no correction is needed for saline matters. If it is wished to determine the sumar produced by the transformation of the starch, a weaker acid must of course be emplured. In case of mucilagimous substances, the starch must be extracted by digestion with a strong solution of chloride of sodium, with which the requisite quantity of cblorbyuric acid has been mixed, and the residue should be 
washed with water to which some alcohol has been added.--Heimebery"s Jownal fïr Landioirthschaft, 1862, p. 206.

Inulin, $\mathrm{C}_{12} \mathrm{II}_{20} \mathrm{O}_{10}$, elosely resembles starch in many points, and appears to replace that body in the roots of the artichoke, elecampane, dahlia, dandelion, chicory, and other plants of the same natural family (compositer). It may be obtained in the form of minute white grains, which dissolve easily in hot water, and mostly separate again as the water cools. Unlike starch, inulin exists in a liquid form in the roots above named, and sepurates in grains from the clear pressed juice when this is kept some time. According to Bouchardat, the juice of the dahlia tuber, expressed in winter, becomes a semi-solid white mass in this way, after reposing some hours, from the separadion of 8 per cent of this substance.

Inulin, when pure, gives no coloration with iodine. It may be recognized in plants, where it occurs in a solution usually of the consistence of a thin oil, by soąking a slice of the plant in strong alcohol. Inulin is insoluble in this liquid, and under its influence shortly separates as a solid in the form of spherical granules, which maly be identified with the aid of the microscope.

When long hoiled with water it is slowly but complete1y converted into a kind of sugar, (levulose); hot dilute acils accomplish the same transformation in a short time. It is digested by animals, and doubtless has the same valuo for food as starch.

In chemical composition, inulin agrees perfectly with cellulose and starch; see p. 60.

Dextrin, $\mathrm{C}_{12} \Pi_{20} \mathrm{O}_{10}$, has been thought to occur in small quantity dissolved in the sap of all plants. According to Von Bibra's late investigations, the substance existing in brearl-rrains which carlier experimenters believed to be dextrin, is in reality gum. Busse, who has still more recently examined various young cereal plants and sceds, 
and potato tubers, for dextrin, found it only in old prtatoes and young whent plants, and there in very small quantity. - Jahresbericht fïr Chemie, 1866, p. 66t.

Dextrin is easily prepared artificially by the transformation of starch, and its interest to us is chiefly due to this fact. When starch is exposed some hours to the heat of an oven, or 30 minutes to the temperature of $415^{\circ} \mathrm{F}$., the grains swell, burst open, and are gradually converted into a light-brown substance, which dissolves rendily in water, forming a clear, gummy solution. This is dextrin, and thus prepared it is largely used in the arts, especially in calicoprinting, as a cheap substitute for gum arabie, and bears the name British gum. In the baking of bread it is formed from the starch of the flour, and often constitutes ten per cent of the loaf. The glazing on the crust of brear, or upon biscuits that have been steamed, is chiefly due to a coating of dextrin. Dextrin is thus an important ingredient of those kinds of food which are prepared from the starchy grains by cooking.

British gum, or commercial dextrin, appears either in translucent brown masses, or as a yellowish-white powder. On addition of cold water, the dextrin readily dissolves, leaving behind a portion of unaltered starch. When the solution is mixed with strong alcohol, the dextrin separates in white flocks, which, upon agitation, unite to translucent salvy clumps. With iodine, solution of comsnercial dextrin gives a fine purplish-red color. Pure dextrin is, however, unaffected by iodine.

Exr. 23.-Cautiously heat a spoonful of powdered starch in a porce lain dish, with constant stirring so that it may not burn, for the space of five minutes; it acquires a yellow, and later, a browu color. Now add thrice its bulk of water, and heat nearly to boiling. Ohscrve that a slimy solution is formed. Pour it upon a filter; the liquid that runs through contains dextrin. To a portion, add twice its bulk of aleohol; dextrin is precipitated. To another portion, add solution of iodine; this shows the presence of dissolved but unaltered starch, which likewise remains solid in considerable quantities upon the filter. To a third portion 
of the filtrite add one drop of strong sulphuric acid, and boil a few minutes. Test with iodine, which will now prore that all the stareh is trinstormed.

Not only heat, but likewise acids and ferments proluce dextrin from starch, and also from cellulose. In the spronting of seeds it is formerl from starch, and hence $\mathbf{i}$. an ingredient of malt liquors. It is often contained ir the animal body. Limpricht obtained nearly a pound of dextrin from $200 \mathrm{lbs}$. of the flesh of a young horse.-Ann. Ch. Ph., 133, p. 295.

The chemical composition of dextrin is the same as that of cellulose, starch, and inulin.

The Gums. - A number of bodies exist in the vegetable kingdom, which, from the similarity of their properties, have received the common designation of Gums. The best known are Gum Arabic, or Arabin; the gum of the Cherry and Plum, or Cerasin; Gum Tragacanth and Bas. sora Gum, or Bassorin; and the Vegetable Nucilage of various roots, viz., of mallow anil comfrey; and of certain seeds, as those of flax and quince

Arabin,-Gum Arabic or Arabin exudes from the stems of various species of acacia that grow in the tropical countries of the East, especially in Arabia and Egypt. It occurs in tear-like, transparent, and, in its purest form, colorless masses. These dissolve easily in their own weight of water, forming a viscid liquid, or mucilage, which is employed for causing adhesion between surfaces of paper, and for thickening colors in calico-printing. Gum Arabic, when burned, leaves about 3 per cent of ash, chiefly earbonates of lime and potash ; it is, in fact, a compound of lime and potash with Arabic acid.

Arabic Acid is obtained pure by mixing a strong solution of grum Arabic with chlorlydric acil, and alding alcohol. It is thus procipitited as a milk-white mass, which, when dried at $212^{\circ}$, becomes transparcnt, and has the composition $\mathrm{C}_{12} \mathrm{H}_{22} \mathrm{O}_{\mathbf{2 1}}$. 
In 100 parts, Arabic acid contains :

\begin{tabular}{lr} 
Carbon & 42.12 \\
Hydrogen & 6.41 \\
Oxygen & 51.47 \\
\cline { 2 - 2 } & 100.00
\end{tabular}

By exposure to a temperature of $250^{\circ}$, Arabic acid loses one moleculo of water, and becomes insoluble in water, being transformed in!? Metarabic Acid, (Fremy's Acide metagummique).

Cerasin.-The gum which frequently forms glassy masses on the bark of cherry, plum, apricot, peach, and almond trees, is a mixture in variable proportions of Arabin, or the arabates of lime and potash, with cerasin, or the metarabates of lime and potash. Cold water dissolves the former, while the cerasin remains undissolved, but swollen to a pasty mass or jelly.

Metarabic cid is prepared, as above stated, by exposing Arabic acid to a temperat ure of $250^{\circ} \mathrm{F}$., and its composition is $\mathrm{C}_{12} \mathrm{H}_{20} \mathrm{O}_{10}$. It is likewise produced by putting solution of gum Arabic in contact with oil of vitriol. On the other hand, metarabic acid is converted into Arabic acid, by boiling with water and a little line or alkali. Metarabic acid, as wcll as its cumpounds with lime, potash, etc., are insoluble in water.

Bassorin, $\mathrm{C}_{12} \mathrm{H}_{20} \mathrm{O}_{10}$, as found in Gum Tragacanth, has much similarity to metarabic acid in its properties, being insoluble in water, but swelling up in it to a paste or jelly.

Vegetable Mucilage, $\mathrm{C}_{12} \mathrm{H}_{20} \mathrm{O}_{10}$, has the same composition, and nearly the same characters as Bassorin, and is possibly identical with it. It is an almost universal constituent of plants.

It is procured in astate of purity by soaking unbroken flixseed in cold water, with frequent agitation, heating the liquid to boiling, straining, and evaporating, until addition of alcohol separates tenacious threads from it. It is then precipitated by alcohol containing a little chlorhydric
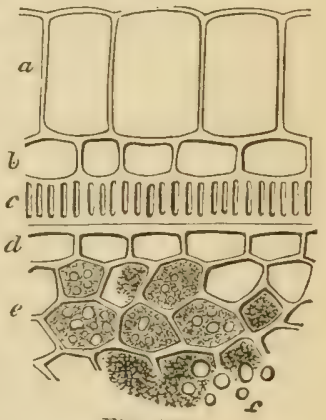

Fig. 1i?. acid, and washed by the same mixture. On drying. it forms a horny, colorless, and friable mass. Fig. 13 represents a liinhly maguilied sec 
tion of the flarsecd. The external cells, $a$, contain the mucilage. When soaked in water, the mucilgge swells, bursts the cells, and exudes.

One or other of these kinds of gum has been found in the following plants, viz., basswood, elm, apple, grap:, castor-oil bean, mangold, tea, sunflower, pepper, in various sea-weerls, anil in the seeds of wheat, rye, barley, oats, maize, rice, buckwheat, and millet.

In the bread-grains, Arabin, or at least a soluble gum, occurs often in considerable proportion.

TABLE OF THE PROPORTIONS (per cent) OF GUM IN VARIOUB AIR-DRX PLANTS OI: PARTS OF PLANTS.

(According to Von Bibra, Die Getreidearten und das Brod.)

Wheat kernel........................ 4.50

Wheat flour, superfine............... 6.25

Spelt flour, (Triticum spelta, $) \ldots \ldots \ldots \ldots .2 .48$

Wheat bran ........................ 8.85

Spelt bran........................12.52

Rye keruel........................ 4.10

Rye floul.......................... 7.25

Rye bran.......................... 10.40

Barley flour...................... 6.33

Barley brat.......................6.68 6.88

Oat meal............................. 3.50

Rice flour......................... 2.00

Millet flour........................10.60

Maize meal........................ 3.05

Buckwheat flour.................... 2.85

The gums are converted into sugar by long boiling with dilute acids.

The recent experiments of Grouven show that, contrary to what has been taught hitherto, gum, (at least gum Arabie, is digestible by domestic animals.

Saccharose or Cane Sugar, $\mathrm{C}_{12} \quad \mathrm{H}_{22} \mathrm{O}_{11}$, so called becalse first and chiefly prepared from the sugar cane, is the ordinary sugar of commerce. When pure, it is a white solid, readily soluble in water, forming a color-

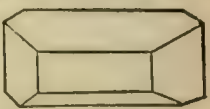

Fig. 14. less, ropy, and intensely sweet solution. It crystallizes in rhombic prisms, fig. 14, which are usually small, as in 
granulated sugar, but in the form of ruck candy may be found an inch or more in length. The crystallizen sugar obtained largely from the sugar-beet, in Europe, and that furnished in the United States by the sugal-maple and สorghum, when pure, are identicul with cane-sugar.

Saccharose also exists in the vernal juices of the walnut, birch, and other trees. It occurs in the stems of umipe maize, in the nectar of flowers, in fiesh honey, in parsnips, turnips, carrots, parsley, sweet potatoes, in the stems and roots of grasses, and in a multitude of fruits.

Exp. 20.-Heat cantiously a spoonful of white sugar until it melts, (ut $356^{\circ} \mathrm{F}$. ) to a clear jellow liquid. On rapid cooling, it wives a transparent miss, known as barley sigar, which is empleyed in coufectionery. At a higher heat, it turus brown, froths, omits pungent vapors, and becomes turnt sugar, or caramel, which is used for coloring soups, ale, ete

The quantity per cent of saccharose in the juice of various plints is given in the annexed table. It is, of course, viriable, depending upon the variety of plant in case of came, beet, and sorghum, ae well as upon the stage of growth.

SACCHAROSE IN PLANTS.

per cent.

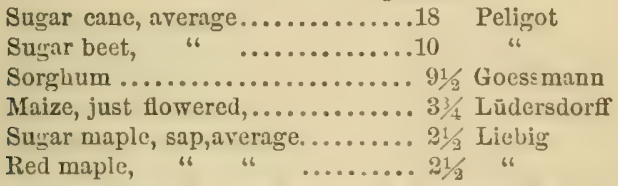

When a solution of this sugar is heated with dilute acids, or when acted on by yeast, it is converted into a mixture of equal parts of levulose, (fruit sugar,) and glucose, (grape sugar.)

The composition of saccharose is the same as that of Arabic acid, and it contains in 100 parts:

Carbon 42.11

Hydrogen 6.43

Oxygen $\quad 51.46$

100.00

Levulose, or Fruit Sugar, (Fructose, ) $\mathrm{C}_{12} \mathrm{H}_{24} \mathrm{O}_{12}$, exists mixed with other sugars in sweet fiults, honey, and mo. 
lasses. Inulin is converted into this sugar by lung boil. ing with dilute acids, or with water alone. When pure, it is a colorless, amorphous* mass. It is incapable of crys. tallizing or granulating, and usually exists dissolved in a small proportion of water as a syrup. Its sweetness is rqual to that of saccharose.

Levulose contains in 100 parts :

$$
\begin{array}{lr}
\text { Carbon } & 40.00 \\
\text { Hydrogen } & 6.67 \\
\text { Oxygen } & 53.33 \\
\cline { 2 - 2 } & \begin{array}{l}
100.00
\end{array}
\end{array}
$$

Glucose or Grape Sugar, $\mathrm{C}_{12} \mathrm{H}_{24} \mathrm{O}_{12}$, naturally occurs associated with levulose in the juices of plants and in honey. Grimules of glucose separate from the juice of the grape in drying, as may be seen in old "candied" raisins. Honey often granulates, or candies, on long keeping, from the crystallization of a part of its glucose.

Glucose is formed from dextrin by the action of hot dilute acids, in the same way that levulose is producei from imulin. In the pure state it exists as minute, colorless crystals, and is, weight for weight, but baif as sweet as the foregoing sugars. In composition it is identical with levulose.

It combines chemically with water in two proportions. Mono-hy. drated rlucose, $\left(\mathrm{C}_{12} \mathrm{II}_{24} \mathrm{O}_{12} \mathrm{II}_{2} \mathrm{O}\right.$ ) or Anthon's hard erystallized grapebugar, which is prepared in Germany by a secret process, is dry to the feel. Bi-liydrated glueose, $\left(\mathrm{C}_{12} \mathrm{II}_{24} \mathrm{O}_{12} 2 \mathrm{H}_{2} \mathrm{O}\right.$, ) occurs in commerce in an impure state as a soft, sticky, erystalline mass, which heeones duughy at a slightly elevated temperature. Both these hydrates lose heir crystalWater at $212^{\circ}$.

Dissolved in water, glucose yields a syrul, which is thin, and destitute of the ropiness of cane-sugar syrup. It does not crystallize, (gramulate, so reatily as eane-sugar.

ExP. 30.-Mix 100 c. c. of water with 30 dropls of Atrong sulphuric acid, and heit to vigorous boiling in a glass flissk. Stir $\mathbf{1 0}$ grams of

- Literally without shape, i. $\varepsilon$, not crystallized. 
starclı with a little water, and pour the mixture into the ho. liquicl, drop by drop, so as not to interrupt the boiling. The starch clissolves, aud passes first into dextrin, and finally into wlucose. Contime the ebullition for several hours, replacing the evaporated water from lime to time. To remove the sulphuric acid, add to the liquid, which may be still milky from inpurilies in the starch, pordered chalk, until the som taste disappear's; filter from the sulphate of lime, (gypsum, ) that is formed, and eviporate the solution of glucose* at a crentle heat to a syrupy consistence. On long standing it may eryst:ullize or granulate.

By this method is prepured the so-called potato-surar, or starch-sugar of commerce, which is atded to grape-juice for making a stronger wine, and is also emplojed to adulterate cane or beet-sugrar.

In the sprouting and malting of grain, glucoset is likewise produced from starch.

Even cellulose is convertible into glucose by the prolonged action of hot dilute acids, and saw-dust has thus been made to yield an impure syrup, suitable for the production of alcohol.

In the formation of glueose from rellulose. starch, and dextrin, the latter substances take up the eiements of "ater as represented by tho equation

$$
\begin{aligned}
& \text { Starch, de. Waure } \\
& \mathrm{C}_{12} \mathrm{H}_{20} \mathrm{O}_{10}+2 \mathrm{H}_{2} \mathrm{O}=\mathrm{C}_{12} \mathrm{H}_{24} \mathrm{O}_{12}
\end{aligned}
$$

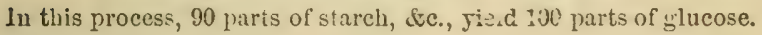

Trommer's Copper test. - A characteristic test for shluense and levulose is found in their deportment towarls an alkiline solıtion of oxide of copper, which readily yichts up oxyeren to these sururs, being itself re. duced to yellow or red suboxide.

Exp. 31.-Prepare the copper text by dissolviner tourether in 30 c. c. of warm water a pinch of sulpliate of coplur and one of tartaric acid; add to the liquid, solution of cuustic potash until it feels slippery to the slin. Place in separate test tubes a ferw drops of solution of cane-suerar, 2 similar amount of the dextrin solution, obtained in Exp. $2 \mathrm{~S}$; of solutio $r$ of glucose, from raisins, or from Exp. 30; and of mulisses; add to anch a little of the copper solution, and place them in a resscl of hot

* Ir the boiling has been kept up hut an hour or so, the alucose will contain dextric, as may be ascertained by mixiner a small portion of the still acid liçuia with 5 times its bulk of strong vlecknol, which will precipitate dextrin, but not glucose.

+ According to some authorities, the sugar of malt is distinct from glucose, and has been designated maltose. Prooably, however, the so-called maltose is a mixture of glucose and dextrin. 
water. Observe that the sacchirose and dextrin suffer no alteration for a long time, while the glucose and molasses shorty cause the separation of suboxide of copper.

Exp. 3:- - Heat to boiling a little white cane-sugar with 30 c. c. of water, aud 3 drops of strong sulphuric acid, in a glass or poreelain dish, for 15 ninutes, supplying the wate of water as needful, and test the liquid as in the list Exy. It will be found that this treatment trans. forms saccharose into glucose, (and levulose.)

The quantit vine estimation of the sugurs and of starch is commonly based upon the reaction just describet. For this purpose the alkaline copper solution is made of a known strength by dissolving a given weight of sulph:te of copper, ete., in a given volume of water, and the glucose, or levilose, or a mixture of both, being likewise made to a known volume of solution, it is allowed to flow slowly from a craduated tube into a measured portion of warm copper solution, until the blue color is discharged. Experiment has demonstrated that one part of glucose or of levilose reduces 2.205 + parts of oxide of copper. Starch and sacch:rose are first converted into glucose and levulose, by heating with an ncid, and then examined in the s:me manner. For the detilils required to ensure accuracy, consult Fresenius' (ylantiundive Analysis.s.

As alrealy stated, cane-sugar, by long boiling of its aqueous solution, and under the influence of hot dilute acids (Exp. 32) and yeast, loses its property of ready crystallization, and is converted into levulose and glucose.

According to Dubrunfant, two molecules of cane-sugar talie up the elements of two molecules, ( 5.26 jer cent,) of water, yielding a mixture of equal parts of lerulose and glucose. This change is expressed in chemical symbols as follows:

$$
\underset{\text { Cinc-sugar. }}{2\left(\mathrm{C}_{12} \mathrm{H}_{22} \mathrm{O}_{11}\right)}+\underset{\text { Water. }}{2 \mathrm{H}_{2} \mathrm{O}}=\underset{\text { Levulose. }}{\mathrm{C}_{12} \mathrm{H}_{24} \mathrm{O}_{12}}+\underset{\text { Glucuse. }}{\mathrm{C}_{12} \mathrm{H}_{24} \mathrm{O}_{12}}
$$

The alterability of saccharose on heating its solutions occasions a loss of one-third to one-half of what is really contained in cane-juice, and is one reason that solid sugar is obtained from the sorrhum with such difficulty. MLolasses, sorghum syrup, and honey, usually contain all three of these sumars. In molasses, both the saccharose and glueose are hindered from crystallization by the levulose, and by saline matters derived from the cauc-juice.

Honey-dew, that sometimes falls in viscid drops from the leaves of the lime and other trees, is essentially a mix. 
ture of the three sugars with some gum. The manuas of Syria and Kurdistan are of similar composition.

The older observers assumed the presence of glucose in the bread grains. Thus $V$ :uquelin found, or thought he found, $8.5^{\circ} \mathrm{l}$ of this sugar in Odessa wheat. More recent. ly, Peligot, Mitscherlich, and Stein have denied the presence of any sugar in these grains. In his work on the Cereals and Bread, (Die Getreiderarten und das Brod, 1860, p. 163 , Von Bibra h:ıs reinvestigated this question, and found in fresh ground whent, etc., a sugar having some of the characters of saccharose, and others of glucose and levulose. It is, therefore, a mixture.

Von Bibra found in the flour of various grains the following quantities of sugar.

PROPORTIONS OF SUGAR IN AIR-DRY FLOUR, BRAN, AND MEAT.

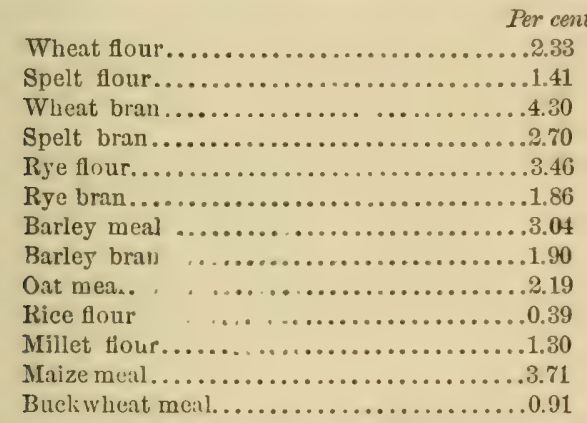

Glucosides. - There occur in the verretable kingdom a large number of bodies, usually bitter in taste, which contain glucose, or a similar sugar, chemically combined with other substances, or yield it on deromposition. Tannin, the bitter principle of oak and hemlock bark; salicin, finm willow bark; phloridzin, from the bark of the apple-tree root, and principles contained in jalap, scammony, the horse chestnut, and almond, are of this kind. The sugar may be obtained from these so-called glucosides by heating with dilute acids. 
Gther sa gars. -Other suyars or saccharoid hodies occurrine in common or cultirated plants, but requiring no extended notice here, are the fo? lowing:-

Mannite, $\mathrm{C}_{6} \mathrm{H}_{14} \mathrm{O}_{6}$, is abundant in the so-called manna of the apothe. cary, which exudes from the bark of sereral species of ash that grow in tus Eastern Homisphere, (Fraximes urnes and rotundifulin.) It likeFise exists in the sap of our fruitrees, in edible mushroome, and some. times is formed in the fermentation of sugur, (viscous fermentation.) It appears in minute colorless crystals, and has a swectish taste.

Quercite, $\mathrm{C}_{6} \mathrm{H}_{12} \mathrm{O}_{5}$, is the sweet principle of the acorrs, from which it may be procured in colorless crystals.

Pinite, $\mathrm{C}_{6} \mathrm{H}_{12} \mathrm{O}_{5}$, exudes from wounds in the hark of a Californian and Australian pine, (Pinus Lambertiuna.) Separated from the resin that usually accompanies it, it lorms a white crystalline mass of a very sweet taste.

Ifycose, $\mathrm{C}_{12} \mathrm{H}_{22} \mathrm{O}_{11}$, is a sugar found in crgot of rye. It may be obtained in crystals, and is very sweet.

Sityar of Jfilk, Lactuse, $\mathrm{C}_{12} \mathrm{H}_{22} \mathrm{O}_{11}+\mathrm{H}_{2} \mathrm{O}$, is the sweet principle of the milk of avimals. It is largely prepared for commerce, in Switzerland, by evaporating whey, (wilk from which casein and lat have been separated for making cheese.) In it state of purity, it forms trinspareut, colorless crystals, whick crackle under the tecth, and are but slightly sweet to the taste. When dissolved to saturation in water, it forms a sweet but thin syrup.

Mutual trangformations of the members of the Cellulose Group.-One of the most remarkable ficts in the history of this group of bodies is the facility with which its members undergo mutual conversion. Some of these changes have been already noticed, but we ma appropriately review them here.

a. Tiansformations in the plant.-The machinery of the vegetable organisin has the power to transform most, if not all, of these bodies into every other one, and we find nearly all of them in every individual of the higher order of plants in some one or other stage of its growth.

In germination, the starch which is largely contained in seeds is converted into dextrin and glucose. It thereby acquires solubility, and passes into the embryo to feed the young plant. Ilere it is again solidified as cellulose, starch, or other organic principle, yielding, in fact, the chief part of the materials for the structure of the seedling. 
At spring-time, in cold climates, the starch stored up orer winter in the new wool of many trees, especially the maple, appears to be converted into the saccharose which is found so abundantly in the sap, and this sugar, carried upwards to the buds, nourishes the young leaves, and is there transformed into cellulose, and into starch again.

The sugar-beet root, when healthy, yiehls a juice con. tzining 10 to $1+$ per cent of saccharose, and is destitute of starch. Schncht has observed that in a certain diseased stite of the beet, its sugar is partiilly converted into starch, grains of this substance making their appealance.

da's Centralblatt, 1863, II., p. 21\%.)

The analysis of the cereal grains sometimes reveals the presence of dextriu, at others of sugar or gum.

Thus Stepf found no dextrin, but botis grum and sugar in maize-meal, (Jour. für Praht. Chcm., 76, 1). 92;) while Fresenius, in a more recent analysis, (Vs. St., 1, 1). 180, ) obtained dextrin, but neither sugir or gum. The sample of maize examined by Stepf contined 3.05 p. c. gum and 3.71 p. e. surar; that analyzed by Fresenius yiclded 2.33 p. c. dextrin.

Gum 'Tragacanth is a result of the trausformation of cellulose, as Mohl has shown by its mieroscopic study.

b. In the animal, the substanees we have ben describing also suffer transformation wheil employed as food. During the process of digestion, cellulose, so far as it is acted upon, starch, dextrin, and probably the gums, are all converted into glucose.

c. Many of these changes may also be proluced apart from physiological agency, by the action of heat, acids, anc? ferments, operating singly or jointly.

Cellulose and starch are converted by boiling with 8 dilute acid, into dextrin and finally into giucose. If papes or cotton be placed in contact with strong chlorhydric acid, (spirit of salt,) it is gradually converted into the same sugar. Cellulose al d starch acted upon for some time by strong nitric acid, (aqua-fortis,) give compounds from which dextrin may be separated. Nitrocellulose, (gun cotton,) sometimes yiulds gum by its spontaneous 
decomposition, (Hoffmann, Quart. Jour. lihem. Soc., p r67.) A kind of gum also appears in solutions of cant. sugar or in beet-juice, when they ferment under certain conditions. Inulin and the gums yield sugar, (levulose, ) but no dextrin, when boiled with weak acids.

d. It will be noticel that while physical and chemical agencies produce these metamorphoses in one direction, it is only under the influence of life that they can be accomplished in the reverse manner.

In the laboratory we can only reduce from a higher, organized, or more complex constitution to a lower and simpler one. In the regetable, however, all these changes, and many more, take place with the greatest facility.

The Chemical Composition of the Cellulose Group.It is a remarkable fact that all the substances just de. scribed stand very closely related to each other in chemical composition, while several of them are identical in this respect. In the following table their composition is expressed in formulæ.

CHEMICAL FORMLLE CF TUE BODIES OF THE CELLULOSE GROUP.

$\left.\begin{array}{l}\begin{array}{l}\text { Cellulosf } \\ \begin{array}{l}\text { Starch } \\ \text { Innlir } \\ \text { Dextru } \\ \text { Bassorin } \\ \text { Veg. Mucilagc } \\ \text { Metarabic acid }\end{array}\end{array} \\ \begin{array}{l}\text { Arabic acid } \\ \text { Cane sugar } \\ \begin{array}{l}\text { Fruit sugar } \\ \text { Grape sugar }\end{array}\end{array}\end{array}\right\} \mathrm{C}_{12} \mathrm{C}_{20} \mathrm{O}_{12} \mathrm{O}_{12}$

It will be observed that all these bodies contain 1 is atoms of carlon, united to as much hydrogen and oxygen as form 10, 11, or 12 molecules of water. We can, therefore, conceive of their conversion one into another, witb ro further change in chemical composition in any cas?, than the loss or gain of a few molecules of water. 
I:omerism.-Bodies which-like cellulose and dextrin, or ilse levilose nnd glucose-are identical in composition, and yet are characterizer. by different properties and modes of occurrence, are termed isomeric; they are examples of isomerism. These words are of Greek derivation, and signify of equal measure.

We must suppose that the particles of isomeric bodies which are com. posed of the same kinds of matter and in the same quantities, exist in different states of arrangenent. The mason can build from a given number of bricks and a certain amount of mortar, a simple will, an aqueduct, a bridge or a castle. The composition of these unlike structures may be the same, both in lind and quantity; but the structures themselves differ immensely, from the fact of the diverse arrangenent of their ma. terials. In the same manner we may suppose starch to be converted into dextrin by a change in the relative positions of the atoms of carbon, hydrogen, and oxygen, which compose them.

3. The Pectose Group.-The pectose group inclurles Pectose, Pectin, Pectosic, Pertic, and Metrpectic acills. These bodies exist in, or are derived from, fleshy fruits, including pumplins and squashes, berries, the roots of the tminip, bect, onion, and carrot, and in cabbage and celery. They are an important part of the food of men and cattle.

Pectose is the name given to a body which is supposed rather than demonstrated to occur with cellulose in the flesh of unripe fruits, and in the roots of turnips, carrots, and beets. Its characters in the pure state are as good as unknown, because we are as yet acquainted with no means of separating it from cellulose without changing its nature. Pectose is thought to constitute the chief bulk of the dry matter of the above-mentioned fruits and roots, and is consluded to be a distinct body by the products of its transformation, either such as are formed naturally, or those procured $\mathrm{b}$ artificial means. In what follows, we shall as. sume, with Fremy, (Ann. de Chim. et de Phys., XXIV, 6 ) that pectose exists, and is the source of pectin, etc.

Pectin is produced from pectose in a manner similar to that by which dextrin is obtained from cellulose or starch, viz., by the action of heat, of acids, and of ferments. When the flesh of fruits, or the roots which consist chinfly of 
pectose, are subjected to the joint action of a moderato heat and an acid, the starch they contain is slowly altered into dextrin and sugar, while the firm pectose shortly softens, becomes soluble in water, and is converted into pectin. It is precisely thes changes which occur in the bak ing of apples and pears, and in the boiling of turnips, car rots, etc., with water. In the ripening of fruits the sime transformation takes place. The firm pectose, under the influence of the acids that exist in all fiuits, gradually softens, and passes into pectin.

Exp. 33.-Expres = as if turbid, filter through muslin the juice of a ripe apple, pear, or seach. Add to the clear licuirl its orrn bulk of alcolool. Pectin is precipitated as a stringy, relatinous mass, which, on drying, shrinks greatly in bulk, and forms, if pure, a white sulustance that may be easily reduced to powder, and is readisy soluble in cold water.

Exp. 34--Reduce several white turuips or beets to pulp by grating. Incluse the pulp in a piece of muslin, and wasl, by squeezing in water until all soluble matters are removel, or until the water comes off nerrly tasteless. Bring the washed pulp into a gluss ressel, will enongh dilute clılorhydric acid, (1 part by bulk of commereial muriatic acid to 15 parts of water, ) to saturate the mass, and let it stand 48 hours. Sqqueeze out, the acid liquid, filter it, anc ald alcohol, when pectin will seprate.

The strong aqueous solution of pectin is viscid or gummy, as seen in the juice that exudes from baked apples or pears.

Pectosic and Pectic acids.-Under the action of a ferment occurring in many fruits, assisted by a gentle heat, pectin is transformed first into pectosic, and afterwarl into pectic acil. These bodies compose the well-known fruitjellies. They are both insoluble in cold water, and remain suspender in it as a gelatinous mass. Pectosic acid is soluble in hoiling water, and hence most fruit jellies borcome liquid when heated to boiling; on cooling, its solu. tion gelatinizes again. Pectic acid is insoluble even in boiling water. It is formed also when the pulp of fruits or roots containing pectose is acted on by alkalies or by ammonia-oxide of copper. The latter agent, (a solvent of cellulose, converts pectose directly into pectic acid, 
which remains in insoluble combination with oxide of copper.

Nerapectic acid. - By too iong boiling, by prolonged contact with acids or alkalies, and by decay, the pectic and pectosic acids, as well as pectin, are transformed into still another sulstance, riz., metapectic aut, which, according to Frems, is a very soluble body of quite sour tistf: It is the last product of the transformation of the bodies of this group with which we are acquainted. It exists, according to Fremy, in beet-molasses and deciyed fruits.

ExP. 35.-Stew a handful of sound cranberries, covered with water; just long enough to make them soft. Observe the speedy solution of the firm pect.se. Strain through muslin. The juice contains soluble pectin, which rany be precipitated from a small portion by alcohol. Keep the remaining juice heated to nenr the boiling point in a water batli, (i. e., by immersing the ressel containine it in a larger one of boiline water.) After a time, which is variable according to the condition of the fruit, and must he ascertained by trial, the juice on cooling or standing solidifies to a jelly, that dissolves on warming, and reapyears agnin on cooling-Fremy's pectosic acid. By further heating, the juice may. form a jelly which is permanent when hot-pectic acid-and on still longer exposure to the same temperature, this jelly may dissolve again, by passing into Fremy's metapectic acid, which alcohol does not precip. itate.

Other ripe fruits, as quinees, strawberries, peaches, grapes, apples, ete., may be employed for thiz experiment, but in any case the time required for the juice to run through these changes cannot be predicted safely, and the student may ensily fail in attempting to follow them.

Chemical composition of the Pectose group.-Our knowledge on this point is very imperfect. Pectose itself, having never been obtained pure, has not been analysed. The other bodies of this group have been examined, but, owing to the difficulty of obtaining them in a state of purity, the results of different observers are discordant.

The formulæ of Fremr are as follows:

$\begin{array}{ll}\text { Pectose, } & \text { unknown. } \\ \text { Pectin, } & \mathrm{C}_{32} \mathrm{H}_{40} \mathrm{O}_{28}+4 \mathrm{H}_{2} \mathrm{O} \\ \text { Pectosic acid, } & \mathrm{C}_{16} \mathrm{H}_{20} \mathrm{O}_{14}+11 / 3 \mathrm{H}_{2} \mathrm{O} \\ \text { Pectic acid, } & \mathrm{C}_{16} \mathrm{H}_{20} \mathrm{O}_{14}+\mathrm{H}_{3} \mathrm{O} \\ \text { Metapectic acid, } \mathrm{C}_{8} \mathrm{H}_{10} \mathrm{O}_{7}+2 \mathrm{H}_{2} \mathrm{O}\end{array}$

Grouven, (2ter Salzmünder Bericht, p. 470,) has prepared pectin on the large scale from beet-root cake, (remaining after the juice was expressed for sugar manufacture,) $b$ w 
digesting ir. with cold dilute chlorhydric acid, precipitat ing and washing with alcohol. Thus oltained, it had all the characters ascribed to pectin. Its centesimal como position, however, corresponded nenrly with that assigned by Fremy to pecti acid, and differs somewhat from that given by this chen ist for pectin, as is seen from the sut joined figures :

\begin{tabular}{|c|c|c|c|}
\hline & $\begin{array}{l}\text { Pectin. } \\
{ }_{32} \mathrm{H}_{48} \mathrm{O}_{32}\end{array}$ & $\begin{array}{l}\text { Pectic acial. } \\
\mathrm{C}_{16} \mathrm{H}_{22} \mathrm{O}_{16}\end{array}$ & Grouven's pectin. \\
\hline Carbon ........ & $\ldots 40.67$ & 42.29 & 42.95 \\
\hline Hydrogen...... & .. 5.08 & 4.84 & 5.44 \\
\hline Oxygen.......... & $\ldots .54 .25$ & 52.87 & 51.61 \\
\hline & 10600 & 100,00 & 100.00 \\
\hline
\end{tabular}

From the best analyses and from analogy with cellulose it is probable that pectose has the same composition as pectin, or differs from it only by a few molecules of water. If we subtract the water, which in the formulæ (p. 83) is separated by + from the remaining symbol, we see that the proportions of Carbon, Ifyorrogen, and Oxygen are the same in all these bodies, and correspond to the formula $\mathrm{C}_{8} \mathrm{H}_{10} \mathrm{O}_{7}$. This nearness of composition assists in comprehending the ease with which the transformations of pectose into the other members of the group are effecter.

Relations of the Cellulose and Pectose Groups.-It was formerly thought that the pectin bodies are convertible into sugar by the prolonged action of acids. Fremy has shown that this is not the ease.

Sacc, (Ann.Ch. et Phys., 25, 218,) and Porter, (Ann. Ch. et itharm., 71,115, ) have investigated a borly having the properties and nearly the composition of pectic acid, which is produced ly the action of nitric acid on wood.

nivers, (Jour. ("iem. Soc., 186:3, p. 91,) has observed - substance having the essential characters of pectic acid among the products of the spontaneous decomposition of nitrocellulose, (gun cotton.)

It is probable, though not yet fairly demonstrated, 
that in the living plant cellulose passes into pectose and pectin. Without loubt, also, the reverse transformations may be readily accomplished.

4. The Veget.able Acids.-The Vegetable Acids are very numerous. Some of them are found in all classes of plants, and nearly every family of the vegetable kingdom contains one or several acids peculinr to itself. Those which concern us here are few in number, and though doultless of the highest importance in the economy of vegetation, are of subordinate interest to the objects of this work, and will be noticed but briefly. They are oxulic, tartaric, malic, and citric acils. They occur in plants either in the free state, or as salts of lime, potash, etc. They are mostly found in fruits.

Oxalic acid, $\mathrm{C}_{2} \mathrm{H}_{2} \mathrm{O}_{4} 2 \mathrm{II}_{2} \mathrm{O}$, exists largely in the com. mon sorrel, and, according to the best. observers, is found in greater or less quantity in nearly all pliants. The pure acid presents itself in the "orm of colorless, brilliant, transpareli。 erystals, not unlike Epsom salts in appearance, (Fig.

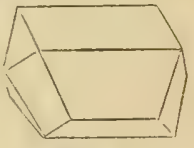

Fig. 15. 15 ,) but having an intensely sour taste.

Oxalic acid forms with lime a salt - the oxalate of lime - which is insolulle in pure water. It nevertheless exists dissolved in the sells of plants, so long as they are in active growth, (Schmilt, Ann. Chem. u. Pharm., 61, 297.) Towards the end of the period of growth, it often accumulates in such quantity as to separate in microscopic crystals. These are found in large quantity in the mature leaves and roots of the beet, in the root of garden rhubarb, and especially in many lichens.

Oxalate of potash is soluble in water, and exists in the juices of sorrel and garlen rhubarb. It was formerly used for removing ink-stains from cloth and leather, under .he name of salt of sorrel. Oxalic acid is now employed for this purpose. Oxalate of soda is soluble in water, and 
is found in the juices of plants that grow on the sea-shore Oxalate of ammonia is employed as a test for lime.

Exp. 36.-Dissulve 5 gtams of oxalic arid in $50 \mathrm{c}$. c. of hot water, add solutior of atnmonia or solid carlsonate of ammonia until the odor of the latter sligrhtly prerails, and allow the liquid to cool slowly. Long, needle like crystals of a sult of oxalic acid and ammonia-the oxalate of ammonia -separate on cooling, the compound being sparingly soluble in cold wa:er. Preserve for future use.

Exr. 37.-Add to any solution of lime, as lime-water, (see note, p. 36, ) cr bard well water, a few drops of oxalate of ammonia solution. Oxalate of lime imuediately appears as a white powdery precipitate, which, from its extreme insolubility, serres to indicate the presence of the minutest quantities of lime. Add a few drops of chlorbydric or nitric acid to the oxalate of line; it disapplears. Hence oxalate of ammonia is a test fo lime only in solutions containiug no free mincral acid. (Acetic anc oxalic acids, however, have lit tle effect upon the test.)

Definition of Acids, $B$ uses, and Salts.-In the popular sense, an acid is any body having a sour taste. It is, in fact, true that all sour substances are acids, but all acids are not sou, some being tasteless, others bitter, and some sweet. A tutter characteristic of an acid is its capability of combining chemically with bases. The strongest acids, i. $e$. those bodies whose acid characters are most strongly developed, if soluble, so as to have any effect on the nerves of taste, are sour, viz., sulphuric acid, phosphoric acid, nitric acid, etc.

Bases are the opposite of acids. The strongest bases, when soluble, are bitter and biting to the taste, and corrode the skin. Potash, soda, ammonia, and lime, are examples. Marnesia, oxide of iron, and many other com. pounds of metals with oxygren, are insoluble bases, and hence destitute of taste. Potash, soda, and ammonia, are termed rellaties; lime and magnesia, alkali-earths.

Salts are compounds of acids and bases, or at least result from their chemical union. Thus, in Exp. 20, the salt, phosphate of lime, was produced by bringing together phisphoric acid, and the base, lime. In Exp. 37, oxalate of lime was made in a similar manuer. Common salt-in 
chemical language, chloride of sodium-is formed when soda is mixed with chlorhydric acid, water being, in this case, produced at the same time.

Test for acids and alkalies. -Many vecetable colors are altered by solu. tle acids or soluble bases, (alkalies, ) in such in manner as to answer the purpose of distinguishing these two clisses of bodies. A solution of cochineal may be employed. It has a ruby-red color when concentrated, but on mixing with much pure water, becomes orange or yellowishorange. Acids do net affect this color, while alkialies turn it to an intense carmine or violet-carmine, which is restored to orange by acids.

Exp. 33.-Prepare tincture* of cochine:n b5 pulverizing 3 ylims of cochineal, and slsalsing frequently with a mixture of 50 c. c. of str ng alcohol and 200 c. c. of water. After a day or two, pour off the clear liquid for use.

To a cup of water add a few drops of strong sulphuric acid, and to another similar quantity add as many drops of ammonia. To the liquids add separately 5 drops of cochineal tincture, ohserving the coloration in each case. D, vide the dilute ammonia into twe portions, aud pour into one of them the dilute acid, until the carmine color just passes into orange. Should excess of acid have heen incautiously used, add ammonia, until the carmine remppears, and destroy it actiu by new portions of acid, added dropwise. The acid and base thrs nentrulize each other, and the solution contains sulphate of ammonia, but no free acid or base. It will be found that the orange-eochineal indicates very minute quantities of ammonia, and the carmine-cochineal correspondingly small quantities or acid. Tincture of litmus, (procurable of the apothecar 5 , ) or of dried red cabbige, may also be employed. Litmus is made red by soluble acids, and blue by soluble bases. With red cabbage, acids derelope a purple, and the bases a green color:

In the formation of salts, the acids and bases more or less nentralize sach other's properties, and their compounds, when soluble, have a less sour or less acrid taste, and act lest vigorously on veretable colors than the acids or bases themselves. Some soluble salts have no taste at all resembline either their base or acid, and have no effect on vegetible colors. This is true of common silt, glanber salts or sulphite of suda, and saltpeter or nitrate of potitsh. Others exhibit the properties of their base, though iu a reduced degree. Carbonate of anmouit, for example, has much of the odor, tiste, and effect on vegetable colors that belong to ammonia. Carbonate of sodil has the taste and other properties of eaustic soda in a greatly mitigated form. On the other hand, sulphates of aluwina, iron, and copper, have slightly acid ciaracters.

Certain acids form with the same base several distinct salts, Thus carionic acid and soda may produce carbonate of soda, $\mathrm{Ni}_{2} \mathrm{O} \mathrm{CO}_{2}$, or

* Tincturea, in the language of the apothecary, are alcoholic solutions. 
bicarburate of soda, $\mathrm{Na} \mathrm{HO} \mathrm{CO}_{2}$. The latter is mu th less allialine than the former, but both turn cochineal to a carmine solor. Again, phusphoric acid may form three distinct salts with soda or with lime, which will be noticed in another place. Oxalic acid also fielels several kinds of salts, as do the other organic acids presently to he described.

Malic acid, $\mathrm{C}_{4} \mathrm{H}_{6} \mathrm{O}_{5}$, is the chief sour principle of ap. ples, currants, gooseberries, plums, cherries, strawberries, and most common fruits. It exists in small quantity in a multitude of plants. It is found abundantiy in combination with potash, in the garden rhubarb, and malate of potash may be obtained in crystals loy simply evaporating the juice of the leaf-stalks of this plant. It is likewise abundant as lime-salt in the nearly ripe berries of the mountain ash, and in barberries. Malate of lime also occurs in considerable quantity in the leares of tobnceo, and is often encountered in the manufacture of maple su. gar, separating as a white or gray sancly powder during the evaporation of the sap.

Pure malic acid is only seen in the chemical laboratory, and presents white, crystilline masses of an intensely sour taste. It is extremely soluble in water.

Tartaric acid, $\mathrm{C}_{4} \mathrm{H}_{6} \mathrm{O}_{6}$, is abund:nt in the grape, from the juice of which, during fermentation, it is deposited in combination with potash as argol. This, on purification, yields the cream of tartar, (bitartrate of potash,) of cummerce. Tartrates of potash or lime exist in small quantities in tamarinds, in the unripe ber-

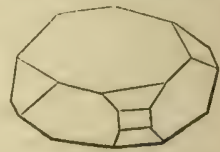

Fig. 16. ries of the momatain asin, in the berries of the sumach, in cucumbers, potatoes, pinc-apples, and many other fruits. The acid itself may be obtained in large glassy crystals, (see Fig. 16,) which are very sour to the taste.

Citric acid, $\mathrm{C}_{6} \mathrm{II}_{\mathrm{d}} \mathrm{O}_{7}$, exists in the free state in the juice of the limon, and in unripe tomatoes. It accompanies malic acil in the currant, gooselerry, cherry, strawberry, and raspleerry. It is found in small quantity, united to 
lime, ir. tobacco leaves, in the tubers of the Jurusalem artichoke, in the bulbs of onions, in beet roots, in coffecberries, and in the needles of the fir tree.

In the pure state, citric acid forms large trinsparent or white crystals, very sour to the taste.

Relations of the Vegetuble Acils to ench other and to the Amyloils. - Tho four acids above noticed usually occur together in our ordiniry fruits and it appears that some of them undergo mutual conversiou in the liv ing plant.

According to Liebie, the unripe berries of the monntain ash contain much tartaric acid, which, as the fruit ripens, is converted iuto malic acid. Schmidt, (Aun. Chem. u. Pham., 11t, 109,) first showed that tartaric acid can be artificially transformed into malic acid. Tle chemiral change ensists merely in the removal of one atom of oxyeren.

$$
\begin{aligned}
& \text { Tartaric acid. Malic acid. } \\
& \mathrm{C}_{4} \mathrm{H}_{6} \mathrm{O}_{6}-\mathrm{O}=\mathrm{C}_{4} \mathrm{H}_{8} \mathrm{O}_{5}
\end{aligned}
$$

When citric, malic, and tartaric acils are boiled with nitric acid, or hented with caustic potash, they all yicld oxalic acid.

Cellulose, starch, dextrin, the sugars, and, according to some, pectic acid, yield oxalic acid, when heated with potash or nitric acil. Commercial oxalic acid is thus made from starch and from saw-dust.

Gum (Arabic,) sugar, starch, and, according to sone, pectin, jield tartaric acid by the action of uitric acid.

5. F $\Delta$ Ts and Olus (TV $\Delta x$ ). - We have only space here to notice this important class of bodies in a very general manner. In all plants and nearly all parts of plants we find some representatives of this group; but it is chiefly in certain seeds that they occur most abundantly. Thus the seels of hemp, flax, colza, cotton, bayluerry, pea-nut, butternut, beech, hickory, almoud, sunflower, etc., contain 10 to 70 per cent of oil, which may be in great part removerl by pressure. In some plants, as the eummon bayberry, and the tallow-tree of Nicaragua, the fit is solid at ordinary temperatures, and must be extracted by air of heat; while, in most cases, the fatty matter is liquid. The ecreal grains, especially oats and maize, comtain oil in appreciable quantity. The mode of occurrence of oil in plants is shown in tig. $1 \%$, which represents a bighly magnified section of the flar-seed. The oil exists 
as minute, transparent globules in the cells, $f$. Frum these seeds the oil may be completely extricted by ether,

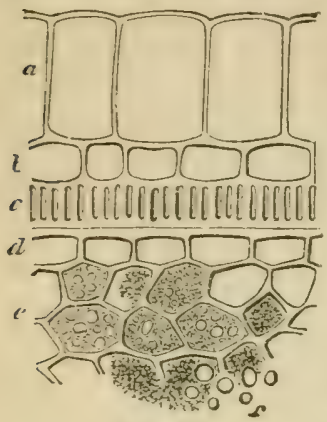

Fig. 1'،. benzine, or sulphide of carbon, which dissolve all fats with readi. ness, but scarcely affect the other vegetable principles.

Many plants yield small quan tities of wax, which either gives a glossy coat to their leaves, or forms a bloom upon their fruit. The lower leares of the oat plant at the time of blossom contain, in the dry state, 10 per cent of fat and wax, (Arendt). Scarcely two of these oils, fixts, or kinds of wax, are exactly alike in their propertir- They differ more or less in taste, odor, and consistency, as well as in their chemical composition.

Exr. 39-Place a handful of fine and fresh corn or oat meal which has been dried for an hour or so at a heat not execedine $212^{\circ}$, in a bottle. Pour on twiee its buik of ether, cork tightly, and aritate frequently for half an hour. Drain off the liquid (nilter, if need be) into at clean porcelain dish, and allow the ether to evaporate. A yellowish oil remains, which, by gently warming for some time, loses the smell of ether and becomes quite pure.

The fatty oils must not be confounded with the ethereal, essentinl, or volatile oils. The former do not evaporate except at a high temperature, and when brought upon japer leave a permanent "grease-spot." The latter readily volatilize, leaving no trace of their presence. The former, when pure, are without smell or taste. The latter usually pr.sess marked odors, which adapt many of them to use as perfumes.

In the animal body, fat (in some insects, wax, ) is formed or appropriated from the food, and accumulates in consid. crable quantities. How to feed an animal so as to cause the most rapid and economical fattening is one of the most imprortant questions of agricultural chemistry. 
However greatly the various fats may differ in external c uacters, they are all mixtures of a few elementary fats. The most abundant and commonly occurring fats, especially those which are ingredients of the food of man and domestic animals, viz.: talluw, olive oil, and butter, con. sist essentially of three substances, which we may briefly notice. These elementary fats are Stearin, Palmitin, and Olein,* and they consist of carbon, oxygen, and hydrogen, the first-named element being greatly preponderant.

Stearin is represented by the formula $\mathrm{C}_{57} \mathrm{H}_{110} \mathrm{O}_{8^{\circ}}$. It is the most abundant ingredient of the common fats, and exists in largest proportion in the harder kinds of tallow.

Exp. 40.-Heat mutton or beef tallow, in a bottle that may be tightly corked, with ter times its bulk of concentrated ether, until a clear solution is obtain z.. Let cool slowly, when stearin will crystallize out in pearly scales.

Palmitin, $\mathrm{C}_{51} \mathrm{H}_{99} \mathrm{O}_{6}$, receives its name from the palm (iil, of Africa, in which it is a lirrge ingredient. It forms a good part of butter, and is one of the chief constituents of bees-wax, and of bayberry tallow.

Olein, $\mathrm{C}_{67} \mathrm{H}_{104} \mathrm{O}_{6}$, is the liquirl ingredient of fats, and occurs most abundantly in the oils. It is prepared from olive oil by cooling down to the freezing point, when the stearin and palmitin solidify, learing the olein sill in the liquid state.

Other elementary fats, viz. : butyrin, laurin, myristin, etc., occur in small quantity in butter, and in Firions vegetable oils. Flaxseed oil cortains linolein; castor oil, ricinolein, etc.

We have already given the formulæ of the principal fats, but for our purposes, a better idea of their composi tion may be gathered from a centesimal statement, viz. :

- Margarin, formerly thought to be a distinct fat, is a mixturc of atearin and Delmitin. 
CENTESIMAL COMPOSITIOX OF THE ELEMENTART FATS.

Stearin. Palmitin. Olein.

\begin{tabular}{|c|c|c|c|}
\hline Carbon, & 76.6 & 75.9 & $77 \% .4$ \\
\hline Hydrogen, & 12.4 & 12.2 & 11.8 \\
\hline Oxygen, & 10.0 & 11.9 & 10.8 \\
\hline & 100.0 & 100.0 & 100 \\
\hline
\end{tabular}

Phosphorized Fats.-The animal brain and spinal cord, and the yolk of the egger, contain a considerable amount of fat which has long been characterized by a small content of phosphorus. Von Bibra fomm the quantity of phosphorus in this (impure) fat to rance from 1.21 to 2.53 per cent. Knop ( $\left.V_{s} . S t .1,1.26\right)$ was the first to show that analogous phosphorized fats exist in plants. From the sugar pea he extracted 2.5 jer cent of a thick brown oil, which was free from sulphur and nitrogen, but contained 1.25 per cent of phosphorus.

The composition of this oil was as follows:

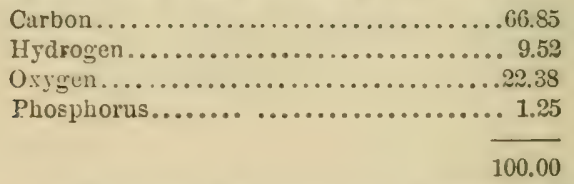

'Töpler (Heineberg's Juhresbericht 1859-1860, p. 161) subsequently examined the rils of a large number of seeds for phosphorus with the subjoined results:

\begin{tabular}{|c|c|}
\hline $\begin{array}{l}\text { Per cent of } \\
\text { phosplorus. }\end{array}$ & $\begin{array}{l}\text { Nor sent } \\
\text { pltosphomis }\end{array}$ \\
\hline Lupine.............29 & Walnut............trace \\
\hline Рea ............17 & Olive..............none \\
\hline Horse bean .......... 0.72 & Wheat.............0.25 \\
\hline Vetch..............0.50 & B:ıley...............28 \\
\hline Winter lentil........0.39 & Rye ...............31 \\
\hline Horse-chestmut...... 0.30 & Oat..............44 \\
\hline Chocolate bean......none & Flax..............nono \\
\hline Millet............ " & Colza............." \\
\hline Рориу............" " & Mustard............ \\
\hline
\end{tabular}


According to Hoppe-Seyler, (Hed. Chem. Unters., I,) the phosphorized principle of oil of maize, and of the brain, nerves, yolk of eggs, etc., is primarily the substance discovered in $186 \pm$ by Liebreich, in the brair and termed rotan. It is a white crystillized body, Laving the following composition :

$\begin{array}{lr}\text { Carbon, } & 67.2 \\ \text { Hydrogren, } & \mathbf{1 1 . 6} \\ \text { Nitrogen, } & 2.7 \\ \text { Plrosphorus, } & 1.5 \\ \text { Oxygen, } & 17.0 \\ & \\ & 100.0\end{array}$

Its formula is $\mathrm{C}_{118}, \mathrm{H}_{241}, \mathrm{~N}_{4}, \mathrm{P}, \mathrm{O}_{22}$. When leated to the boiling point it is decomposed, and yields among other products glyerin, phosphor. ic acid, and stearic acid. (Ann. Ch. Ph., 134, p. 30).

Saponification. - The fits are characterized by forming soaps when heated with strong potash or soda-lye. They are by this means decomposed, an il give rise to futty acids. which remain combined with the alkalies, and to glycerin, a kind of liquid sugar.

Exr. 41.-Heat a bit if tallow with strong solution of caustic jotash until it completely disappears, and a soap, soluble on water, is obtained. To one-half the hot solution of soap, add chlorhydric acid until the latter predomiuates. An oil in ill separate which gathers at the top of the liquid, and on cooling, solidifies to a cake. This is not, lowwever, the original fat. It has a different melting point, and a different chemical composition. It is composed of one or several fatty acids, corresponding to the elementary fits from which it was produced.

When saponified by the action of potash, stearin yields stearic acid, $\mathrm{C}_{33} \mathrm{H}_{36} \mathrm{O}_{2}$; palmitin yields palmitic acich, $\mathrm{C}_{18} \mathrm{II}_{32} \mathrm{O}_{2}$; and olein gives oleic acid, $\mathrm{C}_{18} \mathrm{II}_{34} \mathrm{O}_{2}$. The so-called stearin candles are a mixture of stearic and palmitic acids. The glycerin, $\mathrm{C}_{3} \mathrm{H}_{8} \mathrm{O}_{3}$, that is simultaItenusly produced, remains dissolved in the liquiul. Glycerin is now found in commerce in a nearly pure state, as a zolorless, syrupy liquid, having a pleasant sweet taste.

The chemical act of saponification consists in the re-arraugement of the elements of one molecule of fat and three molecules of water in. to three molecules of fatty acid, and one molecule of fiscerin.

$$
\begin{gathered}
\text { Water. } \\
\text { Palmitin } \\
\mathrm{H}_{38} \mathrm{O}_{6}+3\left(\mathrm{H}_{2} \mathrm{O}\right)-3\left(\mathrm{C}_{18} \mathrm{H}_{32} \mathrm{O}_{2}\right)+\mathrm{C}_{3} \mathrm{H}_{8} \mathrm{O}_{2}
\end{gathered}
$$


Saponification is likewise effected by the influence of strong an ds and by heating with water alone to a temperature of vear $400^{\circ} \mathrm{F}$.

Orlinary soap is nothing more than a mixture of stearate, pal.nitate, and oleate of potash of soda, with or without wlycerin. Common soft soap ensists of the potash eompounds of the above-named acils: unived with glycerin and water. Had soap is usually the correspouding solat-compound, free from glycerin. Then soft potash-soap is 'joiled with common salt (chloricle of sodium), hard soda-soap) and chlo: de of potassium are formed by transposition of the ingredients. On cooling, Eodi-soap forms a solid cake upon the liquid, and the glycerin remains dissolved in the latter.

Relutions of Futs to Amyloids. - The oil or fat of plants is in many cases a product of the transformation of starch or other member of the cellulose group, for the oily seeds, when immature, contain starch, which vanishes as they ripen, and in the sugar-cane the quantity of wax is said to be largest when the sugar is least abuniant, and vice versa. In germination the il of the seed is converted back again into starch, sugar, etc.

The Estimation of Fat (including wax) is made by warming the pulver. ized and dry substance repeatedly with renewad quantities of ether, or sulphide of (:urbon, as long as the solvent tanes ap anything. On evaporating the solutions, the fat remains nearly in a state of purity, and after drying thoroughly, may be weighed.

PROPORTIONS OF FAT IN VARIOUS VEGETABLE PRODUCTS.

\begin{tabular}{|c|c|c|c|}
\hline Per cent. & \multicolumn{3}{|r|}{ Per cent } \\
\hline Meadow grass............0.8 & Turni & $\ldots .$. & $\ldots 0.1$ \\
\hline Red clover (green).......0.7 & Whea & kern & .... 1.6 \\
\hline Cabbage................4 & Oat & " & .... 1.6 \\
\hline Mendow hay............3.0 & Maize & " & .... 7.0 \\
\hline Clover hay..............3.2 & Pea & “ & $\ldots 3.0$ \\
\hline Wheat straw............ & Cotto & seed & ... 34.0 \\
\hline Oat straw $\ldots \ldots \ldots \ldots \ldots \ldots .0$ & Flax & “ & $\ldots 34.0$ \\
\hline Wheat bran............. 1.5 & Colza & & ..........45.0 \\
\hline Potato tuber............ 0.3 & & & \\
\hline
\end{tabular}

6. The $\Lambda$ libunnoms or Protein Bodies.-The bodie of this class differ from the groups hitherto noticed in the fact of their containing in addition to carbon, oxygen, and hydrogen, 15 to 18 per cent of nitiogen, with a small quantity of sulphur, and, in some cases, phosphorus. 
In plants, the Protein Bodies occur in a variety of modifications, and though found in small 1 ,roportion in all their parts, being everywhere necessary to growth, they are chicfly accumulated in the seeds, especially in those of the cereal and leguminous grains.

The albuminoids, as we shall designate them, that occur in plants, are so similar in many characters, are, in fact, so nearly identical with the albuminoids which constitute a large portion of every animal organism, that we may advantageously eonsider them in connection.

IVe may describe the most of these bodies under three sul-groups. The type of the first is albumin, or the white of egg; of the second, fibrin, or animal muscle; of the third, casein, or the curd of milk.

Common Characters.-The greater number of these substances oceur in several, at least two, modifications, one soluble, the other insoluble in water.

In living or undecayed animals and plants we find the albuminoids in the soluble, and, in fact, in the dissolved state. They may be obtained in the solid form by evaporating off at a gentle heat the water which is naturally associated with them. They are thus mostly obtained as transparent, colorless or yellowish solids, destitute of odor or taste, which dissolve again in water, but are insoluble in alcohol.

Recently, both in the animal and vegetable, soluble alhuminoids have been observed in colorless or red crystals, (or crystalloids,) often of considerable size, but so assoiated with other bodies as, in general, not to admit of sep" wation in the pure state.

The insoluble albuminoids, some of which also occur naturally in plants and animals, are, when purified as much as possible, white, flocky, lumpy or filrous bodies, quite odorless and tasteless.

As further regards the deportment of the aibuminoids towards solrents, some are dissolred in alcohol, none in ether. They are soluble in 
pulath aud soda.lye; acids separate them from these solutions, strcug acutir acid dissulves them with one exception. In very dilute mineral acids (sulpinuric and chlorhydric) some of them dissolve in great part, others swell up like jelly.

Cougulation.-A remarkable characteristic of the group, of hodies now under notice is their realy conversion from the soluble to the insoluble state. In some cases this coagulation happens spontaneously, in others by eleration of temperature, or by contact with acids, metallic oxides, or various salts.

The albuminoids, when subjected to heat, melt and burn with a smoky flame and a peculiar odor-that of burnt hair or horn,-while a shinung charcoal remains which is difficult to consume.

Tests for the Albuminoids.-The chemist employs the bebavior of the albuminoids towards a number of reagents * as tests for their presence. Some of these are so de!icate and characteristic as to allow the distinction of this class of substances from all others, even in microscopic observations.

1. Todine colors them intensely yellow or bronze.

2. Warm and strong chlorhydric acid coiors all these bodies blue or riolet, or, if applied in large excess, dissolves them to a liquid of these colors.

3. In contact with nitric acill they are stained a deep and vivid yellow. Silk and wool, which consist of bodies clusely approaching the albuminoirls in composition, are commonly dyed or printed yellow by menus of nitric acid.

4. A solution of nitrate of mercury in excess of nitric acid, + tinges them of a deep red color. This test enables us to detect albumin, for eximple, even where it is dissolved in 100,000 parts of wates.

Albumin.-Animal Albumin.-'The white of a hen's egg on drying yields about 12 per cent of albumin in a state of tolerable purity. The fresh white of egg serves

* Reagents are subutances commonly employed for the recognition of bodins, or, generally, to produce chemical changes. All chemical phenomena reBult from the mutual action of at least two elements, which thus act and react on each other. Ifeuce the rubstance that excites chemical changes is termed a reacrent, and the phenomena or resizlts of its application are called reactions.

+ This solution, known as Millon's test, is prepared by dissolving mercury In its own weight of nitric acid of 8 p. gr. 1.4, heating towarls the close of the process, and unally addiug to the liquid twice its bulk of water. 
to illustrate the peculiarities of this substance, and to exhibit the deportment of the albuminoirls generally towards the above-named reagents.

Exr. 42.-Beat or whip the white of an egg so as to destroy the deli. cate transparent membrane in the cell of which the albumin is held, aud agitate a portion of it with water; observe that it dissolves readily in the litter.

Exp. 43.-Heat a part of the uncliluted white of egg in a tube or cup at $165^{\circ} \mathrm{F}$; it hecomes opaque, white, and solid, (coarulates) and is converted into the insoluble molification. A hivher heat is needful to congulate solutions of albumin, in proportion as they are diluted with water.

Exr. 44.-Add strong alcohol to a portion of the solution of albumin of Exp. 42. It produces congulation.

ExP. 45.-Observe that albumin is coagulated by dilute acids applied In small quantity, especially by nitric acid.

ExP. 46.-Put a little allumin, either soluble or congulated, into each of four test tubes. To one, add solution of iodine; to a second, strong chlorhydric acid; to a third, nitric acid; and to the last, nitrate of mercury. Observe the charicteristic colorations that appear immediately, or after a time, as described above. In the last three cases the reaction is hastened by a gentle heat.

Albumin occurs in the soluble form in the blood, and in all the liquids of the healthy animal body except the urine. In some cases its characters are slightly different from those of egg-albumin. The albumin of the blorl, which may be separater by heating blood-serum (the clear yellow liquid that floats above the clot), contains a little less sulphur than coagulated egg-albumin. In the crystalline lens of the eye, anit in the blood corpuscles, the albumin has again slightly different characters, and has been termed globulin. Under certain conditions the blood of animals yields a substance known as hoemoglolin, which, while having nearly the composition and many of the properties of albumin, commonly requires a much larger proportion of water for solution, and forms distinct crystals of a transparent red color.

Vegetable Albumin.-In the juices of all plants is found 2 minute quantity of a substance which agrees in nearly all respects with animal albumin. and is hence termed 
vegetable albumin. The clear juice of the potativ tuiber (which may be procured by grating potatoes, squeczing the pulp in a cloth, and letting the liquor thus obtained stand in a cool place until the starch has deposited,) con. tains albumin in solution, as may be shown by heating to near the boiling point, when a coagulum separates, which, after boiling suceessively with alcohol and ether to remove fat and coloring matters, is scarcely to be distinguished, either in its chemical reactions or composition from the congulated albumin of eggs.

The juice of succulent vegetables, as cabbage, yields vegetable albumin in larger quantity, though less pure, by the same treatment.

Water which has been agitated for some time in contact with flour of wheat, rye, oats, or barley, is found by the same method to have extracted albumin from these grains.

The coagulum, thus prepared from any of these sources, exhibits the reactions characteristic of the albuminoids, when put in contact with nitrate of mercury, nitric or chlorhydric acid:

ExP. 47.-Prepare impure reget:ule albumin from potatoes, cabliage, or tlour, as above described, and apply the nitrate of mercury test.

Fibrin.-Blood-Fibrin.-The blood of the higher animals, when in the body or when fresh drawn, is perfectly. fluicl. Shortly after it is taken from the veins it partially solidifies - it coagulates or becomes clottert. It hereby s"parates into tro portions, a clear, pale-yellow liquidthe serum, and the clot. As already staterl, the serum contains albumin. The clot con-istis ehrefly of filmm. On squeezing and washing the clot with water, the coloring matter of the blood is removed, and a white stringy mass remains, which is one form of the substance in question. Blood-fibrin is not known in the soluble state, except in fresn blood, from which it camnot be separated, as it so soon coagulates spontaneously.

Prepared as just described, fibrin has many of the propertiez of albumin. Placed in a solution of saltpeter, espe- 
cially if a little potash lye be added, it dissolves in a few days to a clear liquid, which coagulates on heating or by addition of metallic salts, in the same manner as a solution of albumin. In very dilute chlorhydric acid, it swells u] b but does not dissolve.

Exr. 48.-Observe the separation of blood into clot and se:um; c3. agulate the albunin of the former by heat, and test it with warm chl. p hydric acid. Tie up the clot in a piece of unslin, and squecze and wash in water until coloring mitter cease's to run off. Warm it with natric icit as a test.

Flesh-fibrin.-If a piece of lean beef or other meat be repeatedly squeezed and washed in water, the coloring matters are gradually removed, and a white residue is obtained, which resembles blood-fibrin in its external characters. It is, in fact, the actual fibers of the animal muscle, and hence its name. It is characterized by dissolving in very dilute chlorhydric acid, (one part acil and 1,000 of water) to a clear liquid, from which it is again separated by carefiul addition of an alkali, or a solution of common salt.

Vegetable-fibrin.-When wheat-flow is mixed with a little water to a thick dough, and this is washed and kneaded for some time in a vessel of water, the starch and albumin are mostly removed, and a yellowish, tenacious mass remains, which bears the name gluten. When wheat is slowly chewed, the saliva carries off the starch and other matters, and the gluten mixed with bran is left behindwell-known to country lads as "wheat-oum."

Exp 49.-Wet a handful of good, fresh, whent flour slowly with a little water to a sticliy dough, and squeeze this under a fine stream of Fater until the latter runs off clear. Heat a portion of this gluten with Villon's test.

Gluten is a mixture of several albuminoids, and contains besides some starch and fat. Vegetable-fibrin is dissolved from it by alcohol, and separates on removing the alerho] by evaporation.

The albuminoids of crude gl:-ten dissolve in very dil ite potash-lye 
(one to one arrel one-half parts potash to 1000 parts of mater), and the lifuid, after stumling some dass at rest, may be poured off from any rexidue of starch. On adeline acetic aciu in slight excess, the purified albumiroids are separated in the solid state. 13y extracting suecese sively with weak, with strong, and with absolute alcohol, a form of easein (gluten-casein of Ri thausen) remains undissolved, which is perb: ns identical with the zasein (legumin) of the pea.

On evaporating ihe alcoholic solution to one-half, there separates, on cooling, a brownish.yellow mass. This, when treated with absolute alcohol, leaves vegetable-fibrin netrly pure.

Vegetable-fibrin is readily soluble in hot alcohol, but slightly so in cold alcohol. It does not at all dissolve in water. It has no fibrous structure like animal fibrim, but forms, when dry, a tough, horn-like mass. In composition it approaches animal-fibrin.

Casein.-Animal casein is the peculiar ingredient of new cheese It exists dissolved to the extent of 3 to 6 per cent in fresh milk, unlike albumin is not congulated by heit, but is coagulated by acids, by rennet, (the membrane of the calf's stomach), and by heating to boiling with salts of lime and magnesia.

ExP. 50.-Observe the coagrulation of casein when milli is treated with a few drops of sulphuric acid. Test the curd with nitrite of mercury.

Exr. 51.-Boil milk with a little sulphate of magnesia (epsom salts) until it curdles.

When casein is separated from milk by rennet, as in making cheese, it carries with it a considerable portion of the phosphates and other salts of the milk; these salts are not found in the casein precipitated by acids, being held in solution by the latter.

The casein of milk coagulates spontaneously when it stands for some time. Casein has recently been detected in the brain of animals. (IIoppe-Seyler, Metl. Chem. Unters., II.)

Vegetable casein.-This substance is found in large proportion ( 17 to 19 per cent) in the pea and bean, and indeed generally in the seeds of the so-called leguminour plants. It closely resembles milk-casein in all respects. 
ExP 52.-Prepare a solution of vegetable casein from crushed peas, oats, almonds, or pea-nuts, liy soaking them for some hours in warm water, and allowing the liquid to settle clear. Congulate the cascin by addition of an acid to the solution. It may be congulated by rennet, and liy salts of magnesia and lime, in the same manner as animal casein.

The Chinese prepare a vegetable cheese by boiling peas to a pap, straining the liquor, adding eypsum until coagulation occurs, and treating the curd thus obtained in the same manner as practiced with milk-cheese, viz.: salting, pressing, and keeping until the odor and taste of cheese are doveloped. It is cheaply sold in the streets of Canton under the name of Tao-foo. Vegetalle casein occurs in small quantity in oats, the potato, and many plants; and may be exhibite l by adding a few drops of acetic acid to turnip juice, for instance, which has been freed from albumin by boiling and filtering. The casein from peas and leguminous seeds has been designated legumin, that of the oat has been named avenin. Almonds yield a casein, which has been termed emulsin. As already mentioned, casein (Ritthausen's gluten-casein) exists in wheat-gluten, and in rye. Each of these sources yields a cissein of somewhat peculiar characters; the causes of these differences are not yet ascertained, but probably lio in impurities, or result from mixture of other albuninoids.

In crude wheat-gluten two other albuminoids exist, viz. :

Gliadin, or vegetable glue, is very soluble in water and alcohol. It strongly resembles animal glue.

Mucidin resembles gliadin, but is less soluble in strong alcohol, and is insoluble in water. When moist, it is yellowish-white in color, has a silky luster, and slimy consistence. It exists also in rye grain. (Ritthausen, Jour. für Prakt. Chem., 88, 141; and 99, 463.)

Composition of the Albuminoids.-There are varions rensons why the exact composition of the bodies just described is a subject of uncertainty. They are, in the first place, naturally mixed and associated with other matters 
from which it is very difficult to separnte them fully Again, if we succeed in remoring foreign substances, it must uspially be done by the aid of acids, alkalies, and other strong reagents, which easily alter or destroy their proper charicters and composition. Finally, if we analyze the pure substances, our methods of analysis are perhapis Ecarcely delicate enough to indicate their differences with entire accuracy.

The results of chemical investigation demonstrate that the albuminoids are either identical in composition or differ but slightly from each other, as is seen from the Table below. The deduction of a correct atomic formula from these analyses is perhaps impossible in the present state of our knowledge.

In the subjoined Table are griven analyses of the albuminoids which have been dweribed. Those inclicated by asterislis are recent results of Dr. Ritthamsen; the others are averare statements of the best analy'ses, (after Gorup-Besanez, Org. Chemie, p. 611.)

\section{COMPOSITION OF ALBUMINOIDS.}

Carbon. Hydrogen. Nitrogen. Oxygen. Su'phur.

\begin{tabular}{|c|c|c|c|c|}
\hline Animal albumir & .....53.5 & 7.0 & 15.5 & 22.4 \\
\hline Vegetable albun & 1iı....53.4 & 7.1 & 15.6 & 23.0 \\
\hline Blood fibrin.... & $\ldots \ldots 526$ & 7.0 & 17.4 & 21.8 \\
\hline Flesh fibrin.... & ......54.1 & 7.3 & 16.0 & 21.5 \\
\hline Whent fibrin*. & $\ldots . .554 .3$ & 7.2 & 16.9 & 20.6 \\
\hline Animal cnsein. & $\ldots \ldots 53.6$ & 7.1 & 15.7 & 22.6 \\
\hline Vegetable caseir & $1 . \ldots .50 .5$ & 6.8 & 18.0 & 24.2 \\
\hline Gluten-casein*? & .....51.0 & 6.7 & 16.1 & 25.4 \\
\hline Gliadin* & wheat 52.6 & 7.0 & 18.1 & 21.5 \\
\hline Mucedin* & $\ldots \ldots . .54 .1$ & 6.9 & 16.6 & 21.5 \\
\hline
\end{tabular}

Phosphorus is not included in the above table, for the reason that In all cases its quantify, and in most instances its very presence, is still $\mathrm{nn}$ certain. Voelclier and Norton found in regetable cusein 1.4 to 2.3 per cent of plusphorus, and smaller quantities bave been mentioned ly otleer of the older analysts as oceurring in albumin and fibrin. The phosphorm of these and of animal cascin is thomght not to belong to the albuminoid, but to be due to an admixture of phosphote of lime.

In lis recent investigation of gluten-casein, Ritthitusen found phos. phoric acid that appears to have been partially uncombined with a fixed hase, and to have therefore resulted from phosphorus in organic combi 
nation. It is not unlikely that regretable casein may contair an admix. ture of pivtayon (p. 93), or the liroducts of its decomposicion, from which it is not easy to procure a sepuratiou.

Mutual Relutions of the Hlouminoids. - Some have supposed that these borlies are illentical in composition, the differences among the analytical results being due to foreign matters, and differ from each other in the same, way that cellulose and starch differ, viz.: on account of different arrangement of the atoms. Other's formerly adopted the notion of Mulder, to the efiect that the albuminoids are compounds of various proportions of hypothetical sulphur and phosphorus compound, with a common ingredient, which he termed protein, (from the Greek signifying "to take the first plawe," because of the great physiological importance of such a body.) Hence the albuminoids are often called the protein-bodies. The transformations which these sulstances are capable of undergoing, sufficiently show that they are closely related, without, however, satisfactorily indicating in what manner.

In the animal organism, the albuminoids of the food, of whatever name, are dissolved in the astric juice of the stomach, and pass into the blowd, where they form bloodalbumin and blood-fibrin. As the bluoul nomishes the inuscies, they are modified into flesh-fibrin, or entering the lacteal system, are converted into casein, while in the ap. propriate part of the circulation they are formed into the albumin of the egg, or embryo.

In the living plant, similar changes of place and of char. acter occur among these substances.

Finally, outside the organism the following transforma tions have been observer: Flesh-fibrin exposed while moist to the air at a sumn er tumperature for some days, dissolves into a liquid; it this liquid be heated to near boiling, coagulation takes place, and the substance which separates has the propertics of albumiu. On removing the albumin and arling vinegar to the remaining liguit, 
a curdy coagulum is formed, which agrees in its properties mith casein. (Bopp, Ann. Ch. Ph., 60, p. 30; Gunnmg, Jour. fur Prakt. Chem., 69, p. 52.)

Lehmann has shown that when albumin is dissolved in potash, and mixed with a little milk-sugar and oily fitt, the mixture coagulates with rennet exactly as milk curdles. (Gorup-Besanez, Phys. Chem., p. 139.)

Sullivan has observed that the casein of milk which was kept in closed air-tight vessels for a long time, at first coagulated, but afterward dissolved again to a nearly clear liquid, which was found to contain no casein, but by heating, coagulated, showing the conversion of easein into albumin, or a similar bolly. (Phil. Murg., 4, XVIII, :03.)

Some maintain that easein is not a distinct albuminoid, but a compound of albumin with potash, containing, accorting to Lieberkühn, $\left.5.55^{\circ}\right|_{0}$ of this alkali. Its peculiarities are in part due to its natural association with phosphate of potash. Kühne, Phys. Chem., 1868, p. 565. See, however, Schwarzenbach, Ann. Ch. u. Ph., 14t, p. 63.

The Albuminoids in Animal Nutrition.-We step asirle for a moment from our proper plan to direct attention to the beantiful adaptation of this group of organic substances to the nutrition of animals. Thiose bodies which we have just notieen as the animal albuminoids, together with others of similar composition, constitute a large share of the healthy animal organism, and especially characterize its actual working machinery, being essential ingrediente of the museles and cartilares, as well as of the nerves and brain. They likewise exist largely in the nutritive fluids of the animal-in lylood and milk. So far as we know, he animal body has not the power to produre a particle of albumin, or fibrin, or casein; it can only transform these bodies as presented to it from external sources. They aro hence indispensable ingreelients of food, and have been aptly designated by Lickig as the plastic elements of motrition. It is, in all cases, the plant which originally con. 
structs these substances, and places them at the disposal of the animal.

The albuminoids are mostly capable of existing in the liquid or soluble state, and thus admit of distribution throughont the entire animal body, as blood, etc. They likewise readily assume the solid condition, thus becoming more permanent parts of the living organism, as well as capable of inlefinite preservation for food in the seeds and other edible parts of plants.

Complexity of Constitution.-The albuminoids are highly complex in their chemical constitution. This fact is shown as well by the multiplicity of sibstances which may be produced from them by destructive and decomposing processes, as by the ease with which they are broken up into other and simpler compounds. Subjected in the soluble or moist state to the action of warm air, they speedily decompose or putrefy, yiclding a large varicty of products. Heated with acicis, alkalies, and oxilizing agents, they all give origin to the same or to analogous products, among which no less than twenty different compounds have been distinguished.

Occurrence in Plants-Aleurone. - It is only in the old and virtually dead parts of a living plant that albuminoids are ever wanting. In the young and growing organs they are abundant, and exist dissolved in the sap or juices. They are especially abundant in seeds, and here they are deposited in an organized form, chiefly in grains similar to those of starch, and are nearly or altogether iusoluble in water.

These grains of albuminoid matter are not, in many cases at least, pure albuminoids. They appear to contain vegetable albumin, casein, fibrin, etc., associated together, though, in general, casein and fibrin are largely predominant. ITartig, who first described them minutely, has distinguished them by the name aleurone, a term which we may conveniently employ. By the word alcurone is not $5^{*}$ 
meant simply an albuminoid, or mixture of albuminoids, but the organized granules found in the plant, of which the albuminoids are chief ingredients.

In Fig. 18 is represented a magnified slice through the outer cells, (bran,) of a husked oat kernel. The cavities of these outer cells, $a, c$, are chicfly occupied with very

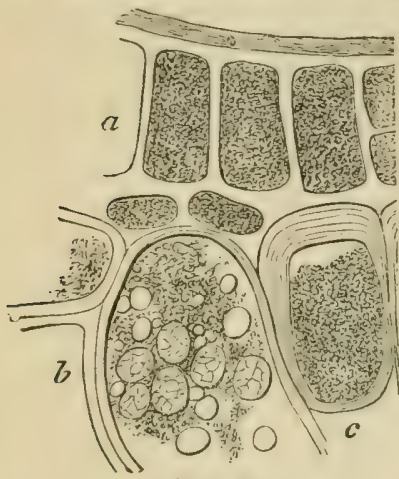

Fig. 18.

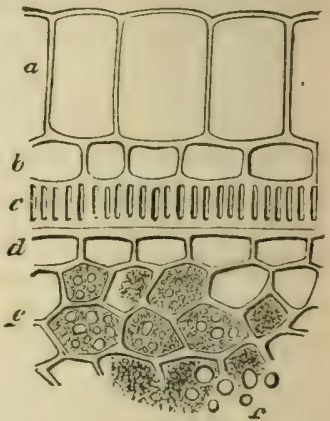

Fig. 19.

fine grains of aleurone, (casein.) In one cell, $b$, are seen the much larger starch grains. In the interior of the oat kerncl and other cereal seeds, the cells are chiefly occupied with st:rch, but throughout grains of aleurone are more or less intermingled.

Fig. 19 exhibits a section of the exterior part of a flaxseed. The outer cells, a, contain vegetable mucilage; the interior cells, $e$, are mostly filled with minute grains of aleurone, among which droplets of oil, $f$, are distributed.

In Fig. 20 are shown some of the forms assumed by individual albuminoidgrains ; $a$ is aleurone

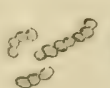
$\sigma^{\circ}$ a from the seed of the vetch, $b$ from the castor bean, $c$ from flax-seed, $d$ from the fruit of the baybery, (Myrica 
cerifer $a$, and $e$ from mace, (an appendage to the nutmeg, or fruit of the Myristica moschata.)

Crystalloid aleurone.-It has been already remarked that crystallized albuminoids may be obtained from the blood of animals. It is equally true that bodies of similar character exist in plants, as was first observed by Hartig, (Entwickelungsgeschichte des Pflanzenkeims, p. 104.) In form they sometimes imitate crystals quite perfectly, Fig. $21, a$; in other cases, $b$, they are rounded masses, having some crystalline plimes or facets. They are soft, yield easily to pressure, swell up to double their bulk when
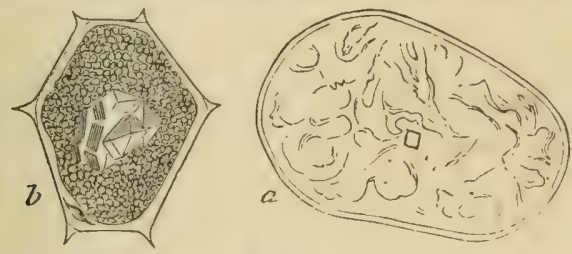

Fig. 21.

soaked in weak acids or alkalies, and their angles have none of the constancy peculiar to proper crystals. Therefore the term crystrbloid, i. c. having the likeness of crystals, is more appropriate than crystallized.

As Cohn first noticel, (Jour. für Prukt. Chem., so, p. 129,) crystalloid aleurone may be observed in the outer portions of the potato tuber, in which it invariably presents a cubical form. It is hest found by examining the cells that arhere to the rind of a potato that has been boiled. In Fig. 21, a represents a cell from a boiled potato, in the centre of which is seen the cube of aleurone. It is surrounded by the exfoliated remnants of starchgrains. In the same figure, $b$ exhibits the contents of a cell from the seel of the bur reed,(Sparganium ramosum, a plant that is common along the borders of ponds. In the center is a comparatively large mass of aleurone, having crystalloid facets. 
According to Maschke, (Jour. für Pr. Ch. 79, p. 148, ) the crystalloid aleurone that is abundant in the Brazil nut, is a compound of casein with some acid of unknoron composition. This aleurone may be dissolved in water, and recorered in its original form on evaporation.

Kubel's analysis of aleurone, prepared from the Brazil nut by Hartig, gave its content of nitrogen $9.46 \mathrm{per}$ cent. Aleurone from the yellow lupin yielded him 9.26 per cent. Since pure casein has 16 to 18 per cent of nitrogen, the aleurone contained about 52 to $59 \mathrm{per}$ cent of albuminoids.

Estimation of the Alluminoids.-The quantitative separation of these bodies is a matter of great difficulty and uncertainty. For most purposes their collective quantity in any organic substance may be calculated with sufficient accuracy from its content of nitrogen. All the albuminoids contain, on the average, alout $16 \mathrm{per}^{\mathrm{c}}$ cent of nitrogen. This divided into 100 gives a quotient of 6.25. If, now, the percentage of nitrogen that exists in a given plant be multiplied by 6.25, the product will represent its percentage of albuminoids, it being assumel that all the nitrogen of the plant exists in this form, which in most cases is prac. tically true.

Frühling and Grouven have recently investigated the condition of the nitrogen of various plants, and have found that nitric acid, $\left(\mathrm{N}_{3} \mathrm{O}_{5}\right)$ which in the form of nitrate of potash has long been known to occur in vegetation, is present in but trifling quantity in most agricultural plants. In mature clover, esparsette, lucern, whear, rye, onts, barley, the pen, and the lentil, it did not exceed 2 parts in 10,000 of the air-iry plant. In maize, they found twice this quantity ; in beet and potato tops alone of all the plants examined was nitrie acid present to the amount of fourtenths of one per rent, ( $\nabla s$. St., IX, 153.) Silts ot ammonic (N II $)$ likewise often exist in plants, but as a rule in quite inconsiderable quantities. 
AFRUAGE QUANTITY OF ALEUMTNOIDS IN VARIOCS VEGETABLE F LODUTTS per cent.

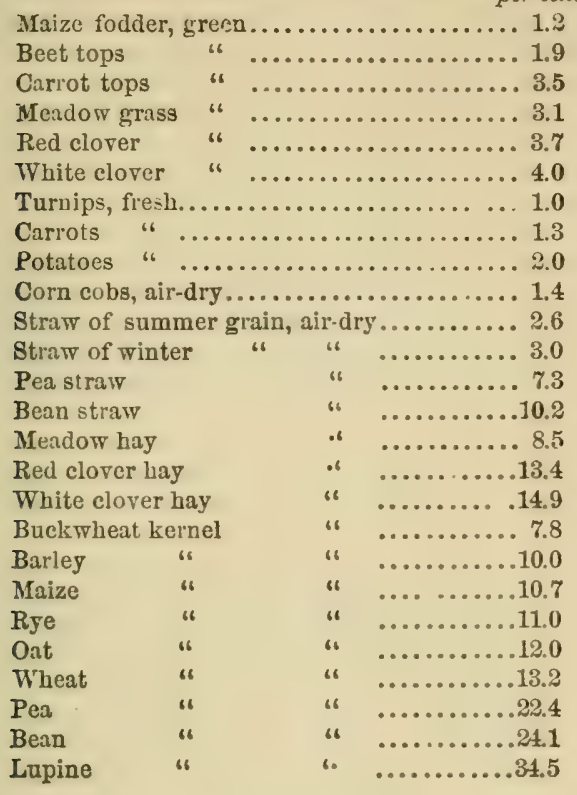

\section{APPENDIX TO \&4.}

\section{ChLoropityll : TANNIN : Alikatordos.}

Before dismissing the subject of the Proximate Elements of plants, we East notice several other substances of subordinate agricultural interest. Two of these, viz., Chlorophyll and Tannin, though not figuring in the analysis of agricultural plauts, are nevertheless of almost universal oceurrence in all forms of vegetation, though usually in very minnte quantity.

Chloroplnyl, i. e. leaf-green, is the name applied to the suistance Thich azcasions the green color in regetation. It is found in all the surface of annual plants and of the annually renewed parts of perennial plants. It might readily be supposed that it constitutes a large portion of the leaves of regetation, but the fact is quite otherwise. 'The green 
parts of plants usunlly contain chloropligll only at their surface. anu in quantity no greater than colored falsrics contain the particles of dye.

Chlorophyll being soluble in ether, accompanies fat or wax when these are removed from green regetable matters by this solvent. It is soluule in chlorhydric and sulpluric acids, impirting to these liquids its intense gren color. According to Pfaundler, the (impure?) chlorophyll of grass kas the following percentuge composition:

$\begin{array}{lr}\text { Carbon } & 60.85 \\ \text { Hydrogen } & 6.39 \\ \text { Oxygen } & 32.78\end{array}$

Fromy has shown that chlorophyll may be easily decomposed into two coloring matters, a yellow, Zanthophyll, and a blue, Cyanophyll. This is accomplished by treating chlorophyll with a mixture of chloriygdric acid and ether; the cynophyll dissolves in the latter, and the zauthophyli is taken up by the former solvent. The yellow color of autumn leares is perhaps due to zanthophyll.

According to Sachs, there exists in those parts of plants, which, though not green, are capable of becoming so, a colorless substance, Leucophyll, which, in contact with oxygen, acquires a green color, being converted into chlorophyll.

Tannin is the general designation of the bitter, astringent priuciples, (used in leather-making,) of the bark and leaves of the hemlock, oak, sumach, plum, pear, and many other trees, of tea, coffee, and of gall-nuts. It is found in small quantity in the young bean plant, and in many germinating seeds.

Tannin is elosely related to the carbohydrates, as is demonstrated alike by the microscopic study of its development in the plant, nud by our knowledge of its chemical composition. The tamnins are weak acids, and are distinguished, according to their origin, as Gallotannic acid (from nut-galls), Caffeotannic acid (from coffee), Quercitannic acid (from the oak), ete. As already hintecl, the tannins are Cllucosides, or compounds of sugar, with some other substance In gall-tannin the sugar is glucose, and the substance associated with, or rather yielded by it on decomposition, is known as Gallic acid. By boiling gall-tannin with a dilute :teid, or hy subjecting its solution to fermentation, decom. position into the two substances named is aceumplisised.

According to Strecker, the composition of gall-tannin and this conversion are indicated by the following formulæ:

$$
\begin{gathered}
\text { Tannin. } \\
2\left(\mathrm{C}_{27} \mathrm{H}_{22} \mathrm{O}_{17}\right)+8\left(\mathrm{H}_{2} \mathrm{~J}\right)=6\left(\mathrm{C}_{7} \mathrm{H}_{8} \mathrm{O}_{5}\right)+\mathrm{C}_{12} \mathrm{H}_{24} \mathrm{O}_{12}
\end{gathered}
$$

The Arkatords are a elass of bodies very numerous in poisonous and meticina! ylants, of which they usually constitute the active principle. Thuse which have an arricultural interest are Nicotin, Caffein, and Theobromin.

Ficolin, $\mathrm{C}_{10} \mathrm{H}_{14} \mathrm{~N}_{2}$, is the uarcotic and extremely poisonuus principle ? $\mathrm{a}$ tobacco, where it exists in combination with nalic and eitrio 
acids. In the pur state it is a colorless, oily liquid, having the odos of tobacco in an extreme degree. It is inflummable and volitile, aud so deadly that $a$ single drop will kill a large dog. French tolıcco cont.ing 7 or 8 p. c., Virgivia, 6 or 7 p. c.; and Maryland and Haranna, about « p. c. of nicotin. Nicotin contiins 17.3 p. c. of nitrogen, but no vxygen.

Canfein, $\mathrm{C}_{8} \mathrm{H}_{10} \mathrm{~N}_{4} \mathrm{O}_{2}$, exists in cuffee and ten combined witu tannic acid. In the pure state it forms white, sillyy, fil,rous crystals, and has a bitter taste. In coffee it is found to the extent of one-hilf per cent; is tea it occurs in wuch larger quantity, sometimes as himb as 6 per cent.

'Nheobromin, $\mathrm{C}_{7} \mathrm{H}_{3} \mathrm{~N}_{4} \mathrm{O}_{2}$, resembles caffein in its characters, and is closely related to it in chemical composition. It is found in the cacao-bean, from which chocolate is manufuctured.

The alkaloids are remarkable from coutaining nitrogen, and from havjng stronely basic chiracters. They derive their desiguation, alkaloids, from their likeness to the alkalies.

\section{CHAPTER II.}

\section{THE ASH OF PLANTS.}

\section{$\S 1$.}

\section{THE INGREDIENTS JF THE ASH.}

As has been stated, the volat le or destructible part of plants, $i . e$. the part which is converted into gases or vapors under the ordinary conditions of burning, consists chiefly of Carbon, Hydrogen, Oxygen, and Nitrogen, together with minute quantities of Sulphur and Phosphorus. These elements, and such of their compounds as are of general occurrence in agricultural plants, viz., the Organic Proximate Principles, have been already described in detail.

The non-volatile part or ash of plants also contains, or may contain, Carbon, Oxygen, Sulphur, and Phosphorus. It is, however, in general, chiefly made up of eight other elements, whose common compounds are fixed at the ordinary heat of burning. 
In the subjoined table, the names of the 1: elements of the ash of plants are given, and they are grouped under two heads, the non-metals and the metals, by reason of an important distinction in their chemical nature.

eleMeNTS OF THE ASH OF PLANTS.

Non-Metals.

Oxygen

Carbon

Sulphur

Phosphorus

Silicon

Chlorine
Metals.

Potassium

Sodium

Calcinm

Magnesium

Iron

Manganese

If to the above be added

Hydrogen and Nitrogen

the list includes all the elementary substances that belong to agricultural vegetation.

Hydrogen is never an ingredient of the perfectly burned and dry ash of any plant.

Nitrogen may remain in the ash under certain conditions in the form of a Cyanide, (compound of Carbon and Nitrogen,) as will be noticed hereafter.

Besides the above, certain other elements are found, either occasionally in common plants, or in some particular kind of vegetation: these are Iodine, Bromine, Fluorine, Titinium, Arsenic, Lithium, Rubidium, Barium, Alıminum, Zinc, Copper.

We may now complete our study of the Composition of the Plant by attending to a description of those elements that are peculiar to the ash, and of those compounds which may occur in it.

It will be convenient also to describe in this section some substance, which, although not ingredients of the ash, may exist in the plant, or are otherwise important to be considered.

The non-metallic elements, which we shall first no. tice, though differing more or less widely among themBelves, have one point of resemblance, viz., they and their compounds with each other have acid properties, $i$ e. they 
either are acids in the ordinary sense of being sonr to the taste, or enact the part of acids by uniting to metals or metallic oxides, to form salts. We may, therelore, desicr. nate them as the acid elemonts. They are Oxygen, Sulphur, Phosphorus, Carbon, Silicon, and Chlorine. (Less com. mon are Arsenic, Titanium, Iodine, Bromine, and Fluorine.)

With the exception of Silicon, (and Titanium,) and the denser forms of Carbon, these elements by themselves are readily volatile. Their compounds with each other, which may occur in vegetation, are also volatile, with two exceptions, viz, Silicie and Phosphoric acids.

In order that they may resist the high temperature at which ashes are formed, they must be combined with the metallic elements or their oxides as salts.

Oxygen, Symbol O, atomic weight 16, is an ingredient cf the ash, since it unites with nearly all the other elements of vegetation, either during the life of the plant, or in the act of combustion. It unites with Carbon, Sulphur, Phosphorus, and Silicon, forming acid bodies; while with the metals it produces oxides, which have the characters of bases. Chlorine alone of the elements of the plant does not unite with oxygen, either in the living plant, or during jts combustion.

\section{CAREON AND ITS COMPOUNDS.}

Carbon, Sym. C, at. wot. 12, has been noticed already with sufficient fulness, (p. 31.) It is often contained as charcoal in the ashes of the plant, owing to its being enveloped in a coating of fused saline matters, which shield it from the action of oxygen.

Carbonic acid, Sym. C O , molecular weight, 44, is the volorless gas which causes the sparkling or effervescence of beer and soda water, and the frothing of yeast.

It is formed by the oxidation of carbon, when vegetable matter is lunned, (Exp. 6.) It is, therefore, found in the ash of plants, combined with those bases which in the liv. 
ing organism existed in union with organic acids; the lat ter being destroyed by burning.

It also occurs in combination with lime in the tissues of many plants. Its compounds with bases are cerbonates to be noticed presently. When a carbonate, as marble or limestone, is drenched with a strong acil, like vinegar on muriatic acid, the carbonic acid is set free with effervescence

Cyanoger, Sym. CN. - This important compound of Carbon and Nitrugen is a gats which has an odor resembling that of pench-pits, and which burns on contact with a lighted taper with a fine purple flame. In its union with oxygen by combustion, curbonic acid is formed, ana nitrogen set free,

$$
\mathrm{CN}+2 \mathrm{O}=\mathrm{CO}_{2}+\mathrm{N} \text {. }
$$

C5anoren may be prepared by heating an intimate mixture of two parts jy weight of ferrocyanide of potassium, (Jellow prussiate of potash,) and three parts of corrosive sublimate. The operation may be conducted in a test tube or small flask, to the mouth of which is titted a cork pene. trated by a narow grass tube. On applyinu heat, the gas issues, and may be set on fire to observe its beantiful tlime.

Cyanogen, cumbined with iron, forms the Prussian blue of commerce. and its name, sinnifying the blue-producer, was giren to it from that circumstance.

Cyanogen unites with the metallic elements, griving rise to a series of bodies which are termed Cyanides. Some of these often occur in small quantity in the ashes of plants, being produced in the act of burning by the union of nitrogen with ca!bon and a metal. For this result, the ten:perature must be very high, carbon must be in exeess, the metal is unually potassium or calcium, the nitrogen may be either free nitrogen of the atmospluere or that oriminaly existing in the organic matter.

IVith hydroyen, eyanogen forms the deadly poison hydrocyanic or prusBic acid, $\mathrm{H} \mathrm{Cy}$, which is produeed from amygrdaline, one of the ingredients of bitter almonds, peach, and chery seeds, when these are crush. ed in contact with water.

When a cyanide is brought in contact with stean at high temperatures, 't is decomposed, all its nitrogen being converted into ammonia.

Cyanogen is a normal ingredient of one common plant. The on of mustard is the sulpho-cyanide of allyle, $\mathrm{C}_{3} \mathrm{H}_{5}$ CNS.

\section{SULPIIUR AND ITS COMPOUNDS.}

Sulphur, Sym. S, at. wot. 32.-The properties of this element have been already described, (p. 42.) Some of 
its compounds have also been briefly alluded to, $\mathrm{k}$ nt requure more detailed notice.

Sulplnyeric scid, Sym $\mathrm{H}_{2} \mathrm{~S}$, mo. $20 \%$. $3 \pm$. This substance, fa, miliarly known as sulphuretted hydrogen, oceurs dissolved in the wates of numerous so called sulphur springs, as those of Aron and Sharon, $\mathrm{N}$ $\mathbf{Y}$., from which it escapes as a felid gas. It is not unfrequently emitted from volcamoes and fumaroles. It is likewise produced in the decay of organic bodies which contain sulphur, especially ergs, the intolerable odor of which, when rotten, is largely due to this gas. It is evoljed from manure heaps, from salt marshes, and eren from the soil of mois: mendows.

The ashes of plants sometimes yield this nas when they are moistened with witer. In such cases, a sulplicle of potassium or calcirm has been formed in small quantity during the incinerition.

Sulphydric acid is set free in the gaseous form by the action of an acid on various sulphides, as those of iron, (Exp. 17,) antimony, etc., as well as by the action of water on the sulphides of the alkali and alkali-eartl metals. It may be also generated by parsiug hjdrogen gas into melted sulphur.

Sulphuretted hydrogen has a slight acid taste. It is highly poisonous and destructive, both to animals and plints.

Sulphuxous Acid, $S y m$. $\mathrm{SO}_{2}, m o$. wt. 61 . When sulphur is burned in the air, or in oxygen gas, it furms copious white suffocating fumes, which consist of one atom of sulphur, united to two atoms of oxyen; $\mathrm{S} \mathrm{O}_{2}$, (Exp. 15.)

Sulphurous acid is characterized by its power of discharginu, for a time at lenst, most of the red and blue regetable colors. It his, however, no action on many yellow colors. Straw and wool are bleached by it in the arts.

Sulphurous acid is emitted from rolcanoes, aud from fissures in the soil of rolemic regions. It is produced when bodies containing sulphur are burned with imperfect access of air, and is thrown into the atmosphere in large quantities from fires which are fed by miveral coal, a; well as from the numerous roasting heaps of certain metallic ores, (sulphides, ) which are wrought in mining regions.

Sulphurous acid may unite with bases, yielding salts known as sul. phites, some of which, viz, sulphite of lime and sulphite of sodil, are em. ployed to check or preveut fermentation, an effict also produced by the acid itself.

Anhydrous* Sulphuric Acid, Sym. SO , mo. vot. 80, is known to the chemist as a white, silky solid, which attracts moisture with great avidity, and, when thrown into water, hisses like a hot iron, forming the hydrated sulphuric acid.

4. e., free from water. 


\section{IIydrated Sulphuric Acid, Sym. $\mathrm{H}_{2} \mathrm{O} \mathrm{SO}_{3}$ or $\mathrm{H}_{3} \mathrm{SU}_{\text {, }}$} mo. vt. 98 - the sulphuric acid of commerce-is a sulstince of the highest importance, its manufacture being the basis of the chemical arts. In its concentrated form it is known as oil of vitriol, and is a colorless, heavy liquid, of an oily consistency, and sharp, sour taste.

It is manufactured on the large scale by mingling sulphurous acil gas, nitric acid gas, and steam, in large leadlined chambers, the floors of which are covered with water. The sulphurous acid takes up oxygen from the nitric acid, and the sulphuric acid thus formed dissolves in the water, and is afterwards boiled down to the proper strength in glass ressels.

The chief agricultural application of commercial sulphuric acid is in the preparation of "superphosphate of lime," which is consumed as a fertilizer in immense quantities. This is made by mixing together dilute sulphurie acid with bone-rlust, bone-ash, or some mineral phosphate.

Sulphuric acid occurs in the free state, thongh extreme. ly dilute, in certain natural water's, as in the Oak Orchard Acid Spring of Orleans, N. Y., where it is produced by the oxidation of sulphide of iron.

Sulphuric acid is very corrosive and destructive to most regetable and animal matters.

ExP. 53,-Stir a little oil of vitriol with a pine stick. The wood is jumediately browned or blackened, and a portion of it dissolves in tho acid, comrnunicating a clark color to the latter. The commercial acid is often brown from contact with straws and chips.

Strong sulphuric acid produces great heat when mixed with water, as is done for making superphosphate.

Exr. 54.-Place in a thin glass vessel, as a heaker glass, 30 c. c. of water; into this pour in a fine stream 120 grams of oil of vitriol stirring all the while with a marrow test tule, containing a teaspoonful of water. If the acitl be of full-trengrh, so much heat is thus generated as to boil the water in the stirring tube.

In mixine oil of vitriol and water, the acid should always be slowly poured into the witer, with stirring, as above dirceted. When water is added to the acid, it floats upon the las. er, or mixes with it but super 
Aclally, and the liquids may be thrown about by the sudden sormation of steam at the points of contact, when subsequently stirred.

Sulphuric acid forms with the bases an important class of salts-the sulphates-to be presently noticed, some of which exist in the ash, as well as in the sap of plants. When organic matters containing sulphur, as hair, albumin, etc., are burned with full access of air, this element remains in the ash as sulphates, or is partially dissipated as sulphurous acid.

\section{PHOSPHORUS AND ITS COMPOUNDS.}

Phosphorus, Sym. P, at. vot. 31, has been sufficiently described, (p. 43.) Of its numerous compounds but two require additional notice.

Anhydrous Phosphoric Acid, Sym. $\mathrm{P}_{2} \mathrm{O}_{5}$, mo. vot. 142, does not occur as such in nature. When phosphorus is burned in dry air or oxygen, anhydrous phosphoric acid is the snow-like product, (Exp. 18.) It has no sensible acid properties until it has united to water, which it combines with so energetically as to produce a hissing noise from the heat developed. On boiling it with water for some time, it completely dissolves, and the solution contains-

Ilydrated Phosphoric Acid, Sym. $\mathrm{P}_{2} \mathrm{O}_{5}, 3 \mathrm{H}_{2} \mathrm{O}, 196$, or $\mathrm{H}_{3} \mathrm{PO}_{4}, 98$. - The chief interest which this compound has for the agriculturist lies in the fact that the combinations which are formed between it and rarious bases -phosphates-are among the most important ingredients of plants and their ashes.

When bodies containing phosphorus in other forms thau phosphoric acid, as protagon, (p. 93,) and, perhaps, some of the albuminoids, are disorganized by heat or decay tho phosphorus appears in the ashes or residue, in the con dition of phosphoric acid or phosphates.

The formation of several phosphates has been shown in 
Exp. 20. Further account of them will be given under the metals.

\section{CHLORINE AND ITS COMPOUNDS.}

Chlorine, Sym. Cl, at. vt. 35.5.-This element exists in the free state as a greenish-yellow, suffocating gas, which has a peculiar odor, and the property of bleaching vegetable colors. It is endowed with the most rigorous aftinities for many other elements, and hence is never met with, naturally, in the free state.

Sprengel claims to have found that Glaux maritima and Salicomia herbacea, plants growing in salt marshes, exhale chlorine. He says that the chloriue thus evolved is very quickiy converted into chlorhydric acid, by acting on the rapor of water which exists in the atmosphere. Such an exhalation of chlorine is manifestly impossible. The gas, were it eliminated within the plats, would be consumed before it could escape into the atmosphere. Chlorhylicic acid is evolved from the mud of salt marshes when left bare by elob of the tide, and exposed to the heat of the summer sun. It comes from the mutual decomposition of chloride of magnesium and water,

$$
\mathrm{M} \stackrel{\mathrm{C} \mathrm{Cl}_{2}}{ }+\mathrm{H}_{2} \mathrm{O}=\mathrm{Mg} \mathrm{O}+2 \mathrm{H} \mathrm{Cl} \text {. }
$$

Exp. 55.-Chlorine may be prepared by heating a misture of chlorhydric acid and black oxide of mamganese or red-lead. The gas being nearly tive times as heavy as common air, may be collected in glass bottles by passing the tube which deliver's it to the bottom of the receiving vessel. Care must be taken not to inlule it, as it energetically attacks the interior of the breathing pissiges, produeing the disagrecable symptoms of a cold.

Chlorine dissolves in water, forming a yellow solution. Very weak chlorine water was found by Iumboldt to facilitate the sprouting of seeds.

In some form of combination chlorine is rlistributed over the whole earth, and is never alsent from the plint.

The compounds of chlorine are termed chlorides, and maly he prepared, in most eases, by simply putting their elements in contact, at ordinary or slightly elevated tem. peratures.

Chlor-hydric acid, also Injtrochloric acid, Sym. H C', mo. wt. 36.5.- When Chlorine and IIydrogen grases are mingled together, they slowly combine if exposed to diffused light; but if plated in the sunshlue, they uni.e explosivuly, and chloride of hydrogen or shlorhydrie 
acid is furmed. This compound is a gas that dissolves with great avidity in water, forming a liquid which has a sharp, sour taste, aud poss'sses all the characters of an acid.

The mariatic acid of the apothecary is water holding in solution several hundred times its bulk of chlorhydric acid gats, and is prepared from common salt, whence its ancient name spirits of salt.

Chlorhydrie acid is the usual souree of chlorine gas. The latter is evolv 3 from a heated mixture of this acid with peroxide of manganese. In th.3 reaction the hydrogen of the chlorhydric acid unites with the oxygen of the peroxide of mang:nese, producing water, while chloride of mangrase and free chlorine are separated.

$$
4 \mathrm{H} \mathrm{Cl}+\mathrm{Mn}_{2}=\mathrm{Mn} \mathrm{Cl}_{2}+2 \mathrm{H}_{2} \mathrm{O}+2 \mathrm{Cl} \text {. }
$$

When chlorine dissolved in water, is exposed to the sun-light, there ensues a change the rever-e of that just noticed. Water is decomposed, its oxygren is set free, and chlorhydric acid is formed,

$$
\mathrm{H}_{2} \mathrm{O}+2 \mathrm{Cl}=2 \mathrm{HCl}+\mathrm{O} \text {. }
$$

This renction probably takes place when the grermination of seeds is hastened by chlorine. The oxygen thus liberated is doubtless the real agent which excites growth in the sleeping germ.

The two reactions just noticed ure instructive examples of the different play of affinities between several elements under unlike circum. stances.

Chlorhydric acid, being volatile, does not occur in the asbes of plint=, nor probably in the plant itself, unless, as may possibly happen, it is formed in, and exhales from the veretation, as it sometimes does from the mud of salt marshes, (p. 118.) Chlorhydric gas is fout in volcauic emanations.

This acid is a ready means of converting various metals or metallic oxides into chloricles, and its solution in water is a valuable solvent and reagent for the purposes of the ehemist.

Fodine, Sym. I, at. wt. 127.-This interesting body is a black solid at ordinary temperitures, having an odor resembling that of chlorine. Gently heated, it is converted into a violet vapor. It occurs in sea-weeds, and is oltained from their ashes. It gives with stareh a blue or purple compound, and is hence employed as a test for that substance, (p. 64.) It is analugrous to clilorine in its chemical relations. It is not known to vccur in sensible quantity in agricultural plants, allhough it m:ly well exist in the grasses of salt-bosrs, and in the produce of soils which are nonured with sen-weed.

13.omince and woriue maly also exist in very small quantity in plants, but these elements require no furtler notice in this treatise.

\section{SILICON AND ITS COMPOUNDS.}

Silicon, Sym. Si, at. vot. 28.-This element, in the free state, is mly known to the chemist. It may be prepared 
in threc mudifications: one, a brown, powlery substauce; another, resembling black-leat, (p. 31,) and a thirl, that occurs in crystals, having the form and nearly the hariness of the diamond.

Anhydrous Silicic Acid, Sym. Si O $\mathrm{O}_{2}$, mo. vet. 60.-This compound, known also as Silica, and anciently termel Eilex, is widrly diffused in nature, and occurs to an enor. mons extent in rocks and soils, both in the fice state and in combination with other bodies.

Free silica exists in nearly all soils, and in many rocks, especially in sandstones and granites, in the form known to mineralogists as quartz. The glassy, white or transparent, often yellowish or red fragments of common sand, which are hurd enough to surutch glass, are almost invariably this mineral. In the purest state, it is rock-crystul. Jasper, flint, and agate, are somewhat less pure silica.

Silicates.-Anhydrous silicic acid is extremely insoluble in pure water and in most acils. It has, therefore, none of the sensible qualities of acids, but is nevertheless capable of union with bases. It is slowly dissolved by strong, and especially by hot solutions of potash and soda, forming soluble silicates of these alkalies.

Exr. 56.-Furmation of silicrte of potesh. Heat a piece of quartz or flut, as larese as a chestnut, as hot as possible in the fire, and quench suldenly in cold water. Reduce it to tine powder in al porcelain mortar, and heil it in a poreclain dish with twiee its weiglat of caustic potash, and eight or ten times as much witer, for two hours, taking care to supply the water as it evagnrates. Pour off the whole into a tall narrow bottle, and leave at rest until the undisolved silica hats settled. Tho clear liquid is a hasie silie:te of potish, i. e. a silicate which contains a number of molecules of base for each molecule of silicit. It has, in fict, the taste and feel of potash solution. The so-called water glass, now employed in the arts, is a similar silicate of potash or soda.

When silica is strongly heaten with potish or socla, or with lime, magnesia, or oxide of iron, it readily melts together and unites with these borlies, though nearly infusible by itself, and silicates are the result. The silicates thus formed with potash and sola are soluble in water, like 
the product of $\mathrm{Ixp}$. 56, when the alkali exceeds a certain proportion-when highly basic; but with silica in excess, (acid silicates,) they dissolve with difficulty. A mixed silicate of alkali and lime, alumina, or iron, with a large proportion of silica, is nearly or altogether insoluble, not only in water, but in most acids-constitutes, in fict, ordinary glass.

A multitude of silicates exist in nature as rocks and minerals. Ordinary clay, common slate, soapstone, mica, or mineral isinglass, feldspar, hornblente, garnet, and other compounds of frequent and abundant occurrence, are silicates. The natural silicates are of two classes, viz., the acid silicates, (containing a preponderance of silica,) and basic silicates, (with large proportion of base): the former are but slowly dissolved or decomposed by acids, while the latter are readily attacked even ly carbonic acir. Many native silicates are anhydrous, or clestitute of water; others are hydrous, $i . e$. they contain water as a large and essential ingredient.

Ilydrated Silica.-Various compounds of silica with water are known to the chemist. Of these but three need be mentioned here.

Soluble Silica.-This body, doubtless a hydrate, is known only in a state of solution. It is formed when the solution of an alkali-silicate is tecomposed by means of a large excess of some strong acid, like the chlorhydric or sulphuric.

Exp. 57.-Dilute half the solution of silicate of potisls obtained in Exp. 56 witl ten times its volume of water, and add diluted chlorlyydric scid eradually until the liquid tastes sour. In this Exp. the chlorhydric a.id decompuses and destroys the silicite of potakh, uniting itself with 'he base with production of chloride of potassium, which dissolves in tha watel present. The silica thus liberated unites chemically with water, and remains also in sulution.

By appropriate methods Doveri and Graham have removed from solutions like that of the last Exp. everything but the silica, and obtained solutions of silica in pure water. Graham prepared a liquid that g:tre, when eraporat- 
ed and reated, 14 per cent of anhylrous silica. This ro lution was clear, colorless, and not viscid. It reddened litmus paper like an acid. Though not sour to the tiste, it prodnced a peculiar feeling on the tongue. Eraporated to dryness at a low temperature, it left a transparent, grlassy mass, which hal the composition $\mathrm{Si} \mathrm{O}_{2}, \mathrm{H}_{2} \mathrm{O}$. This dry residue was insoluble in water. These solutions of silica in pure water are incapable of existing for a long time without suffering a remarkable change. Even when protected from all external agencies, they sooner or later, usually in a tew days or weeks, lose their fluidity and transparency, and coagulate to a stiff jelly, from the separation of a ne:rly insoluble hydrate of silica, which we shall designate as gelutinous silica.

The addition of Tỡō of an alkali or earthy carbonate, or of a few bubbles of carhonic acid gas to the strong solutions, occasions their immediate gulatinization. A minute quantity of potash or soda, or excess of chlorhydric acid, prevents their coagulation.

Gelatinous Silica.-This substance, which results from the coagulation of the soluble silica just described, usually appears also when the strong solution of a silicate has strong chlorhydric acid added to it, or when a silicate is decomposed by direct treatment with a concentrated acid.

It is a white, opaline, or transparent jelly, which, on drying in the air, becomes a fine, white powder, or forms transparent grains. This powder, if dried at ortinary temperatures, is $3 \mathrm{Si} \mathrm{O}_{2}, 2 \mathrm{M}_{2} \mathrm{O}$. At the temperature of $212^{\circ} \mathrm{F}$, it loses half its water. At a red heat it becomes anhydrous.

Gelatinous silica is listinctly, though very slightly, sol uble in water. Ifuchs and Bresser have found by experiment that 100,000 parts of water dissolve 13 to 14 parts of gelatinous silica.

The hydrates of silica which hove been subjected to a 
heat of $212^{\circ}$ or more, appear to be totally insoluble in pi re water.

All the hydrates of silica are rendily solıble in soluticns of the alkalies and alkali carbonates, and readily unite with moist, slaked lime, forming silicates.

ExP. 58.-Gelatinons Silica.-Pour a small portion of the solution of Filicate of potash of Exp. 56, into strong chlorhydric acid. Gelatinons silica separates and falls to the bottom, or the whole liquid becomes a trius parent jelly.

EXP. 59.-Conversion of soluble into insoluble hydrated silica. - Evaporate the solution of silica of Exp. 57, which contains free chlorhydric acid, in a poreelain dish. As it beeomes concentrated, it is very likely to gelatinize, as happened in Exp. 58, on account of the removial of the solvent. Evaporate to perfuct dryness, fin:lly on a water-batlı (i. e. on a vessel of boiling water which is cuvered by the dish containing the sulution). Add to the residue water, which dissolves away the chloride of potassium, and leaves insoluble hydrated silica, $3 \mathrm{Si}_{2}, \mathrm{H}_{2} \mathrm{O}$, as a gritty powder.

In the ash of plants, silica is usually found in combination with alhalies or lime, owing to the high temperature to which it has been subjected.

In the plant, however, it exists chiefly, if not entirelv, in the free state.

Titanium, an element which has many aualogics with silicon, thougb rarely oceurring in large quantities, is yet often present in the form of Titanic acid, Ti $\mathrm{O}_{2}$, in rocks and soils, and according to Salm Horstmar may exist in the ashes of barley and oats.

Arsenic, in minute quantity, has been found by Dary in turnips which had been masured with a fertilizer (superphosphate), in whose preparation, oil of vitriol, containing this substance, was employed.

The metallic elements which remain to be noticed, viz. : Potassium, Sodium, Calcium, Magnesium, Iron, Miınganest, (Lithium, Rubidiun, Caesium, Aluminum, Zinc, and Copper, ) are basic in their character, i. e., they unite with the acid bodies that have just been lescribed to produce salts. Each one is, in this sense, the base of a series of saline compounds.

Arkali-Metars.-The elements Potassium, Sodium, (Lithium, Rubidium, and Caesium) are ternued alkali 
metrls. Their oxides are very soluble in witer, and are called alhillies. The metals themselves do not occur in nature, and can only be prepared by tedious chemical processes. They are silvery-white bollies, and alle lightor than vouter. Exposed to thc air, they quickly tami-h from the absorption of oxygen, and are rapidly converted into the corresponding alkalies. Thrown upon water, they mostly inflame and bum with great violence, decomposing the liquid, Exp. 11.

Of the alkali-metals, Potassium is invariably found in all plants. Sorlium is especially abundant in marine and strand vegetation; it is generally found in agricultural plants, but is oceasionally absent from them.

\section{POTASSIUM AND ITS COMPOUNDS.}

Potassium, sym. K; ${ }^{*}$ at. rot. 39.-When heated in the air, this metal burns with a beautiful violet light, and forms potash.

Potash, $\mathrm{K}_{2} \mathrm{O}, 94$, is the alkali, and base of the potashsalts.

Iydrate of Potash, $\mathrm{K}_{2} \mathrm{O}, \mathrm{H}_{2} \mathrm{O}, 112$, or $\mathrm{K} \mathrm{H} \mathrm{O}, 56$, is the caustic potush of the apothecary and chemist. It may be procured in white, opaque masses or sticks, which rapidly absorb moisture and carbonic acid from the air, and readily dissolve in water, forming potush-lye. It strongly corrodes many vegetable and most animal matters, and dissolves fits, forming potash-soaps. It unites with acids like $\mathrm{K}_{2} \mathrm{O}$, water being set free.

\section{SODIUII AND ITS COMPOUNDS.}

Sodium, $\mathrm{Na}, \dagger$ 23.-Burns with a brilliant, orange-yellow fiame.

- From tbe Iatin name Kalium.

1 From the Latin name -Natrim. 
Soda, $\mathrm{Na}_{2} \mathrm{O}, 62$. - This alkali, the base of the soda salts, is not distinguishable from potash by its sensible properties.

IIydrate of Soda, or Caustic Soda, $\mathrm{Na}_{2} \mathrm{O}, \mathrm{II}_{2} \mathrm{O}, 80$, or $\mathrm{NaH} \mathrm{O,40.-This} \mathrm{body} \mathrm{is} \mathrm{like} \mathrm{caustic} \mathrm{potash} \mathrm{in} \mathrm{appear}$ ance and general characters. It forms soaps with the various fats. While the potash-soaps are usually soft, those made with soda are commonly hard.

LITIIUM : RUBIDIUM : CAESIOA.

Euth: :az:1, Li, 7.-The compounds of this metal are of much raret nceurrence th:m these of Potassium and Sodium. Tlre element itself is the lightest metal knowu, being but little more thin half as heary as water. It burns with a vivid white light when heated in the air.

Lithia, $\mathrm{Li}_{2} \mathrm{O}, 30$, and its Hydrate, closely resemble the corresponding componds of the two elements ahove described. They yield by union with acids the lithia-salts.

Heubidium, lib, 8.5.5, and Cac-ium, Cs, 133 -Bisites P'ot:ts. sium, Sodium, and Lithiam, there are two other recently discovered alkali-metals, viz. : Rubilium and Cilesinm. These telements are comparatively rare, although they appear to be midely distributed in nature in minute quantity.

Rubidium has besn found in the ashes of tobaceo and sugat-beet, as well as in commercial putash. Cilesium, which is the rarer of the two, Las as yet not been detected in the ashes of plints, but undoubtedly oc. curs in them. These metals and their compounds have, in general, the closest similiuity to the other alkali-metals.

Alkali-entru Metals. - The two metallic elements next to be noticed, viz.: Calcium and Magnesium, give, with oxygen, the alkolli-earths, lime aud magnesia. The metals are only procurable by difficult chemical procusses, and from their eminent oxidability are not found in nature. They are but a little heavier than water. Their oxides are but slightly soluble in water.

\section{CALCTUM AND ITS COMPOUNDS.}

Calcium, $\mathrm{Ca}, 40$, is a brilliant ductile metal having a light yellow culor. In moist air it rapidly tarnishes and aequires a coating of lime 
Lime, $\mathrm{CaO}, 56$. - Is the result of the oxidation of cal. cium. It is prepared for use in the arts by subjecting limestone or oyster-shells to an inte!sse he:t, and usually retains the form and much of the barlness of the material from which it is made. It has the bitter taste and corrod. ing properties of the alkalies, though in a less degree. It is often called quick-lime, to listinguish it from its compuund with water. It may oceur in the ashes of plants when they have been maintained at a high hent after the volatile matter has been bumel away. It is the base of the salts of lime.

Hydrate of Lime, $\mathrm{CaO}, \mathrm{H}_{2} \mathrm{O}$, or $\mathrm{CaH}_{2} \mathrm{O}_{2}, 74$. - Quickcime, when exposed to the air, gradually absorbs water and falls to a fine powder. It is then sail to be air-slaked. When water is poured upon quick-lime it penetrates the pores of the latter, and shortly the falling to powder of the lime and the development of much heat, give ev:dence of chemical union between the lime and the water. This chemical combination is further proved by the increase of weight of the lime, $56 \mathrm{lbs}$. of quick-lime becoming $74 \mathrm{lbs}$. by water-slaking. On heating slaked lime to redness, its water may be expelled.

When lime is agitated for some time with much water, and the mixture is allowed to settle, the clear liquid is found to contain a small amount of lime in solution (one part of lime to 700 parts of water). This liquid is called lime-wuter, and has already been noticed as a test for carbonic acid. Lime-water has the alkaline taste in a marked degree.

\section{MAGNESIUA AND ITS COMPOUNDS.}

Magnesium, Mg, 21-Metallic magnesium has a silverwhite color. When heated in the air it burns with extreme brilliancy (magnesium light), and is converted into magnesia 
Magnesia $\mathrm{Mg} \mathrm{O}, 40$, is the oxide of mignesium. It is found in the drug-stores in the shape of a bulky white powder, under the name of calcined marnesia. It is prepared by subjecting either hydrate, carbonate, or nitrate, of magnesia to a strong heat. It occurs in the ashes of plants.

IIydrate of Magnesia, $\mathrm{Mg} \mathrm{O} \mathrm{H}_{2} \mathrm{O}$, is produced slowly and without heat, when magnesia is mixed with water. It occurs as a transparent, glassy mineral (Brucite) at Texas, Penn., and a few other plices. It readily absorbs carbonic acil, and passes into carbonate of m:ignesia. Hydrate of magnesia is so slightly soluble in water as to be tasteless It requires 55,000 times its weight of water for solution, (Fresenius).

Heavy Metals.-The two metals remaining to notice are Iron and Manganese. These again considerably resemble each other, though they differ exceedingly from the metals of the alkalies and alkali-earths. They are about eight times heavier than water. Each of these metals forms two basic oxides, which are totally insoluble in pure water.

\section{IRON AND ITS COMPOUNDS.}

Iron, $\mathrm{Fe}, * 56$. -The properties of metallic iron are so well known that we need not occupy any space in recapitulating them.

Protoxide $\nmid$ of Iron, Fe O, rg.-When sulphuric acid in a diluted state is put in contact with metallic iron, hy. drogen gas shortly begins to escape in bubbles from the liquid, and the iron dissolves, uniting with the acid to form the protosulphate $\nmid$ of iron, the salt known commonly as copperas or green-vitriol.

* From the Latin name Ferrum.

+ The prefix prot or proto, from the Greek, meaning first, is employed to distingruish t'is oxide and its salts from the compounds to te subsequently do acribed 


$$
\mathrm{H}_{3} \mathrm{O}, \mathrm{SO}_{3},+\mathrm{Fe}=\mathrm{Fe} \mathrm{O}, \mathrm{SO}_{3}+\mathrm{H}_{2} \text {. }
$$

If, now, lime-water or potash-lye be added to the scidi. tion of iron thus obtained, a white or greenish-white precipitate seprarates, which is a hydrated protoxide of iron, $\left(\mathrm{Fe} \mathrm{O}, 2 \mathrm{\textrm {II } _ { 2 }} \mathrm{O}\right)$. This precipitate rapitlly absorks oxygen from the air, becoming black and finllly brown. The anhydrous protoxide of iron is black. Carbonate of protoxide of iron is of frequent occurrence as a mineral (spathic iron), ani exists dissolved in many mincral waters, especially in the so-called chalybeates.

Sesquioxide of Iron, ${ }^{*} \mathrm{Fe}_{2} \mathrm{O}_{3}, 160$. W When protoxide of iron is exposed to the air, it acquires a brown color from union with more oxygen, and becomes hydrated sesquioxide. The yetlow or brown rust which forms on surfaces of metallie iron when exposed to moist air is the same body. Iron in the form of sesquioxile is found in the ashes of all agricultural plants, the other oxides of iron passing into this when exposed to air at high temperatures. It is found in immense beds in the earth, and is an important ore, (specular iron, hematite). It dissolves in acids, forming sesquisalts of iron, which have a yellow color.

Magxetic Oxine of Irov, $\mathrm{Fe}_{3} \mathrm{O}_{4}$, or $\mathrm{FeO}, \mathrm{Fe}_{2} \mathrm{O}_{3}$, is a combination of the two oxides above mentioned. It is blick, and is strongly attracted by the magnet. It constitutes, in fact, the native magnet, or loadstone, and is a viluable ore of iron.

\section{MANGANESE AND ITS COMPOUNDS.}

Manganese, Mn, 5.5.-Metallic manganese is diflicult to procure in the free state, and much resembles iron. Its oxiles which concern the agriculturist are analogous to those of iron just noticed.

Protoxile of Hanganese, $\mathrm{In}_{\mathrm{n}} \mathrm{O}$, 71, has an olivegreen color: It is the base of all the usually occurring

* The prefix songui (one cend a hulf) is applied to th ose oxides in which the ratio of metal to oxysen is as one to one and a half, or, what is the anase, a two to tivee. The above compound is also called peroxide of iron. 
Buts of manganese. Its hydrate, prepared by decompos. ing yrotosulphate of manganese by lime-water, is a white substance, which, on exposure to the air, shortly becomes brown and finally black from absorption of oxygen. The salts of protoxide of manganese are mostly pale rose-red ir colur.

Sesquioxille of Thanganese, $\mathrm{Mn}_{2} \mathrm{O}_{3}$, occurs native as the mineril braunite, or, combined with water, as manganite. It is a subetance having a red or black-brown color. It dissolves in cold acids, forming salts of an intensely red color. These are, howerer, easily decomposed by heat, or by organic bodies, into oxygen and protosalts.

ERed Oxide of Prananese, $\mathrm{In}_{3} \mathrm{O}_{4}$, or $\mathrm{Mn} \mathrm{O}, \mathrm{Mn}_{2} \mathrm{O}_{3}$. This oxide remains when manganese or any of its other oxides are subjected to a high temperature with aceess of air. The metal and the protoxile gain oxygen by this treatment, the higher oxides lose oxygen until this compound oxide is formed, which, as its symbol shows, corresponds to the magnetic oxide of iron. It is found in the ashes of plants.

EBlack Oxide or Manganese, $\mathrm{Mn} \mathrm{O}_{2}$.-This body is found extensively in nature. It is empluyed in the preparation of oxyen and chlorine, (bleaching powder), and is an article of commerce.

Some other metals occur as oxides or salts in ashes, though not in such quantity or in such plints as to possess any agricultural significance in this respect.

Alumina, the sesquioxide of the metal Alominum, is found in considerable quantity (20 to 50 per cent) in the ashes of the ground pine (Iycopodium). It is united with an organic acid (tartaric, according to Berzelius; malic, according to Ritthausen) in the plant itself. It is often found in small quantity in the ashes of agricultural plants, but whether an ingredient of the plint or due to particles of adhering clay is not in all cases clenr.

Zinc has been found in a variety of yellow violet that grows in the zinc mines of Aix la Chapelle.

Copper is frequently present in minute quantity in the ash of trees, especially of such as grow in the vicinity of maufacturing establish. ments, where dilute solutions containing copper are thrown to waste.

\section{The salts or compounds of metals with non-metals} found in the ashes of plants or in the unburned plant remain to be considered.

Of the elements, acids, and oxides, that have been noticed as constituting the ash of plants, it must be remark. ed that with the exception of silica, magnesia, oxide of 
iron, and oxide of manganese, they all exist in the ash in the form of salts, (compounds of acils and bases). In the living agricultural plant it is probable, that of them all, only silica occurs in the uncombined state.

We shall notice in the first place the salts which may occur in the ash of plants, and shall consider them under the following heads, viz.: C:rrbonates, Sulphates, Phosphates, and Chlorides. As to the Silicates, it is unneces. sary to add anything here to what has been already mentioned.

Tie Carbonates which occur in the ashes of plants are those of Potash, Soda, and Lime. (Carbonate of Rubidia, similar to carbonate of sod:a, and Carbonate of Lithia, rather insoluble in water, may also, be present, but in exceelingly minute quantity.) The Carbonates of Magnesia, Iron, and Manganese, are decomposed by the heat at which ashes are prepared.

Carbonate of Potash, $\mathrm{K}_{2} \mathrm{O} \quad \mathrm{CO}_{2}, 114$. -The pearl-ash of commerce is a tolerably pure form of this salt. When wood is burned, the pot:sh which it contains is found in the ash, chiefly as carbonate. If wood-ashes are repentedly washed or leached with water, all the salts soluble in this liquid are removed; by boiling this solution down to dryness, which is done in large iron pots, crude potash is obtained, as a dark or brown mass. This, when somewhat purified, yields pearl-ash. Carbonate of potash, when pure, is white, has a bitter, biting taste-the so-called alkaline taste. It has such attraction for water, that, when exposed to the air, it absorbs moisture and becomes a liquid.

If chlorhyilrie acid be poured upon earbonate of potash a brisk effervescence immediately takes place, owing to the escape of carbonic acid gas, and chloride of potassium and water are formed which remain behind.

$$
\mathrm{K}_{2} \mathrm{OCO}+2 \mathrm{II} \mathrm{Cl}=2 \mathrm{~K} \mathrm{Cl}+\Pi_{2} \mathrm{O}+\mathrm{CO}_{2} \text {. }
$$

Ricarbonate of Potash, $\mathrm{KHO} \mathrm{CO}_{2},-\mathrm{A}$ solution of 
carbonate of potash when exposed to carbonic acid gas absorbs the latter, and the bicarbonate of potash is produced, so called because to a given amount of potassium it contains twice as much carbonic acid as the carbonate. Potash-salceratus consists essentially of this salt. It probably exists in the juices of various plants.

Carbonate of Sorla, $\mathrm{Na}_{2} \mathrm{O} \mathrm{CO}$, 106. - This substance, so important in the arts, was formerly made from the ashes of certain marine plants (Salsola and Sulicornia), in a manner similar to that now employed in wooded countries for the preparation of potash. It is at present almost wholly obtained from common salt by a somewhat complicated process. It occurs in commerce in an impure state under the name of Soda-ash. When nearly pure it forms salsoda, which usually exists in transparent crystals or crystallized masses. These contain 63 per cent of water, which slowly escapes when the salt is exposed to the air, leaving the anhydrous (water-free) carbonate as a white, opaque powder.

Carbonate of soda has a nauseons alkaline taste, not nearly so decided, however, as that of the carbonate of potash. It is often present in the ashes of plants.

Bicarbonate of Soda, $\mathrm{NaHO} \mathrm{CO}_{2}$ - The supercarbonate of soda of the apothecary is this salt in a nearly pure state. The soda-salceratus of commerce is a mixture of this with some simple carhonate. It is prepared in the same way as the bicarbonate of potash. The bicarbonates. both of potash and soda, give off half their carbonic acid at a moderate heat, and lose all of this ingredient by con tact with excess of any acid. Their use in baking dependo "pon these facts. They neutralize any acid (lactic or acetic) that is formed during the "rising" of the dough, and assist to make the bread "light" by inflating it with arbonic acid gas.

Carbonate of Lime, $\mathrm{CaO} \mathrm{CO}_{3}, 112$. - This compound is 
the white powder formed by the contact of carbonic acid with lime-water. When hydrate of lime is exposed to tice air, the water it contains is gradually displaced by carbonic acid, and carbonate of lime is the result. Airslaked lime always contains much carbonaté. This salt is distinguished from hydrate of lime by its being destitute of any alkaline taste.

In nature carbonate of lime exists to an immense cxtent as coral, chalk, marble, and limestone. These rocks, when strongly heater, especially in a current of air, part with their carbonic acid, and quick-lime remains behind.

Carbonate of lime occurs largely in the ashes of most plants, particularly of trees. In the manufacture of potash, it remains undissolverl, and constitutes a chief part of the residual leached ashes.

The carbonate of lime found in the ashes of plants is supposed to come mainly from the decomposition by heat of organic salts of lime, (oxalate, tartrate, malate, etc.,) which exist in the juices of the vegetalle, or are abundantly reposited in its tissues in the solid form. Carbonate of lime itself is, however, not an unusual component of vegetation, being found in the form of minute, rhombic crystals, in the cells of a multitude of plants.

The Sulphutes which we shall notice at length are those of Potash, Soda, and Lime. Sulphate of Magnesia is well known as epsom salts, and Sulphate of Iron is copperas or green-vitriol. (Sulphate of Lithia is very similar to sulphate of potash.)

Sulphate of Potash, $\mathrm{K}_{2} \mathrm{O} \mathrm{SO}_{3}, 174$. - This salt may bu procured by dissolving potash or carbonate of potash in diluterl sulphuric acid. On evaporating its solution, it is olntained in the form of hard, brilliant crystals, or as a white powiler. It has a litter taste. Ordinary potash, or pearl-ash, contains several per cent of this salt.

Sulphate of Soda, $\mathrm{Na}_{2} \mathrm{O} \mathrm{So}, 142$. - Glauber's salt is 
the common name of this familiar substance. It has a bitter taste, and is much employed as a purgative for cat. tle and horses. It exists, either crystallized and transparent, containing 10 molecules, or nearly 56 per cent, of water, or anhydrous. The crystals rapidly lose their water when exposed to the air, and yield the anhydrous salt as a white powder.

Sulphate of Lime, $\mathrm{CaO} \mathrm{SO}_{3}$; 136.-The burned Plaster of Paris of commerce is this salt in a more or less pure state. It is readily formed by pouring diluted sulphuric acid on lime or marble. It is found in the ash of most plants, especially in that of clover, the bem, and other legumes.

In nature, sulphate of lime is usually combined with two molecules of water, and thus constitutes Gypsum, $\mathrm{CaO} \mathrm{SO}_{3} 2 \mathrm{H}_{2} \mathrm{O}$, which is a rock of frequent anil extensire occurrence. In the cells of many plants, as for instance the bean, gypsum may be discorered by the microscope in the shape of minute erystals. It requires 400 times its weight of water to dissolve it, and being almost universally distributed in the soil, is rarely absent fiom the water of wells and springs.

The Phospinates which require special description are those of Potash, Soda, and Lime.

There exist, or may be prepared artificially, numerous phosphates of each of these bases. The chemist is acquainted with no less than thirteen different phosphates of soda. But three classes of phosphates have any immediate interest to the agriculturist. As has been stated ( $p$. 117), hydrated phosphoric acid prepared by boiling anhy. drots phosphoric acid with water, is represented by the symbol $3 \mathrm{H}_{2} \mathrm{O}, \mathrm{P}_{2} \mathrm{O}_{5}$. The phosphates may be regincled as hydrated phosphoric acid in which one, two, or all the molecules of water are substituted by the same number of molecules of one or of several bases. We may illuse 
trate this statement with the three phosphates of limo giving in one riew their mode of derivation, their symbols, and the names which we shall employ in this treatise. a. $-3 \mathrm{H}_{2} \mathrm{O}, \mathrm{P}_{2} \mathrm{O}_{5}$ and $\mathrm{CiO}$ give $\mathrm{H}_{2} \mathrm{O}$ and $2 \mathrm{H}_{2} \mathrm{O}, \mathrm{CaO}$, $\mathrm{P}_{2} \mathrm{O}_{5}$, the monocalcic* phosphate or acid-phosphate of lime.

b. $-3 \mathrm{II}_{2} \mathrm{O}, \mathrm{P}_{2} \mathrm{O}_{5}$ and $2 \mathrm{CaO}$ give $2 \mathrm{H}_{2} \mathrm{O}$ and $\mathrm{If}_{2} \mathrm{O}, 2 \mathrm{Ca}$ $\mathrm{O}_{2} \mathrm{O}_{6}$, the dicalcic* phosphate or neutral phosphate of lime.

c. $-3 \mathrm{H}_{2} \mathrm{O}, \mathrm{P}_{2} \mathrm{O}_{5}$ and $3 \mathrm{CaO}$ give $3 \mathrm{H}_{2} \mathrm{O}$ and $3 \mathrm{CaO} \mathrm{P}_{2}$ $\mathrm{O}_{5}$, the tricalcic * phosphate or basic-phosphate of lime.

Phosphates of Potash.-Of these salts, the neutral and subphosphates exist largely (to the extent of 40 to 50 per cent) in the ash of the kernels of wheat, rye, maize, and other bread grains. None of these phosphates occur in commerce; they closely resemble the corresponding sodasalts in their external characters.

Phosphates of Soda.-Of these the disodic, or noutral phosphate, $2 \mathrm{Na}_{2} \mathrm{O}, \mathrm{H}_{2} \mathrm{O}, \mathrm{P}_{2} \mathrm{O}_{5}+12 \mathrm{Aqt}$, alone needs notice. It is found in the drug-stores in the form of glassy crystals, which contain 12 molecules (56 per cent) of water. The crystals become opaque if exposed to the air, from the loss of water. This salt has a cooling, saline taste, and is very soluble in water.

Phosphates of Lime.-Both the neutral and subphosphate of lime probably occur in plants. The neutral or Ticalcic salt, $\left(2 \mathrm{CaO} \mathrm{H} \mathrm{H}_{2} \mathrm{O}, \mathrm{P}_{2} \mathrm{O}_{5}+2 \mathrm{Aq}\right)$, is a white crystalline powder, nearly insoluble in water, but easily soluble in acids. In nature it is found as a urinary concretion in

* These names indicate the proportions of acid and base in the compounds, and may be translated into common English, thus: One-lime phosphate, two-lime phosphate, and three-lime phosphate respectively.

t The water which is found in crystallized salts and which ustually may be ezpellerl at a gentle heat, is termed water of crystallization, and is often degignated by Aq., (from the Latir. Aqua), to distinguish it from basic water, which is more intimately combined. 
the sturgeon of the Caspian sea. It is also an ingredient of guanos, and probably of animal excrements in general.

The tricalcic phosphate, or, as it is sometimes termed, the bone-phosphate, $3 \mathrm{CaO}, \mathrm{P}_{2} \mathrm{O}_{5}$, is a chief ingredient of the bones of animals, and constitutes 90 to 95 per cent of the ash or earth of bones. It may be formed by adding a solution of lime to one of phosphate of soda, and appears as a white precipitate. It is insoluble in pure water, but dissolves in acids and in solutions of many salts. In the mineral kingdom tricalcic phosphate is the chief ingredient of apatite and phosphorite. These minerals are employed in the preparation of the so-called superphosphate of lime, which is consumed to an enormous extent as a turnip-fertilizer. The superphosphate of commerce, when genuine, is essentially a mixture of sulphate of lime with the three phosphates above noticed, of which the monocalcic phos. phate should predominate.

\section{The Phosphates of Magnesia, Iron, and Manganese,} are bodies insoluble in water, and require no particular notice.

The Chlorides are all characterized by their ready soluvility in water. The chlorides of Tithium, Calcium, and Magnesium, are deliquescent, i. e., they liquefy by absorbing moisture from the air. The chlorides of Potassium and Sodium alone need to be described.

Chloride of Potassium, $\mathrm{K} \mathrm{Cl}, 74.5$. - This body may be produced either by exposing metallic potassium to chlorine gas, in which case the two elements unite together directly; or by dissolving caustic potash in chlorhydric acid. In the latter case water is also formed, as is expressed by the equation $\mathrm{K} \mathrm{IIO}+\mathrm{H} \mathrm{Cl}=\mathrm{K} \mathrm{Cl}+\mathrm{H}_{2} \mathrm{O}$.

Chloride of potassium closely resembles common salt (chloride of sodium) in appearance, solubilıty in water, taste, etc. It is but rarely an article of commerce, but is present in the ash and in the juices of pl:usts, especially of nea-weeds, and is likewise found in all fertile soils. 
Chloride of Sodium, $\mathrm{Na} \mathrm{Cl}$, 58.5-This substance is common or culinary salt. It was formerly termed muriate of soda. It is scarcely necessary to speak of its occurrence in immense quintities in the water of the ocean, in saline springs, and in the solid form as rock-salt, in the earth. Its properties are so fimiliar as to require no description. It is rarely absent from the ash of plants.

Besides the salts and compounds just described, there occur in the living plant other substances, most of which have been indeed already alluded to, but may be noticerl again connectedly in this place.

These compounds, being destructible by heat, do not appear in the analysis of the ash of a plant.

Nitrates: Nitric acid-the compound by which nitrogen is chiefly furnished to plants for the elaboration of the albuminoid principles-is not unfrequently present as a nitrate in the tissues of the plant. It usually occurs there as Nitrate of Potash, (niter, saltpeter.)

The properties of this salt searcely need description. It is a white, cryst:lline body, readily soluble in water, and has a cooling, saline taste. When heated with carbonaceons matters, it yields oxygen to them, and a deflugration, 1)r rapid and explosive combustion, results. Touch-paper is paper soaked in solution of niter, and dried. The leaves of the sugar-beet, sminflower, tobacco, and some other plants, have been found to contain this salt. When such vegetables are burned, the nitric acid is decomposed, often with slight ileflagration, or glowing like touch-paper, and the alkali remains in the ash as carbonate. The characters of nitric acid and the nitrates will be noticed at length in another volume, "How Crops Feed."

Oxalates, Citmates, Mlanates, Thatrates, and salts of other less common organic acids, are generally to be found in the tissues of living plants. On burning, the bases with which they were in combination-potash and lime in most cases-remain as carbonates. 
SAlts of Amronis exist in minute amount in some plants. What particular salts thus occur is uncertain, and special notice of them is unnecessary in this chapter.

Since it is possible for each of the acils above described to unite with each of the bases in one or several propor. tions, and since we have as many oxiles and chlorides as there are metals, and cren more, the question at once arises-which of the 60 or more compounds that may thus be formed outside the plant, do actually exist within it? In auswer, we must remark that all of them may exist in the plant. Of these, however, but few have been proved to exist as such in the vegretable organism. As to tho state in which iron and manganese occur, we know little or nothing, and we cannot assert positively that in a given nlant yotash exists as phosphate, or sulphate, or carbonite. We judge, indeed, fiom the predominance of potash and phosphoric acid in the ash of wheat, that phosphate of potash is a large constituent of the grain, but of this we are not sure, though in the absence of evidence to the contrary we are warranted in assuming these two ingrerlients to he united. On the other hand, carbonate of lime and sulphate of lime have been discovered by the microscope in the cells of various plauts, in crystals whose characters are unmistakeable.

For most purposes it is unnecessary to know more than that certain elements are present, without paying attention to their mode of combination. And yet there is choice in the manner of representing the composition of a plint as regaris its ash-ingredients.

We do not, indeed, speak of the calcium or the silicon in the plant. but of lime and silica, because the idea of these rarely sten elements is much more vague, except to the chemist, than that of their oxides, with which every one is familiar.

Again, we do not speak of the sulphates or rhloriles, 
when we desire to make statements which may be com pared together, beeause, as has just been remarked, we cannot always, nor often, say what sulphates or what chlorides are present.

In the paragraphs that follow, which are devoted to a more particular statement of the mode of occurrence, rebutive abundance, special function, and indispensability of the fixed ingredients of plants, will be indicated the customary and best method of defining them.

\section{\&2.}

QUANTITY, DISTRIBUTION, AND VARIATIONS OF THE ASH. INGREDIENT'S.

The ash of plants consists of the various fixed acids. oxides, and salts, noticed in $\S 1$.

The ash-ingredients are always present in each cell of every plant.

The ash-ingredients exist partly in the cell-wall, incrusting or imbedded in the cellulose, and partly in the plasma or contents of the cell, (see p. 2:4.)

One portion of the ash-ingredients is soluble in water, and occurs in the juice or sap. This is true, in general, of the salts of the alkalies, and of the sulphates and chlorides of magnesium and calcium. Another portion is insoluble, and exists in the tissnes of the plant in the solid form. Silica, the phosphates of lime, and the magnesia compounds, are mostly insoluble.

The ash-ingreilints may be separated from the volatile matter by burning or by any process of oxidition. In burning, portions of sulphur, chlorine, alk:alies, and phosphorus, may be lost under certiin circumstances, by vola tilization. The ash remains as a skelston of the plant, and often actually retains and exhibits the microscopic form of the tissues.

The Proportion of Ash is not invariable, even in the 
Eane kind of plant, and in the same part of the plant. Different kinds of plants often manifest very marked differences in the quantity of ash they contain. The following table exhibits the amount of ash in 100 parts, (of dry matter,) of a number of plants and trees, and in their several parts. In all cases is given the average proportion, as de. duced from a large number of the most trustworthy examinations. In some instances are cited the extreme proportions hitherto put on record.

PROPORTIONS OF ASH IN VARIOUS VEGETABLE MATTERS. ENTIRE PLANTB, ROOTS EXCEPTED.

\begin{tabular}{|c|c|}
\hline & \\
\hline clover...............6. 6.7 & Turnips, $10.7-19.7 \ldots \ldots \ldots .15 .5$ \\
\hline White " $\quad \ldots \ldots \ldots \ldots \ldots \ldots .7 .2$ & $, 15.0-21.3, \ldots \ldots \ldots, 17.1$ \\
\hline thy............ & $\ldots \ldots \ldots \ldots \ldots$ \\
\hline ....... & $\mathrm{He}$ \\
\hline & \\
\hline eld beet, $14.0-21.8 \ldots$ & Heath.. \\
\hline
\end{tabular}

ROOTS AND TUBERS.

Potato, 2.6-8.0.............4.1 | Turnip, 6.0-20.9...........12.0

Sugar beet, $2.9-6.0 \ldots \ldots \ldots . .4 .4$ Carrot, $5.1-10.9 \ldots \ldots \ldots \ldots .8 .2$

Ficld bect, $2.8-11.3 . . . \ldots \ldots .7 .7$ Artichoke............... 5.2

STRAW AND STEMS.

Wheat, 3.8-6.9 ...........5.4 $\mid$ Pens, $6.5-9.4 \ldots \ldots \ldots \ldots \ldots .7 .9$

Rye, $4.9-5.6 \ldots \ldots \ldots \ldots \ldots \ldots .5 .3 \mid$ Beins, $5.1-7.2 \ldots \ldots \ldots \ldots \ldots .6 .1$

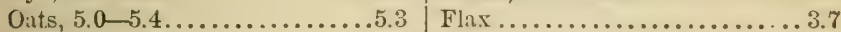

Barley....................

GRAINS AND SEED.

Wheat, $1.5-3.1 \ldots \ldots \ldots \ldots \ldots \ldots .0$ Buckwheat, 1.1-2.1............

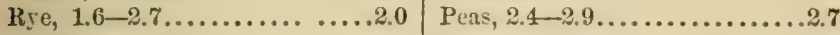

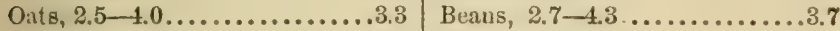

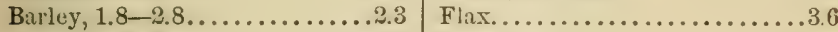

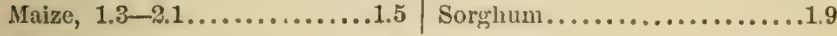
WooD.

Beech.....................1.0 Red Pine.................. 0.3

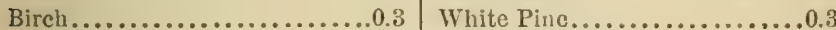

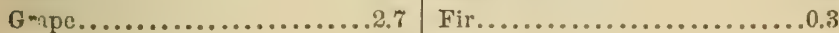

Appie ...................... 1.8 Larch ..................... 0.3

BAIRT.

Birch..................1.3 Fir...................... . . . .

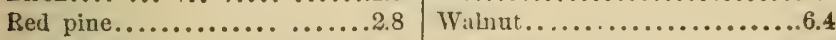

White pine................3.3 Cauto tree.... ..........344 
From the above table we gather:-

1. That different plants yield different quantities of ash. It is alundant in succulent foliage, like that of the bect, (1s per cent,) and small in seeds, woorl, and bark.

2. That different parts of the same punt yield unlike proportions of ash. Thus the wheat kemel contains 2 per cent, while the straw yields 5.4 per cent. The ash in sugar-beet tops is 17.5 ; in the roots, 4.4 per cent. In the ripe oat, Arendt found (Das Wachsthum der Haferpflanze, p. 84,)

In the three lower joints of the stem... 4.6 per cent of ash

In the two middle joints of the stem... 5.3 " "

In the one upper joint of the stem.....6.4 "6 "

In the three lower leives............10.1 " "

In the two upper leaves... .......... "

In the ear................ "

3. We further finil, that in generrl, the upper and outer parts of the plant contain the most ash-ingredients. In the oat, as we see from the above figures of Arendt, the ash increases from the lower portions to the upper, until we reach the ear. If, however, the ear be dissected, we shall find that its outer parts are richest in ash. Norton found

In the husked kernels of brown oats....2.1 per cent of ash

In the husk of brown onts.......... 8.2 " "

In the chaff of brown oats............ " " "

Norton :lso found that the top of the ont-leaf gave 16.22 per cent of ash, while the bottom yielded but 13.66 per cent. (Am. Jour. Science, Vol. 3, 184\%.)

From the table it is seen that wool, (0.3 to 2.7 per cent, and seeds, (1.5) to $3 . \%$ per eent,) (lower or inner parts of the plint, are poorest in ash. The stems of herbaceous plants, ( $8 . \%$ to 7.9 per ecent, ) are next richer, while the leaves of herbacenus plants, which have such an extent of surfice, are the richest of all, ( 6 to 8 per cent.)

4. Investigation has demonstrated further inat the same plent in different st'iges of growth varies in the propor 
tions of ash in dry matter, yielded both by the entire plant and by the several organs or parts.

The following results, obtained by Norton, on the oat, illustrate this variation. Norton examined the various parts of the oat-plant at intervals of one week throughout its entire period of growth. He found:

Leaves. Stem. Knots. Chaff. Grain unhusked

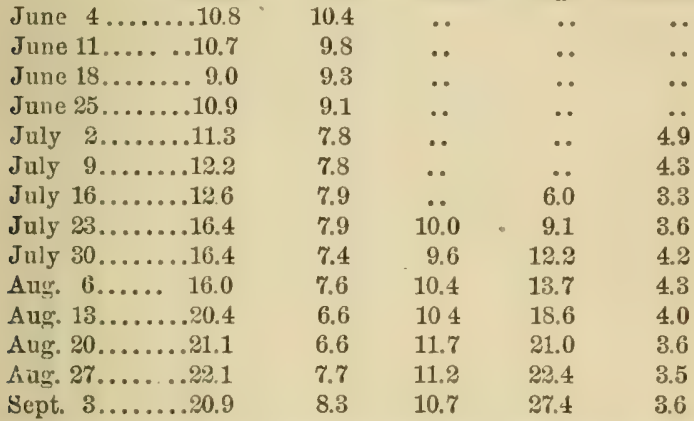

Here, in case of the leaves and chaff, we observe a constant increase of ash, while in the stem there is a constant decrease, except at the time of ripening, when these relations are reversert. The knots of the stem preserved a pretty uniform ash-content. The unhusked grain at first suffered a diminution, then an increase, and lastly a decrease again.

Areudt found in the cat-plant fluctuations, not in all respects accordant with those observed by Norton. Arendt obtained the following proportions of ash :

3 lower 2 middle Upper Lower Upper Ears. Entire joints of joints of joint of leaves. leaves. plant.

$\begin{array}{lrrrrrr}\text { June } 18 \ldots 4.4 & \ldots & \ldots & 9.7 & 7.7 & \ldots & 8.0 \\ \text { June } 30 \ldots 2.5 & 2.9 & 3.5 & 9.4 & 7.0 & 3.8 & 5.2 \\ \text { July } 10 \ldots .5 & 4.7 & 5.2 & 10.2 & 6.9 & 3.6 & 5.4 \\ \text { July } 21 \ldots 4.4 & \mathbf{5 . 0} & 5.5 & 10.1 & 9.7 & 2.8 & 5.2 \\ \text { July } 31 \ldots 6.4 & 5.3 & 6.4 & 10.1 & 10.5 & 2.6 & 5.1\end{array}$

Here we see that the ash increased in the stem and in each of its several parts after the first examination. The 
lower leares exhibited an increase of fixed matters after the first period, while in the upper leaves the ash dimin ished toward the third period, and thereafter increaved. In the ears, and in the entire plant, the ash decrensed quite regularly as the plant grew older. Pierre found that the proportion of ash of the colza, (Brassica olerace., ) diminished in all parts of the plant, (which was examined at fiva periods, ) except in the leaves, in which it increased. (Juhresbericht über Agriculturchemie, III, p. 122.) The sugar beet, (Bretschneider,) and potato, (Wolff,) exhibit a decrease of the per cent of ash, both in tops and roots.

In the turnip, examined at four perinds, Anderson, (Trans. High. and Ag. Soc., 1859-61, p. 371, found the following per cent of ash in dry matter:

\begin{tabular}{|c|c|c|c|c|}
\hline aves... & $\begin{array}{l}\text { July } 7 . \\
\ldots 7.8\end{array}$ & $\underset{20.6}{\text { Aug. }} 11$. & $\begin{array}{c}\text { Sept. } 1 . \\
\text { j8.8 }\end{array}$ & $\begin{array}{r}\text { Oct. } 5 \\
16.2\end{array}$ \\
\hline ulbs..... & $\ldots 17.7$ & 8.7 & 10.2 & 20.9 \\
\hline
\end{tabular}

In this case, the ash of the leaves increased during about half the period of growth from 7.8 to 20.6 , and thence diminished to 16.2. The ash of the bulbs fluctuated in the reverse manner, falling from 17.7 to 8.7 , then rising again to 20.9 .

In general, the proportion of ush of the entire plant diminishes regularly as the plant grous old.

5. The influence of the soil in causing the proportion of ash of the same kind of plant to vary, is shown in the following results, obtained by Wunder, (Versurhs-Stationen, $I V, p, 266$, ) on turnip bulbs, raised during two successive sears, in different soils.

Per cent of ash....13.9 $\overbrace{\begin{array}{c}1 \text { st year. } 2 d \text { year. } \\ 11.3\end{array}}^{\text {In sandy soil. }} \overbrace{\begin{array}{c}\text { 1st year. } \\ 9.1\end{array} \quad \begin{array}{c}\text { 2d year. } \\ 10.9\end{array}}^{\text {In loamy snil. }}$

6. $\Lambda$ s might be anticipated, different varieties of the same plant, grown on the same soil, take up different quantities of non-volatile matters.

In five varieties of potatoes, cultivated in the same soil 
and under the same conditions, Herapath, (Qu. Jour. Chem. Soc., II, $p$. 20, found the percentages of ash in dry matter of the tuber as follows:

$\begin{array}{lccccc}\text { Variety of potalo. } & \begin{array}{c}\text { White } \\ \text { Apple. }\end{array} & \begin{array}{c}\text { Prince's } \\ \text { Bcauly. }\end{array} & \begin{array}{c}\text { Axbridge } \\ \text { Kilney. }\end{array} & \text { Magpie. } & \text { Forty. } \\ \text { Ash per cent............4.8 } & 3.6 & 4.3 & 3.4 & 3.9\end{array}$

7. It has been observed further that different individuals of the same variety of plant, growing side by side, on the s:ime soil, (in the same field at least,) contain different proportions of ash-ing!edients, according as they are, on the one hand, healthy, vigorous plants, or, on the other, weak and stunted. Pierre, (Jahresbericht über Agriculturchemie, III, $p .125$, found in entire colza plants of various degrees of vigor the following percentages of ash in dry matter:

In extremely feeble plants, $1856 \ldots \ldots \ldots 8.0$ per cent of ash

In very feeble plants, $1857 \ldots \ldots . . . . . .990$ " "

In feeble plants, $1857 . . . \ldots \ldots \ldots \ldots \ldots . . .11 .4$ " "

In strong plants, $1857 \ldots \ldots \ldots \ldots \ldots \ldots . . .11 .0$ " "

In extremely strong plants, $1857 . \ldots \ldots . .14 .3$ " "

Pierre attributes the larger per cent of ash in the strong plants to the relatively greater quantity of leaves devel. oped on them.

Similar results were obtained by Arendt in case of oats. Wunder, (Versuchs-St., $I V, p .115$, ) found that the leaves of small turnip plants yielded somewhat more ash, per cent, than large plants. The former gave 19.7, the latter 16.8 per cent.

8. The reader is prepared from several of the foregoing statements to understand partially the cause of the variations in the proportion of ash in different specimens of ths same kind of plint.

The fact that different parts of the plant are unlike in their composition, the upper and outer portions being, in general, the richer in ash-iugredients, may explain in some degree why different observers have obtained different analytical results.

It is well known that a variety of circumstances in. 
1luences the relative derelopment of the organs of a plant. In a dry scason, plants remain stunted, are rongher on the surtace, have more and harsher hairs and prickles, if these belong to them at all, and develope firut earier than "therwise. In moist weather, and uniler the influence of rich manures, plints are more succulent, and the stems and Eliage, or vegetative parts, grow at the expense of the ro. froductive organs. Again, different varieties of the same plant, which are often quite unlike in their style of derelopment, are of necessity classed together in our table, and under the same head are also bromght together plints gathered at different stages of growth.

In order that the wheat plant, for example, shoulı always have the sime percentage of ash, it womld be necessary that it should always attain the same relative development in each individual part. It must, then, always grow under the same conditions of temperature, light, moisture, and suil. This is, however, as good as impossible, and if we admit the wheat plant to vary in form within certain lim. its without losing its proper characteristics, we must ad mit corresponding variations in composition.

The difference between the Tusean whent, which is cultivated exclusively for its straw, of which the Leghorn hats are made, and the "pedinree wheat" of Mr. Hallett, (Journal Roy. Ay. Soc. of Eny, Vol. 2:2,p. 37t,) is in some respects as great as betwcen $t w$ entirely different plants. The hat wheat has a short, loose, beaded ear, contuining not more than a dozen small kernels, while the pedigree wheat has shown beardless ears of 8 inches in length, closely packerl with large kernels to the number of 1:20!

Now, the hat wheat, if cultivated and propagated in the same careful manner as has been done with the pedigree wheat, would, no doubt, in time become as prolific of grain as the latter, while the pedigree wheat might perhaps with greater ease be made more valuable for its straw than itg grain. 
We easily see then, that, as circumstances are perpetually making new varieties, so analysis continually finds diversities of composition.

9. Of all the parts of plants the seeds are the lerist liable to vary in composition. Two varieties or two individuals may differ enormously in their relative proportions of foliage, stem, chaff, and seed; but the seerls themselves nearly agree. Thus, in the analyses of 67 specimens of the wheat kernel, collated by the author, the extreme percentinges of ash were 1.35 and 3.13 . In 60 specimens out of the 67 , the range of variation fell between 1.4 and 2.3 per cent. In 42 the range was from 1.7 to 2.1 per cent, while the average of the whole was 2.1 per cent.

In the stems or straw of the grains, the variation is much more considerable. Wheat-straw ranges from 3.8 to 6.9 ; pea-straw, from 6.5 to 9.4 per cent. In fleshy roots, the variations are great; thus turnips range from 6 to 21 per cent. The extremest variations in ash-content are, however, found, in general, in the succulent foli.ege. Turnip tops range from 10.7 to 19.7 ; potato tops vary from 11 to near 20 , and tobacco firom 19 to 27 per cent.

Wolff, (Die naturgesetalichen Grundlugen des Ackerbaues, 3. Aufl., $p .117$,) has deduce l from a large number of analyses the following averages for three important classes of agricultural plants, viz.:

\section{Grain.}

Cereal crops

Leguminous crops

Oil-plants
2

3

4
Strano.

5.25 per cent.

5 " "

4.5 " "

More general averages are as follows, (Wolff loc. cit.) : Anmual and biemial plants. Seeds - - 3 per cent Stems - - - 5 " " Roots - - 4 " " Leaves - . - 15 " " Perennial plants. Seeds - - 3 per cent Wood - - - - 1 " " Bark - - - 7 " " Leaves - - 10 " " 
We may conclude this section by stating three propositions which are proved in part by the ficts that have been already presented, and which are a summing up of tho most imprortant points in our knowledge of this subject.

I. Ash-ingredients are indispensuble to the life und growth of all plants. In mold, yeast, and wther plints of che simplest kind, as well as in those of the higher orders, analysis never fails to recognize a proportion of fixed matters. We must hence conclule that these are necessary to the primary acts of vergetation, that atmospheric food cannot be assimilated, that vegetable matter cimnot he organ. ized, except with the coüperation of those substances, which are found in the ashes of the plant. This proposition is demonstrated further in the most conclusive manner by numerons svithetic experiments. It is, of course, impossible to attempt producing a plant at all withont some ashingredients, for the latter are present in all seeds, and during germination are transferred to the seedling. By causing seeds to sprout in a totally insoluble medium, we can olserve what happens when the limited supply of fixed matters in the seeds themselves is exhausted. Wiegmann \& Polstorf, (Preisschrift über die unoryanischen Bestundtheile der Pflanzen, ) planted 30 seeds of cress in fine platinum wire contained in a platinum vessel. The contents of the ressel were moistened with distilled water, and the whole was placed under a glass shade, which served to shield from clust. Through an aperture in the shade, connection was made with a gasometer, by which the atmosphere in the interior could be renewed with an artificial mix ture, comsisting in 100, of 21 parts oxygen, is parts nitrogen, and 1 part cartonic acid. In two days 28 of the seeds germinated; afterwards they developed leaves, and grew slowly with a healthy appearance during 26 days, reaching a height of two to three inches. From this time on, they refised to grow, beg:m to turn yellow, and died down. The plints were collected, and bumed; the ash from them 
weighed precisely as much as that obtained by burning 28 seeds like those originally sown. This experiment demonstrates most conclusively that a plant cannot grow in the absence of those substances found in its ash. The development of the cresses ceased so soon as the fixed matters of the seed had served their utmost in assisting the or gan. ization of new cells. We know from other experiments that, had the ashes of cress been applied to the plants in the abore experiment, just as they exhibited signs of unhealthiness, they would have recovered, and developed to a much greater extent.

II. The pioportion of ash-ingredients in the plant is variable within a narrow range; but cannot full below or exceed certain limits. The evidence of this proposition is to be gathered both from the table of ash-percentages, and from experiments like that of Wiegmann \& Polstorf above described.

III. We have reason to believe that each part or organ, (each cell,) of the plunt contains a certain, nearly invuriable arrount of fixed matters, which is indispensable to the vegetative functions. Euch part or organ may contain, besides, a variable and unessential or recidental quantity of the same. What portion of the ash of any plant is essen. tial and what accidental is a question not yet bronght to a satisfactory decision. By assuming the truth of this proposition, we account for those variations in the amount of ash which cannot be attributed to the causes already noticed. The evidences of this statement must be reserved for the subsequent section.

\section{$\S 3$.}

8PECIAL COMPOSI?LON OF THE ASH OF AGRICULTURAL PLANTS.

The results of the extended inquiries which have been recently made into the subject of this section mar be con. 
reniently presented and discussed uncer a series of propo. sitions, viz.:

1. Among the substances which have been descrihed, $(\$ 1$,$) as the ingredients of the ash, the following are in-$ vuriably present in all ugricultural plants, and in nearly ull parts of them, viz.

Basts $\left\{\begin{array}{l}\text { Potash } \\ \text { Soda } \\ \text { Litne } \\ \text { Magnesia } \\ \text { Oxide of iron }\end{array} \quad\right.$ Acids $\left\{\begin{array}{l}\text { Chlorine } \\ \text { Sulphuric acid } \\ \text { Phosphoric acid } \\ \text { Shlicica acid } \\ \text { Carbonic acid }\end{array}\right.$

2. Different normal specimens of the same kind of plant have a nerly constant composition. The use of the word nearly in the above statement implies what has been already intimated, viz., that some variation is noticed in the relative proportions, as well as in the total quantity of ash-ingredients occurring in plants. This point will shortly be discussed in full. By taking the average of many trustworthy ash-analyses, we arrive at a result which does not differ very widely from the majority of the individual analyses. This is especially true of the seeds of plants, which attain nearly the same development under all ordinary circumstanees. It is less true of foliage and roots, whose dimensions and char:acter vary to a great extent. In the following tables (p.150-156) is stated the composition of the ashes of a number of agricultural products, which have been repeatedly subjected to analysis. In most cases, instead of quoting all the individual analyses, a series of averages is given. Of these, the first is the mean of all the analyses on record or obtainable by the writer, * while the subsequent ones represent either the results obtained in the examination of a number of samples by one analyst, or are the mean of several single anal-

* The numerous ash-annlyses, published by Dr. E. Emmons and Dr. J. II. Salisbury, in the Nutural IIistory of New York, and in the Trans. of the N. Y. State Ag. Society, have been disregarded on account of their manifest worthless. ness and absurdity. 
gres. In this way, it is believed, the real variations of composition are pretty truly exhibited, independently of the errors of analysis.

The lowest and highest percentages are likewise given. These are doubtless in many cases exaggerated by errors of analysis, or by impurity of the material analyzed. Chlorine and sulphuric acid are for the most part too low, because they are liable to be dissipated in combustion, while silica is often too high, from the fact of sand and soil adhering to the plant.

In two cases, single and perhaps incorrect analyses by Bichon, which give exceptionally large quantities of soda, are cited separately.

A number of analyses that came to notice after making out the averages, are given as additional.

The following table includes both the kernel and straw of Wheat, Rye, Barley, Oats, Maize, Rice, Buckwheat, Beans, and Peas; the tubers of Potitoes; the roots and tops of Sugar Beets, Ficld Bects, Carrots, Turnips, and various parts of the Cotton Plant.

For the average composition of other plants and vegetable products, the reader is referred to a table in the appendix, p. 376, compiled by Prof. Wolff, of the Royal Agricultural Academy of Wurtemberg. That table in. cludes also the averayes obtained by Prof. Wolff for most of the substances, cotton excepterl, whose composition is represented in the pages immediately following. Any discrepancies between Prof. WVolff's and the author's figures are for the most part due to the use of fewer analyses by the former.

In both tables, the carbonic acid, which occurs in most ashes, is excluded, from the fact that its quantity varies according to the temperature at which the ash is prepared. 


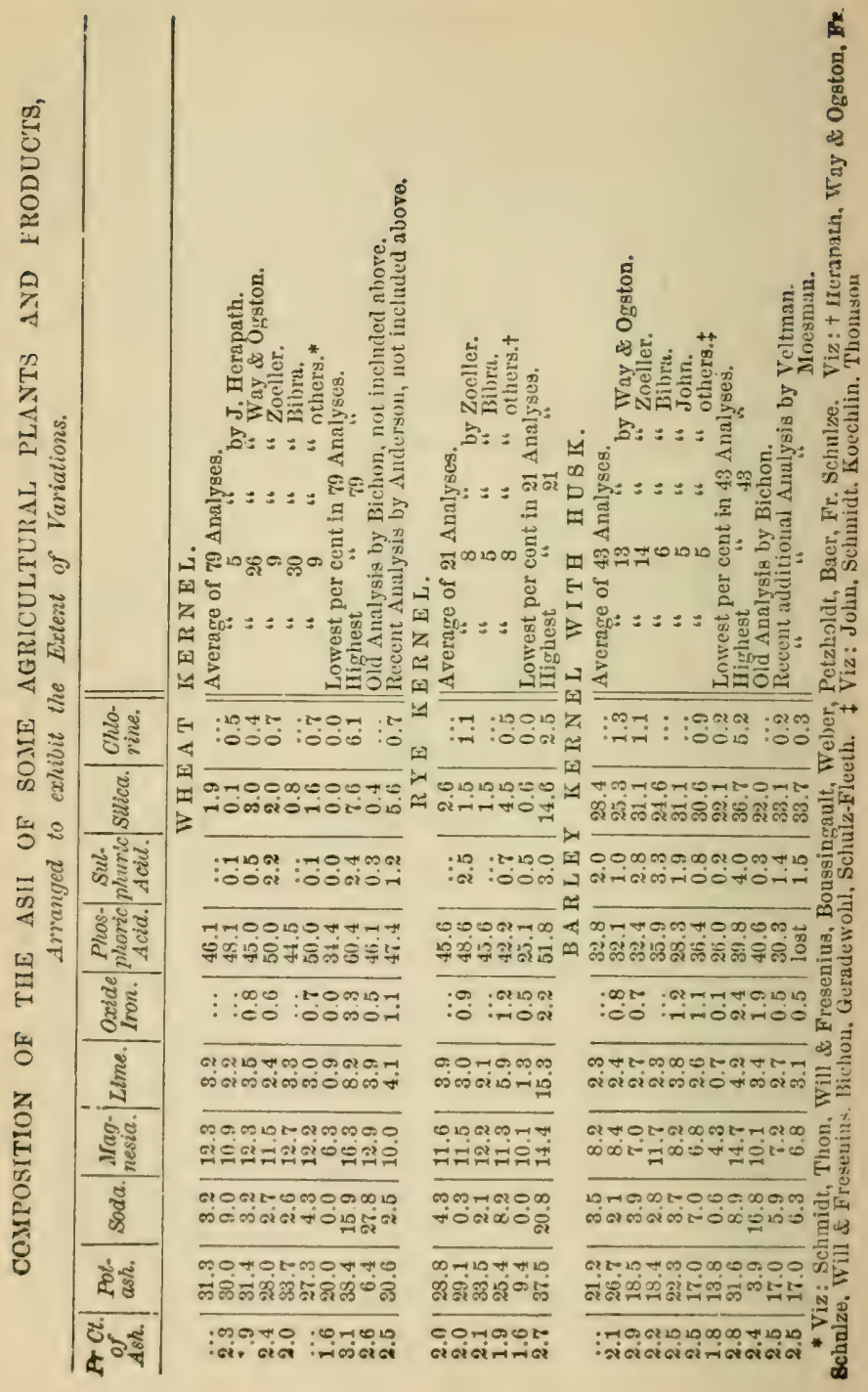


TAE ASU OF PLANTS.
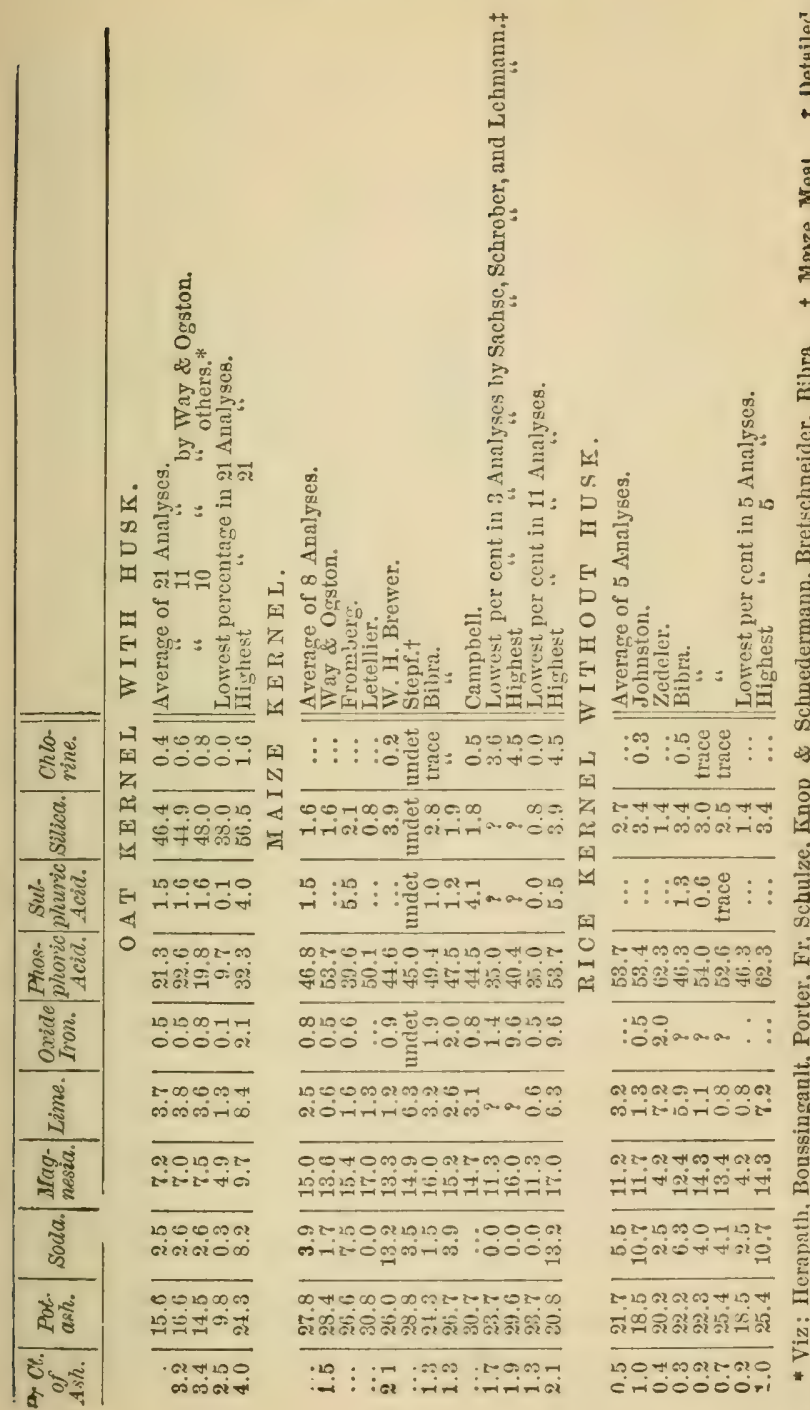

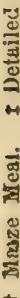

i.

인

$e^{*}+\infty$

on

10.

뉸

D: 4

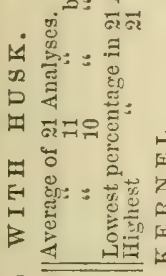

$\infty$
0
$w$
$D$

릴

हैं.

0

ठ

म०

뵈 000 -

Z

क्ष

मी स.0.0.0 <

ध

nsecono

E मान्नं०

4

कe⿻

हो होन्न बं

党.

$\infty \frac{8}{02}$

हैं

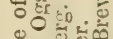

Ery

ह

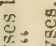

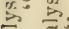

麦

$\therefore=E$.

$\Xi$

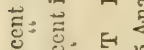

50

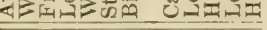

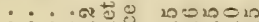

$:::$ : :

$\infty 0-\infty 00+\infty 0 \infty$

-1...

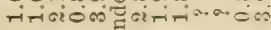

年

U.

0
$=1$
$=$

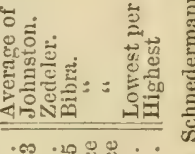

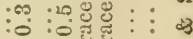

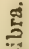

के

a

(

sartron

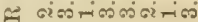
되

10.10 . गुणना ON - : : : :

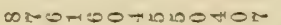
EI

: : : :

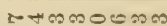

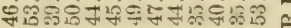

$10200 \mathrm{H}$

00006

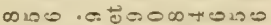
o0 :0

rosen m

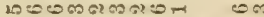

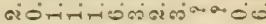

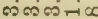

C20100R

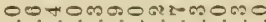

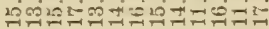

in- is

Lo $0000 \mathrm{ar}$

ormogis no :00062

n-ix-onntin ióng

00100000

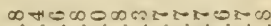
I2

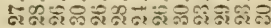

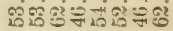

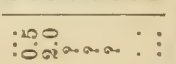

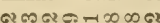
m-II-10-100

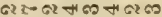

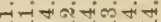

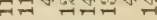

10502004250

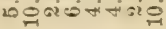

$1-10650502+15+1$

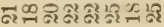

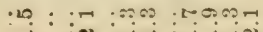

युonthestaso

crióoiori

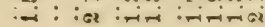




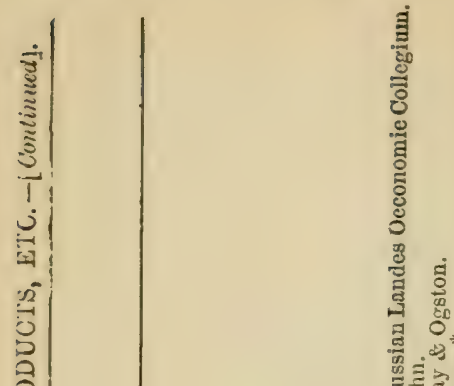

$\infty$ H

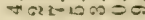

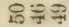

\section{$\pi \infty$}

-icis

$\Rightarrow$

$=$

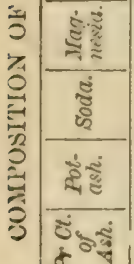

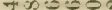

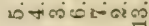

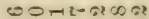

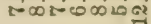

유류 유류

0.0200 บิเป็

$20 \mathrm{r}-4$ $x-t=$

बरा क्र क 5 rọ.

बi०

$x-\infty$

व दरादर

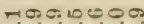

ข่อั

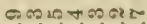

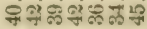

개무

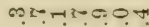

$x=00-0 \pi$

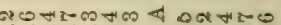

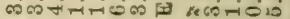
$\pi$

0.2तentark

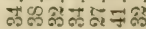

a) 02000 : 0 :000ரi

cos ०ैन

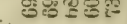

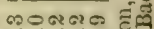
10 co vi $00^{\circ}$.

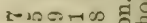
c0001020200100 कू

$a x-2-a+20$

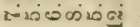

$10+5006$ बirision

OOLTOML

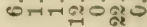

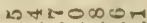

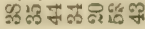

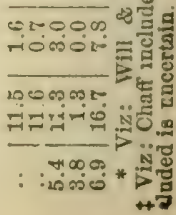




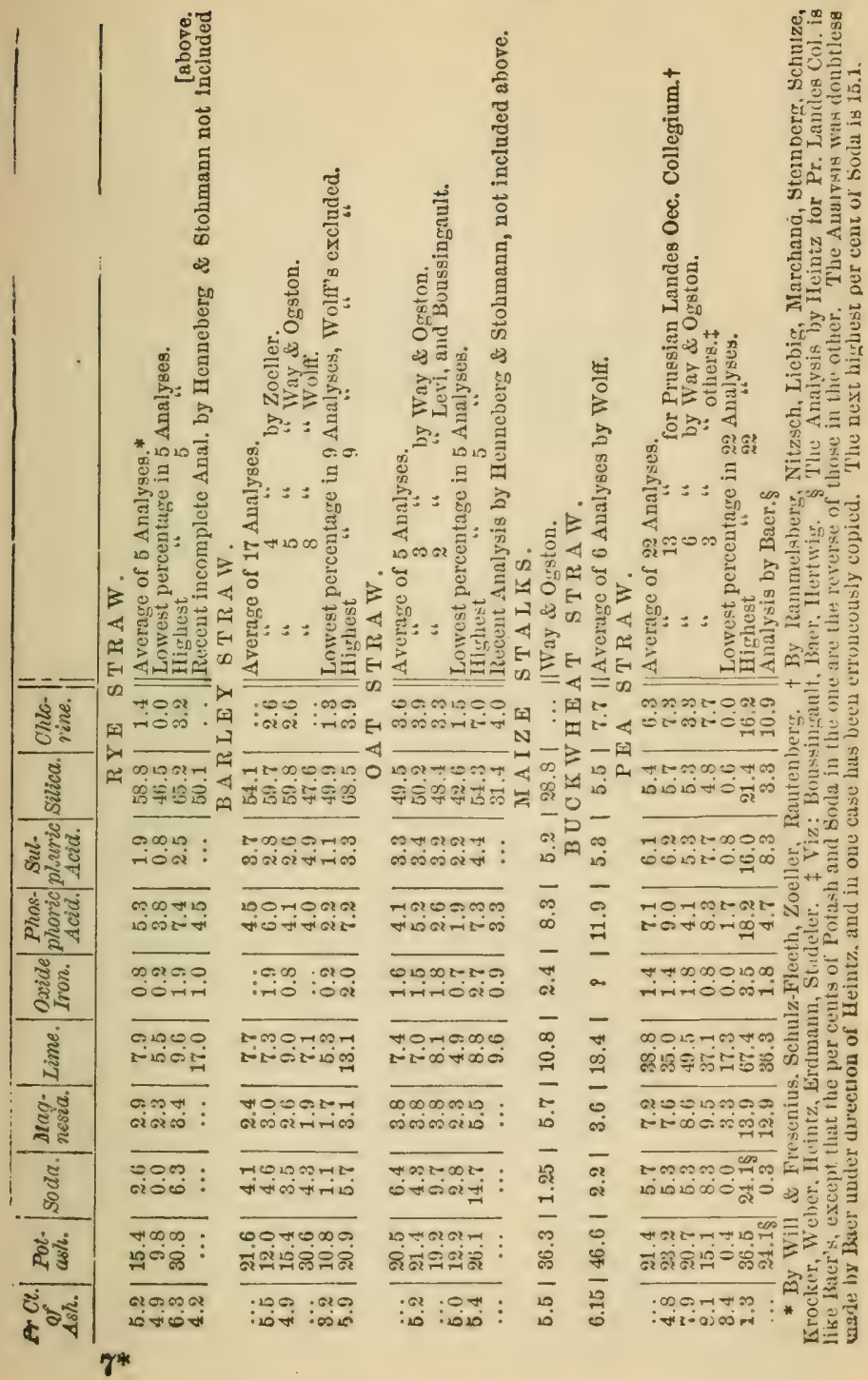




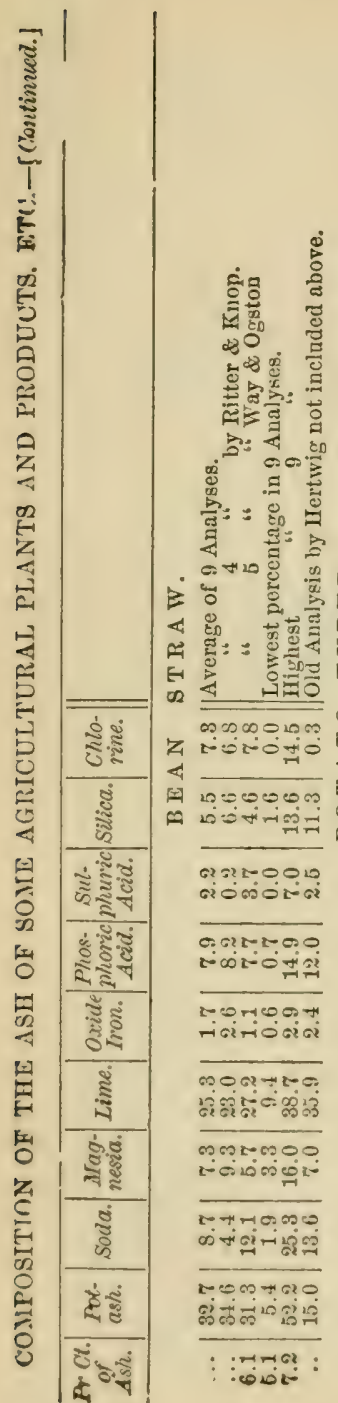

붕

है

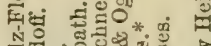

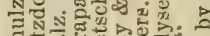

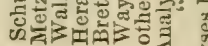

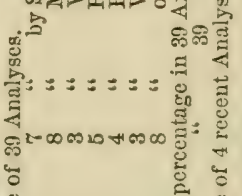

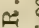
के

पू है

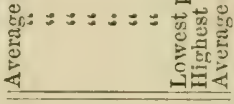

○ $5=100 \pi \cos 200 \cos 0 \mathrm{x}$

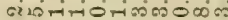

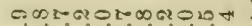

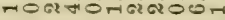

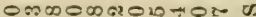
โ

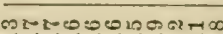

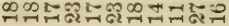

or 2000000000 000monnitoon

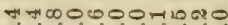

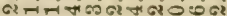

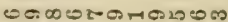

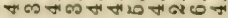

L- . . . -10 :

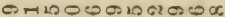

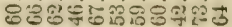

:

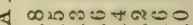
mentimsio

b

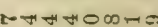

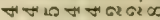

सuconorin

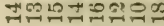

onconang ल० मान त० जर

Anomonos

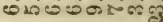

$10 \pi \cos c 5102000$

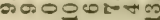

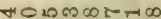
웅소

$060 \pi 0 m 00$

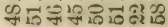

incolescoso

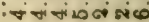



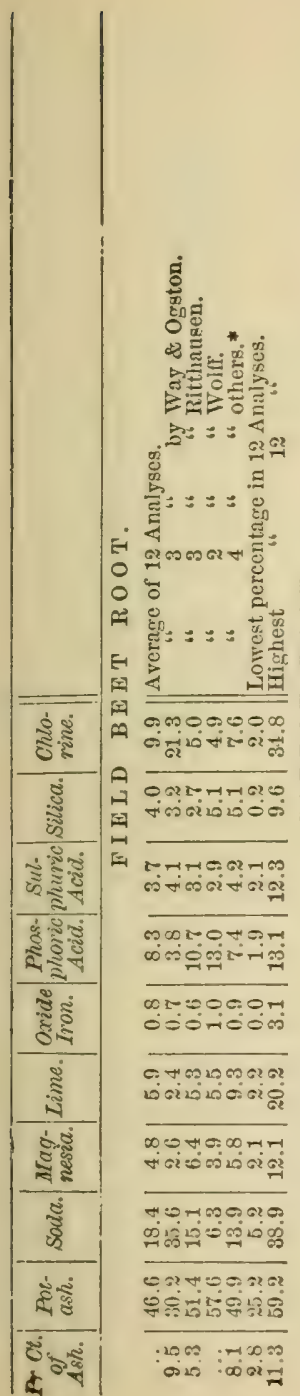

현
t.
to
0

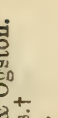

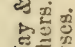

E完:

¿:

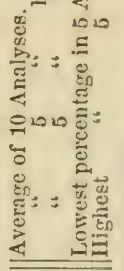

स

$0, \infty \theta \pi+4$

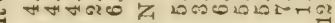

西

$0+2000$

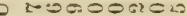

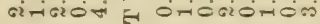

$\cos \pi$

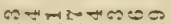

$\sin =$

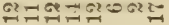

$620 \pi, 020$

कल6?6?6) 두음 50010

0,000

rifior

extos $=10$

으은

$\cos =\cos \pi$

$15+15-10$

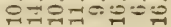

स6100200-000

orico00.

- 00 onsong cicio $=02010$

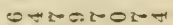

बiचं चi

$i=\pi, \pi$

rentraton

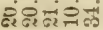

ono 00 का

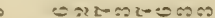

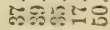

$10=0-\infty$ $-\infty \infty \mathrm{\infty})$

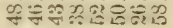

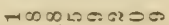

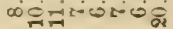

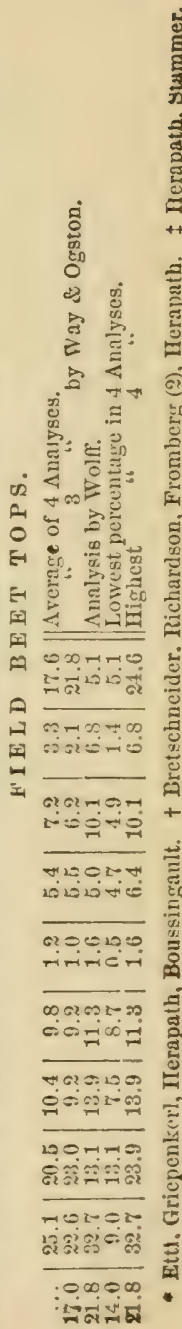

, 


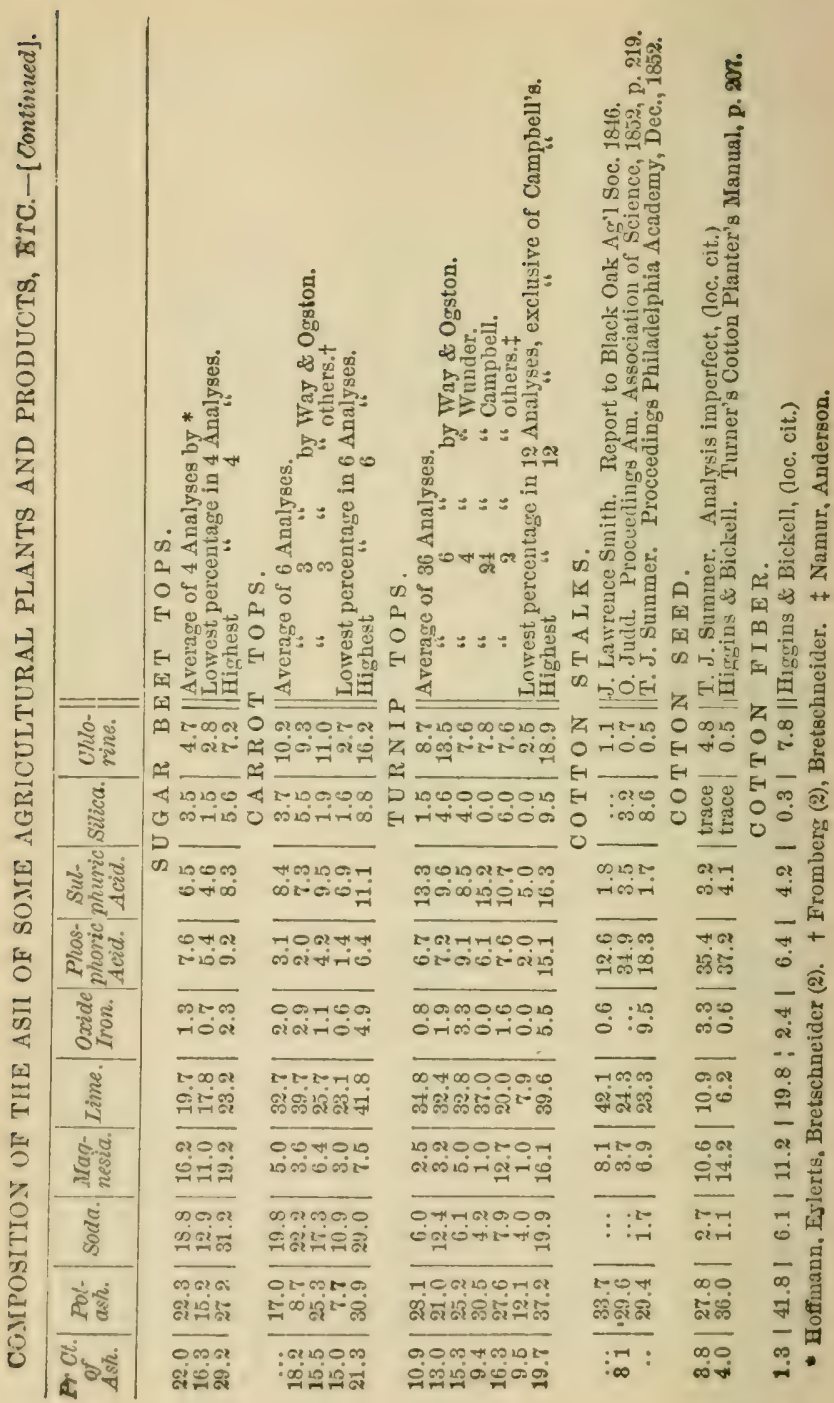


The composition of the ash of a number of ordinary crops is concisely exhibited in the subjoined general statement.

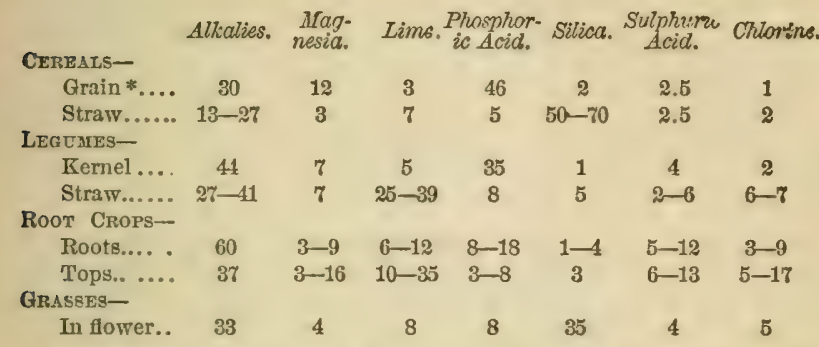

3. Different parts of any plant usually exhibit decided differences in the composition of their ash. This fact is made evident by a comparison of the figures of the table above, and is more fully illustrated by the following analyses of the parts of the mature oat-plaut, by Arendt, 1 to 6 , (Die Huferpflanze,p. 107,) and Norton, 7 to 9, (Am. Joun: Sci., 2 Ser. 3, 318.)

\begin{tabular}{|c|c|c|c|c|c|c|c|c|c|}
\hline & $\begin{array}{c}1 \\
\text { Lover } \\
\text { Stem. }\end{array}$ & $\begin{array}{c}2 \\
\text { Mitilile } \\
\text { Stem. }\end{array}$ & $\begin{array}{c}3 \\
\text { typer } \\
\text { Stem. }\end{array}$ & $\begin{array}{c}4 \\
\text { Lower } \\
\text { Leacies }\end{array}$ & $\begin{array}{c}\mathbf{5} \\
\text { Tpper } \\
\text { Lecteres. }\end{array}$ & $\begin{array}{c}6 \\
\text { Ears. }\end{array}$ & Chaff & $\stackrel{8}{\text { Husk: }}$ & $\begin{array}{c}9 \\
\text { Ternet } \\
\text { lstied. }\end{array}$ \\
\hline atgeh &. .81 .2 & 68.3 & 55.9 & 36.9 & 24.8 & 13.0 & 10.6 & 12.4 & 31.7 \\
\hline & $\begin{array}{ll} & 0.4 \\
\therefore & 2.1\end{array}$ & & $\begin{array}{l}1 . \\
3 .\end{array}$ & & $\begin{array}{l}0 . \\
3 .\end{array}$ & $\begin{array}{l}0 . \\
8 .\end{array}$ & & 2.3 & \\
\hline & $.3 . t i$ & & & 16. & 17.2 & 7. & & & \\
\hline & 1. & & 0 . & & 0.5 & trace & 11.2 & 0.3 & 0. \\
\hline & 2. & & & & & 36. & & & 49. \\
\hline & 0. & & & & & & & & \\
\hline & & & 20. & 34. & 41. & 26. & & 74. & \\
\hline orne & .. 8.6 & 11.7 & & 1.6 & 2.4 & 3.8 & 3.1 & 1.4 & 0.2 \\
\hline
\end{tabular}

The results of Arendt and Norton are not in all respects strictly com. parable, having been obtained by different methods, but serve well to establish the fact in question.

We see from the above figures that the ash of the lower stem consists chiefly of potash, $(81 \%$. $)$ This alkali is predominant throughout the stem, but in the upper parts, where the stem is not covered by the leaf sheaths, silica and lime occur in large quantity. In the asb of the leaves,

- Excluairs ol husie. 
silica, potash, and lime, are the principal ingredients. In the chaff and husk, silica constitutes three-fourths of the ash, while in the grain, phosphoric acid appears as the characteristic ingredient, existing there in connection with a large amount of potash, $(32 \%$ ) and considerable mas. nesia. Chlorine acquires its maximum, $\left(\left.11.7^{\circ}\right|_{0}\right)$ in the middle stem, but in the kernel is present in small quantity, while sulphuric acid is totally wanting in the lower stem, and most abundant in the upper leaves.

Again, the unequal distribution of the ingredients of the ash is exhibited in the leaves of the sugar beet, which have been investigated by Bretschneider, (Hoff. Jahresbe. richt, 4, 89.) This experimenter divided the leaves of 6 sugar beets into 5 series or circles, proceeding from the outer and older leaves inward. He examined each series separately with the following results:

\begin{tabular}{|c|c|c|c|}
\hline I. & II. & III. & IV. \\
\hline Potash...............18.7 & 25.9 & 32.8 & 37.4 \\
\hline Soda.................15.2 & 14.4 & 15.8 & 15.0 \\
\hline Chloride of Sodium... 5.8 & 6.4 & 5.8 & 6.0 \\
\hline Lime ...............24.2 & 19.2 & 18.2 & 15.8 \\
\hline Magnesia............24.5 & 22.3 & 13.0 & 8.9 \\
\hline Oxide of Iron......... 1.4 & 0.5 & 0.6 & 0.6 \\
\hline Phosphoric acid....... 3.3 & -4.8 & 5.8 & 8.4 \\
\hline Sulphuric acid....... 5.4 & 5.6 & 5.6 & 5.2 \\
\hline Silica............... 1.5 & 0.8 & 2.7 & 2.1 \\
\hline
\end{tabular}

From these data we perceive that in the ash of the leaves of the sugar bcet, potash and phosphoric acid regularly and rapidly increase in relation to the other ingredients from without inward, while lime and magnesia as rapidly diminish in the same direction. The per cent of the other ingredients, viz., soda, chlorine, oxide of iron, sulphuric acid, and silica, remains nearly invariable throughout.

Auother illustration is furnished by the following anal. yses of the ashes of the varions parts of the horse-chestnut tree, marle by Wolff, (Ackerbuu, 2. Auf., 1:t) 
Bark. Wood. Leaf-stems. Leaves. Flover-stems. Calyx.

\begin{tabular}{|c|c|c|c|c|c|}
\hline Potash ..............12.1 & 25.7 & 46.2 & 27.9 & 63.6 & 61.7 \\
\hline Lime...............76.8 & 42.9 & 21.7 & 29.3 & 9.3 & 12.3 \\
\hline Magnesia .......... 1.7 & 5.0 & 3.0 & 2.6 & 1.3 & 5.9 \\
\hline Sulphuric acid......trace & trace & 3.8 & 9.1 & 3.5 & trace \\
\hline Phosphoric acid.... 6.0 & 19.2 & 14.8 & 22.4 & 17.1 & 16.6 \\
\hline Silica............ 1.1 & 2.6 & 1.0 & 4.9 & 0.7 & 1.7 \\
\hline Chlorine ...........2.8 & 6.1 & 12.2 & 5.1 & 4.7 & 2.4 \\
\hline
\end{tabular}

Ripe Fruit.

Stamens Petals. Green Fruit. Fiernel. Green Brown

\begin{tabular}{|c|c|c|c|c|}
\hline Potash ............60.7 & 61.2 & 58.7 & 61.7 & $\begin{array}{c}\text { Shell. } \\
75.9\end{array}$ \\
\hline Lime. . . . . . . . . . . . 13.8 & 13.6 & 9.8 & 11.5 & 8.6 \\
\hline Maguesia ........... 3.1 & 3.8 & 2.4 & 0.6 & 1.1 \\
\hline Sulphuric acid......trace & trace & 3.7 & 1.7 & 1.0 \\
\hline Phosphoric acid ...19.5 & 17.0 & 20.8 & 22.8 & 5.3 \\
\hline Silica ............. 0.7 & 1.5 & 0.9 & 0.2 & 0.6 \\
\hline Chlorine.......... 2.8 & 3.8 & 4.8 & 2.0 & 7.6 \\
\hline
\end{tabular}

4. Similar kinds of plants, and especially the same parts of similar plants, exhibit a close general agreement in the composition of their ashes; while plunts which are unlike in their botanical charactei's are also unlike in the proportions of their fixed ingredients.

The three plants, wheat, rye, and maize, belong, botanically speaking, to the same natural order, gramineo, and the ripe kernels yield ashes almost identical in composition. Barley and the oat are also graminaceous plants, and their seeds should give ashes of similar composition. That such is not the case is chiefly due to the fact, that, unlike the wheat, rye, and maize-kernel, the grains of barley and oats are closely invested with a husk, which forms a part of the kernel as ordinarily seen. This husk yields an ash which is rich in silica, and we can only properly compare barley and oats with wheat and rye, when the former are hulled, or the ash of the hulls is taken out of the account. There are varieties of both oats and barley, whose husks separate from the kernel-the so-called naked or skinless oats and naked or skinless barley-and the ashes of these glains agree quite nearly in composition with those of wheat, ryr. and maize, as may be seen from the following table: 


\begin{tabular}{|c|c|c|c|c|}
\hline $\begin{array}{l}\text { Wheat. } \\
\text { Average } \\
\text { of } \\
\text { seventy-nine } \\
\text { analyses. }\end{array}$ & $\begin{array}{l}\text { Rye. } \\
\text { Average } \\
\text { of } \\
\text { twenty-one } \\
\text { analyses. }\end{array}$ & $\begin{array}{l}\text { Araize. } \\
\text { Average } \\
\text { of } \\
\text { seven } \\
\text { analyses. }\end{array}$ & $\begin{array}{l}\text { Skinless } \\
\text { oats. } \\
\text { Analysis } \\
\text { by Fr. } \\
\text { Schulie. }\end{array}$ & $\begin{array}{l}\text { Shatrless } \\
\text { barley. } \\
\text { Analysis } \\
\text { by Fr. } \\
\text { Schulze. } \\
\text { Si. }\end{array}$ \\
\hline $\begin{array}{l}\text { Potasb ..........31.3 } \\
\text { Soda ........... 3.2 }\end{array}$ & $\begin{array}{r}28.8 \\
4.3\end{array}$ & $\begin{array}{r}27.7 \\
4.0\end{array}$ & 30.4 & $\begin{array}{r}35.9 \\
1.0\end{array}$ \\
\hline 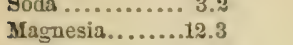 & 11.6 & 15.0 & 11.3 & $: 3.7$ \\
\hline Lime........... 3.2 & 3.9 & 1.9 & 3.6 & 2.9 \\
\hline Oxide of Iron... 0.7 & 0.8 & $=1.0$ & 0.8 & 0.7 \\
\hline Phosphoric acid.46.1 & 45.6 & 47.1 & 46.9 & $\mathbf{t 5 . 0}$ \\
\hline Sulphuric acid... 1.2 & 1.9 & 1.7 & $\longrightarrow$ & - \\
\hline Silica........... 1.9 & 2.6 & 2.1 & 2.4 & 0.7 \\
\hline Chlorine........ 0.2 & 0.7 & 0.1 & - & 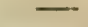 \\
\hline
\end{tabular}

By reference to the tahle, (p. 15:2, it will be observed that the per and bean kernel, together with the allied vetch and lentil, (p. 379,)also nearly agree in ash-composition.

So, too, the ashes of the root-crops, turnips, carrots, and beets, exhibit a general similarity of composition, as may be seen in the table, (p. 154-5).

The seeds of the oil-bearing plants likewise constitute a group whose members agree in this respect, p. 379.

5. The ash of the same species of plant is more or less variable in composition, according to circumstunces.

The conclitions that have alrearly been noticed as influencing the proportion of ash are in general the same that affect its quality. Of these we may specially notice:

a. The stage of growth of the plant.

b. The vigor of its development.

c. The variety of the plant or the relative development of its parts, and

d. The soil or the supplies of food.

a. The stage of gronoth. The facts that the different parts of a plant yield ashes of different composition, and that the different stages of growth are mirked by the development of new organs or the unequal expansion of those already formed, are sufficient to sustain the point now in question, and renter it needless to cite analytical evidence. In a subsequent chapter, wherein we shall at. tempt to trace some of the various ateps in the progressive 
development of the plant, numerous illustrations will be ardaced, (p. 214.)

b. Vigor of development. Arendt, (Die Haferpflanze, $r .18$,) selected from an oat-field a number of plants in bl.ssiom, and divided them into three parcels-1, composed of very vigorous plants; 2 , of medium; and, 3 , of very weak plants. IIe analyzed the ashes of each parcel, with results as below :

\begin{tabular}{|c|c|c|}
\hline 1 & 2 & 3 \\
\hline Silica...................37.0 & 39.9 & 42.0 \\
\hline Sulphuric acid..........4.8 & 4.1 & 5.6 \\
\hline Phosphoric acid........ 8.2 & 8.5 & 8.8 \\
\hline Chlorine ............... 6.7 & 5.8 & 4.7 \\
\hline Oxide of Iron........... 0.4 & 0.5 & 1.0 \\
\hline Lime................ 6.1 & 5.4 & 5.1 \\
\hline Magnesia, Potash \& Soda.45.3 & 34.3 & 30.4 \\
\hline
\end{tabular}

Here we notice that the ash of the weak plants contains 15 per cent less of alkalies, and 15 per cent more of silica, than that of the vigorous ones, while the proportion of the other ingredients is not greatly different.

Zoeller, (Liebig's Ermühnung der Vegetabilien, p. 3-10,) examined the ash of two specimens of clover which grew on the same soil and under similar circumstances, save that one, from being shaded by a tree, was less fully developed than the other.

Six weeks after the sowing of the seed, the clover was cut, and gave the following results on partial analysis:

Shaded clover. Unshaded clover.

$\begin{array}{lr}\text { Alkalies...............54.9 } & 36.2 \\ \text { Lime..................14.2 } & 22.8 \\ \text { Silica................. 5.5 } & 12.4\end{array}$

c. The variety of the plant or the relative developmens of its parts must obviously influence the composition of the ash taken as a whole, since the parts themselves are unlike in composition.

Herapath, (Qu. Jour. Chem. Sir., II, p. 20,) analyzed the ashes of the tubers of five varieties of potatoes, raised on the same soil and under precisely similor erreumstances. His results are as follows : 


\begin{tabular}{|c|c|c|c|c|}
\hline $\begin{array}{l}\text { White } \\
\text { Apple. }\end{array}$ & $\begin{array}{l}\text { Prince's } \\
\text { Beauty. }\end{array}$ & $\begin{array}{l}\text { Axbridge } \\
\text { Kidney. }\end{array}$ & Magrie. & Fiorty $f \alpha$ \\
\hline Potash ...........69.7 & 65.2 & 70.6 & \%0.0 & 621 \\
\hline Chloride of Sodium. & - & - & - & 25 \\
\hline Lime............. 3.0 & 1.8 & 5.0 & 5.0 & 3.3 \\
\hline Magnesia.........6.6.5 & 5.5 & 5.0 & 2.1 & 3.5 \\
\hline Phosphoric acid....17.2 & 20.8 & 14.9 & 14.4 & 20.7 \\
\hline 8ulpharic acid..... 3.6 & 6.0 & 4.3 & 7.5 & 7.9 \\
\hline Blica ............. & - & 0.2 & - & - \\
\hline
\end{tabular}

d. The soil, or the supplies of food, manures includtel. have the greatest influence in varying the proportions of the ash-ingredients of the plant. It is to a considerable degree the character of the soil which determines the vigor of the plant and the relative development of its parts. This condition then, to a certain extent, includes those already noticed.

It is well known that oats have a great range of weight per bushel, being nearly twice as heavy when grown on rich land, as when gathered from a sandy, inferior soil. According to the agricultural statistics of Scotland, for the year 18.)\%, (Tions. Highland and Ag. Soc., 1857-9, $p$. 213,) the bushel of oats prontuced in some districts weighed 44 pounds por bushel, while in other districts it was as low as 35 pounds, and in one instance but 24 pounds per bushel. Light oats have a thick and bulky husk, and an ash-analysis gives a result quite unlike that of good oats. IIerapath, (Jour. Roy. Ag. Society, XI., p. 10\%,) ha: pul)lished analyses of light oats from sandy soil, the yield being six bushels per acre, and of heavy oats from the same soil, after "warping," where the produce was $6 \pm$ bushels per acre. Some of his results, per cent, are as follows :

$\begin{array}{lr}\text { Light oats. } & \text { Heavy oats. } \\ \text { Potash.......... } 9.8 & 13.1 \\ \text { Soda........... } 4.6 & 7.2 \\ \text { Lime........... } 6.8 & 4.2 \\ \text { Phosphoric acid... } 9.7 & 17.6 \\ \text { Silica ............56.5 } & 45.6\end{array}$

Wolff, (Jour. für Pralut. Chem., 52, p. 103,) has anal.

- Thickly covering with sediment from muddy tide-water. 
ysed the ashes of several plants, cultivated in a poor soil, with the addition of various mineral fertilizers. The influence of the added substances on the composition of the plant is very striking. The following figures comprise his results on the ash of buckwheit straw, which grew on the unmanured soil, and on the same, after application of the substances specified below:

\begin{tabular}{|c|c|c|c|c|c|}
\hline 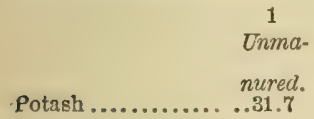 & $\begin{array}{l}2 \\
\text { Chioride } \\
\text { of } \\
\text { socitum. } \\
21.6\end{array}$ & $\begin{array}{c}3 \\
\text { Nitrate } \\
\text { of } \\
\text { potash. } \\
39.6\end{array}$ & $\begin{array}{c}4 \\
\text { Carbonate } \\
\text { of } \\
\text { poiash. } \\
40.5\end{array}$ & $\begin{array}{l}\mathbf{5} \\
\text { Sulphate } \\
\text { of } \\
\text { magnesia. } \\
23.2\end{array}$ & $\begin{array}{c}6 \\
\text { Carbonats } \\
\text { of } \\
\text { lime. } \\
23.9\end{array}$ \\
\hline Chloride of potassium. 7.4 & 26.9 & 0.8 & 3.1 & 6.9 & 9.7 \\
\hline Chloride of sodium... 4.6 & 3.0 & 3.2 & 3.8 & 3.4 & 1.7 \\
\hline Lime... .......... 15.7 & 14.0 & 12.8 & 11.6 & 14.1 & 18.6 \\
\hline Magnesia .. .......... 1.7 & 1.9 & 3.3 & 1.4 & 4.7 & 4.2 \\
\hline Sulphuric acid.........4 4.7 & 2.8 & 2.7 & 4.3 & 7.1 & 3.5 \\
\hline Phosphoric acid.......10.3 & 9.5 & 6.5 & 8.9 & 10.9 & 10.0 \\
\hline Carbonic acid........20.4 & 16.1 & 27.1 & 22.2 & 20.0 & 23.2 \\
\hline Silica ................ 3.6 & 4.2 & 4.2 & 4.2 & 4.8 & 5.2 \\
\hline$\overline{100.0}$ & 100.0 & 100.0 & 100.0 & 100.0 & 100.0 \\
\hline
\end{tabular}

It is seen from these figures that all the applications employed in this experiment exerted a manifest influence, and, in general, the substance adderl, or at least one of its ingredients, is found in the plant in increased quantity.

In 2, chlorine, but not sodium; in 3 and 4 , potash; in 5, sulphuric acid and magnesia, and in 6, lime, are present in larger proportion than in the ash from the unmanured soil.

6. What is the Normal Composition of the Ash of a Plant? It is evident from the foregoing facts and considerations that to pronounce upon the normal composition of the ash of a plant, or, in other words, to ascertain what ash-ingredients and what proportions of them are propes to any species of plant or to any of its parts, is a matter of much dificulty and uncertainty.

The best that can be done is to alopt the average of a great number of trustworthy analyses as the approximate axpression of ash-composition. From such data, however, re are still unable to decide what are the absolutely es. 
sential, and what are really accidental ingredients, or what amount of any given ingredient is essential, and to what extent ic is accidental. Wolff, who appears to have first suggested that a part of the ash of plants may be accidental, encleavored to approach a solution of this question, by comparing together the ashes of samples of the same plant, cultivated under the same circumstances in all respects, save that they were supplied with unequal quantities of readily available ash-ingredients. The analyses of the ashes of buckwheat-stems, just quoted, belong to this inrestigation. Wolff showed that, by assuming the presence in each specimen of buckwheat-straw of a certain excess of certain ingredients, and deducting the same from the total ash, the residuary ingredicnts closely approximated in their proportions to those observed in the erop which grew in an unmanured soil. The analyses just quoted, (p. 163,) are here "corrected" in this manner, by the subtraction of a certain per cent of those ingredients which in each case were furnisher to the plant by the fertilizer applied to it. The numbers of the analyses correspond with those on the previous page.

\section{$\begin{array}{lllllll}1 & 2 & 3 & 4 & 5 & 6\end{array}$}

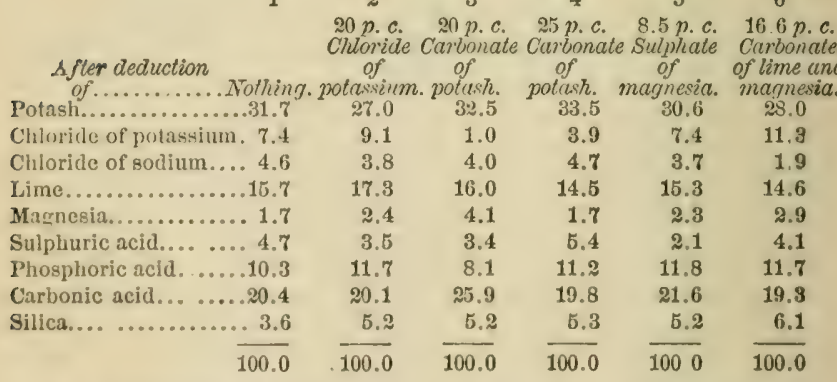

The correspondence in the above analyses thus "cor rected," already tolerably close, might, as Wolff remarks, (loc. cit.) be marle much more exact by a further correction, in which the quantities of the two most variable in. 
gredients, viz. chlorine and sulphuric acid, snould be reduced to uniformity, and the analyses then be recalculated to per cent.

In the first place, however, we are not warranted in assuming that the "excess" of chloride of potassium, carbonate of potash, etc., deducted in the abore analyses respectively, was all accidental and unnecessary to the plant, for, under the influence of an increased amount of a nutritive ingredient, the plant may not only mechanically contain more, but may chemically employ more in the vegetative processes. It is well proved that vegetation grown uniler the influence of large supplies of nitrogenous manures, contains an increased proportion of nitrogen in the truly assimilated state of albumin, gliten, etc. The same may be equally true of the various ash-ingredients.

Again, in the second place, we cannot say that in any instance the minimum quantity of any ingredient necessary to the vegetative act is present, and no more.

It must be remarked that these great variations are only seen when we compare together plants produced on poor $s o i l s, i . e$. on those which are relatively deficient in some one or several ingredients. If a fertile soil harl been em. ployed to support the buckwheat plants in these trials, we should doubtless have hall a very different result.

In 1859, Metzdorf, (Wilda's Centrulblatt, 186?2, 2, p. $36 \%$, analysed the ashes of eight samples of the red-onion potato, grown on the same field in Silesia, but differently manured.

Without copying the analyses, we may state some of the most striking results. The extreme range of variation in potash was $5 \frac{1}{2}$ per cent. The ash containing the highest percentage of potash was not, however, obtained from potatoes that had been manured with 50 pounds of this substance, but from a parcel to which had been applied a poudrette containing less than 3 pounds of potash for the quantity used. 
The unmanued potatoes were relatively the richest ir lime, phosphoric acid, and sulphuric acid, although several parcels were copiously treated with manures containing considerable quantities of these substances. These facts are of great interest in reference to the theory of the action of manures.

7. To what Extent is each Ash-ingredient Essential, and how fur may it be Accidentul? Bufore the art of ahemicil analysis had arrived at much perfection, it was believed by many men of science, that the ashes of the plant were either unessential to growth, or else were the products of growth-were generated by the plant.

Since the substances found in ashes are universally dis tributed over the earth's surface, and are invariably pres. ent in all soils, it is not possible by analysis of the ash of plants growing under natural conditions, to decide whether any or several of their ingredients are inilispensible to vegetative life. For this purpose it is necessary to institute experimental inquiries, and these have been prosecuted with great pains-taking, though not with results that are in all respects satisfactory.

Experiments in Artificial Soils.-The Prince SalmHorstmar, of Germiny, has been a most laborious student of this question. IIis pl:m of experiment was the following: the seeds of a plint were sown in a soil-like medium, (sugar-charcoal, pulverizerl quartz, purified sand,) which was as thoroughly as possible freed from the sulstance whose special influence on growth was the subject of study. All other sulstances presumably necessary, and all the usual external comditions of growth, (light, warmth, moisture, etc.,) were supplied.

The results of 195 trials thus made with oats, wheat, barley, and colza, subjected to the influence of a great variety of artificial mixtures, have been described, the most important of which will shortly be given. 
Experiments in Solutions,-Water-Culture.-Sachs, W. Kinop, Stohmann, Noble, Siegert, and others have likewise studied this subject. Their method was like that of Prince Salm-Horstmar, except that the plants were made to germinate and grow independently of any soil; and, throughout the experiment, hail their roots immersed in water, containing in solution or suspension the sub. stances whose action was to be observed.

Water-Culture has recently contributed so much to our knowledge of the conditions of vegetable growth, that some account of the morle of conlucting it may be properiy given in this place. Cause a number of seeds of the plant it is desired to experiment upon to germinate in moist cotton or coarse sand, and when the roots have become an inch or two in length, select the strongest seedlings, and support them, so that the roots shall be immersed in water, while the seeds themselves shall be just above the surface of the liquid.

For this purpose, in case of a single maize plant, for example, provide a quart cylinder or bottle, with a wide mouth, to which a cork is fitted, as in Fig. 22. Cut a vertical notch in the cork to its center, and fix therein the stem of the seedling by packing with cotton. The cork thus serves as a support of the plant. Fill the jar with pure water to such a beight that when the cork is brought to its place, the seed, $S$, shall be a little above the liquid. If the endosperm

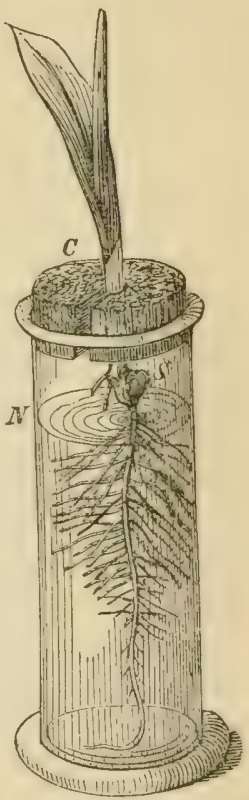

Fing. 2x. or cotyledons dip into the water, they will speedily mould and rot; they require, however, to be kept in 
a moist atmosphere. Thus arranged, suitable warmth, rentilation, and illumination, alone are requisite to continue the growth until the nutriment of the seed is nearly exhaustel. As regards illumination, this should be as full as possible, for the foliage; but the roots should be proterted from it, by enclosing the vessel in a shichl of black parer, as, otherwise, minute parasitic alga woulh in time develop upon the roots, and disturb their functions. For the first days of growth, pure distilled water may adrantageously surround the roots, but when the first green leaf appears, they should be placed in the solution whose nutritive power is to be testeit. The temperature should be properly proportioned to the light, in imitation of what is observed in the skillful management of conservatory or house-plants.

The experimenter should first learn how to produce targe and well-developed plants, by aid of an appropriate liquid, before attempting the investigation of other prob. lems. For this purpose, a solution or mixture must be prepared, containing in proper proportions all that the plant requires, save what it can derive from the atmos. phere. The recent experience of Nobbe \& Siegert, Wolff, and others, supplies valuable information on this point. Prof. Wolff has obtained striking results with a variety of plants in using a solution made esventially as follows:

Place 20 grams, (300 grains,) of the fine powiler of wellburned bones with a half pint of water in a lirge glass 1lask, heat to boiling, and arli nitric acid cautiously in quantity just suflicient to dissolve the bone-ash. In order to remove any injurious excess of nitric acid, pour into the hot liquid, solution of carbonate of potash until a slight permanent turbidity is produced; then add 11 grams, (180 grains, ) of nitrate of potash, 7 grams, (107 grains, ) of crystallizerl sulphate of magnosia, and 3 grams, (60 grains, ) of chloride of potassium, with water enough to make the solution up to the bulk of one liter, (or quart.) Mix 30 
cubic cent., (one fluid omnce,) of this liquit with a liter, (or quart,) of water and a single drop of strong solution of sulphate of iron, and employ this diluted solution to feed the plant.

Wolff's solution, thus prepared, contained in 1000 parts \&s follows, exclusive of iron:

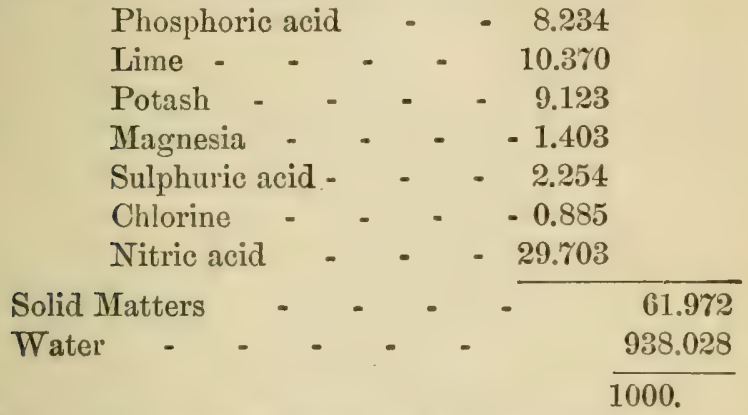

This solution was diluted to a liquid containing but one part of solid matters to 1000 or 2000 parts of water.

The solution should be changed every week, and as the plants acquire greater size, their roots should be transferred to a larger vessel, filled with solution of the same strength.

It is important that the water which escapes from the jar by evaporation and by transpiration through the plant, should be daily or oftener replaced, by filling it with pure water up to the original level. The solution, whose preparation has been described, may be turbid from the separation of a little white sulphate of lime before the last dilutinn, as well as from the precipitation of $p^{1}$ osphate of iron r. adding sulphate of iron. 'The former deposit may be dissolved, though this is not needful; the latter will not dissolve, and should be oceasionally put into suspension by stirring the liquid. When the plant is half grown, further addition of iron is unnecessary.

In this manner, and with this solution, Wolff produced 
a maize plant, five and three quarters feet high, and equal in every respect, as regards size, to plants from similar seed, cultivated in the ficld. The ears were not, however, fully dereloped when the experiment was interrupted by the plant becoming unhealthy.

With the o:t his suceess was better. Four plants wero linought to maturity, having 46 stems and 1535 well-devel-

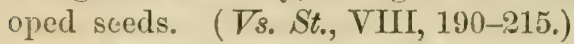

In similar experiments, Nobbe obtained buckwheat plants, six to seven feet high, bearing three hundred plump and perfect seeds, and barley stools with twenty grain. bearing stalks. ( $\bar{s}$. St., VII, \%2.)

In water-culture, the composition of the solution is suffering continual alteration, from the fact that the plant makes, to a certain extent, a selection of the matters pre. sented to it, and does not necessarily absorb them in the proportions in which they originally existed. In this way, distubances arise which impede or become fatal to growth. In the early experiments of S:lchs and Krnop, in 1560, they frequently observed that their solutions suddenly acquired the ottor of sulphydric acid, and black sulphide of iron formed upon the roots, in consequence of which they wero shortly destroyed. This reluction of a sulphate to a sulphicle takes place only in an alkaline liquid, and Stohmann was the first to notice that an acid liquid might be made alkaline by the action of liring roots. The plant, in fict, has the power to decompose salts, and by appropriating the acids more abunilantly th:m the bases, the litter aceumulate in the solution in the free state, or as carbonates with alkaline properties.

To prevent the reluetion of sulphates, the solution must be kept slightly acid, best by aldition of a very little fiee nituc acir, and if the roots blacken, they must be rivashed with a dilute accil, and, after rinsing wilh water, must be trinsferred to a fiesh solution.

On the other hanl, Kühn has shown that when chlorile 
of ammonium is employed to supply maize with nitrogen, this salt is decomposer, its ammonia assimilated, and its chlorine, which the plant cannot use, accumulates in the solution in the form of chlorhychic acid, to such an extent as to prove fatal to the plant, (ITenneberg's Journal, 1864, pl. 116 and 135.) Such disturbances are avoided by employing large volumes of solution, and by frequently renewing them.

The concentration of the solution of is by no means a matter of indifference. While certain aquatic plants, as sea-weeds, are naturally adapted to strong saline solutions, agricultural land-plants rarely succeed well in water-culture, when the liquid contains more than $\left.{ }^{2}\right|_{1000}$ of solid matters, and will thrive in considerably weaker solutions.

Simple well-water is often rich enough in plant-food to nourish vegetation perfectly, provided it be renewed sufficiently often. Sachs' earliest experiments were made with well-water.

Birner and Lucanus, in 186t, ( $\nabla$ s. St., VIII, 15t, ) raised oat-plants in well-water, which in respect to entire weight were more than half as heavy as plants that grew simul. taneously in garden soil, and, as regurds seerl-production, fully equalled the latter. The well-water employed, con. tained in 100.000 parts :

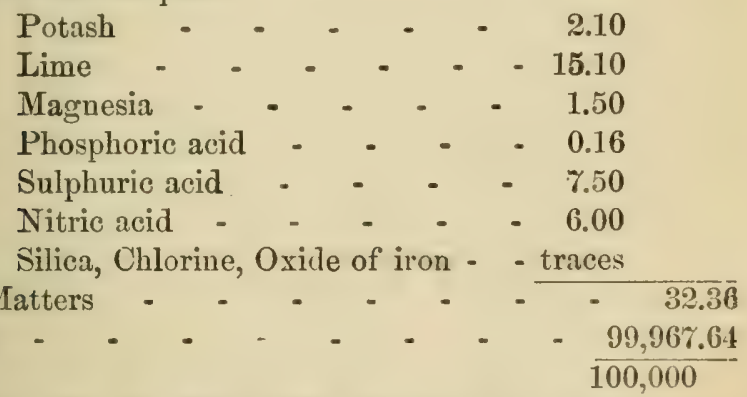

Nobbe, (Vs St., VUI, 337, ) found that in a solution con. taining but $\left.{ }^{2}\right|_{20090}$ of solid matters, which was continually 
renewed, warley made no progress beyond germination, and a buckwheat plant, which at first grew rapidly, was soon arested in its development, and yielded but a fer ripe sceils, and but $1.7 \pm 6$ grm. of total diry matter.

While water-culture does not provide all the normal conlitions of growth-the soil having important functions that cannot be enacted by any liquid medium-it is a method of producing highly-developed plants, under circumstances which admit of accurate control and great variety of alteration, and is, therefore, of the utmost value in regetable physiology. It has taught important facts which no other means of study could reveal, and promises to enrich our knowledge in a still more eminent degree.

Potash, Lime, Magnesia, Phosphoric Acid, and Sulphuric Acid, are absolutely necessary for the life of Agricultural Plants, as is demonstrated by all the experi. ments hitherto made for studying their influence.

It is not needful to recount here the evidence to this effect that is furnished by the investigations of SalmHorstmar, Sachs, Knnop, and others. (See, especially, Birner \& Lucanus, Vs. St., VIII, 128-161.)

\section{Is Soda Essential for Agricultural Plants? This} question has occasioned much discussion. A glance at the table of ash-analyses, (pp. 150-56,) will show that the range of variation is very great as regards this alkali. Among the older analysts, Bichon found in the ash of the pea 13 , in that of the bean 19 , in that of rye 19 , in that of wheat $2 \%$ per cent of sod:t. Herapath found 15 per cent of this substance in wheat-ash, and 20 per cent in ash of rye. Brewer found 13 per cent in the ash of maize. In a few other analyses of the grains, we find similar high jercentages. In most of the analyses, however, sodia is present in much smaller quantity. The average in the ashes of the grains is less than 3 per cent, and in not a few of the analyses it is entively manting. 
In the older analyses of other classes of agricultural plants, especially in root urops, similiurly great variations oceur.

Some uncertainty exists as to these older data, for the reason that the estimation of sorla by the processes custom. arily empioyed is liable to great inaccuracy, especially with the inexperienced analyst. On the one hand, it is not easy, (or has not been easy until lately,) to detect, much less to estimate, minute traces of soda, when mixed with much potash; while on the other hand, soda, if present to the extent of a per cent or more, is very liabie to be estimated too high. It has therefore been doubted if these high percentages in the ash of grains are correct.

Again, furthermore, the processes formerly empliyed for preparing the ash of plants for analysis were such as, by too elevated and prolonged heating, might easily occasion a partial or total expulsion of soda from a material which properly should contain it, and we may hence be in deulut whether the olier analyses, in which soda is not mentioned, are to be altogether depended upon.

The later analyses, especially those by Bibra, Zoeller, Arendt, Bretschneider, Ritthausen, and others, who have employed well-sclected ani carefully-cleaned materials for their investigations, and who have been aware of all the various sources of error incident to such an:lyses, must therefore be appealed to in this discussion. From these recent analyses we are leil to precisely the same conclusions as were warranted by the older investigations. Here fol. lows a statement of the range of percentages of soda in the ush of several field crops, according to the newest analyses :

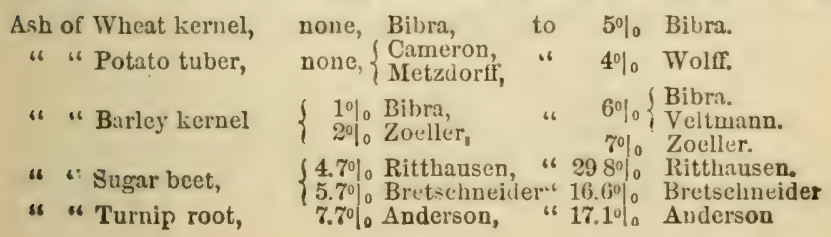


Although, as just indicated, soda has been found want. ing in the wheat kernel and in potato tulers, in some instances, it is not certain that it was absent from other parts of the same plants, nor has it been proved, so far as we know, that soda is wanting in any entire plant which has grown on a natural soil.

Weinhold found in the ash of the stem and leares of the common live-for-ever, (Sedum telephium,) no trace of soda detectable by ordinary means; while in the ash of the roots of the same plant, there occurred 1.8 per cent of this substance. ( $\boldsymbol{V}_{s}$. St., IV, p. 190.)

It is possible, then, that, in the above instances, soda really existed in the plants, thongh not in those parts which were subjected to analysis. It should be added that in ordinary analyses, where soda is stated to be ab. sent, it is simply implied that it is present in unweighable quantity, ${ }^{*}$ if at all, while in reality a minute amount may be present in all such cases. $†$

The grand result of all the analytical investigations hitherto made, with regari to cultivated agricultural plants, then, is that soda is an extremely variable ingredient of the ash of plunts, and though generally present in some proportion, and often in large proportion, has been observed to be absent in veeighable quentity in the seeds of grains and in the tubers of potatoes.

Salm-Horstmar, Stohmann, Knop, and Nobbe \& Sicgert, have contributed eertain synthetical data tłat boar on the question before us.

The investigations of Salm-Horstmar were made with the greatest nicety, and especial attention was bestowed on the influence of very minute quantities of the various

"Unweirhable quantities are designated as "trace" or "traces."

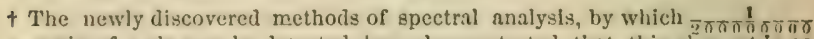
of a frain of soda may be detected, have demonstrated that this element is so aniversally distributed that it is next to imposaible to find or make anything that is free from it. 
substances employed. He gives as the result of numerous experiments, that for wheat, oats, and barler, in the early vegetative stages of grouth, sod:", vohile advantugeous, us not essential, tut that for the perfection of frut an apmeciable though minute quantity of this substance is in. ilispensable. (Versuche und Resultate über die Nahrung der Pflanzen, pp. 12, 27, 29, 36.)

Stohmann's sincle experiment led to the similar conclusion, that maize may dispense with soda in the earlier stages of its growth, but requires it for a full derelopment. (Henneberg's Jour. fïr Landroirthechaft, 186:2, p. 25.)

Iinop, on the other hand, succeederl in bringing the maize plant to full perfection of parts, if not of size, in a solution which was intenled and asserted to contain no soda. ( $\nabla_{s}$. St., III, p. 301.) Nobbe \& Siegert came to the same results in similar trials with buckwheat. ( $V s$. St., IV, p. 339.)

The experiments of Kinop, and of Nobhe \& Siegert, while they prove that much soda is not needful to maize and buckwheat, do not, however, satisiactorily demonstrite that a trace of soda is not neressary, because the solutions in which the roots of the plints were immersed stood for months in glass ressels, and could scarcely fail to dissolve some soda from the glass. Again, slight impurity of the substances which were employed in making the solution could scarcely be avoider without extriordinary precautions, and, finally, the scerls of these plants might originally have containeil enongh soda to supply this substance to the plants in appreciable quantity.

To sum up, it alpenr's from all the facts before us:

1. That soda is never totully absent from plants, but that,

2. If inclispensable, but a minute amount of it is requisite

3. That the foliage and succulent portions of the plant 
may include a considerable amount of soda that is not nec. essary to the plint, that is, in other words, ilecidental.*

Can Soda replace Potash ?-The close similarity of potash and soda, and the variable quantities in which the latter especially is met with in plants, has led to the assumption that one of these alkalies can take the place of the other.

Salm-Horstmar, and, more recently, Kinop \& Schreber, have clemonstrated that soda cannot entirely take the place of potash-in other words, potash is indispensable to plant life. Cameron conclutes from a series of experiments, which it is unnecessary to deseribe, that sorla can particlly replace putash. A partial replacement of this kind wonld appear to be indicated by many facts.

Thus, II ripath has made two analyses of asparignus, one of the wild, the other of the cultivated plant, both gathered in flower. The former was rich in soda, the latter almost destitute of this substance, but contained correspondingly more potash. Two analyses of the ash of the bect, one by Wolff, $(1 .$,$) the other by Way, (2 .$,$) ex-$ hibit similar differences:

\begin{tabular}{|c|c|c|c|}
\hline Aspo & ragues. & & \\
\hline Wild. & Ciltivated. & 1. & 2. \\
\hline Potash..............18.8 & 50.5 & $5 \% .0$ & 25.1 \\
\hline Soda...............16.2 & trace & 7.3 & 34.1 \\
\hline Lime.............. . 28.1 & 21.3 & 5.8 & 2.2 \\
\hline M:ınesia............ 1.5 & - & 4.0 & 2.1 \\
\hline Chlorine.............16.5 & 8.3 & 4.9 & 34.8 \\
\hline Sulphuric acid....... 9.2 & 4.5 & 3.5 & 3.6 \\
\hline Phosphoric acid.......12.8 & 12.4 & 12.9 & 1.9 \\
\hline Silica............ 1.0 & 3.7 & 3.7 & 1.7 \\
\hline
\end{tabular}

The'se results go to show-it being assumed that only a very minute amount of soila, if any, is alisolutely ne-as. sary to plint-lile-that the sodit which appears to replace potath is accidental, and that the replaced potash is acci-

* Sula appears to be ciscential un animal life. since all the food of animale 18 derived, indirectly at least, from the veretable kingdom, it is a wire provieis a that soda is contained in, if it be not indispensable to plants. 
lental alsn, or in excess above what is really needed by the plant, and leaves us to infer that the quantity of these bodies absorbed, depends to some extent on the composition of the soil, and is to the same degree independent of the wants of vegetation.

Alkalies in Strand and Marine Plants.-The above conclusions cannot as yet be accepted in case of plants which grow only near or in salt water. Asparagus, the beet and earrot, though native to saline shores, are easily capable of inland cultivation, and inceed grow wild in total or comparative absence of soda-compounds.*

The common saltworts, Salsola, and the samphire, Sali. comia, are plants, which, unlike those just mentioned, never stray inlaud. Göbel, who has analyzed these plants as occurring on the Caspian steppes, found in the soluble part of the ash of the Salsole brachiata, 4.8 per cent of potash, and 30.3 per cent of sodin, and in the Salicornia herbacea, 2.6 per cent of potash and 36.4 per cent of sodis; the soda constituting in the first instance no less th:m $\left.{ }^{1}\right|_{16}$ and in the latter $\left.{ }^{1}\right|_{24}$ of the entire weight, not of the ash, lut of the air-diy plant. Potash is never absent in these forms of vegetation. (Agricultur-Chemie, 3te Auf., p. 66.)

Accoriling to Callet, (Liebig's Ernährung der Veg., p. 100 ,) the seeds of the Salsola kali, sown in common garden soil, gave a plant which contained both soda and potash; from the seeds of this, sown also in garden soil, grew plants in which only potish-silts with traces of soda could be found.

Another class of plants-the sea-weeds, (algae,)-derive their nutriment exclusively from the sea-water in which they are immersed. Though the quantity of potash in se:water is but $\left.{ }^{1}\right|_{30}$ that of the soda, it is yet a fact, as shown by the analyses of Forchhammer, (Jour fü Prokt. Chem.,

- This is unt, indeed, proved by analysis, in case of the carrot, but is doubt loss true. 
36, p. 391,) and Anderson, (Trans. High. and Ag. Soc., $185 \tilde{5}-7$, p. 319 ,) that the ash of sea-weeds is, in general, as rich, or even richer, in potash than in soda. In 14 analyses, by Forchhammer, the average amount of soda in the dry weed was 3.1 per cent; that of potash 2.5 per cent. In Anderson's results, the percentage of potash i invariably higher than that of soda.*

Analogy with land-plants would lead to the inference that the soda of the seit-weeds is in a great degree accidental, although, necessarily, special investigations are required to establish a point like this.

oxide of Iron is essential to plants.-It is abundantly proved that a minute quantity of oxide of iron, $\mathrm{Fe}_{2} \mathrm{O}_{3}$, is essential to growth, though the agricultural plant may be perfect if provided with so little as to be discoverable in its ash only by sensitive tests. Accord ing to Salm-IIorstmar, the protoxide of iron is indispensable to the colza plant. (Versuche, etc., p. 35.) Knnop as Eerts that maize, which refuses to grow in entire alsence of oxide of iron, flourishes when the phosphate of iron, which is exceedingly insoluble, is simply suspended in the solution that bathes its roots for the first four weeks only of the growth of the plant. ( $\bar{s}$. S St. V,p. 101.)

We find that the quantity of oxide of iron given in the analyses of the ashes of agricultural plants is small, being asually less than one per cent.

IIere, too, considerable variations are observed. In the analyses of the seerls of cereals, oxide of iron rimges firom an unweighable trace to 2 and even $\left.3^{\circ}\right|_{0}$. In root crops it as kieen found as high as $\left.5^{\circ}\right|_{0}$. Kekule found in the ash if gluten from wheat $7.1^{\circ} \%$ of oxide of iron. (Jahres bericht der Chem., 1851, p. 715.) Schulz-Flecth found $\left.17.5^{\circ}\right|_{1}$ in the ash of the albumin from the juice of the

* Doubtless due to the fact that the material used by Anderson was freed by washing from aclhering common salt. 
po ato tuber. The proportion of ash is, however, so small that in case of potato-albumin, the oxide of iron amounts to but 0.12 per cent of the dry substance. (Der Rationelle Ackerbau, p. 82.)

In the wood, and especially in the bark of trees, oxide of iron often exists to the extent of $5-\left.10^{\circ}\right|_{0^{*}}$. The largest percentages have been found in aquatic plants. In the ash of the duck-meat, (Lemna trisulca, Liebig found $7.4^{\circ} \mathrm{l}_{0^{*}}$ Gorup-Besanez found in the ash of the leaves of the Trapa natans $\left.29.6^{\circ}\right|_{0}$, and in the ash of the fruit-envelope of the same plant $\left.68.6^{\circ}\right|_{0^{*}}$ (Ann. Ch. Ph., 118. p. 223.)

Probably much of the iron of agricultural and land plants is accidental. In case of the Trapa natans, we cannot suppose all the oxide of iron to be essential, because the larger share of it exists in the tissues as a bromn powder, which may be extracterl by acids, and has the ap. pearance of having accumulated there mechanically.

Doubtless a portion of the oxide of iron encountered in analyses of agricultural vegetation has never once existed within the vegetable tissues, but comes from the soil which adheres with great tenacity to all parts of plants.

\section{Oxide of Manganese, $\operatorname{Mn}_{3} \mathbf{O}_{4}$, is unessential to Agri-} cultural Plants.-This oxide is commonly less abundant than oxide of iron, and is often, if not usually, as good as wanting in agricultural plants. It generally accompanies oxide of iron where the latter occurs in consirlerable quan. tity. Thus, in the ash of Trapa, it was found to the extent of $7.5-\left.14.7^{\circ}\right|_{0^{\circ}}$ Sometimes it is found in much larger quar. tity than oxide of iron; e. g., C. Fresenius found $11.2^{\circ}$ 。 of oxide of manganese in ash of leaves of the red beech, (Fagus sylvatica,) that contrined but $\left.1^{\circ}\right|_{0}$ of oxile of iren. In the ash of oak leaves, ( Quercus robur,) Neubauer found, of the former 6.6 , of the latter but $\left.1.2^{\mathrm{C}}\right|_{0^{\circ}}$.

In ash of the wood of the lareh, (Larix Europoea,) Böttinger found $13.5^{\circ} \mathrm{l}_{\mathrm{n}} \mathrm{Mn}_{8} \mathrm{O}_{6}$ and $4.2^{\prime \prime} \mathrm{F}_{0} \mathrm{Fe}_{2} \mathrm{O}_{3}$, and in 
ash of wood of Pinus sylvestris $\left.18.2^{\circ}\right|_{0} \mathrm{Mn}_{3} \mathrm{O}_{4}$, and $3.5 \%$ $\mathrm{Fe}_{2} \mathrm{O}_{3^{\circ}}$. In ash of the seed of colza, Nitzsch found $16.1^{\circ}$ ! $\mathrm{Mn}_{3} \mathrm{O}_{4}$ and 5.5 $\mathrm{Fe}_{2} \mathrm{O}_{3}$. In case of land plants, these high percentages are accidental, and specimens of most of th: F-iants just named have been analyzed, which were firee from all but traces of oxide of manganese.

Saln-Horstmar concluded from his experiments that oxide of manganese is indispensable to regetation. Sachs, Knop, and most other experimenters in water-culture, make no mention of this substance in the mixtures, which in their hands have served for the more or less perfect development of a variety of agricultural plants. Birner \& Lucanus have demonstrated that manganese is not needful to the oat-plant, and cannot take the place of iron. ( $V s$. St., VIII, p. 43.)

\section{Is Chlorime indispensable to Crops?-What has} been written of the occurreuce of soda in plants appears to apply in most respects equally well to chlorine. In nature, soda, or rather sodium, is generally associated with chlorine as common salt. Ic is most prob:bly in this form that the two substances asually enter the plant, and in the majority of cases, when one of them is present in large quantity, the other exi ts in corresponding quantity. Less commonly, the chlon ine of plants is in combination with potassium exclusively.

Chlorine is doubtless never ab ent frow 1 the perfect agricultural plant, as produced under natural conditions, though its quantity is liable to great variation, and is often very small-so small as to be overlooked, except by the careful an:alyct. In many analyses of grain, chlorine is not mentimend. Its absence, in many cases, is due, without doubt, to the fact that chlorine is readily clissipateil from the ash of suls:tane sich in phosphorie, silicie, or sulphurie acids, on prolonged exposure to a high temperature. In the later analyses, in which the recetalle substance, instead of beirg at once burned to ashes, at a high red heat, is 
first charred at a heat of low redness, and then leached with water, which dissolves the chloriles, and separates them from the unburned carbon and other matters, chlorine is invariably mentioned. In the tables of analyses, the averages of chlorine are undeniably too low. This is especiully true of the grains.

The average of chlorine in the 26 analyses of wheat by Way \& Ogston, p. 150, is but $\left.0.08^{\circ}\right|_{0}$, it not being found at all in the ash of 21 samples. In Zoeller's later analyses, chlorine is found in every instance, and averages $0.7^{\circ} \%_{0}$. Weber's analysis, as compared with the others, would indicate a considerable range of variability. Weber extracted the charred ash with water, and found $\left.6^{\circ}\right|_{0}$ of chlorine, which is six times as much as is given in any other recorded analysis of the wheat kernel. This result is in all probability erroneous.

Like soda, chlorine is particularly abundant in the stems and leaves of those kinds of regetation which grow in soils or other media containing much common salt. It accompanies soda in strand and marine plants, and, in general, the content of chlorine of any plint may be largely increased or diminished by supplying it to, or withholding it from the roots.

As to the indispensableness of chlorine, we have somewhat conflicting data. Salm-Horstmar concludes that a trace of it is needful to the wheat plant, though many of his experiments in reference to the importance of this eloment he himself regards as unsatisfactory. Nobbe \& Siegert, who have made an elaborate investigation on the nutritive relations of chlorine to buckwheat, were led to conclude that while the stems and foliage of this plant are able to attain a considerable derelopment in the alsence of chlorine, (the minute amount in the seed itself excepted,) presence of chlorine is essential to the perfection of the kernel.

On the other hand, Knop excludes chlorime from the 
list of necessary ingredients of maize, and from not yot fully described experiments doubts that it is necessary for buckwheat.

Leydhecker, in a more recent investigation, has come to the same conclusions as Nobbe \& Siegert, regarding the udispensableness of chlorine to the perfection of buck wheat. ( $\nabla$ s. St., VIII, 17\%.)

From a series of experiments in water-culture, Birner \& Lucauus, ( $\nabla$ s. St., VIII, 160,) conclude that chlorine is not indispensable to the oat-plant, and has no specific effect on the production of its fruit. Chloride of potassium increased the weight of the crop, chloride of sodium gave a larger development of foliage and stem, chloride of magnesium was positively deleterious, under the conditions of their trials.

Lucanus, (Vs. St., VII, 363-71,) raised clover by water-culture without chlorine, the crop, (dry,) weighing in the most successful experiments 240 times as much as the seerl. Addition of chlorine gave no better result.

Nobbe, (notes to above paper,) has produced normally developer vetch and pea plants, but only in solutions containing chlorine. Knop, still more recently, (Lehrbuch der Agricultur-Chemie, p. 615, gives his reasons for not crediting the justness of the conclusions of Nobbe \& Siegert and Leydhecker.

Until further more decisive results are reached, we are warranted in adopting, with regard to chlorine as related to agricultural plants, the following conclusions, viz.:

1. Chlorine is never totally absent.

2. If indispensable, but a minute amount is requisite in case of the cerenls and clover.

3. Buckwheat, vetches, and perhaps peas, require a not inconsiderable amount of chlorine for full development.

4. The foliage and succulent parts may incluile a con siderable quantity of ch orine that is not indispensable to the life of the plant 
Necessity of Chlorine for Strand Plants.-A single oloservation of Wiegmann and Polstorf, (Pieisschrift, indicates that Salsola kali requires chlorine, thongh whether it be united to potassium or sodium is indifferent. These experimenters transplanted young salt-worta into a pot of garden soil which contained but traces of chlorine, and watered them with a weak solution of chloride of potassium. The plants grew most luxuriantly blossomed, and completely filled the pot. They were then put out into the earth, without receiving further applications of chlorine-compounds, but the next year they became unhealthy, and perished at the time of blossoming.

Silica is not indispensable to crops. - The numerous analyses we now possess indicate that this substance is alwalys present in the ash of all parts of agricultural plants, when they grow in natural soils.

In the ash of the wood of trees, it usually ranges from 1 to $\left.3^{\circ}\right|_{0}$, but is often found to the extent of $10-\left.20^{\circ}\right|_{0}$, or even $30^{\circ}{ }_{0}$, especially in the pine. In leaves, it is usually more abundant than in stems. The ash of turnip-leaves contains $3-10^{\circ} \%_{0}$; of tobacco-leaves, $5-18^{\circ} \%_{0}$; of the oat, $11-$ $\left.58^{\circ}\right|_{0}$. (Arendt, Norton.) In ash of lettuce, $20^{\circ} \%_{0}$; of beech leaves, $\left.26^{\circ}\right|_{0}$; in those of oak, $\left.31^{\circ}\right|_{0}$ have been observed. (Wicke, Henneberg's Jour., 1862, p. 156.)

The hark or cuticle of many plants contains an extraordinary amount of silica. The Cauto tree, of South Americi, (Hirtella silicea,) is most remarkable in this respect. Its bark is very firm and harsh, and is difficult to cut, having the texture of soft s:mdstone. In Trinidad, the natives mix its ashes with clay in making pottery. The bark of the Cauto yields $\left.34^{\circ}\right|_{0}$ of ash, and of this $\left.96^{\circ}\right|_{0}$ is silica. (Wicke, Henneberg's Jour., 1862, p. 143.)

Another plant, remarkable for its content of silica, is the bamboo. The ash of the rind contains $\left.70^{\circ}\right|_{0}$, and in the joints of the stem are often found concretions of silica, re sembling flint-the sorealled Tabashir. 
The ash of the common scouring rush, (Equisetum hyo male, ) has been foun to contain $\left.97.5^{\circ}\right|_{\text {o }}$ of silica. The straw of the cereal grains, and the stems and leaves of grasses, both belonging to the botanical family Graminere, are specially characterized by a large content of silica, ranging from 40 to $70^{\circ} \mathrm{F}_{0}$. The sedge and rush fanilieg likewise contain much of this substance.

The position of silica in the plint would appear, from the percentages above quoted, to be, in general, at the surface. Although it is found in all parts of the plant, yet the cuticle is usually richest, and this is especially true in cases where the content of silica is large. Davy, in 1799, drew attention to the deposition of silica in the cuticle, and adranced the idea that it serves the plant an office of sup port similar to that enacted in animals by the bones.

In the ash of the pine, (Pinus sylcestris,) Wittstein has obtained results which inclicate that the age of wood or bark greatly influences the content of silic:a. He found in

\begin{tabular}{|c|c|c|c|c|c|c|}
\hline \multicolumn{7}{|c|}{ Wood of a tree, 220 years old, $32.5^{\circ} \mathrm{l}$} \\
\hline 6 & 666 & 6 & $1 \% 0$ & "6 & 6 & 24.1 \\
\hline "6 & 1666 & 6 & 135 & "6 & 6 & 15.1 , and in \\
\hline Bark & "6 "6 & 6 & $2: 20$ & "6 & " & 30.3 \\
\hline 66 & 66 "6 & " & 170 & "6 & 16 & 144 \\
\hline 66 & 66 & "6 & 135 & 16 & 16 & 11.9 \\
\hline
\end{tabular}

In the ash of the straw of the oat, Arendt found the percentage of silica to increase as the plant approached maturity. So the leares of forest trees, which in autumn are rich in silica, are nearly lestitute of this substance in spring time. Silic:a accumulates then, in general, in the older and less active parts of the plant, whether these be external or intermal, and is relatively deficient in the younger and really growing portions.

This rule is not without exceptions. Thu*, the chaff of wheat, rye, and oats, is richer in silica than any other part of these plants, and Büttinger found the sceds of the pine richer in silica than the wood.

In numerous instances, silica is so deposited in or upon 
the cell-wall, that when the organic matters are destroyed by burning, or removed by solvents, the form of the eell is preserved in a silicious skeleton. This has long been known in case of the Equisetums and Deutzias. Here, the roughnesses of the stems or leaves which make these plant? aseful for scouring, are fully incrusted or interpenetrated by silica, and the ashes of the cuticle present the same appearance under the microscope as the cuticle itself.

Lately, Kindt, Wicke, and Mohl, have observed that the hairs of nettles, hemp, hops, and other rough-leaved plants, are highly silicious.

The bark of the beech is coated with silica-hence the smooth and undecayed surface which its trunk presents. The best textile materials, which are bast-fibers of various plants, viz., common hemp, manilla-hemp, (Musa textilis,) aloe-hemp, (Agave Lmerieanc,) common flax, and New Zealand flax, (Phormium tenux,) are enmpletely incrusted with silica. In jute, (Corchorus textilis,) some cells are partially incrusted. The cutton fiber is free from silica. Wicke, (loc. cit.,) suggests that the durabiiity of textile fibers is to a degree dependent on their content of silica.

The great variableness observed in the same plant, and in the same part of the plant, as to the content of silica, would indicate that this substance is at least in some degree accidental.

In the ashes of ten kinds of tobacco leares, Fresenius \& Will found silica to range from 5.1 to 18.4 per cent. The analysis of the ash of 13 samples of pea-straw, grown on different suils from the same seel during the same year under direction of the "Landes Oeconomie Collegium," of Prussia, gave the following percentages of silie:a, viz.: $0.56 ; 0.75 ; 2.30 ; 2.32 ; 2.80 ; 3.29 ; 3.5 \% ; 5.15 ; 5.52$; $8.03 ; 8.32 ; 9.77 ; 21.35$. Analyses of the ash of 9 sampli's of colza-straw, all produced fiom the same seed on dilit.r. ent soils, gave the following percentages: $1.00 ; 1.14 ; 3.0:$; $3.57 ; 4.65 ; 508 ; 7.81 ; 11.88 ; 17.12$. (Joumal für pictkt. 
Chem., xlviii, 47t-\%.) Such instances might be greatly multiplied.

The idea that a part of the silica is accitental is further sustained by the fact observed hy Saussure, the earliest in. restigator of the composition of the ash of plants, (Recherches sur la Vegetation, p. 28., ) that crops raised on :I silicious soil are in general richer in silica than those grown on a calcareous soil. Norton found in the ash of the chaft of the Hopeton oat from a light loam 56.7 per cent, from a poor peat soil 50.0 of silica, while the chaff of the potatoout fiom a sandy soil gave 70.9 per cent.

Salm-Hor:tmar obtained some remarkable results in the course of his synthetical experiments on the mineral food of plants, which fully confirmed him in the opinion that silica is indispensable to vegetation. IIe found that an oat plant, having for its soil pure quartz, (insoluble silica,) with addition of the elements of growth, soluble silica excepted, not only grew well, but contained in its ash $23^{\circ} \%$ of siliea, or as great a proportion as exists in the plant raised uniler normal enditions. This silica maty, however, have been mostly derived from the husk of the seed, for the plant was a very small one.

Sachs, in 186:, was the first to publish evidenee indicating strongly that silica is not a necessary ingredient of maize. He obtained in his early essays in water-culture a maize plant of considerable development, whose ashes con. tained but $0.7^{\circ} \%$ of siliea. Shortly afterwards, Knop produceed a maize plant with 140 ripe seeds, and a dry-weight of 50 grammes, (nearly $20 \%$ av., ) in a medium so free frcm siiic'a that a mere trace of this sub-tance could be found in the root, but half a milligramme in the stem, and 22 milligrammes in the 15 leaves and sheaths. It was altogether alsent from the seeds. The ash of the leaves of this plant thus container but 0.54 per eent of silica, and the stem but 0.07 per cent. Way \& $\mathrm{Ogston}$ found in the ash of anize, leaf and stem together, 27.98 per cent of silica. 
Iinop inclined to believe that the little silica he found m his maize plant was due to dust, and did not helong to the tissues of the plant. He remarkerl, "I believe that silica is not to be classed among the nutritive elements of the Graminex, since I have made similar observations in the analysis of the ashes of barley."

In the numerous experiments that have been made more recently upon the growth of plints in aqueous solutions, by Sachs, Knop, Nobbe \& Siegert, Stohmann, Rautenberg \& Kühn, Birner \& Lucanus, Leydhecker, Wolff, and Hampe, silica, in nearly ali cases, has been excluded, so far as it is possible to do so in the use of glass vessels. This has been done without prejudice to the derelopment of the plants. Nobbe $\&$ Siegert and Wolff especially have succeeded in producing buckwheat, maize, and the oat, in full perfection of size and parts, with this exclusion of silica.

Wolff, ( $\boldsymbol{V}$ s. St., VIII, p. 200,) obtained in the ash of maize thus cultivated, $2-\left.3^{\circ}\right|_{0}$ of silica, while the same two varieties from the field contained in their ash $11 \frac{1}{2}-\left.13^{\circ}\right|_{0}$. The proportion of ash was essentially the same in both cases, viz., about $\left.6^{\circ}\right|_{0}$. Wolff's results with the oat plant were entirely similar. Birner \& Lucanus, ( $\nabla_{s}$. St., VIII, 141 ) found that the supply of soluble silicates to the oat made its ash very rich in silica, $\left(\left.40^{\circ}\right|_{0}\right)$ but diminisher the growth of straw, without affecting that of the seed, as compared with plants nearly destitute of silica.

While it is not thus demonstrater that utter absence of silica is no hindrance to the growth of plants which are ordinarily rich in this substance, it is certain that very little will suffice their needs, and highly probable that it is in no way essential to their physiological development.

\section{The Ash-Ingredients, which are indispensable to (rops,} may be taken up in larger quantity than is essential.More than sixty year's ago, Saussure described a simple 
experiment which is conclusive on this point. He gathured a number of peppermint plants, and in some determined the amount of lly-matter, which was 40.3 per cent. The roots of others were then immersed in pure water, and tne plants wre allowed to regetate 2.1 months in a place ex. posed to air and light, but sheltered from rain.

At the termination of the experiment, the plants, which originally weighed 100 , had increased to 216 parts, and the dry matter of these plants, which at first was 40.3 , had become 62 parts. The plants could have acquired from the glass vessels and pure water no considerable quantity of mineral matters. It is pliin, then, that the ash-ingredients which were contained in two parts of the peppermint were sufficicnt for the production and existence of three parts. We may assume, therefore, that at least one-third of the ash of the original plants was in excess, anc accidental.

The fict of excessive ahsorption of essential ash-in. gredients is also demonstrated by the precise experiments of Wolff on buckwheat, already described, (see p. 16t, where the point in question is incidentally alluder to, and the difficulties of deciling how much excess may occur, are brought to notice. (See also pp. 176 and $1 \% 9$ in regard to potash and oxide of iron.)

As a further striking instance of the influence of the nourishing medium on the quantity of ash-ingredients in the plant, the following is adiuced, which may serve to put in still stronger light the fact that a plant does not always require what it contains.

Nobbe \& Siegert have made a comparative study of the composition of buckwheat, grown on the one hand in garilen soil, and on the other in an aqueous solution of saline matters. (The solution contained sulphate of mag. nesia, chloride of calcium, phosphate and nitrate of potash, with phosphate of iron, which together constituted $0.316^{\circ}$ । of the liquid.) 'The ash-percentage was much higher in 
the water-plants than in the garden-plants, as shown by the subjoined figures. ( $\left.\nabla_{s} . S t ., \mathrm{V}, \mathrm{p} .132.\right)$

\begin{tabular}{cccc}
\multicolumn{5}{c}{ Per cent of ash in } \\
Stems and Leaves. & Poots. & Seeds. & Entire Plant. \\
Water-plant.....18.6 & 15.3 & 2.6 & 16.7 \\
Garden-plant... 8.7 & 6.8 & 2.4 & 7.1
\end{tabular}

We have seen that well-developed plants contain a larger proportion of ash than feeble ones, when they grow side by sirle in the same medium. In disregard of this general rule, the water-plant in the present instance has an ash-percentage double that of the land-plant, although the former was a dwarf comparer with the latter, yielding but $\left.{ }^{1}\right|_{6}$ as much dry matter. The seeds, however, are scarcely different in composition.

Disposition by the Plant of excessive or superfluous ash-ingredients. - The ash-ingredients taken up by a plant in excess beyond its actual wants may be disposed of in three ways. The soluble matters-those soluble by themselves, and also incapable of forming insoluble combinations with other ingredients of the plant-viz., the alkali chlorides, sulphates, carbonates, and phosphates, the chlorides of calcium and magnesium, nay-

1., Remain dissolved in, and diffused throughout, the juices of the plant; or,

2., May exude upon the surface as an efflorescence, and be washed off by rains.

Exudation to the surfice has been repeatedly observed in case of cucumbers and other kitchen regetables, growing in the garden, as well as with buckwheat and barley in water-culture. (Vs. St., VI, p. 3\%.)

Saussure found in the white incrustations upon cucum. ber leaves, besides an organic body insoluble in water and alcohol, chloride of calcium, with a trace of chloride of magnesium. The organic sulstance sc enveloped the chloride of calcium as to prevent deliquescence of the larter. (Recherches sur la Veg., p. 265.) 
Saussure proved that foliage readily yields up saline matters to water. He placed hazel leaves eight successive times in renewerl portions of pure water, leaving them therein 15 minutes ench time, and found that by this treat ment they lost ' ${ }_{15}$ of their ash-ingredients. The portion thus dissolved was chiefly alkaline salts; but consisted in part of earthy phosphates, silica, and oxide of iron. (Recherches, p. 28\%.)

Ritthausen has shown that clover which lies exposed to rain after being cut, may lose by washing more than ${ }^{1}$. of its ash-ingredients.

Mulder, (Chemie der Alkerkrume, II, p. 305,) attributes to loss by rain a considerable share of the variations in percentage and composition of the fixed ingredients of plants. We must not, however, forget that all the experiments which indicate great loss in this way, have been made on the cut plant, and their results may not hold good to the same extent for uninjured vegetation, which certainly does not admit of soaking in water. Further investigations must decide this point.

3. The insoluble matters, or those which become insoluble in the plant, viz., the sulphate of lime, the oxalates, phosphates, and carbonates of lime and magnesia, the oxides of iron and manganese, and silica, may be deposited as crystals or concretions in the cells, or may incrust the cellwalls, and thus be set aside from the sphere of vital action.

In the denser anil comparatively juiceless tissues, as in bark, old wood, and ripe seeds, we find little variation in the content of soluble matters. These are present in large and variable quintity only in the succulent organs.

In b:urk, (cuticle,) wood and seed envelopes, (husks, shellis, chatf',) we often find silica, the oxides of iron and manrganese, and carbonate of lime-all insoluble substances - - iccumulated in considerable amount. In bran-the unticle of the kernels of cereals--phosphate of magnesia 
exists in comparatively large quantity. In the dense teak wood, coneretions of phosphate of lime have heen noticed. Of a certain species of cactus, (ructus senilis, $\left.80^{\circ}\right|_{0}$ of the dry matter consists of erystals, probably a lime salt.

That the quantity of matters thus segregatel is in some degree proportionate to the excess of them in the nourishing medium in which the plant grows has been observed by Nobbe \& Siegert, who remark that the two poltions of buckwheat, cultivated by them in solutions aml i: g:urden soil respectively, (p. 1s., ) both contained crrstals and globular erystalline masses, consisting probibly of oxalates and phosphates of lime and magnevia, deposited in the rind and yith; but thet these voere by far most abundunt in the witer-plants, whose ash-percentrige 20is twice as great as that of the land-plants.

These insoluble subst:unces may either be cntirely unessential, as appears to be the case with silica, or, having once servel the wants of the plant, may be rejected as no longer useful, and by assuming the insoluble form, are removed from the sphere of vitil action, and become as good as dear matter. They are, in fict, excreted, though not, in general, formally expelled beyond the limits of the plant. They are, to some extent, thrown off into the bark, or into the older wood or pith, or else are virtually encysted in the living cells.

The occurrence of crystallized salts thus segregated in the cells of plants is illustrated by the following cuts. Fig. 23 represents a crystallized concretion of oxalate

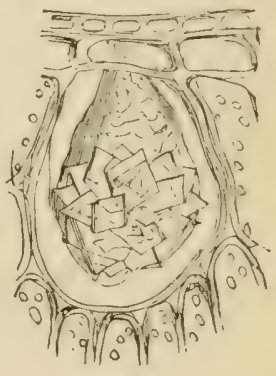

Fin. : : : of lime, having a hasis or skeleton of cclinlo-e, fiom a leaf of the walnut. (Payen, Chimie Industielle Pl. XII.) Fig. 24 is a mass of crystals of a lime salt, from the leaf stem of rhubarb. Fig. 25, similar crystals from the beet rout. 
In the root of the roung bean, Sachs found a ring of cells, containing erystals of sulphate of lime. (Sitzungsberichte
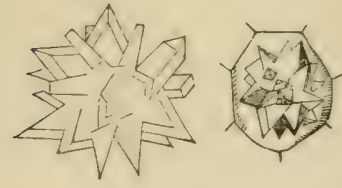

Fig. 21. Fig. 25. der Wien. Akad., 37, p. 106.) Bailey observed in certain parts of the inner bark of the locust a series of cells, each of which contained a crystal. In the onion-bulb, and many other plants, crystals are abundant. (Gray's Struct. Botany, 5th Ed., p. 59.)

Instances are not wanting in which there is an obvious excretion of mineral matters, or at least a throwing of them off to the surface. Silica, as we have seen, is often found in the cuticle, but it is usually imberlded in the cellwill. In certain plants, other substanees accumulate in consilerable quintity without the cuticle. A striking example is furnished by Saxifraga crustata, a low European plant, which is found in lime soils. The leaves of this saxifrage are entirely coated with a scaly incrustation of carbonate of lime and carbonate of magnesia. At the edges of the leaf, this incrustation aequires a considerable thickness, as is illustrated by figure 26 , a. In an analysis made by Unger, to whom these facts are due, the fresh, (undried,) leaves yielded to a dilute acid $\left.4.14^{\circ}\right|_{0}$ of carbonate of lime, and $0.82^{\circ} \%_{0}$ of carbonate of magnesia.

Unger learned by mieroscopic

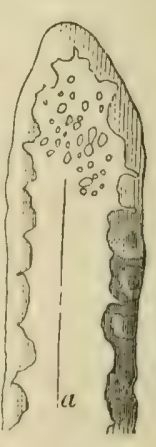

c. दी $\quad d(8)$

Fig. 26. investigation that this excretion of carbonates proceeds mosily from a series of glandular expansions at the margin of the leaf, which are direetly commected with the sap-duets of the plant. (Sitz'berichte der Wien, Aliad., 43, p. 519.) 
In flare 26, a represents the appenrince of a leaf, mamniffed $41 / 2$ diam. etcis. Around the borders are seen the sciles of carbmate of lime; some of these have been detached, leaving round pits on the surface of the leaf: $c, d$, exlibit the scales themselves, $e$ in protile: $b$ shows a leaf, freed from its incrustition by an acid, and from its cuticle by potasilsolution, so as to exhibit the veins, (clucts,) ancl glands, whose course the carhonate of lime chietly takes in its pissige through the plant.

Further as to the state of ash-ingredients.-It is by no means true that the ash-ingredients always exist in plants in the forms unler which they are otherwise familiar to us.

Arendt and Hellriege! have studied the proportions of soluble and insoluble matters, the former in the ripe oat plant, and the latter in clover at various stages of growth.

Arendt extracted from the leaves and stems of the oatplant, after thorough grinding, the whole of the soluble matters by repeated washings with water.* He fouml that all the sulphuric acid and all the chlorine were soluble. Nearly all the phosphoric acid was removed by water. The larger share of the lime, magnesia, soda, and potash, was soluble, though a portion of each escaped solution. Oxide of iron was found in both the soluble and insoluble state. In the leaves, iron was found among the insoluble matters after all phosphoric acil had been removed. Finally, silica was mostly insoluble, though in all cases a small quantity occurred in the soluble condition, viz., $3-8$ parts in 10,000 of the dry plint. (Wachsthum der Huferpflanze, pp. 108, 183-4. See, also, table on p. 198.)

Weiss and Wiesner have found by merochemical investigation that iron exists as insolulle compounds of protoxide anil sesquinxide, both in the cell-membrane and in the ceil contents. (Sitz'berichte der Wiener Akad., 40, 278.)

Hellriegel found that a larger proportion of the various bases was soluble in young clover than in the mature plant. As a rule, the leaves gave most soluble matters,

* To extract the soluble parts of the grain in this way way impossibie. 
the leaf-stalks less, and the stems least. He obtained, among others, the following results. ( $\nabla$ s. St., IV, p. 59.)

Of 100 parts of the following fixed ingredients of clover, were dissolved in the sap, and not dissolved-

\begin{tabular}{|c|c|c|}
\hline \multirow{3}{*}{ Potask } & \multirow{2}{*}{\multicolumn{2}{|c|}{ In young leaves. In full-grown leares. }} \\
\hline & & 37.3 \\
\hline & \{undissolred.......24.8 & 62.7 \\
\hline Lime & $\{$ dissulved ........6.69.5 & $7 \% .4$ \\
\hline & ( nndissolved......30.5 & 27.6 \\
\hline Maguesia & $\left\{\begin{array}{l}\text { dissorved } \ldots \ldots \ldots .436,6 \\
\text { undissolved }\end{array}\right.$ & 6.3 \\
\hline Plosphoric & I dissolved ........20.9 & 19.9 \\
\hline acid & \{ undissolved....... 79.1 & 80.1 \\
\hline Silica & $\left\{\begin{array}{l}\text { dissolved ........2. } \\
\text { undissolved }\end{array}\right.$ & $\begin{array}{l}16.1 \\
83.9\end{array}$ \\
\hline
\end{tabular}

These researches demonstrate that potash and sodabotlics, all of whose commonly ocenring compound; silicates exceptel, are readily soluble in water-enter into insoluble combinations in the plant; while phosphoric acil, which forms insoluble salts with lime, magnesia, and iron, is freely soluble in connexion with these bases in the sap.

It should be added that sulphates may be absent from the plant or some parts of it, although they are found in the ashes. Thus Arendt discovered no sulphates in the lower joints of the stem of oats after blossom, though in the upper leaves, at the same period, sulphuric acid, $\left(\mathrm{S}_{3}\right)$ formed nearly $7^{\circ} \%_{0}$ of the sum of the fixed ingredients. ( We:hsthum der Heferpf., p. 15\%.) Ulbricht found that sulphates were totally absent from the lower leaves and stems of red clover, at a time when they were present in the upper leaves and blossom. ( $V_{s} . S t$. IV, p. 30, Titlielle.) Both Arendt and Ulbricht observed that sulphur existed in all parts of the plants they experimented ipon; in the parts just specified, it was, however, no longer combined to oxygen, but had, doubtless, become an integral prirt of sone albuminoid or other complex organic body. Thus the oat stem, at the period above cited, contained a quintity of sulphur, which, had it been converted into oulphuric acid, would have amounted to $14^{\circ} \%$ of the fixed 
ingredients. In the clover leaf, at a time when it was totally destitute of sulphates, there existed an amount of sulphur, which, in the form of sulphuric acid, would have male $13.7^{\circ} \%$ of the fixed ingredients, or one per cent of the dry leaf itself**

Other ash-ingredients.-Silm-Horstmar has describerl sume experiments, from which he infers that a minute amount of Lithia and Fluorine, (the latter as fluoride of potassium, are indispensable to the fruiting of barley. (Jour. für prakt. Chem., 8t, p. 140.) The same observer, some years ago, was led to conclude that a trace of Titanic. acid is a necessary ingredient of plants. The later results of water-culture would appear to lemonstrate that these conclusions are erroneous.

It is, however, possible, as Mulder has suggested, (Che mie der Ackerkinme, II, 341,) that the failure of certain crops, after long-continued cultivation in the same soil, may be due to the exhaustion of some of these less abundant and usually overlooked substances. Land not unfrequently becomes "clover-sick," i. e., refuses to produce good crops of clover, even with the most copious manurings. In Vaucluse, according to Mulder, the madder crop has suffered a deterioration in quality-the coloring effect of the root having liminished one-fourth-as an apparent result of long cultivation on the same soil, although the seed is annually renewed from Asia Minor, and great care is bestowed on its culture.

The newly discovered element, Rubidium, has been found in the sugar-beet, in tobacco, coffee, tea, and the

* arendt war the nirst to estimate sulphuric acid in vegetable matters with accuracy, and to discriminate it from the sulphur in organic compounds. This chemist determined the sulphuric acid of the oat-plant by extracting the pulverized material with acidulated water. He likewise estimated the total sulphur by a special method, and by subtracting the sulpiur of the sulphuric acid from the total, he obtained as a difference that portion of sulplur which belonged to the albuminoids, etc. In his analyses of clover, Clbricht followed a similar plan. (Fs. St., III, p. 147.) As has already been stated, many of the older analysen are wholly untrustworthy as regards sulphur and sulphuric acid. 
grape. It doubtless occurs perhaps, together with $C$ av sium, in many other plants, though in vrry minute quan. tity. It is not unlikely that small quantities of these alkali-metals may be found to be of decided influence on the growth of plants.*

The late investigations of $\mathrm{A}$. Braun and of Risse, (Sache, Exp. Physiologie, 153,) show that Zinc is a usual ingredient of plants growing about zinc mines, where the soil contains carbonate or silicate of this metal. Certain marked varieties of plants are peculiar to, and appear to have been produced by, such soils, viz, a violet, (Viola tri:olor, var. calaminaris, $\dagger$ and a shepherd's purse, (Thlaspi alpestre, var. calaminaris.) In the ash of the leaves of the latter plant, Risse found $13^{\circ} \%_{0}$ of oxide of zinc; in other plants he found from 0.3 to $\left.3.3^{\circ}\right|_{0}$.

Copper is often or commonly found in the ashes of plants; and other elements, viz., Arsenic, Baryta, and Lead, have been discovered therein, but as yet we are not fairly warranted in assuming that any of these substinces are of importance to agricultural vegetation. The same is true of Iodine, which, though an invariable and probably a necessary constituent of many algæ, is not known to exist to any considerable extent or to be essential in any cultivated plants.

\section{$\S 4$.}

\section{FUNCTIONS OF THE ASH-INGREDIENTS.}

But little is certainly known with reference to the subject of this section.

Sulphates.-The albuminoids, which contain sulphur as an essential ingredient, obviously cannot be produced in absence of sulphuric acil, which, so far as we know, is the

- Since the above was written, Birner \& Lucanus I ave found that these bodies, in the alsence of potash, act as poisons to the oat. (V.s St., VIIL. p. 147.'

+ By some botaulats ranker as a distiuct species. 
single source of sulphur to plants. The sulphurized oils of the onion mustard, horseradish, turnip, etc., likewise require sulphates for their organization.

Phosphates. - The phosphorized oils (protagon) require to their elaboration that phosphates or some source of phosphorus be at the disposal of the plant. The physio logical function of the phosphates, so abundant in the ce reals, admits of partial explimation. The soluble albumi noils which are formed in the foliage must pass thence throngh the eells and ducts of the stem into growing parts of the plant, and into the seed, where they accumulate in iarge quantity. But the albuminoils penctrate membranes with great difficulty and slowness when in the pure state. According to Schumacher, (Physik der Pflanze, p. 128,) the phosphate of potash considerably increases the diffusive rate of albumin, and thus facilitates its translocation in the plant.

Alkalies and alkali-earths,-The organic acids, viz. : oxalic, malic, tartaric, citric, etc., require alkalies and alkali-earths to form the salts which exist in plants, e. g. bitartrate of potash in the grape, oxalate of lime in beetleaves, malate of lime in tobacco; and without these bases it is, perhaps, in most cases impossible for the acids to be formed, though in the orange and lemon, citric acid exists in the uncombined or free state, and in various plants, as Sempervivum arboreum, and Cacalia ficoides, acids are formed during the night which disappenr in the day. The leaves of these plants are sour in the morning, tasteless at noon, and bitter at night. (Heyne \& Link).)

Silica.-The function of silica might appear tu be, in caso of the grasses, sedges, and equisetums, to give rigidity to the slender stems of these plants, and enable them to sustain the often heavy weight of the fruit. Two circumstances, however, embarrass the unqualified acceptance of this notion. The first is, that the proportion of silica is not great 
est in those parts of the plant which, on this view, would most require its presence. Thus Norton, (Am. Jour. of $S c i .,[2$,$] rol. iii, pp. 235-6, found that in the sandy oat$ the upper half of the dry leaf yiclded 16.2 per cent ash, while the lower half gave but 13.6 per cent. The ash of the upper part contained 52.1 per cent of silica, while that from the bottom part hal but $4 \% .5$ per cent of this ingredient. According to Arendt, (Das Wachsthum der Ilaferpflanze, p. 180,) the different parts of the oat contain the following quantities of silica respectively:

Amount of silica in 1000 parts of dry substance. Tiemoved Insoluble by water. in water. Total.

Lower part of the stem.....0.33

Middle part of the stem....0.30

Upper part of the stem.....0.36

Lower leaves............. 0.86

Upper leaves............. 0.52

1.4

4.8

1.7

13.0

5.1

34.3

13.3

43.3

35.2

43.8

We see then, plainly, that the upper part of the stem and leaves contains more silica than the lower parts, while the lower parts certainly need to possess the greatest degree of strength.

We must not forget, however, as Knop has remarked, that the lower part of the leaf of most cereals and grasses which envelopes the stem like a sheath, is really the support of the plant as much as, or even more, than the stem itself.

The results of the many experiments in water-culture by Sachis, Knop, Wolff, and others, (see p. 186, in which the supply of silica has been reduced to an extremely small amount, without detriment to the development of plants, commonly rich in this substance, would seem to demnnstrate that silica does not essentially contribute to the stiffiness of the stem.

Wolff distinctly informs us that the maize and oat plants proluced by lim, in solutions nearly free from silica, were is firm in stalk, and as little inclined to lodge or "lay; as those which grew in the field. 
The recommendation to supply silex to grain crops, in order to stiffen the straw and prevent falling of the crop before it ripens, either by directly applying alkali-silicates, or by the use of fertilizers and amendments that may render the silica of the soil soluble, must, accordingly, be sonsidered entirely futile from the point of view of the need: of the crop, as it is from that of the resources of the soil.

Chlorine.-As has been mentioned, both Nobbe and Leydhecker found that buckwheat grew quite well up to the time of blossom without chlorine. From that period on, in absence of chlorine, remarkable anomalies appeared in the development of the plint. In the ordinary course of growth, starch, which is organizel in the mature leaves, does not remain in them to mnch extent, but is transferred to the newer organs, and especially to the fruit, where it also accumulates in large quantities. In absence of chlorine, in the experiments of Nobbe and Leydhecker, the terminal leaves became thick and fleshy, from extraordinary development of cell-tissue, at the same time they curled together and finally fell off, upon slight clisturbance. The stem became knotty, transpiration of water was suppressed, the blossoms withered without fructification, and the plant prematurely died. The fleshy leares were full of starch-grains, and it appeared that in absence of chlorine the transfer of stareh from the foliage to the flower and fruit was rendered impossible; in other words, chlorine (in combination with potassium or cilcium) was concluded to be necessary to, was, in fitet, the agent of this transfer. Knop believes, howerer, that these phenomena are due tc some other cause, and that chlorine is not essential to the perfection of the fruit of buckwheat, (see p. 18:2).

Iron.-We are in possession of some interesting ficts, which appear to throw light upon the function of this metal in the plant. In case of the deficiency of this element, foliage loses its natural green color; and beconıes pale or white even in the full sunshine. In alosence of iron a 
plant may unfold its buds at the expense of already organ. ized matters, as a potato-sprout lengthens in a clark cellar, or in the manner of fungi and white resetable parasites; but the leaves thus developel are incapilble of assimilating carbon, and actual growth or increase of total werght is imposible. Salm-IIorstmar showed that plants which grow in soils or meliil destitute of iron, are very pale in color, and that adilition of iron-salts very speelily gives them a healthy green. Sachs found that maize-secdlings, vegetating in solutions free from iron, had their first three or four leaves green; several following were white at the base, the tips being green, and afterwari, perfuctly white leares unfililed. On adiling a few drops of sulphate or chloride of iron to the nourishing medium, the foliage was plainly altered within 24 hours, and in 3 to 4 days the plant ac puivel a leep, lively green. Being afterwards transferred to a solution lestitute of iron, perfectly white leaves were again developed, and these were brought to a normal color by addition of iron.

E. Gris was the first to trace the reason of these effects, an'l first tount, (in 1813,) that watering the roots of plants with solutions of iron, or applying such solutions externally to the leaves, shortly developed a green color where it was previously wanting. By microscopic studies he found that in the absence of inom, the protoplasm of the leaf-ells remains a celorless or yellow mass, destitute of visilse organization. Uniler the influence of iron, grains of chlmopinyll hegin at once to appear, and pass through the rarisus stares of normal derelopment. We know that the power of the leaf to decompose carbonic acid and assimilate carbon, resides in the cells that contain chlorophyll, ol, we may say, in the chlorophyll-rains themselves. We undirstani at once, then, that in the absence of iron, which is essential to the formation of chlorophyll, there can be no proper growth, no increase at the expeuse of the external atmospheric food of vegetation. 
Risse, under Sachs' direction, (Exp. Physiologie, 143,) demonstrated that manganese cannot take the place of iron in the office just described.

Functions of other Ash-Ingredients.-As to the speia. uses of the other fixel matters we know little $Y_{t}$ ap pears to be proved beyond doubt that potash, hate, and magnesia, are indispensable to the life and health of animals, and since all animals derive the chief part of their sustenance from the regetable world, it is obvious that these substances must be ingredients of plants in order to fit the latter for their nutritive office; but why no veget:lble cell ean be elaborated without potash, why lime and magnesia are imperative necessities to plants, we are as yet not able to comprehend.

\section{CHAPTER III.}

\section{$\S 1$.}

QUANTITATIVE RELATIONS AMONG THE INGREDIENTS OF PLANTS.

Various attempts have been made to exbibit definito numerical relations between certain different ingredients of plants.

Equivalent Replacement of Bases.-In 1810, Liebig, in his Chemistry applied to Agriculture, suggested that the various bases might displace each other in equivalent puntities, i. e., in the ratio of their molecular weights, and that were such the case, the discrepancies to be observ. ('d among analyses should disappear, if the latter were interpreted on this view. Linbig instanced two analyses of the ashes of fir-wood and tro of pine-wood made by Berthier and Saussure, as illustrations of the correctness of this theory In the fir of Mont Breven, carbonate of 
magnesia was present; in that of Mont La Salle, it was absent. In the former existed but half as much carbonate of potash as in the latter. In both, however, the same total percentage of alkali and earthy carbonates was found, and the amount of oxygen in these bases was the same in both instances.

Since the unlike but equivalent quantities of potash, lime, and magnesia, contain the same quantity of oxygen, these bases, in the case in question, do displace each other in equivalent proportions. The same was true for the ash of pine-wooā, from Allevard and from Norway. On apply. ing this principle to other cases it has, however, signally failed. The fact that the plant can contain accidental or unessential ingredients, renders it obvious that, however truly such a law as that of Liebir may in any case apply to those substances which are really concerned in the vital actions, it, will be impossible to read the law in the results of analyses.

Relation of Phosphates to Albuminoids.-Liebig likewise considers that a definite relation must and does exist between the phosphoric acil and the albuminoids of the ripe grains. That this relation is not constant, is evident from the following statement of the data, that have been as yet obtained, bearing on the question. In the table, the amount of nitrogen $(\mathrm{N})$, representing the albuminoids (see p. 108) found in various analyses of rye and wheat grain, is compared with that of phosphoric acid $\left(\mathrm{PO}_{6}\right)$, the latter being taken as unity.

in 7 Samples of Rye-kernel Fehling \& Faiszt found the ratio of ${ }_{\mathrm{PO}}^{\mathrm{PO}_{5}}$ to $\mathrm{N}$ to range from.....1 $\overbrace{1.97-3.06}^{\mathrm{N}}$

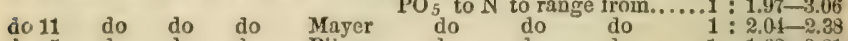

tio 5 do do do Bibra do do do $1: 1.68-2.81$

do 6 do do do Siegert do do do $1: 2.35-2.96$

do 25 do do do the extreme range was from..........1 : $1.68-3.06$

do 2 do of Wheat-kernel Fehling \& Faiszt found the ratio of

$\mathrm{PO}_{5}$ to $\mathrm{N}$ to range from.......1: $2.71-2.86$

do 11 do do dc Mayer do do do $1: 1.83-2.19$

do 2 do do do Zoeller do do do $1: 2.02-216$

do 30 do do do Bibra do do do $1: 1.87-3.55$

do 6 do do do Siegert do do do $1: 2.30-3.33$

do 51 do do do the extreme range was from......... 1: $1.83-3.55$ 
Siegert, who has collected these data, ( $V_{\mathcal{S}}$. St., III, 14\%) and whu experimented on the influence of phosphatio and nitrogenous fertilizers upon the composition of wheat and rye, gives as the general result of his special inquiries, that Phosphoric acid and Nitrogen stand in no constant relation to each other. Nitrogenous manures increase the per cent of nitrogen and diminish that of phosphoric acid.

Other Relations.-All attempts to trace simple and constant relations between other ingredients of plants, viz. : between starch and alkalies, cellulose and silica, etc., etc., have proved fruitless.

It is much rather demonstrated that the proportions of the constituents is constantly changing from day to day as the relative mass of the individual organs themselves undergoes perpetual variation.

In adopting the above conclusions, it is not asserted that such genetic relations between phosphates and albuminoids, or between starch and alkalies, as Liebig first suggested and as rarious observers have labored to show, do not exist, but simply that they do not appear from the analyses of plants.

\section{$\S 2$.}

THE COMPOSITION OF THE PLANT IN SUCCESSIVE STAGES OF GROWTH.

We have hitherto regarded the composition of the plast mostly in a relative sense, and have instituted no compari. sons between the absolute quantities of its ingredients at different stages of growth. We have obtained a series of isolated views of the entire plant, or of its parts at some certain period of its life, or when placed under certain conditions, and have thus sought to ascertain the peculiarities of these periods and to estimate the influence of these con. 
ditions. It now remains to attempt in some degree the combination of these sketches into a panoramic pictureto give an illea of the composition of the plant at the successive steps of its development. We shall thus gain some insight into the rate and manner of its growth, and acquire data that have an important bearing on the requisites for its perfect nutrition. For this purpose we need io study not only the relative (percentage) composition of the plant and of its parts at various stages of its existence, but we must also inform ourselves as to the total quantities of each ingredient at these periods.

We shall select from the data at hand those which illustrate the composition of the oat-plant. Not only the ashingredients, but also the organic constituents, will he noticed so far our information and space permit.

\section{The Composition and Growth of the 0at-Plant may} be studied as a type of an important class of agricultural plants, viz.: the annual cerenls-plants which complete their existence in one summer, ant which yield a large quantity of nutritious seeils-the mist valuable result of culture. The oat-plant was first studied in its various parts and at different times of development $b_{y}$ Prof. John Pitkin Norton, of Yale College. His laborious research published in 18t6, (Trans. Highlend and Ag. Soc. 1845-7, also Am. Jour. of Sci. and Arts, Vol. 3, 18.7, was the first step in advance of the single and discomected analyses which had previously been the only data of the agricultural phywiologist. For several reasons, however, the work of Norton was imperfect. The analytical methods employed by him, thourh the best in use at that day, and handled by him with great skill, were not arlapterl to fir. nish results trustworthy in all particulars. Fourteen years l:ter, Arendt, " at Mockern, and Bretschneider, $\nmid$ at Saarau,

- Wachsthumsverh iltnisse der IIaferpflanze, Jour. fur Prakt. Chem., 76, 193.

+ Das Wachsthum der Haferpflanze, Leipzig. 1859. 
in Germany, at the same time, but independently of each other, resumed the subject, and to their labor's the subjoined figures and conclusions are due.

IIere follows a statement of the Periods at which the plants were taken for analysis.

Ist Period $\}$ June 18, Arendt-Three lower leaves unfolded, two upper still closed.

2 Period June 30, (12 days,) At.--Shortly before the plants were fully headed. 8d Period July 10, (10 days, ) At.-Immediately after bloom.

4th Period $\}$ July 21, (11 days.) At.-Beginning to ripen.

5th Period $\left\{\begin{array}{l}\text { July 31, (10 (lays, ) At.-Fully ripe. } \\ \text { Ang, 6, (9 days, }) \text { Br, " "6 }\end{array}\right.$

It will be seen that the periods, though differing somewhat as to time, correspond almost perfectly in regard to the development of the plants. It must be mentioned that Arendt carefully selected luxuriant plants of equal size, so as to analyze a uniform material, (see p. 210, ) and took no account of the yield of a given surface of soil. Bretschneider, on the other hand, examined the entire prorluce of a square rod. The former procedure is best adapted to study the composition of the well-nourished individual plant; the latter gives a truer view of the crop.

The unlike character of the material as just indicated is but one of the various causes which might render the two series of observations discrepant. Thus, differences in soil, weather, and seeding, would necessarily influence the relative as well as the absolute development of the two crops. The results are, notwithstanding, strikingly accordant in many particulars. In all cases the roots were not and could not be included in the investigation, as it is impossible to free them from adhering soil.

The Total Weight of Crop per English acre, at the end of each period, was as follows: 
TABLE I. - Br.

1st Period, 6,358 lbs. aroirdup sis.

$\begin{array}{lllll}2 \mathrm{~d} & \text { " } & 10,603 & \text { " } & \text { " } \\ 3 \mathrm{~d} & \text { " } & 16,523 & \text { " } & \text { " } \\ \text { 4th } & \text { " } & 14,981 & \text { " } & \text { " } \\ \text { 5th } & \text { " } & 10,622 & \text { " } & \text { " }\end{array}$

The Total Weights of Water and Dry IItter for all but the $2 d$ Period-the material of which was accidentally lost-were :

$$
\text { TABLE II.-Br. }
$$

$$
\text { Dry Matter, Water, }
$$

lbs, av. per acre. Ibs, av. per acre.

$\begin{array}{lrr}\text { 1st Period, } & 1,284 & \mathbf{5 , 0 7 4} \\ \text { 3d "6 } & 4,383 & 12,210 \\ \text { 4th "6 } & \mathbf{5 , 4 2 7} & \mathbf{1 4 , 9 8 3} \\ \mathbf{5 t h} \text { "6 } & 6,886 & \mathbf{3 , 7 3 6}\end{array}$

1.-From Tab. I it is seen: That the weight of the live crop is greatest at or before the time of blossom.* After this period the total weight diminishes as it had previously increased.

2.-From Tab. II it becomes manifest: That the organic tissue (dry inatter) continually increases in quantity up to the maturity of the plant; and

3.-The loss after the $3 \mathrm{~d}$ Period falls exclusively upon the water of vegetation. At the time of blossom the plant has its greatest absolute quantity of water, while its least absolute quantity of this ingredient is found when it is fully ripe.

By taking the difference between the weights of any two Periods, we obtain:

\section{The Increase or Loss of Dry Matter and Water during each Period.}

$\begin{array}{lcc} & \text { TABLE III.-Br. } & \\ & \text { Dry Dfatter, } & \text { Water, } \\ \text { 1bs. per acre. } & \text { 1bs. per acre. } \\ \text { 1st Period, } & 1,284 \text { Gain. } & 5,073 \text { Gain. } \\ \text { 8d "6 } & 3,099 \text { "6 } & 7,166 \text { " } \\ \text { 4th " } & 1,014 \text { "6 } & 2,684 \text { Loss. } \\ \text { 5th " } & 1,459 \text { " } & 5,820 \text { " }\end{array}$

- In Arendi's Esperiment at the time of "Leadiug out," 3d Putiod. 
On diriding the above quantities by the number of days of the respective periods, there results:

\section{The Average Daily Gain or Loss per Acre during} each Period.

TABLE IV.-Br.

Dry Matter.

1st Period,

$3 d$ "

4 th "

5 th "6
22 lbs, Gain.

163 " "6

65 6 6

112 6 "6
Water.

87 Ibs. Gain.

382 " "

167 " Loss.

447 " "6

4.-Table III, and especially Tab. IV, show that the gain of organic matter in Bretschneider's oat-crop went on most rapidly at or before the time of blossom, (according to Arendt at the time of heading out.) This was, then, the period of most active growth. Afterward the rate of growth diminished by more than one-half, and at a later period increased again, though not to the maximum.

Absolute Quantities of Carbon, IIydrogen, Oxygen: Nitrogen, and $\mathbf{A s h}$, in the dry oat crop at the conclusion of the several periods; (lbs. per acre.)

\section{TABLe V.-Br.}

\begin{tabular}{|c|c|c|c|c|c|}
\hline 1st Period, & $\begin{array}{c}\text { Carbon. } \\
593\end{array}$ & $\begin{array}{c}\text { Hydrogen. } \\
80\end{array}$ & $\begin{array}{c}\text { Oxygen. } \\
455\end{array}$ & $\begin{array}{c}\text { Nitrogen. } \\
46\end{array}$ & $\begin{array}{c}\text { Ash.* } \\
110\end{array}$ \\
\hline d 6 & 2,137 & 286 & 1,575 & 122 & 263 \\
\hline$"$ & 2,600 & 343 & 2,043 & 150 & 291 \\
\hline "6 & 3,229 & 405 & 2,713 & 167 & 372 \\
\hline
\end{tabular}

\section{Relative Quantities of Carbon, Iydrogen, 0xygen,} Nitrogen, (Organic Matter, and Ash in the dry oat crop, at the end of the several Periods; (per cent.)

TABte VI.-Br.

Carbon. Bydrogen. Oxygen. Nitrogen. (Organic Matter.) Ash.

$\begin{array}{lllllll}\text { 1st Pcriod, } & 46.22 & 6.23 & 35.39 & 3.59 & 91.43 & 8.57 \\ \text { 3d "6 } & 48.76 & 6.53 & 35.96 & 2.79 & 94.04 & 5.96 \\ \text { 4th "6 } & 47.91 & 6.33 & 37.65 & 2.78 & 94.67 & 5.33 \\ \text { 5th " } & 46.89 & 5.88 & 39.40 & 2.43 & 94.60 & 5.40\end{array}$

* In Bretschneider's analyses, "ash" signifies the residue left after carefully burning the plant. In Arendt's investigration the sulphur and chlorine were do cermined in the unburned plant. 


\section{Relative Quantities of Carbon, IIydrogen, Oxygen,} and Nitrogen, in dry substance, after deducting the somewhat rariable amount of ash, (per cent).

TABLE VII.-Br.

\begin{tabular}{|c|c|c|c|c|}
\hline & Carbon. & Hydrogen. & Oxygen. & Nitrages \\
\hline Ist Period, & 50.55 & 6.81 & 38.71 & 3.93 \\
\hline $3 \mathrm{~d}$ & 51.85 & 6.95 & 38.24 & 2.86 \\
\hline 4th & 50.55 & 6.96 & 39.83 & 2.93 \\
\hline 5th & 49.59 & 6.21 & 41.64 & 2.56 \\
\hline
\end{tabular}

5.-The Tables V, VI, and VII, demonstrate that while the absolute quantities of the elements of the dry oat plant continually increase to the time of ripening, they do not increase in the same proportion. In other words, the plant requires, so to speak, a change of diet as it advances in growth. They further show that nitrogen and ash are relatively more abundant in the young than in the mature plant; in other words, the rite of assimilation of Nitrogen and fixed ingredients falls behind that of Carbon, Hydrogen, and Oxygen. Still otherwise expressed, the plant as it approaches maturity organizes relatively mors amyloids and relatively less albuminoids.

The relations just indicated appear more plainly when we compare the Quantities of Nitrogen, Iydrogen, and oxygen, assimilated during each period, calculated upon the amount of Carbon assimilated in the same time and assumed at 100 .

TABLE VIII.-Br.

\begin{tabular}{|c|c|c|c|c|}
\hline & Carbon. & Nitrogen. & Hydrogen. & Oxygen. \\
\hline $\begin{array}{l}\text { 1st Period, } \\
3 \mathrm{~d}\end{array}$ & $\begin{array}{l}100 \\
100\end{array}$ & $\begin{array}{l}7.8 \\
4.9\end{array}$ & $\begin{array}{l}13.4 \\
13.3\end{array}$ & $\begin{array}{l}73.6 \\
72.5\end{array}$ \\
\hline 4 th & 100 & 6.1 & 12.3 & 100.8 \\
\hline 5 th & 100 & 2.6 & 10.6 & 106.5 \\
\hline
\end{tabular}

From Table VIII we see that the ratio of IIydrogen to Carbon resularly diminishes as the plant matures; that of Nitrogen fills greatly from the infincy of the plant to the period of full bloom, then strikingly inereases during the 
fist stages of ripening, but falls off at last to minimum. The ratio of Oxygen to Carbon is the same during the 1st and $3 d$ periods, but increases remarkably from the period of full blossom until the plant is ripe.

As alrearly stated, the largest absolute assimilation of all ingredients-most rapil growth-takes plice at the time of heading out, or blossom. At this period all the volatile elements are assimilated at a nearly equal rat", and at a rate equal to that at which the fixerl matters (ash:) are absorbed. In the first period Nitrogen and Ash; in the fourth period Nitrogen and Oxygen; in the fifth perivd Oxygen and Ash are assimilated in largest proportion.

This is made evident by calculating for each pcriod the Daily Increase of Each Ingredient, the amount of the in. grelients in the ripe plant bein assumed at 100 as a point of comparison. The figures resulting from such a cisleulation are given in

TABLE IX.-Br.

\begin{tabular}{|c|c|c|c|c|}
\hline 1st Period, & $\begin{array}{c}\text { Carbon } \\
0.31\end{array}$ & $\begin{array}{c}\text { Hydrogen. } \\
0.33\end{array}$ & $\begin{array}{c}\text { Oxygen. } \\
0.28\end{array}$ & $\begin{array}{c}\text { Nitrogen. } \\
0.47\end{array}$ \\
\hline $3 d \quad 6$ & 2.51 & 2.68 & 2.17 & 2.39 \\
\hline 4th & 0.89 & 0.83 & 1.07 & 1.06 \\
\hline 5 th & 1.49 & 1.16 & 1.89 & 0.75 \\
\hline
\end{tabular}

The inereased assimilation of the 5 th over the 1 in period is, in all probability, only apparent. The results of anal. ysis, as before mentioned, refer only to those parts of the plant that are above ground. The activity of tne foliage in gathering food from the atmosphere is doubtless greatly liminished before the plant ripens, as evidenced by the leares turning yellow and losing water of vegetation. The increase of weight in the plant above ground probably proceerls from matters previously stored in the roots, which now are transferred to the fiuit and foliage, and maintain the growth of these parts after their power of assimilatir $g$ inorganic food $\left(\mathrm{CO}_{2}, \mathrm{H}_{2} \mathrm{O}, \mathrm{NH}_{2}, \mathrm{~N}_{2} \mathrm{O}_{8}\right)$ is lost. 
The following statement exhibits the Arerage Daily Increase of Carbon, Hydrogen, Oxygen, Nitrogen, and $\mathbf{A s h}$ (in lbs. per acre) during the several periods.

TABLE X.-Br.

\begin{tabular}{|c|c|c|c|c|}
\hline & Carbon. & Hydrogen. & Oxygen. & Nitrogen. \\
\hline d 6 & $\begin{array}{r}8.45 \\
66.95\end{array}$ & $\begin{array}{l}1.13 \\
8.94\end{array}$ & $\begin{array}{r}6.30 \\
48.06\end{array}$ & $\begin{array}{l}0.65 \\
3.30\end{array}$ \\
\hline 6 & 23.81 & 2.95 & 24.06 & 1.47 \\
\hline 66 & 39.85 & 3.89 & 42.44 & 1.04 \\
\hline
\end{tabular}

Turning now to Arendt's results, which are carried more into detail than those of Bretschneider, we will notice

\section{A.-The Relative (percentage) Composition of the} Entire Plant and of its Parts* during the several periods of vegetation.

1. Fiber $t$ is found in greatest relative quantity-40 ${ }_{0}^{\circ}$ in the lower joints of the stem, and from the time when the grain "heads out," to the period of bloom. Relatively considered, there occur great variations in the same part of the plant at different stages of growth. Thus, in the ear, which cont:lins the least fiber, the quantity of this substance regularly diminishes, not absolutely, but only relatively, as the plant becomes older, sinking from $27^{\circ} \hat{l}_{0}$, at heading, to $\left.12^{\circ}\right|_{0}$, at maturity. In the leaves, which, as regards fiber, stand intermediate between the stem and ear, this substance ranges from $222^{\circ} \%_{0}$ to $38^{\circ} \%_{0}$. Previous to blossom, the upper leaves, afterwards the lower leaves, are the richest in fiber. In the lower leaves the maximum,

* Arendt selected large and well-developed plants, divided them into six parto snd analyzed each part separately. His divisions of the plants were 1, the thres lowest joints of the stem: 2, the two middle joints; 3 , the upper joint; 4, the three lowest leavey: 5, the two upper leaves; 6 , the ear. The stems were cut Just above the nodes, the leaves included the sheaths, the ears were stripped from the stem. Arendt rejected all plants which were not perfect when gathered. When neariy ripe, the cereals, as is well known, often lose one or more of their lower leaves. For the numerous analyses on which these conclusions are based we must refer to the original.

11. e., Crude cellulase; see p. 60 
$\left(33 \%_{0}\right)$ is found in the 4 th ; in the upper leaves, $\left(38^{\circ} \%_{0}\right)$ in the $2 d$ period.

The apparent diminution in amount of fiber is due in all cases to increased production of other ingredients.

2. Fat and $W a x$ are least abundant in the stem. Their proportion increases, in general, in the upper parts of the stem, as well as in the later stages of its growth. The range is from $\left.0.2^{\circ}\right\}_{0}$ to $\left.3^{\circ}\right|_{0}$. In the ear the proportion increases from $\left.2^{\circ}\right|_{0}$ to $3.7^{\circ} \%_{0}$. In the leaves the quantity is much larger and is mostly wax. The smallest proportion is $4.8^{\circ} \mathrm{O}$, which is found in the upper leaves, when the plant is ripe. The largest proportion, $\left(\left.10^{\mathrm{C}}\right|_{0}\right)$ ) exists in the lower leaves, at the time of blossom. The relative quantities found in the leaves undergo considerable variation from one stage of growth to another.

3. Non-nitrogenous matter's, other than fiber,--starch, sugar, etc., ${ }^{*}$-undergo great and irregular variation. In the stem the largest percentage, $\left(\left.57^{\circ}\right|_{0},\right)$ is found in the young lower joints; the smallest, $\left(\left.43^{\circ}\right|_{0}\right)$ in ripe upper straw. Only in the ear occurs a regular increase, viz., from 54 to $\left.63^{\circ}\right|_{0}$.

4. The Albuminoids, $\nmid$ in Arendt's investigation, exhibit a somewhat different relation to the vegetable substance, from what was observed by Bretschneider, as seen from the subjoined comparison of the percentages found at the different periods.

\begin{tabular}{ccccc} 
& \multicolumn{3}{c}{ Periods. } \\
I. & II. & III. & IV. & V. \\
Arendt...........20.93 & 11.65 & 10.86 & 13.67 & 14.30 \\
Bretschweider ....22.73 & & $1 \% .67$ & 17.61 & 1539
\end{tabular}

These differences may be variously accounted for. They are due, in part, to the fact that Arendt analyzed only large and perfect plants. Bretschneider, on the other

* What remaing after deducting fat and wax, albuminoids, fiber, and anh, trom the dry substance, is here included.

+ Calcrlated by multiplying the percentage of nitrogen by 6.33 . 
hand, examined all the plants of a given plot, large and small, perfect and injured. The differences illustrate what has been already insisted on, riz, that the development of the plant is greatly modified by the circumstances of its growth, not only in reference to its external figure, but aboo as regards its chemical composition.

The relative distribution of nitrogen in the parts of the plant at the end of the several periods is exhibited by the following table, simple inspection of which shows the fluctuations, (relative, in the content of this element. The percentages are arranged for ench period separately, proceeding from the highest to the lowest:

\section{ins.}

I.

II.

$\begin{array}{ccccc}\text { Upper leaves. Lower lenves. Upper leaves. } & \text { Ears. } & \text { Ears. } \\ 3.74 & 2.39 & 2.27 & 2.85 & 3.04\end{array}$

Lower leaves. Upper lerres. Lower leaves. Upper leaves. Upper leaves.
3.38
2.19
2.18
1.91
1.74

Lower leaves. Ears

Ears.

Lower leaves. Upper stem.

2.15

2.06

1.85

1.62

1.56

Middle stem. Upper stem. Upper stem. Lower lęvee.
1.52
1.31
1.60
1.43

Upper stem. Middle stem. Middle stem. Middle stem.
0.57
0.95
1. 20
1.17

Lower stem. Lower stem. Lower stem. Lower stem.

0.80

0.88

0.83

0.79

5. Ash.-The agreement of the percentages of ash in the entire plant, in corresponding periods of the growth of the oat, in the independent examinations of Bretschneider and Arendt is remarkibly close, as appears from the figures below.

\begin{tabular}{cccccc} 
& \multicolumn{5}{c}{ PERIODS. } \\
Bretschneider $\ldots . .8 .57$ & II. & III. & IV. & V. \\
Arendt...........8.03 & 5.24 & $\mathbf{5 . 4 4}$ & 5.33 & $\mathbf{5 . 4 0}$
\end{tabular}

The diminution at the $2 d$, increase at the $3 d$, and subsequent diminution at the 4 th period, are observed to run parallel in both cases.

As regards the several parts of the plant, it was found 
by A rendt that of the stem the upper portion was richest in ash thronghout the whole period of growth. Of the leaves, on the contrary, the lower contained most fixed matters. In the ear there occurred a continual decrease from its first appearance to its maturity, while in the stem and lea res there was, in general, a progressive increase towarits the time of ripening. The greatest percentage, $\left(\left.10.5^{\circ}\right|_{0}\right)$ was found in the ripe leaves; the smallest, $\left(0.78 \%_{0}\right)$ in the ripe lower straw.

Far more interesting and instructive than the relative proportions are

\section{$B$-The absolute quantities of the ingredients found} in the plant at the conclusion of the several periods of growth.-These absolute quantities, as found by Arendt, in a given number of carefully selected and vigorous plants, dr, not accord with those obtained by Bretschneider from a given area of ground, nor could it be expected that they should, because it is next to impossible to cause the same amount of vegetation to develope on a number of distinct plots.

Though the results of Bretschneider more nearly represent the crop as obtained in farming, those of Areudt give a truer idea of the plant when situated in the best possible conditions, and attaining a uniformly high development We shall not attempt to compare the two sets of observa tions, since, strictly speaking, in most points they do not admit of comparison.

From a knowledge of the absolute quantities of the sub. stances contained in the plant at the ends of several periods, we may at once estimate the rate of grovoth, $i . e$. , the rapictit? with which the constituents of the plant are either taken up or organized.

The accompanying table, which gives in alternate col. umns the total weights of 1,000 plants at the end of the several perints, and, (by subtracting the first from the 
second, the second from the third, etc.,) the gain from matters absorbed or produced during each period, wil serve to justify the deductions that follow, which are taken from the treatise of Arendt, and which apply, of course, only to the plants examined by this iuvestigator.

1,000 Entire Plants, (Water-Free.)

\begin{tabular}{|c|c|c|c|c|c|c|c|c|c|}
\hline & 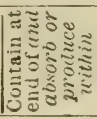 & 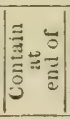 & 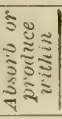 & 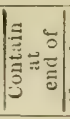 & 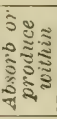 & 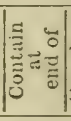 & 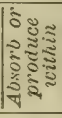 & 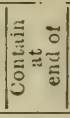 & 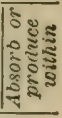 \\
\hline - & $\mid \begin{array}{c}\text { Period I. } \\
3 \text { leaves } \\
\text { open.* }\end{array}$ & $\begin{array}{r}\text { Perio } \\
\text { Hea } \\
\text { ou }\end{array}$ & $\begin{array}{l}\text { d II. } \\
\text { ding } \\
\text { at. }\end{array}$ & $\begin{array}{l}\text { Period } \\
\text { Blosso }\end{array}$ & $\begin{array}{l}1 \\
\text { III. } \\
\text { med. }\end{array}$ & $\begin{array}{l}\text { Perioc } \\
\text { Begin } \\
\text { to rip }\end{array}$ & $\begin{array}{l}\text { div. } \\
\text { nuning } \\
\text { pen. }\end{array}$ & $\begin{array}{r}\text { Perio } \\
\text { Rip }\end{array}$ & $\begin{array}{l}\text { od V. } \\
\text { pe. }\end{array}$ \\
\hline 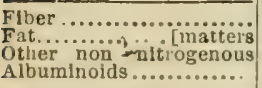 & $\begin{array}{r}103.3 \\
20.1 \\
201.4 \\
95.4\end{array}$ & $\begin{array}{r}4.59 .7 \\
43.9 \\
624.6 \\
158.9\end{array}$ & $\begin{array}{r}355.4 \\
2.8 \\
423.2 \\
63.5\end{array}$ & $\begin{array}{r}561.8 \\
83.9 \\
916.7 \\
202.8\end{array}$ & $\begin{array}{r}105.1 \\
34.0 \\
293.1 \\
43.9\end{array}$ & $\left|\begin{array}{r}5+5.0 \\
97.6 \\
1212.6 \\
317.8\end{array}\right|$ & $\left|\begin{array}{c}\text { Los.s } \\
14 . \tilde{.} \\
325.9 \\
115.0\end{array}\right|$ & $\begin{array}{r}550.6 \\
89.8 \\
1310.0 \\
351.6\end{array}$ & \begin{tabular}{|c|} 
Loss \\
Los. \\
97.4 \\
31.2
\end{tabular} \\
\hline Organlc matter........... & 419.2 & 1292.2 & 873.0 & $176 \pi .2$ & $47 \overline{45.1}$ & 2203.0 & $\mid \overrightarrow{43.5 .8}$ & 2331.6 & 128.6 \\
\hline 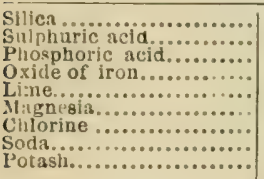 & $\begin{array}{r}6.39 \\
1.06 \\
3.27 \\
0.20 \\
4.48 \\
1.53 \\
2.28 \\
0.86 \\
17.05\end{array}$ & $\begin{array}{r}15.82 \\
2.71 \\
5.99 \\
0.46 \\
8.50 \\
2.71 \\
3.62 \\
1.28 \\
31.11\end{array}$ & $\begin{array}{r}9.43 \\
1.6 .5 \\
2.72 \\
0.26 \\
4.04 \\
1.18 \\
1.34 \\
0.42 \\
14.06\end{array}$ & $\mid \begin{array}{r}23.4 .5 \\
2.63 \\
10.32 \\
0.61 \\
11.6 ! \\
3.71 \\
5.39 \\
1.47 \\
40.20\end{array}$ & $\begin{array}{l}9 . f i 3 \\
0 \\
4.33 \\
0.15 \\
3.10 \\
1.01 \\
1.70 \\
0.19 \\
9.09\end{array}$ & $\left|\begin{array}{r}34.615 \\
4.83 \\
12.90 \\
0.53 \\
14.49 \\
5.42 \\
5.94 \\
1.1 .3 \\
44.38\end{array}\right|$ & $\begin{array}{r}9.21 \\
2.12 \\
2.58 \\
0.22 \\
2.89 \\
1.71 \\
0.64 \\
20.8 .8 \\
4.13\end{array}$ & $\mid \begin{array}{r}36.32 \\
5.34 \\
14.23 \\
0.53 \\
14.71 \\
6.45 \\
5.78 \\
0.87 \\
43.76\end{array}$ & $\begin{array}{l}1.66 \\
0.41 \\
1.33 \\
L 088 \\
0.22 \\
1.03 \\
\text { Loss } \\
\text { Los. } \\
\text { Loss }\end{array}$ \\
\hline Ash........... & 36.60 & 70.031 & $\overline{33.47}$ & 100.41 & 30.33 & $1 \div 0.7 .5$ & 20.31 & 126.93 & 7.18 \\
\hline Dry Matter........ & 4555.8 & $1363,6 !$ & 902.81 & $|1867.6|$ & 501,0 & 3.28 & 456.2 & 458.5 & 134.7 \\
\hline
\end{tabular}

1. The plant increases in total weight, (dry matter,) through all its growth, but to unequal degrees in different periods. The greatest growth occurs at the time of heading out; the slowest, within ten days of maturity.

We may add that the increase of the oat after blossom takes place mostly in the seed, the other organs gaining but little. The lower leaves almost cease to grow after the $2 d$ period.

2. Fiber is produced most largely at the time of heading out, (:d period.) When the plant has finished blog. suming, (end of $3 d$ period,) the formation of fiber entirely ceases. Afterward there appears to occur a slight diminu-

- The weights in this table are grams. One gram $=15.434$ grain's. As the weights have mostly a comparative value, reduction to the English standard iv енuесезвагу 
tion of this substance, probably due to unaroidable loss of lower leaves, but not to a resorption or metamorphosis in the plant.

3. Fat is formed most largely at the time of blossom. It ceases to be produced some weeks before ripening.

4. The formation of Albuminoids is irregular. Tho yreatest amount is organizerl during the th period, (after blossoming.) The gain in albuminoids within this period is two-fifths of the total amount found in the ripe plant, and also is nearly two-fifths of the entire gain of organic substance in the same period. The absolute amount organized in the 1st period is not much less than in the 4 th, but in the $2 \mathrm{dl}, 3 \mathrm{~d}$, and 5 th periods, the quantities are considerably smaller.

Bretschneider gives the data for comparing the production of albuminoids in the oat crop examined by him with Arendt's results. Taking the quantity found at the con. clusion of the 1st period as 100, the amounts gained during the subsequent periods are related as follows:

PERIODS.

I. II. III. (II \& III.) IV. (II, III \& IV.) V.

$\begin{array}{lcccccc}\text { Arendt. ........100 } & 67 & 46 & (113) & 120 & (233) & 36 \\ \text { Bretschneider ...100 } & \text { ? } & \text { ? } & (165) & 62 & (227) & 3 \text { s. }\end{array}$

We perceive striking differences in the comparison. S Bretschneider's crop, the increase of albuminoids goes on most rapidly in the $3 d$ period, and sinks rapidly dusing the time when in Arendt's plants it attained the maxim'xm. Curiously enough, the gain in the $2 d, 3 d$, anl th perinds, taken together, is in both cases as gool as identical, (233 and $22 \%$, and the gain during the last period is also equal. This coincilence is doubtless, however, merely accidental. Comparisons with other crops of oats, examined, though very incompletely, by Stöckhardt, (Chemischer Ackersmann, 1855,) and Wolff, (Die Erschöpfing des Bodens durch die Cultur, 1856,) demnnstrate that the rate of assimilition is not related to any special times or periods of dex:elopi ent, 
but depends upon the stores of food accessible to the plant und the firroilleness of the weather to grouth.

'The follwwing figures, which exhibit for ench period of both croins a comparison of the gain in albuminoids with the increase of the other organic matters, further demon. strate that in the act of organization, the nitrogenous prin. riples hare no close quantitative relations to the non-nitrogenous bodies, (amyloids and fats.)

The quantities of albuminoids gained during each period being represented by 10, the amounts of amyloids, etc., are seen from the subjoined ratios:

PERIODS.

$\begin{array}{ccccc}\text { I. } & \text { II \& III. } & \text { IV. } & \text { V. } & \begin{array}{c}\text { Patio in } \\ \text { Ripe Plant. }\end{array} \\ \text { Arendt.........10:34 } & 10: 114 & 10: 28 & 10: 25 & 10: 66 \\ \text { Bret.chneider..10:30 } & 10: 50 & 10: 46 & 10: 120 & 10: 51\end{array}$

5. The Ash-ingredients of the oat are absorbed through out its entire growth, but in regularly diminishing quantity. The gain during the 1 st period being 10 , that in the $2 d$ period is 9 , in the $3 d, 8$, in the 4 th, $5 \frac{1}{2}$, in the 5 th, 2 nenrly.

The ratios of gain in ash-ingrenlients to that in entire dry substance, are as follows, ash-ingredients being assumed as 1 , in the successive periods:

$$
1: 12 \frac{1}{2}, 1: 27,1: 16,1: 23,1: 19 .
$$

Accordingly, the absorption of ash-ingredients is not proportional to the growth of the plant, but is to some degree accidental, and inlependent of the wants of regetation.

Recapitulation.-Assuming the quantity of each proxirate element in the ripe plant as 100 , it contained at the end of the several periods the following amounts:

\begin{tabular}{|c|c|c|c|c|c|}
\hline & Fiber. & Fat. & Amyloids. & Albuminolds. & Ash. \\
\hline $\begin{array}{l}\text { I. Period, } \\
\text { II. " }\end{array}$ & $\begin{array}{l}18 \% \\
81 \%\end{array}$ & $\begin{array}{l}20^{\circ} \%_{0} \\
50 " 1\end{array}$ & $\begin{array}{l}1500 \\
4766\end{array}$ & $\begin{array}{l}270 \% \\
45 \%\end{array}$ & $\begin{array}{l}29^{\circ} \% \\
55 \%\end{array}$ \\
\hline III. & $100 "$ & $85^{\prime \prime}$ & $70^{6}$ & 57 is & 79 แ \\
\hline IV. & $100 " 6$ & $100 "$ & 926 & $90 " 6$ & 854 \\
\hline$\nabla$ & $100 " 6$ & 100 & $100^{\prime 4}$ & $100 *$ & $100^{4}$ \\
\hline
\end{tabular}


The gain during each period was accordingly as follows:

\begin{tabular}{|c|c|c|c|c|c|}
\hline I. Period & $\begin{array}{l}\text { Fiber. } \\
180\end{array}$ & Fat. & Amyinids. & Albuminoids. & Ash. \\
\hline II. " & $63^{\prime 6}$ & $30^{66}$ & 32 6 & $18^{6}$ & $26^{66}$ \\
\hline III. “ & 19 6 & 35 . & 23 " & 12 " & $24 "$ \\
\hline IV. & 0 " & $15^{66}$ & $22 " 6$ & 334 & 16 \\
\hline $\mathbf{V}$ & 0 " & 0 " & $8 “$ & $10^{\prime 6}$ & $5 \cdot 6$ \\
\hline & $100 " 6$ & $100 "$ & $100^{\prime 6}$ & $100 " 6$ & $100^{\prime \prime}$ \\
\hline
\end{tabular}

6.-As regards the individual ingredients of the ash, the plant contained at the end of each period the following amounts,-the total quantity in the ripe plant being taken at 100. Corresponding results from Bretschneider enclosed in ( ) are given for comparison.

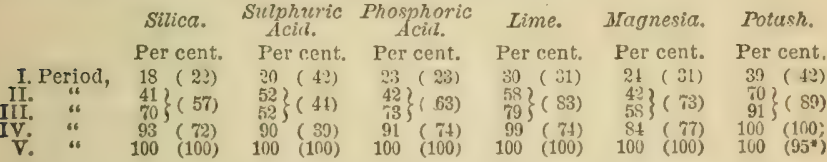

The gain (or loss, indicated by the minus sign-) in these ash-ingredients during each period is given below.

Silica. Sulphuric Phosphoric Lime. Jragnesia. Potash.

Per cent. Per cent. Per cent. Per cent. Per cent. Per cent.

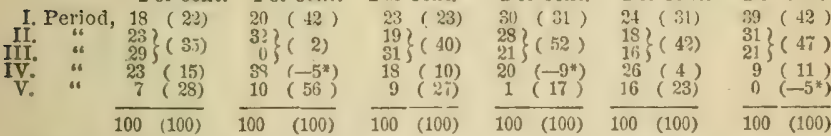

These two independent investigations conld hardly give all the discordant results observed on comparing the above figures, as the simple consequence of the unlike mode of conducting them. We observe, for example, that in the last period Arendt's plants gathered less silica than in any nther-only $\left.7^{\circ}\right|_{0}$ of the whole. On the other hand, Bretschneider's crop grained more siliea in this than in any

* In these instances Bretachreider's Iater crops contained less sulpliuric acid, ltme, and potash, than the earlier. This result may lye due to the washing of the crop t? calns, but is probably caused by unequal development of the several plots. 
other single period, viz.: $28^{\circ} \mathrm{l}_{0^{\circ}}$ A similar statement is true of phosphoric acid. It is obvious that Bretschneider's crop was taking up fixed matters much more vigor. cusly in its last stages of growth, than were Arenit's plants. As to potash we observe that its accumulation ceased in the 4 th period in both cases.

It is, on the whole, plain that we camnot safely draw from these interestiug researches any very definite conclusions as to the rate and progress of assimilation and growth in the oat plant, beyond what have been already pointed out.

C.-Trauslocation of substauces in the Plant.-The translocation of certain matters from one part of the plant to another is revealed by the anilyses of Arendt, and since such changes are of interest from a physiologieal point of view, we may recount them here briefly.

It has been mentioned alrealy that the growth of the stem, leaves, and e:l', of the oat plant in its later stages probably takes place to a great degree at the expense of the roots. It is also probable that a transfer of amyloids, and certain that one of albuminoils, goes on from the leaves through the stem into the ear.

Silica appears not to be subject to any change of position after it has once been fixerl by the plant. Chlorine likewise reveals no noticeable mobility.

On the other hand phosphoric acid passes rapidly from the leaves and stem towards or int the fruit in the earlier as well as in the liter stages of growth, as shown by the following figures :

1,000 plants contained in the various periods, quantitieg (grams) of phosphoric acid as follows:

1st Period. $2 d$ Period. 3 a Period. 4 th Period. 5 th Period,

\begin{tabular}{|c|c|c|c|c|c|c|}
\hline \multicolumn{2}{|c|}{3 lower joints of stem } & 0.47 & 0.20 & 0.21 & 0.20 & 0.19 \\
\hline 2 middle $\quad 6$ & 6 & - & 0.39 & 1,14 & 0.46 & 0.18 \\
\hline Lpper joint & 16 & - & 0.66 & 1.73 & 0.31 & 0.39 \\
\hline ¿lower leaves & $*$ & 1.05 & 070 & 0.69 & 0.51 & 0.35 \\
\hline 2 upper leaves & "6 & 1.75 & 1.67 & 1.18 & 0.74 & 0.53 \\
\hline Ear & & - & 2.36 & 536 & 10.67 & 12.52 \\
\hline
\end{tabular}


Observe that these absolute quantities diminish in the stem and leaves after the 1 st or $3 d$ period in all cases, and increase very rapidly in the ear.

Arendt founil that sulphuric acid existed to a much greater degree in the leaves than in the stem, throughout the entire growth of the oat plant, and that after blow. soming the lower stem no longer contained sulphur in the form of sulphuric acid at all, though its total in the plant considerably increased. It is almost certain, then, that sulphuric acid originates, either partially or wholly, by oxidation of sulphur or some sulphurized compound, in the upper organs of the oat.

Magnesia is translated from the lower stem into the tpper organs, and in the fruit, especially, it constintly increases in quantity.

There is no evidence that lime moves upward in the plant. On the contrary, Arendt's analyses go to show that in the ear during the last periorl of growth, it diminishes in quantity, being, perhaps, replaced by magnesia.

As to potash, no transfer is fairly indicated except from the ears. These contained at blossoming (period III) a maximum of potash. During their subsequent growth the amount of potash diminished, being probably displaced by magnesia.

The data furnished by Arendt's analyses, while they indicate a transfer of matters in the cases just named and in most of them with great certainty, do not and cannot from their nature disprove the fact of other similar changes, and sannot fix the real limits of the movements which they noint out. 


\section{DIVISION II.}

\section{TIE S'IRUCTURE OF 'IHE PLANT ANI) OFFICES OF ITS ORGANS.}

\section{CHAPTER I.}

\section{G E N E R A L I T I E S.}

We have given a brief description of those elements and compounds which constitute the plant in a chemical sense. They are the materials - the stones and timbers, so to speak-out of which the vegetable edifice is built. It is important in the next place to learn how these building materials are put together, what positions they occupy what purposes they serve, and on what plan the edifice is constructed.

It is impossible for the builder to do his work until he has mastered the plans and specifications of the architect. So it is hardly possible for the farmer with certainty to contribute in any great, especially in any new degree, to the upbuilling of the plant, unless he is acquainted with the mode of $\mathrm{i}^{\mathrm{t}} \mathrm{s}$ structure and the elements that form it. It is the happy province of science to add, to the vague and general information which the olservation and experience of generations has taught, a more definite and particular knowlerlge,-a knowledge acquired by study purposely and carefully directed to special ends.

An acquaintance with the parts and structure of the plant is indispensable fir undertanting the mode by which 
it derives its food from external sourees, while the ingenicus methods of propagation practiced in fruit and flower culture are only intelligible by the help of this knowledge.

Organism of the Plant. - We have at the outset spoken of organic matter, of organs and organization. It is in the world of life that these terms have their fittest application. The vegetable and animal consist of numerous parts, differing greatly from each other, but each essential to the whole. The root, stem, leaf, flower, and seed, are cach instruments or organs whose co-operation is needful to the perfection of the plant. The plant (or animal), being thus an assemblage of organs, is called an Organism; it is an Organized or Organic Structure. The atmosphere, the waters, the rocks ar.t soils of the earth, are mineral matters; they are inorgasic and lifeless.

In inorganic nature, chemical affinity rules over the transformations of matter. A plant or animal that is dead, under ordinary cireumstances, soon loses its form and characters; it is gradually consumed by the atmospheric oxygen, and virtually burnerl up to air and ashes.

In the organic world a something, which we call the Vitul Principle, resists and overcomes or modifies the affinities of oxygen, and ensures the existence of a continuous and perpetual succession of living forms.

The organized structure is characterized and distinguish. ed from mineral matter by two particulars:

1. It builds up and increases its own mass by appropriating external matter. It assimilates surrounding substances. It growos by the absorption of food.

2. It reproduces itself. It comes from, and forms again a. seed or germ.

Ultmate and Complex Organs. - In our account of the Structure of the Plant we shall first consider the elements of that structure - the Primary Organs or Vegetable Cells-which cannot be divided or wounded without ex. 
tinguishing their life, and by whose expansion or multipli. cation all growth takes place. Then will follow an account of the complex parts of the plant-its Compound Organs - which are built up by the juxtaposition of numerous cells. Of these we have one class, viz. : the Rrots, Stems, and Leaves, whose ofice is to sustain and nourish the Individual Plant. These may be distinguished as the Vegetative Organs. The other class, comprising the Flower and Fruit, are not essential to the existence of the individual, but their function is to maintain the Race. They are the Reproductive Organs.

\section{CHAPTER II.}

THE PRIMARY ELEIIENTS OF ORGANIC STRUCTURE

\section{$\S 1$.}

\section{THE VEgEtABLE CELL.}

One of the most interesting discoveries that the microscope has revealed, is, that all organized matter originates in the form of minute vesicles or cells. If we examine by the microscope a seed or an egg, we find nothing but a cell-structure - an assemblage of little globular bags or vesicles, lying closely together, and more or less fillerl with solid or liquid matters. From these cells, then, comes the frame or structure of the plant, or of the animal. In the process of maturing, the original vesicles are often greatly modified in shape and appearance, to suit various purposes; but still, it is always easy, especially in the plant, to find cells of the same essential characters as those occurring in the seed. 
Cellular Plants. - In those classes of regetation which depart structurally to the least degree from the seed, and which belong to what are called the "lower orders," we find plants which consist entirely of cells throughout all the stages of their life, and indeed many are known which are but a single cell. The phenomenon of red snow, frequently olserverl in Alpine and Aretic regions, is due to a microscopic one-celled plant which proplagates with great

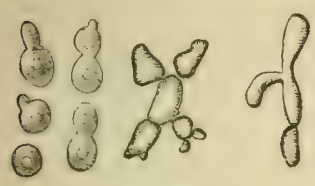

Fig. 27. rapidity, and gives its color to the surface of the snow. In the chemist's laboratory it is often observed that, in the clearest solutions of salts, like the sulphates of soda and magnesia, a flocculent mould, sometimes red, sometimes green, most often white, is formed, which, under the microscope', is seen to be a vegetation consisting of single cells. Brewer's yeast, fig. $2 \pi$, is nothing more than a mass of one or ferr-celled plants.

In the mushrooms and sea-weeds, as well as in the moulds that grow on damp walls, or upon bread, cheese, etc., and in the brand or blight which infests many of the farmer's crops, we have examples of plants formed exclusively of cells.

All the plants of higher orders we find likewise to consist chiefly of globular or angular cells. All the growing parts especially, as the tips of the roots, the leaves, flowers, and fruit, are, for the most part, aggregations of such minute vesicles.

If we examine the pulp of fruits, as that of a ripe apple or tomato, we are able, by means of a low magnifier, to distinguish the cells of which it almost entirely con-

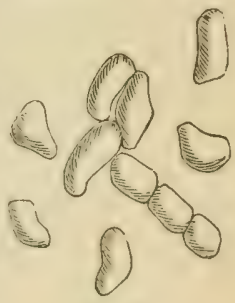

Figr. 2S. sists. Fig. 28 represents a bit of the flesh of a ripe pippin,

* Viz.: the Cryptogams. including Moulds, and Mushrooms, (Fungi, ) Mosses, Ferns, and Sea-Weeds, (Alga). 
magnified 50 diameters. The cells mostly cohere together, but readily admit of separation.

Structure of the cell. - By the aid of the microscope it is pussible to learn something with regard to the internal structure of the cell itselt. Fig. 29 cxhibits the appearance of a cell from the flesh of the Jeru-alem Artichoke, magnified :-:0 diameters; externally the membrane, or wall of the cell, is seen in section. This membrane is

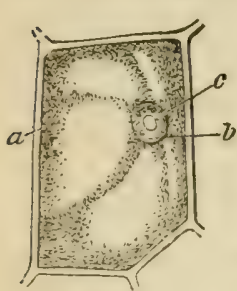

Fic. 29. filled and distended by a transparent liquid, the sap or free water of vegetation. Within the cell is observed a round body, $b$, which is callerl the mucleus, and upon this is seen a smaller nucleolus, c. Lining the interior of the cell-membrane and connected with the nucleus, is a yellowish, turbid, semi-fluid substance of mucilaginous consistence, $a$, which is designated the protoplasm, or formitive layer. This, when more highly magnified, is found to contain a vast number of excessively minute granules.

By the aid of chemistry the microscopist is able to dissect these cells, which are hardly perceptible to the unassisterl eye, and ascertin to a good degree how they are constituted. On moistening them with solution of indine, and afterward with sulphuric acid, the outer membranethe cell-xall-shortly becomes of a fine blue color. It is accorlingly rellulose, the only regetable substance yet known which is made blue by iodine after, and only after, the action of sulphuris acicl. At the same time we ohserve that the interior, half-liquid, protoplasm, hats coigulater and shrunk torgether,-has therefore separated from the cell-wall, and including with it the nucleus and the smaller grainules, lies in the center of the all like a collapsed bladder. It has also alsumed a deep yellow or brown color. If we moisten one of these cells with nitric acid, the cell-wall is not affected, but the liquid penctrates it, 
coagulates the inner membrane, and colors it yellow. In the same way this meminane is tinged violet-blue by chlorhydric acid. These reactions leave no room to doubt that the slimy inner lining of the cell is chiefly an albuminoid. It has been termed by vegetable physiol. ogists the protoplasm or formative layer, from the fact that it is the portion of the cell first formed, and that from which the other parts are developed. The protoplasm is not miscible with or soluble in water. It is contractile, and in the living cell is constantly changing its figure, while the granules commonly suspended in it move and circulate as in a stream of liquid.

If we examine the cells of any other plant we find almost invariably the same structure as above described, provided the cells are young, i. e., belong to growing parts. In some cases cells consist only of protoplasm and nucleus, being destitute of cell-walls during a portion or the whole of their existence.

In studying many of the maturer parts of plants, viz. : such as bave ceased to enlarge, as the full-sized leaf, the perfectly formed wood, etc., we find the cells do not correspond to the description just given. In external shape, thickness, and appearance of the cell-wall, and especially in the character of the contents, there is indefinite variety. But this is the result of change in the original cells, which, so far as our observations extend, are always, at first, formed closely on the pattern that has been explained.

Vegetable Tissue.-It does not, however, usually happen that the individual cells of the higher order's of plants admit of being obtained separately. They are attached together more or less firmly by their outer surfaces, so as to form a coherent mass of cells-a tissue, as it is termed. In the accompanying cut, fig. 30 , is shown a highly magnified view of a portion of a very thin slice across a young cabbage stalk. It exhibits the outline of the in 
regular empty cells, the walls of which are, for the most part, externally united and appear as one, $a$. At the points indicated by $b$, cavities between the cells are seen, called intercellulur spices. A slice across the potato-tuber, (see fig. 5:, p. $2 r \%$, has a similar appearance, except that the

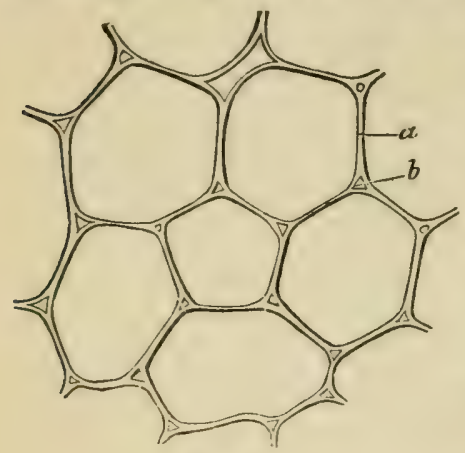

Fig. 30. cells are filled with starch, and it would be scarcely possible to dissect them apart; but when a potato is boiled, the starchgrains swell, and the cells, in consequince, separate from each other, a practical result of which is to make the potato mealy. A thin slice of vegetable ivory (the seed of Phytelephas macrocarpa), under the microscope, dry or moistened with water, presents no trace of cell-structure, the cells being united as one; however, upon soaking in sulphuric acid, the mass softens and swells, and the individual cells are at once reve:led, their surfaces separating in six-sided outlines.

Form of Cells. - In the soft, succulent parts of plants, the cells lie loosely together, often with considerable intercellular spaces, and have mostly a rounded outline. In denser tissues, the cells are crowded together in the least possible space, and hence often appear six-sided when seen in cross-section, or twelve-sided if viewed entire. A piece of honey-comb is an excellent illustration of the appearance of many forms of vegetable cell-tissue.

The pulp of an orange is the most evident example of coll-tissue. The individual cells of the ripe orange may be easily separated from each other, as they are one-fourth of an inch or more in length. Being mature and incapable of further growth, they possess neither protoplasm nor 
nucle:ss, but are filled with a sap or juice containing citric acid and sugar.

In the pith of the rush, star-shaped cells are found. In

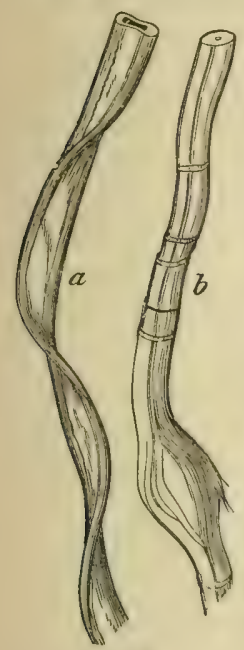

Fig. 31 . common mould the cells are long and thread-like. In the so-called frog-spittle they are cylindrical and attached end to end. In the bark of many trees, in the stems and leaves of grasses, they are square or rectangular.

Cotton-fiber, flax and hemp consist of long and slender cells, fig. 31. Wood is mostly made up of elongated cells, tapered at the ends and adhering together by their sides. Fig. 49, c. h., p. 271.

Each cotton-fiber is a siugle cell which forms an exterual appendare to the seed-vessel of the cotton plant. When it has lost its free water of vegetation and become air-dry, its sides collapse and it resembles a twisted strip. $A$, in fig. 31 , exhibits a portion of a cotton-fiber highly magnified. The flax-fiber, from the inner bark of the flaxstem, $b$, fis. 31 , is a tube of thicker walls and smaller bore than the cotton-fiber, and hence is more durable than cotton. It is very flexible, and even when crushed or bent short, retains much of its original tenacity. Hemp-fiber closely resembles flax-fiber in appearance.

Thicheming of the Cell-Membrame.-The growth of the cell, which, when young, always has a very delicate outer membrane, often results in the thickening of its walls by the interior deposition of cellu. lose and lignin. This thickening may take place regularly and uniformly, or interruptedly. The flas-fiber, $b$, fig. 31 , is an example of nearly uniform thickening. The irregular deposition of cellulose is shown in fig. 32 , which exhibits a section from the seeds (cotyledons) of the com-

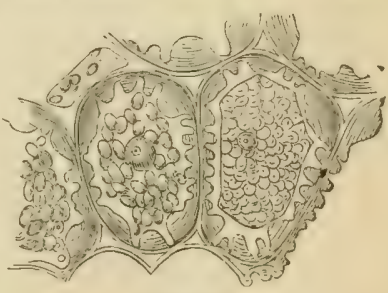

Fig. 32. mon nasturtium, (Tropeculum majus). The original inembrane is coated interiorly with several distinct and successively-formed linings, which are not continuous, but are irregularly dereloped. Seen in section, the 
thickening has a wared outline, and at points, the original cell-ment. brane is bare. Wrere these cells viewed entile, we should sce at the-e points, on the ext rior of the cell, dots or circles alpearing like orificsi, but being sinply the unthickened portions of the cell-wall. The cells in fig. 32 exhibit e:ch a central nucleus surrounded by gratus of alenrune:

Cell Contents. - Besides the protoplasm and nucleus, the cell usually contains a variety of bodies, which have been, incleed, noticel already as ingredients of the plant, but which may be here recapitulated. Many cells are altogether empty, and consist of nothing but the cell-wall. Such are found in the bark or epidermis of most plants, and often in the pith, and although they remain connected with the actually liviug parts, they have no proper life in themselves.

All living or actire cells are distended with liquid. This consists of water, which holds in solution gum, dextrin, inulin, the sugars, "rganic acids, and other less important vergetable principles, torgether with various silts, and constitutes the sap of the plint. In oil-plants, iroplets of oil occupy cert:in cells, fig. 17 , p. 90 ; while in numerous kinds of regetation, colored and milky juices are found in certain spaces or channels between the cells.

The water of the cell comes from the soil, as we shall hereafter see. The matters, which are dissolvel in the sap or juices of the plant, together with the seni-solit protoplasm, undergo transformations resulting in the production of solid substances. By observing the various parts of a plant at the successive stages of its development, under the microscope, we are able to trace within the colls the formation and growth of starch-grains, of crystalloid and granular bodies consisting chiefly of vegetable casein, am of the various matters which give color to leaves anit flowers.

The circumstanes under which a cell developes deter. mine the character of its contents, according to liws that arc hidilen from our knowledge. The outer cells of the potato-tuler are incrusted with corky matter, tho innes 
ones, most of them, are occupied entirely with starch, fig. $5.2,11.2 \% \%$. In oats, wheat, and other cereals, we find, just within the empty cells of the skin or epidermis of the grain, a few layers of cells that contain scarcely anything but albuminoids, with a little fat; while the interior cells are chiefly fillell with starch; fig. 18, p. 106.

Transformations in Cell Contents.-The same cell may exhibit a great variety of aspect and contents at different periods of growth. This is especially to be observed in the seed while developing on the mother plant. Hartig has traced these changes in numerous plants under the microscope. According to this observer, the cell-contents of the seed (cotyledons) of the common nasturtium, (Tropoolum majus, run through the following metamorphoses. Up to a certain stage in its development the interior of the cells are nearly devoid of recognizable solid matters, other than the nucleus and the adhering protoplasm. Shortly, as the growth of the seed alvances, green grains of chlorophyll make their appearince upon the nucleus, completely covering it from view. At a later stage, these griains, which have enlarged and multiplied, are seen to have mostly become detached from the nucleus, and lie neal to and in contact with the cell-wall. Again, in a short time the grains have lost their green color and have assumed, both as regards appearance and deportment with iodine, all the characters of starch. Subsequently, as the seed hardens and becomes firmer in its tissues, the microscope reveals that the starch-grains, which were situated near the cell-wall, have vanished, while the cell-wall itself has thickened inwardly-the starch having been converto ed into cellulose. Again, later, the nucleus, about which, in the meantime, more starch-grains have been formed, undergnes a change and disaplears; then the starch-grains, some of which have enlarged while others have vanished, are found to be imbedded in a pasty matter, which has the reactions of an albuminoid. From this time on, the 
starch-grains are gradually converted from their surfaces inwardly into smaller grains of alcurone, which, finally, when the seed is mature, completely occupy the cells.

In the sprouting of the seed similar chinges oceur, but in reversed order. The nucleus reappears, the aleurone dissolves, and even the cellulose stratified upon the interior of the cell, fig. 32, wastes away and is converted into soluble food (sugar?) for the seedling.

The Dimensions of Vegetable Cells are very various. A creeping marine plant is known-the Caulerpa prolifera,

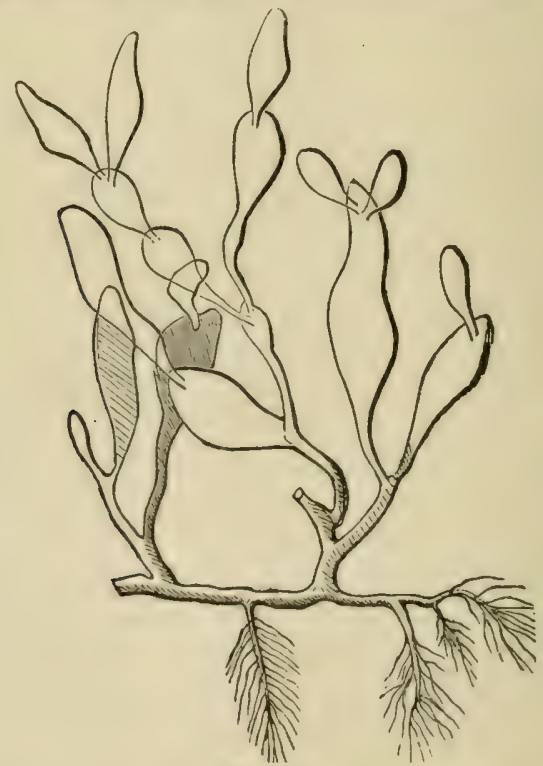

Fig. 33.

fig. 33,-which consists of a single cell, though it is often a foot in length, and is branched with what have the appearance of leaves and roots. The pulp of the orange consists of cells which are one-guarter of an inch or more in diameter. Every fiber of cotton is a single cell. In most 
cases, however, the cells of plants are so small as to require a powerful microscope to distinguish them,-are, in fact, no more than 1-1200th to 1-200th of an inch in diameter; many are vastly smaller.

Growth.-The growth of a plant is nothing more than the aggregate result of the enlargement and multiplication of the cells which compose it. In mont cases the cells attain their full size in a short time. The continuous growth of plants depends, then, chiefly on the constant and rapid formation of new cells.

Cell-multiplication.-The young and active cell always contains a nucleus, (fig. $34, b$.) Such a cell may produce

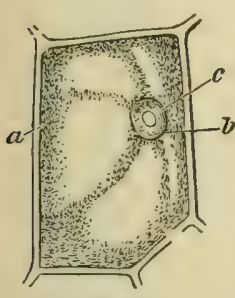

Fig 3t. a new cell by division. In this process the nucleus, from which all cell-growth appears to originate, is observed to resolve itself into two parts, then the protoplasm, $\alpha$, legins to contract or infold across the cell in a line corresponding with the division of the nucleus, until the opposite infolded eilges meet-like the slin of a sausage where a string is tightly tied around it,- - thus separating the two nuclei and inclosing each within its new eell, which is completed by a further external growth of cellulose. •

In one-celled plants, like yeast, (fig. 35 ,) the new cells thus formed, bud out from the side of the parent-cell, and before they obtain full size become entirely detached from it, or, as in higher plants, the new cells remain adhering to the old, forming a tissue.

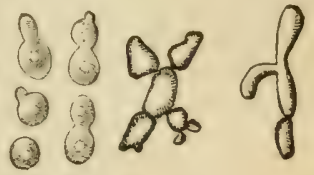

Fig. 35.

In free cell-formation nuclei are observed to develope in the protoplasm of a parent cell, which enlarge, surround themselves with their own protoplasm and cell-membrane, and by the resorption or death of the parent cell become independent of the latter. 
The rapidity with which the vegetable cells may multi ply and grow is illustrated by many familiar facts. The most striking cases of quick growth are met with in the mushroom family. Many will recollect having seen on the morning of a June day, huge puff-balls, some as large as a peck measure, on the surface of a moist meadow, where the day before nothing of the kind was noticed. In such sudden growth it has been estimated that the cells are produced at the rate of three or four hundred millions per hour.

Permeability of Cells to Liquids. - Although the highest magnifying power that can be brought to bear upon the membranes of the vegetable cell filils to reveal any apertures in them,--they being, so far as the best-assisted vision is concerned, completely cont inuons and imperforate, - they are neverthel ss readily permeable to liquids. This fact may be elegantly shown by placing a delicate slice from a potato-tuber, immersed in water, under the microscope, and then bringing a drop of solution of iodine in contact with it. Instantly this reagent penetrates the walls of the unbroken cells without perceptibly affecting their appearance, and being absorbed by the st:ureh-grains, at once colors them intensely purplish-blue. The particles of which the cell-ywalls and their contents are composed, must be separated from each other by distances greater than the diameter of the particles of water or of other liquid matters which thus permeate the cells.

\section{$\S 2$.}

THE VEGETABLE TISSUES.

As already stater, the cells of the higher kinds of plants are united together more or less firmly, and thus constitute what are known as Vegetambe Tissules. Of these, a large number have been distinguished by vegetable anat 
omists, the distinctions being based either on peculiarities of form or of function. For our purposes it will be neces. sury to define but a few rarieties, viz., Cellulur Tissue, Woody Tissue, Bast-Tissue, and Vusculur Tissue.

Cellular or Cell-Tissue is the simplest of all, being a mere aggregation of globular or polyhedral cells whose walls are in close adhesion, and whose juices commingle more or less in virtue of this connection. Cellular tissue is the groundwork of all vegetable structure, being the only form of tissue in the simpler kinds of plants, and that out of which all the others are dereloped. The term parenchyma is synonymous with cell-tissue.

Wood-Tissue, in its simplest form, consists of cells that are several or many times as long as they are broad, and that taper at each end to a point. These spindle-shaped cells cohere firmly together by their sides, and "break joints" by overlapping each other, in this wily forming the tough fibers of wood. Wood-cells are oft n more or less thickened in their walls by depositions of cellulose, lignin, and coloring matters, according to their age and position, and are sometimes lotted and perforated, as will be explained hereafter, fig. 53, p. 278.

Bast-Tissue is made up of long and slender cells, similar to those of rcod-tissue, but commonly more delicate and flexible. The name is derived from the occurrence of this tissue in the bast, or inner bark. Linen, hemp, and a!l textile materials of vegetable origin, cotton excepted, con. sist of bast-fibers. Bast-eclls occupy a place in rind, corresponding to that held by wood-cells in the interior of the stem, fir. 49, p. 271 . Prosenchyma is a name applied to all tissues composed of elongated cells, like those of wood and bast. Parenchyma and prosenchyma insensibly shaile into each other.

Vascular Tissue is the term applied to those unbranched Tubes and Ducts which are found in all the higher orders 
of plants, interpenetrating the cellular tissue. There are several varieties of ducts, viz., dotted ducts, ringed or an. nulur dects, and spiral ducts, of which illustrations will be given when the minute structure of the stem comes under notice, fig. 49 , p. 271 .

The formation of rascular tissue takes place by a simple alteration in cellular tissue. A longitudinal series of adhering cells represents a tube, save that the bore is obstructed with numerous transverse partitions. By the removal or perforation of these partitions a tube is developed. This removal or perforation actually takes place in the living plant by a process of absorption.

\section{CHAPTER III.}

\section{THE VEGETATIVE ORGANS OF PLANTS.}

\section{$\S 1$.}

\section{THE ROOT.}

The Roors of plants, with few exceptions, from the first moment of their development grow downward, in obedience to the force of gravitation. In general, they require a moist medium. They will form in water or in moist cotton, and in many cases originate from branches, or even leaves, when these parts of the plant are buried in the earth or immersed in water. It cannot be assumed that they seek to aroid the light, because they may attain a full development without being kept in darkness. Tho 
action of light upon them, however, appears to be unfavor. able to their functions.

The Growth of Roots occurs mostly by lengthening, and very little or very slowly by increase of thickness. The lengthening is chiefly manifested toward the outer extremities of the roots, as was neatly demonstrited by Wigand, who divided the young root of a sprouted pea into four equal parts by ink-marks. After three days, the first two divisions next the seed had scarcely lengthened at all, while the third was double, and the fourth eight times its previous length. Ohlerts made precisely similar observations on the roots of various kinds of plants. The growth is confined to a space of about $\left.{ }^{1}\right|_{6}$ of an inch from the tip. (Linnea, 1837, pp. 609-631.) This peculiarity adapts the roots to extend through the soil in all direc tions, and to occupy its smallest pores, or rifts. It is likewise the reason that a root, which bas been cut off in transplanting or otherwise, never afterwards extends in length.

Although the older parts of the roots of trees and of the so-called root-crops acquire a considerable diameter, the roots by which a plant feeds are usually thread-like and often exceedingly slender.

Spongioles.-The tips of the rootlets have been termed spongioles, or spongelets, from the idea that their texture adlapts them especially to collect food for the plant, and that the absorption of matters from the soil goes on exclusively through them. In this sense, spongioles do not exist. The real living apex of the root is not, in fact, the outmost extremity, but is situated a little within that point.

Root-Cap.-The extreme end of the root usually consists of cells that have become loosened and in part detached from the proper cell-tissue of the root, which, therefore, shortly perish, and serve merely as an elastic cushion or 
cap to protect the true termination or living point of the root in its act of penetrating the soil. Fi.y. :i6 represents

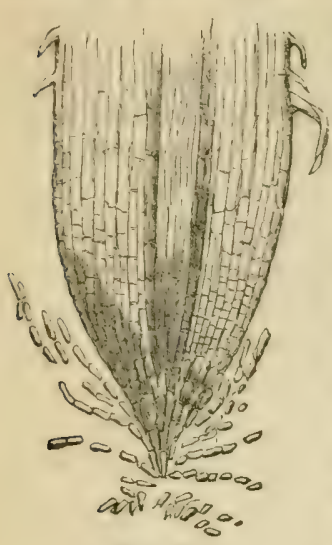

Fir. 36.

a magnified section of part of a barley root, showing the loose cells which slough off from the tip. These cells are filled with air instead of sap. A most strik: ing illustration of the root-cap is furnished by the air-roots of the $\mathrm{so}^{-}$ called Screw Pine, (Pandanus odorntis-

simus, exhibited in natural dimensions, in fig. $3 \%$. These air-roots issue from the stem above the ground, and, growing downwards, enter the soil, and become roots in the ordinary sense.

When fresh, the dismeter of the root is quite uniform, but the parts above the root-cap shrink on drying, while the root-cap itself retains nearly its oriminal dimensions, and thus reveals its different structure.

\section{Distinction between Root and} Stem.-Not all the subterranean parts of the plant are roots in a proper

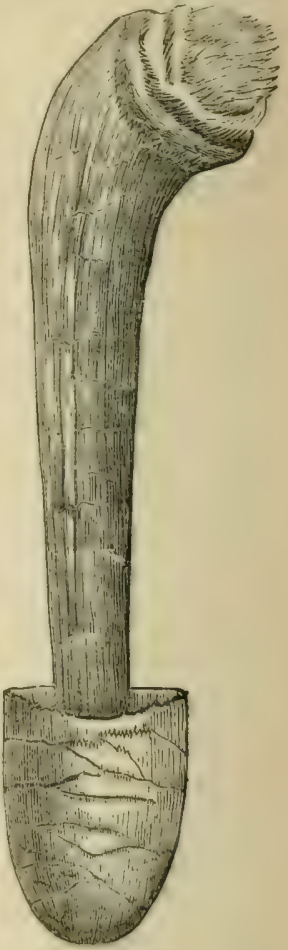

Fir. 37. sense, althong commonly spoken of as such. The tubers of the potato and artichoke, and the fleshy horizontal parts of the sweet flate and pepper-root, are merely underground stems, of which many varieties exist.

These and all other stems are easily distinguished from 
true roots by the imbricated buds, of which indications may usually be found on their surfaces, $e . y$, the eyes of the potato-tuber. The side or secondary roots are indeed marked in their earliest stages by a protuberance on the primary root, but these have nothing in common with the structure of true buds. The onion-bulb is itself a fleshy buk, as will be noticed subsequently. The true roots of the onion are the fibers which issue from the base of the bulb. The roots of many plants exhibit no buds upon their surface, and are incapable of developing them under any conditions. Other plants may produce them when eut off from the parent plant during the growing season. Such are the plum, apple, poplar, and hawthorn. The roots of the former perish if deprived of commection with the stem and leaves. The latter may strike out new stems and leaves for themselves. Plants like the plum are, therefore, capable of propagation by root-cuttings, $i$. e., by placinc pieces of their roots in warm and moist earth.

Tap-Roots.-All plants whose seerts readily divide into two parts, and whose stems increase externally by addition of new rings of growth-the so-cailerl dicotyledonous plants, or Exogens, have, at first, a single descending axis, the tap-root, which penetrates verically into the ground. From this central tap-root, lateral roots branch out more or less regularly, and these lateral roots subdivide again and again. In many cases, especially at first, the lateral roots issue from the tap-root with great order and regularity, as much as is seen in the branches of the stem of a fir-tree or of a young grape vine. In oller plants, this order is lost, because the soil opposes mechanical hindrances to regular development. In many cases the tap-root grows to a great length, and forms the most striking feature of the radication of the plant. In others it enters the ground but a little ray, or is surpassed in extent by its side brancues. The tap-root is conspicuous in the Canada thistle, dock, (Rumex, and in seedling fruit trees. The 
npper portion of the tap-root of the beet, turnip, carrot, and radish, expands under cultivation, and becomes a fleshy, nutritive mass, in which lies the value of these plints for agriculture. The lateral roots of other plants, as of the dahlia and sweet potato, swell out at their extremities to tubers.

Crown Roots.-Monocotyledonous plants, or Endogens, $i$.e., plants whose seeds do not split with ease into two nearly equal parts, and whose stems increase by inside growth, such as the cerenls, grasses, lilies, palms, etc., have no siugle tap-root, but produce crown roots, $i . e_{\text {., }}$ a number of roots issue at once in quick succession from the base of the stem. This is strikingly seen in the onior. and hyacinth, as well as in maize.

Rootlets.-This term we apply to the slenter roots, usually not larger than a knitting needle, and but a few inches long, which are formed last in the order of growth, and correspond to the larger roots as twigs correspond to the branches of the stem.

THe Offices of trie Root are threefold:

1. To fix the plant in the earth and maintain it, in most cases, in an upright position.

2. To absorb nutriment from the soil for the growth of the entire plant, and,

3. In case of many plants, especially of those whose terms of life extend through several or many years, to serve as a store-house for the future use of the plant.

1. The Firmness with which a Plant is fixed in the Ground depends upon the nature of its roots. It is easy to lift an onion from the soil, a carrot requires much more force, while a dock may resist the full strength of a pow. sful man. A small beech or seedling apple tree, which has a tap-root, withstands the force of a wind that would prostrate a maize-plant or a poplar, which has only side roots. In the nursery it is the custom to cut off the tap-ront of 
apple, peach, and other trees, when very young, in order that they may be readily and safely transplanted as occar sion shall require. The depth and character of the soil, however, to a certain degree influence the extent of the roots and the tenacity of their hold. The roots of maize, which in a rich and tenacious earth exter d but two or three feet, have been traced to a length of ten or even fifteen feet in a light, sandy soil. The roots of clover, and especially those of lucern, extend very deeply into the soil, and the latter acquire in some cases a length of 30 feet. The roots of the ash have been known as many as 95 feet long. (Jour. Roy. Ag. Soc., VI, p. 342.)

2. Root-absorption.-The Office of absorbing Plant Food fiom the Soil is one of the utmost importance, and one for which the root is most wisely adapted by the fol. lowing particulars, viz.:

a. The Delicacy of its Structure, especially that of the newer portions, the cells of which are very soft and absorbent, as may be readily shown by immersing a young seedling bean in solution of indigo, when the roots shortly acquire a blue color from imbibing the liquid, while the stem, a portion of which in this plant extends below the seed, is for a considerable time unaltered.

It is a common but erroneous idea that absorntion from the soil can only take place through the ends of the roots -through the so-called spongioles. On the contrary, the extreme tips of the rootlets cannot take up liquids at all. (Ohlerts, loc. cit., see p. 249.) All other paris of the roots which are still young and delicate in surface-texture, are constantly active in the work of imbibing nutriment from the soil.

In most perennial plants, indeed, the larger branches of the roots become after a time coated with a corky or oth. erwise nearly impervious cuticle, and the function of $a b$ sorption is then transferred to the rootlets. This is demou. 
strated by placing the old, brown-colored roots of a plant in water, but keeping the delicate and unindurated extremities above the liquid. Thus situated, the plant withers nearly as soon as if its root-surface were all exposed to the air.

\section{b. Its Rapid Extension in Length, and the vast Sur-} face which it puts in contart with the soil, further adapts the root to the work of collecting foor. The length of roots in a clirect line from the point of their origin is not, indeed, a criterion by which to judge of the efficiency wherewith the plant to which they belong is nourished; for two plants may be equally flourishing-be equally fed by their roots-when these organs, in one case, reach but one foot, and in the other extend two feet from the stem to which they are attached. In one case, the roots would be fewer and longer; in the other, shorter and more numerous. Their aggregate length, or, more correctly, the aggregate absorbing surface, would be nearly the same in both.

The Medium in which Roots Grow has a great influence on their extension. When they are situated in concentrated solutions, or in a very fertile soil, they are short, and numerously branchet. Where their food is sparse, they are attenuated, and bear i comparatively small number of rootlets. Illustrations of the former condition are often seen. Bones and masses of manure are not infrequently found, completely covered and penetrated by a fleece of stout roots. On the other hand, the roots which grow in poor, sandy soils, are very long and slender.

Noble has described some experiments which com. pletely establish the point under notice. ( $\boldsymbol{V}_{s}$. St., IV, p. 21\%.) Ile allowed maize to grow in a poor clay soil, contained in glass cylinders, each vessel having in it a quantity of a fertilizing mixture dieposed in some peculiar manner for the purpose of oliserving its influence on the roots. When the plants had been nearly four months in growth, 
the vessels were placed in water until the earth was softened, so that by gentle agitation it could be completely removed from the roots. 'The atter, on being suspended in a glass vessel of water, assumed nearly the position they had occupied in the soil, and it was observed that where the fertilizer had been thoroughly mixed with the soil, the roots uniformly occupied its entire mass.

Where the fertilizer had been plicel in a horizontal layer at the lepth of about one inch, the roots at that depth formed a mat of the finest fibers. Whire the fertilizer was situated in a horizontal linyer at half the depth of the vessel, just there the root-system was spheroidally expanted. In the eylinders where the fertilizer formed a vertical layer on the interior walls, the external roots were developed in numberless ramifications, while the interior roots were comparatively mubranched. In pots, where the fertilizer was disposed as a central vertical core, the inner roots were fur more greatly developed than the outer ones. Finally, in a vessel where the fertilizer was placed in a horizontal layer at the bottom, the roots extended through the soil, as attenuated and slightly branched fibers, until they came in contact with the lower stratum, where they greatly increased and ramified. In all cases, the principal development of the roots occurred in the immediate vicinity of the material which could furnish them with nutriment.

It has often been observed that a plant whose aerial branches are symmetrically disposed about its stem, has the larger share of its roots on one side, and again we find ronts which are thick with rootlets on one sile, and nearly devoid of them on the other.

Apparent Search for Food.-It would almost appear, on superficial consideration, that roots are endowed with a kind of intelligent instinct, for they serm to go in search of nutriment. 


\section{HOW CROYS GRUW.}

The roots of a plant make their first issue ir lependently of the nutritive matters that may exist in their neighborhood. They are organized and put forth from the plant itself, no matter how fertile or sterile the medium that surrounds them. When they attain a certain develop. ment, they are realy to exercise their office of collecturg food. If food be at hamd, they absorb it, and, together with the entire plant, are nourisher by it-they grow in consequence. The more abundint the food, the better they are nourished, and the more they multiply. The plant sends out rootlets in all directions; those which come in contict with food, live, enlarge, and ramify; those which find no nourishment, remain undeveloped or perish.

The Quantity of Roots actually attached to any plant is usu:lly far greater than can be estimated by roughly lifting them from the soil. To extricate the roots of wheat or clover, for example, from the earth, completely, is a matter of no little difficulty. Schubart has made the most satisfactory observations we possess on the roots of several importint crops, growing in the ficld. He separatel them from the soil by the following expedient: An excaration was made in the ficld to the depth of 6 feet, and a stream of water was directed agiinst the vertieal wall of soil until it was washed away, so that the roots of the plants growing in it were laid bare. The roots thus exposed in a field of rye, in one of beans, and in a bed of garden peas, presented the appearance of a mat or folt of white fibers, to a depth of about 4 feet from the surfice of the ground. The roots of winter wheat he observed as deep as $\gamma$ feet, in a light subsoil, forty-seven days after sowing. The depth of the roots of winter wheat, winter rye, and winter colza, as well as of clover, was : -4 feet. The roots of clover, one year old, were :3! feet long, those of two yearrold clover but 4 inches longer. The quantity of roots in per cent of the entire plant in the dry state was found to be as follows. (Chem. Ackersmann, I, p. 193.j 
Winter wheat-exnmined last of April.........40 $40^{4}$

"6 6 "6 " Мay.........22"

6. rye " " " April... ....34 "

Peas examined four weeks after sowing. .......44" at the time of blossom........24"

Hellriegel has likewise studied the radication of barley and onts, (Hoff, Jahresbericht, 1861, p. 106.) He raised plants in large glass pots, and separated their roots from the soil by careful washing with water. He observed that directly from the base of the stem 20 to 30 roots branch off sideways and downward. These roots, at their point of issue, have a diameter of $\left.{ }^{1}\right|_{25}$ of an inch, but a little lower the diameter diminishes to about $\left.{ }^{2}\right|_{100}$ of an inch. Retaining this diameter, they pass downward, dividing and branching to a certain depth. From these main roots branch out innumerable side roots, which branch again, and so on, filling every crevice and pore of the soil.

To ascertain the total length of root, Hellriegel weighed and ascertained the length of selected average portions. Weighing then the entire root-system, he calculated the entire length. He estimated the length of the roots of a vigorous barley plant at 128 feet, that of an oat plant at 150 feet.* He found that a small bulk of good fine soil sufficed for this development; $\left.{ }^{1}\right|_{40}$ cub. foot, $\left(t \times 4 \times:\left.2^{3}\right|_{4}\right.$ inr., $)$ answered for a barley plant; $\left.{ }^{1}\right|_{32}$ euls. fort for an oat plant, in these experiments.

Hellriegel observed also that the quality of the soil influenced the development. In rich, porous, garden-soil, a barley plant produced 128 feet of roots, but in a coar'segrained, compacter suil, a similar p'aut had but $\rightarrow 0$ f'eet of roots.

Root-IIairs.-The real absorbent surface of roots is, in most cases, not to be appreciated without microscopic aicl. The roots of the onion and of many other bulbs, i. e., the fibers which issue from the base of the bulbs, are perfectly 
smooth and unbranched throughout their entire length.

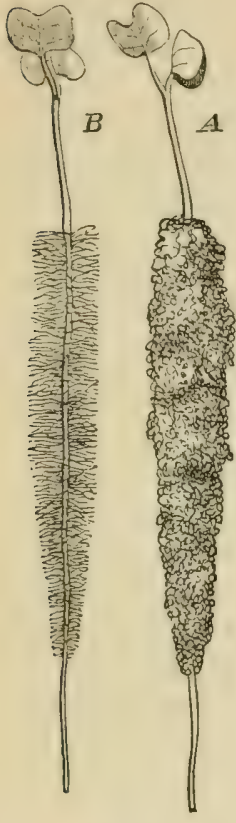

Fig. 38.

Other agrieultural plants have roots which are not only visibly branched, but whose finest fibers are more or less thickly corered with minute hairs, scarcely perceptible to the unassisted eye. These root-hairs consist always of tubular elongations of the external root-cells, and through them the actual root-surface exposed to the soil becomes something almost incalculable. The accompanying figures illustrate the appearance of root-hairs.

Fig 38 represents a young, seedling, mustard-plant. $A$ is the plant, as carefully lifted from the sand in which it grew, and $B$ the same plant, freed from adhering soil by agitating in water. The entire root, save the tip, is thickly beset with hairs. In fig. 39 a minute portion of a barleyroot is shown highly magnified. The hairs are seen to be slender tubes that proceed from, and form part of, the onter cu?ls of the root.

The older roots lose their hairs, and suffer a thickening of the outermost layer of cells by the deposition of cork. These dense-walled and nearly impervious cells cohere together and constitute a rind, which is not found in the young and active roots.

As to the development of the root-hairs, they are more

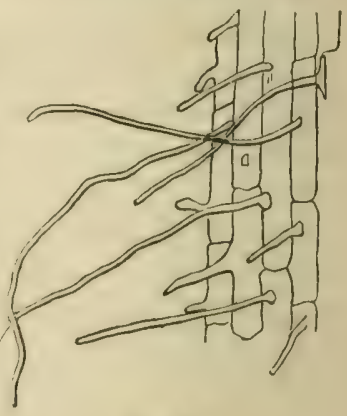

Fig. 39. 
abundant in poor than in good solls, and appear to be most numerously prolucel from roots which have otherwise a dense and unabsorbent surface. The roots of thoso plants which are destitute of hairs are commonly of considerible thickness and remain white and of delicate tex. ture, preserving their absorbent power throughout the whole time that the plant feeds from the soil, as is the case with the onion.

The Silver Fir, (Abies pectinata, has no root-hairs, but its rootlets are covered with a very deiicate cuticle highly favorable to absorption. The want of root-hairs is further compensated by the great number of rootlets which are formed, and which, perishing mostly before they become superficially indurated, are continually replaced by new ones during the growing season. (Schacht, Der Buum, p. 165.)

Contact of Roots with the Soil.-The root-hairs, as they extend into the soil, are naturally brought into close contact with its particles. This contact is much more intimate than has been usually supposed. If we carefully lift a young whent-plant from dry earth, we notice that each rootlet is coated with an envelope of soil. This adheres with considerable tenacity, so that gentle shaking fails to displace it, and if it be mostly removed by vigor. ous agitation or washing, the root-hairs are either found to be broken, or in many places inseparably attached to the particles of earth.

Fig. 40 exhibits the appearance of a young wheat. plant as lifted from the soil and pretty strongly shaken. $S$, the seed; $b$, the blade; $e$, roots covered with hairs and enveloped in soil. Only the growing tips of the roots, $w$, which have not put forth hairs, come out clean of soil. Fig. 41 represents the roots of a wheat-plant one month older than those of the previous figure. In this instance not only the root-tips are naked as before, but the older 


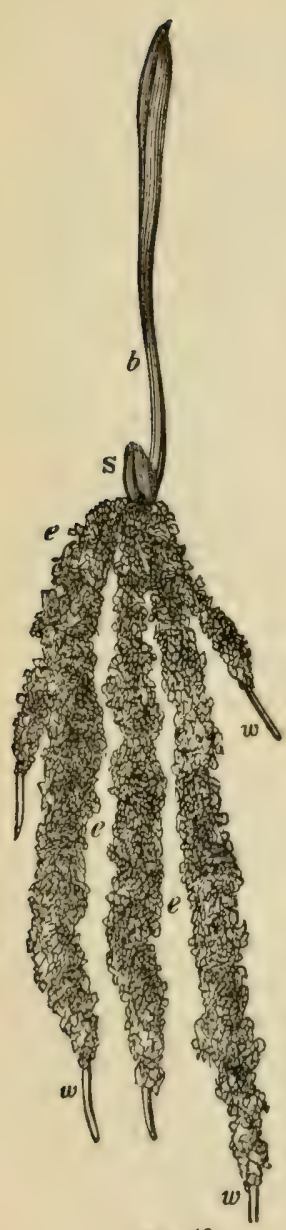

Fig. 40.

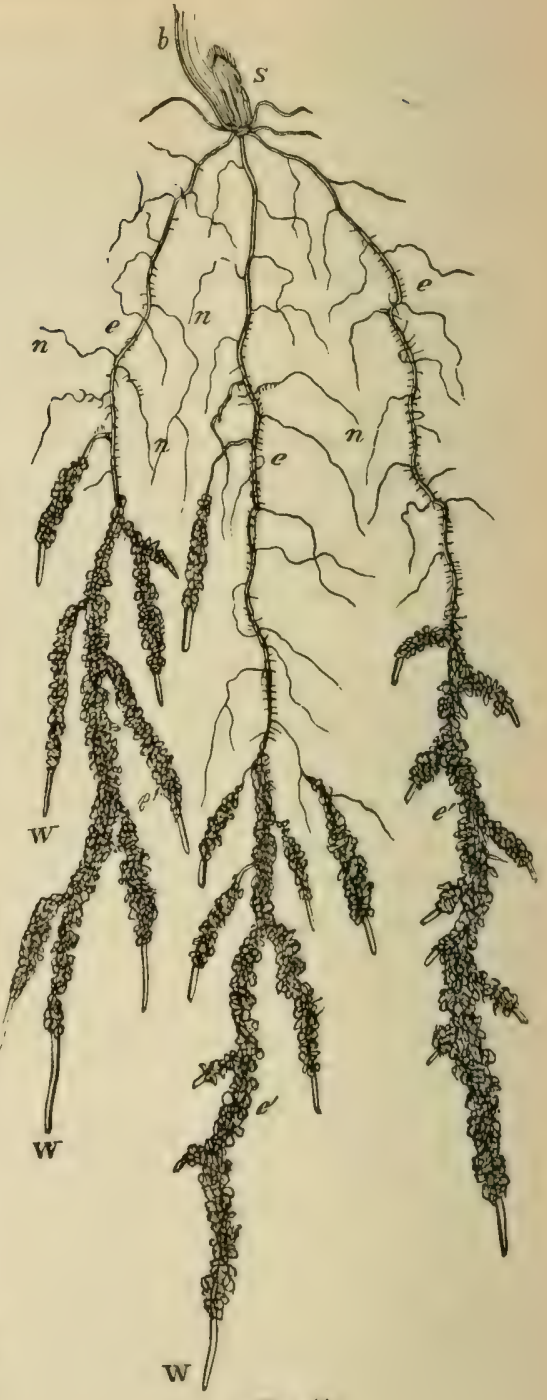

Fig. 41. 
parts of the primary roots, $e$, and of the secondary roots, n, no longer retain the particles of soil; the hairs upon them being, in fact, dead and decomposed. The newer parts of the root alone are clothed with active hairs, and to these the soil is firmly attached as before. The next il

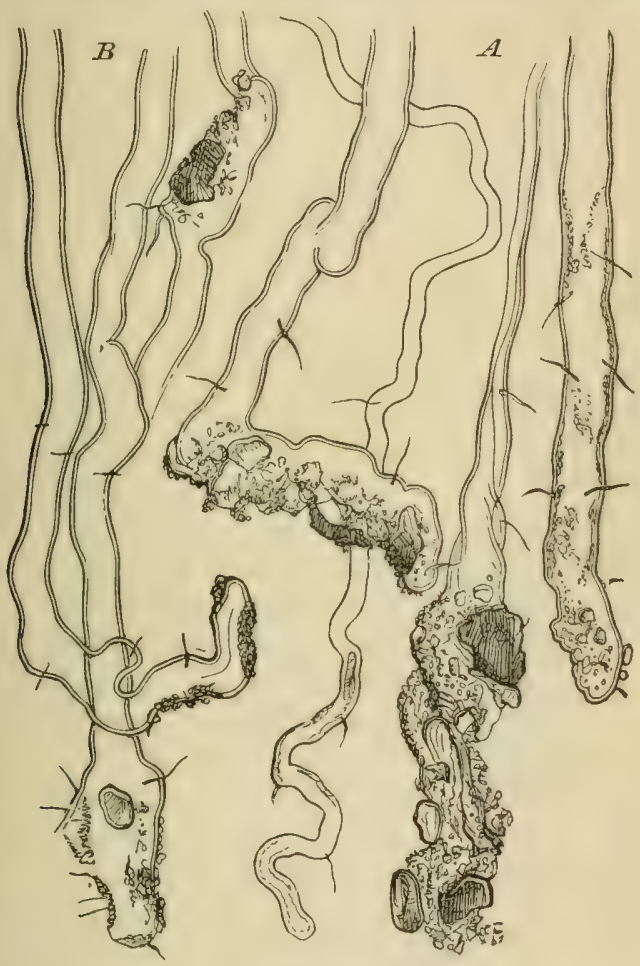

Fig. 4\%.

lustration, fig. 42 , exhibits the appearance of root-hairs with arlhering particles of earth, when magnified 800 diameters- $A$, root-hairs of wheat-seedling like fig. $40 ; B$, of ont-plant, both from loamy soil. Here is plainly seen the intimate attachment of the soil and root-hairs. The 
latter, in forcing their way against considerable pressure, often expand around, and partially envelope, the particles of earth.

Imbibition of Water by the Root.-The degree of force with which active roots imbibe the water of the soil is very great, is, in fact, sufficient to force the liquil upward

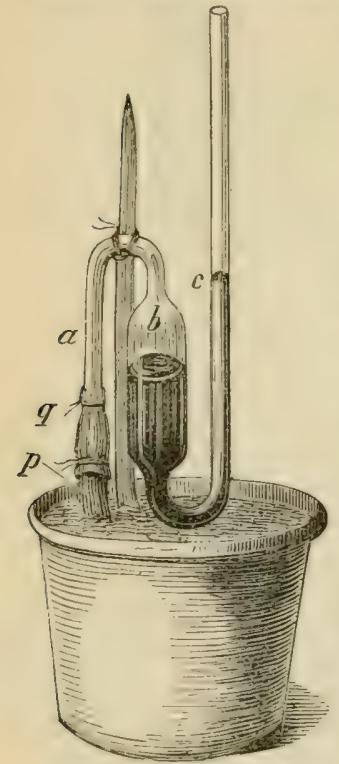

Fig. 43. into the stem and to exert a continual pressure on all parts of the plant. When the stem of a plant in vigorous growth is cut off near the root, and a pressure-gange is attached to it as in fig. 43 , we have the means of observing and measuring the force with which the roots alsorb water. The pressure-gauce contains a quantity of mercury in the middle reservoir, $b$, and the tulse, $c_{\text {. }}$ It is attached to the stem of the plant, $p$, by a stout india-rubber pipe, $q *$ For accurate measurements the space, $a$ and $b$, should be filled with water. Thus arranged, it is found that water will enter $a$ through the stem, and the mercury will rise in the tube, $e$, until its pressure becomes sufficient to balance the absorptive power of the roots. IIales, who first experimented in this mamner 140 years ago, found in one instance, that the pressure exerted on il gauge attached in spring-time to the stump of a grape vine, supported a column of mercury 392 inches high, which is equal to a column of water of $: 36 ! 2 \mathrm{ft}$. IIofmeister obtained on other plant-, rooted in pots, the following results:

* For 'xperimenting on small plants, a simple tube of glass may be adjusted to the stump vertically by help of a rubber connector. 
Bean (Phaseolus multiflomus) 6 inches of mercury.

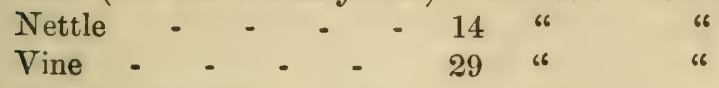

Seat of Absorptive Force-Dutrochet demonstrated that this power resides in the surface of the young and active roots. At least, he found that absorption was exerted with as much force when the gauge was applied to near the lower extremity of a root, as when attached in the vicinity of the stem. In fact, when other conditions are alike, the column of liquid sustained by the roots of a plant is greater, the less the length of stem that remains attached to them. The stem thus resists the rise of liquid in the plant.

While the seat of absorptive power in the root lies near the extremities, it appears from the experiments of Ohlerts that the extremities themselves are incapable of imbibing water. In trials with young pe:l, flax, lupine, and horseradish plants with unbranched roots, he found that they withered speedily when the tips of the roots were immersed for about one-fourth of an inch in water, the remaining parts being in moist air. Ohlerts likewise proved that these plants flourish when only the middle part of their roots is immersed in water. Keeping the root-tips, the so-called spongioles, in the air, or cutting them away altogether, was without apparent effect on the freshness and vigor of the plants. The absorbing surface would thus appear to be confined to those portions of the root upon which the development of roothairs is noticed.

The absorbent force is manifesteu by the active rootlets, and most vigorously when these are in the state of most ripid development. For this reason we find, in case of t'.e vine, for example, that during the autumn, when the plant is entering upon a period of repose from growth, the ab sorbent power is trifling. The effect of this forcible en. trance of water into the plant is oftentimes to cause the $11^{*}$ 
exudation of it in drops upon the foliage. This nay be noticed upon newly sprouted maize, or other cereal plants, where the water escapes from the leaves at their extreme tips, especially when the germination has proceeded under the most farorable conditions for rapid developrent.

The bleeding of the vine, when severed in the spring. time, the abundant flow of sap from the sugar-maple, and the water-elm, are striking illustrations of this imbibition of water from the soil by the roots. These examples are, indeed, exceptional in degree, but not in kind. Hofineister has shown that the bleeding of a severed stump is a general fact, and occurs with all plants when the roots are active, when the soil can supply them abundantly with water, and when the tissues above the absorbent parts are full of this liquid. When it is otherwise, water may be absorbed from the gange into the stem and large roots, until the conditions of activity are renewed.

Of the external circumstances that influence the absurptive power of the root, may be noticed that of temperature. By observing a gauge attached to the stump of a plant during a clear summer day, it will be usually noticed that the mercury begins to rise in the morniig as the sun warms the soil, and continues to ascend for a number of hours, but fills agrain as the sun declines. Sachs found in some of his experiments that at a temperature of $41^{\circ} \mathrm{F}$., absorption, in case of tobacco and squash plants, was nearly or entirely suppressed, but was at once renewed by plunging the pot into warm water.

The external supplies of water, -in case a plant is stationed in the soil, the degree of moisture contained in this medium,-obviously must influence, not perhaps the imbibing force, but its manifestation.

The Rate of Absorption is subject to changes dependent on other causes not well understood. Sachs observed that the amount of liquid which issued from potato stalks 
cut off just above the ground, underwent great and continual variation from hour to hour (during rainy weather) when the soil was saturated with water and when the thermometer indicated a constant temperature. Hofmeister states that the formation of new roots and buds on the stump is accompanied by a sinking of the water in the pressure-gauge.

Absorption of Nutriment from the Soil.-The food of the plant, so fir as it is derived from the soil, enters it in a state of solution, and is absorber with the water which is taken up by the force acting in the rootlets. The absorption of the matters dissolved in water is in some degree independent of the absorption of the water itself, the plant having, to a certain extent, a selective power.

3. The Root as a Magazine. - In fleshy roots, like those of the carrot, beet, and turnip, the absorption of nutriment from the soil takes place principally, if not entirely, by means of the slenrler rootlets which proceed abundantly from all parts of the main or tap-root, and especially from its lower extremity; while the fleshy portion serves as a magazine in which large quantities of pectose, sugar, etc., are stored up during the first year's growth of these, (in our latitude,) biennial plants, to supply the wants of the flowers and seed which are developed the second year. When one of these roots is put in the ground for a second year and produces seed, it is found to be quite exhausted of the nutritive matters which it preriously contained in so large quantity.

In cultivation, the farmer not only greatly increases the size of these roots and the stnres of organic nutritive materials they contain, but by removing them from the ground in autumn, he employs to feed himself and his cat. tle the substances that nature primarily designed to nourish the grewth of flowers and seeds during another sum. mer. 
Soil-Roots: Water-Roots: Air-Roots.-We may distinguish, according to the medium in which they are formed and grow, three kinds of roots, viz.: soil-roots, water-roots, and air-roots.

MLit agricultural plants, and indeed by far the greater number of all plants found in temperate climates, have roots adapted exclusively to the soil, and which perish by drying, if long exposed to air, or rot, if immersed for a time in water.

Many aquatic plants, on the other hand, die if their roots be removel from water, or from earth saturated with water.

Air-roots are not common except among tropical plants. Indian corn, however, often throws out roots from the lower joints of the stem, which extend through the air several inches before they reach the soil. The Banyan of India senils ont roots from its branches, which penetrate the earth in like manner. Many tropical plints, especially of the tribe of Orchids, emit roots which hang free in the air, arrl never come in contact with water or soil.

A plant, known to botanists as the Zumict spiralis, not only throws out air-roots, $c c$, Fig. 44, from the crow a the main soil-root, but the side rootlets, $b$, after extending some distance horizontally in the soil, send from the same point, roots downward and upward, the latter of which, $d$, pass into and remain permanently in the air. $A$ is the stem of the flant. (Schacht, Anatomie der Geroüchse, Bd. II, p. 151.)

Some plants have roots which are equally able to exist and perform their functions, whether in the soil or submerged in water. IIny forms of vegetation found in our swampls and marshes are of this kind. Of agricultural plints, rice is an example in point. Rice will grow in a soil of ordinary charicter, in respect of moisture, as the mpland cotton-soils, or even the pinc-barrens of the Carolinas. It flourishes admirably in the tide swamps of 
the coast, where the land is laid under water for weeks at a time during its growth, and it succeeds equally well in fields which are flowed from the time of planting to that of harvesting. (Russell. North America, its Agriculture and Climate, p. 176.) The willow and alder, trees which grow on the margins of streams, send a part of their roots into soil that is constantly saturated with water, or into

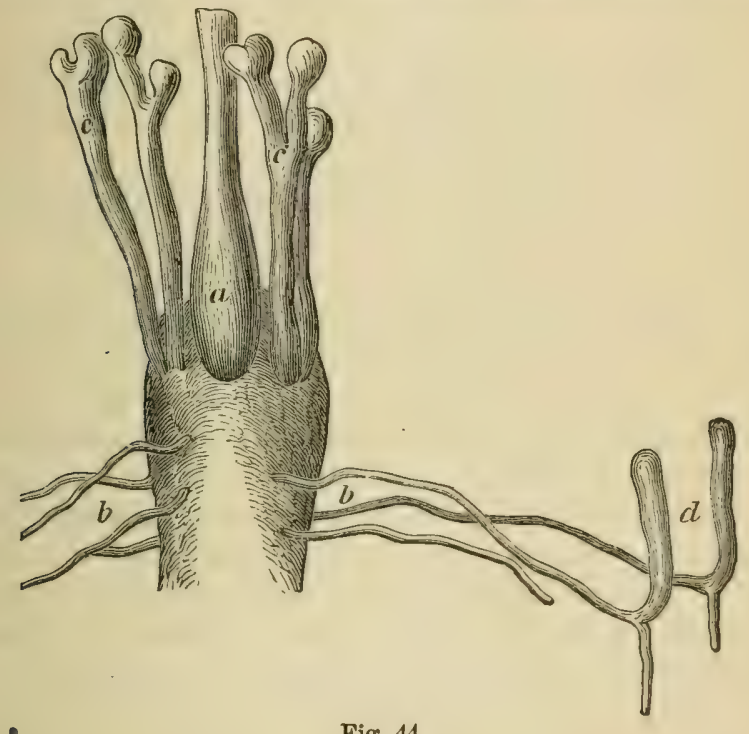

Fig. 44 .

the water itself; while others occupy the merely moist or even diy earth.

Plants that customarily confine their growth to the soil, occa-ionally throw out roots as if in search of water, and sometimes choke up drain-pipes or even wells, by the profusion of water-roots which they emit.

At Welbeck, England, a drain was completely stopped by roots of horseradish plants at a depth of $r$ feet. $\Lambda \mathrm{t}$ Thornsby Park, a drain 16 feet deep was stopped en. 
tirely by the roots of gorse, growing at a distance of 6 feet from the drain. (Jour. Roy. Ag. Soc., 1, 364.)

In New Haven, Conn., certain wells are so obstructed by the aquatic roots of the elm trees, as to require cleaning out every two or three years.

This aquatic tendency has been repeatedly observed in the poplar, cypress, laurel, turnip, mangel-wurzel, and grasses.

Honrici surmised that the roots which most cultivated plants send down deep into the soil, even when the latter is by no means porous or inviting, are designed especially to bring up water from the subsoil for the use of the plant. The following experiment was devised for the purpose of testing the truth of this view. On the 13th of May, 1862, a youncr raspberry plant, having but two leaves, was transplanted into a large glass funnel filled with garden soil, the throat of the funnel being closed with a paper filter. The funnel was supported in the month of a large glass jar, and its neck reached nearly to the bottom of the latter, where it just dipped into a quantity of water. The soil in the funnel was at first kept moderately moist by occasional waterings. The plant remained fresh and slowly grew, putting forth new leaves. After the lapse of several weeks, four strong roots penetrated the filter and extended down the empty funnel-neck, through which they emerged, on the 21st of June, and thenceforward spread rapidly in the water of the jar. From this time on, the soil was not watered any more, but care was taken to maintain the supply in the jar. The plant continued to develope slowly; its leaves, however, did not acquire a vivid green color, but remained pale and yellowish; they did not wither until the usual time late in autumn. The roots continued to grow, and filled the water more and more. Near the end of December the plant had r-s leaves, ant a height of 8 inclies The water-roots were vigorous, very long, and beset with numerous fibrils and 
buds. In the funnel tube the roots made a perfuct tissue of fibers. In the dry earth of the funnel they were less extensively developed, yet exhibited some juicy buls. The stem and the young axillary leaf-buds were also full of sap. The water-roots being cut away, the plant was put into garden soil and placed in a conservatory, where it grew vigorously, and in May bore two offshoots.

The experiment would indicate that plants may extend a portion of their roots into the subsoil chicfly for the purpose of gathering supplies of water. (Henneberg's Jour. Jür Landwirthschaft, 1863, p. 280.) This growth towards water must be accomnted for on the principles asserted in the paragraph-Apparent Search for Food, (p. 241).

The seeds of many ordinary land plants-of plants, indeed, that customarily grow in a dry soil, such as the bean, squash, maize, etc.,-will readily germinate in moist cotton or saw-dust, and if, when fairly sprouted, the young plants have their roots suspencled in water, taking care that the seed and stem are kept above the liquid, they will continue to grow, and if duly supplied with nutriment will run through all the customary stages of derelopment, producing abundant foliage, flowering, and perfecting seels, without a moment's contact of their roots with any soil. (See Water Culture, p. 16\%.)

If plants thus growing with their roots in a liquid mediun, after they have formed several large leares, be cartfully transplanted to the soil, they wilt and perish, unless fieruently watered; whereas similar plants started in the soil, may be transplanted without suffering $n$ the slightest degree, though the soil be of the usual dryness, and receive no water.

The water-bred seedlings, if abundantly watered as often as the foliage wilts, recover themselves after a time, and thenceforward continie to grow without the need of watering.

It might appear that the first-formed water-roots are in- 
capable of feeding the plant from a dry soil, and hence the soil must be at first profusely watered; atter a time, howerer, new routs are thrown out, which are adapted to the altered situation of the plant, and then the growth proceeds in the usual manner.

The reverse experiment would seem to confirm this view. If a seedling that has grown for a short time only in the soil, so that its roots are but twice or thrice branched, have these immersed in water, the roots already formed mostly or entirely perish in a short time. They indeed absorb water, and the plant is sustained by them, but im. mediately new roots grow from the crown with grent rapidity, and t:lke the place of the original roots, which become disorganized and useless. It is, however, only the young and active rootlets, and those covered with hairs, which thus refuse to live in water. The older parts of the roots, which are destitute of fibrils and which have nearly ceased to be active in the work of absorption, are not affected by the change of circumitance. These ficts, which are due to the researches of Dr. Sachs, ( $\nabla s . S t ., 2$, p. 13, ) would naturally lead to the conclusion that the absorbent surface of the root undergoes some structural change, or produces new roots with modified characters, in orler to adapt itself to the medium in which it is placed. It would appear that when this adaptation proceeds rapidly, the plant is not permanently retarded in its growth by a gradual change in the character of the medium which surrounds its roots, as may happen in case of rice and marsh-plants, when the saturated soil in which they may be situatel at one time, is slowly dried. Sudden chinges of medium about the roots of plants slow to adapt themselves, would be fatal to their existence.

Noblue has, however, carefully compared the roots of buckwheat, as developed in the soil, with those emitted in water, without being able to observe any structural differ ences. The fact: detailed above admit of partial, if not 
completc explanation, without recourse to the supposition that soil and water-roots are essentially diverse in nature. When a plant which is routed in the soil is taken up so that the fibrils are not broken or injured, and set into watrir, it does not suffer any hindrance in growth, as Sachs has found by late experiments. (Experimental PhysiJogie, p. 1\%\%.) Ordinarily, the suspension of growth and decay of fibrils and rootlets is due, doubtless, to the mechanical injury they suffer in removing from the suil. Again, when a plant that has been reared in water is planted in earth, similar injury occurs in packing the soil about the roots, and moreover the fibrils cannot be brought into that close contact with the soil which is necessary for them to supply the foliage with water; hence the plant wilts, and may easily perish unless profusely watered or shielded fiom evaporation.

The issue of water or soil-roots, either or both, from the same plant, according to the circumstances in which it is placed, finds something andogous in reference to airroots. As before stated, these chiefly occur on tropical plants, or in shaded, warm, and very moist situstions. Schacht informs us that in the dark and humid forest ravines of Madeira and Teneriffe, the Laums Canariensis, a large tree, sends out from its stem during the autumn rains, a profusion of fleshy air-roots, which cover the trunk with their interlacing branches and grow to an inch in thickness. The following summer, they dry away and fall to the ground, to be replacel by now ones in the ensuing an. tumn. (Dev, Baum, p. 172.)

The formation of air-routs may be very easily observed by filling a tall vill with water to the deptl of hilf an inch, inserting therein a branch of a common house-plant, the Tradeseantia zebrina, so that the cut end of the stem shall stand in the water, and finally corking the rial air-tight. The plant, which is very tenacious of life, and usually grows well in spite of all neglect, is not checked in its regetative derelspment by the treatment just describel, but immerliately benins to adant itself to its new circumstanees. In a few days, if the temperature be $70^{\circ}$ or there about, air-roots will be seen to issue from the joints of the stem. Thess 
3re fringed with a profusion of delicate hairs, and rapilly ertend to a iength of from nne to two inches. The lower ones, if they chance to penetrate the water, become discolored and decay; the other's, howerer, lemain for a long time fresh, and of "t white color.

As already mentioned, Indian corn frequently produces air-roots. The sime is true of the oat, of buckwheat, of the grape-vine, and of other plants of temperate regions when they are placed for some time in tropical conditions, i. e., when they grow in a rich soil and their overground organs are surrounded by a very warm and very moist atmosphere.

It has been conjectured that these air-roots serve to absorb moisture from the air and thus aid to maintain the growth of the plant. This subject has been studied by Unger, Chatin, and Duchartre. The observers first named were led to conclule that these orgins do absorb water from the air. Duchartre, however, denies their absorptive power. It is probably true that they can and do absorb) to some extent the water that exists as vapor in the at. mosphere. At the same time they may not usually con. dense enough to make good the loss that takes place in other parts of the plant by evaporation. Hence the results of Dıchartre, which were obtained on the entire plant and not on the air-roots alone. (Eléments de Botanique, 1. 216.) It certainly appears improbable that organs which only develope themselves in a humid atmosphere, where the plant can have no lack of water, should be specially charged with the office of collecting moisture from the air.

Root-Excretions.-It has been supposed that the roots of plants perform a function of excretion, the reverse of absorption-that plants, like animals, reject matters which are no longer of use in their organism, and that the rejectel matters are poisonous to the kind of vegretation from which they originated. De Caniolle, an eminent Froun botanist, who first advanced this doctrine, founded 
if upon the observation that certain plants exude drops of liquid from their roots when these are placed in dry sand, and that odors exhale from the roots of other plants. Numerous experiments have been instituted at various times for the purpose of testing this question. The most extensive inquiries we are aware of, are those of $\mathrm{Dr}$. Al. fred Gyde, (Trans. Highland and Agr. Soc., 1845-7, p. 273-92). This experimenter planted a variety of agricultural plants, viz., wheat, barley, oats, rye, beans, peas, vetches, cabbage, mustard, and turnips, in pots filled either with garden soil, sand, moss, or charcoal, anil after they had attained considelable growth, removed the earth, etc., from their roots by washing with water, using care not to injure or wound them, and then immersed the roots in vessels of pure water. The plants were allowed to remain in these circumstances, their roots being kept in darkness, but their foliage exposed to light, from three to seventeen Jays. In most cases they continued apparently in a good state of health. At the expiration of the time of experiment, the water which had been in contact with the roots was evaporated, and was found to leave a very minute amount of yellowish or brown matter, a portion of which was of organic and the remainiler of mineral origin. $\mathrm{Dr}$. Gycle concluded from his numerous trials, that plants do throw off organic and inorganic excretions similar in composition to their s:lp; but that the quantity is exceedingly small, and is not injurious to the plants which furuish them.

In the light of newer investigations touching the struc. ture of roots and their adaptation to the medium which happens to invest them, we may well doubt whether agricultural plants in the healthy state excrete any solid or liquid matters whatever from their roots. The familiar excretion of gum, resin, and sugar, ${ }^{*}$ from the stems of

* From the wounded bark of the Sugar Pine, (Pinus Lambertiana, of Cals. arnis 
trees appears to result from wounds or disease, and the matters which in the experiments of Gyde and others were observed to be communicated by the roots of plants to pure water, probably came either from the contiuual pushing off of the tips of the rootlets by he interior crowing point-a process always naturally accompanying the growth of roots-or from the disorganization of the absorbent root-hairs.

Under certain circumstances, small quantities of mineral salts may indeed diffuse out of the root-cells into the water of the soil. This is, however, no physiological action, but a purely physical process.

Vitality of Roots.-It appears that in case of most plants the roots cannot long contiuue their vitality if their connection with the leaves be interrupterl, unless, indeed, they be kept at a winter temperature. Hence weeds may be effectually destroyed by cutting down their tops; although, in many cases, the process must be several times repeated before the result is attained.

The roots of our root-crop: properly so-called, viz, beets, turnips, carrots, and parsnips, when harvested in autumn, contain the elements of a second year's growth of stem, etc., in the form of a bud at the crown of the root. If the crown be cut away from the root, the latter cannot vegetate, while the growth of the crown itself is not thereby prevented.

As regards internal structure, the root closely resembles the stem, and what is stated of the latter on subsequent yages, applies in all essential points to the former.

$$
\S 2 .
$$

THE STEM.

Shortly after the protrusion of the rootlet from a germinating seed, the STEm makes its appearance. It has, in general, an upward direction, which in many plants is per- 
manent, while in others it shortly falls to the ground and grows thereafter horizontally.

All plants of the higher orders have stems, though in many instances they do not appear above ground, but extend beneath the surface of the soil, and are usually considered to be roots.

While the root, save in exceptional cases, does not develop other organs, it is the special function of the stem to bear the leaves, flowers, and seed, of the plint, and even in certain tribes of vegetation, like the cacti, which have no leaves, it performs the offices of these organs. In general, the functions of the stem are subordinate to those of the organs which it bears-the leaves and flowers. It is the support of these orgaus, and only extends in length or thickness with the alparent purpose of sustaining them either mechanically or nutritively.

Buds.-In the seed the stem exists in a rudimentary state, associated with unleveloped leaves, forming a bud. The stem always proceeds at first from a bud, during all its growth is terminated by a hul at every growing point, and only ceases to be thus tipped when it fully accomplishes its growth by the production of seed, or dies from injury or disease.

In the leaf-bud we find a number of embryo leaves and leaf-like scales, in close contact and within each other, but all attached at the base, to a central conical axis, fig. 45. The opening of the bud con-
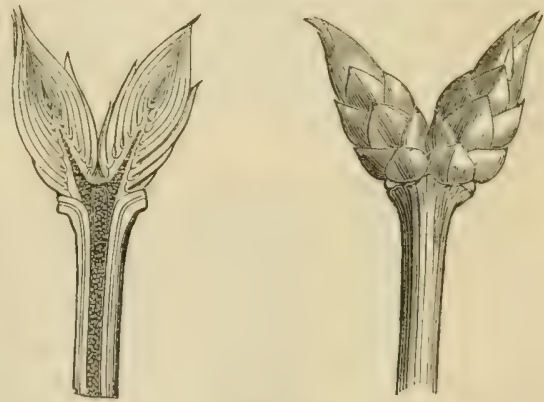

Fig. 45.

sists in the lengthening of this axis, which is the stem, and the consequent, separation of the leares from each 
other. If the rudimentary leares of a buil be represented by a nest of flower-pots, the smaller placed. within the larger, the stem may be signified by a rope of Indiarubber passer through the boles in the brittom of the pots. The growth of the stem may now be shown by stretching the rope, whereby the pots are brought away from each other, and the whole combination is marle to assunne the character of a fully developed stem, bearing its leaves at regular intervals; with these important differences, that the portions of stem nearest the root extend more rapidly than those above them, and the stem has within it the matcrial and the mechanism for the continual formation of new buds, which unfold in successive order.

In fig. 45 , which represents the two terminal buds of a lilac twig, is shown not only the external appearance of the buds, which are covered with leaf-like scales, imbricated like shingles on a roof; but, in the section, are seen the edges of the undeveloped leares attached to the conical axis. All the leaves and the whole stem of a twig of one suramer's growth thus exist in the bud, in plan and in miniature. Subsequent growth is but the developinent of the plan.

In the flower-bud the same structure is manifest, save that the rudimentary flowers and fruit are enelosed within the leaves, and may often be seen plainly on cutting the bud open.

Culms; Nodes; Internodes.-The grasses and the com. mon cereal grains have single, unbranched stems, termer culms in botanical language. The leaves of thrse plants clasp the stem entirely at their base, and at thes point is formerl a well-defined, thickened knot or node in the stem The portions of the stem between these nodes are termed internodes.

Branching Stems,-Other agricultural plants besides those just mentioned, and all the trees of temperate elj 
mates, have branching stems, originating in the following manner: As the principal or main stem elongates, so that the leaves arranged upon it separate from each other, we may find one or more side or axillary buis at the point where the base of the leaf or of the leaf-stalk unites with the stem. From these buds, in case their growth is not checked, side-stems or branches issue, which again subdivide in the same manner into branchlets.

In perennial plants, when young, or in their young shoots, it is easy to trace the nodes and internodes, or the points where the leaves are attached and the intervening spaces, even for some time after the leares, which only cndure for one year, are fallen away. The nodes are manifest by the enlargement of the stem, or by the scar covered with corky matter, which marks the spot where the leafstalk was attacheri. As the stem grows older these indications of its early derelopment are gradually obliterated.

In a forest where the trees are thickly crowder, the lower branches die away from want of light; the scars resulting from their removal are covered with a new growth of wood, so that the trunk finally appears as if it had always been destitute of branches, to a great height.

When all the buds develop normally and in due proportion, the plant, thus regularly built up, has a symmetrical appear:ance, as frequently happens with many herbs, and also with some of the cone-bearing trees, especially the balsam-fir.

Latent Buds.-Often, however, many of the buds remain undeveloped either permanently or for a time. Many of the sile-buds of most of our forest and fruit trees fiil entirely to grow, while others make no progress until the summer succeeding their first appearance. When the active buds are destroyed, either by frosts or by pinching off, other buds that would else remain latent, are pushed into growth. In this way, trees whose young leaves are destroyed by spring frosts, cover themselves again after a 
time with folinge. In this way, too, the gardener molds a straggling, ill-shaped shrub or plant into almost any form he chooses; for by remoring branches and buds where they have grown in undue proportion, he not only checks excess, but also calls forth derelopment in the parts before fuppressed.

Adrentitious or irregular Buds are produced from the stems is well as older roots of many plants, when they are mechanically injured during the growing season. The soft or red maple and the chestnut, when cut down, habitially throw out buds and new stems from the stump, and the basket-willow is annually polled, or pollarded, to induce the growth of slender shoots from an old trunk.

Elongation of Stems. - While roots extend chiefly at their extremities, we find the stem elongates equally, or nearly so, in all its contiguous parts, as is manifest from what has already been stated in illustration of its development from the bud.

Besides the upright stem, there are a variety of prostrate and in part subterranean stems, which may be briefly noticed.

Runners and Layers are stems that are sent out horizontally just above the soil, and coming in contact with the earth, take root, forming new plants, which may thenceforward grow independently. The gardener takes advantage of these stems to propagate certain plants. The strawberry furnishes the most fimiliar example of rumers, while many of the young shoots of the currant fall to the ground and become layers. The runner is a somewhat feenliar stem. It is:ues horizontally, and usually bears but few or no leaves. The layer does not differ from an ordinary stem, except by the circumstance, often accidental, of becoming prostrate. Many plants which usually seml out no layers, are nevertheless artificially layered by bending their stems or branches to the ground, or by at- 
taching to them a ball or pot of exrth. The striking out of roots from the layer is in many cases facilitated by cutting half off, twisting, or otherwise wounding the stem at the point where it is buried in the soil.

The tillering of wheat and other cereals, and of many grasses, is the spreading of the plint by layers. The first stems that appear from these plants ascend vertically, but, subsequently, other stems issue, whose growth is, for a time, nearly horizontal. They thus come in contact with the soil, and enit roots from their lower joints. From these again grow new stems and new roots in rapid succession, so that a stool produced from a single kernel of winter wheat, having perfect freedom of growth, has been known to carry 50 or 60 grain-bearing culms. (IIallet, Jour. Roy. Soc. of Ein.y., 22, p. 372.)

Subterranean Stems.-Of these there are three forms agriculturally interesting. They are usually thought to be roots, from the fact of existing below the surface of the soil. This circumstance is, however, quite accilental. The pods of the pea-nut ripen beneath the ground-the flower-stems lengthening and penetrating the earth as soon as the blossom falls; but per-nuts are not by any means to be confounded with roots.

Root-stocks.-As before remarked, true roots are destitute of buds, and, we may add, of leares. This fact distinguishes them from the so-called creeping-root, which is a stem that extends just below the surface of the soil, emitting roots throughout its entire length. At intervals along these root-stocks, as they are appropriately named, scales are formed, which represent rudimentary leaves. In the axils of the scales may be traced the buds from which aërial stems proceed. Examples of the root-stock are very common. Amoug them we may mention the blond-root and pepper-root as abundant in the woods of the Northem and Middle States, and the quack-grass, 
represented in fig. 46, which infests so many farms. Each node of the root-stock, being usually supplied with roots, and having latent buds, is ready to become an indepentent growth the moment it is detached from its parent flant. In this way quack-grass becomes especially troub-

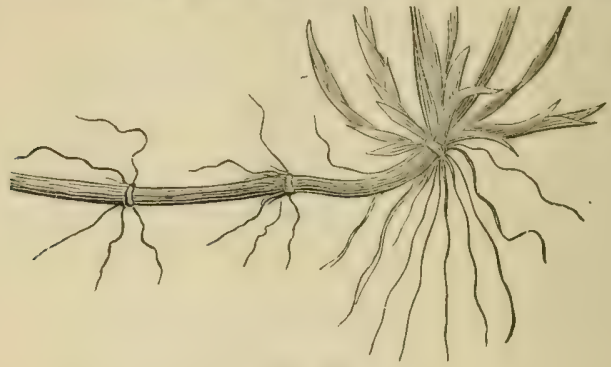

Fig. 46.

lesome to the farmer, for, within certain limits, the more he harrows the fields where it has obtained a footing, the more does it spread and multiply.

Suckers.-The rose, raspherry, and cherry, are examples of plants which send out subterrancan branches, analogous to the root-stock. These coming to the surfice, become aërial stems, and are then termed suckers.

The Tubers of most agricultural plants are fleshy enlargements of the extremities of subterranean stems. Their eyes are the points where the buds exist, usually three together, and where minute scales-rulimentary leaves-may be observed. The common potato and artichoke are instances of tubers. Tubers serve excellently for propagation. Lach eye, or lud, may become a new plant. From the quantity of starch, ete., accumulated in them, they are of great importance as foot. The number of tulers produced by a putato-plant appears to be increased by planting originally at a considerable depth, or by "hilling up" earth around the base of the aerrial stems during the early stages of its growth. 
Bulbs are the lower parts of stems, greatly thickened, the internodes being undeveloped, while the leares-usually scales or concentric coats-are in close contact with each other. The bultb is, in fact, a fleshy, permanent bud, asually in part or entirely subterranean. From its apex, the proper stem, the foliage, etc., proceel; while from its base, roots are sent out. The structural identity of the bulb with a bud is shown by the fact that the onion which furnishes the commonest example of the bulb, often bears bulblets at the top of its stem, in place of flowers. In like manner, the axillary buds of the tiger-lily are thickened and fleshy, and fall off as bulblets to the ground, where they produce new plants.

Structure of the Stemr.-The stem is so complicated in its structural composition that to discuss it fully would occupy a volume. For our immediate purposes it is, however, only necessary to notice it very concisely.

The rudimentary stem, as found in the seerl, or the newformed part of the maturer stem at the growing points just below the terminal buis, consists of cellular tissue, i. e., of an aggregate of rounded and cohering cells, which rapidly multiply during the vigorous growth of the plant.

In some of the lower orders of vegetation, as in mush. rooms and lichens, the stem, if any exist, always preserves a purely cellular character; but in all flowering plants the original cellular tissue of the stem, as well as of the root, is shortly penetrated by vascular tissue, consisting of ducts or tubes, which result from the obliteration of the horizontal partitions of cell-tissue, and by wood-cells, which are many times longer than wide, and the walls of which are nuch thickened by internal deposition.

These ducts and wood-cells, together with some other forms of cells, are usually found in close connection, and are arranged in bundles, which constitute the fibers of the stem. They are always disposed lengthwise in the stem and branches. They are found to some extent in the soft 
est herbaceous stems, while they constitute a large share of the trunks of most shrubs and trees. From the toughness which they possess, and the manner in which they are woren through the original cellular tissue, they give to the stem its solidity and strength.

The flowering plants of temperate climates may be divided into two great classes, in consequence of important and obvious differences in the structure of their stems and sceds. These are, 1, Endogenous or Monocotyledonous; and, 2, Exogenous or Dicotyledonous plants. As regards their stems, these two classes of plants differ in the arrangement of the vascular or woody tissue.

Endogenous Plants are those whose stems enlarge by the formation of new wood in the interior, and not by the external growth of concentric layers. The seeds of endogenous plants consist of a single piece-do not readily split into halves,-or, in botanical language, have but one cctyledon; hence are callerl monocotyledonous. Indian corn, sugar cane, sorghum, wheat, oats, rye, barley, the onion, asparagus, and all the grasses, belong to this tribe of plants.

If a stalk of maize, asparagus, or bamboo, be cut across, the bundles of ducts are seen disposed somewhat uni-

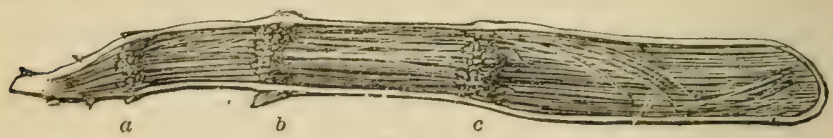

Fir. 47.

formly throughout the section, though less abundantly towards the eenter. On splitting the fresh stalk lengthwise, the vascular bumiles may be torn out like strings. It the nodes, where the stem branches, or where leaf-stalks are attarhed, the vascular bundles likewise divide and form a nut-work, or plexus. In a ripe maize-stalk which is exposerl to circumstances faroring decay, the soft cell-tissue first suffers change anl often quite disapprars, leaving 
the firmer vascular bundles unaltered in form. A portiors of the base of such a stalk, cut lengthwise, is represented in figure 47 , where are seen the dist-fibers arranged parallel to each other in the internodes, and curiously interwoven and branched at the nodes, either those, $x$ and $b$, 1rom which roots issue, or that, $c$, which was clasped by the bise of a leaf.

The endogenous stem, as represented in the maize-stalk, has no well-defined bark that admits of being strijped off externally, and no separate central pith of soft cell-tissue free from vascular bundles. It, like the aërial portions of all flowering plants, is covered with a skin, or epidermis, composed usually of one or several layers of flattened cells, whose walls are thick, and far less penetrable to fluid than the delicate texture of the interior cell-tissue. The stem is denser and harder at the circumference than towards the center. This is due to the fact that the fibers are more numerous and older towards the outside of the stem. The newer fibers, as they continually form, grow in the inside of the stem, and hence the designation endogenous, which in plain English means inside-grower.

In consequence of this inner growth, the stems of most woody endogens, as the palms, after a time become so indurated externally, that all lateral expansion ceases, and the stem increases only in height. It grows, nevertheless, internally, new fibers developing in the softer portions, until, in some cases, the tree dies because its interior is so closely packed with fibers that the formation of new ones, and the accompanying vital processes, become impussible.

In herbaceous endogens the soft stem admits the indefinite growth of new vascular tissue.

The stems of the grosses are hollow, except at the nodes. Those of the rushes have a central pith free from vascular tissue.

The Minute Structure of the Endogenous Stem is exhibited in the accompanying cuts, which represent highly 
magnifiri sections of a Vuscular Bundle or fiber from the maize-stalk. As before remarked, the stem is composed of a ground-work of delicate cell-tissue, in which bundles of vascular tissue are distributed. Fig. 48 represents a cross section of one of these bumlles, $c, g, h$, as well as

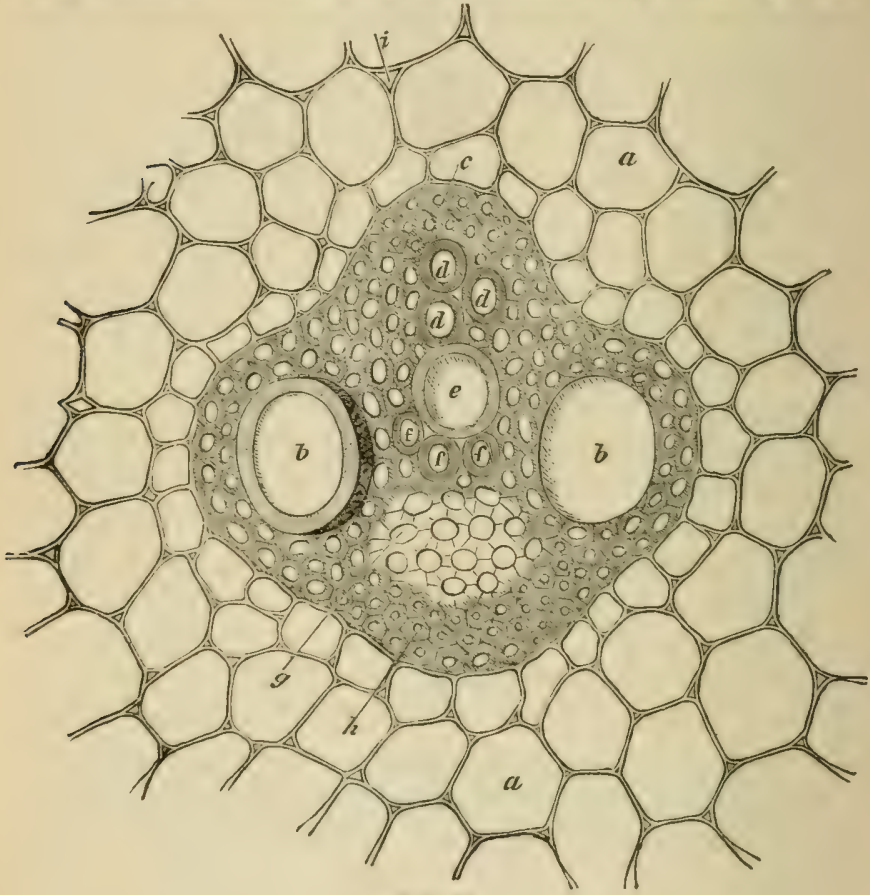

Fir. $4 \mathrm{~S}$.

of a portion of the surrounding cell-tissue, $a, a$. The latter consists of quite large cells, which, being but loosely packed together, have between them considerable intercellular spaces, $i$. The vascular bundle itself is composed externally of narrow, thick-walled cells, of which those nearest the exterior of the stem, $h$, are termed bast-cells, as they correspond in character and position to the cells 
of the bast or inner bark of our common trees; those nearest the centre of the stem, $c$, are voond-cells. In the maize stem, bast and wood-cells are quite alike, and are distinguished only by their position. In other plants, they are often mnlike as regards length, thickness, and pliability, though still, for the most part, similar in form. Among the wood-cells we observe a number of ducts, $d$, $e, f$, and between these and the bast-rells is a delicate and transparent tissue, $g$, which is the cambium-in which all the grovoth of the bundle goes on mitil it is complete. On

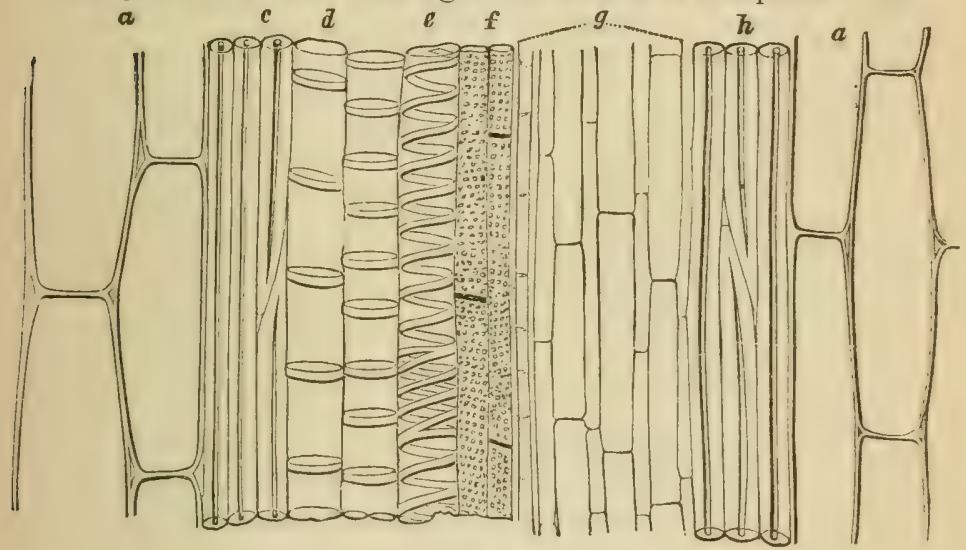

Fig. 49.

either hand is seen a remarkably large duct, $b, b$, while the residue of the bundle is cumposed of long and rather thick-walled wood-cells.

Our understanding of these parts will be greatly aided by a study of fig. 49 , which represents a section made vertically through the lumdle from $c$ to $h$, cutting the various tissues anil revealing more of their structure. In this the letters refer to the same parts as in the former cut: $a, a$, is the cell-tissue, enveloping the rascular bundle; the cells are observed to be much longer than wide, but are separated from each other at the ends as well as sides 
by an imperforate membrane. The wood and bast-cells, $c$, $h$, are seen to be long, narrow, thick-walled cells running obliquely to a point at either end. The wood-cells of oak, hickory, and the toughest woods, as well as the bast-cells of flax and hemp, are quite similar in form and appearances The proper ducts of the stem are next in the order of our section. Of these there are several varieties, as riny-dructs, $d$; spiral ducts, $e$; dutted ducts, $f$. These are continuous tubes produced by the resorption of the transverse membrines that once divided them into such cells as $a, a$, and they are thickened internally by ring-like, spiral, or punc. tate depositions of cellulose, (see fig. 32, p. 22\%.) Woodcells that consist exclusively of cellulose are pliant and elastic. It is the deposition of lignin in their walls which renders them stift' and brittle.

At $g$, the cambium tissue is observed to consist of delicate cylindrical cells. Among these, partial resorption of the separating membrane often occurs, so that they communicate directly with each other through sieve-like partitions, and become continuous channels or ducts, (sieve-cells, 1. 280.)

The cumbium is the seat of growth by cell-formation. Accordingly, when a vascular bundle has attained maturity, it no longer possesses a cambium; the latter has grown awaly from it, has reprorluced itself in originating a new vascular bundle, which, in case of the endogens, branches off from the present bundle, and with exogens, runs parallel with, and exterior to the latter.

To complete our view of the vascular bunile, fig. 50 represents a vertical section made at right angles to the last, cutting two large ducts, $b, b ; a, a$, is cell-tissue; $c$. $c$, are bast or wood-cells less thickened by interior deposi t:on than those of fig. $49 ; d$, is a ring and spirial duct; $b$, D, are large dotted ducts, which exhibit at $\ell, g$, the places where they were once crossed by the double membrane nemposing the ends of two adhering cells, by whose ab. 
sorption and removal an uninterrupted tube has been formed. In these large dotterl ducts there appears to be no direct communication with the surrounding cells through their sirles. The dots or pits are simply very thin points in the cell-wall, through which sap may soak of iliffuse laterally, but not flow. When the cells become mature and cease growth, the pits often become pores by

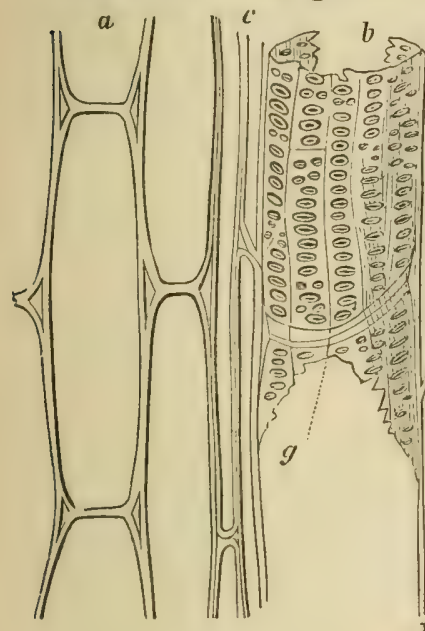

Fig. 50 .

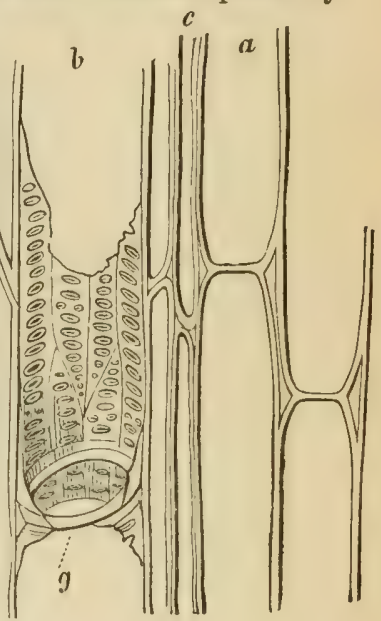

9

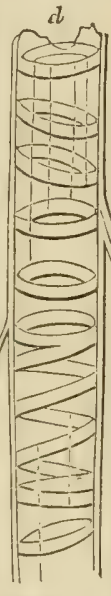

absorption of the membrane, so that the ducts thus enter into direct communication with each other.

Exogenous plants are those whose stems continually enlarge in diameter by the formation of new tissue near the outside of the stem. They are outside-growers. Their seeds are usually made up of two loosely united parts, or cotyledons, wherefore they are designated dicotyledonous. All the forest trees of temperate climates, and, among agricultural plants, the bean, pea, clover, potato, beet, turnip, flax, etc., are exogens.

In the exogenous stem the bundles of ducts and fibers that appeal in the cell-tissue are always formed just within 
the epidermis. They occur at first separately, as in the endogens, but instead of being scattered throughout the cell tissue, are disposed in a circle. As they grow, they usually close up to a ring or zone of wood, which, within, inoloses unaltered cell-tissue-the pith-and without, in shrubs and trees, is covered by rind.

As the stem enlarges, new rings of fibers may be formed, but always outside of the older ones. In hard stems of slow growth the rings are close together and chiefly consist of very firm wood-cells. In the soft stems of herbs the cell-tissue preponderates, and the ducts and cells of the vascular zones are delicate. The hardening of herbaceous stems which takes place as they become mature, is due to the increase and induration of the wood-cells and ducts.

The circular disposition of the fibers in the exogenous stem may be readily seen in a multitude of common plants.

The potato tuber is a form of stem always accessible for observation. If a potato be cut across near the stemend with a sharp knife, it is usually easy to identify upon the section a ring of vascular tissue, the general course of which is parallel to the circumference of the tuber except where it runs out to the surface in the eyes or buds, and in the narrow stem at whose extremity it grows. If a slice across a potato be soaked in solution of iodine for a few minutes, the vascular rings become strikingly apparent. In its active cambial cells, albuminoids are abundant, which assume a yellow tinge with iodine. The starch of the cell tissue, on the other hand, becomes intensely blue, making the vascular tissue all the more evident.

Since the structure of the root is quite similar to that of the stem, a section of the common bect as well as one of a branch from any tree of temperate latitudes may Berve to illustrate the concentric arrangement of the vascular zones when they are multiplied in number. 
Pith is the cell-tissue of the center of the stem. In young stems it is charged with juices; in older ones it often becomes dead and sapless. In many cases, especially when growth is active, it becomes broken and nearly obliterated, leaving a hollow stem, as in a rank pea-vine, or cloverstalk, or in a hollow potato. In the potato tuber the pithcells are occupied throughout with starch, although, as the coloration by iodine makes evident, the quantity of starch diminishes from the vascular zone towards the center of the tuber.

The Rind, which, at first, consists of mere epilermis, or short, thick-walled cells, overlying soft cellular tissue, becomes penctrated with cells of unusual length and tenacity, which, from their position in the plant, are often termed bast-cells. These, together with ducts of various kinds, all united firmly by their sides, constitute the socalled bast-fibers, which grow chiefly upon the interior of the rind, in close proximity to the wood. With their abundant development and with age, the rind becomes bark as it occurs on shrubs and trees. The bast-cells give to the bark its peculiar toughness, and cause it to come off the stem in long and pliant strips.

Bast-mats are made by weaving together strips of the inner bark of the Linden (bass or bast-wood) tree; and all the textile materials employed in making cloth and cordage, with the exception of cotton, as flax, hemp, New Zealand flax, etc., are bast-fibers. The leather-wood or moosewood bark often employed for tying flour-bags, has bastfibers of extraordinary tenacity.

The external rind, like the interior pith, becomes sapless and dead in perennial plants, and after a longer or shorter period falls away. The outer bark of the grape separates in long shreds a year or two after its formation. On most forest trees the bark remains for several or many years. The expansion of the tree furrows the bark with numerous 
and deep longitudinal rifts, and it gradually decays or drops away extcriorly as the newer bark forms within.

Cork is one form which the epiclermal cells assime on the stem of the cork oak, on the potato tuber, and many other plants.

Pith Ruys. - Those portions of the first-formed celltissue which were interposerl between the young and originally munited wood-fibers remain, and comnect the pith

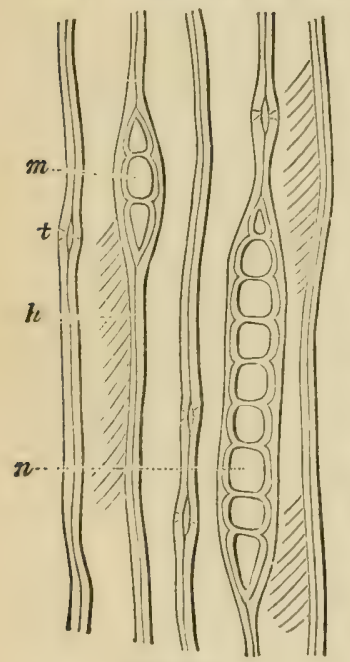

Fig. 51.

with the rind. In hard stems they become flattened by the pressure of the fibers, and are readily seen in most kinds of wood when split lengthwise. They are especially conspicuous in the oak and maple, and form what is commonly kunwn as the silver-grain. The botanist terms them pith-rays or medullary rays.

Fig. 51 exhibits a scction of a lit of wood of the Red Pine, (i'inus piceu,) magnified $200 \mathrm{di}$ ameters. The section is made tangential to the stem and lengthwise of the wood-cells, four of which are in part represented, $h$; it cuts across the pith-rays, whose cri-structure and position in the wood are seen at $m, n$.

Cambium of Exoyens. - The growing part of the exog. joous stem is thus found between the wood and the bark, or rather between the fully formed wood and the mature bark. There is, in fact, no definite limit where wood censes anct latk liegins, for they are connected by the cambial or formative tis-ue, from which, on the one hamd, wond-fibers, and on the other, bast-filers, or the tissues of the bark, rapidly develope. In the cambium, likewise, the pith-rays 
which connect the inner and outer parts of the stem, continue their outward growth.

In spring-time the new cells that form in the cambial region are very delicate and easily broken. For this reason the rind or bark may be stripped from the wood without difficulty. In autumn these cells become thickened and indurated, become, in fact, full-grown bast and woodcells, so that to peel the bark off s!moothly is impossible.

Minute Structure of Exogenous Stems.-The accompanying figure (5:) will serve to convey an idea of the minute structure of the elements of the exogenous stem. It

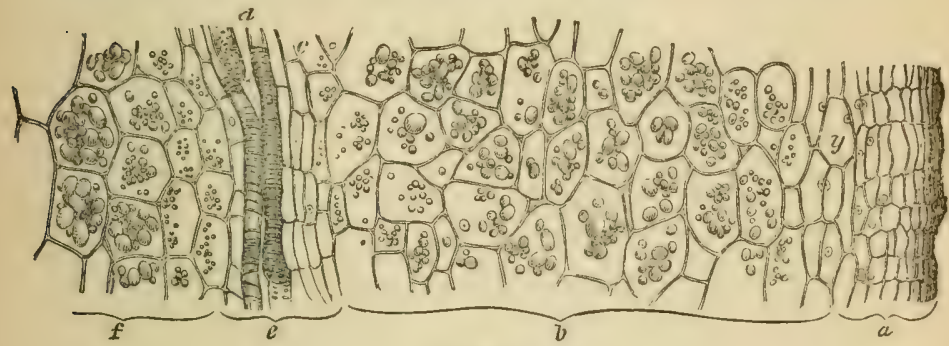

Fig. 52.

erhibits a highly magnified section lengthurise, through a young potato tuber. $A, b$, is the rind; $e$, is the vascular ring; $f$, the pith. The onter cells of the rind are converted into cork. They have become empty of sap and are nearly impervious to air and moisture. This corky-layer, $a,{ }^{*}$ constitutes the thin coat or skin that may be so reatily peeled off from a boiled potato. Whenever a potato is superficially wounded, even in winter time, the exposed part heals over by the formation of cork-cells. The celltissue of the rind consists at its center, $b$, of full-formed cells with delicate membranes which contain numerous and large starch grains. On either hand, as the rind apcuk.

* The bracket, $a$, is much too long, and $b$ is correspondingly too Ehort in the 
proaches the corky-layer or the vascular ring, the cells are smaller, and contiin smaller starch grains; either side of these are noticed cells containing no starch, but having nuclei, $c, y$. These nucleated cells are capable of multiplication, and they are situated where the growth of the

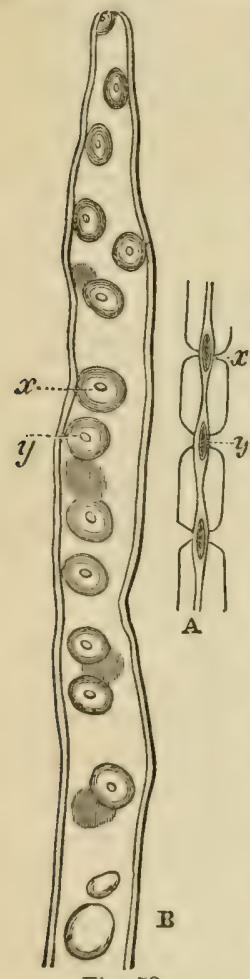

Figr. 53 . tuber takes place. The rind, which makes a large part of the flesh of the potato, increases in thickness by the formation of new cells within and without. Without, where it joins the corky skin, the latter likewise grows. Within, contiguous to the vascular zone, new ducts are formed. In a similar manner, the pith expands by formation of new cells, where it joins the vascular tissue. The latter consists, in our figure, of ring, spiral, and dotted ducts, like those already described as occurring in the maize-stalk. The delicate cambial cells, $c$, are in the region of most active growth. At this point new cells rapidly develope, those to the right, in the figure, remaining plain cells and becoming loosely filled with starch; those to the left developing new ducts.

In the slender, orergruund potatostem, as in all the stems of most agricultural plants, the same relation of parts is to be observed, although the vascular and woody tissues often preponderate. Wood-cells are especially abundant in those stems that need strength for the fulfilment of their offices, and in them, especially in those of our trees, the structure is commonly more complicated.

Perforation of Wood-Cells in the Conifers.--In the wood of cone-bearing trees there are no proper ducts, such 
as have been described. To answer the purpose of air and sap-chinnels, the wood-cells which constitute the concentric rings of the old wood are constructer in a special manner, being provided laterally with visible pores, through which the contents of one cull mary pass directly into those of its neighbors. Fig $53, B$, represents a portion of an isolated woodcell of the Scotch Fir, (Pinus sylvestris,) magnified 200 diameters. Upon it are seen nearly cireular disks, $x, y$, the structure of which, while the cell is young, is shown by a section through them lengthwise. $A$ exhibits such a section through the thickened walls of two contiguous and adhering cells. $x$, in both $A$ and $B$, shows a cavity between the two primary cell-walls; $y$ is the narrow part of the channel, that remains while the membrane thickens around it. This is seen in $B, y$, as a pore or opening in the cell. In

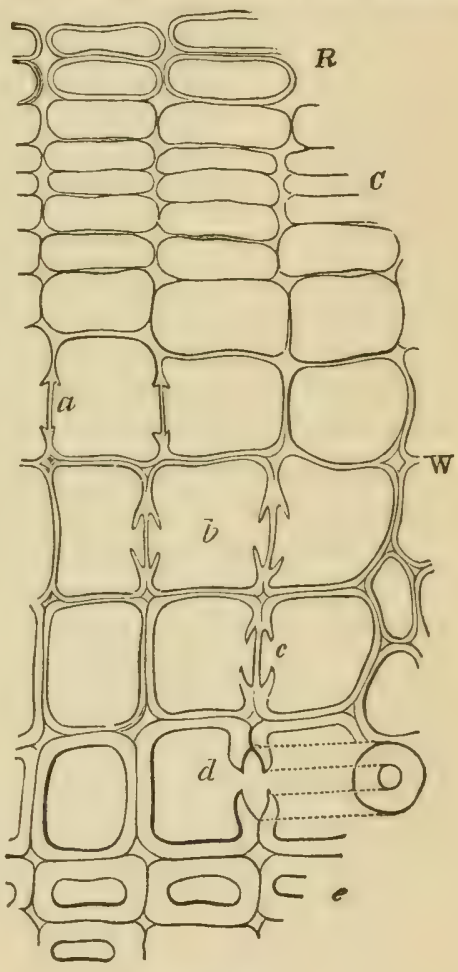

Fig. 54 . $A$ it appears closed because the section passes a little to one side of the pore.

In the next figure, (5f,) representing a transverse section of the spring wood of the same tree magnified 300 diameters, the structure and the gradual formation of 
these pre disks is made evident. The sertion, likewise, gives an instructive illustration of the general character of the simplest kind of wood. $R$, are the young cells of the rind; $C$, is the cambium, where cell multiplication goes on; $W$, is the wood, whose cells are more developed the older they are, i. e., the more distant from the cambium, as is seen from their figure and the thickness of their walls. At $a$ is shown the disk in its earliest stage; $b$ and $c$ exhibit it in a more advanced growth before it becomes a pore, the original cell-wall being still in place. At $d$, in the finished wond-cells, the disk has become a pore, the primary membrane has been absorbed, and a free channel made between the two cells. The dotted lines at $d$ lead ont laterally to two eoncentric circles, which represent the disk-pore seen flatwise, as in fig. 53. At $e$, the section passes through the new annual ring into the autumn wood of the preceding year.

Sieve-cells or sieve-ducts.-The spiral, ring, and dotted ducts and porous wood-cells already noticed, appear only in the older parts of the vascular bundles, and although they are occupied with sap at times wher the stem is surcharged with water, they are ordinarily filled with air alone. The real transmission of the nutritive juices of the growing plant, so far as it goes on through actual tubes, is now admitted to proceed in an independent set of ducts, the so-called sieve-cells, which are usually near to, and originate from the cambium. These are extremely delicate, elongated cells, whose transverse or lateral walls aro perforated, sieve-fashion, (by absorption of the original membrane, so as to establish direct communication from one to another, and this occurs while they are yet charged with juices and at a time when the other ducts are oceupied with air alone. These sieve-ducts are believed to be the channels through which the matter's organized in the foliage most abundantly pass in their downward movement to nourish the stem and root. Fig. 55 represents 
the sieve-cells in the overground stem of the potato; $A$, $B$, cross-section of parts of vascular bundle- $A$, exterior part towards rind; $B$, interior portion next to pith-a, $a$, cell-tissue inclosing $A$ the smaller sievecells, $A, B$, which contain sap turbid with minute granules; $b$, cambium cells; $c$, wood-cells (which are absent in the potato tuber ;) $d$, ducts intermingled with wood-cells. $C$ represents a section lengthwise of the sieve-ducts; and $D$, more highly magnified,exhibits the finely perforated, transverse partitions, through which the liquid contents free$1 y$ pass.

Milk Ducts,-Besides the ducts already described, there is, in many plants, a system of irregularly branched channels containing
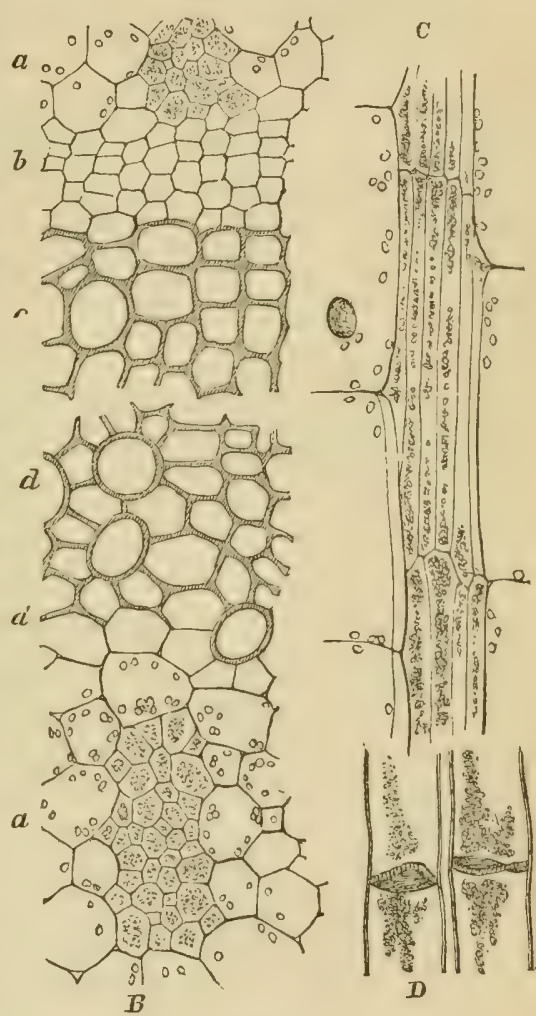

Fig. 55. a milky juice, as in the sweet potato, danclelion, milkweed, ete. These milk-ducts, together with many other details of stem-structure, are imperfectly understood, and require no further notice in this treatise.

Herbaceous Stems.-Annual stems of the exogenous 
kind, whose growth is entirely arrested by winter, consist usially of a single ring of woody tissue with interior pith and surrounding bark. Often, however, the zone of wood is thin, and possesses but little solidity, while the chief part of the stem is made up of cell-tissue, so that the stem is herbaceous.

Woody Stems.-Perennial exogenous stems consist, in temperate climates, of a series of rings or zones, corresponding in number with that of the years during which their growth has been progressing. The stems of our shrubs and trees, especially after the first few years of growth, consist, for the most part, of woody tissue, the proportion of cell-tissue being very small.

The annual cessation of growth which occurs at the approach of winter, is marked by the formation of smaller or finer wood-cells, as shown in fig. 5t, while the vigorous renewal of activity in the cambium at spring-time is exhibited by the growth of larger cells, and in many kinds of wood in the production of ducts, which, as in the oak, are visible to the eye at the interior of the annual layers.

Sap-wood and Ileart-wood.--The living processes in perennial stems, while proceeding with most force in the cambium, are not confined to that locality, but go on to a considerable depth in the wood. Except at the cambial layer, however, these processes consist not in the formation of new cells, nor the enlargement of those once formed-not properly in growtl - but in the transmission of sap and the deposition of organized inatter on the interior of the wood-cells. In consequence of this deposition the inner or heart-wood of many of our forest trees becomes much denser in texture and more durable for industrial purposes. It thea acquires a color different from the outer or sap-wood (alburnum, becomes brown in most cases, though it is yellow in the barberry and red in the red cedar. 
The final result of the filling up of the cells of the heartwood s to make this part of the stem almost or quite impassable to sap, so that the interior wood may be removed by decay without disturbing the vigor of the tree.

Passage of Sap through the Stem.-The stem, besides supporting the foliage, flowers, and fruit, has also a most important office in admitting the passage upward to these organs, of the water and mineral matters which enter the plant by the roots. Similarly, it allows the downward transfer to the roots, of substances gathered by the foliage from the atmosphere. To this and other topics connected with the ascent and descent of the sap we shall hereafter recur.

The stem constitutes the chief part by weight of many plants, especially of forest trees, and serves the most important uses in agriculture, as well as in a thousand other industries.

\section{§3.}

\section{LEAVES.}

These most important organs issue firom the stem, are at first folded curiously together in the bud, and afterwards expand so as to present a great amount of surface to the air and light.

The leaf consists of a thin membrane of cell-tissue, arranged upon a skeleton or net-work of fibers and ducts. It is directly connected with, and apparently proceeds from, the cambial-layer of the stem, of which it may, ace cordingly, be considered an expansion.

In certain plants, as the cactus (prickly pear), there scarcely exist any leaves, or, if any occur, they do not differ, except in external form, from the sterns. Mauy of these plants, above ground are in form, all stem, while in structure and function, they are all leaf. 
In the grasses, although the stem and leaf are distinguish. able in shape, they are but little unlike in other external characters.

In forest trees, we find the most obvious and striking differences between the stem and leaves.

Green Color of Leares.-A peculiarity most characteristic of the leaf, so long as it is in vigorous discharge of its proper vegetative activities, is the possession of a green color. This color is also proper in most cases to the young bark of the stem, a fict further indicating the connection between these parts, or rather demonstrating their identity of origin ancl function, for it is true, not only in the case of the cactuses, but also in that of all cther young plants, that the green (young) stems perform, to some extent, the same offices as the leaves.

The liss of green color that occurs in autumn, in case of the foliage of our deciduous trees, or on the maturing of the plant in case of the cereal grains, is connected with the cessation of growth and death of the leaf.

There are plants whose foliage has a red, hrown, white, or other than a green erlor during the period of active growth. Many of these are cultivated by florists for ornamental purposes. The cells of these colored leaves are by no means de-titute of chloroplyll, as is shown by microscolic examination, though this substance is associated with other coloring matters which mask its green tint.

Structure of Leaves, - While in shape, size, modes of arrangement upon, and attachment to the stem, we find among leaves no end of diversity, there is great simplicity in the matter of their internal structure.

The whole surfice of the leaf, on both sides, is covered with epictermis, a coating, which, in many cases, may be readily stripped off the leaf, and consists of thick walled cells, which are, for the most part, deroid of liquid contents, except when very young. ( $E$, $\mathbb{E}$, fig. 56.)

The acrompanying firme (56) represents the appearance of a bit of bean-leaf as seen on a section from the upper to the lower surfane and uighly magnified. 
Below the upper epidermis, there often occur one or more layers of oblong cells, whose sides are in close contact, and which are arranged endwise, with reference to the flat of the leaf. Below these, down to the lower epidermis, for one-half to three-quarters of the thickness of the leaf, the cells are commonly spherical or irregular in figure and arrangement, and more loosely disposed, with numerous and large interspaces.

The interspaces among the leaf-cells are occupied with air, which is also, in most cases, the only content of the epidermal cells. The active cells of the leaf contain some or all of the various proximate principles which have been already noticed, and in addition the coloring matter of vegetation, - the so-called chlorophyll, or leaf-green, p. 109. Under the microscope, this substance is commonly seen in the form of minute grains attached to the walls of the cells, as in fig. 56, or coating starch granules, or else floating free in

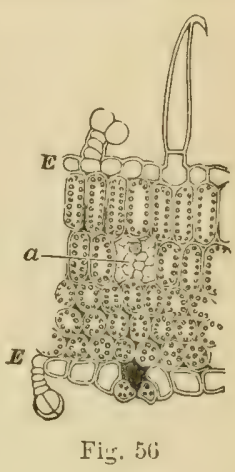
the cell-sap.

The structure of the veins or ribs of the leaf is similar to that of the vascular bundles or fibers of the stem, of which they are branches. At $a$, fig. 56, is seen the cross section of a vein in the bean-leaf.

The epidermis, while often smooth, is frequently beset with hairs or glands, as seen in the figure. These are variously shaped cells, sometimes empty, sometimes, as in the nettle, filled with an acid liquil. Their office is little understood.

Leaf-Pores.-The epidermis is further provided with a vast number of curious "breathing pores," or stomata, by means of which the intereellular spaces in the interior of the leaf may be brought into direct communication with the outer atmosphere. Each of these stomata consists 
usually of two curved cells, which are disposed toward each other nearly like the two siles of the letter $O$, or like the halves of an elliptical carriage-spring, (figs. 52 and 53).

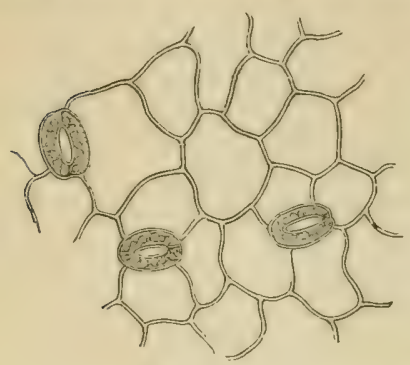

Fig. 57.

The opening between them is an actual orifice in the shin of the leaf. The size of the orifice is, however, constantly changing, as the atmosphere becomes drier or more moist, and as the sunlight acts more or less intensely on its surface. In moist air, they curve outwards, and the aperture is enlarged; in dry air, they straighten and shut together like the springs of a heavily loaded carriage, and nearly or entirely close the entrance. The effect of strong light is to enlarge their orifices.

In fig. 56 is represented a section through the shorter diameter of a pore on the under surface of a bein-lenf. The air-space within it is staded black. Unlike the other epidermal cells, those of the leaf-pore contain griins of chlorophyll.

Fig. $5 \%$ represents a portion of the epidermis of the upper surfice of a potato-leaf, and fig. 55 a similar portion of the under surface of the same leaf, magnified 200 diameters. In both firures are secn the open pores between the semi-elliptical eclls. The outline of the other epidermal cells is marked by irregular double lines. The round bodies in the cells of the pores are starch-grains, often present in these cells, wheu not existing in any other part of the leaf.

The stomata are with fow exceptions altogether wanting on the submerged leaves of aquatic plants. On floating leaves they occur, but only on the upper surface. 'Thus, as a rule, they

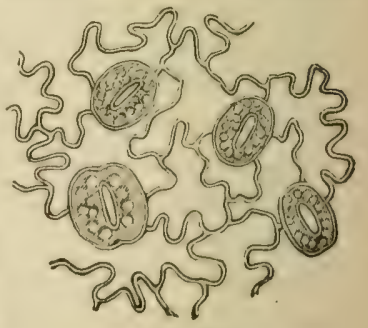

Fig. 58. are not found in contact with liquid water. On the other hand, they are either absent from, or comparatively few in 
number upon, the upper surfaces of land plants, which are exposed to the heat of the sun, while they exist in great numbers on the lower sides of all green leaves. In number and size, they vary remarkably. Some leaves possess but 800 to the square inch, while others have as many as 170,000 to that amount of surface. About 100,000 may be counted on an average-sized apple-leaf. In general, they are largest and most numerous on plants which belong in damp and sharled situations, and then exist on both sides of the leaf.

The epidermis itself is most dense-consists of thick walled cells and several layers of them-in case of leaves which belong to the vegetation of sandy soils in hot climates. Often it is impregnated with wax on its upper surface, and is thereby made almost impenetrable to moist. ure. On the other hand, in rapidly growing plants adapted to moist situations, the epitermis is thin and delicate.

Exhalation of Water-Vapor.-A considerable loss of water goes on from the leaves of growing plants when they are freely exposed to the atmosphere. The water thus lost exhales in the form of invisible vapor. The quantity of water exhaled from any plant may be easily ascertained, provided it is growing in a pot of glazed earthen, or other impervious material. A metal or glass cover is cemented air-tight to the rim of the vessel, and around the stem of the plant. The cover has an opening with a cork, through which weighed quantities of water are added from time to time, as required. The amount of exhalation during any given interval of time is learned with a close approach to accuracy by simply noting the loss of weight which the plant and pot together suffer. Hales, who first experimented in this manner, found that a sunflower, whose foliage had an aggregate surfice of 39 square feet, gave off $31 \mathrm{lbs}$. of water in a space of 24 hours. Knop observed a maize-plant to exhale, between 
May 2:d and September 4th, no less than 36 times its reight of water.

Exhalation is not a regular or uniform process, but varies with a number of circumstances and conditions. It de. pends largely upon the dryness and temperature of the air. When the air is in the state most favorable to evaporation, the loss from the plant is rapid and large. When the air is saturated with moisture, as during dewy nights or rainy weather, then exhalation is nearly or totally checked.

The temperature of the soil, and even its chemical com. position, the condition of the leaf as to its age, texture, and number of stomata, likewise affect the rate of exhalation.

Exhalation is a process not necessary to the life of the plant, since it may be suppressed or be reduced to a minimum, as in a Wardian case or fernery, without evident influence on growth. Neither is it detrimental, unless the los: is greater than the supply. If water escapes from the leares faster than it enters the roots, the plant wilts; and if this disturbance goes on too far, it dies.

Exhalation ordinarily proceeds to a large extent from the surface of the epidermal cells. Although the cavities of these cells are chiefly occupied with air, their thickened walls transmit outward the water which is supplied to the interior of the leaf through the cambial ducts. Otherwise the escape of vapor occurs through the stomata. These pores appear to have the function of regulating the exhala tion, to a great extent, by their property of closing, when the air, from its dryness, fivors rapid evaporation. They are, in fict, self-acting valves which protect the plant from too sudden and rapid loss of water.

\section{Access of Air to the Interior of the Plant.-Not only} does the leaf allow the escape of vapor of water, but it admits of the entrance and exit of gaseous bodies. 
The particles of atmospheric air have easy access to the interior of all leaves, however dense and close their epidermis may be, however few or small their stomata. All leaves are actively engaged in absorbing and exhaling certain gaseous ingredients of the atmosphere during the whole of their healthy existence.

The entire plant is, in fict, pervions to air through the stomatr of the leaves. These communicate with the intercellular spaces of the leaf, which are, in general, occupied exclusively with air, and these again connect with the ducts which ramify throughout the veins of the leaf and branch from the vascular bundles of the stem. In the bark or epidermis of woody stems, as Hales long ago discovered, pores or cracks exist, through which the air has communication with the longitudinal ducts.

These facts admit of demonstration by simple meaus. Sachs employs for this purpose an apparatus consisting of a short wide tube of glass, $B$, fig. 59 , to which is adapted, below, by a tightly fitting cork, a bent glass tube. The stem of a leaf is passed through a cork which is then secured air-tight in the other opening of the wide tube, the leaf itself being included in the latter, and the joints are made air-tight by smearing with tallow. The whole is then placed in a glass jir con-

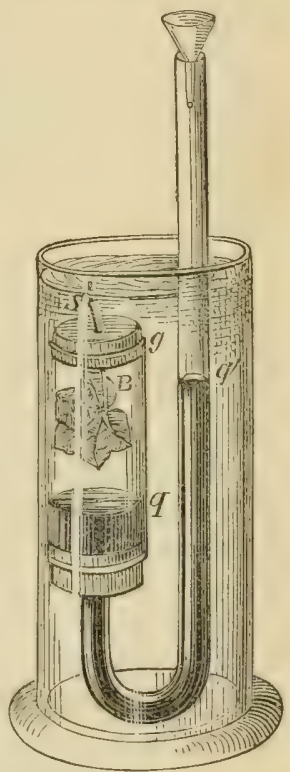

Fig. 59. taining enough water to cover the projecting leaf-stem, and mercury is quickly poured into the open end of the bent tube, so as nearly to fill the latter. The pressure of the column of this clense liquid immediately forces air in to the stomatiz of the leaf, and a corresponding quintity i forced on throurh the interecllular spaces and through the rein lucts into the ducts of the leaf-stem, wheuce it issues in fine bubbles at $S$. It is even easy iu many cases to demonstrate the permeability of the leaf to air by immersing it in water, and, taking the leaf-stem between the lips, produce a current by blowing. In this case the air escipes from the stomata.

The air passiges of the stem may be shown ly a similur arangement, 
or in many instances, as, for example, with a stalk of malze, by simply immersing one end in water and blowing into the other.

On the contrary, roots are destitute of any visiblo pores, and are not pervious to external air or vapor in the sense that leaves and young stems are.

The air passages in the plant correspond roughly to the mouth, throat, and breathing carities of the animal. TVe have, as yet, merely noticerl the direct communication of these passages with the external air by means of microscopically visible openings. But the cells which are not visibly porous readily allow the access and egress of water and of gases by osmose. To the mode in which this is effected we shall recur on subsequent pages, (pp. 354366.)

The Offices of Foliage are to put the plant in communication with the atmosphere and with the sun. On the one hand it permits, and to a certain degree regulates, the escape of the water which is continually pumped into the plant by its roots, and on the other hand it absorbs from the air, which freely penetrates it, certain gases whicb furnish the principal materials for the organization of vege. table matter. We have seen that the plant consists of elements, some of which are volatile at the heat of ordina ry fires, while others are fixed at this temperature. When a plant is burned, the former, to the extent of 90-99 per cent of the plant, are converted into gases, the latter remain as ashes.

The reconstruction of vegetation from the products of its combustion (or decay) is, in its simplest phase, the gatbering by a new plant of the ashes from the soil through its roots, and of these gases from the air by its leaves, and the compounding of these compuratively simple substances into the highly eomplex ingredients of the vegetalble organism. Of this work the leaves have by fir the larger share to perform; hence the extent of their surface and their iudispensability to the welfare of tho plint. 
The assimilation of carbon in the plant is most intimately connected with the chlorophyll, which has been no. ticed as the green coloring matter of the leaf, and depends also upon the solar rays.

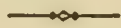

\section{CHAPTER IV.}

\section{REPRODUCTIVE ORGANS OF PLANTS.}

\section{$\S 1$.}

\section{THE FLOWER.}

The onward growth of the stem or of its branches is not necessarily limited, until from the terminal buds, instead of leaves, only Flowers unfold. When this happens, as is the case with most annual and biennial plants, raised on the farm or in the garden, the vegetative energy has usually attained its fullest development, and the reproductive function begins to prepare for the death of the individual by providing seeds which shall perpetuate the species.

There is often at first no apparent difference between the leaf-buds and flower-buds, but commonly in the later stages of their growth, the latter are to be readily distinguished from the former by their greater size, and by peculiar shape or color.

The Nlower is a short branch, bearing a collection of org:ans, which, though usually having little resemblance to foliage, may be considered as leaves, more or less modified in form, color, and office.

The flower commonly presents four different sets of organs, viz, Calyx, Corolla, Stamens, and Pistils, and is then said to be complete, as in case of the apple, potato 
and many common plants. Fig. 60 represents the complete flower of the Fuchsia, or ladies' ear-drop, now universally cultivated. In fig. 61 the same is shown in section.

The Calyx, (cup,) $c x$, is the outermost floral envelope. Its color is red or white in the Fuchsia, though generally it is green. When it consists of several distinct leaves,

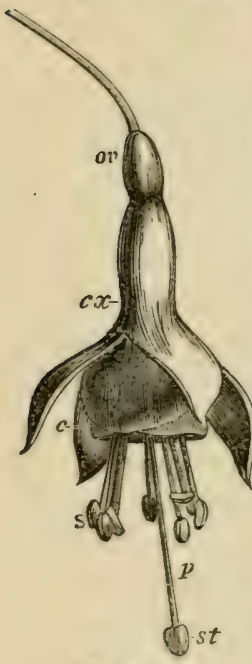

Fig. $\mathrm{CO}$. they are called sepals. The calyx is frequently small and inconspicuous. In some cases it falls away as the flower opens. In the Fuchsia it firmly adheres at its base to the seedvessel, and is divided into four lobes.

\section{The Corolla,} (crown,) $c$, or $c a$, is one or several series of leaves which are situated within the calyx.

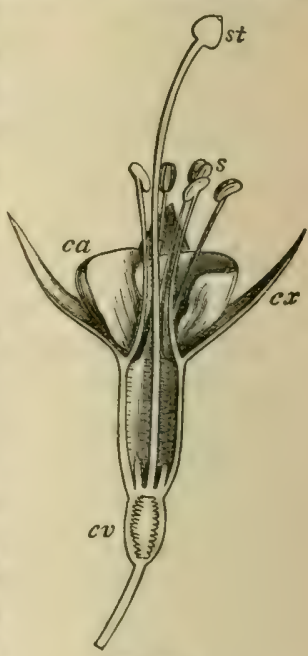

Fig. 61.

It is usually of some other than a green color, (in the Fuchsia, purple, etc.,) often has marked peculiarities of form and great delicacy of structure, and thus chiefly gives beanty to the flower. When the corollit is divided into separate leaves, these are termed petals. The Fuchsia has four petals, which are attached to the calyx-tube.

The Stamens, $s$, in fig's 60 and 61 , are generally slender, thread-like organs, terminated by an oblong sack, the anther, which, when the flower attains its full growth, discharges a fine yellow or brown dust, the so-called pollen. 
'Tlie forms of anthers, as well as of the grains of pollen, vary with nculy every kind of plant. The yellow pullen of pine and spruce trees is not infrequently transported by the wind to a great distance, and when brought down by rain in considerable quantities, has been mistaken for. sulphur.

The Pistil, $p$, in fig's 60 and 61 , or pistils, occupy the center of the perfect flower. They are exceedingly various in form, but always have at their base the seed-vessels or ovaries, ov, in which are found the ovules (little egrgs) or rudimentary seeds. The summit of the pistil is destitute of the epidermis which covers all other parts of the plant, and is termed the stigma, st.

As has been remarkerl, the floral organs may be considered to be modified leaves; or rather, all the appendages of the stem-the leaves and the parts of the flower to. gether-are different developments of one fundamental organ.

The justness of this idea is sustained by the transforma. tions which are often observed.

The rose in its natural state has a corolla consisting of five petals, but has a multitude of stamens and pistils. In a rich soil, or as the effect of those agencies which are uniterl in "cultivation," nearly all the pistils and stamens lose their reproductive function and proper structure, and revert to petals; hence the flower becomes double. The tulip, poppy, and numerous garden-flowers, illustrate this interesting metamorphosis, and in these flowers we may often see at once the change in virrions stages intermediate between the perfect petal and the unaltered pistil.

On the other hand, the reversion of all the floral organs into ordinary green leaves has been observed not infrequently, in case of the rose, white clover, and other plants.

While the complete flower consists of the four sets of organs above described, only th: stamens and pistils are essential to the production of see.l. The latter, accord. 
ingly, constitute a perfect flower even in the absence of calyx and coroll..

The flower of buckwheat has no corolla, but a white or rinkish calyx.

The grasses $h$,ve flowers in which calyx and corolla are representel by scale-like leaves, which, as the plants ma. ture, become craff.

In various olints the stamens and pistils are borne in separate foovers. Such are called monoecious plants, of which the wrch and oak, maize, melon, squash, cucumber, and ofte: $\mathrm{I}^{\prime}, \mathrm{rres}^{\mathrm{r}}$ the strawberry, are examples.

In cas of maize, the staminate flowers are the "tassels" at the summit of the stalk; the pistillate flower's are tr young ears, the pistils themselves being the "silk," each fiber of which has an ovary at its base, that, if fertiiize l, developes to a kernel.

Dioecious plants are those which bear the staminate (rale, or sterile) flowers and the pistillate (female, or fertile) flowers on different individuals; the willow tree, the hop-vine, and hemp, are of this kind.

Fertilization and Fructification.-The grand function of the flower is fructification. For this purpose the pollen must fall upon or be carried by wind, insects, or other agencies, to the naked tip of the pistil. Thus situated, each pollen-grain sends out a slender tube of microscopic diameter, which penetrates the interior of the pistil until it enters the seed-sack and comes in contact with the ovule or rudimentary seed. This contact being established, the orule is fertilized and begins to grow. Thenceforward the corolla and stamens usually wither, while the base of the pistil and the included ovules rapidly increase in size until the seeds are ripe, when the seed-vessel falls to the ground or else opens and releases its contents.

Fig. 62 exhibits the process of fertilization as observed in a plant allied to buckwheat, viz., the Polygonum con 
volvulus. The cut represents a magnified section lengthwise through the short pistil; $a$, is the stigma or summit of the pistil; $b$, are grains of pollen; $c$, are pollen tubes that have penetrated into the seedressel which forms the base of the pistil; one has entered the mouth of the rudimentary seed, $\mathscr{l}$, and reached the embryo sack, $e$, within which it causes the development of a germ; $d$, represents the interior wall of the seed-vessel; $h$, the base of the seed and its attachment to the seed-vessel.

Darwin has shown that certain plants, which have pistils and stamens in the same flower, are incapable of self-fertilization, and depend upon insects to carry pollen to their stigmas. Such are many Orchids.

Artificial Fecundation has been proposed by Hooibrenk, in Belgium,

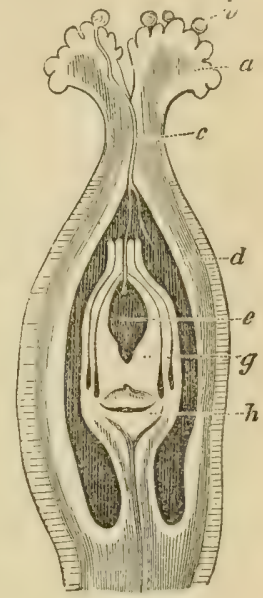

Fig. 62. as a means of increasing the yicld of cert:in crops. Hooi brenk's plan of agitating the heads of gratin at the time when the pollen is ripe, in order to ensure is distribution, which is done by two men traversing the field carrying a rope between them so as to lightly brush over the heads, appears to have been found very useful in some cases, though in many trials no good effects have followed its application. We must therefore conclude that agitation by the rints and the good offices of insects commonly render artificial assistance in the fecuadating process entirely superfluous.

Ilybridizing. $-\boldsymbol{A}$ s the union of the sexes of different kinds of animals sometimes results in the birth of a hybrict, so among plints, the ovules of one kind may be fertilized by the pollen of another, and the seed thus developed, in its growth, produces a hybrid plant. In both the animal 
and vegetalle kingdoms the limits within which hybridiza tion is possible appear to be very narrow. It is only between clusely allied species that fecundation can take place. Wheat, oats, and barley, show no tendency to " $\mathrm{mix}$ "; the pollen of one of these similar plants being inc:pable of fertilizing the ovules of the others.

In flower and fruit-culture, hybridization is practised or attempterl, as a means of producing new kinds. Thus the celebrated Rogers' Seedling Grapes are helieved to be hy. brids between the European grape, Ditis vinifera, and the allied but distinct Vitis labrusec, of North America.

II rbridization between plants is effected, if at all, by removing from the flower of one kind, the st:mens before they shed their pollen, and dusting the summit of the pistil with pollen from another kind.

The mixing of different varieties, as commonly happens among maize, melons, etc., is not properly hybrilization, this word being used in the long-established sense. We are thus led to brief notice of the meaning of the terms species and variety, and of the distinctions employed in botanical classification.

Species.-The idea of species as distinct from variety whith has been held by most scientific authorities hitherto, is based primarily on the faculty of continued reproduction. The horse is a species comprising many varietice. Any two of these varieties by sexual union may propacate the species. The same is true of the ass. The horse and the ass by sexual union produce a hybril-the mule,-but the sexual union of mules is without result. They camnot continue the mule as a distinct kind of animal-as a species. Among animals a species therefore comprises all those individuals which are related by eommon origin or fraternity, and which are capable of sexual fer tility. This conception involves original and permaneut differences between different species. 
Species, therefore, cannot change any of their essential characters, those characters which are hence termed specific.

Varieties.-Individuals of the same species differ. In fact, no two individuals are quite alike. Circumstances of temperature, food, and habits of life, increase these differEnces, and varieties originate when such differences assume a comparative permanence and fixity. But as external conditions cause variation away from any particular representative of a species, so they may cause variation back again to the original, and although variation may take a seemingly wide range, its bounds are fixed and do not tuuch speeific characters.

The causes that produce varieties are numerons, but in many cases their nature and their mode of action is difficult or impossible to understand. The influence of scarcity or abundance of nutriment we can easily comprehend may dwarf a plant or lead to the production of a giant individual; but how, in some cases, the peculiarities thus impressed upon individuals acquire permanence and are tr:ınsmitted to subsequent generations, while in others they disappear, is beyond explanation.

Among plant, varieties may often be perpetuated by the seed. This is true of our cereal and leguminous plants, which reproduce their kind with striking regularity. Other plants cannot be or are not reproduced unaltered by the seed, but are continued in the possession of their peculiarities by cuttings, layers, and grafts. Here the individual plant is in a sense divided and multiplied. The species is propagated, but not reproduced. The fact that the seeds of a potato, a grape, an apple, or pear, cannot be depended upon to reproduce the variety, may perhaps be more commonly due to unavoidable contact of pollen from other varieties, than to inability of the mother plant. to perpetuate its peculiarities. That such inability often exists, is, however, well established, and is, in general, most obvious in case of varieties that have to the greatest 
degree departed from the original specific type. Thus nature puts the same limit to variation within a species that she has established against the mixing of species.

Darmin's Hypothesis, which is now accepted by many naturalists, is to the effect that species, as above definerl, do not exist, but that new kinds (so-called species) of ani mals and plants may arise by variation, and that all exist. ing animals and plants may have developed by a process of "natural selection" from one original type. Our object here is not to discuss this intricate question, but sinfly to put the reader in possession of the meaning attach. ed to the tcrms currently employed in science-terms which must long continue in use and which are necessarily found in these pages.*

Genus, (plural Genera.) - In the language of anti-Darwinianism, any set of oaks that are capable of reproducing their kind by seed, but cannot mix their seed with other oaks, constitute a species. Thus, the white oak is one species, the red oak is another, the water oak is a third, the live oak a fourth, and so on. All the oaks, white, red, ete., taken together, form a group which has a series of characters in eommon that distingnishes them from all other trees and plants. Such a group of species is called a genus.

Families or Orders, in botanical language, are groups of genera that a $q r e e$ in certain particulars. Thus the several plants well-known as mallows, hollyhock, okra, and cotton, are representatives of as many different genera. They all agree in a number of points, especially as regards the structure of their fruit. They are accordingly grouped together into a natural family or order, which differs from all others.

\section{Classes, Scries, and Classification.-Classes are groups}

* For a masterly statement of the facts and evidence bearing on these points, which are of the greatest importance to the arriculturist, see Darwin's works "On the Origin of Species," and "On the Variation of Auimals and Plants vedor Domestication." 
ot cirders, and Series are groups of classes. In botanical classification as now universally employed-classification after the Natural System-all plants are separated into two series, as follows:

1. Flowering Plants (Phonogams) which produce flowers and seeds with embryos, and

2. Flowerless Plants (Cryptogams) that have no proper flowers, and are reproduced hy spores which are in most cases single cells. This series includes Ferns, Iforse-tails, Mosses, Liverworts, Lichens, Sea-weeds, Mushrooms, and Molds.

The use of classification is to give precision to our notions and distinctions, and to facilitate the using and acquisition of knowledge. Series, classes, orders, genera, species, and varieties, are as valuable to the naturalist as pigeon holes are to the accountant, or shelves and drawers to the merchant.

Botanical Nomenclature.-So, too, the Latin or Greek names which botanists employ are essential for the discrimination of plants, being equally received in all countries, and belonging to all languages where science has a home. They are made necessary not only by the confusion of tongues, but by confusions in each vernacular.

Botanical usage requires for each plant two names, one to specify the genus, another to indicate the species. Thus all oaks are lesignated by the Latin word Quercus, while the red oak is Quercus rubra, the white oak is Quercus alba, the live oak is Quercus virens, etc.

The designation of certain important families of plants is derived from a peculiarity in the form or arrangement of the flower. Thus the pulse family, comprising the bean, pea, and vetch, as well as lucern and clover, are called Papilionaceous plants, from the resemblance of their flowers to a butterfly, (Latin, pupilio). Again, the mustard family, including the radish, turnip, cabbage, war 
ter-cress, etc., are termed Cruciferous plants, hecause their flowers have four petals arranged like the four arms of a cross, (Latin, crux).

The flowers of a large natural orler of plants are arrangerl side by side, often in great numbers, on the expand. ed extremity of the flower-stem. Examples are the thistle, dindelion, sun-flower, artichoke, China-aster, etc., which, from bearing such compound heads, are called Composite plants.

The Coniferous (cone-bearing) plants comprise the pines, larches, hemlocks, etc., whose flowers are arranged in conical receptacles.

The flowers of the carrot, parsnip, and caraway, are arranged at the extremities of stalks which radiate from a central stem like the arms of an umbrella; hence they are caller Umbelliferous plants, (from ur:bel, Latin, for little screen).

\section{$\S 2$.}

THE FRUIT

Tine Frott comprises the seed-ressel and the seed, together with their various appendages.

The Seed-vesset, consisting of the base of the pistil in its matured state, exhibits a great variety of forms and characters, which serve, chiefly, to define the different kinds of Fruits. Of these we shall only adduce such as are of common occurrence and belong to the firm.

The Wut has a hard, leathery or hony shell, that does not open spuntaneonsly. Examples are the acorn, chest. nut, beech-nut, and hazel-nut. The cup of the acorn and the bur of the others is a sort of fleshy calyx.

The stonc-fruit or Dorupe is a nut enveloped by a lleshy or leathery coating, like the peach, cherry, and pium, 
also the butternut and hickory-nut. Raspberries and blackberries are clusters of small drupes.

Pome is a term applied to fruits like the apple and pear, the core of which is the true seed-vessel, originally belonging to the pistil, while the often edible flesh is the enormously enlarged and thickened calyx, whose withered tips are always to be found at the end opposite the stem.

The Berry is a many-seeded fruit of which the entire seed-vessel becomes thick and soft, as the grape, currant, tomato, and huckleberry.

Gourd fruits have externally a hard rind, but are fleshy in the interior. The melon, squash, and cucumber, are of this kind.

The Akene is a fruit containing a single seed which does not separate from its dry envelope. The so-called seeds of the composite plants, for example the sun-flower, thistle, and dandelion, are akenes. On removing the outer husk or seed-ressel we find within the true seed. Many akenes are furnished with a pappus, a downy or hairy appendage, as seen in the thistle, which enables the seed to float and be carried about in the wind. The fruit or grain of buckwheat is akene-like.

The Grains are properly fruits. Wheat and maize consist of the seed and the seed-vessel closely united. When these grains are ground, the bran that comes off is the seed-vessel together with the outer coatings of the seed. Barley-grain, in addition to the seed-vessel, has the petals of the flower or inner chaff, and oats have, besides these, the calyx or outer chaff adhering to the seed.

Pod is the name properly applied to any dry seed-vessel which opens and scatters its seeds when ripe. Several kinds have received special designations; of these we need only notice one.

The Legume is a pod, like that of the bean, which gillits into two halves, along whose inner edges sceils are 
borne. The pulse family, or papilionaceous plants, are also termeil leguminous from the form of their fruit.

The Seed, or ripened ovule, is borne on a stalk which connects it with the seed-vessel. Through this stalk it is supplied with nutriment while growing. When matured and detached, a sear commonly indicates the point of former connection.

The seed has usually two distinct coats or integuments. The outer one is often hard, and is generally smooth. In the case of cotton-seed it is covered with the valuable cotton fiber. The second coat is commonly thin and delicate.

The Kernel lies within the integuments. In many cases it consists exclusively of the embryo, or rudimentary plant. In others it contains, besides the embryo, what has received the name of endosperm.

The Endosperm forms the chief bulk of all the grains. If we cut a seed of maize in two lengthwise, we observe extending from the point where it was attached to the cob the soft "chit," $b$, fig. 63 , which is the embryo, to be presently noticed. The remainder of the irernel, $a$, is endoeperm; the latter, therefore, yields in great part the flour or meal which is so important a part of the food of man and animals.

The endosperm is intended for the support of the young plant as it developes from the embryo, before it is capable of depending on the soil and atmosphere for sustenance. It is not, however, an indispensable part of the seed, and may be entirely removed from it, without thereby preventing the growth of a new plant.

The Embryo or Germ is the essential and most import. ant portion of the seed. It is, in fact, a ready-formed plant in miniature, and has its root, stem, leaves, and a bud, although these organs are often as undeveloped in form as they are in size.

As above mentioned, the chit of the seeds of maize and 
the other grains is the embryo. Its form is with difficulty distinguishable in the dry seeds, but when they have been soaked for several days in water, it is readily removed from the accompanying endosperm, and plainly exhilits its three parts, viz., the radicle, the plumule, and the cotyledon.

In fig. 63 is represented the embryo of maize. In $A$ and $B$ it is seen in section imbedder in the endosperm. $C$ exhibits the detached embryo. The Radicle, $r$, is the rootlet of the seed-plant, or rither the point from which downward growth proceeds, fiom which the first true roots are produced. The Plumule, $c$, is the ascending axis of the plant, the central bud, out of which the stem with new leaves, flowers, etc., is developed. The Cotyledom, b, is in structure a ready-formed leaf, which clasps the plumule in the embryo, as the proper leaves clasp the stem in the mature maize-plant. The cotyledon of maize does not, however, perform the functions of a leaf; on

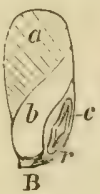

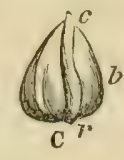

Fig. 63.

the contrary, it remains in the soil during the act of sprouting, and its contents, like those of the endosperm, are absorbed by the plumule and radicle. The leaves which appear above-ground, in the case of maize and the other grains (buckwheat excepted,) are those which in the embryo were wrapped together in the plumule, where they can be plainly distinguished by the aid of a magnifier.

It will be noticed that the true grains (which have sheatling leaves and hollow jointed stems) are monocotylectonous (one-cotyledonerl) in the seed. As has been mentioned, this is characteristic of plants with Endogenous or inside-growing stems, (p. 268.)

The seeds of the Exoyens (outside-growers) (p. 273) are dicntyledonous, i. e., have two cotyledons. Those of 
buckwheat, flax, and tobacco, contain an endosperm. The seeds of nearly all other exogenous agricultural plants are destitute of an endosperm, and, exclusive of the coats, consist entirely of embryo. Such are the seeds of the Leguminosæ, viz., the bean, pea, and clover; of the Cruciferæ, viz., turnip, radish, and cabbage; of ordinary fruits, the apple, pear, cherry, plum, and peach; of the gourd family, viz, the pumpkin, melon and cucumber; and finally of many hard-wooded trees, viz., the oak, maple, elm, birch, and beech.

We may best observe the structure of the two-cotyledoned embryo in the garden or kidney-bean. After a bean has been soaked in warm water for several hours, the coats may be easily removed, and the two fleshy cotyledons, $c$, $c$, in fig. 61 , are found divided from ench other save at the point where the radicle, $\alpha$, is seen projecting like a blunt

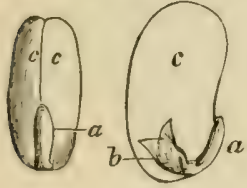

Fig. 64 .

spur: On carefully breaking away one of the cotyledons, we get a side view of the radicle, $a$, and plumule, $b$, the former of which was partially and the latter entirely imbedded between the cotyledons. The plumule plainly exhibits two delicate leaves, on which the unaided eye may note the veins. These leaves are folded together along their mid-ribs, and may be opened and spread out with help of a needle.

When the kidney-bean (Phaseolus) germinates, the cotyledons are carried up into the air, where they become green and constitute the first pair of leaves of the new plant. The second pair are the tiny leaves of the plumule just described, between which is the bud, whence all the sulssequent aerial organs develope in succession.

In the horse-bean, (Fib bu), as in the pea, the cotyledons never assume the office of leaves, but remain in the soil and gradusliy yicld a lirge slare of their contents to the 
growing plant, shriveling and shrinking greatly in bulk, and finally falling away and passing into decay.

\section{$\S 3$.}

VITALITY OF SEEUS AND THEIR INFLUENCE ON THE PLANTS THEY PRODUCE.

Duration of Vitality. - In the mature seat when kept lrom excess of moisture, the embryo lies dormant. The duration of its vitality is very various. The seeds of the willow, it is asserted, will not grow after having once become dry, but must be sown when fresh; they lose their germinative power in two weeks after ripening.

With regard to the duration of the vitality of the seeds of agricultural plants there is no little conflict of opinion among those who have experimented with them.

The leguminous seeds appear to remain capable of germination during long periods. Girarlin sproutel beans that were over a century old. It is said that Grimstone with great pains raised peas from a seel taken from a sealed vase found in the sircophagus of an Egyptian mummy, presented to the British MIıseum by Sir G. Wilkinson, and estimated to be near 3,000 years old.

The seeds of wheat usually lose their power of growth after having been kept 3-7 years. Count Sternberg and others are said to have succeeded in germinating wheat taken from an Egyptian mummy, but only after soaking it in oil. Stemberg relates that this ancient wheat minifested no vitality when placed in the soil under ordinary circumstances, nor even when submitted to the action of acids or other substances which garleners sometimes employ to promote sprouting. Vilmorin, from his own trials, doubts altogether the authenticity of the " mummy wheat."

Dietrich, (Hoff. Jahl., 186:3-3, 1. 77,) experimented with seeds of wheat, rye, and a species of Bromus, which 
were 185 years old. Nearly every means reputed to faror germination was employed, but without success. After proper exposure to moisture, the place of the germ was usually found to be occupied by a slimy, putrefying liquid.

The fact appears $t_{\text {, }}$ be that the circumstances und ('r which the seed is kept greatly influence the duration of its vitality. If seeds, when first gathered, be thoroughly Iried, and then sealed up in tight vessels, or otherwise kept out of contact of the air, there is no reason why their vitility should not endure for ages. Oxygen and moisture, not to mention insects, are the agencies that usually put a speedy limit to the duration of the grerminative power of seeds.

In agriculture it is a general rule that the newer the seed the better the results of its use. Experiments have proved that the older the seed the more numerous the falures to germinate, and the weaker the plants it produces.

Londet made trials in $1856-7$ with seed-wheat of the years 1856, 'วิ5๊, '54, and 'ร3.

The following table exhibits the results, which illustrate the statement just made.

\begin{tabular}{|c|c|c|c|}
\hline & $\begin{array}{l}\text { Per cent of seeds } \\
\text { sprouted. }\end{array}$ & $\begin{array}{l}\text { Length of leaves foner alays } \\
\text { after coming up. }\end{array}$ & $\begin{array}{l}\text { Number of stalks } \\
\text { and ears per } \\
\text { hundred seeds. }\end{array}$ \\
\hline Beed of 1853 , & none & - & - \\
\hline " " 1854, & 51 & 0.4 to 0.8 inches & 269 \\
\hline “ "6 1855 , & 73 & 1.26 & 365 \\
\hline " " 1856 , & 74 & 1.6 & 401 \\
\hline
\end{tabular}

The results of similar experiments made by Haberlandt on various grains, are contained in the following table:

\begin{tabular}{|c|c|c|c|c|c|c|c|c|}
\hline & \multicolumn{8}{|c|}{ Per cent of seeds that germinated in 1861 from the years: } \\
\hline & 1850 & '51 & 54 & 55 & 157 & '58 & 59 & '60 \\
\hline Wheat, & 0 & 0 & 8 & 4 & 73 & 60 & 84 & \\
\hline Rye, & 0 & 0 . & 0 & 0 & 0 & 0 & 48 & 100 \\
\hline Barley, & 0 & 0 & 24 & 0 & 48 & 33 & 92 & \\
\hline Oats, & 60 & 0 & 56 & 48 & 72 & 32 & 80 & \\
\hline Maixe, & a & not tried. & 76 & $56)$ & not tried. & 77 & 100 & \\
\hline
\end{tabular}


Results of the Use of long-kept Seeds.-The fact that oll seeils yield weak plants is taken advantage of by the florist in producing new varieties. It is said that while the oneyear-old seeds of Ten-weeks Stocks yield single flowers, those which have been kept four years give mostly double flowers.

In case of melons, the experience of gardeners yoes to show that seeds which have been kept sever:al, even seven years, though less certain to come up, yield plants that give the greatest returns of fruit; while plantings of new seeds run excessively to vines.

Unripe Seeds.-Experiments by Lucanus prove that seeds gathered while still unripe,-when the kernel is soft and milky, or, in case of cereals, even before starch has formed, and when the juice of the kernel is like water in appearance,- -are nevertheless capable of germination, especially if they be allowed to dry in connection with the stem (after-ripening.) Such immature seeds, however, have less vigorous germinative power than those which are allowed to mature perfectly; when sown, many of them fail to come up, and those which do, yield comparatively weak plants at first and in poor soil give a poorer harvest than well-ripened seed. In rich soil, however, the plants which do appear from unripe seed, may, in time, become as vigorous as any. (Lucanus, Vs. St., IV, p. 253.)

According to Siegert, the sowing of unripe peas tends to produce earlier varieties. Liebig says: "The gardener is aware that the flat and shining seeds in the pod of the Stock Gillyflower will give tall plants with single flowers, while the shriveled seeds will furnish low plants with double flowers throughout."

Dwarfed or Light Seeds.-Dr. Müller, as well as IIellriegel, found that light grain sprouts quicker lut yields weaker plants, and is not so sure of germinating as heav $y$ grain. 
Baron Liebig asserts (Natural Laws of Husbandry, Ain. Ed., 1863, p. 24) that "the strength and number of the roots and leaves formed in the process of germination, are, (as regards the non-nitrogenous constituents, ) in di. rect proportion to the amount of starch in the seed." Further, "poor and sickly seeds will produce stunted plants, which will again yield seeds bearing in a great measure the same character." On the contrary, he states (on page 61 of the same book, foot note,) that "Boussingault has observed that even seeds weighing two or three milligrames, (1-30th or 1-20th of a grain,) sown in an absolutely sterile soil, will produce plants in which all the organs are developed, but their weight, after months, does not amount to much more than that of the original seed. The plants are reduced in all dimensions; they may, however, grow, flower, and even bear seed, which only requires a fertile soil to produce again a plant of the natural size." These seeds must be diminutive, yet placed in a fertile soil they give a plant of normal dimensions. Ve must thence conclude that the amount of starch, gluten, etc.-in other words the weight of a seed-is not altogether in index of the vigor of the plant that may spring from it.

Schubert, whose observations on the roots of agricultural plants are detailed in a former chapter (p. 242,) says, as the result of much investigation-" the vigorous development of plants depends far less upon the size and weight of the seed than upon the depth to which it is covered with earth, and upon the stores of nourishment which it finds in its first period of life."

\section{Value of seed as related to its Density. - From a series} of experiments made at the Royal $\Lambda \mathrm{g}$. College at Cirenrester, in 1863-4, Prof. Church concludes that the value of seed-whent stands in a certain connection with its specific gravity, (Practice with Science, p. 107, London, 1865.) He found:- 
1. That seed-wheat of the greatest density produces the densest seed.

2. The seed-whent of the greatest density yields the greatest amount of dressed corn.

3. The seed-wheat of medium density generally gives the largest number of ears, but the ears are poorer than those of the densest seed.

4. The seed-wheat of medium density generally produces the largest number of fruiting plants.

5. The seed-wheats which sink in water but float in a liquid having the specific gravity 1.247 , are of very low value, yielding, on an average, but $34.4 \mathrm{lbs}$. of dressed grain for every 100 yielded by the densest seed.

The densest grains are not, according to Church, always the largest. The seeds he experimented with ranged from sp. gx. 1.354 to 1.401 . 


\section{DIVISION III.}

\section{J I F E O F THE PLA N T.}

CHAPTER I.

GERMINATION.

§. 1.

INTRODUCTORY.

Having traced the composition of vegetation from its altimate elements to the proximate organic compounds, and studied its structure in the simple cell as well as in the most highly developed plant, and, as far as needful, explained the characters and functions of its various organs, we approach the subject of Vegetable Life and Nutrition, and are ready to inquire how the plant increases in bulk and weight and produces starch, sugar, oil, albuminoids, etc., which constitute directly or indirectly almost the entire food of animals.

The beginning of the individual plant is in the seed, at the moment of fertilization by the action of a pollen tube on the contents of the embryo-sack. Each embryo whose development is thus ensured, is a plant in miniature, or rather an organism that is capable, under proper circumstances, of unfolding into a plant. 
The first process of development, wherein the young plant commences to manifest its separate life, and in which it is shaped into its proper and peculiar form, is called germination.

The General Process and Conditions of Geruituation are familiar to all. In agriculture and ordinary garden. ing we bury the ripe and sound seed a little way in the soil, and in a few days, it usually sprouts, provided it finds a certain degree of warmth and moisture.

Let us attend somewhat in detail first to the phenomena of germination and afterward to the requirements of the awakening seed.

\section{$\S 2$.}

\section{THE PHENOMENA OF Germination.}

The student will do well to watch with care the various stages of the act of germination, as exhibited in several species of plants. For this purpose a dozen or more seeds of each plant are sown, the smaller, one-half, the larger, one inch deep, in a box of earth or saw-dust, kept duly warm and moist, and one or two of each kind are uncovered and dissected at successive intervals of 12 hours until the process is complete. In this way it is easy to trace all the visible changes which occur as the embryo is quickened. The seeds of the kidney-bean, pea, of maize, buckwheat, and barley, may be employed.

We thus observe that the seed first absorbs a large amount of moisture, in consequence of which it swells and becomes more soft. We see the germ enlarging beneath the seed coats, shortly the interuments burst and the radicle appears, afterward the plumule becomes manifest.

In all agricultural plants the radicle buries itself in the soil. The plumule ascends into the atmosphere and seeks exposure to the direct light of the sun. 
The endosperm, if the seed have one, and in many cases the cotyledons (so with the horse-bean, pea, maize, and barley), remain in the place where the seed was deposited. In other cases (kidney-bean, buckwheat, squash, rarlish, etc.,) the cotyledons ascend and become the first pair of leaves.

The ascending plumile shortly unfolds new leaves, and if coming from the seed of a branched plant, lateral buds make their appearance. The radicle divides and subdivides in beginning the issue of true roots.

When the plantlet ceases to derive nourishment from. the mother seed, the process is finished.

\section{$\S 3$.}

\section{THE CONDITIONS OF GERMINATION.}

As to the Conditions of Germination we have to con. sider in detail the following :-

a. Temperature. $-A$ certain range of warmth is essential to the sprouting of a seed.-Göppert, who experiment. ed with numerous seeds, observed none to germinate be. low $39^{\circ}$.

Sachs has ascertained for various agricultural seeds the extreme limits of warmth at which germination is possible. The lowest temperatures range from $41^{\circ}$ to $55^{\circ}$, the highest, from $102^{\circ}$ to $116^{\circ}$. Below the minimum temperature a seed preserves its vitality, above the maximum it is killed. Ire finds, likewise, that the point at which the most rupid germination occurs is intermediate between these two extremes, and lies between $79^{\circ}$ and $93^{\circ}$. Either elevation or reduction of temperature from these degrees retards the act of sprouting.

In the following table are giren the special tempera. tures for six common plants. 


\begin{tabular}{|c|c|c|c|}
\hline Whent, & $\begin{array}{l}\text { Lowoest } \\
\text { Temperature. } \\
41^{\circ} \mathrm{F} \text {. }\end{array}$ & $\begin{array}{c}\text { Highest } \\
\text { Temperature. } \\
10\left\llcorner^{\circ} \mathrm{F}\right.\end{array}$ & $\begin{array}{c}\text { Temperatire of most } \\
\text { rapid Germination. } \\
84^{\circ} \mathrm{F} .\end{array}$ \\
\hline Birley, & 41. & $10 t$ & St. \\
\hline Pea, & 44.5 & 103. & 81. \\
\hline Maize, & 48 & 115. & 93. \\
\hline Scarlet-beau, & 49. & 111. & 79. \\
\hline Bquash, & 54. & 115. & 93. \\
\hline
\end{tabular}

For all agricultural plants cultivated in New England, a range of temperature of from $55^{\circ}$ to $90^{\circ}$ is allapted for healthy and speedy germination.

It will be noticed in the above Table that the seeds of plants introduced into northern latitudes from tropical regions, as the squash, bean, and maize, require and endure higher temperatures than those native to temperate latitudes, like wheat and barley. The extremes given above are by $n 0$ me:ns so wide as would be found were we to experiment with other plints. It is proballe that some seeds will germinate nearly at $32^{\circ}$, or the freezing point of water, while the cocoa-nut is said to yield seedlings with greatest certainty when the heat of the soil is $120^{\circ}$.

Sachs has observed that the temperature at which germination takes place materially influences the relative development of the parts, and thas the form of the seedling. According to this industrious exprimenter, very low temperatures retard the production of new rootlets, buds, and leaves. The rootlets which are rudimentary in the embryo become, however, very long. On the otlur haud, very high temperatures cause the rapid formation of new roots and leares, even before those existing in the frerm are fully unfolded. The melium and most favor:ble temperatures bring the parts of the embryo first into development, at the same time the ludiments of new organs are formed which are afterward to unfold.

b. Moisture.-A certain amount of moisture is indis vensable to all growth. In germination it is needful that 14 
the seed should absorb water so that motion of the enn. tents of the germ-cells can t:lke place. Until the sced is more or less imbued with moisture, no signs of sprouting are manifested, and if a hall-sprouter seed be allowed to dry the process of growth is effectually checked.

The degree of moisture different seeds will endure or recuire is exceedingly valions. The seeds of aquatic plants niturally germinate when immersel in water. Tho seeds of many land-plants, indeed, will quicken under water, but they germinate most healthfully when moist but not wet. Excess of water often causes the seed to rot.

c. Oxygen Gas,-Free Oxygen, as contained in the air, is likewise essential. Saussure demonstrated by experiment that proper germination is impossible in its absence, and cannot proceed in an atmosphere of other gases. As we shall presently see, the chemical activity of oxygen appears to be the means of exciting the growth of the embryo.

d. Light.-It has been taught that light is prejudicial to germination, and that therefore seen must be covered. (Johnstori's Lertures on Ag. Chem. \& Geolory, ad Eng. Ed., 1p. 2:26 \& 2:37). When, however, we consider that nature does not bury seeds but seatters them on the surfice of the ground of forest anil prairie, where they are, at the most, half-covered and by no means removed from the light, we cannot accept such a doctrine. The warm and moist forests of tropical regions, which, though shaded, are by no means dark, are covered with sprouting seels. The gardener knows that the seeds of heaths, calceolirias, and some other ornamental plants, germinate best when uncovered, and the seeds of common acrieultural plants will sprout when plared on moist sand or silw-dust, with anparently no less readiness than when burierl out of ighlit.

Finally, R. IIoffmamn (Jelleshericht äber Agrirultur Chem., 1864, p. 110) has found in experiments with 24 
kinds of agrivultural seeds that light exercises no aplneciable influence of any kind on germination.

The Time required for Germination varies exceentirgly according to the kind of seed. As ordinarily observed, the fresh seeris of the willow begin to spront within 1: hours after falling to the ground. Those of clover, wheat, and other grains, germinate in three to five days. The fruits of the walnut, pine, and larch, lie four to six werks before sprouting, while those of some species of ash, beech, and maple, are said not to germinate before the expiration of $1 \frac{1}{2}$ or 2 years.

The starchy and thin-skinned seeds quicken most readily. The oily seeds are in general more slow, while such as are situated within thick and horny envelopes require the longest periods to excite growth.

The time necessary for germination depends naturally upon the fitvorableness of other conditions. Cold and drought dulay the process, when they do not check it altogether. Seeds that are buried deeply in the soil may remain for years, preserving, but not manifesting, their vitality, because they are either too dry, too cold, or have not sufficient access to oxygen to set the germ in motion.

To speak with precision, we should distinguish the time from planting the dry seed to the commencement of germination which is marked by the rootlet becoming visible, and the period that elapses until the process is complete, i. e., until the stores of the mother-seer are cxhansted, and the young plant is wholly cast upon its own resoures.

At $41^{\circ} \mathrm{F}$. in the experiments of Haberlandt, the rotlet issued after 4 days, in the case of rye, and in $5-7$ days in that of the other grains and elover. The sugar-beet, however, lay at this temperature $2: 2$ days before beginning to sprout.

At $51^{\circ}$, the time was shortened ahout one-half in case of the searls just mentioned. Maize required 11, kidney. beans 8 , and tobacco 31 days at this temperature. 
At $65^{\circ}$ the grains, clover, peas, and flax, began to sprout In one to two days; maize, beans, and sugar-beet, in $\mathbf{3}$ days, and tobacco in 6 days.

The time of completion varies with the temperature much more than that of beginning. It is, for example, according to Sachs,

$$
\text { at } 41-55^{\circ} \text { for wheat and barley } 40-15 \text { days, }
$$

At a given temperature small seeds complete germinstion much sooner than large ones. Thus at $55-60^{\circ}$ the frocess is finished with beans in $\mathbf{3 0 - 4 0}$ days.

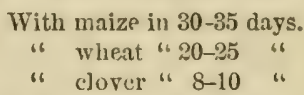

These differences are simply due to the fact that the smaller seeds have smaller stores of nutriment for the young plant, and are therefore more quickly exhausted.

Proper Depth of Sowing.-The soil is usually the medium of moisture, warmth, etc., to the seed, and it affects germination only as it influences the supply of these agencies; it is not otherwise essential to the process. The burying of seeds, when sown in the field or garden, serves to cover them away from birds and keep them from drying up. In the forest, at spring-time, we may see innumerable seerls sprouting upon the surface, or but half covered with decayed leaves.

While it is the searly universal result of experience in temperate regions that agricultural seeds germinate most surely when sown at a depth not exceeding 1-3 inches, there are circumstances under which a widely different practice is admissible or even essential. In the light and porous soil of the gardens of New IIaven, peas may be scwn 6 to 8 inches deep without detriment, and are thereby better secured from the ravages of the domestin! pigeon.

The Moqui Indians, dwelling upon the tab!e lands 
of the higher Colorado, deposit the seeds of maize 12 or 14 inches below the surfice. Thus sown, the piant thrives, while, if treated according to the plan usual in the United States and Europe, it might never appear above ground. The reasons for such a procedure are the following: The country is without rain and almost without dew. In summer the sincly soil is continuonsly parched by the sun at a temperature often exceeding $100^{\circ}$ in the sharle. It is only at the repth of a foot or more that the seed finds the moisture neeiful for its wrowth,-moisture furnished by the melting of the winter snows.*

R. Hoffmann, experimenting in a light, loamy sand, upon 24 kinds of agricultural and maket-garden seeds, found that all perished when buried 122 inches. When planted 10 inches deep, peas, vetches, beans, and maize, alone cam $€$ up; at 8 inches there appeared, besides the above, wheat, millet, onts, barley, and colza; at 6 inches those already mentioner, together with winter colza, buckwheat, and sugar-veets; at 4 inches of depth the above, and must:mrl, red and white clover, flax, horseradish, hemp, and turnips; finally, at 3 inches, lucern also appeared. Hoffimann states that the deep-planted seeds generally sprouted most quickly, and all early differences in deve'opment disappeared before the plants blossomed.

On the other hand, Grouven, in trials with sugar-beet seed, made, most probably, in a well-manured anit rather heavy soil, found that sowing at a depth of $\frac{3}{5}$ to $1 \frac{1}{t}$ inches, gave the enrliest and stronge.t plants; seeds deposite l at a depth of 21 inches requiverl 5 days longer to come up than those planted at $\frac{3}{8}$ in. It was further shown thit seeds sown shallow in a fine wet clay required 4-5 Jaye longer to come up than those placed at the same depth in the ordinary soil.

Not only the character of the soil, which influences the

* For these interesting facts the writer is indebted to Prof. J. S. Newberry. 
supply of air, anil warmth; but the kind of weather which determines both temperature and degree of moist. we, have their effect upon the time of germination, and since these conditions are so rariable, the rules of practice are laid down, and must be received with, a certain latiturle.

\section{$\S 4$.}

\section{THE CHEMICAL PHYSIOLOGY OF GERMINATION.}

The Nutritios of the Seedirs.-The young plant grows at first exclusively at the expense of the seed. It may be aptly compared to the suckling animal, which, when new-born, is incapable of proviling its own nourishment, but depends upon the milk of its mother.

The Nutrition of the Seedling fills into three processes, which, thongh distinct in character, proceed simultaneonsIv. These are, 1, Solution of the Nutritive Matters of the Cotyledons or Endosperm ; 2, Tiansfer ; and $3, A_{s}$ similation of the same.

1. The Act of Solution has no difficulty in case of dextrin, gum, the sugars, albumin, and casein. The water which the seed imbibes to the extent of one-fourth to five-fourths of its weight, at once dissolves them.

It is otherwise with the fats or oils, with starch anil with gluten, which, as such, are nearly or altogether insoluble in water. In the act of germination provision is malde for transforming these bodies into the soluble ones above mentioned. So far as these changes have been traced, they are as follows:

S'slution of firts.-Sachs has recently found that squash. seerls, which, when ripe, contain no starel, sugar, or dextrin. bat are very rich in oil $\left(50^{\circ} \digamma_{0}\right)$ and albuminoids 
$\left(40^{\circ} \%_{0}\right)$ suffer by germination such chemical change that the oil rapilly diminishes in quantity (nine-tenths disappears,) while at the same time strich, and, in some cases, sugar, is

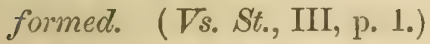

Solution of Stanch.-The starch that is thus organized from the fat of the oily seeds, or that which exists realy. formed in the firrinaceous (floury) seeds, undergoes fint her changes, which have been previously alluded to (1. 78 ), whereby it is converted into substances that are soluble in water, viz., lextrin and grape or cane sugar.

Solution of Albuminoids.-Finally, the insoluble albuminoids are gradually transformed into soluble modifications.

Chemistry of Malt.-The preparation and properties of malt may serve to give an insight into the nature of the chemical metamorphoses that have just been indicated

The preparation is in this wise. Barley or wheat (sometimes rye) is soaked in water until the kernels are soft to the fingers; then it is drained and thrown up in heaps. The masses of soaked grain shortly dry, become heated, and in a few days the emiryos send forth their radicles. The heaps are shoveled over, and spreal out so as to avoid too great a rise of temperature, and when the sprouts are about half an inch in length, the germination is checked by drying. The dry mass, after removing the spronts (radicles,) is malt, such as is usert in the manufic. ture of beer.

Malt thus consists of starchy seeds whose germination has been checked while in its early starges. The only prod. uct of the beginning growtr- - the spronts-being remov ed, it exhibits in the residual seed the first results of tho process of solution.

The following figures, derived from the rescarches of Stein, in Dresden, (TVilda's Centralblatt, 1S60, 2, pp. 823,) exhibit the composition of 100 parts of Barley, and 
of the 92 parts of Malt, and the $2 \frac{1}{2}$ of Sprouts which 100 parts of barley yield.*

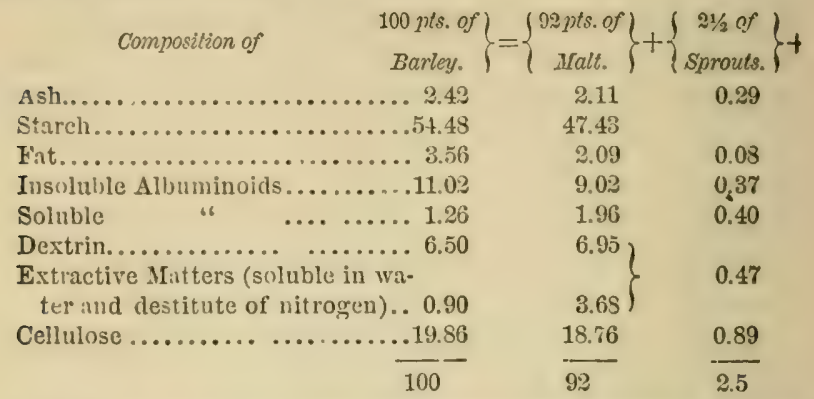

It is seen fiom the above statement that starch, fat, and insoluble albuminoids, have diminished in the malting process; while soluble albuminoids, dextrin, and othor soluble non-nitrogenous matters, have somewhat increased in quantity. With exception of $\left.3^{\circ}\right|_{0}$ of soluble " extractive matters," + the diversities in composition between barley and malt are not striking.

The proplerties of the two are, however, remarkably different. If malt be pulverized and stirred in warm water (15.) F.) for an hour or two, the whole of the starch clisappears, while sugar and dextrin take its place. The former is reconnized by the sweet taste of the wort, as tho sulution is called. On heating the wort to boiling, a quamtity of albumin is coagulated, and may be separated by filtering. This eomes in part from the trinsformation of the insoluble albuminoirs of the barley. On adding

\footnotetext{
* The analyoes refer to the materials in the dry state. Ordinarily they cor. tain from 10 to 16 jer cent of witur. It must not lie omitted to mention that the proportions of malt and sprouts. as well as their composition, vary gomewhat accorling (o) circumstances; and furthermore, the best antlyses which it is pos sible to make arc but approximate.

t The term extructice mutlers is here applied to soluble substances, whoso precise nature is not understood. They constitute i mixture which the cremist la not alie to analyze.
} 
to the filtered liquid its own bulk of a.cois jl, dextriu becomes evident, being precipitated as a whits puwder.

Furthermore, if we mix $2-3$ parts of starch with one of malt, we find that the whole undergoes the same change. An additional quantity of starch remains unaltered.

The process of germination thus developes in the seed an agency by which the conversion of starch into soluble carbohydrates is accomplished with great rapidity.

Diastase.-Payen \& Persoz attribute this action to a nitrogenous substance which they term Diastase, and which is found in the germinating seed in the vicinity of the embryo, but not in the radicles. They assert that one part of diastase is caprable of transforming 2,000 parts of starch, first into dextrin and finally into sugar, and that. malt yields ${ }_{500}^{\frac{1}{0}}$ th of its weight of this substance.

A short time previous to the investigations of Payen \& Persoz $(1833$,) Saussure found that Mucidin,* the soluble nitrogenous body which may be extracted from gluten (p. 101,) transforms starch in the manner above described, and it is now known that any albuminoid may produce the same effect, although the rapidity of the action and the amount of effect are usually far less than that exhibited by the so-called diastase.

In order, however, that the albuminoids may transform starch as above deseribed, it is doubtless necessary that they themselves enter into a state of alteration; they are in part decomposed and disappear in the process.

These bodies thus altered become ferments.

It must not be forgotten, however, that in all cases in which the conversion of starch into dextrin and sugar is accomplished artificially, an elevated temperature is re. quired, whereas in the natural process, as shown in the

* Saussure designated this body mucin, but this term being established as the name of the characteristic ingredient of animal mucus, Ritthausen uas replaced it by mucidin. 
germinating seed, the change goes on at ordinary or even low temperatures.

It is generally taught that oxygen acting on the albuminoids in presence of water and within a certain range of temperature induces the decomposition which confers on them the power in question.

The necessity for oxygen in the act of germination has been thus accounted for, as needful to the solution of the starch, etc., of the cotyledons.

This may be true at first, but, as we shall presently see, the chicf action of oxygen is probably of another kind.

How liastase or other similar substances accomplish the change in question is not certainly known.

Soluble Starch.-The conversion of starch into sugar and dextrin is thus in a sense explamed. This is not, however, the only change of which starch is susceptible. 'In the bean, (Phaseolus multiflorus), Sachs (Sitzungsberichte der Wiener Akad., XXXVII, 57) informs us that the starch of the cotyledons is dissolved, passes into the seedling, and reappoars (in part, at least) as starch, without conversion into dextrin or sugar, as these substances do not

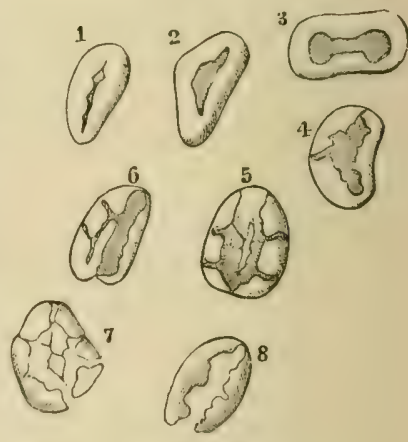

Fig. 65. appear in the cotyledons during any period of germination, except in small quantity near the joining of the scedling. Comprare p. 6t, Unorganized Starch.

The sarne authority gives the following account of the microscopic changes observed in the stareh-grains themselves, as they undergo solution. The starch-grains of the bran have a namow interior cavity, (as scen in fig. 6.j, 1.) This at first becomes filled with a liquid. 
Next, the cavity appears enlarged $(2$,$) its borders assume$ a corroded appearance $(3,4$,$) and frequently channels are$ seen extending to the surface $(t, 5,6$.) Finally, the cavity becomes so large, and the channels so extended, that the starch-grain falls to pieces $(7,8$.) Solution continues on the fragments until they have completely disap peared. In this process it is most probible that the starch assumes the liquid form without loss of its proper chemical characters, though it ceases to strike a blue colnr with iodine.*

Soluble Albuminoids.-As we have seen (p. 101, insoluble animal fibrin and casein, by long keeping with imperfect access of air, pars into solnble bodies, and latterly E. Mulder has shown that diastase rapidly accomplishes the same change. It would appear, in fact, that the conversion of a small quantity of any albuminoid into a ferment, by oxidation, is sufficient to render the whole soluble. The ferment exerts on the bodies from which it is formed, an action similar to that manifested by it to wards starch and other carbohydrates.

The production of small quantities of acetic and lactio acids (the acids of vinegar and of sour milk) has been observed in germination. These acids perhaps assist in the solution of the albuminoids.

Gaseons Products of Germination. - Before leaving this part of our subject, it is proper to notice some other results of germination which have been thought to belong to the process of solution. On referring to the table of the composition of malt, we find that 100 parts of dry barliy yield 92 parts of malt and $2 \frac{1}{2}$ of spronts, leaving $5 \frac{1}{2}$ parts unaccounted for. In the malting process $1 \frac{1}{2}$ parts of the grain are dissolved in the water in which it is souked. The remaining 4 parts escape into the atmosphere in the gaseous form.

* Accrding to riebir, this blue reaction depends upon the adhesion of the locine to the starch, aud is not the result of a chemical combination. 
Of the elements that assume the gaseous conilition, cas bun does so to the greatest extent. It unites with atmus. Fheric oxygen (partly with the oxygen of the seel, according to Oudemans) producing carbonic aciul gas $\left(\mathrm{CO}_{2^{\circ}}\right)$ Mydrogen is likewise separated, partly in union with oxygen, as water $\left(\mathrm{H}_{2} \mathrm{O}\right)$, but tu some lecree in the free state. Free nitrogen appears in considerable amount, (Schulz, Jour. für Prikt. Chem., 87, p. 163,) while very minute quantities of Hydrogen and of Nitrogen combine to gaseous ammonia $\left(\mathrm{NH}_{3}\right.$ )

Heat developed in Germination. - These chemical changes, like all processes of oxidation, are accompanied with the production of heat. The elevation of temperature may be impereeptible in the germination of a single seed, but it nevertheless occurs, and is doubtless of much importance in favoring the life of the young plant. The he:lps of sprouting grain seen in the malt-house warm so rapidly and to such an extent, that much care is requisite to resulate the process; otherwise the malt is damaged by over-heating.

\section{The Transfer of the Nutriment of the Seedling} from the cotyledons or endosperm where it has undergone solution, takes place throngh the medium of the water which the scel absorbs so largely at first. This water fills the cells of the seed, and, dissolving their contents, carries them into the young plant as rapidly as they are required. The path of theil transter lies through the point where the embryo is attached to the cotyledons; thence they are listributen at first chiefly downwaris into the extending radicles, after a little while both downwards and "1) warls toward the extremities of the seedling.

Sachs has observed that the carbohychates (sugar and dextrin) ocenpy. the collular tissue of the rind and pith, which are penetrated by numerous air-passages; while at first the albuminoids chiefly dittuse themselves through 
the intermerliate crmbial tissue, which is destitute of airpassages, and are present in largest relative quantity at the extreme ends of the rootlets and of the plumule.

In another chapter we shall notice at length the phenom. ena and physical laws which govern the diffusion of liquidis into each other and through membranes similar to those which constitute the walls of the cells of plarts, and there shall be able to gather some idea of the curses which set up and maintain the transfer of the materials of the seed into the infant plant.

3. Assimilation is the conversion of the transferred nutriment into the substance of the plant itself. This process involves two stages, the first being a chemical, the second, a structural transformation.

The chemical changes in the embryo are, in part, simply the reverse of those which occur in the cotyledor..; viz., the soluble and structureless proximate principles are metamorphosed into the insoluble and organized on:s of the same chemical composition. Thus, dextrin may jass into cellulose, and the soluble albuminoids may revert in part to the insoluble condition in which they existed in the ripe seed.

But many other and more intrieate changes proceed in in the act of a-similation. With regart to a few of these we have some imperfect knowledge.

Dr. Sachs informs us that when the embryo begins to grow, its expansion at first consists in the enlargement of the ready-formed cells. As a part elongates, the starch whish it contains (or which is formed in the early stages of this extension), disappears, and sugar is found in its steat, dissolved in the juices of the cells. When the orean has attained its full size, sugar can no longer le detecterl; while the walls of the cells are found to have grown both in circumference and thickness, thus indicating the accumu lation of cellulose. 
Oxygen Gas needful to Assimilation.-Traube has made some experiments, which seem to prove conclusively that tite jrocess of assimilation requires free oxygen to surround and to be absorbed by the growing parts of the germ. This olsserver found that newly-sprouted pea-seedlings continued to develope in a normal manner when the cot yledons, radicles, and lower part of the stem, were with drawn from the influence of oxygen by coating with varnish or oil. On the other hand, when the tip of the plumule, for the length of about an inch, was coated with oil thickened with chalk, or when by any means this part of the plant was withdrawn from contact with free oxygen, the seedling ceased to grow, withered, and shortly perished. Traube observed the elongation of the stem by the following expedient.

A young pea-plant was fastened by the cotyledons to a rod, and the stem and rod were both graduated by delicate cross-lines, liid on at equal intervals, by means of a brush dipped in a mixture of oil and indigo. The growth of the stem was now manifest by the widening of the spaces between the lines; and by comparison with those on the rol, Traube remarked that no growth took place at a distance of more than 10-12 lines from the base of the terminal bud.

Here, then, is a coincidence which appears to demonstrate that free oxygen must have access to a growing part. The fact is further shown by varnishing one side of the stem of a young pea. The varnished side ceases to extend, the uncoated portion continues enlarging, which results in, and is shown by, a curvature of the stem.

Traube further indicates in what manner the elabora. tion of cellulose from sugar may require the coüperation of oxygen and evolution of carbonic acid, as expressed by the subjoined equation.

$$
\begin{gathered}
\text { Glucase. Oxygen. Carbonic Acid. Water. Cellulose. } \\
2\left(\mathrm{O}_{12} \mathrm{H}_{26} \mathrm{O}_{19}\right)+3 \mathrm{H}=12\left(\mathrm{CO}_{2}\right)-\mathbf{1 4}\left(\mathrm{H}_{2} \mathrm{O}\right)+\mathrm{C}_{19} \mathrm{H}_{20} \mathrm{O}
\end{gathered}
$$


When the act of germination is finished, which occurs as soon as the cotyledons and endosperm are exhausted of all their soluble matters, the plant begins a fully independent life. Previously, however, to being thus thrown upon its own resources, it has developed all the orrans: needful to collect its food from without; it has unfolder its perfect leaves into the atmosphere, and pervaded a portion of soil with its rootlets.

During the latter stages of germination it gathers its nutriment both from the parent seed and from the external sources which afterward serve exclusively for its support.

Being fully provided with the apparatus of nutrition, its development suffers no check from the exhaustion of the mother seed, unless it has germinated in a sterile soil, or under other conditions adverse to vegetative life.

\section{CHAPTER II.}

\section{$\S 1$.}

THE FOOD OF THE PLANT IVHEN INDEPENDENT OF THE SEED.

This subject will be sketched in this place in but the briefest outlines. To present it fully would necessitate entering into a detailed consideration of the Atmosphere and of the Soil whose relations to the Plant, those of the soil especially, are very numerous and complicated. A separate volume is therefore required for the adequate treatment of these topics.

The Roots of a plant, which are in intimate contact with the soil, absorb thence the water that flls the active 
cells; they also imbibe such salts as the water of the soil holds in solution; they likewise act directly on the soil, and dissolve substances, which are thus first made of avail to them. The compoun! ? that the plant mist derive from the soil are those which are found in its ash, since these are not volatile, and cannot, therefore, exist in the atmosphere. The root, however, commonly takes up some other elements of its nutrition to which it has immediate access. Leaving out of view, for the present, those matters which, though found in the plant, appear to be unessential to its growth, viz., silica, soda and manganese, the roots absorb the following substances, viz. :

\begin{tabular}{|c|c|c|}
\hline $\begin{array}{l}\text { Sulphates } \\
\text { Phosphates } \\
\text { Nitrates and } \\
\text { Chlorides }\end{array}$ & of & $\begin{array}{l}\text { Potash. } \\
\text { Lime. } \\
\text { Magnesia and } \\
\text { Iron. }\end{array}$ \\
\hline
\end{tabular}

These salts enter the plant by the absorbent surfaces of the younger rootlets, and pass upwards through the active portions of the stem, to the leaves and to the new-forming buds.

The Leaves, which are unfolded to the air, gather from it Carbonic Acid Gas. This compound suffers decomposition in the plant; its Carbon remains there, its Oxygen or an equivalent quantity, very nearly, is thrown off into the air again.

The decomposition of carbonic acid takes place only by day and under the influence of the sun's light.

From the earbon thus acquired and the elements of water with the coöperation of the ash-ingredients, the plant organizes the Carbohydrates. Probably glucose, perhaps dexirin or soluble starch, are the first products of this synthesis.

The formation of carbohydrates appears to proceed in the chlorophyll-cells of the leaf.

The Albuminoids require for their production the pres. exce of a componud of Nitrogen. The salts of Nitrin 
Acid (nitrates) are commonly the chief, and may be the only supply of this element.

The other proximate principles, viz. pectose, the fats, the alkaloids, and the acids, are built up from the sims food-elements. In all cases the steps in the construc. (ion of organic matters are unknown to us, or subjects of uncertain conjecture.

The carbohydrates, albuminoids, etc., that are organized in the folinge, are not only transformed into the solir tissues of the leaf, but descend and diffuse to every active organ of the plant.

The plant has within certain limits a power of selecting its food. The sea-weed, as has been remarked, contains more potash than soda, although the latter is 30 times more abundant than the former in the water of the ocean. Vegetation cannot, however, entirely shut out either : $\mathrm{x}$ cess of nutritive matters or bodies that are of no use or even poisonous to it.

The functions of the Atmosphere are essentially the same towards plants, whether growing under the conditions of aqueculture, or under those of agriculture.

The Soil, on the other hand, has offices which are peculiar to itself. We have seen that the roots of a plant have the power to decompose salts, e. g. nitrate of putash and chloride of ammonium (p. 170, in order to appropriate one of their ingredients, the other being rejected. In aqueculture, the experimenter must have a care to remove the substance which would thus : tccumulate to the rletriment of the plant. In agriculture, the soil, by virtue of its chemical and physical qualities, renders such rejectell matters comparatively insoluble, and theretore innos. nous.

The Atmosphere is nearly invariable in its composition at all times and over all parts of the earth's surface. Its power of directly feeding crops has, therefore, a natural limit, which cannot be increased by art. 
The Soil, on the other hind, is very variable in cumpo sition and quality, and may be enriched and improved, or deteriorated and exhausted.

From the Atmosphere the crop can derive no apprecj. alle cuantity of those elements that are found in its $\Lambda$ sh.

In the Soil, howerer, from the waste of both plants and animals, may accumulate large supplies of all the elements of the Volatile part of Plants. Carbon, certainly in the form of carbonic acid, probably or possibly in the condition of Humus (Vegetable Mould, Muck), may thus be put, as food, at the disposition of the plant. Nitrogen is chiefly furnished to crops by the soil. Nitrates are formed in the latter from various sources, and ammonia-salts, together with certain proximate animal principles, viz., ure:l, guanin, tyrosin, uric acid and hilpuric acid, likewise serve to suplily nitrogen to vegetation and are ingredients of the best manures. It is, too, from the soil that the crop gather's all the Water it requires, which not only serres as the fluid medium of its chemical and structural metamorphoses, but likewise must be regarded as the mar terial from which it mostly appropriates the Hydrogen and Oxygen of its solid components.

\section{$\S 2$.}

THE JUICES OF THE PLANT, THEIR NATURE AND MOVEMENTS.

Very erroneous notions are entertained with regard to the nature and motion of saty. It is commonly taught that there are two regular and opposite currents of sap circulating in the plint. It is stated that the "cruile sap" is taken up from the soil by the roots, ascends through the 
ressels (ducts) of the wood, to the leaves, there is concen. trated by evaporation, "elaborated" by the processes that go on in the foliage, and thence descenoss through thro ressels of the inner bark, nourikhing these tissucs in its way down. The facts from which this theory of the sapp first arose, all admit of a very different interpretation: while numerous considerations demonstrate the essential falsity of the theory itself.

\section{Flow of sap in the plant-not constant or necessary.} -We speak of the Flow of Sup as if a rapid current were incessantly streaming through the plant, as the blood circulates in the arteries and veins of an animal. This is an erroneous conception.

A maple in early March, without foliage, with its whole stem enveloped in a nearly impervious bark, its buds wrapped up in horny scales, and its roots surrounded by cold or frozen soil, cannot be supposed to have its sap in motion. Its juices must be nearly or absolutely at rest, and when sap runs copiously from an orifice made in the trunk, it is simply because the tissues are chargen with water under pressure, which escapes at any outlet that may be opened for it. The sap is at rest until motion is caused by a perforation of the bark mil new wool. So, ton, when a plant in early leaf is situated in an atmosphere chargel with moisture, as happens on a rainy day, there is little motion of its sap, although, if wounded, notion will 2e established, and water will stream more or less from all parts of the plant towards the cut.

Sap does move in the plant when evaporation of water goes on from the surface of the foliage. This always hap. pens whenever the air is not saturated with vapor. When a wet cloth hung out, dries rapidly by giving up its moisture to the air, then the leaves of plants lose their water more or less readily, according to the nature of the foliage.

Mr. Lawes found that in the moist climate of England 
common plants (Wheat, Barley, Beans, Peas, and Clorer). exhaled during 5 months of growth, more than 200 times their (dry) weight of water. The water that thus evaporates from the leaves is supplied by the soil, and entering the roots, rapidly streams upwards through the stem as long as a waste is to be supplied, but ceases when evaporation from the foliage is checked.

The uproard motion of sap is therefore to a great degree independent of the vital processes, and comparatively unessential to the welfure of the plant.

Flow of sap from the plant. "Bleeding."-It is a familiar fict, that from a maple tree "tapped" in springtime, or from a grape-vine wounded at the same season, a copius flow of sap takes place, which continues for a num. ber of weeks. The escape of liquid from the vine is commonly termed "hleeding," and while this rapid issue of sap is thus strikingly exhibited in comparatively few cases, bleeting appears to be a universal phenomenon, one that may occur, at least, to some degree, under certain conditions with every plant.

The conditions unler which sap flows are varions, according to the character of the plant. Our perennial trees have their annual period of active growth in the warm season, and their regetative functions are nearly suppressed during cold weather. As spring approaches the tree renews its growth, and the first evilence of change within is furnished by its bleerling when an opening is made through the bark into the young wood. A maple, tapped for making sugar, loses nothing until the spring warmth sttains a certain intensity, and then sap begins to flow from the wounds in its trunk. The flow is not constant, but fluctnates with the thermometer, being more copious when the weather is warm, and falling off or suffering check altogether as it is colder.

The stem of the living maple is always charged with 
water, and nerer more so than in winter.* This water is either pumped into the plant, so to speak, by the rootpower already noticed (p. 248, or it is generated in the trunk itself. The water contained in the stem in cold weather is undoubtedly that raised from the soil in the autumn. That which first flows from an angur-hole, in March, may be simply what was thus stored in the trunk; but, as the escape of sap goes on for 14 to 20 dlays at the rate of several gallons per day from a single tree, new quantities of water must be continually suppliecl. That these are pumped in from the root is, at first thought, difficult to understand, because as we have seen (p. 250) the root-power is suspended by a certain low temperature (unknown in case of the maple) and the flow of sap often begins when the ground is covered with one or two feet of snow, and when we cannot suppose the soil to have a higher temperature than it had during the previous winter months. Nevertheless, it must be that the deeper roots are warm enough to be active all the winter through, and that they begin their action as soon as the trunk acquires a temperature sufficiently high to admit the movement of water in it. That water may be produced in the trunk itself to a slight extent is by no means impossible, for chemical changes go on there in spring-time with much rapidity, whereby the sugar of the sap is formed. These changes have not been sufficiently investigated, however, to prove or disprove the generation of water, and we must, in any case, assume that it is the root-power which chiefly maintains a pressure of liquid in the tree.

The issue of sap from the maple tree in the sugar-season

- Experiments made in Tharand, Sarony, under direction of Stoeckhardt. show that the proportion of water, both in the bark and wood of trees, varieg considerably in different seasuns of the year, ranging. in case of the beech, from 35 to 49 per cent of the fresh-felled tree. The greatest proportion of water in the wood was found in the months of December and Janury; in the bark, in March to May. The minimum of water in the wood occurred in May, Jane, and Jüy; in the bark, much irregularity was observed. Chem. Ackergmans, 1866 p. 159 
is closely ccnnected with the changes of teniperature that take place above ground. The sap begins to flow from a cut when the trunk itself is warmed to a certain point ant, in general, the flow appears to be the more rapir the warmer the trunk. During warm, clear days, the radiant heat of the sun is absorbed by the dirk, rough surface of the tree most abundantly; then the temperature of the latter rises most speedily and acquires the greatest elevation-even surpasses that of the atmosphere by several degrees; then, too, the yild of sap is most copious. On clear nights, cooling of the tree takes place with corresponding rapidity; then the snow or surface of the ground is frozen, and the flow of sap is checked altogether. From trees that have a sumny exposure, sap rins earlier and faster than from those having a cold northern aspect. Sap starts sooner from the spiles on the south sile of a tree than from those towards the north.

Duchartre, (Comptes Rendus, IX, 754,) passed a vine situated in a grapery, out of doors, and back again, through holes, so that a midille portion of the stem was exposed to a steady winter temperature ranging from 18 to $10^{\circ} \mathrm{F}$, while the remainler of the vine, in the house, was surrounded by an atmosphere of $70^{\circ} \mathrm{F}$. Under these circumstances the buds within developed vigorously, but those without remained dormant and opened not it day sooner than buds upon an arljacent vine whose stem was all out of doors. That sap pinssed through the cold part of the stem was shown by the fatet that the interior shoots sometimes wilted, but again recovered their turgor, which could only happen from the partial suppression and renewal of a supply of water through the stem. Payen examiner the woor of the vine at the conclusion of the experiment, and found the starch which it originally contained to have been equally removed from the warm and the exposed parts.

That the rate at which sap passed through the stem was 
influenced by its temperature is a plain deduction from the fact that the leaves within were found wilted in the morning, while they recovered toward noon, although the temperature of the air without remained below freezing. The wilting was no doubt chiefly due to the diminisher power of the stem to transmit water; the return of the leaves to their normal condition was probably the consequence of the warming of the stem by the sun's radiant heat.*

One mode in which changes of temperature in the trunk influence the flow of sin is very obvious. The woor-cells contain, not only water, but air. Both are expanded by heat, and both contract by cold. Air, especially, under. goes a decided change of bulk in this way. Water expands nearly one-twentieth in being warmed from $32^{\circ}$ to $212^{\circ}$, and air increases in volume inore than one-third by the same change of temperature. When, therefore, the trunk of a tree is warmed by the sun's heat the air is expanded, exerts a pressure on the sap, and forees it out of any wound made through the bark and woorl-cells. It only requires a rise of temperature to the extent of a few degrees to occasion from this cause alone a considerable flow of sap from a large tree. (Hartig.)

If we admit that water continuously enters the deep-lying roots whose temperature and absorbent power must remain, for the most part, invariable from day to day, we should have a constant slow escape of sap from the trunk were the temperature of the latter uniform and suficiently high. This really happens at times during every sugarzeason. When the trunk is cooled down to the freezing point, or near it, the contraction of air and water in the tree makes a vacrum there, sap ceases to flow, and air is

* The temperature of the air is not always a sure indication of that of the Bolid bodies which it surrounds. A thermometer will often rise by ezposure of the bub to the direct :ays of the sun, 30 or $43^{\circ}$ above its indicatious when in the arsde. 
sucked in through the spile; as the trunk becomes heated again the gaseous and liquid contents of the ducts $\in \mathbf{S}^{-}$ pand, the flow of sap is renewed, and proceeds with increased rapidity until the internal pressure passes its maximum.

As the season ailvances and the soil becomes heated, the 1oot-power undoubtedly acts with increased vigor anil larger quantities of water are forced into the trunk, but at a certain time the escape of sap from a wound suddenly ceases. At this period a new phenomenon supervenes. The buts which were formed the previous summer begin to expand as the vessels are distended with sap, and finally, when the temperature attains the proper range, they unfold into leaves. At this point we have a proper motion of sap in the tree, whereas before there was little motion at all in the sound trunk, and in the tapped stem the motion was towards the orifice and thence out of the tree. The cessation of flow from a cut results from two circumstances: first, the vigorous cambial growth, whereby incisions in the bark and wood rapilly heal up; and second, the extensive evaporatior that goes on from foliage.

That evaporation of water from the leaves often proceeils more rapidly than it can be supplied by the roots is shown by the facts that the delicate leaves of many plints wilt when the soil about their roots becomes dry, that water is often rapidly sucked into wounds on the st ms of trees which are covered with foliage, and that the proportion of water in the wood of the trees of temperate latitudes is le'st in the months of May, Jume, and July.

Evergreens do not bleed in the spring-time. The oak loses little or no s:tp, and among other trees great diver:ity is noticed as to the amount of water that escapes at a wound on the stem. In case of overgreens we have a stem destitute of all pruper vasoular tissue, and almitting a flow of liquid only through the perforations of the wood. 
cells, which, from their content of resinous matters, should imbilue water less readily than other kinds of wood. Again, the leaves armit of continual evaporation, and furnish an outlet to the water The colored heart-wood existing in many trees is impervious to water, as shown by the experiments of Boucherie and Hartig. Sap can only flow through the white, so-cilled sap-wood. In early June, the new shoots of the vine do not bleed when cut, nor does sap flow from the wounds made by breaking them off close to the older stem, although a gash in the latter bleeds profusely. In the young branches, there are no channels that permit the rapid eflux of water.

Composition of Sap.-The s:up in all cases consists chiefly of water. This liquid, as it is absorbed, hrings in from the soil a small proportion of certain saline matters -the phosphates, sulphates, nitrates, etc., of the alkalies and alkali-earths. It finds in the plant itself its organic ingredients. These may be derived from matters stored in reserve during a previous year, as in the spring sap of trees; or may be newly formed, as in summer growth.

The sugar of maple-sap, in spring, is undoubtedly produced by the transformation of stirch which is found abundantly in the wool in winter. Accorling to Hartig, (Jour. fïr Prakt. Ch., 5, 1). 21\%, 1835,) all deciduous trees contain starch in their wood and yicld a sweet spring sap, while evergreens contain little or no starch. Hartig reports having been able to procure from the root-wool of the horse-chestnut in one instance no less than $26 \mathrm{per}$ cent of starch. This is deposited in the tissues during sumure and autumn to be rissolved for the use of the plint in developing new foliage. In evergreens anil amual plants the organic matters of the sap are derived more directly from the foliage itself. The leaves absorb cirbonic acid and unite its carbon to the elements of water, with the proluction of sugar and other carbohyliates. In the leaves, also, probably nitrogen from the nitrates and am- 
monia-salts gatherel by the roots, is uniterl to carbon, hydrogen, and oxygen, in the formation of albuminoils.

Besides sugrar, malie acid and minute quantities of albumin exist in maple sap. Towarls the close of the sugrar-season the sap appears to contain other organic substances which render the sugur impure, brown in color, and of diffe:ent flavor.

It is a matter of observation that maple-sugar is whiter, purer, and "grains" or crystallizes more reaclily in those years when spring-rains or thaws are lea-t frequent. This fact woull appear to inilicate that the brown organic matters which water extracts from leaf-mould may enter the roots of the trees, as is the belief of practical men.

The spring-sap of many other deciduous trees of temperate climates contains sugar, but while it is cane sugar in the maple, in other trees it consists mostly or entirely of grape sugar.

Sugar is the chief organic ingredient in the juice of the sugar cane, Indian corn, beet, carrot, turnip, and parsnip.

The sap that flows from the vine and from many cultivated herbacenus plants contains little or no sugar; in that of the vine, gum or dextrin is found in its ste:tl.

What has already been stated makes evident that we camnot infer the quantity of sap in a plant from what may run out of an incision, for the sap that thus issues is for the most part water forced up from the soil. It is equally plain that the sap, thus collected, has not the normal composition of the juices of the plant; it must be diluted, and nutst be the more diluted the longer and the more rap idly it flows.

Ulbricht has made partial annlyses of the salp obrainer from the stumpss of potato, trbacco and sum-flow er plints. He formd that snecessive portion', collecterl septaticly, exhibited a decreasing eoncentration. In sunflower sap, gathered in five successive purtions, the liter contained the following quantities (grams) of solid matter: 


\section{$\begin{array}{lllll}1 & 2 & 3 & 4 & 5\end{array}$ \\ $\begin{array}{lllllll}\text { Volatile substance } & -1.45 & 0.60 & 0.30 & 0.25 & 0.21\end{array}$ \\ $\begin{array}{lllllll}\text { Ash - - - - } & 1.58 & 1.56 & 1.18 & 0.70 & 0.60\end{array}$

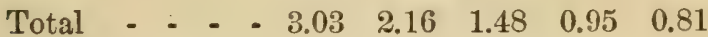

The water which streams from a wound dissolves and carries forward with it matters, that in the uninjured plant would probab y suffer a much less rapid and extensive translocation. From the stump of a potato-stalk would issue by the mere mechanical effect of the flow of water substances generated in the leaves whose proper movement in the uninjured plant would be downwards into the tubers.

Different kinds of sap.-It is necessary at this point in our discussion to give prominence to the fact that there are different kinds of sap in the plant. As we have seen, (p. 267,) the cross section of the plant presents two kinils of tissue, the cellular and rascular. These carry different juices, as is shown by their chemical reactions. In the cell-tissues exist chiefly the non-nitrogenous principles, sugar, starch, oil, etc. The liquid in these cells, as Sachs has shown, commonly contains also organic acids and acidsalts, and hene gives a blue color to red litmus. In the vascular tissue albuminoids preponclerate, and the sap of the ducts commonly has an alkaline reaction towards test papers. These different kinds of sap are not, however, always strictly confined to either tissue. In the root-tips and buis of many plants (maize, squash, onion) the young (new-formed) cell-tissue is alkaline from the preponderance of albuminords, while the spring sap flowing from the lucts and wood of the maple is fintly acid.

In many plants is found a system of channels (milk. ducts) independent of the vascular bundles, which contain an opaque, white, or yellow juice. This liquid is seen to 
exude from the broken stem of the milk-weed (Asclepias,) of lettuce, or of celandine (Chelidonium,) and may be nutieed to gather in drops upon a fresh-cut slice of the swect putato. The milky juice often differs not more strikingly in appearance than it does in tapte, from the iransparent sap of the cell-tissue and rascular bundles. The former is commonly acrid and bitter, while the latter is sweet or simply insipid to the tongue.

Motion of the Nutrient Hatters of the plant. - The occasional rapisl passage of a current of water upwards through the plant must not be confoumderl with the normal, necessary, and often contrary motion of the nutrient matters out of which new growth is organized, but is an independent or highly subordinate process by which the plant adapts itself to the constant changes that are taking place in the soil and atmosphere as regards their content of moisture.

A plant supplied with enough moisture to keep its tissues turgid is in a normal state, no matter whether the water within it is nearly free from upward flow or ascends rapidly to compensate the waste by evaporation. In both cases the motion of the matters dissolved in the sap is nearly the same. In both cases the plant derelopes nearly alike. In both cases the nutritive matters gathered at the root-tip: ascend, and those gathered by the leaves descend, being listributed to every growine cell; and these motions are comparatively independent of, and but little influenced by, the motion of the water in which they are dissolved.

The upward flow of sap in the plant is eonfined to the rascular bundles, whether these are arranged symmetrically and compactly, as in exogrnous plants, or clistributed singly through the stem, as in the cmlogens. This is not only seen upon a bleerling stump, but is male evident by the oft-observed fact that colored liquids, when absorbed into a plant or cutting, visibly follow the course of the 
vessels, though they do not commonly penetrate the spira. ducts, but ascend in the sieve-cells of the cambium.*

The rapid supply of water to the foliage of a plant either from the roots or firom a vessel in which the cut stem is immersed, goes on when the cellular tissues of the burk and pith are remored or interrupted, but is at once checked by severing the vascular bundles.

The proper motion of the nutritive matters in the plant -of the salts dissolved from the soil and of the organic principles compounded from crrbonic acil, water, and nitric acid or ammonia in the leares-is one of slow diffusion mostly through the walls of imperforate cells, and groes on in all directions. New growth is the formation and expansion of new cells into which nutritive substances are imbibed, but not pourer through visible pasiges. When closed cells are converted into ducts or visibly communicate with each other by pores, their expansion has censed. Henceforth they merely become thickened by interior deposition.

\section{Morements of Nutrient Matters in the Bark or Rind.} -The ancient observation of what ordinarily ensues when a ring of bark is removed from the stem of an exogenous tree, led to the erroneous assumption of a formal downward current of "elaborated" sap in the bark. When a cutting from one of our common trees is girtled at its middle and then placed in circumstances favorable for growth, as in moist, warm air, with its lower extremity in witer, roots form chietly at the edge of the bark just above the removed ring. The twisting, or half-brealing as well as ringing of a layer, promotes the development of roots. Latent buds are often called forth on the stems of fruit trees, and branches grow more vigorously, by making a transverse incision through the bark just below

\footnotetext{
* As in Unger's experiment of placing a hyacinth in the juice of the poie weed (Phytolasca, ) or in Hallier's obscrvations on cuttiugs dipped in cherry-juice (Fe. St., IX, p. 1.)
} 
the point of their issue. Girdling a fruit-bearing branch of the vine near its junction with the older wood has the effect of greatly enlarging the grapes. It is well known that a wite wound made on the stem of a tree heals up by the formation of new wood, and commonly the growth is most rapil and abundant above the cut. From these facts it was concluded that sap descends in the bark, and, not being able to pass below a wound, leads to the organization of new roots or wood just above it.

The accomplanying illustration, fig. 66 , represents the base of a cutting from an cxoyenous stem (pear or curran:) girdled at $B$ and kept for some days immersed in water to the depth inclieated by the line $L$. The first minnifestation of growth is the formation of a protuberance at the lower edge of the bark, which is known to gardeners as a callous, $C$. This is an extension of the cellular tissue. From the callous shortly appear rootlets, $R$, which originate from the vaseular tisstie. Rootlets also break from the stem above the callous and ulso above the water, if the air be moist. They appear likewise, thourh in less number, below the rirdled place.

Nearly all the organic substances (carbohydrates, albuminoils, lignin, etc.,) that

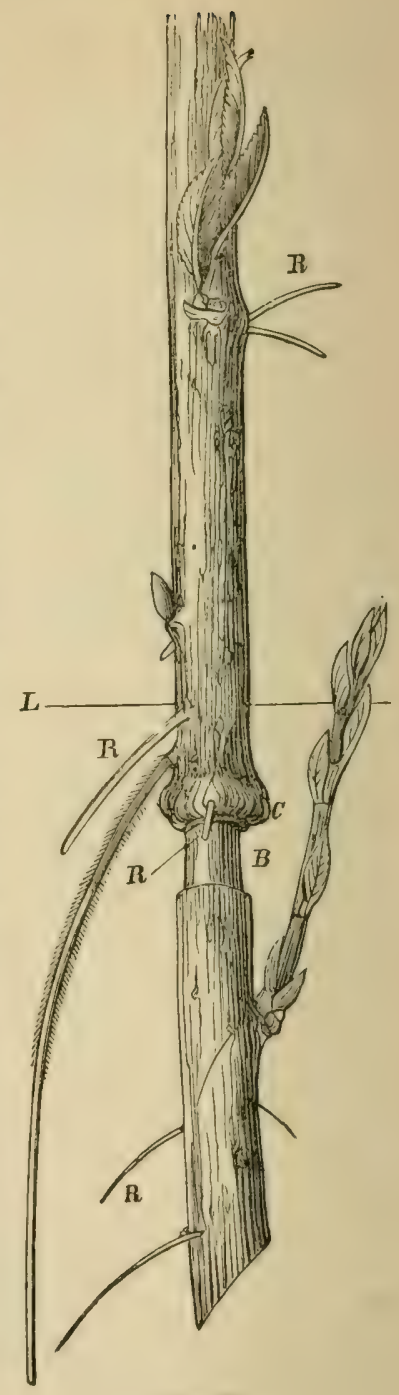

Fig. 66. 
are formed in a plant are produced in the leaves, and must necessarily find their way down to nourish the stem and roots. The facts just mentioned demonstrate, indeerl, that they do go down in the bark. W have, however, no proof that there is a downwarl Tcro of sap. Such a flow is not indicated by a siugrli livet, for, as we have before seen, the only current of water in the uninjured plint is the upward one which results from root-action and evaporation, and that is variable and mainly independent of the distribution of nutritive matters. $\mathrm{Closer}$ investigation has shown that the most abundant downward movement of the nutrient matters generated in the leaves proceeds in the thin-walled sieve-cells of the cambium, which, in exogens, is young tissue common to the outer wood and the inner bark-which, in fact, unites bark and wook. The tissues of the leaves communicate directly with, and are a continuation of, the cambium, and hence matter's formed by the leaves must move most rapidly in the cambium. It they pass with greatest freedom through the sieve-cells, the fart is simply demonstration that the latter communicate most clireetly with those parts of the leaf in which the matter's they concturt are organized.

In emilogenous plints and in some exogens (Piper medium, Amaranthus sanguiners) the vasenlar bundles containing sieve-cells pass into the pith and are not confined to the exterior of the stem. Girdling such plants does not give the result above described. With them, roots are formed chiefly or entirely at the base of the cutting, (Hanstein, and not above the girdled place.

In all cases, without exception, the matters organized s. the leaves, though most readily and abundantly moving downards in the vascular tissues, are not confined to them exclusively. When a ring of bark is removed from a tree, the new cell-tissues, as well as the visculir, are interrupted. Notwithstanding, matters are transmitted lownwards, through the older wood. When but a narror 
ring of bark is removed from a cutting, roc ts often appear below the incision, though in less number, and the new growth at the elges of a wound on the trunk of a tree, though most copious above, is still decided below-goes on, in fact, all around the gash.

Both the cell-tissue and the vascular thus admit of the transport of the nutritive matters downwarls. In the former, the carbohydrates-starch, sugar, inulin-the fats, and acils, chiefly occur and move. In the large ducts, air is contained, except when by vigorous root-action the stem is surcharged with water. In the sieve-ducts (cambium) are found the albuminoids, though not ummired with carbohydrates. If a tree have a deep gash cut into its stem, (but not reaching to the colored heart-woor?, growth is not suppressed on either side of the cut, but the nutritive matters of all kinls pass out of a vertical direction around the incision, to nourish the new wood above and below. Girdling a tree is not fatal, if done in the spritz or early summer when growth is rapid, provided that the young cells, which form externally, are protected from iryness and other destructive influences. An artificial bark, i. e., a covering of cloth or clay to keep the exposed wood moist and away from air, saves the tree until the wound heals over:* In these cases it is obvious that the substances which commonly preponderate in the sieveducts must pass through the cell-tissue in order to reach the pint where they nourish the growing organs.

Evidence that nutrient matters also pass upwards in the bark is furnisherl, not only by tracing the course of colored liquids in the stem, but also by the fact that ender veloped luds perish in most cases when the stem is girdled betwen them and active leaves. In the exceptions to this rule, the vascular bundles penetrate the pith, and

* If the freshly exprosed woon be rubbed or wiped with a clath, whereby the moint amlian layer (of cells containing nuclei and capable of $\mathrm{m}$ itiplyings is re moved, no growth can occur. Ratzeburg. 
thereby demonstrate that they are the channels of this movement. A minority of these exceptions again makes evident that the sieve-cells are the path of transier, for, as H:nnstein has shown, in certain plants (Solanacer, Asclepiader, etc.,) sieve-cells penetrate the pith unaccompanied by any other clements of the vascular bundle, and girdled twigs of these plants grow above as well as beneath the wound, although all leaves above the girdled place be cut off, so that the nutriment of the buds must come fiom below the incision.

The substances which are organized in the foliage of a plant, as well as those which are imbibed by the roots, move to any point where they can supply a want. Carbohyirates pass from the leaves, not only downivards, to nourish new roots, but upwards, to feed the buds, flowers, and fruit. In case of cereals, the power of the leaves to gather and organize atmospheric fool nearly or altogether ceases as they approach maturity. The seed grows at the expense of matters previously stored in the foliage and stems (p. 218, ) to such an extent that it may ripen quite perfectly although the plant be cut when the kernel is in the milk, or even earlier, while the juice of the seeds is still watery and before starch-grains have begun to form.

In biemnial root-crops, the root is the focus of motion for the matters organized by growth during the first year; but in the second year the stores of the root are completely exhausted for the support of flowers and seed, so that the direction of the movement of these organized matters is reversed. In both years the motion of water is always the same, viz., from the soil upwards to the leaves.*

The summing up of the whole matter is that the nutri-

* The motion of water is always upwards because the soil always contains more water than the air. If a plant were so situated that its roots should eteadily lack water while its foliagre had an excess of this liquid, it cannot be doubted that then the "sap" would pass down in a regnlar flow. In this case; nevertheless, the nutrient matters would take their normal course. 
ent sulstances in the plant are not absolutely confined to any path, and may move in any direction. The fact that they chiefly follow certain channels, and move in this or that direction, is plainly dependent upon the structure and arrangement of the tissues, on the sources of nutriment, and on the seat of growth or other action.

\section{$\S 3$.}

THE CAUSES OF Motion of the VEgetable JUICes.

Porosity of Vegetable Tissues,-Porosity is an universal property of massive bodies. The word porosity implies that the molecules or smallest particles of matter are always sejarated from each other by a certain space. In a multitude of cases bodies are visibly porous. In many more we can see no pores, even by the aid of the highest magnifying powers of the microseope; nevertheless the fact of porosity is a necessary inference from another fact which may be observed, viz., that of absorption. A fiber of linen, to the unassisted eye, has no pores. Under the microscope we find that it is a tubular cell, the bore being much less than the thickness of the walls. By immersing it in water it swells, becomes more transparent, and increases in weight. If the water be colored by solution of indigo or cochineal, the fiber is visibly penetrated by the dye. It is therefore porous, not only in the sense of having an interior cavity which becomes visible by a high magnifying power, but likewise in having throughout its aplarently imperforate substance innumerable channels in which liquids can frecly pass. In like manner, all the vegetable tissues are more or less porous and penetrible to water.

Imbibition of Liquids by Porous Bodies.-Not only do the tissues of the plant admit of the access of water into 
their pores, but they forcibly drink in or absorb this liquid, when it is presented to them in excess, until their pores are full.

When the molecules of the porous body have freedom of motion, they separate from each other on imbibing a liquid; the body itself swells. Even powdered glass or fine sand perceptibly increases in bulk by imbibing water. Clay swells much more. Gelatinous silica, pectin, gum tragacanth, and boiled starch, hold a vastly greater amount of water in their pores.

In case of vegetable and animal tissues, or membranes, we find a greater or less degree of expansibility from the same cause, but here the structural connertion of the molecules puts a limit to their separation, and the result of saturating them with a liquid is a state of turgidity and tension, which subsides to one of yielding flabbiness when the liquid is partially removed.

The energy with which vegetable matters imbibe water may be gathereil from a well-known fact. In granite quarries, long blocks of stone are split out by driving plugs of dry wood into holes drilled along the desired line of fracture and pomring water over the plugs. The liquid penctrates the wood with immense force, and the toughest rock is easily broken apart.

The imbibing power of different tissues and regetable matters is widely diverse. In general, the younger organs or parts take up water most realily and freely. The sap-wood of trees is fir more absorbent than the heartwood and bark. The cuticle of the leaf is often comparatively impervious to water. Of the proximate elemenis we have cellulose and starch-grains able to retain, even when air-dry, $10-15^{\circ} \%_{0}$ of water. Wax and the solid fats, as well as resins, on the contrary, do not greatly attract water, and cinnot easily be wetted with it. They render cellulose, which las been impreguated with them, unabsorbent. 
Thuse regetable substances which ordunarily manifest the greatest absorbent power for water, are pectin, pectic and pectosic acids, vegetable mucilage, bassorin, and albumin. In the living plant the protoplasmic membrane exhibits great absorbent power. Of mineral matters, gelatinous silica (Exp. 58, p. 123) is remarkable on account of its attraction for water.

Not only do different substances thus exhibit unlike adhesion to water, but the same substance deports itself variously towards different liquids.

100 parts of dry ox-blatder were found by Liebig to absorb during 24 hours:-

$\begin{aligned} & 268 \text { parts of pure Water. } \\ & 133 \text { " " " } \\ & 38 \text { " } \\ & 17 \text { " } \text { " Alcohole }\left(\left.84^{\circ}\right|_{0} \text {. }\right) \\ &\end{aligned}$

A piece of dry leather will absorb either oil or water, and aplarently with equal avility. If, however, oiled leather be immersed in water, the oil is grradually and perfectly lisplaced, as the farmer well knows from his experience with greased boots. India-rulber, on the other hand, is impenetrable to water, while oil of turpentine is imbibed by it in large quantity, causing the caoutchouc to swell up to a pasty mass many times its original bulk.

The absorbent power is influenced by the size of the pores. Other things being equal, the finer these are, the greater the force with which a liquid is imbibed. This is shown by what has been learned from the study of a kind of pores whose effect admits of accurate measurement. A tube of glass, with a narrow, uniform caliber, is such a pore. In a tube of 1 millimeter, (about $\frac{1}{2} 5$ of an inch) in cliameter, water rises $30 \mathrm{~mm}$. In a tube of $\mathrm{ji}$ millimeter, the liquid ascends $300 \mathrm{~mm}$., (about 11 inches); and in a tube of $, 2, \mathrm{~mm}$. a column of $3,000 \mathrm{~mm}$. is sustainerl. In perous borlies, like chalk, plaster stucio, closely packed ashes or starch, Jamin fisund that water was 
absorbed with force enough to overcome the pressure of the atmosphere from three to six times; in other wordsto sustain a column of water in a wile tube 100 to $200 \mathrm{ft}$. high. (Comptes Rendus, 50, p. 311.)

Absorbent power is influenced by temperature. Warm water is absorbed by wood more quickly and abundantly than cold. In cold water starch does not swell to any striking or even perceptible degree, although considerable liquid is imbibed. In warm water, however, the case is remarkably altered. The starch-grains are forcibly burst open, and a paste or jelly is formed that holds many times its weight of water. (Exp. 2\%, p. 65.) On freezing, the particles of water are mostly withdrawn from their adhesion to the starch. The ascent of liquids in narrow tubes whose walls are unabsorbent, is, on the contrary, diminished by a rise of temperature.

Adhesive or Capillary Attraction.-The absorption of a liquid into the cavities of a porous body, as well as ats rise in a narrow tube, are but expressions of the general fact that there is an attraction between the molecules of the liquid and the solid. In its simplest manifestation this attraction exhibits itself as Adhesion, and this term we shall employ to designate the kind of force under consideration. If a clean plate of glass be dipped in water, the liquid touches, and sticks to, the glass. On withdrawing the glass, a film of water comes away with it. If two squares of glass be set up together upon a plate, so that they shall be in contact at their vertical edges on one side, and one-eighth of an inch apart on the other, it will be seen, on pouring a little water upon the plate, that this liquid rises in the space between them several inches or feet where they are in very near proximity, and curves down wards to their base where the interval is large.

Capillary attraction-the common designation of the force that causes liquids to rise in fine tubes-is the s:me aulhesion which is manifested in all the cases of absorp 
tion, which have been alluded to. In many phenomens of absorption, however, chemical affinity appear's to supervene with more or less vigor.

Adhesive attraction is not manifested universally between solids and liquids, as already hinted. Glass dipped in mereury is not touched or wetted by it, and when a capillary tube is plunged in this liquid, we see no rise, but a depression within the bore. A greased glass tube deports itself similarly towards water.

Adlesion may be a Cause of Continual Morement under certain circumstances. When a new cotton wick is dipper into oil, the motion of the oil may be followed by the eye, as it slowly ascends, until the pores are filled. At this moment the adhesive attraction between cotton and oil is satisfied, and motion ceases. Any cause which removes oil from the pores at the apex of the wick will unsatisfy their attraction and disturb the equilibrium which had been establisher between the solid anil the liquill. A burning match held to the wick, by its heat destroys the oil, molecule after molecule, and this process becomes permanent when the wick is lighted. As the pores at the base of the flame give up oil to the latter, they fill themselves again from the pores beneath, and the motion thus set up propagates itself to the oil in the vessel bolow and continues as long as the flame burns or the oil holds out.

In this process, the pores, if of the same material and of equal size, exert everywhere an equal attriction for the molecules of oil. The wick, above, contains indeed less oil than below, for two reasons. In the first place, gravitation, or the earth's attraction, acts most powerfully on the oil below, and secondly, time is required for the particles of oil to pass upwards, and they camnot reach the summit as rapidly as they might be consumed. We get a further incight into the nature of this motion when we consider what happens after the oil has all been surked up into the wick. Shortly thereafter the dimes. 
sions of the flame are seen to dimmish. It does rot, how. ever go out, but burns on for a time with continually da. creasing vigor: When the supply of liquirl in the porus bolly is insufficient to saturate the latter, there is still the same tendency to equalization and equilibrium. If, at last, when the flame expires, because the combustion of the oil falls below that rate which is needful to generate heat sufficient to decompose it, the wick be placed in contact at a single point, with another dry wick of equal mass and porosity, the oil remaining in the first will enter again into motion, will pass into the seconll wick, from pore to pore, until equilibrium is again restored and the oil has been shared equally between them.

In case of water contained in the cavities of a porous body, evaporation from the surface of the latter becomes remotely the cause of a continual upward motion of the liquid.

The exhalation of water as vapor from the foliage of a plant thus necessitates the entrance of water as liquid at the roots, and maintains a flow of it in the sap-ducts, or causes it to pass by absorption from cell to cell.

Liquid Difiusion. - The movements that proceed in plants, when exhalation is out of the question, viz., such as are manifested in the stump of a vine cemented into a guage, (fig. 43, p. 248, are not to be accounted for by calillarity or mere absorptive force under the conditions as yet noticed. To approach their elucidation we require to attend to other considerations.

The partic'es of many different kinds of liquids attract each other. IVater and alcohol may be mixed together in all proportions in virtue of their adhesive attraction. If we fill a vial with water to the rim and carefully lower it to the bottom of a tall jar of alcohol, we shall find after some hours that alcohol has penetrated the vial, and water has passed out into the jar, notwithstanding the latter liquid is considerably heavier than the former. If the wa 
ter be colored by indigo or cherry jice, its motion mas be followed by the eye, and after a certain lapse of time the water and alcohol will be seen to have become uniformly mixed throughout the two ressels. This manifesta. tion of adhesive attraction is termed Liquid Diffusion.

What is true of two liquids likewise holds for two solutions, i. e., for two solids made liquid by the action of a solvent. A vial filled with colored brine, or syrup, and placed in a vessel of water, will discharge its contents into the latter, itself receiving water in return; and this motion of the liquids will not cease until the whole is uniform in composition, i. e., until every molecule of salt or sugar is equally attracted by all the molecules of water.

When several or a large number of soluble substances are placed together in water, the diffusion of each one throughout the entire liquid will go on in the same way until the mixture is homogeneous.

\section{Liquid Diffusion may be a Cause of Continual More-} ment whenever circumstances prorluce continual disturb. ances in the composition of a solution or in that of a mix. ture of liquids.

If into a mixture of two liquids we introduce a solid body which is able to combine chemically with, and solid. ify one of the liquids, the molecules of this licquid will be. gin to move toward the solid body from all points, and this motion will cease only when the solid is able to $\mathrm{com}$. bine with no more of the one liquil, or no more remains for it to unite with. Thus, when quicklime is placed in a mixture of alcohol and water, the water is in time com. pletely conitenseil in the lime, and the alcohol is renilered anliydrous.

Rate of IDiffusion.-The rate of diffusion varies with the nature of the liquids; if solutions, with their degree of eoncentration and with the temperature.

Colloids and Crystalloids.--There is a class of bodies q- Lose molecules are singularly inactive in many resperts, 
and have, when dissolved in water or other liquid, a very low capacity for diffusive motion. These bodies are termed Colloids, ${ }^{*}$ and are characterizel by swelling up or uniting with water to bulky masses (hydlates) of gelati. nous consistence, by inability to crystallize, and by feeble and poorly-defined chemical affinitios. Starch, dextrin, the gums, the uncrystallized albuminoids, pectin and pectic acid, gelatin (glue), tannin and gelatinous silica, are colloids. Opposed to these, in the properties just specified, are those bodies which crystallize, such as saccharose, glucose, oxalic, citric, and tartaric acids, and the ordinary salts.

Other bodies which have never been seen to erystallize have the sime high diffusive rate; hence the class is termed by Graham Crystalloids.t

Colloidal bollies, when ansolıble, are capable of imbibing liquids, and admit of liquid diffusion through their molecular interspaces. Intoluble crystalloils are, on the ther hand, impenetrable to liquids in this sen-e. The colloids swell up more or less, often to a great bulk, from absorbing a liquid: the volrsme of a crystalloid rumains unchanged.

In his study of the rates at difiusion of various substances; dissolved in water to the extent of one per cent of the liquid, Graham found the xullowing

APPROXIMATE TIMES OF FQUAL DIFFUSION.

Chlorhydric acid,

Chloride of sodium,

Sugar (cane,)

Sulphate of magnesia,

Alburnen,

Caramel, ystalloid, 1.

"6

"6

66

nlloid, 49.

6 98.

- From two Greek words which signify glue-liYe.

+ We have already employed the worl Crystulw tit to distinoryal, the amne phous albuxinoids from their modifications or comneptinns whu ax me?ent the

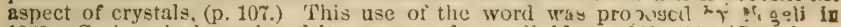

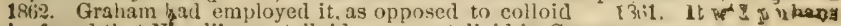
be found that Nugeli's crystalloids are crystalloid in Grumany s sozus. 
The table shows that the diffusive activity of chlor hydrie acirl through water is 98 times as great as that of caramel, (see p. 73, Exp. 29). In other worts, a molecule of the acid will travel 98 times as far in a given time as the molecule of caramel.

Osmose,* or Membrane Diffusion.-When two miscil),e liquids or solutions are separated by a porous diaphragm, the phenomena of diffusion (which depend upon the mutral attraction of the molecules of the different liquids or dissolved substances), are complicated with those of imbibition or capillarity, and of chemical affinity. The adhesive or other force which the septum is able to exert xpon the liquid molecules supervenes upon the mere diffusive tendency, and the movements may suffer remarkable modifications.

If we should separate pure water and a solution of common salt by a membrane upon whose sulstance these liquids could exert no action, the diffuion would proceed to the same result as were the membrane absent. Molccules of water would penetrate the membrane on one side and molecules of salt on the other, until the liquid should become alike on both. Should the water move faster than the salt, the volume of the brine would increase, and that of the water would correspondingly diminish. Were the membrane fixed in its place, a change of level of the liquids would occur. Graham has observed that common salt actually diffuses into water, through a thin membrane of ox-bladder deprived of its outer muscular coating, at very nearly the same rate as when no membrane is inter posed.

Dutrochet was the first to study the phenomena of membrane diffusion. IIe took a glass fumnel with a long and slender neck, tied a piece of bladder over the wide opening, inverted it, poured in brine until the funnel was

- From a Greek word meaning impulsion. 
filled to the neck, and immersed the bladder in a ressel of water. IIe saw the liquid rise in the narrow tube and fall in the outer vessel. He designated the passage of water into the fumel as endosmose, or inward propulsion. At the same time he found the water surrounding the funnel to acquire the taste of salt. The outward transfer of salt was his excosmose. The more general word, Osmose, expresses both phenomena; we may, however, employ Dutrochet's terms to de-ignate the direction of osmose.

Osmometer.- When the apparatus employed by Dutrochet is so constructed that the size of the narrow tube has a known relation to, is, for example, exactly $\frac{1}{10}$ that of the membrane, and the narrow tube itself is provided with a millimeter scale, we have the Osmometer of Graham, fig. $6 \%$. The ascent or descent of the liquid in the tube gives a measure of the amount of osmose, provided the hydrostatic pressure is counterpoised by making the level of the liquid within and without equal, for which purpose water is poured into or removed from the outer ressel. Graham designates the increase of volume in the osmometer as positive osmose, or simply osmose, and distinguishes the fall of liquid in the narrow tube as nega-

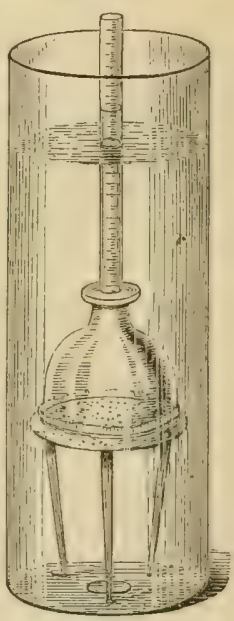

Fig. 67 . tive osmose.

In the figure, the external ressel it intended for the reeption of water. The funnel-shined interior vessel is closed below with membranc, and stands upon a sheif of perforated zine for support. The griduated tube fits the neck of the funnel by a ground joint.

Action of the Membrane.- When the membrane itself has an attraction for one or more of the substances between which it is interposed, then the rate, amount, and even direction, of diffusion may be greatly changed. 
Water is imbibed by the membrane of biadder nuch more freely than alcohol; on the other hanct, a film of collodion (nitro-cellulose left from the evaporation of its solution in ether,) is penetrated much more easily by alco. hol than by water. If now these liquids be separated by bladiler, the apparent flow will be towards the aleohol; but if a membrane of collodion divide them, the more rapid motion will be into the water.

When a vigorous chemical action is exerted upon the membrane by the liquid or the dissolved matters, osmose is greatly heightened. In experiments with a septum of porous earthenware (porcelain biscuit,) Graham found that in case of neutral organic bodies, as sugar and alcohol, or neutral salts, like the alkali-chlorides and nitrates, very little osmose is exhibited, $\mathrm{i}$. e., the diffusion is not perceptibly greater than it would be in absence of the porous diaphragm.

The acirs, -oxailic, nitric, and chlorhydric,-manifest a sensible but still morlerate osmose. Sulphuric and phosphoric acids, and salts having a decided alkaline or acid reaction, viz, acid oxalate of potash, phosphate of sola, anil carbonates of potash and soda, exhibit a still more vigorous osmose. For example, a solution of one part of carbonate of potash in 1,000 parts of water gains volume rajidly, and to one part of the salt that passes into the water 500 parts of water enter the solution.

In all cases where diffusion is greatly modified by a membrane, the membrane itself is strongly attacked and altered, or dissolved, by the liquiris. When animal men lrane is used, it constantly undergoes decomposition and its osmotic action is exhaustible. In case earthenware is employed as a diaphragm, lime and alumina are always found in the solutions upon which it exerts osmose.

Graham asterts that to inluce osmose in blarder, the chemical action on the membrane must be different on the two sides, and apprarently not in degree only, but alse in 
kini, viz., an alkaline action on the albuminoid substance of the membrane ori the one side, and an acid action on the other. The water appears always to accumulate on the alkaline or basic sirle of the membrane. Hence with an alkaline salt, like carbonate of potash, in the osmometer, and water ontside, the flow is inwaris; but with an acid in the osmometer, there is nerative osmose or the flow is outwards, the liquid then falling in the tube.

Osmotic activity is most highly manifested in such salts as easily admit of decomposition with the setting free of a part of their acid, or alkali.

Hydration of the membrane.- It is remarkable that the rapid osmose of carbonate of potash and other alkalisalts is greatly interfered with by common salt, is, in fact, reduced to almost nothing by an equal quantity of this substance. In this case it is probable that the physical effect of the salt in diminishing the porer of the membrane to imbibe water (p. 3t8,) operates in a sense inverse to, and neutralizes the chemical action of the carbonate. In fact, the osinose of the carbonate, as well as of all other salts, ncid or alkaline, may be due to their effect in modifying the hydration* or power of the membrane to imbibe the liquid which is the rehicle of their motion. Gratum suggests this view as an explanation of the osmotic influence of colloid memoranes, and it is not mlikely that in case of earthenware, the chemical action may exert its effect indirectly, viz., by producing hydrated silicates from the burned clay, which are truly colloid and analogous to animal membranes in respect of imlilition. Graham has shown a connection between the hydrating effect of acils and alkalies on colloid memhranes and their osmotic rate.

"It is well known that fibrin, albumin and animal membr:me, swell much more in very dilute acids and alkalies, than in pure water. On the other hand, when the proportion of

* In case water is employed as the liquid. 
acid or alkali is carried beyond a point peculiar to each sulistance, contraction of the colloid takes place. The colloids just named acquire the power of combining with an increased proportion of witer and of forming ligher gelatinous hydrates in conscquenee of contact with dilute acil or alkaline reagents. Even parchment-paper is more elongater in an alkaline solution than in pure water. When this l:ydrated and dilated, the colloids present an extreme osmotic sensibility."

An illustration of membrane-diffusion which is highly instructive and easy to pruduce, is the following:

A cavity is scooped out in :i carrot, as in fig. 68 , so that

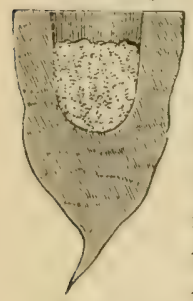
the sides remain $\frac{1}{4}$ inch or so thick, and a quantity of dry, crushed sugar is introduced; after some time, the previously dry sugar will be converted into a syrup by withdrawing water from the flesh of the carrot. At the same time the latter will visibly shrink from the loss of a portion of its liquid contents. In

Fig. 68. this case the small portions of juice moistening the cavity form a strong solution with the sugar in contact with them, into which witer diffuses from the arjoining cells. Doubtless, also, sugar penetrates the parenchyma of the carrot.

In the same manner, sugar, when sprinkled over thinskinned fruits, shortly forms a syrup with the water which it thus withdraws from them, and salt packed with fresh meat runs to brine by the exosmose of the juices of the flesh. In these cases the fruit and the meat shrink as a result of the loss of water.

(iraham olscrved gum tragacanth, which is insoluble in water, to "ause a mapid passage of water through a membrane in the same inamer from its power of imbibition, although lere there could be no exosmose or outward movement.

The application of these facts and principles to explain- 
ing the movements of the liquids of the plant is obvious. The cells and the tissues composed of cells furnish precisely the conditions for the manifestation of motion $\mathrm{by}$ the imbibition of liquids and by simple diffusion, as well as by osmose. The constant disturbances needful to main. taiu constant motion are to be founil in fully adequate de gree in the chemical changes that accompany the processes of nutrition. The substances that normally exist in the vegetable cells are numerous, and they suffer remarkable transformations both in chemical constitution and in physical properties. The rapidly diffusible salts that are presented to the plant by the soil, and the equally diffusible sugar and organic acids that are generated in the leaf-cells, are, in part, converted into the sluggish, soluble colloids, soluble starch, dextrin, albumin, etc., or are deposited as solid matters in the cells or upon their walls. Thus the diffusible contents of the plant not only, but the membrimes which occasion and direct osmose, are sulject 10 perpetual alterations in their nature. More than this, the plant grows; new cells, new membrines, new proportions of soluble and diffusible matters, are unceasingly brought into existence. Imbibition in the cell-membranes aud their solid, colloid contents, Diffusion in the liquid con. tents of the individual cells, and Osmose between the liq uids and dissolved matters and the membranes, or colloid contents of the cells, must unavoidably take place.

That we cannot follow the details of these kinds of action in the plant does not invalidate the fact of their operation. The plant is so complicated and presents such a number and variety of changes in its growth, that we can never expect to understant all its inysteries. From what has been briefly explained, we can comprehend some of the more striking or obvious movements that proceed in the vegetable organism.

Absorption and 0smose in Germimation.-The absorp. tion of water by the seed is the first step in Germination. 
The coats of the dry seed when put into the moist soil imlibe this liquid which follows the cell-walls, from cell to cell, until these membranes are saturated and swollen. At the same time these membranes occtsion or pernit osn:ose into the cell-earities, which, dry before, become distended with liquid. The soluble contents of the cells or the soluble results of the transtormation of their organized matters, diffuse from cell to cell in their passage to the expanding embryo.

The quantity of water imbibed by the air-dry seed commoniy amounts to 50 and may exceed 100 per cent. R. Hoffmanu has made observations on this subject, ( $V$ s. St., VII, p. 50.) The absorption was usually complete in 48 or 72 hours, and was as follows iu case of eertain agricultural plants :-
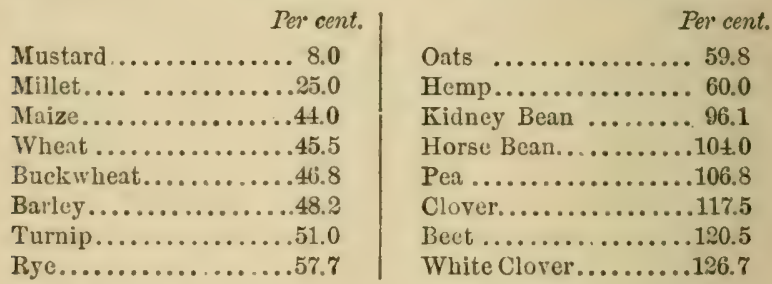

Root-Action.-Absorption at the roots is unquestionably an osmotic action exereised by the membrane that bounds the young rootlets and root-hairs externally. In principle it does not differ from the absorption of water by the seed. The mode in which it occasions the surprising phenomena of blecding or rapid flow of sap from a wound on the trunk or liurger roots is doubtless essentially as IIofmeister fir t elucidated by experiment.

This flow proceeds in the ducts and intercommunicating wood-cells. Between these and the soil intervenes loose cell-tissue surrounderl by a compacter epilermis. Osmose takes place in the epidermis with such energy as not only to distend to its utmost the cell-tissue, but to cause the water of the cells to filter through their walls, and thus gain arcess to the ducts. The latter are formed in young 
cambial tissue, and when new, are very telicate in their walls.

Fig. 69 represents a simple apparatus by Sachs for imitating the supposed mechanism and process of Root-action. In the fig., $\mathscr{g} g$ represents a short, wide, open glass tube; at $a$, the tube is tied over and securely

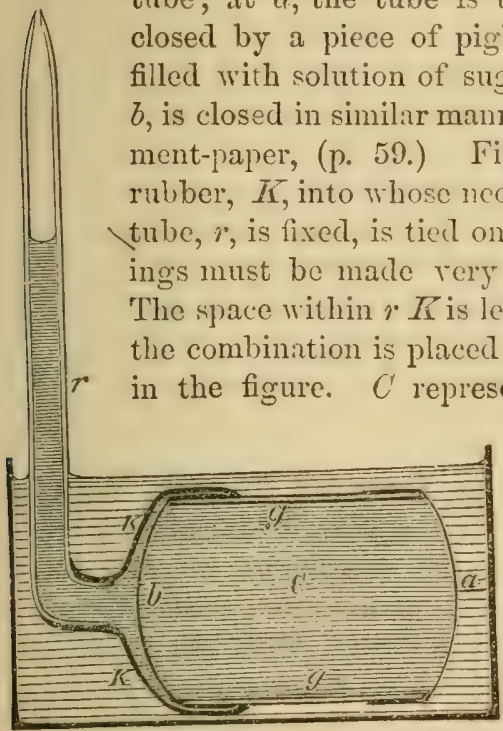

Fig. 69. exterior wall (cuticle, $a$, is less pene. trable under pressure than its interior, $b$; $r$ corresponds to a duct of vascular tissue, ancl the surrounding water takes the place of that existing in the pores of the soil. The water shortly penetrates the cell, $C$, distends the previously flabby membinnes, unter the accumulating tension filters through $b$ into $r$, and rises in the tube; where in Sachs' experiment it attainel a height. of 4 or 5 inches in 21 to 48 homrs, the tube, $r$, being about 5 millimeters wide and the area of $b, \gamma(0) \mathrm{sog}$. mm. When we consider the vast root-surface exposed to the soil, in case of a vine, and that myriads of rootlets and root-hairs unite their action in the comparatively narrow stcm, wc must admit that the apparatus above figured gives us is very satisfactory glance into the causes of bleeding. 
Rapid Motion of Sap in the Stem.-In the stem of the plant we have commonly a resistance to root-action, so far as a flow of liquid is concerned. The ducts and siere. cells,-in conifers, the wood-cells-though offering visibly continuous channels for the transmission of juices, are nevertheless in mo:t cases extremely small, and while they raise liquids with enormous capillary foree, they retain them with the same force, ant continuous motion can only be the result of a correspondingly energetic disturbance. The root-iction which can sustain a column of mercury many inches, or one of water many feet high, in a wide tube, is greatly neutralized by capillarity as we ascend the stem from the root, or the root from its young extremities. Root-action is, however, unsteady in its operition, and when it declines from any cause, it is capillarity which acts rapidly within the ducts and visible chamnels to supply waste by evaporation.

Motion of Nutritive or Dissolved Matters: Selective Power of the Plant.-The motion of the substances that enter the plant from the soil in a state of solution and of those organize l within the plant is to a great legree separate from and inilependent of that which the water itself takes. At the same time that water is passing upwaris through the plant to make good the waste by evaporation from the foliage, sugar or other carbohydrate generated in the leaves is diffusing against the water, and finding its way down to the very root-tips. This diffusion takes place mostly in the cell-tissue, anil is undoubtedly greatly ailed by osmose, i. e., by the action of the membranes themselves. The very thickening of the cell-walls by the deposition of cellulose would indieate an attraction for the miterial from wirich cellulose is organizerl. The sime transfer groes on simultaneonsly in all clireetions, not only into roots and stem, but into the new buits, into flowers and fiuit. We have considered the tendency to equaliz:tion between two masses of liquid separated from each 
other by penetrable membranes. This tendency makes valid for the organism of the plant the law that demind creates supply. In two contiguous cells, one of which contains solution of sugar, and the othe:; solution of nitrate of potash, these subst:nces must diffice until they are mingled equally, unless, indeed, the membranes or some other substince present exerts an opposing an'l preponderating attraction.

In the simplest phases of liffusion each substance is to a certain $\}$ egree independent of every other. Nitrate of potash dissolved in the water of the soil must diffuse into the root-cells of a plant if it be absent from the sap of this root-cell and the membrane permit its passage. When the root-cell has acquired a certain proportion of nitritte of potash, a proportion equal to that in the soil-witer, the nitrate camot enter it any more. So soon as a molecule of the salt has gone on into another cell or been removed from the sap by any chemical transformation, then a molecule may and must enter from without.

Silica is much more abmudant in grisses ant cereals than in leguminous plants. In the former it exists to the cxtent of about 2.; parts in 1,000 of the air-iry foliage, while the leaves and stems of the latter contain but 3 parts. (See Wolff's Table in Appendix.) When these crops grow side by side, their roots are equally bathed by the same soil. water. Silica enters both alike, and, so far as regards itself, brings the cell-contents to the s:me state of saturation that exists in the soil. The cereals are able to dispose of silica by giving it a place in the cuticular cells; the '(eguminous crops, on the other hand, cannot remove it rrom their juices; the latter remain saturated, and thus firther diffision of siliea from without becomes inpossible except as room is male by new growth. It is in this way that we have a rational and adequate explanation of thr selective power of the plant, as manifested in its deportinent towards the mediun that invests its roots. The 
same principles govern the transfer of matters from cell to eell, or from organ to organ, within the plant. Whereerer there is unlike composition of two miscible juices, diffusion is thereby set up, and proceeds as long as the canse of listurbance lasts, provided impenetrable membranes do not intervene. The rapid movement of water groes on because there is great loss of this liquid; the slow motion of silica is a consequence of the little use that arises for it in the plant.

Strong chemical affinities may be overcome by osmose. Graham long ago ubserved the decomposition of alum (sulphate of alumina and potash,) by mere diffusion; its sulphate of potash having a higher diffusive rate than its sulphate of alumina. In the same manner acid sulphate of potash, put in contact with water, separates into sulphate of potash and free sulphuric acid.

We have seen (p. 170-1) that the plant when regetating in solutions of salts, is able to decompose them. It separates the components of nitrate of potash-appropriating the acid and leaving the base to accumulate in the liquid. It resolves chloride of ammonium,--taking up ammonia and rejecting the chlorine. The action in these cases, we eamnot definitely explain, but our analngies leave no doubt as to the general nature of the agencies that coöperate to such results.

The albuminoids in their usual form are colloid bodies and very slow of diffusion through liquids. They pass a membrane of nitrocellulose somewhat (Schumacher); but can searcely penetrate parchment-p:ıper. (Graham.) I'I the plant they are found chiefly in the sieve-cells and ailjoining parts of the cambium. Since for their production, they uniloubtedly require the concourse of a carbohydrate and a nitrate, they are not mulikely generated in the cambium itelf, for here the descending carbohydrates from the foliage come in contact with the nitrates as they rise from the soil. On the other baud, the albuminoils be 
come more diffusible in some of their combinations. Schumacher asserts that carbonates and phosphates of the alk:llies considerably increase the osmose of albumin through membranes of nitrocellulose, (Physik der Pfleze, p. 128.) It is probable that those combinations or modi. fic:tions of the alluminoids which occur in tho soluble crystalloids of aleurone (p. 105,) and haemoglobin (p. 97, are highly liffusible. The fact of their having the form of crystals is of itself presumptive evidence of this viem, which desekves to be tested by experiment.

Gaseous bodies, especially the carbonic acid and oxygen of the atmosphere, which have free access to the intercellular cavities of the foliage, and which are for the most part the only contents of tne larger ducts, may be distributed throughout the plant by osmose after having been dissolved in the sap or otherwise absorbed by the cellcontents.

Influence of the Hembraues.-The sharp separation of unlike juices and soluble matters in the plant indicates the existence of a remarkable variety and range of ad. hesive attractions. In oringe-colored flowers we see upon microscopic examination that this tint is produced by the united effect of yellow and red pigments which are contained in the cells of the petals. One cell is filled with yellow pigment, and the adjoining one with red, but these two colo:s are never contained in the same cell. In fruits we have coloring matters of great tinctorial power and fieely soluble in water, but they never forsake the cells where they appear, never wander into the contiguous parts of the plant. In the stems and leaves of the dandelion, lettuce, and many other plants, a white, millky, and bitter juice is contained, but it is strictly confined to certain special channels and never visibly passes beyond them. 'The loosely disposed cells of the interior of leaves contain grains of chlorophyll, but this substance does not appear in the epidermal cells, 
those of the stomata excepted. Sachs found that solution of indige quickly entered the routs of a seedling bean, but requred a consideralle time to penctrate the stem, (p. 2:39.) Hallier, in his experiments on the absorption of colored liquids by plants, noticed in all cases, when leaves or green stems were immersed in solution of indigo, or black-cherry juice, that these dyes readily passed into and r sured the epidermis, the vaseular and cambial tissue, and the parenchyma of the leaf-veins, keeping strictly to the cell-walls, but in no instance communicated any color to the cells containing chlorophyll. (Phytopathologie, Leipzig, 1868, p. 67.) We must infer that the coloring matters either cannot penetrate the cells that are occupied with chlorophyll, or else are chemically transfurmed into colorless substances on entering them.

Sachs has shown in mumerous instances that the juices of the sieve-cells and cambial tissue are alkaline, while those of the adjoining cell-tissue are acid when examined by test-paper. (Koxp. Phys. der Pflanzen, p. 39t.)

When young and active cells are moistened with solution of iodine, this substance penetrates the cellulose without producing visible change, but when it acts upon the protoplasm, the latter separates from the outer cellwill and collapses torvards the center of the cavity, is if its contents passed out, without a corresponding endosmose being possible, (p. 224.)

We may conclude from these facts that the membranes of the cells are capable of effecting and maintaining the separation of substances which have considerable attractions for each other, and obviously accomplish this result. by exerting themselves superior attractive or repulsive force.

The influence of the membrane must vary in character with those alterations in its chemical and structural constitution which result from growth or any other cause. It is thus, in part, that the assimilation of external frod by the 
plant is directed, now more to one class of proximate ingredi'nts, as the carbohydrates, and now to another, as the albuminoids, although the supplies of food presented are aniform both in total and relative quantity.

If a slice of rel-beet be washerl and put into water, the pigment which gives it color does not readily dissolve and diffuse ont of the cells, but the water remains colorless for several days. The pigment is, howerer, soluble in water, as is seen atpnce by crushing the beet, whereby the cells are forcibly broken open and their contents displaced. The cell-membranes of the uninjured root are thus apparently able to withstand the solvent power of water upon the pigment and to restrain the latter from diffusive motion. Upon subjecting the slice of beet to cold until it is thoroughly frozen, and then placing it in warm water so that it quickly thaws, the latter is immediately and deeply tinged with red. The sudden thawing of the water with. in the pores of the cell-membrane has in fact so altered them, that they ean no longer prevent the diffusive tendency of the pigment. (Sachs.)

\section{$\$ 4$.}

MECHANICAL EFFECTS OF OSMOSE ON THE PLANT.

The osmose of water from without into the cells of the plant, whether occurring on the root-surface, in the buds, or at any intermeliate point where chemical changes are going on, cannot lail to exereise a grent mechanical influence on the phenomena of growth. Root-action, for example, being, as we have se'n, often sufficient to over"ome a consilerable hyllostatic pressure, might naturally be expected to accelerate the dev lopment of buds and young foliage, especially since, is common observation shows, it operates in perennial plants, as the maple and grape-vine, most energetically at the season when the issue of foliage takes place. Experiment demonstrates this to be the fact. 
If a twig be cut from a tree in winter and be placed in a room having a summer temperature, the buils, before dormant, shortly exhibit signs of growth, and if the cut end be immersed in water, the buds will enlarge quite after the normal manner, as long as the nutrient matters of the twig last, or until the tissues at the cut begin to decay. It is the summer temperature which excites the chemical changes that result in growth. Water is needful to occupy the cxpanding and new-forming cells, and to be the vehicle for the translocation of nutrient matters from the wood to the buds. IVater enters the eut stem by imbibition or capillarity, not merely enough to replace loss by exhalation, but is sucked in by osmose acting in the growing cells. Under the same conditions as to temperature, the twigs which are connected with active roots expand earlier and more rapidly than cuttings. Artificial pressure on the water which is presented to the latter acts with an effect similar to that which the natural stress caused by the rootpower exerts. This fict was demonstrated by Boehm (Sitzungsberichte der Wiener Akad., 1863) in an experiment which may be marle as illustrated by the cut, fig. 70. $\Lambda$ twig with buds is secured by means of a perforated cork into one end of a short, wide glass tube, which is closed below by another cork through which passes a narrow syphon-tube, $B$. The cut end of the twig is immersed in

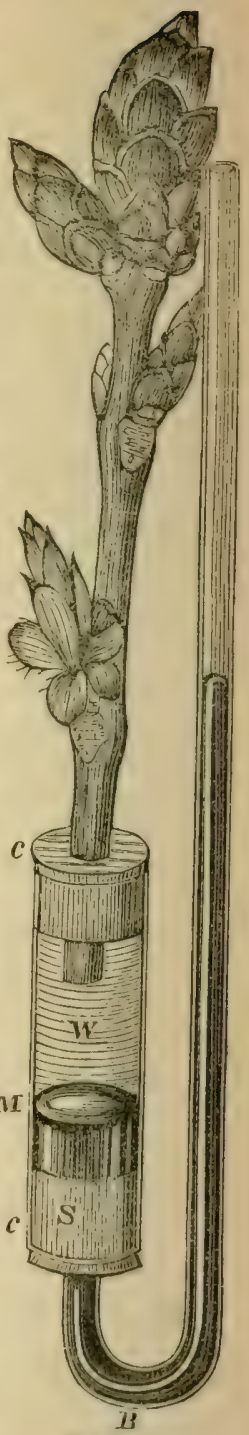

Fig. 70. 
water, $W$, which is put under pressure by pouring mercury into the upper extremity of the syphon-tube. Horsechestnut and grape twigs cut in February and March and thus treated,- the pressure of mercury being equal to $6-8$ inches above the level, $M$, - after 4-6 weeks, unfolder their buds with normal vigor, while twigs similarly circum. stancel but without pressure opened 4-8 days later and with less appearance of strength.

Fr. Schulze (Kursten's Bot. Unters., Berlin, II, 143) found that enttings of twigs in the leaf, from the horsechestnut, locust, willow and rose, subjected to hydrostatic pressure in the same way, remained longer turgescent and advanced much farther in development of leaves and flow: ers than twigs simply immersed in water.

The amount of water in the soil influences both the absolute and relative quantity of this ingredient in the plant. It is a common observation that rainy spring weather causes a rank growth of grass and straw, while the yield of hay and grain is not correspondingly increased. The root-action must operate with greater effect, otber things being equal, in a nearly saturated soil than in one which is less moist, and the young cells of a plant situated in the former must be subjected to greater internal stress than those of one growing in the latter-must, as a consequence, attain greater dimensions. It is not uncommon to find fleshy roots, especially radishes which have grown in hot-beds, split apart lengthwise, and Hallier mentions the fact of a sound root of petersilia splitting open after immersion in water for two or three days. (Phytopathot ngie, p. 87.) This mechanical effect is indeed commonly (:onjoined with others resulting from abundant nutrition, but increased bulk of a plant without corresponding in. crease of dry matter is doubtless in great part the consequence of large supplies of water to the rots and its vig orous osmose into the expanding plant. 


\section{$\S 5$.}

\section{DIRECTION OF VEGETABLE GROWTH.}

One of the most obvious peculiarities of regetation is that the roots and stems of plants manifest more or less regular and often opposite directions of growth. Roots, in general, grow downwards; stems, in general, upwards, though this is by no means a universal rule, both roots and stems oftentimes manifesting either tendency in different points or at lifferent times of their growth.

Sachs describes the following mode of observing the directive tendency of root and stem.

$E$, fig. $\% 1$, is a glass flask containing some water; it is closed above by a cork from which a young seedling is suspended by means of a wire. The flask stands upon a plate of sand, and it is shielded from the light by a paste-board cover, $R$, the lower edge of which is forced down into the sanil. The water in the flask keeps the enclosed air in a moist state. In the experiment, a sprouted nasturtium seed (Tropoeolum majus) having a perfectly straight descending rarlicle, was placed at night in the apparatus with the radicle pointing upwards

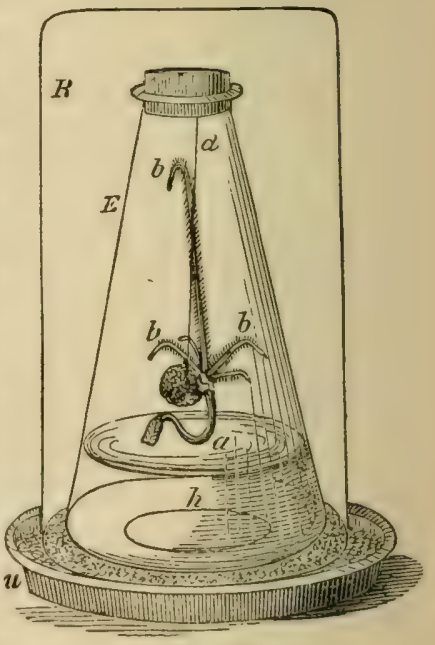

Fig. 71. and the plumule downwards. The next morning the seedling had the appearance of the figure. During the night the tip of the root curved over and the plumule sensibly raised itself. By continuing a similar experiment 
for a week or more, the rootlet will grow down into the water and the stem will reach the cork. As often as the position of the seedling is reversed, so often the root and stem will reverse the direction of their growth. This experiment being carried on in total darkness, save during the short interrals necessary for observation, the directive tendency is shown to be independent of the action of light.

Causes of Directive Power.-The direction of growth in plants appears to be for the most part the consequence of the action either of gravitation simply, as in those parts which extend directly downwaris, or of internal tension overcoming gravitation, as in the parts which grow rerticilly upwards, or lastly of a combination (resultant) of the two forces in the parts which extend in the inter. mediate directions.

The parts of a plant, whether the individual cells or aggregates of cells, are either in a state of tension greater or less and varying at different times, or they are entirely passive.

In general, tension prevails in most parts of common plants; the full-formed roots, stems, leaves, etc., maintain their relative positions against opposing forces, and when bent, recover thenselves with more or less elasticity and completeness.

There are, however, points where tension is absent or equally exerted towards all sides, and is hence unable to give direction to growth. This may be the case where the tissue, consisting exclusively of newly-formed and immature cells, having delicate walls, possesses but little firmness, but is plastic lilie a semifluid substance. In such a condition of growth the cells follow the stress of gravitation or of any external force that may be accidentally applied.

Influence of Gravitation.-Most young roots are in this passive condition near the tins in the region where 
their elongation occurs. The new growth at these points simply obeys the attraction of the earth like any other limp or yielding mass, and a root made to grow on a horizontal plate of glass, for example, is pusheil along by the expansion of its young cells and the formation of new ones until it ruaches the edge, when the tip inclines down ward as a wet string would do. If, however, as many times happens, the yielling tissue of new cells is partially or entirely enveloped by the more rigid root-cap, the downwarl tendency may be overcome to a corresponding degree. In this case the tip keeps more or less closely the direction already given to the root, resembling in its growth a balf meltei substance protuded from a tube and stiffening as it issues. The passive section of the root is translated forwaril as the root itself extends; the cells that to-day yield to the gravitating force, to-morrow become so rigid anil firmly grown to each other as to resist the tendency of this force to coerce them to a vertical, while new cells are developed beyond, which conform to the gravitating tendency.

Internal Tension.-In the upward-growing stem the different parallel and concentric tissues, viz, the cuticle, the cell-tissue of the rind, the wood-cells and ducts, and the pith, exist in a state of unequal tension.

This is shown by well-kuown facts. If a hollow, succulent stem, like that supporting a dandelion blossom, be cut lengthwise, the parts curve away from each other, thus, )(, ancl may by a little assistance be rolled together in flat voils. The sime separation of the halves may be olserved in any succulent stem, provided it be fresh and turgicl. It is plitin then that the pith-cells of the growing stem are compressed by the cuticle; in other words the pith-cells are in a state of tension, while the cuticular cells are passively stretched by this interior strain. Closer investigation indicates that the matter is somewhat compliaated. If we strip off the "skiu," from a stalk of garden 
rhubarb (pie-plant,) we shall notice that it curves to a coil or spiral. This skin consists of the true cuticle with a conting of cell-tissue adhering. The tension of the latter and the passivity of the former occasion the curvature. Further dissection demonstrates that in general the cuticle, the wood-cells, and the rascular bundles, are passive while the cell-tissues of the rind and pith, and the corresponding cell-tissues of the leaves, are tense.

It follows from these considerations that the length of a fresh growing stem must be different from the length of its parts when separate from each other. If we divide a succulent stem lengthwise, into the pith, the wood and the rinil or the corresponding parts, and accurately measure them, we shall find in fact that they differ as to length from each other and from the stem as a whole. The pith, when the wood is cut away, elongates, the wood shortens, the rind shortens still more. In the oricinal stem the cell-tissue being united to the vascular, stretches the latter and is at the same time restrainel by it. On their being cut apart, the one is free to extend and the other to shorten. Sachs gives the following comparative measurements of the stem of a tobacco plant, and of its parts after separation-the length of the stem being as. sumed as 100 :

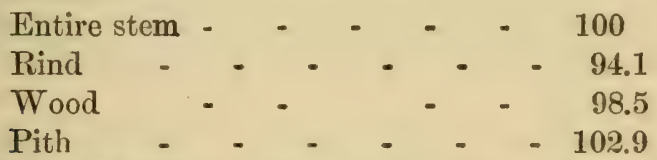

Causes of Tension.-This tense condition of the considerably developeil stem depends partly upon the unequal nutrition of the different tissues. Those part, in fact, exert tension in which rapid growth-cell-multiplication-is taking place. In the simple cell similar tension may exist, caused by the tendency of the furmative layer to expand beyond the limits of the cell-wall. Another cause of tension is the different imbibing and osmotic power of the 
tissuis for sap. When a fiesh stem or leaf losess a few per cent of water, it becomes flabby and, execpt so far ag supported by indurated woody-tissue, has no self-sustaining power and dioops from an upright direction. On dissecting the flabby stem lengthwise, the halves no longer curve ap:art. and the tension noticed in the fresh stem does not exist. The water being restored through the root, the normal turgor and original position are both recovered. In the cell-tiswue, the cells themselves, so long as tension manifests itself, are fully occupied and distenderl with sap, and contain a highly o motic protoplasm; the vascular tissues being the result of age and alteration in the celltissue, are therefore more rigid in their walls and less sensitive to mechanical strain.

Upward Growth. - If a stem whose terminal parts are in a state of highly unequal tension be brought into a horizontal position, it will be found that as it makes new growth the tip curves upward until it becomes vertical. This is due to the fact that while the whole growing part elongates, the under side extends most rapidly. IIof. meister has demonstrated that this currature is not the result of increased tension in the active cell-tissue of the luwer longitudinal section of the stem, but of increased extensibility on the part of the cuticular and vascular tis. sues of that region, for on removing the entire cuticle from a curved onion-stalk the curvature was not increased but diminished.

The question now arises, why do the passive parts of the under side of the stem that is out of the vertical armit of greater expansion by the stress of the rapilly growing tissues, than those of the upper? The only cause hitherto assigned is the action of gravitation on the juives of the tissues. In a stem inclined from the vertical, the cells of the lower sile experience not only the general pressure of the water which renders the whole turgirl, but, in addition, they sustain a portion of the 
weight of the liquid in the cells above them. In other words, they are subject not only to the equal hydraulio pressure originating in the roots, but also to a slight hy drostatic pressure from the overlying cells. This pro. duces the greater extension of the lower passive tissues, and accounts for the curvature upward. When the stem becomes vertical the hydrostatic pressure is equal on both sides of the stem, and the latter is accordingly maintained in that position. (Hofineister, Sachs.)

Efrect of Light.-Besides the influence of gravitation and of interior tension, that of the solar light must be regarded, as it assists largely in producing the more complex phenomena of direction in the growth of plants. The explanations already given refer to the plant when unaffected by light. As is well known, the stems, leaves and roots of plants, when growing where they are unequally illuminated, as in a window, in most cases curve or turn towards the light. More rarely is curvature away from the light observed, as in case of the stems of ivy, (Hetera helix), and the young rootlets of the mistletoe, (Viscum album). The common nasturtium, (Tropcoolum majus), exhibits in its young stems inclination towards, in its older stems inclination away from, the light. Its leaves turn always towards, its roots growing in water often curve towards, often away from the light. 


\section{APPENDIX.}

\section{TABLE I.}

Contositioy of the Ash of Agricultural Plants axd Producto giving the Arernge of all trustworthy Analyses published up to August, 1865, by Professor Evil WolfF, of the Royal Academy of Agriculture, at Hohenheim, Wirtemberg.*

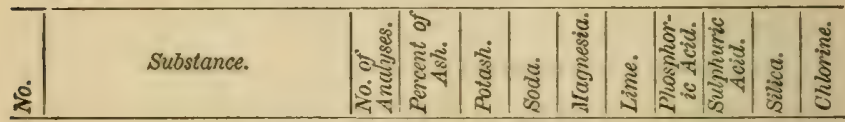

I.-NEADOW HAY AND GRASSES.

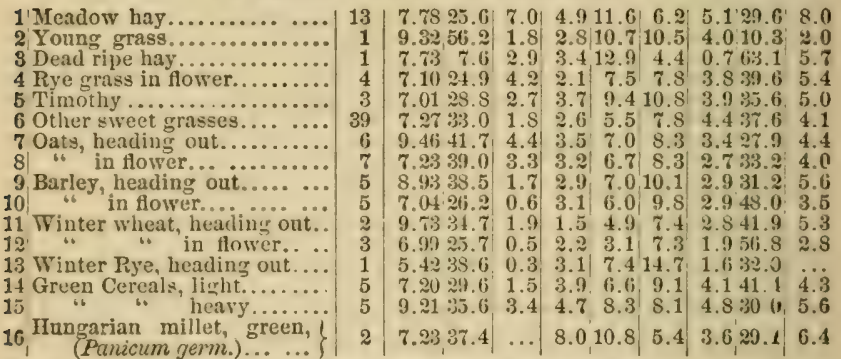

II.-CLOVER AND FODDER PLANTS.

17 Red clover .............. 56

a. 15-25 percent potash...... 15

(b. $25-3.5$ " $\quad$ "

lc. $35-50$ " " ... 18

18, White clover............... 2

19 Litcern................. 7

20) Esparectte..................

21 Swedish clover............ 2

2.3 Anthyllis vulneraria......... 1

2:) Grech Vetches..............

21 Green p

25 Grecn rape, younc........ \begin{tabular}{ll|l|l|l|l|l|l|l|l|l|l|l|l|}
6.72 & 34.5 & 1.6 & 12.2 & 34.0 & 9.9 & 3.0 & 2.7 & 3.7
\end{tabular} 6.01 $30.5 \quad 1.918 .2: 39.7 \quad 9.4 \quad 3.8$ 1.4. 5.4

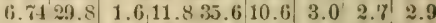
\begin{tabular}{lll|lllllll}
7.19 & 41.3 & 1.4 & 7.8 & 27.3 & 9.2 & 2.2 & 2.5 & 3.2
\end{tabular} \begin{tabular}{ll|l|l|l|l|l|l|l|l|l|l|l|l|l|l|}
7.16 & 17.5 & 7.8 & 10.0 & 32.2 & 14.1 & 8.8 & 4.6 & 3.2
\end{tabular} \begin{tabular}{lll|lllll|l}
7.14 & 25.3 & 1.1 & 5.8 & 48.0 & 8.5 & $\mathbf{6 . 1}$ & $\mathbf{2} .0$ & $\mathbf{1 . 9}$
\end{tabular} \begin{tabular}{ll|l|l|l|l|l|l|l}
5.39 & 39.4 & 1.7 & 5.832 .2 & 10.4 & 3.3 & 4 & 0 & 3.0
\end{tabular}

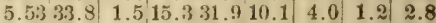
\begin{tabular}{lll|llllll}
$5 .(30$ & 10.3 & 4.5 & 4.6 & 68.9 & 7.0 & 1.6 & 2.9 & 0.2
\end{tabular} \begin{tabular}{ll|l|l|l|l|l|l|}
8.74 & 42.1 & 2.9 & 6.826 .3 & 12.8 & 3.7 & 1.8 & 3.1
\end{tabular}

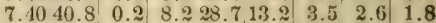

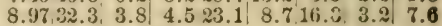

* From Prof Wolfrs Millere Zusammensetzung der Asche, aller land- und

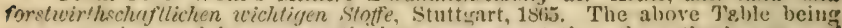
more conplete and in most particulars more exact than the author's means of reference enable him to consirnct, and being moreover likely to be the hasis of calculations hy atricultural chemists abroad for some years to come, has been peprotuced here literally. The references and important explanatis,ns accompniyine the vifinal, wint of space precludes quoting. In the table, oxide of Iron, an ingerefient momally present to the extent of less than oar, per cent, is conitfed. Chatrine is often onitferl, not becante absent from the pl ar t. but from nucertainty as to its amount. Carbonic acid is also oxcladed in ass woses for the eake of nniformity and farility of comparison. 
Composition of the Ash of Agricultural Pui vts and Products.

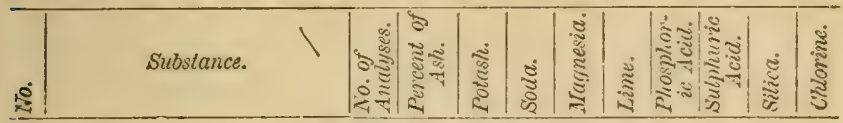

III.-ROOT CROPS.

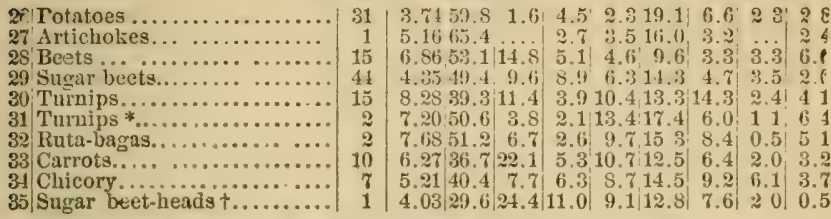
IV.-LEAVES AND STEMS OF ROOT CIOPS.

36. Potatoes, August............

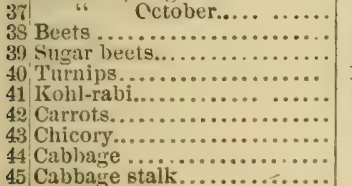

V.-REFUSE AND MANUFACTURED PRODUCTS.

46) Sugar beet cake.

a. Common cake.............

b. Residate of maceration..

c. Rusilue from Centrifugal| machille .............

47 Beet molasses...............

48 Molasses slump $\neq . . . . . . . . . . .$.

49. Raw beet sugar..

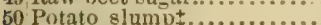

51 Potato fiber

52 Potato juice 9 .

53 Potato skins $\$ \ldots \ldots \ldots \ldots \ldots . . . . . . . .$.

54 Fine wheat flour...........

55 Rye flour...................

56 Barley flour.

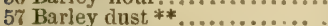

58 Maize meal.... ............

59 Millet meal. ..................

60 Buckwheat grits............

61 Wheat bran..............

6: Rye bran...............

6.3 Brewer's grains..............

GH Mlalt .... ...............

(ji) Malt sprouts................

(66) Wine grounds... ........

67 Grape skius................

6s Buer . ....................

69) Grape ninst. ................

70 Rape cake. ................ \begin{tabular}{|l|l|l|l|l|l|l|l|l|l|l|l|l|}
8.92 & 14.5 & 2.8 & 16.8 & 39.0 & 6.1 & 5.6 & 8.0 & 4.6
\end{tabular}

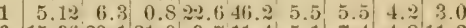
\begin{tabular}{l|l|l|l|l|l|l|l|l|}
6 & 15.96 & 29.1 & 21.0 & 9.711 .4 & 5.1 & 7.4 & 4.8 & 11.3
\end{tabular}

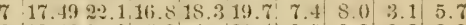
$\begin{array}{lllllllllll}16 & 13 .(582.9 & 2.8 & 4.5 & 32.4 & 8.9 & 9.9 & 3.8 & 8.2\end{array}$

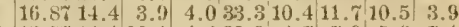
\begin{tabular}{|l|l|l|l|l|l|l|l|l|l|l|}
\hline & 13.57 & 14.1 & 23.1 & 4.633 .0 & 4.7 & 7.9 & 5.6 & 7.1
\end{tabular} $\begin{array}{llllllllll}12.46 & 60.0 & 0.7 & 3.2 & 14.3 & 9.0 & 9 & 5 & \text { i.e } & 1.7\end{array}$ \begin{tabular}{l|l|l|l|l|l|l|l|l|l}
10.81 & 45.6 & 3.9 & 3.3 & 15.3 & 15.8 & 5.5 & 1.2 & 2.5
\end{tabular}

\begin{tabular}{ll|l|l|l|l|l|l|l|l|l|l}
6.46 & 43.9 & 5.5 & 4.1 & 11.320 .9 & 11 & 1.1 & 1.2
\end{tabular}

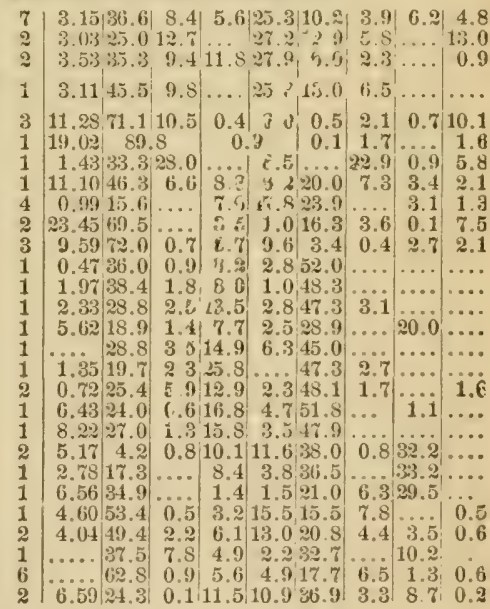

* White turnips in the original, but apparently no speciai kind. + Probably the crowns of the roots, removed in sugar-making. $¥$ The residuc after fermentIng and distilling off the spirit. \| Refuse of starcis manufacture. T Undiluteu. From boiled potatoes. ** Refuse in making barley grits. 
Cosposition of the Ash of Aglicejotual Plants and Flodtets

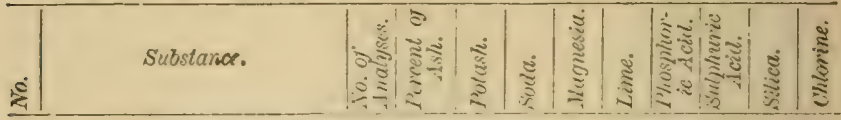

V.-REFUSE AND MIANUT'ACTUIRED PRODLCTS.

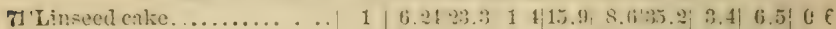

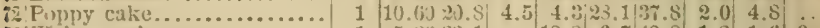

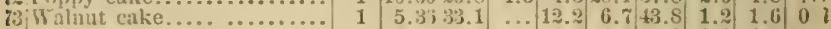

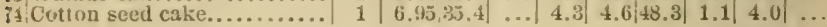

VI.-STRAW.

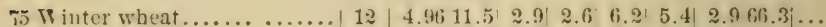

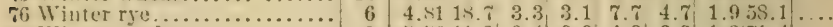

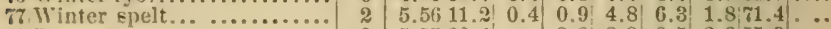

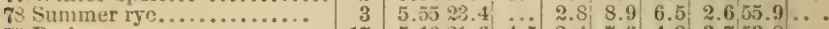

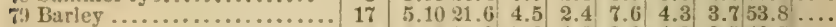

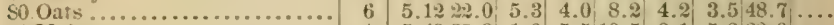

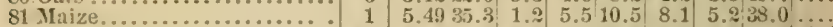

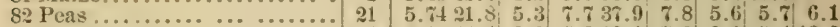

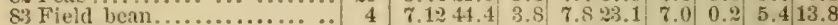

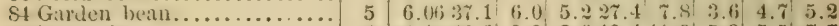

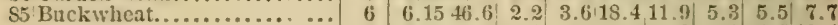

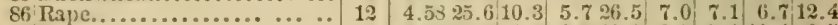

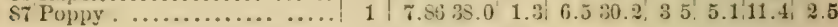
VII.-CHAFF, ETC.

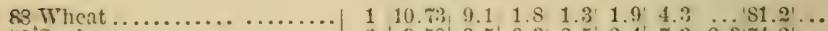

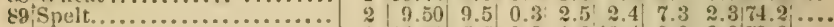

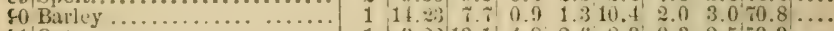

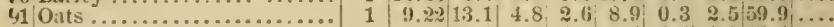

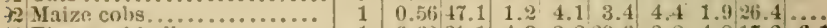
33 Flas seed hulls........... VIII-TEXTILE PLANTS, ETC.

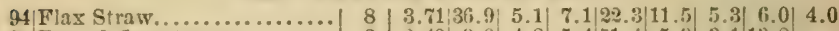

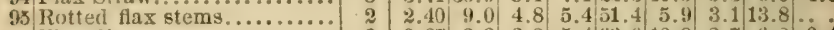

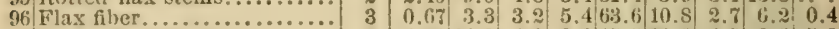

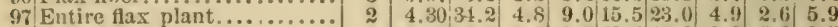

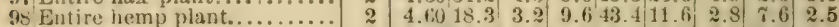

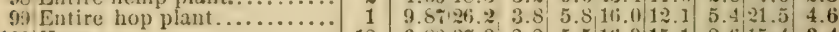

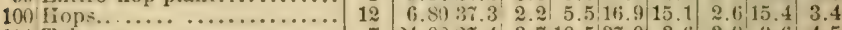

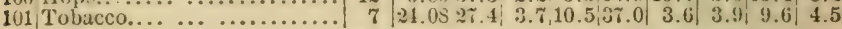

\section{IX.-LITTER.}

102 Heath. .

10:3 Broum (Spartium)..

104 Fern (Aspidium).

11.) Sicuriug ru-h (Equisetum)...

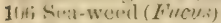

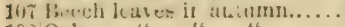
$10 \mathrm{~s}$ O:3k

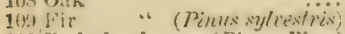
110 Ted pine leaves (Pinus I'icea)

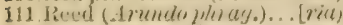
112 Jown grass (Psamma area-

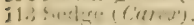

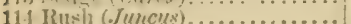

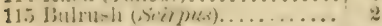

\begin{tabular}{|l|l|l|l|l|l|l|l|l|}
4.51 & 13.2 & 5.3 & 8.4 & 18.8 & 5.1 & 4.4 & 35.2 & 2.1
\end{tabular}

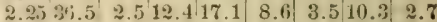
\begin{tabular}{ll|l|l|l|l|l|l|l|l|l|l|l|l|}
7.0142 .8 & 4.5 & 7.7 & 14.0 & 9.7 & 5.1 & 6.1 & 10.2
\end{tabular}

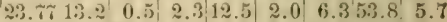
14.21 14.521 .09 .513 .93 .121 .01 .710$.

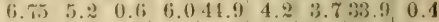

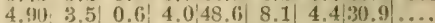
\begin{tabular}{ll|l|l|l|l|l}
1.4010 .1 & $\ldots$ & 9.4 & 41.416 .4 & 4.413 .1 & 4.4
\end{tabular} \begin{tabular}{ll|l|l|l|l|l|l|l|l|l|l|l|}
5.82 & 1.5 & $\ldots$ & 2.3 & 15.2 & 8.2 & 2.8 & 70.1
\end{tabular}

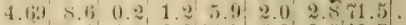
\begin{tabular}{ll|l|l|l|l|l|l|l|l|}
30.8 & 4.0 & 3.8 & 16.5 & 7.2 & 3.6 & 18.5 \\
\hline
\end{tabular}

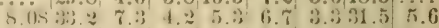

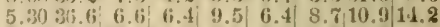

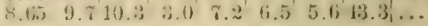

\section{$\mathrm{X}$-GIRAINS AND SEEDS OF AGRICULTURAL PLANTS.}

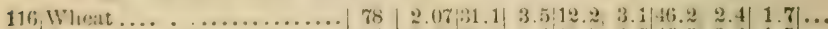
117 [R

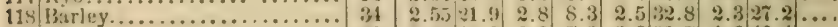

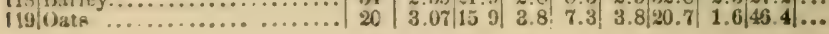


Composition of the Asir of Agricultural Plants and Producta.

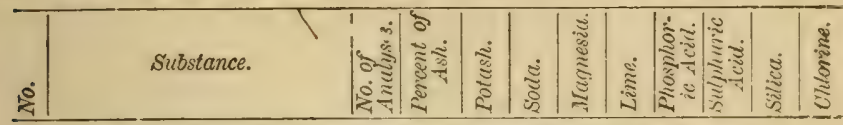

X.-GEAINS AND SEEDS OF AGRICULTURAL PLANTS.

120 Spelt with husk.

1:21 Mrize..

12-) Rice with husk

1.2. 6 husked

12t Millet with husk...........

125 ". husked..............

126 Sorghum................

$12 \pi$ Buckwheat................

12S Rape seed...............

1 in Flax

1:30 Hemp

131 Puppy

1:32) Madia

13:3 Mustard

134 Beet

196) Carrot "6 $\ldots \ldots \ldots \ldots \ldots$.

$1 ; 8$ Vetches.

13:) Field Beans..

141 Lentils.

14: Lupines. .

143 Clover seed.

144, Esparsette seed.
135 Turnip

4.2017.3 1.8 5.8! 2.620 .0 2.6:14 $\gamma^{\prime} \ldots$ $1.4227 .0 \quad 1.514 .6,2.74 .71 .1,2.2 \ldots$ \begin{tabular}{ll|l|l|l|l|l|l|l|l}
7.84 & 18.4 & 4.5 & 8.6 & 5.1 & 47.2 & 0.6 & 0.6 & $\ldots$
\end{tabular}

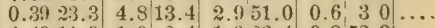
\begin{tabular}{ll|l|l|l|l|l|l|l}
4.49 & 11.9 & 1.0 & 8.4 & 1.0 & 23.4 & 0.252 .3 & $\ldots$
\end{tabular}

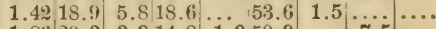
\begin{tabular}{l|l|l|l|l|l|l|l|l|l|l|}
1.81 & 20.3 & 3.3 & 14.8 & 1.350 .9 & $\ldots$ & 7.5 & $\ldots$
\end{tabular}

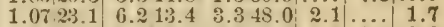

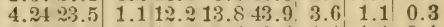

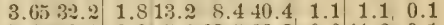
$\begin{array}{lllllllll}5.48 & 20.1 & 0.8 & 5.6 & 23.5 & 36.3 & 0.2 & 11.5 & 0.1\end{array}$ $\begin{array}{lllllllll}6.12 & 13.6 & 1.0 & 9.5 & 35.4 & 31.4 & 1.9 & 3.2 & 4.4\end{array}$

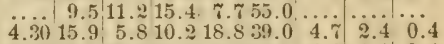

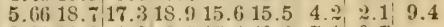
$\begin{array}{lllllll}3.9821 .9 & 1.2 & 8.7 & 1 \% .4 & 40.2 & 7.1 & 0.7\end{array}$ \begin{tabular}{ll|lllllll}
8.50 & 19.1 & 4.8 & 0.7 & 35.8 & 15.8 & 5.6 & 5.3 & 3.3
\end{tabular}

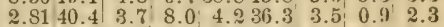

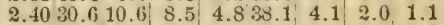
\begin{tabular}{lll|l|l|l|l|l|l|l|l|l|l|}
3.45 & 40.5 & 1.2 & 6.7 & 5.2 & 39.2 & 5.1 & 1.2 & 2.9
\end{tabular} \begin{tabular}{ll|l|l|l|l|l|l|l}
3.063 & 44.1 & 2.9 & 7.5 & 7.7 & 30.4 & 3.5 & 0.8 & 0.9
\end{tabular} \begin{tabular}{ll|l|l|l|l|l|l|l}
2.06 & 27.8 & 9.9 & 2.0 & 5.1 & 29.1 & $\ldots$ & 1.1 & 3.3
\end{tabular} \begin{tabular}{lll|l|l|l|l|l}
$\ldots .033 .5$ & 17.8 & 6.2 & 7.8 & 25.5 & 6.8 & 0.9 & 1.8
\end{tabular}

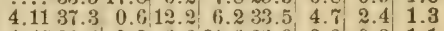

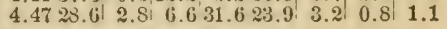

\section{XI.-FRUTTS AND SEEDS OF TREES, ETC.}

14.) Grape seeds. 14ij Alcler.. ...................

147 White pine..

14 Red pine..................

149 Beech nuts..................

15i) Acorns...........

151, Horse-chestiut.............. 15: " green husk... 15.3 Apple, entire fiuit..........

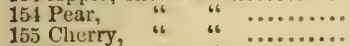
155 Clierry, " 156 Plum,
"6 $\ldots \ldots \ldots$.

\begin{tabular}{|l|l|l|l|l|l|l|l|l|l|l|l|}
$2.81 \mid 28.6$ & $\ldots$ & 8.6 & 33.9 & 21.0 & 2.5 & 1.1 & 0.3
\end{tabular} \begin{tabular}{lll|l|l|l|l|l|l}
5.14 & $3 \% .6$ & 1.6 & 8.0 & 30.7 & 13.0 & 3.4 & 3.2 & 0.1
\end{tabular}

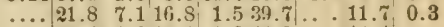

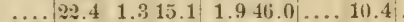
$3.3022 .810 .011 .624 .520 .8 \quad 2.2 \quad 1.90 .5$ \begin{tabular}{ll|lllllll}
$\ldots .$. & 64.5 & 0.7 & 5.4 & 7.0 & 16.2 & 2.8 & 1.1 & 1.7
\end{tabular} $\begin{array}{lllllllll}2.36 & 58.9 & \ldots & 0.5 & 11.6 & 22.4 & 1.4 & 0.2 & 6.4\end{array}$

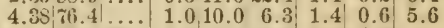
\begin{tabular}{l|l|l|l|l|l|l|l|l|l|l|l|}
$\ldots .$. & 35.7 & 26.1 & 8.8 & 4.1 & 13.6 & 6.1 & 4.3 & $\ldots$
\end{tabular}

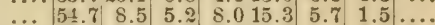

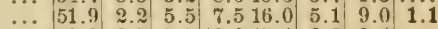

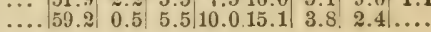

\section{XII.-LEAVES OF TREES.}

15\% Mulberry..................... 158, Horse-chestnut, spring......
$159^{\text {i }}$ 160, Walnut, spring............ 161 il autum $\ldots \ldots \ldots \ldots . .$. 16is Beech, summer ........... 1613 "4 antmmn............

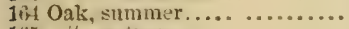
Ifis) 66 autmun ...............

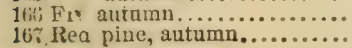

\begin{tabular}{|c|c|c|c|c|}
\hline & & & & \\
\hline 3.5319 .6 & & $5.4 ! 25.7: 10.2$ & 0.533 .5 & 0.1 \\
\hline 7.17 .38 .8 & & $3.9 \approx 1.3 \approx 3.4$ & 6.02 .9 & 3.8 \\
\hline $7.5 \div 19.6$ & & \begin{tabular}{l|l|l|}
7.840 .5 & 8.2
\end{tabular} & 1.713 .9 & 41 \\
\hline 7.724 .2 .7 & & 4.626 .921 .1 & \begin{tabular}{l|l}
2.6 & 1.2
\end{tabular} & $0 . \overline{5}$ \\
\hline $7.012 ; .6$ & & $9.853 .7 \mid 4.0$ & 2.7 & 0.8 \\
\hline $4.8: 318.5$ & 1.8 & 8.636 .5 & 3.115 .2 & \\
\hline 6.7.) 5.2 & 0.6 & $6.0+1.9$ & 3.733 .9 & 0.4 \\
\hline 4.6033 .1 & & $13.5 \%$ & 2.74 .4 & J. \\
\hline $4.90 \mid 3.5$ & 0.6 & $4.045 .6 ; 8.1$ & 4.430 .9 & \\
\hline $1.40: 10.1$ & $\ldots$ & $9.9,41.416 .4$ & 4.413 .1 & \\
\hline $5.82 \mid 1.5$ & & 2. & 2.8 .70 & \\
\hline OL & & & & \\
\hline 29.81 & 6.7 & 12 & 0.8 & \\
\hline 6.5 & 11. & 5.757 .3 & 3.6 & \\
\hline 11.6 & 5.8 & $8.9 ! 60.0$ & 0.3 & \\
\hline & & & & \\
\hline
\end{tabular}

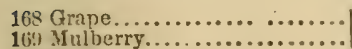

171 Beech, body-wood. 1\%0. Birch.

\begin{tabular}{ll|l|l|l|l|l|l|l|l|}
0.65 & 16.1 & 3.4 & $10.8,56: 4$ & 5.3 & 1.0 & 4.7 & 0.1
\end{tabular} 
Composition of the Asir of Agricultural Plantg ind Prindets.

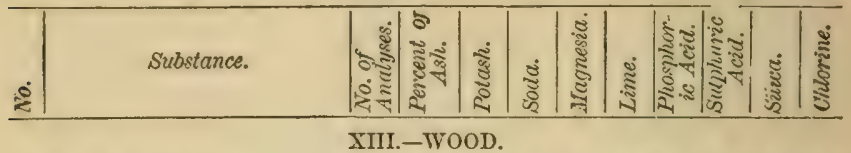

17 Beech, small wood..........

17.) ". Oak, body-wood................. bark

17.5 "s small branches with

17i Morse-chestunt twigs, autu'n

17 Walnut twige, autumn.....

17. Poplar, young twigs.........

17? Willow, "6 "........

1.i) Elm, "6 "6 ......

1.1 Elm, body-wood............

182 Linden ....................

183 Apple trec..................

1s4 Red pine...................

185 White pine................

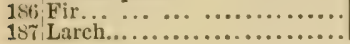

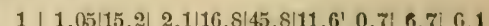

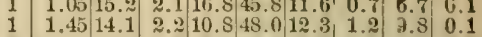

$\begin{array}{llllllllll}2 & \ldots & 10.0 & 3.6 & 4.8 & 73.5 & 5.5 & \mathbf{1 . 4} & \mathbf{1 . 1} & 0.2\end{array}$

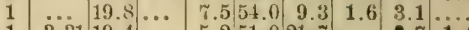

$\begin{array}{lllllllll}1 & 3.31 & 19.4 & \ldots & 5.251 .0 & 21.7 & \ldots & 0.7 & 1.4\end{array}$

$\begin{array}{llllllllll}1 & 2.99 & 15.3 & \ldots & 8.1 & 55.9 & 12.2 & 3.2 & 2.9 & 0.3\end{array}$

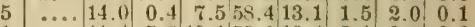

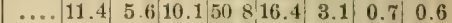

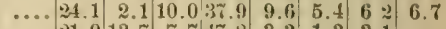

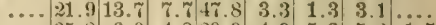

$\begin{array}{llllllll}\ldots . .35 .8 & 6.0 & 4.2 .09 .9 & 4.9 & 5.3 & 5.3 & 1.5\end{array}$

$\begin{array}{lllllllll}1.29 & 12.0 & 1.6 & 5.7 & 1.0 & 4.6 & 2.4 & 1.8 & 0.2\end{array}$

$\begin{array}{lllllllllll}0.25 & 5.2 & 26.8 & 6.2 & 47.9 & 5.1 & 3.0 & 2.0 & 4.0\end{array}$

$\begin{array}{llllllllll}0.28 & 5.3 & 9.9 & 5.9 & 50.1 & 5.5 & 3.0 & \text { (5.0) } & 0.2\end{array}$

\begin{tabular}{ll|l|l|l|l|l|l|l}
0.31 & 11.8 & 4.6 & 9.1 & 50.1 & 5.8 & 2.3 & 15.0 & 0.4
\end{tabular}

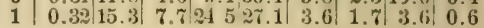

\section{XIV.-BARL.}

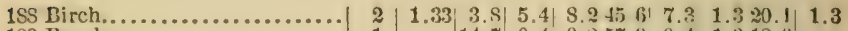

18 Beech 190 Horse-chestnut, young, aut'n

191 Whalunt,

19: E.m...

19:3 Linden.......................

194 Red pine...................

195 White pine.

185 Fir .

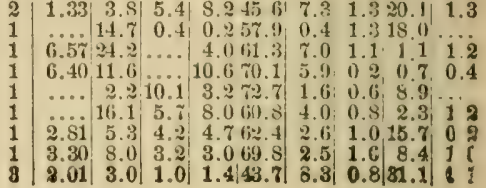




\section{TABLE II.}

Coy-asition of Fresi on Air-ory Agri jutural F. coducts, giving the average quantity of Water, Sulphur, Ash, and Ash ingredients, in 1,000 parts of substance, by Prof. WrolfF.

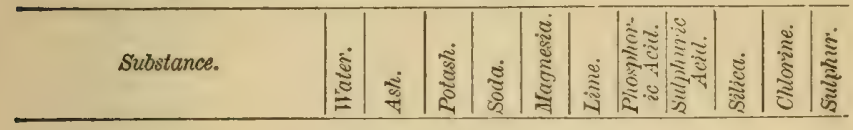

\section{I.-HAY.}

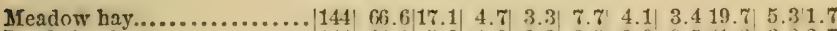

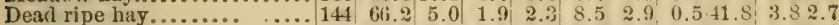
Red clover................ $160 \mid \begin{aligned} & 56.5 \\ & 19.5\end{aligned}$

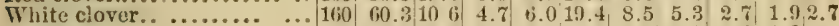

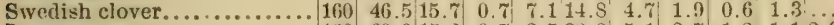

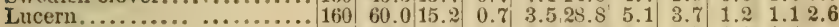

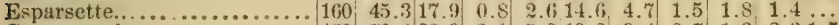

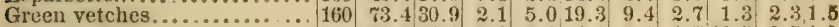
Green oats............... 145| 61.S|24.1 $2.0|2.0| 4.1,5.1|1.720 .5| 2.5,1.5$

\section{II.-GREEN FODDER.}

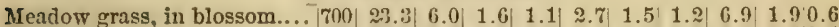

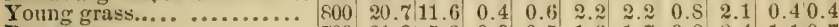

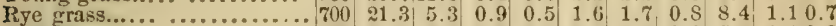

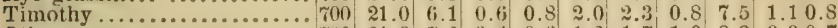

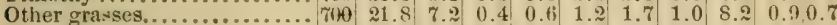

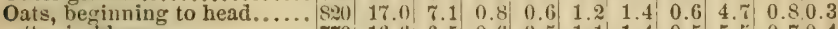
"6 in blossom...........

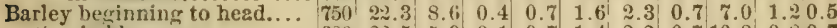

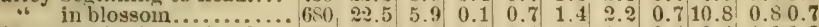

Wheat, berinning to head....

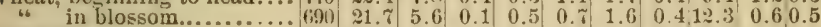

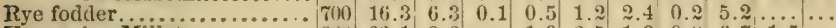
Hungarian M̈iliet.............6.6.

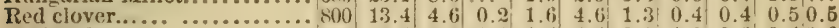

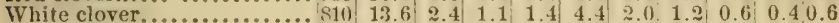

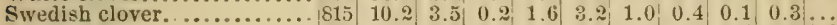

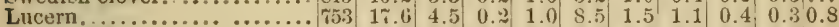

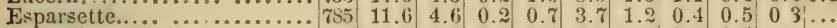

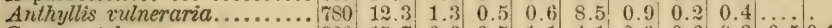

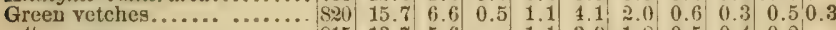
"

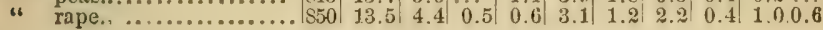
III.-ROOT CROPS.

Potato......................

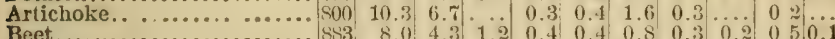

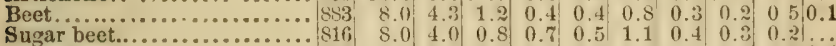

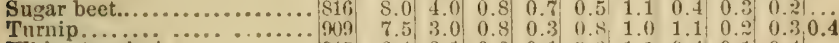

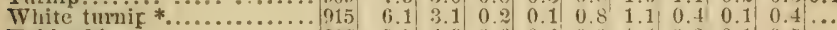

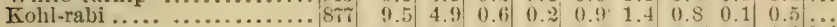

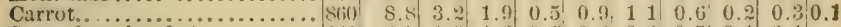

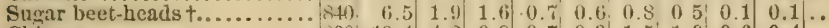

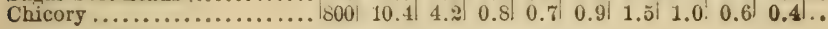




\section{Composition of Fresir or Air-drt Agricultural Prodents}

\begin{tabular}{|c|c|c|c|c|c|c|c|c|c|c|c|}
\hline Substance. & $\frac{\dot{j}}{2}$ & 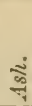 & $\frac{20}{\stackrel{\partial}{\Sigma}}$ & 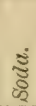 & $\begin{array}{l}\text { \&్ } \\
\text { हू } \\
\text { है }\end{array}$ & ¿્న & 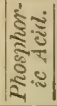 & 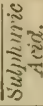 & & 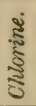 & $\frac{3}{5}$ \\
\hline
\end{tabular}

IV.-I.EAVES AND STEVIS OF ROO' CROPS.

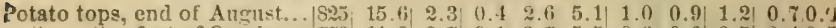

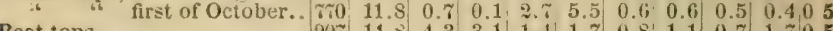

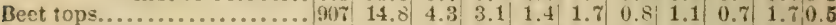

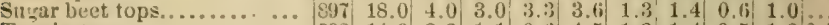

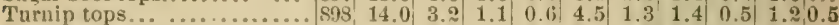

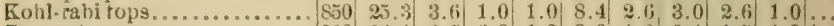

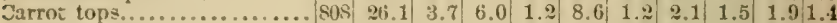

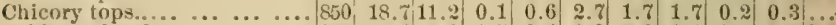

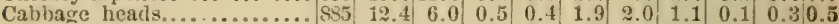

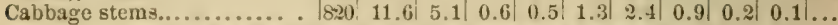
V.-MANUFACTURED PRODUCTS AND REFUSE.

Sugar beet cake............ fig.

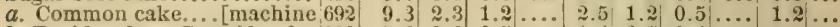
\begin{tabular}{ll|l|l|l|l|l|l|l|l|l} 
b. Residue from Centrifugal & 820 & 5.6 & 2.6 & 0.5 & $\ldots$ & 1.4 & 0.7 & 0.4 & $\ldots$ & $\ldots \ldots$
\end{tabular}

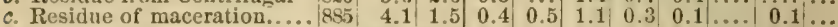

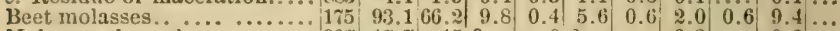

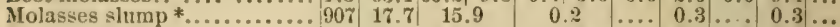

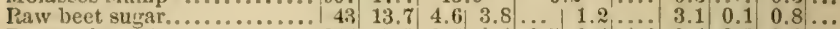

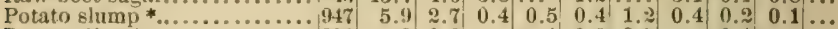

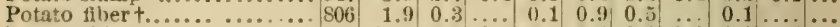

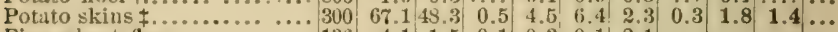
Fine wheat flour............. $136 \mid$\begin{tabular}{l|l|l|l|l|l|l|l|l|l|}
4.1 & 1.5 & 0.1 & 0.3 & 0.1 & 2.1 & $\ldots$ & $\ldots$ & $\ldots \ldots$ & $\ldots$
\end{tabular}

Rye flour ...

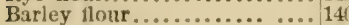

Barley dust $\mid . . . . . . . . . . . . .113$

Maize meal... .............. 140

Millet meal................. 14

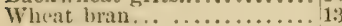

Rye bran.................... 18

Brewer's grains............. 76

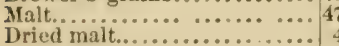

Mait sprouts................ .

Grape slins.................. 600

Beer........................ 90

Wave cake..................... 15

Iinseed cake.............. 115

Poppy cake.................... 10

Walnut cake............... 136 \begin{tabular}{ll|l|l|l|l|l|}
16.9 & $\mathbf{6 . 5}$ & 0.3 & 1.4 & 0.2 & 8.5 & $\cdots$ \\
20.0 & 5.8 & 0.5 & 2.7 & 0.6 & 9.5 & 0.6
\end{tabular} \begin{tabular}{|l|l|l|l|l|l|}
49.8 & 9.4 & 0.7 & 3.8 & 1.214 .4 & $\ldots$
\end{tabular} \begin{tabular}{rr|r|r|r|r|r|r}
9.5 & 2.7 & 0.3 & 1.4 & 0.6 & 4.3 & $\ldots$ \\
\hline 11.6 & 2.3 & 0.3 & 3.0 & $\ldots$ & 5.5 & 0.3
\end{tabular} $\ddot{9} 9 \ldots \ldots$

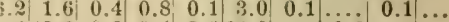
$\begin{array}{lllllllllll}55.6 & 13.3 & 0.3 & 9.4 & 2.6 & 23.8 & \ldots & 0.6 & \ldots & \ldots\end{array}$

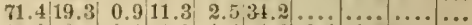
$\begin{array}{lllllllllll}12.0 & 0.5 & 0.1 & 1.2 & 1.4 & 4.6 & 0.1 & 3.9 & \ldots & \ldots\end{array}$

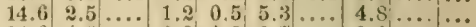
\begin{tabular}{|l|l|l|l|l|l|l|l|l|l|l|l}
26.6 & 4.6 & $\ldots$ & 2.2 & 1.0 & 0.7 & $\ldots$ & 8.8 & $\ldots$ & $\ldots$
\end{tabular} \begin{tabular}{ll|l|l|l|l|l|l|l|l|}
59.6 & 20.8 & $\ldots$ & 0.8 & 0.9 & 12.5 & 3.8 & 17.7 & $\ldots$ & $\ldots$
\end{tabular} \begin{tabular}{ll|l|l|l|l|l|l|l|l|l|l}
16.1 & 8.6 & 0.1 & 0.5 & 2.5 & 2.5 & 1.2 & $\ldots$ & 0.1 & $\ldots$
\end{tabular} $\begin{array}{lllllllllllll}16.2 & 8.0 & 0.4 & 1.0 & 2.1 & 3.4 & 0.7 & 0.6 & 0.1 & \ldots\end{array}$ \begin{tabular}{llllllll|l|l|l|l}
3.9 & 1.5 & 0.3 & 0.2 & 0.1 & 1.3 & 0.1 & 0.4 & 0.1 & $\ldots$
\end{tabular} \begin{tabular}{lll|llllllll}
2.8 & 1.8 & $\ldots$ & 0.2 & 0.2 & 0.5 & 0.1 & 0.1 & $\ldots$ & $\ldots$ \\
\hline
\end{tabular} $\begin{array}{llllllllllll}56.0 & 13.6 & 0.1 & 6.4 & 6.1 & 20.7 & 1.9 & 4.9 & 0.1 & \cdots\end{array}$ $\begin{array}{lllllllllll}55.2 & 12.9 & 0.8 & 8.8 & 4.7119 .4 & 1.9 & 3.6 & 0.3 & \ldots\end{array}$ \begin{tabular}{ll|l|l|l|l|l|l}
95.4 & 19.8 & 4.3 & 4.1 & 26.836 .1 & 1.9 & 4.6 & $\ldots$
\end{tabular}$\ldots$ \begin{tabular}{ll|l|l|l|l|l|l|l|l|l|l}
46.4 & 15.4 & $\ldots$ & 5.7 & 3.1 & 21 & 0.3 & 0.5 & 0.7 & 0.1 & $\ldots$
\end{tabular} -STR.1W.

Winter whent............|141| $42.6|4.9| 1.2|1.1| 2.6|2.3| 1.2|28.2| \ldots \mid 1.6$

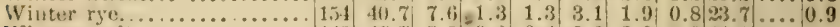

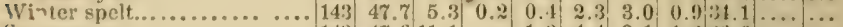

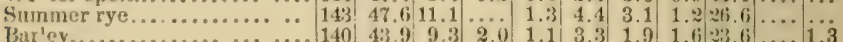

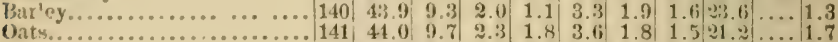

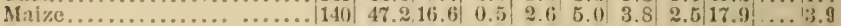

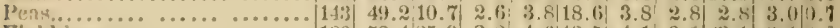

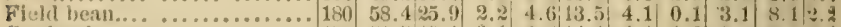
Giarden bean............... $150|51.5| 19.1|3.1| 2.7|1.1 .1| 4.1|1.8| 2.1|27|: 1$

- Rcoldne from spirit manufacture + Refuse of starch manufacture. \$From boiled potatoes. I Refise from making burley arits. 
Composition of Fresp or Alr-dry Agriculturat Pronucts.

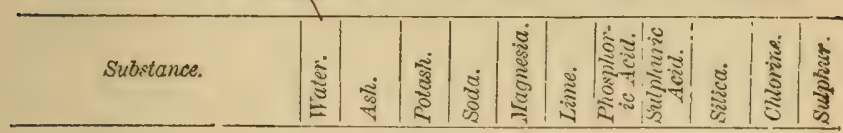

VI.-STRAW.

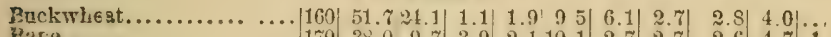

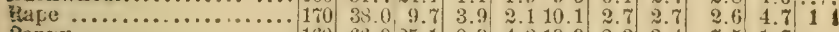

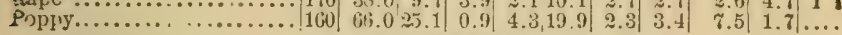
VII.-CIIAFF.

\begin{tabular}{ll|l|l|l|l|l|l|l|l|l|l} 
Whe at ................. $13 S$ & 93.5 & $S .4$ & 1.7 & 1.2 & 1.9 & 4.0 & $\ldots$ & 75.1 & $\ldots$ & 0.8
\end{tabular}

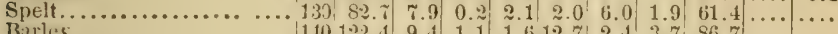

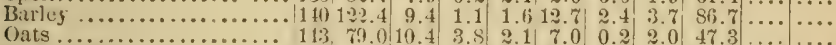

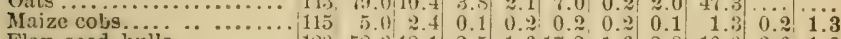

Flax secd hulls............. 1 VIII.TEXTILE PLANTS, ETC.

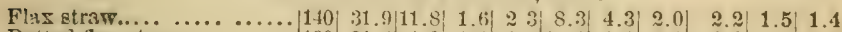

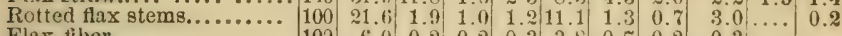

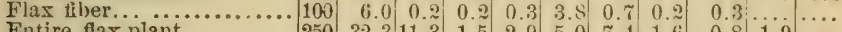

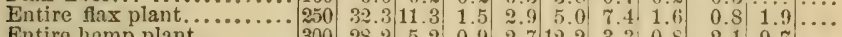

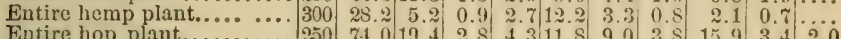

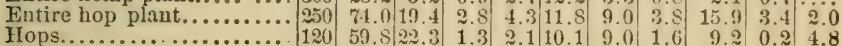

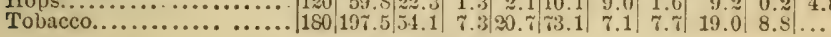
IX.-LITTER.

\begin{tabular}{ll|lll|l|l|l|llll} 
Heath .................... & 300 & 36.1 & 4.8 & 1.9 & 3.0 & 6.8 & 1.8 & 1.6 & 12.7 & 0.8 & $\ldots$
\end{tabular}

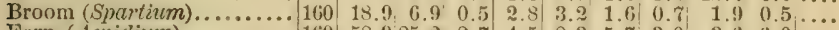

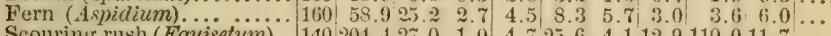
Scouring rush (Equisetum).. 140201.427 .0 1.0 $4.725 .6,4.112 .9110 .011 .7 \ldots \ldots$

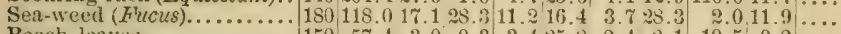
Beech leaves.............. 150 57.4. 3.0 0.3 $3.4 .25 .52 .4,2.1 \quad 19.5,0.2 \ldots$

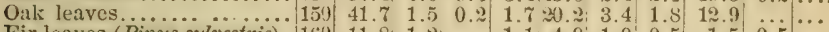

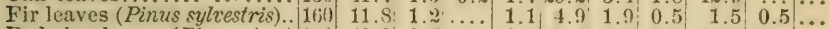

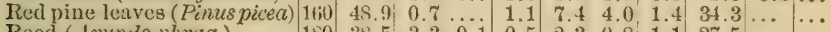

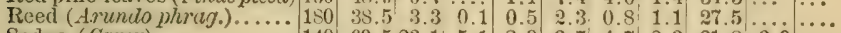
Sedre (Carex). ............ 140 69.5 23.1 5.1 2.9.

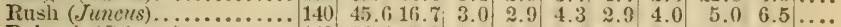

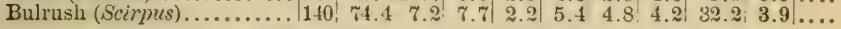
X.-GRAINS AND SEEDS OF AGRICULTURAL PLANTS.

\begin{tabular}{|c|c|c|c|c|c|c|c|c|c|}
\hline Wheat... & & & & & 0.1 & & 0.3 & & \\
\hline & 149 & $\begin{array}{ll}17.3 & 5.4\end{array}$ & 0.3 & 1.9 & 0.5 & 0.4 & 0.3 & & \\
\hline arley.. ..... & 145 & $21.8 \quad 4.8$ & 0.6 & 1.8 & 0.5 & 0.5 & 5.9 & & 1.4 \\
\hline ( O b & $1+0$ & 36.4 & 10 & 1.8 & 1.0 & 0.4 & 12.3 & & 1.7 \\
\hline elt, with husk......... & 148 & $\begin{array}{lll}35.8 & 6.2\end{array}$ & 0.6 & 2.1 & 0.9 & 0.6 & 15.8 & & \\
\hline Miazo................... & 136 & $\begin{array}{lll}12.3 & 3.3\end{array}$ & 0.2 & 18 & 5.5 & 0.1 & 0.3 & & 1.2 \\
\hline $\begin{array}{l}\text { Rice, with hask } \ldots \ldots \ldots \ldots \\
\text { husked } \ldots\end{array}$ & 130) & 69.012 .7 & 3.1 & 5.9 & $3.53-2.6$ & 0.4 & 0.4 & & \\
\hline Millet, with husk. & $\begin{array}{l}150 \\
180\end{array}$ & \begin{tabular}{ll|l|}
3.4 & 0.3 \\
3.1 & 4.7
\end{tabular} & $\begin{array}{l}0.2 \\
0.4\end{array}$ & $\begin{array}{l}0.5 \\
3.3\end{array}$ & $\begin{array}{l}0.1 \\
0.4\end{array}$ & 0.1 & $\begin{array}{r}0.1 \\
205\end{array}$ & & 1.8 \\
\hline " husked..... & 151 & $\begin{array}{ll}12.3 & 2.3\end{array}$ & 0.7 & 2.3 & 6.6 & 0.2 & & & \\
\hline טמו & 1110) & 16.04 & 5 & & 0.2 & & 1.2 & & \\
\hline wheat.. & 141 & 9.2 & 36 & $z$ & 4.4 & & & & \\
\hline seed. & $1 \div(9)$ & 37.3, & 0.4 & 4 & 5.216 .4 & 1.3 & $(1$ & 0.1 & \\
\hline Flix & & 32.210 & 0.6 & & 2713 & 0.4 & & & \\
\hline Hemp & $1 \div 2$ & $44.1,9$ & & & & & & & \\
\hline Poppy" " & $1+\tau$ & & & & & & & & \\
\hline Mnstird "6 .. & $12 \geq 1$ & $3 \%$ & $3 .:$ & & & & & & \\
\hline Preet. " & 116 & $44.7,9$ & & & $7.6 \%$ & & & & \\
\hline urnip " & $1 * 3)$ & 35.07 & & & & & & & \\
\hline$"$ " & 120 & & & & & & & & \\
\hline ....... & 138 & & & & & & & & \\
\hline & & & & & & & & & \\
\hline
\end{tabular}


Compobition of Fresh or Air-drt Agricultural Prodects.

\begin{tabular}{|c|c|c|c|c|c|c|c|c|c|c|}
\hline Substance. & 这 & 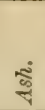 & 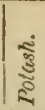 & $\begin{array}{l}\text { కేँ } \\
\text { ईँ }\end{array}$ & $\begin{array}{l}\text { हूँ } \\
\text { हूँ } \\
\text { हूँ }\end{array}$ & 胥 & 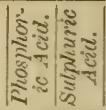 & 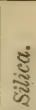 & हूँ & 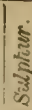 \\
\hline
\end{tabular}

X.-GRAINS AND SEEDS OF AGRICULTURAL PLANTS.

Field beans................ $141 \mid$\begin{tabular}{l|l|l|l|l|l|l|l|l}
29.6 & 12.0 & 0.4 & 2.0 & 1.5 & 11.6 & 1.5 & 0.4 & 0.52 .3
\end{tabular}

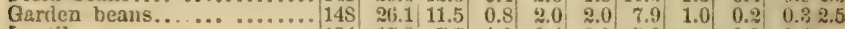

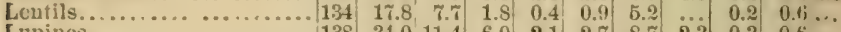

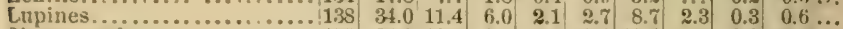

\begin{tabular}{ll|l|l|l|l|l|l|l|l|l|l} 
Clover seed.................... 150 & 36.9 & 13.8 & 0.2 & 4.5 & 2.3 & 12.4 & 1.7 & 0.9 & 0.5 & $\ldots$
\end{tabular}

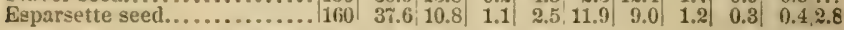
XI,-FRUITS AND SEEDS OF TREES, ETC.

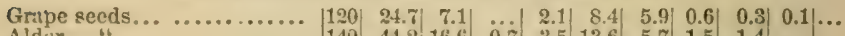

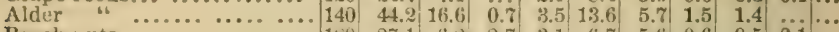

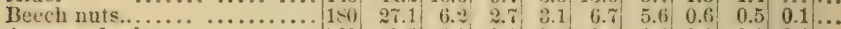

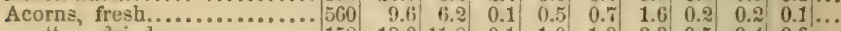

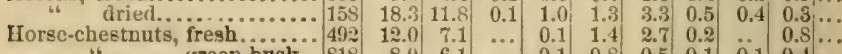

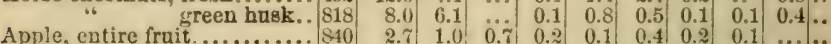

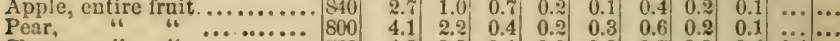

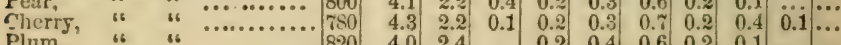

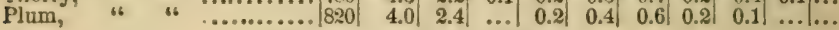
XII.-LEAVES OF' 'TREES.

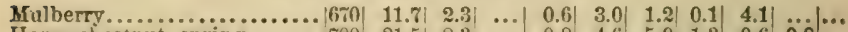

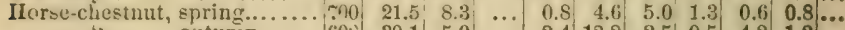

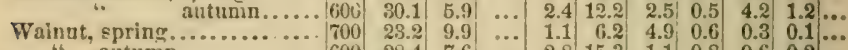

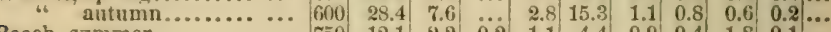

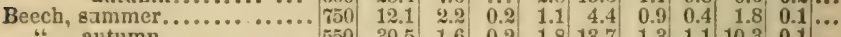

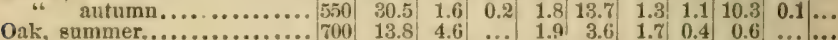

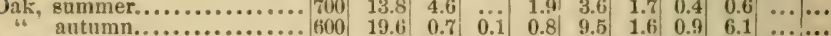

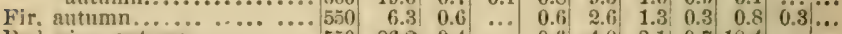

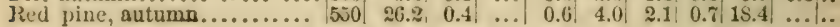

XIII,-WOOD. (AIT-DRY.)

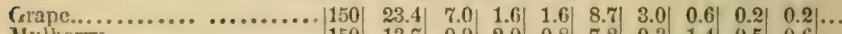

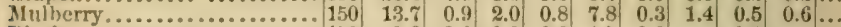

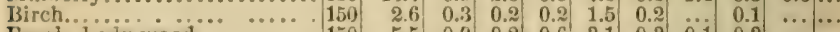

$\begin{array}{llllllllllll}\text { Beech, body-wood ........... } & 150 & 5.5 & 0.9 & 0.2 & 0.6 & 3.1 & 0.3 & 0.1 & 0.3 & \ldots & \ldots\end{array}$ \begin{tabular}{lll|l|l|l|l|l|l|l|l} 
" small wood............ 150 & 8.9 & 1.4 & 0.2 & 1.5 & 4.1 & 1.0 & 0.1 & 0.6 & $\ldots$ & $\ldots$
\end{tabular}

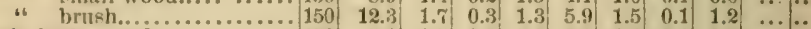

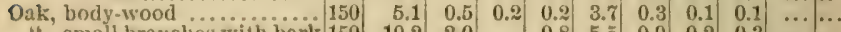

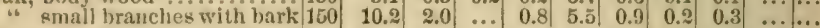
Horec-chestnut, young wood

in autumn............... 150

iValnut...................... 150 Apple tree................ 150

Red pine................... 150

White pine.............. 15it

Fir ..................... 150

Larch........................, 150

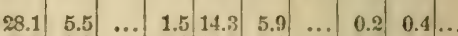
\begin{tabular}{l|l|l|l|l|l|l|l|l|l|l}
25.5 & 3.9 & $\ldots$ & 2.0 & 14.2 & 3.1 & 0.8 & 0.7 & 0.1 & $\ldots$
\end{tabular}

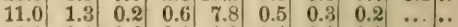
$\begin{array}{lllllllllll}2.1 & 0.1 & 0.6 & 0.1 & 1.0 & 0.1 & 0.1 & 0.1 & \ldots & \cdots\end{array}$ \begin{tabular}{ll|ll|llllll}
2.4 & 0.4 & 0.2 & 0.1 & 1.2 & 0.1 & 0.1 & 0.2 & $\cdots$ & $\cdots$ \\
\hline & 0.3 & 0.1 & 0.1
\end{tabular} \begin{tabular}{llllllllll}
2.6 & 0.3 & 0.1 & 0.2 & 1.3 & 0.2 & 0.1 & 0.4 & $\cdots$ & $\cdots$ \\
\hline
\end{tabular} \begin{tabular}{l|l|l|l|l|l|l|l|l|l|l|l}
2.7 & 0.4 & 0.2 & 0.7 & 0.7 & 0.1 & 0.1 & 0.1 & $\cdots$ & $\cdots$ \\
\hline
\end{tabular}

XIV.-BAKK.

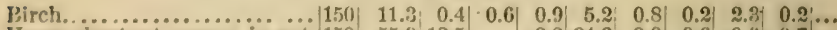

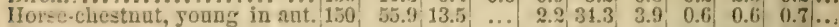
\begin{tabular}{llll|l|l|l|l|l|l|l|l|l} 
Walnut, & "6 & 150 & 51.4 & 6.3 & $\ldots$ & 5.8 & 38.1 & 3.2 & 0.1 & 0.4 & 0.2 & $\ldots$
\end{tabular}

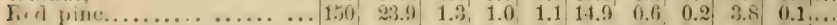

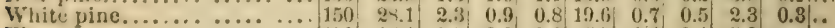

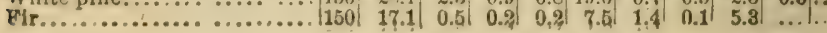




\section{TABLE III.}

Proznate Courosition of Agricultural Plants and Products, giving the average quantities of Water; Organic Matter, Ash, Albuminoids, Carbohydrates, etc., Crude Fiber, Fat, etc., by Professors WOLFF and KNOP.*

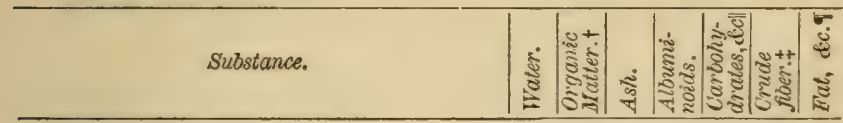

\section{HAY.}

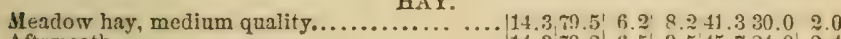

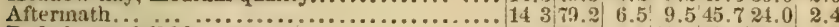

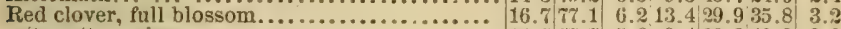

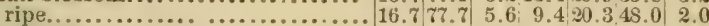

White clover, full blossom................. 16.774 .8 8.5.14.9 31.3 25.6 3.5 Swedish or Alsike clover (Trifolium hybridum) $16.755 .0 \quad 8.315 .3 * 9.230 .5 \quad 3.3$ "6 clover, ripe...................... $16.778 .3 \mid 5.010 .223 .145 .0$ 2.2

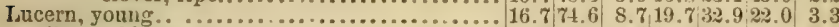
in blossom...................... 16.7 $76.96 .414 .422 .5-40.02 .5$

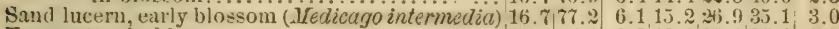

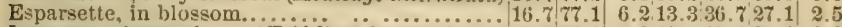
Incarnate clover, do (Trifolium incamatum).. 16.7 76.1 7.2 12.230 .133 .53 .0

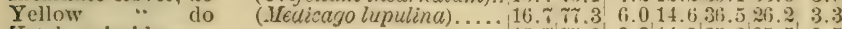
Vetches, in blossom........................ 16.7/75.0 8.314.2 35.325 .5 2.5

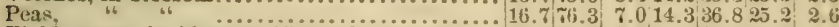
Field spurry, in blossom (spergula arvensis).... 16.7 73.8 $9.512 .0 .39 .822 .0 \quad 3.2$

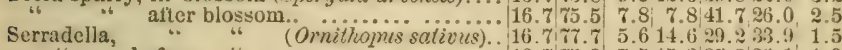

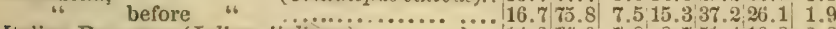
Italian Rye grass (Lolium itaticiom) ................ Timothy (Phleum pratense)................. Early meadow grass (Poc annu(t) $\ldots \ldots \ldots$........... Crested dog's tail (C'ynosurus cristatus)....... Suft brome grass (Bromiss mollis).............. Orchard grass (Dxctylis glomercta)........... Barley grass (Horleum pratense)............ Meadow foxtail (Alopecurus pratensis)........ Oat grass, French rye grass (Arrhenatherum

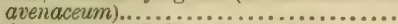

English rye grass (Litium perenne)............. Hiarter Schwingel (Festuca $\left.F^{\prime}\right)$................. Sweet-scented vernal grass (Anthoxanthum odoratum $). . . . . . . . . . . . . . . . . . . . .$.

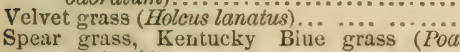
pratensis $). . . . . . . . . . . . . . . . . . . .$.

Rough nealow grass (Poa trivialis)...........

Yellow vat grass (Avena fluvescens)........... $14.37 \% .97 .8$ 8.751.4 16.9 2.8 14.381 .24 .5 9.7 $45.822 .7,3.0$ 14.383 .32 .410 .147 .225 .92 .9 $\begin{array}{lllll}14.380 .2 & 5.5 & 9.545 .0 & 22.6 & 2.8\end{array}$ \begin{tabular}{l|l|l}
14.380 .7 & 5.014 .835 .031 .0 & 1.8
\end{tabular} $14.381 .1 \quad 4.611 .640 .723 .9$ ' 2.7

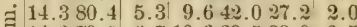
- $14.3 \quad 79.0 \quad 6.710 .6,39.5 \quad 29.0 \quad 2.5$

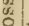

$\begin{array}{llllll}14.3 & 75.8 & 9.9 & 11.1 & 35.329 .4 & 2.7\end{array}$ 14.379 .26 .510 .235 .930 .22 .7 $\Xi 14.381 .0 \quad 4.710 .437 .533 .2 \quad 2.5$

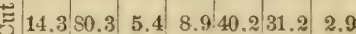
\begin{tabular}{ll|l|l|l|l|l|}
14.3 & 80.2 & 5.5 & 9.9 & 36.7 & 33.6 & 3.1
\end{tabular} $\begin{array}{lllllll}14.380 .6 & 5.1 & 8.9 & 39.1 & 32.6 & 2.3\end{array}$ $14.375 .6 \quad 7.1 \% 8.437 .6 .39 .6 \quad 3.2$

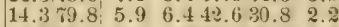

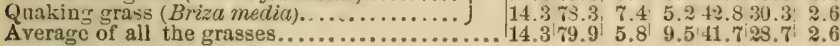

* Lundwirthschaftlicher Kalender, 18f7, throngh Knop's Agricultur-Chsmie, 1868, pp. 715-720. This Tahle is, as reraris water and ast, a repetition of Table II, but includes the newer analyses of $18 t ; j-7$. Therefore the averatges of water and ash do not in all cases agree with those of the former Tables. It gives besides, the proportions of nitrogenous and non-nitrogenons compounds. i. e., Albuminoids and Carbohyilrates, etc. It also states the averages of Crute tiber and of Fat, etc. The discussion of the data of this Table belongs to the subjects of Food and Cattle-Feeding. They are, however, itsserted here. as it is believed they are not to be found elsewhere in the Enentish languace. - + Organic matter here signifies the combustible part of the plant.-I Curboflydrutes, etc., includes fat, starch, surar, pectin, etc., all in fact of Org. matler, except Albuminoids and Crude tiber.- $\%$ Crule fiher is impure cellulose obtained by the processes described on pages 60 and 61.- F Fitt. etc., is the ether-extract p. ?t, and contains be gides fat, wax, chlorophyll, and in some cuses resius. 
Proximate composition of Agricultural Plants and Pronucta.

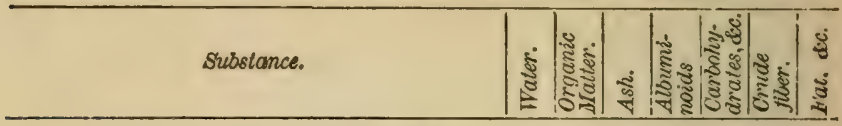

STRAW.

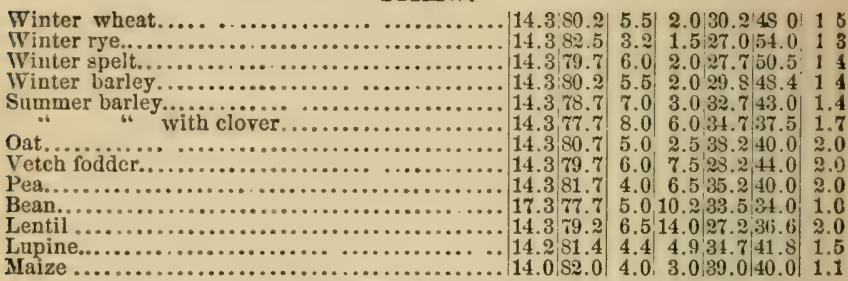

CHAFF AND HULLS.

Wheat.................................. 14.3 \%3.7|12.0| $4.5|33.236 .0| 1.4$

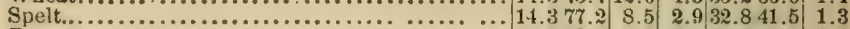

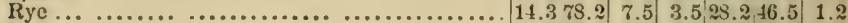

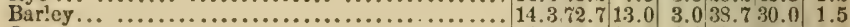
Oat.................................. $14.367 .718 .0 \quad 4.029 .7,34.01 .5$

Vetch................................ $15.077 .0 \quad 8.0 \quad 8.532 .5346 .02 .0$

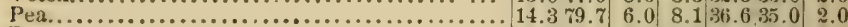

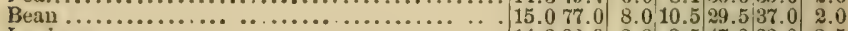

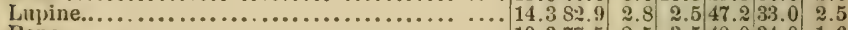

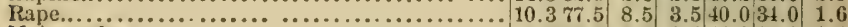
Maize cobs.............................. $10.383 .2|2.8| 1.4|44.0,37.8| 1.4$

\section{GREEN FODDER.}

Grass, before blossom ..................

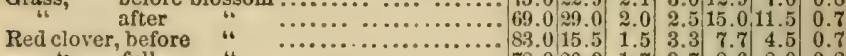

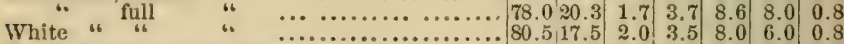

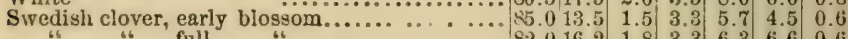

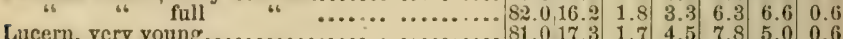

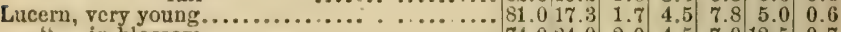
in blossom........................... 74.024 .0 2.0 4.5 7.0 12.50 .7

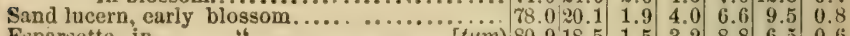

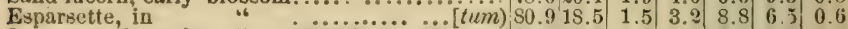

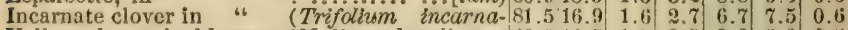

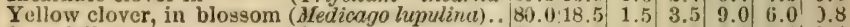
$\begin{array}{llllllllll}\text { Serradella, " } & \text { (Ornithopus sativus).. } & \text { s0.0 } & 18.7 & 1.3 & 3.6 & 7.0 & 8.1 & 3.4\end{array}$ Vetches, " "

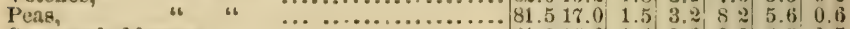

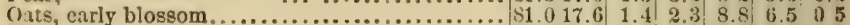

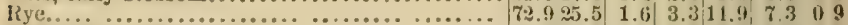

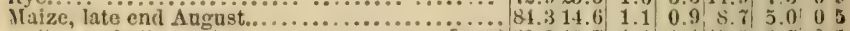

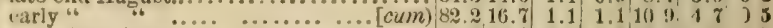
11 ungarian millet, in blossiom (Panicum germani- 6 .

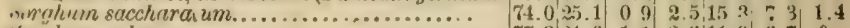

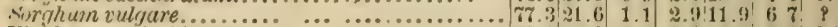

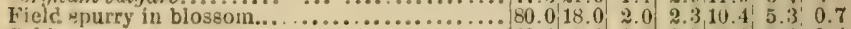

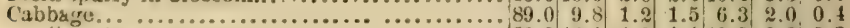

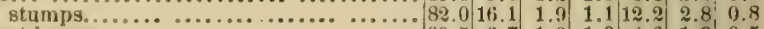

Field bect leaves........................

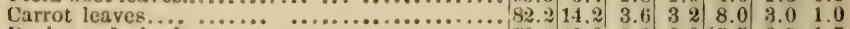

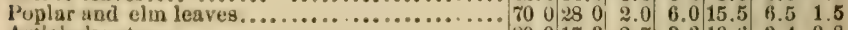

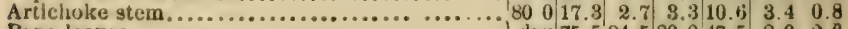
Rape leares................................ d dryl75.5 $\left.24.5\right|_{20} 047.5800$ 
Proximate Composition of Agricultural Plants and Products.

\begin{tabular}{|c|c|c|c|c|c|c|c|}
\hline Substance. & $\frac{\check{2}}{\Sigma}$ & 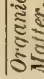 & ذ্் & 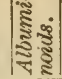 & 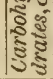 & కँ : & 8 \\
\hline
\end{tabular}

ROOTS AND TUBERS.

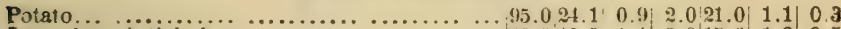

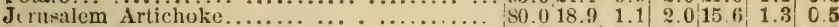
'Turnip Chervil? (Koerbelvibe)............

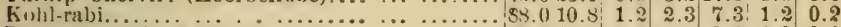

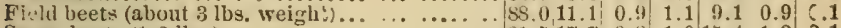

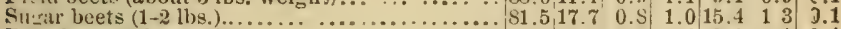

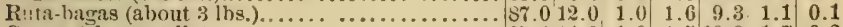

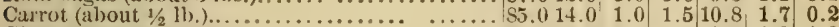

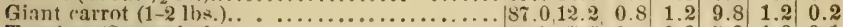

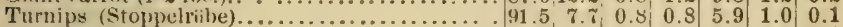

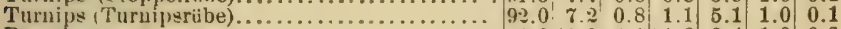

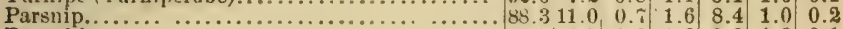

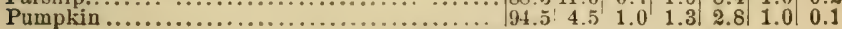

GRACNS AND SEEDS.

\begin{tabular}{|c|c|c|c|c|}
\hline & & & & \\
\hline & & & & \\
\hline Vheat flour..... & & & & \\
\hline pelt. & 14.881 .3 & 3.910 .054 .8 & 16.5 & \\
\hline 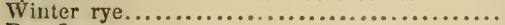 & 14.383 .7 & 2.011 .069 .2 & -3.5 & \\
\hline 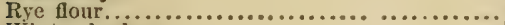 & $1.0,84.4$ & $1.610 .5,72.5$ & 1.5 & \\
\hline 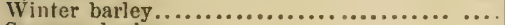 & 14.383 .4 & $2.3 \quad 9.0,65 . ?$ & 8.5 & \\
\hline 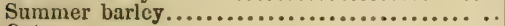 & 14.383 .1 & 9.566 .6 & 7.0 & \\
\hline 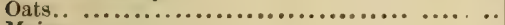 & 14.382 .7 & $3.0-12.060 .9$ & 10.3 & \\
\hline Iaize ............................... & 14.483 .5 & 2.110 .068 .0 & 5.5 & \\
\hline Iillet.$\ldots \ldots \ldots \ldots \ldots \ldots \ldots \ldots \ldots \ldots \ldots \ldots \ldots$. & 14.083 .0 & 3.0 .14 .5 & 6.4 & \\
\hline 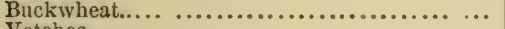 & 14.083 .6 & 2.49 .0 & 15.0 & \\
\hline Vetches ............................... & 14.383 .4 & 2.327 .5 & & \\
\hline 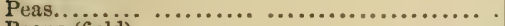 & .383 .2 & 2.52 & & \\
\hline 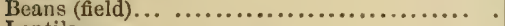 & 4.582 .0 & 3.5 & & \\
\hline 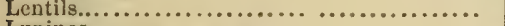 & 14.5825 & $3.0 \mid 23.852$ & & \\
\hline 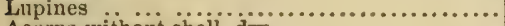 & 32.0 & 3.531 .5 & & \\
\hline Acorns withnut shell, dry $\ldots \ldots \ldots \ldots \ldots \ldots \ldots \ldots$ & 78.4 & 1.6 & & \\
\hline 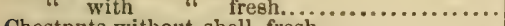 & 56.043 & 1.0 & & \\
\hline hout shell, fresh.................. & & 3.0 & 0.8 & \\
\hline 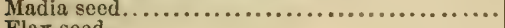 & & 4.722 & & \\
\hline 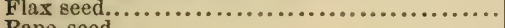 & & & & \\
\hline 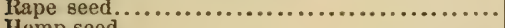 & & 3.9 & & \\
\hline 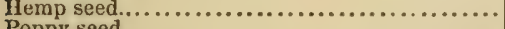 & & & & \\
\hline & & 3.0 & & \\
\hline teches & & & & \\
\hline $\mathbf{R}$ & & & & \\
\hline ugar beet cake................. & & & & \\
\hline " " residue from centrifugal ma- & -82.01 & 1.012 .2 & 3.6 & \\
\hline "6 "6 "6 "s maceration...... & $92.6 \quad 6.6$ & $0.8 \mid 4.4$ & 1.4 & \\
\hline 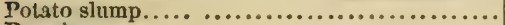 & $94.8 \quad 4.6$ & 1.0 & 0.6 & \\
\hline 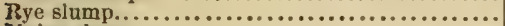 & 89.010 .5 & 0.5 & 1.6 & \\
\hline p................... & 89.010 .5 & 2.0 & 1.3 & \\
\hline 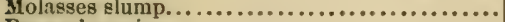 & 92.0 & 1.7 & & \\
\hline 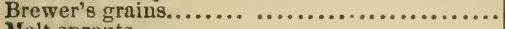 & 76.622 .2 & $1 . 2 \longdiv { 4 } . 9 1 1$ & & \\
\hline s. $\ldots \ldots \ldots \ldots \ldots \ldots \ldots \ldots \ldots \ldots \ldots$ & 8.085 .2 & 6.823 .041 .7 & 17.5 & \\
\hline 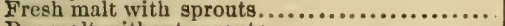 & 47.550 .8 & 1.7. 6.5 & 4.3 & \\
\hline ithoat sprouts... & 4.2 & 2.7 & & \\
\hline n........................ & 13.18 & 5.114 & & \\
\hline .................... & 12.583 .0 & 4.51 & & \\
\hline 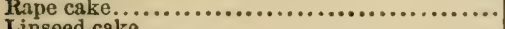 & 15.0 & 7.42 & & \\
\hline lesewre cake $\ldots \ldots \ldots \ldots \ldots \ldots \ldots$ & & 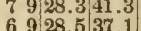 & & \\
\hline & & & & \\
\hline
\end{tabular}


Proxmate Composition of Agrioulturai. Planrs and Prodoct

Substance.

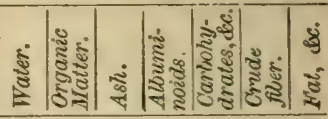

\section{REFUSE.}

Poppy cake.... ..... ...................... 10.0'\$1.6| 8.4|32.5|37.7|11.4: 8.1

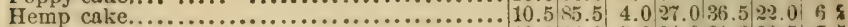
Beechnut cake........................... 10.0 $84.8 \quad 5.224 .031 .320 .5 .7 .5$

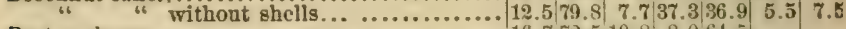

Beet molasses............................ 16.7 72.5 10.8 $8.061 .5 \ldots \ldots \ldots$ Potato fiber............................ S2.6 $17.1|0.3| 0.8,15.0|1.3| 0.1$ COFFEE. TEA.

Coffee besn............................ $12.093 .0|7.0| 10.0|49.0| 34.0 \mid 12.0$

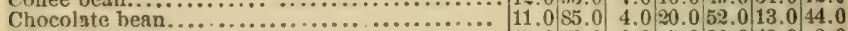

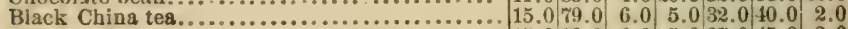

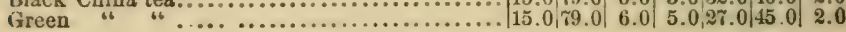

\section{TABLE IV.}

DETAILED ANALYSES OF BREAD GRAINS.

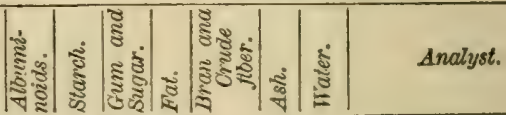

WHEAT.

From Elsas.............14.6 59.7| 7.2 1.2

"Sasony............... 11.864 .4 1.4 2.6

" America........... $10.963 .4 \quad 3.81 .2$

" Flanders.............. 10.7 (i1.0 9.21 .0

"Odessa............... 14.359 .6 6.3 1.5

“Tanganrock.......... 13.6 57.9 7.91 .9

" Polind .............. 21.5 53.4 6.81.5

" Humrary............ 13.4 6:.2 5.41 .1

" Egypt...............

RYE.

From Hegaia............ 13.6 $50.5|8.9| 0.9 \mid 10.1$ | $1.8|15.0|$ Fresenius.

"France............. 11.6 56.5 10.2 1.9 3.5 2.214.1 Payen.

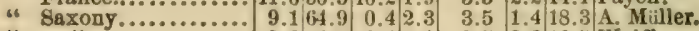

14

\begin{tabular}{|l|l|l|l|l|l|l|l|}
9.6 & 56.7 & 6.4 & 2.1 & 8.5 & 3.3 & 16.5 & W \\
\hline
\end{tabular}

\section{BARLEY.}

|10.5 50.3| 5.5|2.0| $13.6|3.8| 15.7 \mid$ Wolff.

13.253.7 4.2 2.6 $11.5 \quad 2.812 .0$ Polson.

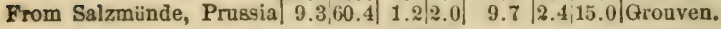

OATS.

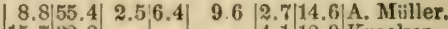

\begin{tabular}{|l|l|l|l|l|l|l|l|}
\hline 15.7 & 2.2 & $\ldots$ & $\cdots$ & $\cdots$ & 4.1 & 12.9 & Krocker.
\end{tabular}

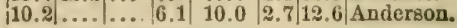

\section{BUCKWHEAT.} \begin{tabular}{|r|c|c|c|c|c|c|c|c|} 
Erusked, from Vienna...... & 2.6 & 78.9 & 3.8 & 0.9 & 1.0 & $\ldots$ & 12.7 & Bibra.
\end{tabular}

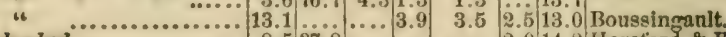

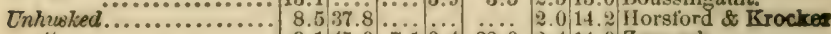

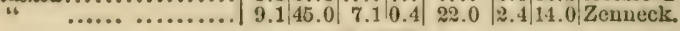

\section{MAIZE.}

From Saxony............ $8.8|59.0| 5.3|9.2| \quad 4.9|3.2| 10.5 \mid$ Hellrlegel.

" America............. 8.854 .4 2.7 4.6 15.\& 1.7 12.0 Polson.

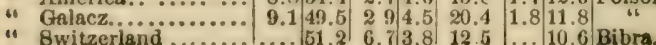


DETAjLed ANaltses of BREAd Gratrg.

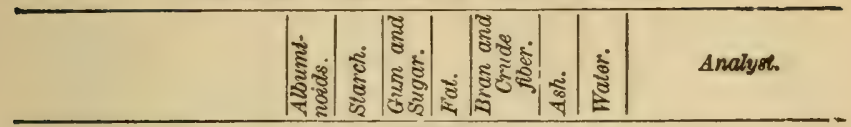

\section{RICE.}

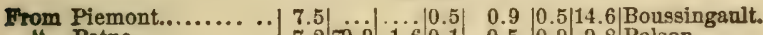

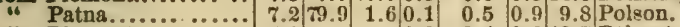

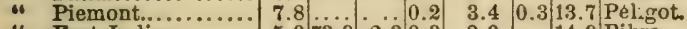

“ East Indics......... $5.9|73.9| 2.3|0.9| 2.0|\ldots| 14.0 \mid$ Bibra.

MILLET.

Husked. Hagenau....... $20.6|\ldots . \ldots| 3.0|2.4| 2.2 .14 .0$ Boussingault.

". Nuremberg ........ 10.3,57.0 11.0,8.0 $2.0|\ldots| 12.2$, Bibra.

\section{TABLE $\nabla$.}

DETAILED ANALYSES OF POTATOES, by GrouveN. (Agricultur-Chemie, 2te Auf., pp. 495 \& 355.)

\begin{tabular}{|c|c|c|c|}
\hline & \multicolumn{2}{|c|}{ White Potatoes, newly dug, } & \multirow{2}{*}{$\begin{array}{l}\text { Varions Scrts. Aver } \\
\text { age of } 19 \text { Analyses. }\end{array}$} \\
\hline & unmanured. & manured. & \\
\hline 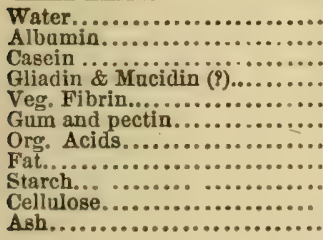 & $\begin{array}{c}74.95 \\
0.47 \\
0.04 \\
0.20 \\
1.31 \\
0.76 \\
2.00 \\
0.07 \\
17.83 \\
1.90 \\
0.88\end{array}$ & -3.19 & $\begin{array}{r}0.30 \\
15.24 \\
1.01 \\
0.95\end{array}$ \\
\hline & 100. & 100. & \\
\hline
\end{tabular}

TABLE VI.

DETAILED ANALYSES OF SUGAR BEETS.

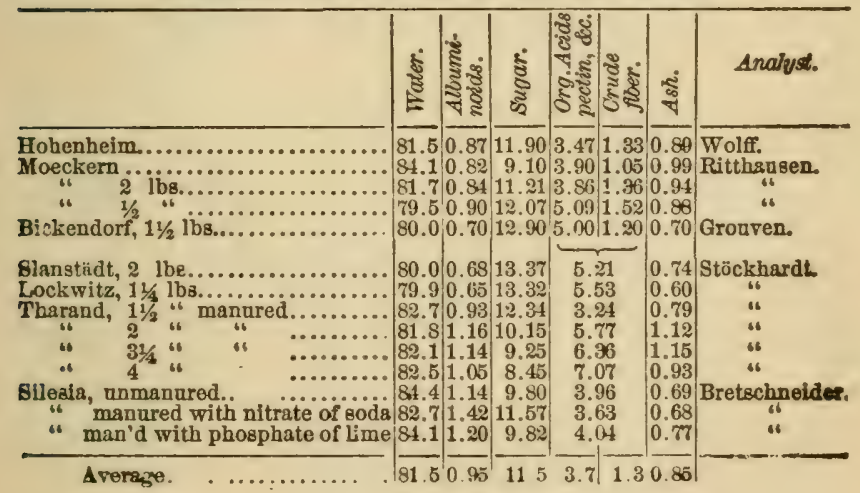




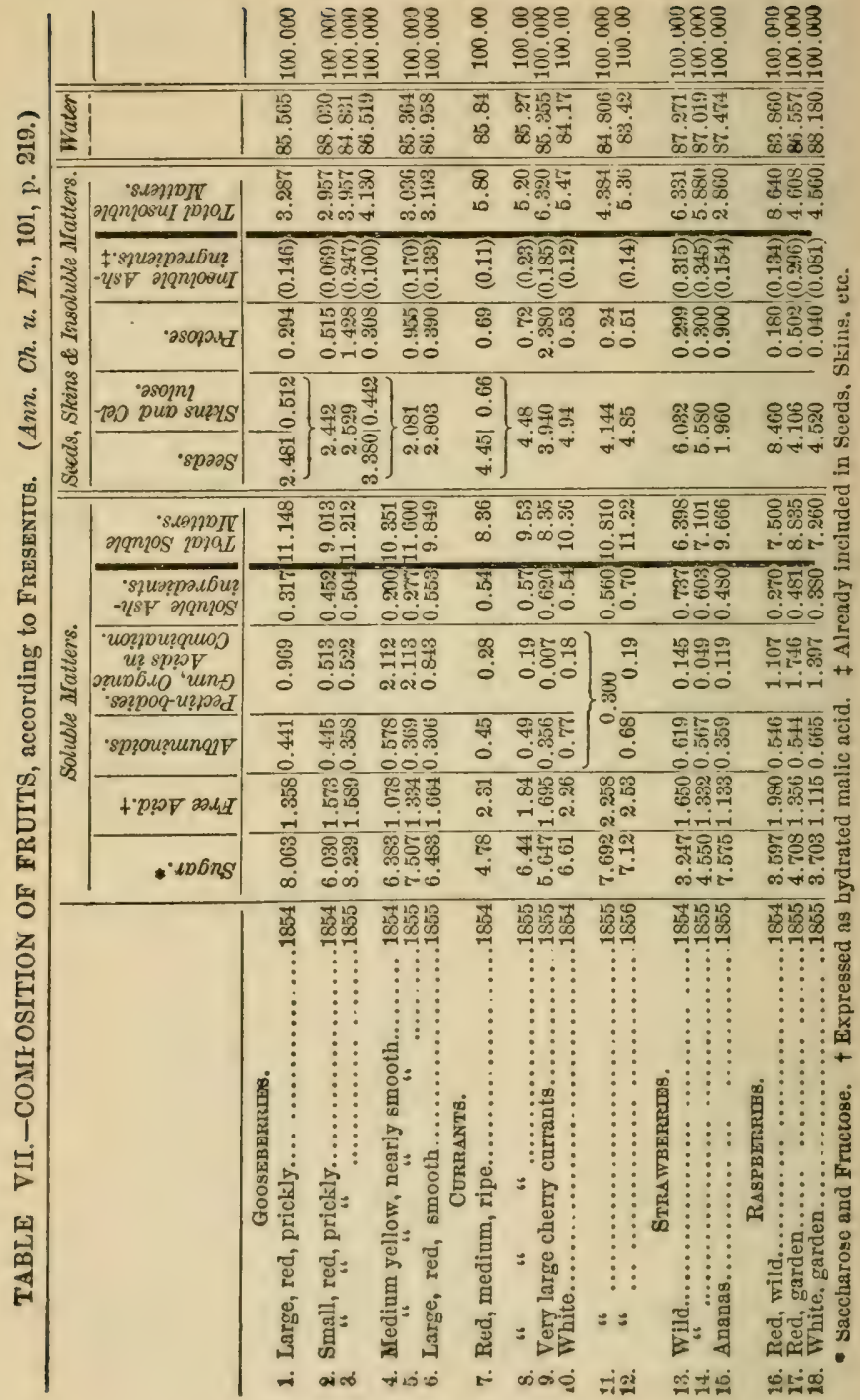




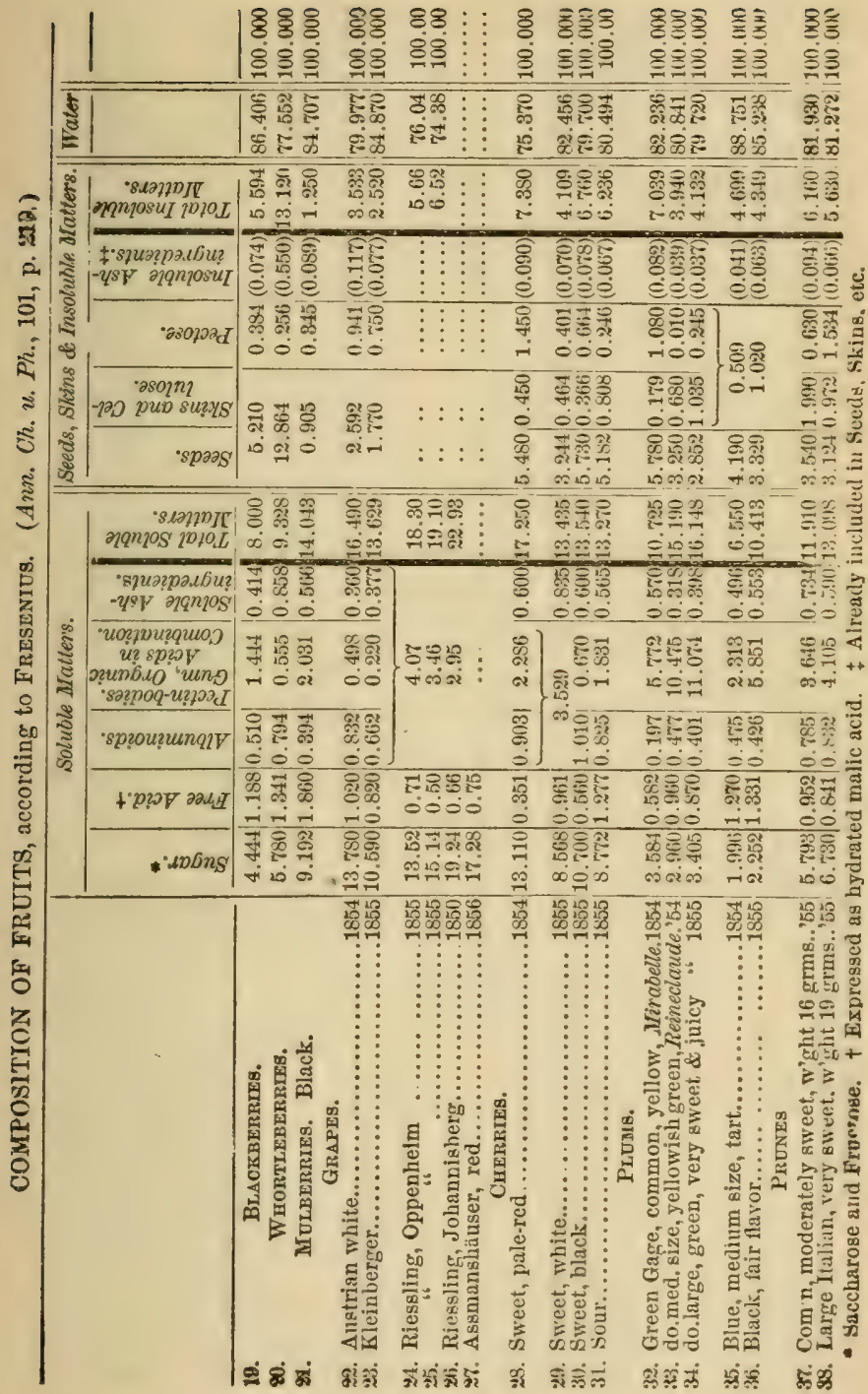




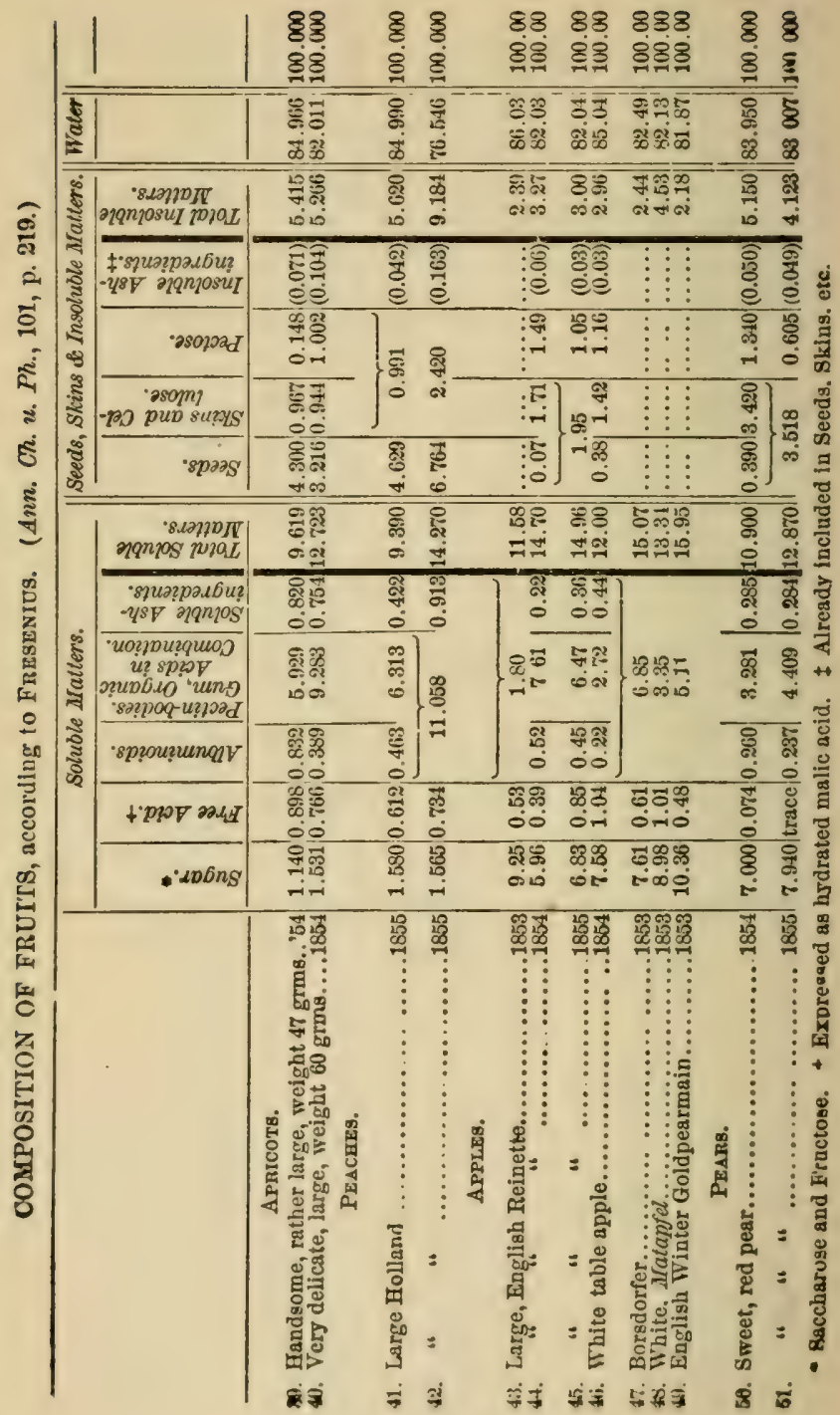




\section{TABIE VIII.}

FWUTTS ARKANGED TN IIIE ORDER OF THELR CONTENT OF SUAAR, (average, Fresenturs.

\begin{tabular}{|c|c|}
\hline $\begin{array}{l}\text { per cent. } \\
\ldots .1 .6\end{array}$ & per cent. \\
\hline 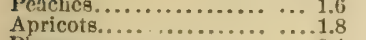 & $\ldots \ldots \ldots \ldots \ldots{ }_{6.3}^{6.1}$ \\
\hline Plums ................ & Gooseberries. \\
\hline 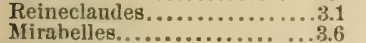 & Red pears............. \\
\hline firabelles..................... & Apples ............. \\
\hline $\begin{array}{l}\ldots 4.0 \\
\ldots .4 .4\end{array}$ & Sour cherries. \\
\hline 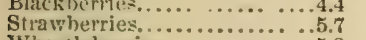 & Mulberries .... \\
\hline Whortleberries............5.8 & 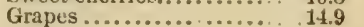 \\
\hline
\end{tabular}

\section{TABLE IX}

IRUITS ARRANGED LN THE ORDER OF THEIR CONTENT OF FREE ACLD EXPRESSED AS HIDRATE OF MIALIC ACID, (average,) FrESENIU,.

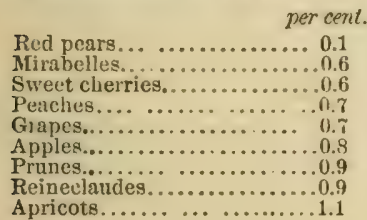

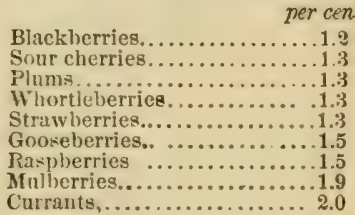

\section{TABLE $X$.}

FRUITS ARRANGED ACCORDING TO THE PROPORTIONS BETWEEN ACID, SUGAR, PECTIN AND GUM, ETC., (averages, Fresentus.

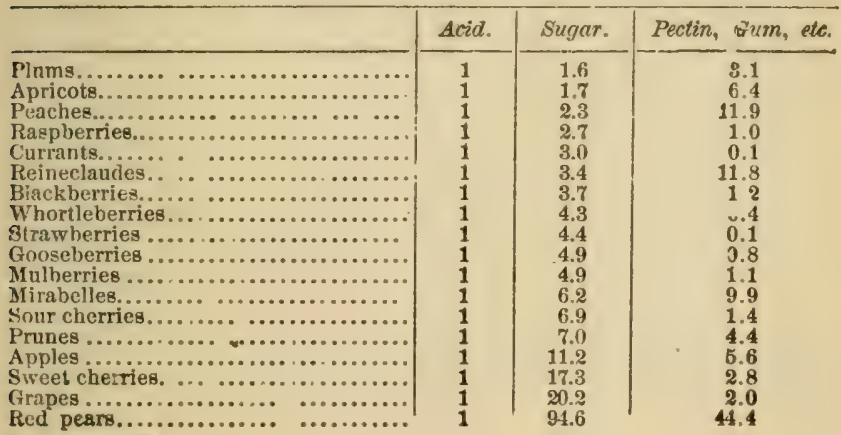




\section{TABLE XI.}

FRUTTS ARRANGED ACCORDINA TO THE PROPORTIONS BETWERN WATER, SOLUBLE MATTERS AND INSOLUBLE MATTERS,

(averages,) Fresentus.

\begin{tabular}{|c|c|c|c|}
\hline & Water. & SolubleMatters. & Jrwoluble Matters. \\
\hline Rzaspherries.... & 100 & 9.1 & 6.9 \\
\hline 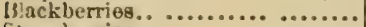 & 100 & 9.3 & 6.5 \\
\hline Strawberries.................... & 100 & 9.4 & 5.2 \\
\hline 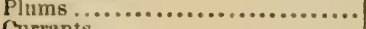 & 100 & 9.7 & 0.9 \\
\hline 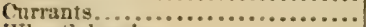 & 100 & 11.0 & 6.6 \\
\hline IVhortleberries.................... & 100 & 12.1 & 16.9 \\
\hline Gonseberries..................... & 100 & 12.2 & 3.6 \\
\hline 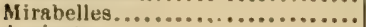 & 100 & 13.0 & 1.5 \\
\hline 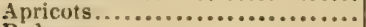 & 100 & 13.3 & 2.1 \\
\hline Red pears........................ & 100 & 14.3 & 5.5 \\
\hline 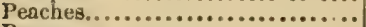 & 100 & 14.6 & 2.1 \\
\hline Pranes............................ & 100 & 15.3 & 3.2 \\
\hline Sour cherries.................. & 100 & 16.5 & 1.3 \\
\hline Mulberries........................ & 100 & 16,6 & 1.5 \\
\hline 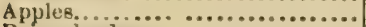 & 100 & 16.9 & 3.6 \\
\hline Reineclandes................ & 100 & 18.5 & 1.2 \\
\hline Cherries........................ & 100 & 18.6 & 1.5 \\
\hline 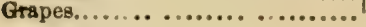 & 100 & 22.8 & 5.8 \\
\hline
\end{tabular}

\section{TABLE XII.}

PROPORTION OF OIL IN VARIOUS AIR-DRY SEEDS, according to BERTOT. (K'nop's Agricultur Chemie, p. 725.)

(The air-dry seeds contain 10-12 per cent of hygroscopic water.)

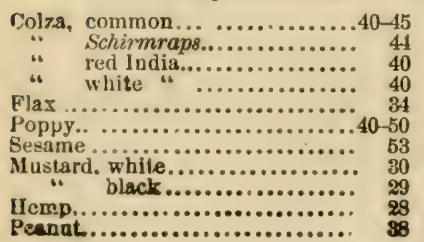

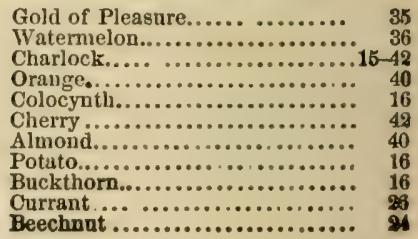




\section{TIE BEST BOOK ON GARDENING EVEIR WRITTEN.}

\section{Gardening for Profit.}

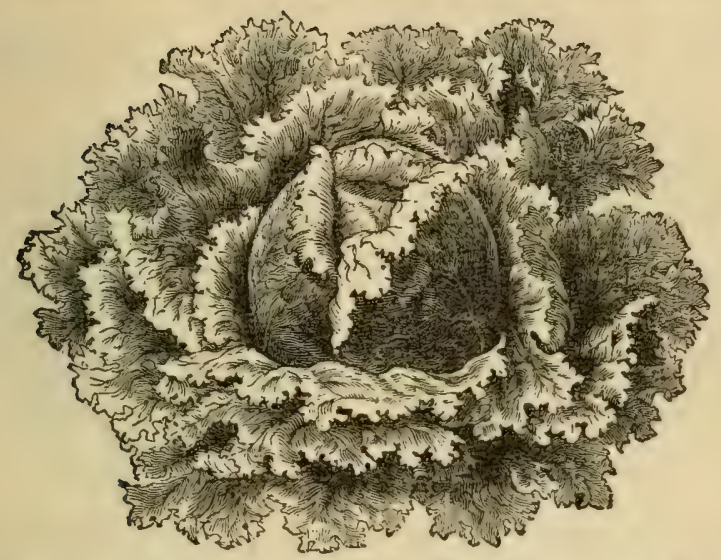

A Guide to the Successful Culture of the Market and Family Garden.

\section{PROFUSELY ILLUSTRATED.}

\section{Entirely Rewritten and Greatly Enlarged. BY PETER HENDERSON,}

Author of "Practical Floriculture," "Gardening for Plcasure," "Garden and Farm Tonics," elc.

The immense and unprecedented sale of the earlier colitions of Mr. Henderson's book, "Gardening for Profit," which sale has been continuous since the first day of its issue, indicates the estimate of its value as a thoronghly practical work. The new book, just issued, contains the best of the formerwork, with large additions drawn from the author's arlded years of experience. It cannot but be regarded by all as the best work on Market and Family Gardening ever published.

Cloth, 12mo. Price, Post-paid, \$2.00. 0. JUDD CO., DAVID W. JUDD, Presti, 751 Broadway, N. Y 


\section{The + Ameriean+Agriculturist.}

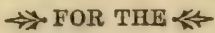

\section{Farm, Garden and Household.}

\section{Established in $\times 842$.}

\section{The Best and Cheapest Agricultural Journal in the World.}
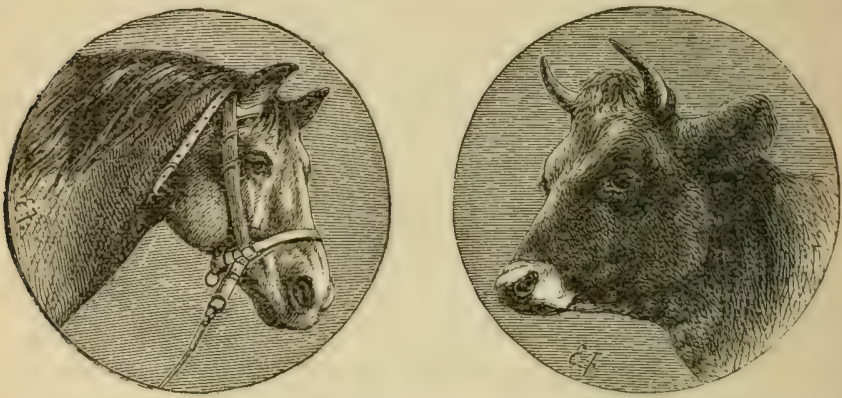

The American Agricullurist (so-called because started in 1S42, as a Rural Periodical) has been greatly enlarged and widened in scope, without change of name, until it now meets the wants of ALL classes, in City, Village and Country; it is literally ETERTBODI' the FrUTT GROWER, the MECHANIC, the FROFESBIONAI, ald BUSINESg man; it greatly aids every HoUsEzEErrn; it pleases and instructs the rourir and tho ITTTLE ONES.

It is ented with great care, laior, and expense. to have every line reliable. while its pages abuund in a great variety of usefnl, practical, reliable information and suguestions.

Every number describes, with engravings, a great raricty of Labor-siving, Labor-helping derices and Houschold Economies, A nimals, Plauts, Flowers, etc. In this r spect it surnasses, by far, all other like journals, aud will be found valuable and he'pful by every one, no matter how many other journals he may have.

It constaut Exposures of $\mathbf{M u m b u g s}$ and Swiniling Schemes are invaluable everywhere, and save many limes its cost to almo:t every resder. It sdmits uo medical adverisements, and no untrustworthy arlverisers. Its large circulation enables the Publishers to issue it at very low rates, and to deal liberally with subscribers in the way of premiums, etc.

Texms, which inciude postage pre-paid by the Publishers : $\$ 1.50$ per annum, in adrance; 3 copies for $\$ 4 ; 4$ copies for $\$ 5 ; 5$ copies for $\$ 6$; 6 copies for $\$ 7 ; 7$ copies for $\$ 8 ; 10$ or more enpies, only $\$ 1$ cach. Siugle Numbers, 15 cents.

\section{$\rightarrow \rightarrow$ HMERIKHISCHER+HGRICUITIRIST. \$}

The only purely Aericultural German paper in the Cuit,d States, and the beat in th: worde. It contains all the principal matter of th: Fnelieh Fition, together with sperial departmenty for ferman cultivatore, jrepared l.y wrtters trained for the work. Terms same as for the Americen Agriculturis!.

0. JUDD C0., DAVID W. JUDD, Pres't, 751 groadway, N. Y. 



1 
